Universidade de São Paulo

Faculdade de Filosofia, Letras e Ciências Humanas

Programa de Pós-Graduação em Sociologia

TEMPOS DE TRABALHO, TEMPOS DE NÃO TRABALHO:

VIVÊNCIAS COTIDIANAS DE TRABALHADORES

Ana Claudia Moreira Cardoso 
Universidade de São Paulo

Faculdade de Filosofia, Letras e Ciências Humanas

Programa de Pós-Graduação em Sociologia

\title{
TEMPOS DE TRABALHO, TEMPOS DE NÃO TRABALHO: VIVÊNCIAS COTIDIANAS DE TRABALHADORES
}

\author{
Ana Claudia Moreira Cardoso
}

Tese apresentada ao Departamento de Sociologia da Faculdade de Filosofia, Letras e Ciências Humanas, da Universidade de São Paulo e à École Doctorale da Universidade de Paris-8, como parte dos requisitos para a obtenção do grau de Doutor em Sociologia em regime de co-tutela

Orientadora:

Profa. Dra. Nadya Araujo Guimarães Co-Orientadora:

Profa. Dra. Helena Sumiko Hirata 
Trabalhem, trabalhem, proletários, para aumentar a riqueza social e suas misérias individuais, trabalhem, trabalhem para que, ficando mais pobres, tenham mais razão para trabalhar e tornarem-se miseráveis. Essa é a lei inexorável da produção capitalista.

Paul Lafargue, "O Direito à Preguiça"

Dedico este trabalho

a nós,

a vocês,

a todos que lutam para

transformar essa sociedade 
A construção dessa tese envolveu muitas e por vezes longas discussões com pessoas muito especiais, às quais agradeço pelo empenho e dedicação. Cada uma, a seu modo e a seu tempo, participou desse processo.

Foram elas: Adenor, Adriana, Ailton, Alécio, Alemão, Alfredo, Ana Lúcia, Ana Paula, André, Andréa, Ângela, Annick, Antônio, Barbosa, Bessin, Bigodinho, Carlos Oliveira, Carolina, Cássio, Catherine, Cédric, Célia, Coutrot, Cristiane, Éder, Edilene, Elaine, Elder, Eliana, Elson, Estela, Fábio, Feliciano, Flávia, Flávio, Freyssinet, Gasola, Geovaldo, Gerson, Gilberto, Gilles, Gisele, Gláucia, Gui, Guilherme, Helena, Hélène, Heleno, Helinho, Heloisa, Inês, Joana, Jorge, José Egito, José Gomes, José Renato, José, Kika, Lallement, Letícia, Linhart, Lúcia, Luciano, Lucio, Lucivaldo, Luis Paulo, Luizão, Magali, Manuel, Marcelo Donizete, Márcia, Márcio, Maria Helena, Mário, Marlene, Melão, Michele, Mônica, Murilo, Nadya, Nelson, Nenê, Odilei, Osmar, Paulo Aviro, Paulo Roberto, Pedro Lourenço, Reinaldo, Roberto, Rogério, Ronaldo, Rosi, San, Sérgio, Sidnei, Sirlei, Sonia, Suzanna, Tais, Tatiana, Téo, Thoemmes, Valéria, Vera, Vicente,Vivian, Viviane, Wagner, Walter, Zarifian

Além das pessoas carinhosamente citadas acima, gostaria de dirigir uma palavra a mais a outras que, por motivos diferentes, me acompanharam mais de perto nesta jornada.

À Helena e, sobretudo, à Nadya, que foram mais do que orientadoras. São pessoas maravilhosas com as quais tive o maior prazer em conviver e que estiveram o tempo todo ao meu lado.

Ao Lucio, meu companheiro que conheci justamente no início da construção desta tese, e que, desde então, vem me ajudando, incentivando e amando.

À minha mãe que esteve sempre ao meu lado, de uma forma ou de outra: uma palavra, um incentivo, uma comidinha deliciosa, um carinho.

Ao meu pai e meu avô (in memoriam) que, apesar de ausentes fisicamente, estiveram mais próximos do que nunca.

Algumas instituições, igualmente, foram fundamentais para a realização do meu doutorado: o Departamento Intersindical de Estatística e Estudos Sócioeconômicos (Dieese), o Conselho Nacional do Desenvolvimento Científico e Tecnológico (CNPq), o Programa de Pós-Graduação em Sociologia da Universidade de São Paulo, a Universidade Paris 8, o Laboratório Genre, Travail, Mobilités (GTM), e a Maison du Brèsil. 
Esta tese é um estudo das vivências cotidianas de trabalhadores em relação ao tempo de trabalho e ao tempo de não trabalho. O locus de análise privilegiado é o espaço do local de trabalho. A pesquisa tomou como caso para estudo a Volkswagen do Brasil, em sua unidade de produção do ABC-São Paulo, exemplo emblemático de iniciativas e negociações dirigidas a flexibilizar a jornada de trabalho. A análise se concentra no período compreendido entre 1995 e 2005, quando foram intensas as mudanças com respeito à organização e gestão do tempo de trabalho. A tese se divide em duas partes. Na primeira, constante de três capítulos, revisa-se a literatura internacional sobre os modos de construção social do tempo e do tempo de trabalho, e apresenta-se o debate recente sobre duas experiências contrastantes, a da França e a do Brasil. Na segunda parte, formada por sete outros capítulos, apresenta-se inicialmente o contexto da Volkswagen do Brasil, com base na analise de material documental e de entrevistas com trabalhadores, dirigentes sindicais e gerentes da empresa; em seguida, analisam-se as vivências temporais cotidianas dos trabalhadores, com base em entrevistas semi-diretivas e diários de usos do tempo.

Palavras-chave: Tempo, jornada de trabalho, Volkswagen-Brasil, flexibilidade, sindicato.

This thesis is a study of daily life of workers regarding their experiences and discourses on the work time and the non- work time. The workplace is the privileged locus of analysis. The empirical research examines the case of Volkswagen-Brazil in its assembly plant in $\mathrm{ABC}$ region, São Paulo, emblematic example of initiatives and negociations driven to achieve flexible work conditions and employment relations. The analysis focuses the period 19952005 when most intense changes took place. The thesis is divided into two parts. The first part begins with a review of the national and international literature on time and work time as societal constructions; the following two chapters present the recent debate on two opposing experiences, France's and Brazil's. In the second part, formed by seven chapters there is an initial presentation of the context of Volkswagen do Brasil, based on the analysis of documental material as well as interviews with workers, union leaders and managers. The last six chapters analyze the daily temporal experience of different groups of workers based on semi-directed interviews and time diaries.

Key words: Time, working day, Volkswagen-Brazil, flexibilility, unions.

\section{RÉSUMÉ}

Cette thèse est une étude des vécus temporels quotidiens des travailleurs en relation au temps de travail et au temps de non-travail. Le locus priviliégé d'analyse est l'espace du local de travail. Cette recherche a pris comme cas d'étude l'entreprise Volkswagen au Brésil, dans son unité de production de l'A.B.C.-São-Paulo, exemple emblématique des initiatives et des négociations axées sur la flexibilisation du temps de travail de travail. L'analyse se concentre sur la pèriode comprise entre 1995 et 2005, quand les changements, en relation à l'organisation et à la gestion du temps de travail, ont été intenses. La thèse se divise en deux parties. La première, répartie en trois chapitres, fait un point sur la littérature internationale concernant les modes de construction sociale du temps, et, du temps de travail. Elle présente le débat actuel de deux expèriences contrastantes, de La France et du Brésil. La seconde partie, constituée de sept chapitres, prèsente d'abord le contexte de la Volkswagen au Brésil, en se basant sur l'analyse du matèriel documentaire et d'entretiens avec des travailleurs, des dirigeants syndicaux et des cadres de l'entreprise. Dans un second temps, elle analyse les vécus temporels quotidiens des travailleurs, en se basant sur les entretiens semi-directifs et les journaux de bords des travailleurs.

Mots-clefs: Temps, durée du travail, Volkswagen-Brésil, flexibilité du temps de travail, syndicats. 


\section{PARTe I - Tempos e Sociedades: em torno da Relevância Social e Sociológica do Tema}

1. A construção temporal nas sociedades contemporâneas $\quad 15$

1.1 - O tempo de trabalho como construção social 18

1.2 - Os processos de construção social do tempo, do trabalho e do tempo dedicado 20 ao trabalho

1.3 - A cultura temporal das sociedades industriais: o tempo de trabalho como tempo único 26

1.4 - Vivências temporais cotidianas 30

1.5 - A cultura temporal das sociedades contemporâneas: tempos de trabalho tensos, 35 urgentes, intensos e flexíveis

2. A construção social do tempo de trabalho na França: um olhar a partir dos anos $90 \quad 44$

2.1 - O tempo de trabalho na França

2.1.1 - A partir dos anos 1980: mudanças na construção do tempo de trabalho 46

2.1.2 - A partir de meados dos anos 1990: negociação, redução e flexibilização 51 do tempo de trabalho 2.1.2.1- Lei Aubry - 2000: mudanças de percurso $\quad 56$

2.1.3 - Novas mudanças de percurso: o novo governo 63

2.2 - Vivências das reduções do tempo de trabalho 67

2.3 - Considerações finais 72

3. Tempo de trabalho: a experiência brasileira recente $\quad 80$

3.1 - Tempo, trabalho e tempo de trabalho: rastreando elementos importantes da 81

sua construção no Brasil

3.2 - Mudanças no tempo de trabalho a partir dos anos $1990 \quad 89$

3.2.1 - Anos 1990: contexto de desemprego, estagnação da redução da jornada 90 de trabalho e aumento da hora extra

3.2.2 - Anos 1990: a intensificação da flexibilização do tempo de trabalho 99

3.3 - Considerações finais 111

PARTE II - Configurações de discursos SObRe AS VIVÊNCIAS TEMPORAIS COtidianas No CONTEXTO da VolKsWagen do ABC

4. A construção de um objeto de estudo: vivências temporais cotidianas 117

$\begin{array}{ll}4.1 \text { - Perspectiva metodológica } & 117\end{array}$

4.2 - O contexto da pesquisa: o caso Volkswagen do ABC 120

4.3 - Procedimentos metodológicos 122

4.4 - As configurações de discursos 127

4.5 - Os sujeitos empíricos da pesquisa 130

$\begin{array}{ll}\text { 4.5.1 - Características pessoais e sociais do grupo } & 130\end{array}$

4.5.2 - O Grupo de acordo com a situação na empresa 132 
5. $O$ contexto da pesquisa: o tempo de trabalho na Volkswagen do $\mathrm{ABC}$

141

5.1 - Dos anos 50 ao final dos 70: expansão da produção, do emprego

e do tempo no trabalho

5.2 - Anos 80: o início da luta pela redução da jornada

5.3 - Meados dos 80 a meados dos 90: a flexibilização não-declarada e não negociada do tempo de trabalho

5.4 - A partir de meados dos anos 1990: redução e flexibilização negociada e

legal do tempo de trabalho

5.4.1 - Mudanças na gestão do trabalho

5.4.2 - As negociações coletivas na segunda metade dos anos 1990

5.4.2.1 - A manutenção da Planta do ABC

5.4.2.2- A multifunção e o trabalho intenso em cada função (PCS)

5.4.2.3 - A meta de absenteísmo (PLR)

5.4.2.4 - As células de produção - maior controle, menos pausas

e maior competição

5.4.3 - Jornada de trabalho: redução, flexibilização e intensificação

5.4.3.1 - Flexibilização do tempo de trabalho, via "semana Volkswagen"

5.4.3.2 - A explicitação do descontentamento

5.4.3.3- Fim da estabilidade no emprego e manutenção da flexibilização

5.5 - Considerações finais

6. Vivências dos tempos no local de trabalho

6.1 - Sob o império da linha de produção: vivências dos tempos impostos no

local de trabalho

6.1.1 - As vivências nas diferentes linhas

6.2 - Mudanças na organização do trabalho sentidas como intensificação

do tempo de trabalho

6.2.1 A multitarefa e o trabalho intenso em cada uma delas

6.2.2 - A redução dos prazos

6.4 - Tempos dentro do local de trabalho como tempos de não trabalho

7. Vivências dos tempos nos turnos de revezamento e no trabalho noturno

7.1 - Na época dos turnos de revezamento

7.2 - Vivências do trabalho noturno, em tempos passados 231

7.3 - Vivências do trabalho noturno, no tempo presente 234

7.4 - Considerações finais

8. Jovens: transições entre tempos dentro e fora da empresa 244

8.1 - Ser jovem na Volkswagen, no tempo presente

8.2 - O tempo passado: uma primeira transição entre tempo de estudo e 
8.3 -Tempos presentes: a expectativa de uma segunda transição

9. Tempos de trabalho e de não trabalho: vivências a partir de uma perspectiva de gênero 267

9.1 - As mulheres na Volkswagen

9.2 - Vivências das trabalhadoras nos tempos de trabalho e de não trabalho

9.2.1 - Giulia, Viviane, Eliana e Tamara

9.2.2 - Luiza

9.2.3 - Lara: vivências cotidianas do tempo fora da Volkswagen

9.2.4 - Joice e Luana: vivências cotidianas do tempo fora da Volkswagen

9.2.5 - Lara, Joice e Luana - vivência dos tempos e do trabalho dentro da Volkswagen

10. Vivências temporais cotidianas fora do local de trabalho

10.1 - O sentimento de falta de tempo e as equações temporais cotidianas

10.2 - Vivências temporais cotidianas

10.3 - Tempos dedicados ao trabalho profissional, fora do local de trabalho

10.3.1 Tempo dedicado ao transporte

10.3.2 Tempo dedicado ao estudo

10.3.3 Ainda pensando no trabalho

10.4 Considerações finais

Reflexões finais, à guisa de conclusão 
$E$

sta pesquisa situa-se no campo dos estudos do trabalho, tendo, como objeto de estudo, o tempo de trabalho. Insiro-me neste debate abordando o modo pelo qual o fenômeno se expressa uma vez observado pela lente das vivências, experiências e representações dos trabalhadores.

Os tempos de trabalho e de não trabalho são compreendidos como categorias organizadoras da vida social, cuja construção se processa socialmente e em cada momento, a partir das interações entre os diversos atores sociais. Nas suas múltiplas formas históricas, as sociedades definem a maneira de utilização do tempo em suas várias dimensões, tanto as que se referem ao tempo do trabalho, como as que se referem ao tempo de não trabalho. Assim, entendo que analisar o tempo e o tempo de trabalho é discutir um dos elementos constitutivos e estruturais das sociedades industrializadas, sobretudo num momento onde ocorrem mudanças fundamentais nesses tempos.

No momento atual, observamos que o tempo de trabalho sofre contínua intensificação e flexibilização, ao mesmo tempo em que o movimento histórico de redução da jornada de trabalho tem evoluído pouco. Além disso, o processo de separação entre os tempos e espaços de trabalho e de não trabalho (Freyssenet,1994) vem sendo substituído por um movimento contrário, de reaproximação, de forma que a definição de onde cada um começa e termina está cada vez mais fluída (Zarifian, 1996). Vê-se ainda a fragmentação e individualização do tempo dedicado ao trabalho e o surgimento de uma pluralidade de novos tempos de trabalho que coabitam com o modo antigo caracterizado como norma única, protegido e previsível. Fragmentação e individualização causadas, sobretudo, pela crescente flexibilização que coloca este tempo em total assincronia na relação com os outros tempos sociais - o da família, do lazer, do amor, da educação, entre outros (Chesneaux, 1996, Grossin, 2001, Mercure, 1995, Mispelblom,1999, Oliva Augusto, 1994 e Sue, 1994). 
Assim, nesse contexto de intensas transformações, este estudo tem como objetivo compreender como se dão as vivências temporais cotidianas dos trabalhadores, contextualizadas, tanto ao nível macro-social pelas mudanças no tempo e no trabalho na sociedade atual, quanto ao nível micro-organizacional pelas transformações nas relações sociais nos locais de trabalho. Vale acrescentar que o desenvolvimento desta tese também partiu de inquietações pessoais, além das profissionais e teóricas. No torvelinho de tais inquietações, as questões centrais que motivaram este percurso foram se reconfigurando ao longo do desenvolvimento da pesquisa, a partir dos esforços realizados no sentido de transformar essas motivações em questões analíticas relevantes.

Parto de algumas indagações de pesquisa formuladas ainda no percurso do mestrado, realizado na Ciência Política da Universidade de São Paulo, e concluído em 1997, quando estudei a ação sindical frente ao emprego e ao desemprego (Cardoso, 1998a) ${ }^{1}$. Naquele processo, a compreensão acerca de como o movimento sindical vinha tratando a questão foi limitada pelo fato de que a pesquisa realizada era de natureza apenas documental ${ }^{2}$. A análise de documentos deixava claro o foco da discussão ou da reivindicação, mas não as motivações e representações que mobilizavam os trabalhadores. Isso me levou a realizar entrevistas com os dirigentes sindicais que me ajudaram a compreender os resultados observados nos documentos. Minhas entrevistas permitiam entrever indagações suscitadas sobre os trabalhadores, mas não desvendavam as indagações dos trabalhadores, revelando os limites da abordagem escolhida. Surgia, então, uma primeira constatação: nessa minha primeira investida interpretativa, eu dera forte ênfase às estruturas e instituições, tratando-as quase como puras objetivações, sem a necessária relação com os trabalhadores. Construíra, parafraseando Giddens (2003), um "abismo entre sujeito e objeto social".

Mais tarde, distante da academia e em contato permanente com o movimento sindical dada a minha inserção profissional como formadora sindical (acho importante colocar as referências disso, pode ser em nota de rodapé. Importante informar que era pelo dieese, setor, data, etc), outras questões foram pouco a pouco me mobilizando. Em 1998, o governo editava uma medida provisória ampliando o prazo de compensação da jornada de trabalho, criando o que

1. Na ocasião analisei os casos dos sindicatos dos metalúrgicos do $\mathrm{ABC}$ e São José dos Campos - (filiados à CUT) e de Osasco e da cidade de São Paulo - (filiados à Força Sindical).

2. Analisei as pautas de reivindicação, os acordos e as convenções coletivas, tanto quanto as resoluções de congressos, e material secundário relativo às greves (através dos boletins do DIEESE), abrangendo o período compreendido entre 1990 e 1995. 
veio a ser denominado "banco de horas", uma iniciativa que revelava uma nova forma de lidar com o tempo de trabalho. Em seguida, no DIEESE, iniciamos a montagem de um seminário tendo como foco a flexibilização do tempo de trabalho. No desenvolvimento dos seminários fui percebendo que, para muitos dirigentes sindicais, era a primeira vez que refletiam sobre o tempo, sobre o tempo dedicado ao trabalho e ao não trabalho, sobre a relação entre esses tempos, e sobre o que era socialmente definido como tempo de trabalho ou de não trabalho.

Parecia ainda evidente a dificuldade deles em compreender que o tempo ou a duração da jornada de trabalho, em suas delimitações atuais, era o resultado de disputas, parte das relações sociais - e não algo natural, naturalizado, que sempre fora assim, em todas as épocas e em todas as culturas. Descortinava-se para mim o paradoxo: aqueles mesmos dirigentes que se autoreconheciam, em seus discursos, como sujeitos que buscavam a transformação da sociedade, denotavam, em sua atuação cotidiana, a dificuldade em entender a realidade como o resultado da interação entre atores sociais, que se (re)fazia ao longo da história, sendo, assim, socialmente construída.

Surgia, desse modo, uma segunda questão: como discutir a flexibilização do tempo de trabalho se a própria natureza deste tempo não era objeto de reflexão? E mais, enquanto discutia com eles sobre as suas próprias vivências em relação ao tempo de trabalho, uma terceira inquietação ficava evidente: refletir sobre o tempo de trabalho implicaria considerar também o tempo de não trabalho, uma vez que os sujeitos vivenciam a totalidade temporal, havendo total relação entre os diversos tempos sociais.

No mesmo período, na equipe de educação do DIEESE, realizávamos discussões sobre o processo de produção do conhecimento. Nelas procurávamos refletir sobre o conhecimento como um processo culturalmente mediado, historicamente desenvolvido e fruto da atividade prática dos sujeitos. Sobressaía-se a questão dos sujeitos como agentes no processo de produção do conhecimento e de construção da sociedade. Explicitava-se, assim, mais um aspecto: os diferentes sujeitos, em função de suas experiências, valores, conhecimentos, desconhecimentos e representações construídas, poderiam vivenciar uma mesma situação objetiva de formas totalmente diferentes. Assim, ao reconhecer a ausência dos verdadeiros sujeitos (os trabalhadores) e de suas vivências no tratamento que dera ao tema na minha dissertação de mestrado, sentia-me cada vez mais mobilizada para desenvolver um novo estudo, cuja concepção teórico-metodológica permitisse uma aproximação da realidade por meio das representações dos sujeitos, delas extraindo o seu significado político. 
Ao refletir sobre o tempo a partir do ponto de vista dos sujeitos, das suas vivências cotidianas dos tempos de trabalho e de não trabalho, ao longo dos inúmeros cursos de formação, fui sendo alertada para a minha própria vivência em relação aos tempos sociais. Percebia-a inserida, igualmente, em uma cultura temporal caracterizada pelo ritmo acelerado de relações que os homens constroem entre si, com as coisas e com os lugares. Essa aceleração do tempo faz com que os intervalos sejam cada vez mais breves, sendo que essa experiência cotidiana engloba a todos e abrange os diversos tempos e espaços: da casa, da escola, da fábrica, do tempo livre; tal qual ouviria posteriormente no relato dos trabalhadores pesquisados. Por que, cada vez mais, o tempo aparece como $\operatorname{algo} o^{3}$ raro, escasso, que nos obriga a criar artifícios para economizá-lo, multiplicá-lo, driblá-lo?

Os inúmeros questionamentos pessoais, profissionais ou teóricos me fizeram decidir voltar à academia, após quatro anos, migrando para área da Sociologia. Fiz escolhas, mesmo sabendo das dificuldades desse novo percurso intelectual. Ao perceber que o tempo é antes de tudo uma experiência subjetiva, fui levada a tomá-lo como objeto de reflexão. Escolhi refletir sobre os tempos, a partir do vivido, do experimentado, do representado cotidianamente pelos trabalhadores em uma empresa, e na relação com a concepção de tempo da própria empresa, conceitualmente objetivo, único, racional, controlado e perfeitamente quantificado.

Tais escolhas dão sentido às minhas intenções e objetivos neste trabalho, sendo essenciais para a localização do lugar de onde falo e para a compreensão das minhas motivações. A intenção é contribuir para a explicitação do tempo como uma construção social e, portanto, como resultado de uma correlação de forças presentes na sociedade, em determinado momento. Isso permite pensar a sociedade e suas instituições como algo passível de mudanças, de intervenção, de reconstrução, seja de um presente ou de um futuro, sob formas e com cursos diferentes. Pois, como bem salientado por Titoni (2006), uma das características das instituições sociais - e neste caso o tempo é pensado como uma das mais importantes instituições da sociedade capitalista - é justamente o fato dos sujeitos as tomarem como dadas e, portanto, como realidades que lhes são exteriores, que estão fora do seu alcance.

Para a construção da tese, algumas questões, que dialogavam entre si e que discuto ao longo deste trabalho, foram tomadas como ponto de partida: que mudanças estão ocorrendo no

3. Ao longo da tese, algumas vezes palavras ou frases estarão em itálico dada a minha intenção em ressaltá-las. Outras vezes, no caso das citações bibliográficas, eu utilizei o sublinhado também para ressaltar algo que considerei mais relevante. 
tempo de trabalho e de não trabalho na sociedade brasileira? Quais as discussões sobre esses tempos no plano macro-social e político? Nos locais de trabalho, o que tem sido negociado e o que não é colocado, por uma das partes, como objeto de negociação coletiva? Quais as principais características do tempo de trabalho e do tempo de não trabalho? Porque temos a impressão de que existe um tempo único, abstrato e quase natural? Que equações temporais são elaboradas pelos sujeitos para harmonizarem os diversos tempos sociais? Porque, na maior parte das vezes, os sujeitos tomam algumas instituições sociais - entre elas o tempo de trabalho e de não trabalho - como dadas naturalmente e não como o resultado da interação entre os seres humanos?

Para buscar respostas a essas questões, estudo as vivências temporais cotidianas de trabalhadores em relação ao tempo de trabalho e ao tempo de não trabalho, tendo como locus de análise privilegiado o espaço do local de trabalho. O caso que tomei para estudo é a Volkswagen do Brasil, em sua unidade de produção do ABC, em São Paulo, exemplo emblemático de iniciativas e negociações sobre o tempo de trabalho. Analiso-o concentrando-me no período compreendido entre 1995 e 2005, momento em que se alteram as normas de gestão do trabalho, da relação assalariada dita tipicamente capitalista, flexibilizando-se com isso, entre outras, as formas de usos do tempo. Vale ressaltar que nesta pesquisa a empresa é apenas a porta de entrada para se compreender o que se passa no âmbito mais amplo, das transformações na cultura temporal da sociedade brasileira e dos locais de trabalho.

Ao estudar o local de trabalho, pude observar os diferentes fatores que afetam o tempo de trabalho e entender como são negociados e vivenciados pelos trabalhadores. Ao longo do primeiro semestre de 2005, recolhi as narrativas dos trabalhadores para conhecer as formas como eles vivenciam e experimentam os tempos sociais de trabalho e de não trabalho e as representações construídas sobre essa vivência. O pressuposto é de que essas vivências determinam e são determinadas pelo meio temporal em que se encontram, vale dizer, a família, os grupos de referência, o local de trabalho, bem como por contextos mais amplos da vida social, numa cidade, num país ou numa cultura temporal.

Os resultados desse estudo estão apresentados em duas grandes partes.

A primeira, intitulada "Tempos e sociedades: em torno da relevância social e sociológica do tema" é constituída por três capítulos. Inicio revisando a literatura nacional e internacional sobre os modos de construção do tempo e do tempo de trabalho, a partir de três pressupostos de natureza teórico-metodológica. Primeiro, que o tempo é uma construção social - o que me leva a considerar construções temporais que resultam de culturas temporais diferentes, a depender, 
portanto, da sociedade e do momento histórico. Segundo, que existe uma multiplicidade de tempos sociais, mesmo que em cada cultura temporal haja um tempo dominante e que busca invadir e sobredeterminar os outros tempos sociais. Terceiro, que a apreensão dessa multiplicidade deve ser realizada a partir da análise dos sujeitos, isto é, de suas vivências, experiências e representações temporais cotidianas.

Nos dois capítulos seguintes, apresento o debate recente sobre o tempo de trabalho em duas experiências contrastantes, a da França e a do Brasil. A escolha da França para estabelecer o diálogo com o caso do Brasil foi motivada, sobretudo, pela centralidade com que o tema pauta a agenda social recente, além do próprio debate sindical. Isso se expressa no intenso processo de negociação iniciado pelo Estado francês, abrangendo trabalhadores e empresários, visando a redução da jornada de trabalho para 35 horas. Essa centralidade se reflete também no volume e riqueza das reflexões teóricas e dos achados empíricos produzidos no meio acadêmico com respeito ao tema do tempo, do tempo de trabalho e de não trabalho. A análise realizada para o caso do Brasil, visou apreender o contexto macro-social em que se desenvolvem, entre nós, as discussões sobre o tempo de trabalho; estas, por sua vez, influenciam e são influenciadas pelas formas como esse tempo é organizado dentro das empresas. Estabelecidos esses marcos macrosociais me foi possível realizar, em seguida, uma análise detalhada do contexto microorganizacional da Volkswagen do ABC, de modo a melhor enquadrar e compreender as vivências temporais cotidianas dos trabalhadores nesta empresa.

A segunda parte da tese, intitulada "Configurações de discursos sobre as vivências temporais cotidianas no contexto da Volkswagen do ABC", é formada por sete outros capítulos. No quarto capítulo, apresento a perspectiva metodológica adotada: a de um estudo qualitativo, de caso, a partir do local de trabalho, analisando discursos sobre vivências. Apresento ainda os motivos que me levaram a escolher a Volkswagen do ABC e a estudar o fenômeno no período compreendido entre os anos de 1995 e 2005 . Indico os procedimentos metodológicos utilizados na pesquisa, o tratamento analítico do material empírico recolhido e, finalmente, apresento os sujeitos empíricos desta pesquisa.

No capítulo 5, discuto o contexto micro-organizacional, e analiso a história da Volkswagen no Brasil, considerando o seu desenvolvimento geral e as mudanças ocorridas no tempo de trabalho, com base na análise de material documental e de entrevistas com trabalhadores, dirigentes sindicais e gerentes da empresa. Estudar um local de trabalho específico, no caso a Volkswagen, me permitiu observar em profundidade quais são e como operam os diversos fato- 
res que afetam o tempo de trabalho, explicitando como eles têm sido negociados e como têm sido vivenciados.

Nos capítulos seguintes, do sexto ao décimo, dedico-me à análise dos achados principais do meu trabalho de campo, depreendidos das narrativas discursivas dos trabalhadores, em que expressam as suas vivências, experiências e representações sobre as inter-relações entre o tempo dentro e fora do local de trabalho. Essa análise busca identificar os elementos que organizam as narrativas com respeito aos diversos tempos sociais, considerando algumas questões, entre elas: Como os trabalhadores falam do tempo? Quais aspectos são mais explicitados? Quais são as equações temporais que eles dizem realizar para organizar esses diversos tempos? Como os seus atributos pessoais e sociais influenciam as suas vivências temporais cotidianas? Como falam do tempo de trabalho, do tempo fora do trabalho e da inter-relação entre ambos?

A análise revela, a propósito do tempo dentro da fábrica, algumas configurações de discursos muito similares, entre outras claramente diferenciadas. Pude identificar, assim, quatro configurações de discursos sobre o tempo de trabalho e de não trabalho em torno das funções e ocupações dentro da fábrica (capítulo 6); do turno de trabalho (capítulo 7); das relações de geração (capítulo 8); e das relações de gênero (capítulo 9). E, apesar das singularidades presentes em cada uma das configurações, há, em comum a todos os trabalhadores, dentro do local de trabalho, uma forte vivência de um tempo controlado, pressionado, intensificado e flexibilizado. No capítulo 10, analiso as vivências temporais cotidianas dos trabalhadores no seu tempo fora da fábrica; nele algumas características são explicitadas, considerando as inter-relações entre os tempos dentro e fora da fábrica: é um tempo curto, insuficiente, corrido, um tempo de cansaço e ainda tomado por diversas atividades relacionadas ao trabalho.

$\mathrm{Na}$ parte das reflexões finais, são expostas algumas considerações que já podem ser formuladas, mesmo com a pouca distância que ainda guardo com respeito ao momento de conclusão desta análise. Nela, em vez de reproduzir as conclusões parciais que procuro apresentar ao final de cada capítulo, tento sistematizar algumas contribuições deste estudo para a melhor compreensão das vivências temporais cotidianas na sociedade brasileira contemporânea. Almejo, ao finalizar, propor subsídios para a discussão em torno da temática do tempo de trabalho tal como ela transcorre nos âmbitos macro-políticos, acreditando na importância dos mesmos para a renovação no processo de negociação coletiva nos locais de trabalho. 
"A sociedade atual tem um interesse vital em que a questão do trabalho não seja discutida. Para evitar todo debate, ela nos inculcou todos os tipos de bons princípios. A duração do trabalho, em particular, aparece determinada com o rigor de um dado natural. Diminuir o horário de 8 horas, fixado há mais de cinqüenta anos, parece tão inconcebível quanto reduzir o número de dias do ano, quanto mudar o número de horas que conta o dia".

Adret ("Travailler deux heures par jour")

\section{PARTE | \\ TEMPOS E SOCIEDADES: \\ EM TORNO DA RELEVÂNCIA SOCIAL E SOCIOLÓGICA DO TEMA}

1. A construção temporal nas sociedades contemporâneas

2. A construção social do tempo de trabalho na França: um olhar a partir dos anos 90

3. Tempo de trabalho: a experiência brasileira recente 


\section{A CONSTRUÇÃO TEMPORAL NAS SOCIEDADES CONTEMPORÂNEAS}

tempo é uma dimensão essencial da relação do homem com o mundo (Grossin, 1991 e Mercure, 1995), o que torna sua discussão relevante tanto do ponto de vista social como sociológico, sobretudo em um momento em que tanto as nossas experiências cotidianas como as discussões teóricas apontam para mudanças fundamentais. Vive-se hoje, no dia a dia, uma temporalidade "urgente" (Bessin, 1999) que envolve a todos; um sentimento de que se é "prisioneiro do imediato". O desenvolvimento das novas tecnologias da informação e da comunicação que implicam a simultaneidade e o imediatismo contribui para esse tempo que parece estar em aceleração contínua (Chesneaux, 1996).

Neste contexto de mudanças na cultura temporal nas sociedades contemporâneas, bem como o meu objetivo de analisar as vivências sobre o tempo, organizei minha pesquisa a partir de três pressupostos de natureza teórico-metodológica. Um deles, considera as definições de tempo de trabalho e de não trabalho como construções sociais. Compreendê-las significa analisar normas, leis, processos de negociação e, portanto, a correlação de forças entre os atores sociais envolvidos nessa construção que incorpora valores, vivências e representações individuais e cotidianas sobre o tempo. É a partir de uma breve discussão sobre essa questão que inicio este capítulo.

Num segundo momento, se tenho como pressuposto que as atuais definições do tempo de trabalho e de não trabalho são construções sociais, entendo que para compreendê-las é necessário analisar como foram sendo socialmente construídas nos diferentes momentos

históricos. É esta análise que realizo neste segundo momento. Tal olhar, por sua vez, contribui também para a apreensão da construção temporal dos dias de hoje.

Em seguida, após a discussão do tempo como construção social e do olhar para essa construção nos diferentes momentos históricos, dois outros pressupostos são discutidos: o de 
que existe uma multiplicidade de tempos sociais, mesmo que em cada cultura temporal haja um tempo dominante. E o de que a possibilidade de apreender essa multiplicidade, para além de um tempo que se coloca como único, se faz pela análise das vivências, das experiências e das representações temporais cotidianas dos sujeitos. Essas duas discussões explicitam outro ponto importante que também é aqui tratado: se me refiro a tempos sociais, falo igualmente de tempos de trabalho, tempos de lazer ou tempos de estudo, sempre no plural. De forma que mesmo que a análise seja feita sobre um único tempo social, ao pensá-lo a partir das vivências temporais cotidianas dos sujeitos, vemos que cada um irá vivenciá-lo e construir representações sobre essa vivência de modo específico e próprio, o que leva a uma pluralidade temporal. Retomo, então, a noção do tempo como construção social.

Finalmente, na última parte deste capítulo, a partir das discussões teóricas desenvolvidas, analiso a construção temporal nas sociedades contemporâneas, tendo como foco o tempo de trabalho. Tal discussão aporta os elementos necessários para a compreensão das diferentes culturas temporais analisadas a seguir, como a francesa e a brasileira, bem como as vivências temporais cotidianas dos trabalhadores na Volkswagen do ABC, no Brasil.

\section{1 - O tempo de trabalho como construção social}

O tema do tempo de trabalho é tanto antigo como fundamental, como já frisava Marx (1985) e como ressaltam alguns autores contemporâneos, como Terssac e Tremblay (2000), ao se questionarem "para onde vai o tempo de trabalho" nas sociedades contemporâneas. Assim, entendo que analisar o tempo e o tempo de trabalho é discutir um dos elementos constitutivos e estruturantes das sociedades industrializadas, sobretudo num momento em que ocorrem mudanças fundamentais nesses tempos. Diversos autores, como se verá no decorrer desta tese, mesmo que a partir de perspectivas diferentes, caracterizam o momento atual como de intensas transformações no tempo de trabalho e de não trabalho, ou seja, nas inter-relações entre os diversos tempos sociais. Olham para essas mudanças, para as definições e delimitações desses tempos enfatizando o seu caráter de serem socialmente construídas, contrapondo-se assim à idéia de que exista um único tempo social, exterior aos homens e às relações sociais.

Diz-se normalmente que o tempo passa, como se existisse uma realidade temporal exterior à ação e ao pensamento dos homens de uma sociedade, porque, na maior parte das vezes, o 
tempo é tomado apenas como uma realidade objetiva. A ênfase dada a esse aspecto natural, objetivo e exterior aos homens não acontece apenas em relação ao tempo e ao tempo de trabalho, mas está presente em uma ampla gama de acontecimentos e processos que são tomados como exteriores às relações sociais. Lopes (2000), por exemplo, ao olhar para a relação trabalhocapital e suas várias configurações do processo de trabalho - formas técnicas e organizacionais, o planejamento dos tempos e ritmos da produção, o layout etc. -, ressalta que "[...] estes aparecem aos olhos dos sujeitos envolvidos não como conseqüência de uma dada relação social, específica de uma época histórica, mas como uma imposição natural e eterna" (idem:108). Todas essas idéias e exemplos remetem para mim à tese de Marx: "o capital não é uma massa de riquezas, mas uma relação social", a relação capital-trabalho. Mas por que isso acontece? Por que naturalizamos o que é social? Por que os próprios atores das construções sociais lidam com elas, na maior parte das vezes, como se fossem fenômenos naturais e não sociais?

Para Elias (1998), a naturalização de alguns conceitos, entre eles o relacionado ao tempo de trabalho, a algumas relações ou instituições ocorre quando um símbolo atinge um grau muito alto de adequação à realidade, tornando-se difícil distingui-lo dessa mesma realidade. Também para Moscovici (2003), às vezes objetivamos algo a tal ponto que esquecemos que são criações, produtos de nossa própria atividade, "que alguma coisa é também alguém” (Moscovici, 2003: 75). Desta forma, devemos entender as definições, os conceitos ou as instituições existentes como objetivações, como materializações da realidade mas não como a própria realidade. Pois, quanto mais a imagem ligada à palavra ou à idéia se separa e se torna autônoma em uma sociedade, mais ela é aceita como a realidade em si mesma “[...] uma realidade convencional clara, mas de qualquer modo uma realidade" (Moscovici, 2003:73), passando a possuir autoridade de um fenômeno natural e não social.

Giddens (2003) frisa que do ponto de vista teórico, muitas explicações sobre a sociedade acabaram por definir os agentes e as estruturas como dois conjuntos de fenômenos independentes. Entretanto, o autor entende que "as propriedades estruturais de sistemas sociais são, ao mesmo tempo, meio e fim das práticas que elas recursivamente organizam [...]" (idem:28), de forma que as estruturas são vistas, simultaneamente, como restritivas e facilitadoras, possibilitando e, ao mesmo tempo, restringindo a ação dos sujeitos. Também Lopes enfatiza que Marx, em sua discussão sobre sujeito e objeto, ressalta que este não é algo fechado em si mesmo, mas sim o resultado da atividade humana criativa. Marx "não absorve o objeto de imediato ao sujeito. Mantém sempre uma tensão entre eles, um não anula o outro. Ao considerar que o objeto possui 
uma realidade própria, reconhece que ele é continuamente determinado e atuado pelo sujeito" (Lopes, 2000:124). O que não pode significar, entretanto, dar total primazia aos sujeitos e desconsiderar as limitações e as padronizações existentes, pois, como evidencia Sader (1988), o sujeito autônomo não é aquele livre de todas as determinações externas, isto seria pura criação voluntarista, mas aquele que é capaz de relembrar tais determinações em função do que deseja e de seus interesses.

As diversas realidades objetivas devem ser compreendidas como construções sociais resultantes de relações sociais que se objetivaram, sendo, ao mesmo tempo porque partem de um mesmo processo, exteriores aos atores sociais e fruto de suas práticas. Sendo assim, "apesar de a realidade aparecer estruturada, é exatamente com base nesta ordem que ela será continuamente reinterpretada e transformada. O homem capta a realidade e dela se apropria com todos os sentidos" (Lopes, 2000: 215). Assim, as diferenças entre sociedades ou momentos históricos devem ser vistas como resultado da interação entre grupos sociais que disputam a definição de limites, que arbitram as fronteiras em relação à realidade que vivem, seja em função de suas necessidades, interesses, conhecimentos, forças ou projetos de vida (Demazière, $1995 \mathrm{e}$ Maruani, 2000).

Quando se trata do tempo, este traz consigo uma imagem tão forte que é quase impossível reconhecer que o tempo não existe, que aquilo que denominamos tempo é conseqüência da atividade humana: "O tempo não é um dado, mas uma obra coletiva que possui a marca da sociedade que lhe dá vida e que lhe sustenta, estabelecendo hierarquias de valores" (Tabboni, 2006: 29). Ou, como salienta Sue, a noção de tempo constitui-se "de acordo com a consciência histórica dos atores sociais em um dado período. Apresentando-se como uma trama na aparência objetiva que organiza os fatos sociais, o tempo com isso nos revela, ao contrário, a natureza construída de um sistema de valores que ele exprime" (Sue:1994:85). Ao longo da história, paralelamente ao processo de transformação do tempo num dos elementos normativos mais fortes e poderosos, sua característica principal - ser um produto social - não foi evidenciada. Tabboni (2006) ressalta que, exatamente por isso, o tempo pode ser entendido como uma instituição. Afinal, a característica de toda a instituição socialmente eficaz é justamente ser vivenciada como se fosse dotada de uma realidade exterior ao indivíduo.

Grossin (1991), ao pensar as situações temporais vivenciadas cotidianamente como desagradáveis e até mesmo insuportáveis, se surpreende com a tolerância dos seres humanos a elas. Ele ressalta que um dos motivos para essa complacência é que as atitudes em relação às 
questões temporais partem de idéias correntes, aceitas e interiorizadas e que, ao não serem discutidas ou justificadas, fazem com que as evidências triunfem. Além disso, as situações vivenciadas pela maior parte das pessoas são entendidas como o destino normal de todos, de forma que as situações temporais mais freqüentes não são percebidas como construção social.

Finalmente, para Demazière (1995) e Maruani (2000), diante da dificuldade de compreensão dos fatos como construções sociais, adotar um olhar histórico possibilita verificar que a cada momento uma mesma realidade é definida de modos diferentes. Além disso, olhar o passado significa provocar rupturas no fluxo contínuo do tempo e possibilitar, ao mesmo tempo, o surgimento de outro projeto de civilização. Contrariamente, quanto mais focamos apenas no presente, mais temos a impressão de mesmice, inclusive projetando a mesma sensação para o futuro (Benjamin,1994). Entretanto, observamos, na sociedade atual, exatamente essa ênfase cada vez maior no presente, desconsiderando o passado e a história (Oliva Augusto, 1994 e Sennett, 2000).

Olhar para o passado significa a possibilidade de descobrir o novo, o diferente, não porque ele não exista no presente, mas por estar muitas vezes escondido. Greco Martins (2001) acentua, no que se refere à contradição existente nas relações de trabalho, que quanto mais o esquecimento dessa contradição vai ocorrendo, mais a relação de trabalho e o próprio trabalho acabam enviados ao campo da natureza e desvinculados das relações sociais e do seu processo histórico, de forma que a subordinação e a exploração passam a ser compreendidas como parte da natureza. Assim, o olhar retrospectivo possibilita o "reencontro de algo que ficou perdido, recalcado e escondido nos escombros da história, permite a identificação do esquecido e das contradições presentes nas relações sociais" (Greco Martins, 2001:19 e 21).

\section{2 - Os processos de construção social do tempo, do trabalho e do tempo dedicado ao trabalho}

Tendo como referência que a atual definição de tempo de trabalho e de não trabalho é resultado de um processo de construções e reconstruções sociais, o melhor caminho para compreender as transformações que estão ocorrendo na sociedade contemporânea é partir de um olhar que possibilite apreender como essas diferentes definições foram sendo construídas nos diversos momentos históricos.

Moscovici (2003) ressalta que quanto mais a origem de uma definição é esquecida e sua natureza convencional é ignorada, mais fossilizada ela se torna. Assim, se em alguns momentos ainda refletimos sobre o processo de construção do significado do trabalho, no que se refere ao 
tempo, sua origem é pouco questionada. De fato, apesar de todos viverem o tempo, cotidianamente, pouco se reflete sobre esta vivência. E é nessa lacuna, na ausência de uma reflexão crítica que precisamos entender como o tempo tornou-se uma representação simbólica de vasta rede de relações de caráter individual, social ou puramente físico, constituindo-se em um símbolo universal, praticamente inquestionável. Entender também como o tempo passou a exercer, sob a forma de calendários, relógios ou agendas, uma forte coerção que se prestou eminentemente a suscitar o desenvolvimento de uma autodisciplina nos indivíduos, e à qual parece impossível escapar (Elias,1984). Finalmente, como essa nova noção do tempo influenciou e foi influenciada pela nova noção de trabalho que, por sua vez, constituiu a noção de tempo de trabalho.

Para Whitrow (1993), a melhor maneira de compreender as diferentes percepções do tempo é colocá-lo em uma perspectiva temporal. Assim, diz o autor que o modo como o dia é dividido em horas, minutos e segundos é puramente convencional e arbitrário, não sendo essas noções inatas e nem automaticamente apreendidas, mas sim, resultantes da experiência e da ação dos homens. Enfatiza também que uma das características que mais distingue a sociedade contemporânea daquela de seus antepassados é a crescente consciência do tempo.

A partir dessa idéia, Whitrow faz uma análise histórica com a intenção de melhor conhecer o conceito de tempo, suas diferentes percepções e representações. Também se ocupa das várias representações que, ao longo da história, os homens tinham de si mesmos, de Deus, da Terra e de suas relações. Como resultado dessa análise, o autor encontrou diferentes construções sociais sobre a noção de tempo em cada momento histórico, tais como: tempo cíclico ou linear, no presente ou projetado para o futuro, estático ou dinâmico, lento ou acelerado.

Whitrow (1993) salienta que as mudanças ocorridas na noção de tempo, no sentido de um tempo cada vez mais preciso, uniforme e igual em todos os lugares, resultaram de diversas necessidades, conflitos, desenvolvimentos tecnológicos e visões de mundo que interagiram e se modificaram. Na Idade Média, por exemplo, a sociedade era muito mais estática e de natureza essencialmente hierárquica, sendo o conceito de evolução pouco presente. Assim, foi em função das observações dos astrônomos que a sociedade construiu medidores de tempo cada vez mais precisos. Também as necessidades dos mosteiros em relação à pontualidade e à disciplina, exerceram forte influência no sentido da medição do tempo. Desta forma, durante o século XIV já pode ser observada a multiplicação dos relógios mecânicos públicos na Europa, sendo que, no ano de 1335, eles já marcavam as horas de trabalho de operários têxteis. 
Durante a segunda metade do século XVII, chegou-se a uma grande precisão na medição maquinal do tempo em função da invenção do relógio mecânico, influenciando o próprio conceito de tempo, dado que este instrumento podia funcionar de modo uniforme e contínuo por diversos anos, reforçando a crença na homogeneidade e continuidade do tempo (Whitrow,1993). No século XVIII, denominado "século das luzes", vai-se construindo um espírito otimista fundado numa atitude prospectiva em relação ao tempo futuro e constituindo a noção de progresso humano. Diferentemente da concepção do século anterior, quando o tempo futuro era representado como algo destrutivo, neste, as pessoas passam a construir visões otimistas e voltadas para o devir, "não importa o que foi feito, o que nos cabe é ver o que pode ser feito" (Bacon, apud Whitrow, 1988),

Embora houvesse visões conflitantes e pessimistas, como as de Voltaire ou Rousseau, para Whitrow (1988), o período entre 1750 e 1900 é caracterizado como o de maior fé no progresso, estimulada, nos diferentes momentos, por Darwin, Comte e Marx. Também as idéias de Giambatista Vico exerceram grande influência neste período. Umas delas era a concepção de que, apesar da existência de traços comuns em diferentes momentos históricos, a história não era estritamente circular, já que novidades eram criadas a todo o momento, apesar de mantida a crença em certa circularidade. Outra reflexão importante foi a de que o homem só poderia ser compreendido historicamente, isto é, do ponto de vista do tempo, a partir de pesquisas sobre o passado, sobre a criação do homem, das instituições, das línguas, costumes ou leis.

De acordo com Oliva-Augusto (1994), entre o final do século XVIII e o início do XIX, foram duas as representações que fundamentaram a forma como a sociedade passou a ser vista pelos indivíduos. A primeira foi a crença na possibilidade de que um progresso sem limites, proporcionado pela ciência e tecnologia, levaria ao total domínio da natureza. A segunda foi a aposta na capacidade humana de criação, na liberdade, mais precisamente na busca do bem através da livre participação nos negócios e atividades públicas. Uma liberdade que ganha uma dimensão tanto individual quanto social.

Weber (1989) também nos fala sobre as mudanças ocorridas a partir do século XVII, em função de transformações nas representações sociais do homem, de Deus, da salvação, da Igreja e da própria sociedade. Mudanças que foram fortemente influenciadas pelo desenvolvimento das possibilidades técnicas, de uma administração cada vez mais racional, da existência de capitais, mas, sobretudo, pela nova "capacidade e disposição dos homens em adotar certos tipos de conduta racional" (Weber,1989:11). Em certos momentos e espaços, esta disposição foi restringida em 
função de obstáculos de ordem religiosa, e pouco se desenvolveu. Em contextos opostos, foi bastante incentivada, como no caso do protestantismo ascético, e rapidamente evoluiu. Nesse momento, o que passa a ser pregado não é um mero bom senso comercial - tempo é dinheiro; crédito é dinheiro; dinheiro pode gerar dinheiro - mas sim, um novo ethos. O trabalho adquire então, outro significado, é, para os protestantes “a única maneira de viver aceitável para Deus não estava na superação da moralidade secular (...) mas sim, no cumprimento da tarefa do século, imposta ao indivíduo pela sua posição no mundo. Nisso é que está sua vocação" (Weber,1989: 53).

E para aqueles que adotaram o protestantismo, a representação sobre o tempo foi muito modificada, passando a ser algo consumido, utilizado racionalmente e permanentemente, para se atingir, através do trabalho, a riqueza e o lucro, que passam a significar a salvação divina. Logo, "a perda de tempo é o primeiro e o principal de todos os pecados" e "de toda hora perdida no trabalho redunda uma perda de trabalho para a glorificação de Deus" (Weber, 1989:112). De forma que quase todo o tempo deve ser dedicado ao trabalho, até o tempo do sono deve ser limitado e o tempo dedicado ao esporte deve ter finalidade racional de restabelecer a eficiência do corpo para a continuidade do trabalho. Neste processo, são alteradas também as concepções de riqueza e lucro, onde a primeira passa a ser bem vista, tornando-se um problema apenas quando utilizada para o consumo, o descanso ou o relaxamento do trabalho. O lucro, por sua vez, passa a ser visto como um sinal de salvação.

Weber ressalta, entretanto, que mesmo nas cidades onde predominou a doutrina calvinista, houve muita resistência a uma nova visão do mundo por parte dos nobres, da Igreja e principalmente daqueles que viriam a constituir a classe trabalhadora. Demonstrando que para além dos conflitos entre países católicos e protestantes, também aconteceram conflitos entre os próprios protestantes, o que mostra que a reforma protestante e sua principal concepção - o trabalho como vocação - foi apropriada de forma diferente pelas diversas camadas sociais.

A nova idéia de um trabalho regular e contínuo entrava em conflito com a forma irregular como os trabalhadores tocavam suas vidas e seu trabalho, com períodos de intensa atividade e períodos de ociosidade, considerando os diversos feriados e festas religiosas. Além desse conflito havia outro relacionado à tentativa dos burgueses de transformar o artesão em trabalhador livre, passando a produzir não mais de acordo com a sua necessidade e de sua família, mas para o capital. Para Thompson (1967), a irregularidade no trabalho deve ser vista como conseqüência da representação social que os trabalhadores tinham da vida, onde o trabalho não ocupava um papel central. Assim, em função da emergência de novas representações sobre o tempo a ser 
dedicado ao trabalho, os detentores do capital se ocuparam em construir um novo pensamento, ou simplesmente obrigaram os trabalhadores a trabalharem todos os dias, de forma regular, no intuito de impedir o ócio. Para isso, várias foram as estratégias implementadas, tais como a invenção do trabalho fora do domicílio, a criação das fábricas, a introdução de máquinas, o pagamento de salários baixos, os diversos códigos de conduta, as multas, o controle rígido dos horários dentro e fora do local de trabalho e, até mesmo, o surgimento do relógio de ponto. Como parte do mesmo processo, também foram muitas as ações dos trabalhadores para se contraporem a estas mudanças. Consequentemente, como mostra Thompson (1967), a transição foi demorada e carregada de muitos conflitos.

A remuneração por tarefa e o pagamento de salários baixos foram amplamente utilizados para obrigar os trabalhadores a trabalharem mais. Weber ressalta, entretanto, que o pagamento de salários baixos tinha certos limites, pois o que os burgueses precisavam era de um trabalho executado como um "fim absoluto em si mesmo, como uma vocação" (Weber, 1989:39). Tal atitude, no entanto, não era um produto da natureza e também não era provocada apenas por baixos ou elevados salários, mas somente poderia ser atingida por meio de um longo processo de educação. Isto porque, para os trabalhadores, a oportunidade de ganhar mais era menos atrativa do que trabalhar menos, dado que trabalhavam em função de suas necessidades e não para enriquecer ou poupar: "O homem não deseja por natureza ganhar cada vez mais dinheiro, mas simplesmente viver como estava acostumado a viver, e ganhar o necessário para este fim" (idem: 38).

Como os burgueses queriam empregar um número cada vez maior de trabalhadores que trabalhassem cada vez mais, eles passaram a se preocupar com a administração eficiente do tempo, abrangendo todos os aspectos da vida e não apenas o que se refere à relação trabalhocapital. Como já salientado por Weber (1989) e Whitrow (1988), foi sendo construída uma relação forte entre preguiça e pobreza, e entre trabalho e riqueza:

“... se o preguiçoso esconde as mãos no colo, em vez de aplicá-las ao trabalho, se ele gasta o tempo com passeios, prejudica a sua constituição pela preguiça, e entorpece seu espírito pela indolência [...], então, ele só pode esperar a pobreza como recompensa" (Conselho amigável aos pobres, 1755, apud Thompson, 1967: 292).

Não apenas as leis e o discurso, mas também a escola, conforme Thompson (1967), muito contribuíram para essa mudança de hábitos e a construção de novas representações sociais 
em relação ao ser humano, ao tempo e ao trabalho. Seu papel foi o de ensinar às crianças sobre o trabalho, a ordem, a regularidade e a disciplina, pois cedo estas deveriam desenvolver esses novos hábitos, onde o trabalho passaria a ocupar um tempo e um espaço cada vez maior.

A crescente substituição da doutrina puritana, que pregava o enriquecimento com o objetivo da poupança e do seu reinvestimento, por um pensamento que enfatizou cada vez mais o consumo, também contribuiu definitivamente para a ênfase na centralidade do trabalho. Conforme Hobsbawm $\left(2000^{\mathrm{a}}\right)$, já em meados do século XIX, os economistas começaram a sugerir teorias defendendo salários acima do nível da sobrevivência, para que os trabalhadores também pudessem se tornar consumidores. A sociedade de consumo teve seu momento de destaque quando Henry Ford decidiu produzir carros padronizados, e principalmente baratos, aumentando, ao mesmo tempo, a remuneração dos trabalhadores com o objetivo de incentiválos a dedicarem cada vez mais tempo de suas vidas ao trabalho e a orientarem parte de seus ganhos para o consumo de carros produzidos por eles próprios.

De acordo com Méda (1999), a partir do século XVIII, além do fim da condenação ao enriquecimento, surgem investigações, ensaios e teorias buscando descobrir como gerar mais riquezas, sendo que o trabalho, quase ausente em obras anteriores, torna-se onipresente. Adam Smith (1991, In Méda, 1999) traz o trabalho para o centro das atenções ao dizer que a riqueza de uma nação depende exclusivamente de sua habilidade no trabalho e da proporção entre o número de trabalhadores úteis e inúteis. Naquele momento, a representação do trabalho sofre uma nova mudança e o trabalho passa a ser visto como fator de criação de valor.

Com isso, o trabalho adquire novo significado. Por um lado, passa a ser definido como dispêndio de força física no processo de transformação material da natureza, e por outro, como uma "substância homogênea idêntica em todos os tempos e todos os lugares, e infinitamente divisível em unidades quantitativas" (Méda, 1999: 60). O objetivo dessa construção teórica é resolver a questão de como os objetos poderiam ser trocados. Para isso, de acordo com a autora, os economistas construíram o conceito de trabalho dando-lhe um significado homogêneo, tendo em sua essência, o tempo. "O trabalho não é, portanto, simplesmente como o tempo, é o tempo, esta é a sua matéria prima, o seu constituinte último" (idem: 66). O trabalho passa então a ser uma categoria econômica, a ter preço e a ser susceptível de se tornar ele próprio objeto de uma troca (Méda, 1999). Por outro lado, se transforma também no "símbolo da autonomia individual", na medida que graças a ele os indivíduos se tornam capazes, pelo exercício de suas próprias faculdades, de satisfazer suas necessidades. 
O trabalho surge então como contribuição para o progresso da humanidade, fundamento do laço social, e como fonte de realização e equilíbrio pessoais, tornando o seu exercício a condição principal de conservação da vida, de modo que o reconhecimento de direito à vida passa pela garantia do livre exercício do trabalho, isto é, o direito à vida confunde-se com o direito ao meio de ganhar a vida.

\section{3 - A cultura temporal das sociedades industriais: o tempo de trabalho como tempo único}

$\mathrm{Na}$ discussão anterior, vimos como foi se constituindo uma nova cultura temporal que, nas sociedades industriais, tem como característica principal a ênfase no tempo abstrato e na definição do tempo de trabalho como tempo único, como veremos de forma mais detalhada neste tópico. Essa análise, por sua vez, apontará elementos para a melhor compreensão da construção temporal nas sociedades contemporâneas.

Uma das características da nova cultura temporal desenvolvida nas sociedades capitalistas foi o crescente valor dado à ciência e à construção de uma nova leitura da relação entre o tempo passado, o presente e o futuro, a partir das concepções de linearidade, continuidade e acúmulo. Mas, a principal inovação está na compreensão da história como evolução, sendo este fundamento ideológico indispensável para as sociedades industriais que passaram a olhar o passado medindo o seu atraso e a ver o futuro como um campo de possibilidades inesgotáveis. Como escreve Elias (1998), o foco da atenção se desloca da concretude do presente para a dimensão do futuro, não passível de experiência direta.

As sociedades industriais têm, cada vez mais, o tempo do relógio como referência principal, um tempo preciso, abstrato, vazio de conteúdo, independente de qualquer evento, fracionado, mensurável e universal. Essa temporalidade mecânica do relógio se expande para os diversos espaços e tempos da vida cotidiana, de forma que a atitude instrumental que consiste em considerar o tempo como um recurso raro não se destinou a limitar e orientar apenas o espaço e o tempo de trabalho industrial. Para Mercure (1995), esse tempo mecânico pode ser considerado um dos símbolos mais marcantes da distância cada vez maior entre o homem e a natureza.

Neste sentido, a sociedade passa a lidar com o tempo da mesma forma como lida com o dinheiro, atribuindo a ele também qualidades objetivas e impessoais, como por exemplo, a escassez. Como conseqüência, o tempo pode ser utilizado, pode ser gasto ou rentabilizado. Para 
Tabboni (2006) a equação "tempo igual a dinheiro" é o símbolo mais forte do tempo totalmente transformado em mercadoria, reduzido a uma coisa e totalmente racionalizado. E como conseqüência, o tempo das experiências, das interações afetivas e pessoais e das relações familiares, situadas no lado oposto das práticas geradas pelo dinheiro, perdem sua importância. Simultaneamente, esses tempos acabam sendo igualmente controlados e estimados em termos quantitativos, pois o tempo que não é traduzido em dinheiro não recebe consideração social (caso emblemático do trabalho doméstico realizado gratuitamente na esfera não mercantil) ou ainda passa a ser considerado como um tempo perdido. Assim, o tempo da experiência é substituído pelo tempo estandardizado no qual uma hora representa uma duração do tempo mensurável pelo relógio, qualquer que seja a situação da vida humana. Por exemplo, aqueles que trabalham mais tempo do que o horário de trabalho convencionado recebem "horas de liberdade" e dias de férias a mais, como se esses tempos fossem equivalentes, isto é, como se o trabalho a mais num domingo tivesse o mesmo valor, do ponto de vista do tempo vivido, que a mesma quantidade de horas trabalhadas a menos num dia da semana, quando a família está ausente (Tabboni, 2006: 93).

Além disso, o trabalho industrial vai impondo uma nova disciplina temporal e espacial através da progressiva e agressiva separação entre o tempo/espaço de trabalho e tempo/espaço de não trabalho, isto é, entre produção e reprodução (Hobsbawm, 2000a). Alguns autores como Zerubavel (1985) e Giddens (1989), baseados em Weber, frisam que essa separação foi um fator determinante para o processo de racionalização das atividades produtivas. Nesse processo de separação, cada vez mais, apenas o trabalho contido no espaço da produção e no tempo da jornada passa a ser remunerado pelos capitalistas (Cattani, 1997).

Trata-se de um processo onde o trabalho remunerado, fechado em um espaço preciso e tendo uma duração determinada, que no início ocupava boa parte das 24 horas, foi introduzindo rupturas entre "o tempo de trabalho apropriado por outros e o tempo fora do trabalho" (Tabboni, 2006: 32). O tempo de trabalho ocupa de modo tão efetivo o lugar central a ponto de ocultar a possibilidade de se perceber outras temporalidades. Essa limitação do trabalho à esfera das instituições produtoras, bem como quase que exclusivamente ao universo masculino, impediu a compreensão do trabalho doméstico como trabalho, pois o tempo de trabalho fora concebido como o tempo de trabalho industrial e masculino (Hirata, 1986, Zarifian, 2001 e Terssac e Tremblay, 2000). E mais do que isso, o espaço doméstico deixa de ser valorizado pela sociedade e tem dificuldade para alçar à condição de objeto da análise sociológica. 
Dentro do espaço fechado das fábricas, a crescente divisão das tarefas (exigindo cálculos exatos dos tempos de trabalho e a coordenação precisa entre elas), a utilização da mão de obra assalariada, a mecanização do trabalho manual, a adoção de minuciosos estudos dos tempos e ritmos de trabalho, conduziram, pouco a pouco à uniformização da medida do valor trabalho. De forma que o valor de um bem passa a ser medido pela quantidade de trabalho necessária à sua produção, e a duração do trabalho torna-se a medida, por excelência, da quantidade de trabalho. A própria divisão das tarefas estava relacionada à economia do tempo, uma vez que ela implicava a especialização em uma pequena parte do trabalho, permitindo uma diminuição drástica do tempo de trabalho necessário para cada tarefa. Essas inovações que levaram ao cálculo do tempo e da produtividade máxima, conseguiram definitivamente estabelecer a medida temporal de cada gesto. Assim, a linha de montagem (e, posterior no tempo, a ferramenta de controle numérico), onde a máquina já contém o tempo que o trabalhador deve utilizar em seu trabalho, constitui a inovação tecnológica mais explícita e mais representativa de todos os aspectos mais penosos do trabalho humano nas sociedades industrialmente desenvolvidas (Tabboni, 2006). O trabalho na linha faz com que o trabalhador perca quase que totalmente sua autonomia em relação ao tempo e ao próprio trabalho.

É um processo em que, desde o início da revolução industrial, o tempo aparece como um dos principais objetos de disputa entre capitalistas e trabalhadores, entre aqueles que buscam implantar uma nova concepção de tempo, de trabalho e de tempo de trabalho e aqueles que tentam resistir. Para os trabalhadores não foi apenas a duração do trabalho que lhes foi imposta, mas também, o ritmo e os processos em si, as atividades metodicamente planificadas, transformando o tempo de trabalho em um conjunto de tarefas repetitivas (Mercure, 1995). Assim, pretende-se eliminar os tempos próprios dos trabalhadores, substituindo-os apenas pelo tempo imposto pela mecanização: "o trabalhador se esvazia do seu próprio tempo" (Grossin, 1991:28).

Do ponto de vista coletivo, se no início os trabalhadores lutaram contra a imposição de um novo tipo de trabalho, de um novo tempo a ser dedicado ao trabalho, ao longo da história vêse que essa nova cultura temporal, aos poucos, acaba fazendo parte de toda a sociedade.

“(...) a primeira geração de trabalhadores aprendeu com seus mestres a importância do tempo; a segunda formou comitês em prol de menos tempo de trabalho no movimento pela jornada de 10 horas; a terceira fez greves pelo pagamento de adicional para as horas extras. Eles tinham aceitado 
as categorias de seus empregadores e aprendido a revidar os golpes dentro desses preceitos, apreendendo muito bem a sua lição, a de que tempo é dinheiro" (Thompson, 1967:294).

De forma que, se num primeiro momento a construção social do valor trabalho fora imposta pelos detentores de capital, pela religião ou pelo Estado, aos poucos se transformou em algo compartilhado por quase toda a sociedade. Faz-se irresistível a lembrança de Paul Lafargue em "O Direito à Preguiça", de 1880, editado na contramão daquele momento histórico que enaltecia a separação entre economia e sociedade e proclamava o direito ao trabalho. Lafargue fala sobre a paixão pelo trabalho diante da observação de que os próprios trabalhadores estavam dominados pelo vício do trabalho e que nada iria convencê-los a abandoná-lo. Então, uma solução possível, isto é, aceita pelos próprios trabalhadores, seria a redução drástica na duração do trabalho ao invés da luta pelo fim do trabalho (Lafargue, 1999). Também, como sublinha Harvey (1989:211), “os trabalhadores e seus representantes aprenderam a reagir dentro dos limites do sentido recém-internalizado de tempo". E isto não significa que coletivamente os trabalhadores não continuem a ter como foco o tempo de trabalho, pois os processos de construções sociais se dão justamente a partir desses embates, mas a questão é saber qual o aspecto do tempo, do trabalho e do tempo de trabalho tem sido questionado.

Assim, vemos que o tempo, definido como neutro, como objetivação econômica e como forma social de dominação, tanto mais forte quanto mais impessoal, e que se coloca fora de toda e qualquer interação social, tem em seu coração o trabalho assalariado, apesar de invadir o conjunto do tempo da vida (Zarifian, 2001). Entretanto, diversos autores fazem questão de explicitar que mesmo que a sociedade busque adotar as características do tempo abstrato para todos os tempos sociais, e mesmo que o tempo de trabalho tenha ocupado um espaço cada vez maior nessas sociedades, nenhuma sociedade jamais teve uma uniformidade temporal completa e jamais teve uma concepção única do tempo (Grossin,1974). Porque em todas coexistem grupos e indivíduos que vivenciam experiências e situações temporais heterogêneas, mesmo que em cada sociedade possamos observar um tempo preponderante. Assim, em nossa sociedade capitalista, o tempo de trabalho pode ser dominante mas não é exclusivo, nem do ponto de vista quantitativo e nem do qualitativo (Sue, 1994). O que nos coloca a necessidade de olhar para os outros tempos sociais e para a forma como os sujeitos vivenciam cotidianamente esses diversos tempos. 


\section{4 - Vivências temporais cotidianas}

Abordar a construção social do tempo, nos diferentes momentos históricos, permitiu explicitar alguns elementos que serão discutidos do ponto de vista teórico e que balizaram a elaboração e a análise de meu trabalho de campo. A primeira consideração é de que o tempo linear, mensurável, calculável, jamais invadiu completamente a vida cotidiana e, quanto mais o tempo de trabalho é reduzido, mais isso é verdadeiro e explícito (Sue, 1994 e Mercure, 1995). Assim, mesmo que as sociedades, nos diversos momentos históricos, tenham construído um tempo dominante que buscou impor suas características aos outros tempos sociais, a multiplicidade desses tempos nunca foi reduzida ao tempo dominante. Aliás, a própria dinâmica social se nutre desse conflito entre os diversos tempos sociais, resultando em culturas temporais diferentes, em cada sociedade e em cada momento histórico (Sue, 1994). Por esse motivo Grossin (1974) faz questão de ressaltar que o reconhecimento de uma multiplicidade de tempos sociais constitui o fundamento da análise sociológica sobre o tempo. Disso resulta que, ainda quando a análise focaliza um tempo específico, como é o meu caso, com respeito ao tempo de trabalho, para melhor compreendê-lo é necessário refletir sobre os outros tempos sociais e, sobretudo, suas inter-relações.

Mais ainda, se adoto a perspectiva da não existência de um único tempo, abre-se a possibilidade de apreender essa pluralidade de tempos sociais e suas inter-relações a partir dos sujeitos. Afinal, como salientam Mercure (1995) e Zarifian (2001), o tempo é antes de tudo uma experiência subjetiva, antes mesmo de se constituir uma medida de duração ou um objeto de reflexão. E são essas vivências cotidianas que não se deixam representar por uma sucessão linear e sim por uma trajetória histórica do tempo (Bicudo, 2003). Por sua vez, ao pensar tal experiência a partir dos sujeitos chego à conclusão de que existem tempos de trabalho, tempos da família ou tempos de lazer, já que cada sujeito, cada grupo social, cada sociedade, em cada momento histórico, irá vivenciar um mesmo tempo de maneiras muito diferentes. Isto é, se o objetivo é ir além do tempo que se coloca como dominante, então, temos que analisá-lo a partir das vivências cotidianas.

Em vista disso, os três princípios balizadores que irão direcionar minha análise são: a) o tempo é uma construção social - o que me leva a falar em construções temporais que resultam em culturas temporais diferentes, a depender, portanto, da sociedade e do momento histórico; b) existe uma multiplicidade de tempos sociais, mesmo que em cada cultura temporal haja um 
tempo dominante; c) a apreensão dessa multiplicidade temporal é feita, sobretudo, a partir da análise dos sujeitos, isto é, de vivências, experiências e representações temporais cotidianas.

Diversos autores ressaltam a necessidade de uma análise temporal que parta dos sujeitos e, para tanto, lançam mão de diferentes conceituações para contrapor o tempo abstrato e o tempo real dos sujeitos: o "temps spatialisé" e a "durée" (Zarifian, 2001), o "Chronos" e o "Kairos" (Bessin, 1998 e 2000), as temporalidades macro e microssociais (Gurvitch, 1963), Bicudo (2003). Outros pensadores como Thompson (1967) e Dubet (1994), a partir da noção de experiência, e Linhart (2005), com a concepção de subjetividade, também se mostraram influentes no modo pelo qual defini o meu objeto de estudo e construí o meu trabalho de pesquisa empírica.

Mas, nesta tese, o centro de gravidade principal para a minha análise advém do arcabouço teórico elaborado por Grossin (1974 e 1991), um dos pioneiros no estudo dos tempos sociais ${ }^{1}$, que dedicou sua obra à discussão das vivências temporais cotidianas (Gadéa e Lallement, 2000 e Maillard, 2006). Dentre as categorias que propõe destaco as de "enquadramento temporal", "meio temporal" e "cultura temporal" possibilita a análise das sociedades do ponto de vista das suas características temporais, por exemplo, a cultura temporal da sociedade industrializada ou a cultura temporal da sociedade francesa. Pois, ressalta Grossin (1991), apesar de termos, em cada momento histórico, uma cultura temporal predominante, cada sociedade específica irá construir a sua cultura, contendo elementos universais mas também particulares. O conceito de meio temporal é construído pelo autor em contraposição ao de enquadramento temporal ${ }^{3}$. O meio temporal comporta vários tempos complementares, dependentes e permeáveis a outros tempos, como exemplo, o meio temporal urbano, ou o próprio tempo biológico do corpo do homem.

O enquadramento temporal, diferentemente do meio temporal, se caracteriza como um único tempo, sendo assim bem mais circunscrito. Para Grossin (1991), cada tempo, fechado e

1. Na língua francesa a palavra tempo se escreve com "s"- temps - e o que diferencia o singular do plural é a utilização do artigo. Grossin (1991) nos conta que muitas vezes quando escrevia um artigo e utilizava o plural "les temps" os corretores alteravam para o singular "le temps", tão forte era a noção da existência de um único tempo social.

2. Os termos em francês, utilizados pelo autor são: cadre temporele, milieu temporel e culture temporelle (Grossin, 1991).

3. O autor faz questão de explicitar as diferenças entre o meio temporal e o enquandramento temporal, definindo as seguintes características: o enquadramento temporal, entendido como rígido, imposto, redutor, unicista, fechado, regular e reiterado, construído a partir da medida do relógio; e o meio temporal, caracterizado como flexível, livre, plural, aberto, modificável, sem relação estreita com o tempo cronológico. 
limitado, forma um enquadramento temporal, contendo características próprias. Há os enquadramentos temporais que são naturais (o tempo biológico), os sociais, que são a grande parte dos tempos; alguns são coletivos e outros pessoais; alguns enquadramentos temporais são mais ativos (o tempo de jogar bola) e outros mais passivos (assistir alguém jogar bola); existem os mais estruturados (o tempo da escola e do trabalho) e os menos estruturados; há ainda aqueles que são obrigados e os escolhidos. Enfim, há uma diversidade enorme e, justamente por terem características tão diferentes, acabam por causar dificuldade para a vivência dos sujeitos que lidam com todos esses enquadramentos temporais e buscam harmonizá-los. Na realidade, para o autor, esses diferentes tempos podem ser justapostos, sobrepostos, interpenetrados e hierarquizados, mas dificilmente, e cada vez menos, harmonizados.

O tempo de trabalho, por exemplo, de acordo com Grossin (1991) tem como características principais a rigidez - em virtude da qual qualquer atraso é castigado e se exige a pontualidade, dado que o trabalho é pago por hora; a coerção, pois é o capitalista que decide o horário do trabalho; a regularidade, desaparecendo as variações de estação, da hora do dia, de saúde do trabalhador e a reiteração. O enquadramento do tempo de trabalho delimita ainda um tempo restrito e cerceado. É estruturado de forma que os tempos próprios dos trabalhadores sejam eliminados e substituídos por tempos impostos. Ele é coletivo, ativo, fracionado e mecanizado, caracterizando-se ainda pela concentração que busca eliminar pausas e dimensionar as paradas em função das tarefas e ritmos. Esse tempo imposto pelos detentores do capital procura dominar os outros tempos que os trabalhadores tentam inserir e reinserir dentro e fora do local de trabalho, resultando em disputas explícitas e implícitas, coletivas e individuais, pontuais ou estruturais, negociadas ou não. Como veremos de forma muito clara tanto na análise dos processos de negociação do tempo de trabalho no Brasil e na França, como ao me fixar no entendimento das vivências temporais cotidianas de trabalhadores em um determinado local de trabalho, no caso da Volkswagen do Brasil.

Na história das relações capital e trabalho, ao longo dos últimos séculos, as disputas em torno do tempo de trabalho são as mais freqüentes e, também, de um modo geral, as mais sangrentas. Esses conflitos se dão justamente porque o trabalho assalariado consiste na utilização, pelo empregador, entre outros elementos, do tempo dos trabalhadores em troca de uma remuneração. Desta forma, se o tempo, no momento que antecede à produção, pertence ao trabalhador, ao ser vendido por certo período ao empregador, este passa a ter o direito de utilizálo da forma que lhe convier, guardados, é claro, os limites da legislação, do poder dos trabalhadores 
e de seus representantes (Marx, 1985). Para Linhart (2005) o conflito que tem, de um lado, a busca da máxima objetivação pela empresa; e, do outro, os trabalhadores procurando se reapropriar subjetivamente desse tempo, é permanente. Justamente porque esse conflito tem uma contradição em sua gênese: o empregador compra algo de que ele não pode se apropriar totalmente, pois tanto o tempo como as capacidades físicas ou psicológicas não podem ser dissociadas do trabalhador. Daí a permanente e cotidiana mobilização e pressão por parte da empresa, seja física ou psicológica, buscando a máxima objetivação do tempo e da capacidade dos trabalhadores. Para estes, a tentativa de desassociá-los de seu tempo e de seus gestos de trabalho é fonte de muitos sofrimentos, frustrações e conflitos, afinal é muito difícil renunciar a dimensões que os constituem como sujeitos (Linhart, 2005).

Analisar as formas como os trabalhadores vivenciam o tempo de trabalho, como recusam um tempo imposto ou ainda como essa vivência do tempo do trabalho produtivo influencia a experiência de outros tempos sociais, me leva à noção de temporalidades sociais (Grossin, 1974 e 1991). Esta noção expressa a multiplicidade de tempos vivenciados ligada à diversidade de situações sociais e permite desvendar a ilusão da uniformidade do tempo. O que supõe relacionar as diversas atividades, tarefas, experiências, representações, concepções, percepções e simbologias sobre o tempo, isto é, as diferentes maneiras de tomar consciência do tempo. Assim, o autor explicita os conflitos vivenciados pelos indivíduos que, a cada momento, estão expostos a tempos qualitativamente muito diferentes, produzindo efeitos perturbadores. Para Grossin (1974), a vida cotidiana de cada um compõe uma multiplicidade de tempos diferentes o que confere a necessidade constante de ajustamentos entre esses tempos sociais. Os sujeitos implementam equações temporais (Grossin,1991) para dar conta dessa diversidade, tanto do ponto de vista quantitativo - encaixar essa diversidade nas 24 horas - como qualitativo, no sentido de harmonizar as vivências em tempos com características diferentes.

Grossin (1974), aponta, igualmente, para a existência de diversas temporalidades entre os grupos de idade, gênero, situações profissionais ou familiares, explicitando os problemas, as contradições e os conflitos latentes e que podem vir a surgir. Isso porque, entre esses grupos há diferenças de ritmo, de tipos de atividade, de posições e expectativas em relação ao futuro, de interpretações em relação ao passado, entre outros. Essas diferenças em relação aos modos de vivenciar e representar os tempos presente, passado e futuro podem, igualmente, ser fontes de diversas tensões. $\mathrm{O}$ autor se questiona ainda sobre as temporalidades particulares das diversas instâncias sociais numa mesma sociedade ou de uma mesma instituição nos diversos tempos. 
Ele ressalta os conflitos que aparecem em relação às distorções temporais nas esferas da vida social, econômica, técnica, religiosa, política e pessoal. Nas sociedades industriais, por exemplo, o ritmo de inovação tecnológica difere muito do ritmo das mudanças de mentalidade moral ou da representação religiosa. Ao mesmo tempo, o autor questiona o papel que se deve atribuir a cada uma das instâncias sociais na construção temporal de uma sociedade, num determinado momento histórico.

Assim, serão as vivências temporais cotidianas e as representações que sobre as mesmas são construídas, que constituirão o foco da minha análise. Vivências e experiências apreendidas nos discursos dos sujeitos, pois, de acordo com Thompson (1967), em sua discussão sobre a experiência, são as falas dos sujeitos que revelam as suas experiências do cotidiano. Nas narrativas discursivas, as vivências aparecem com o significado atribuído pelo próprio sujeito, isto é, o sujeito se expressa e confere significados às experiências que compõem sua vida e seu cotidiano. É no cotidiano que se instituem formas de agir que fazem parte do dia a dia dos sujeitos, nele se estabelecem as relações com o trabalho, o bairro, as atividades de lazer, entre outras. Esse cotidiano, de acordo com Sader (1988), é um espaço da articulação temporal, histórica e espacial das formas de vivenciar e experimentar as situações objetivas. No cotidiano "articulam-se diferentes representações sobre as experiências vividas que têm sua tradução nos conteúdos simbólicos do discurso e nas práticas decorrentes” (Tittoni, 1994:31).

Os sujeitos atuam em função de suas experiências e igualmente das representações que constroem do mundo, considerando o ato de representar como parte dos processos de construção e de reconstrução da sociedade. É por intermédio da representação (Moscovici, 2003) que os sujeitos revelam seu modo particular de vivenciar, experimentar e elaborar suas relações objetivas. O que significa dizer que as diferentes histórias de vida dos sujeitos são construídas a partir das diferentes vivências/experiências e representações que têm do real, de forma que o sujeito fala não dos fatos em si, mas da representação que tem dos fatos.

Vivências, experiências, representações formam o que podemos chamar de subjetividade dos sujeitos, de maneira que, analisá-las significa buscar compreender os motivos (desejos, idéias, interesses, sonhos, paixões, expectativas, experiências) que levam os sujeitos à ação. Logo a subjetividade é ao mesmo tempo individual e socialmente construída, é determinada e determinante das resignificações e dos sentidos da ação, ao mesmo tempo em que é instituída e instituinte dessas resignificações. Ela é definida pela dinâmica existente entre a biografia e a história, mediada pela noção de experiência que, de acordo com Thompson (1967), relaciona-se 
à dinâmica de conflitos, contradições e estranhamentos através dos quais se constroem as condições de desenvolvimento tanto da biografia quanto da história. A subjetividade é ao mesmo tempo "constituída pelos elementos de ordem particular relativos à biografia de cada indivíduo e pelo conjunto das relações sociais gerais presentes na história" (Lopes, 2000:15). De acordo com Lopes, o dado biográfico nunca tem um conteúdo somente pessoal, mas tem pontos que o relacionam à comunidade local e à sociedade mais ampla. O que significa dizer que "a construção subjetiva do mundo é pensada através de vínculos que o indivíduo estabelece com o estoque cultural da sua época", havendo uma estreita relação entre a representação social e as condições concretas de existência (idem: 70).

Será a partir da análise da subjetividade - das vivências, experiências e representações que poderei encontrar também o particular, o específico e o fragmento. Mas isto não significa dizer que só encontrarei o novo, a criação e a invenção, em contraste com o tempo único. Pois, como salienta Zarifian (2001), em sua discussão sobre a duração do tempo, entendida como o tempo concreto onde se realiza a ação e a transformação, tal duração comporta tanto a conservação como a novidade. Entretanto, conservação, neste caso, não tem o significado de repetição ou reprodução. Para os sujeitos da ação, a duração é o momento de criação, considerando sua determinação por uma força social, de forma que a duração se inscreve entre persistência e invenção, logo, a questão principal para o autor é como considerar conjuntamente essas duas características.

Finalmente, como salienta Grossin (1974), mesmo que as sociedades industriais tenham buscado construir a predominância do tempo da produção, é justamente a existência de tempos pessoalmente construídos que protegem os indivíduos da dominação excessiva dos tempos que lhes são exteriores. Uma exterioridade diante de sujeitos individuais e não em relação às relações sociais. A seguir, discutirei a cultura temporal nas sociedades contemporâneas, tendo como foco principal o tempo de trabalho.

\section{5 - A cultura temporal das sociedades contemporâneas: tempos de trabalho tensos, urgentes, intensos e flexíveis}

Retomo as questões pelas quais iniciei este capítulo, isto é, a construção temporal nas sociedades contemporâneas, para aprofundá-las. Essa construção tem como características principais tempos urgentes, tensos, intensos, flexíveis e incertos o que é muito diferente de outros momentos históricos, como já foi discutido ao longo deste capítulo. 
No tempo presente, as sociedades se caracterizam por um ritmo acelerado de renovação das relações que os seres humanos constroem entre si, com as coisas, os lugares, as organizações, enfim, com a vida. A aceleração do tempo faz com que os intervalos sejam cada vez mais breves, sendo que essa experiência cotidiana engloba todos e se dá nos diferentes espaços sociais. E se a experiência humana do tempo engloba tanto a mudança como a continuidade, é a mudança que tem sido a regra principal nas sociedades contemporâneas (Mercure:1995 e Chesneaux, 1996). Mudam-se as relações com o tempo presente e também com o tempo futuro, pois, de acordo com Chesneaux (1996), as próprias pressões do imediato acabam por ameaçar a capacidade das sociedades pensarem o futuro. Isso faz com que, enquanto a rapidez e a intensidade das mudanças aumentam continuamente, os horizontes temporais se restrinjam cada vez mais. E se antes o futuro era colocado como um tempo melhor, com possibilidades amplas, as críticas contemporâneas à modernidade têm como foco a incapacidade deste futuro cumprir todas as suas promessas construídas em torno da sua representação. Multiplicam-se assim a incerteza e a dificuldade de projetar o devir.

Sue (1994) ressalta que há uma hiper-valorização do presente, por oposição à modernidade que foi orientada no sentido do futuro e por oposição ainda à sociedade tradicional, orientada para o passado. Isto porque, se não há longo prazo (Sennet, 2000) e o futuro é incerto, mais do que nunca o "agora" ganha o estatuto do tempo absoluto, "o que exaspera a necessidade de consumi-lo exaustivamente. Ganhar tempo e não perdê-lo tornou-se uma obsessão das pessoas: elas são esmagadas pelos ritmos e pelos programas que se lhes impõem através de todas as malhas sociais, tanto no trabalho como fora deste" (Oliva Augusto, 1994:98). Tudo é pensado em função do tempo e são diversas as estratégias sociais e individuais para economizar o tempo. E como a duração do dia continua sendo de 24 horas, aceitam-se cada vez mais atividades simultâneas que permitem, ao preço de considerável tensão física e psicológica, multiplicar a quantidade de tempo que cada um dispõe. "A vida se resume cada vez mais a uma corrida contra o relógio" (idem), e a qualidade mais exaltada é a capacidade de ser rápido, de conseguir fazer mais coisas ao mesmo tempo ou então a mesma coisa num tempo cada vez mais curto. Vive-se assim, sob uma forte pressão temporal; o que leva Sue (1994) a se perguntar como podemos falar em autonomia do homem se este não consegue nem controlar o seu próprio tempo.

Nas sociedades contemporâneas, a estandardização, a sincronização ou ainda a separação clara entre tempo livre e tempo de trabalho, estão desaparecendo. Também a aparente 
uniformidade do tempo individual de trabalho cede, lentamente, lugar para uma grande diversificação de tempos de trabalho. De forma que o movimento histórico de separação entre o tempo de trabalho e o tempo de não trabalho, estaria sendo substituído por um movimento contrário, de reaproximação entre os dois tempos (Zarifian, 1996). O autor salienta ainda que o tempo de trabalho, desenvolvido no local de trabalho, passa a se organizar tendo como modelo o modo de viver o tempo de trabalho doméstico. Ou seja, um tempo caracterizado pela ausência de limites, de contabilidades, a partir de um controle muito mais interiorizado, indireto e impessoal. Estas características do trabalho doméstico estariam cada vez mais presentes no tempo de trabalho remunerado.

Entre as mudanças que assistimos na construção temporal atual, uma outra merece destaque: os itinerários pessoais e profissionais, no caso das sociedades que conseguiram incorporar uma parte da população ao mercado de trabalho, cada vez menos se compõem por etapas sucessivas, mais ou menos imutáveis e amplamente previsíveis. Ao contrário, os itinerários são cada vez mais diversificados, descontínuos e imprevisíveis (Bessin, 2000). Para Sue (1994), a antiga sucessão de tempos sociais é substituída por sua interpenetração, onde as referências ficam cada vez mais fluídas.

As transformações mencionadas anteriormente explicitam que o trabalho não se resume ao local de trabalho. Primeiro porque ele nunca se resumiu, como foi ressaltado nas discussões sobre o trabalho doméstico; mas também devido a um movimento do trabalho remunerado que extrapola o local de trabalho. Entretanto, vemos que o tempo de trabalho passou a ser considerado apenas como aquele restrito ao local de trabalho, contratado e remunerado (Guedj e Vindt, 1997), como se todo o tempo para além deste fosse um tempo de não trabalho. Socialmente esta construção ganha maior visibilidade quando as metodologias de cálculo da duração anual efetiva de trabalho envolvem uma estimativa da duração média do trabalho, levando-se em conta apenas o absenteísmo, os períodos de greve, os feriados, dias de descanso, férias anuais e horas extras individuais (Cette e Taddéi, 1997 e Fracalanza, 2001).

Dal Rosso (1996), parece, num primeiro momento, ampliar o conceito de tempo de trabalho para além do local de trabalho, do contratado e do remunerado, quando define esse tempo como aquele ocupado pelos sujeitos com atividades que visem produzir sua subsistência. E define como tempo de não trabalho aquele que "exprime os momentos da vida das pessoas que não estão sujeitos às atividades necessárias à preservação da sobrevivência” (Dal Rosso, 1996:26). Entretanto, ao igualar esse último ao tempo fora da jornada de trabalho, novamente 
ele identifica todo o tempo de trabalho ao tempo restrito em uma jornada de trabalho, como se o tempo fora desta não fosse utilizado também para produzir subsistência.

Mas, além da discussão mais ampla sobre a existência de diversas temporalidades sociais, conforme visto em autores como Grossin $(1974,1991)$, essa restrição do tempo dedicado ao trabalho ao que é contratado, remunerado, contido em uma jornada, ou considerado pelas estatísticas, também foi muito questionada por pensadores que analisam temas como o tempo de lazer e o trabalho da mulher. Surgem, então, novas definições para o que chamamos de tempo de trabalho e de não trabalho.

Alguns autores fazem uma diferenciação entre o que denominam tempo disponível/ liberado da jornada e tempo livre/lazer, enfatizando que nem todo tempo liberado da jornada de trabalho pode ser considerado um tempo livre ou de lazer. Isto porque consideram que o tempo liberado pode ainda conter diversas obrigações, sejam elas profissionais, familiares ou sociais. Para Bacal (1988), o tempo livre é aquele que o homem dispõe após o tempo necessário para a execução de tarefas de trabalho, pressupondo a liberdade de escolha do que fazer ou não fazer, compreendendo tanto o lazer como o ócio. Também Dumazedier (1999) pensa o lazer como um tempo dedicado ao conjunto de ocupações às quais os indivíduos podem se entregar de livre vontade, seja para repousar, divertir-se, recrear-se e entreter-se, desenvolver sua formação desinteressada, sua participação voluntária ou sua livre capacidade criadora, após livrar-se das obrigações profissionais, familiares ou sociais.

Na bibliografia referente ao trabalho da mulher, como Hirata (1986) e Maruani (2000), também podemos observar a ênfase em um tempo dedicado ao trabalho para além do contido na jornada de trabalho. Para Hirata (1986), no caso das mulheres, diferentemente dos homens, nunca se constituiu uma clara separação entre tempo de trabalho e de não trabalho, dado que os espaços da casa e do trabalho permaneceram misturados. Isto porque no imaginário social o lugar da mulher sempre foi em casa e esta representação reforçou o papel secundário da mulher no mercado de trabalho. Mesmo nos momentos em que está inserida no mercado de trabalho, dificilmente a mulher deixa de cumprir o papel que socialmente lhe foi definido no espaço da casa. Daí a necessidade de pensarmos um tempo dedicado ao trabalho não restrito ao que é negociado com o setor patronal, no espaço do mercado de trabalho.

Assim, ao analisarmos as vivências cotidianas relacionadas ao tempo de trabalho remunerado, temos que nos questionar ainda sobre alguns tempos de trabalho, fora do local de 
trabalho. Por exemplo, o tempo gasto com o deslocamento dos indivíduos da casa ao trabalho 4 e o crescente tempo dedicado às atividades de qualificação ${ }^{5}$. Veremos que na França, por exemplo, no recente processo da redução da jornada de trabalho para 35 horas, as empresas utilizaram a estratégia de expulsar do tempo de trabalho alguns tempos dedicados à qualificação, transformando-os em novos tempos de não trabalho, assim como o tempo de troca de roupa. No caso no Brasil, esses tempos raramente fizeram parte da definição do tempo de trabalho. Teríamos que nos indagar ainda sobre outros tempos de trabalho como as denominadas horas de "sobreaviso" e o tempo dedicado às tarefas levadas para casa que, na maior parte das vezes, ocorre de maneira informal e não são contabilizadas, sendo sua utilização cada vez mais facilitada em função da criação de diversos instrumentos como o fax, o celular, o computador portátil, internet, entre outros, que servem para acionar os trabalhadores a qualquer momento e em qualquer local.

Caberia refletir, igualmente, sobre aqueles tempos nos quais os trabalhadores passam a buscar soluções para o processo de trabalho, principalmente, a partir da ênfase dada à sua participação (caixas de sugestão, CCQ, grupos semi-autônomos), levando-os a permanecer "plugados" no trabalho mesmo estando distantes da empresa. Isto porque, de acordo com Hirata (1986), esta gestão baseada na integração dos trabalhadores pela técnica da motivação e da participação requer um grande número de horas de atividades e estudo desenvolvidos fora das horas contidas na jornada de trabalho. Sem contar a crescente exigência das empresas que se autodenominam cidadãs, ao incentivarem seus trabalhadores a investir em atividades associativas fora do seu tempo de trabalho, mas ainda controladas pelas empresas. Assim, entendo esses tempos como tempos dedicados ao trabalho, pois contém atividades ainda relacionadas ao trabalho, direta ou indiretamente, mesmo que não contratadas e não remuneradas.

No que se refere ao tempo de trabalho, vemos que, quando a duração do trabalho é reduzida, em função de pressão dos trabalhadores, ela é, ao mesmo tempo, por pressão do capital,

4. Por exemplo, de acordo com Guedj e Vindt, o tempo de transporte na região parisiense, passou de $1 \mathrm{~h} 06$, no ano de 1959, para 1h16, em 1974. Sobre uma semana de cinco dias representou um aumento de 50 minutos, absorvendo mais de $1 / 3$ da redução da jornada semanal. No Brasil, o tempo médio de viagem - ida e volta - era de 1 h58 (Folha de São Paulo, 2002). Além disso, o fato da legislação brasileira prever o pagamento do vale transporte, nos leva a crer que há um entendimento social de que esta é uma atividade relacionada ao trabalho, no entanto, o tempo gasto não é remunerado, ou seja, não é considerado como tempo de trabalho. Também na França o empregador paga uma parte da "carte orange" (carta de transporte) mas também não remunera o tempo de transporte.

5. Conforme informações do Sistema de Acompanhamento de Contratações Coletivas SACC-DIEESE, são raros os acordos/convenções coletivas onde a empresa considera como tempo de trabalho aquele dedicado à educação formal ou à qualificação profissional. O que diferencia esta realidade do caso francês, como já vimos anteriormente. 
flexibilizada e intensificada. Ou ainda, como veremos no caso do Brasil, a partir dos anos 1990 que, mesmo quando o tempo de trabalho não é reduzido, ainda assim ele é flexibilizado e intensificado. Mesmo que esse movimento venha se desenvolvendo de modo muito diferente em cada sociedade, como veremos nas construções temporais na França e no Brasil, de qualquer forma, podemos observar um movimento universal no sentido de maior intensificação e flexibilização do tempo de trabalho. E se o tempo de trabalho fica cada vez mais flexível, o mesmo acontece com os tempos de não trabalho, ou melhor, com os tempos fora dos locais de trabalho, afinal, ambos ocupam as mesmas 24 horas. Logo, a questão principal que diversos autores $^{6}$ se colocam é saber quem decide quando o trabalhador irá trabalhar mais ou menos, pois, a depender da resposta, essa flexibilização pode ter significados totalmente diferentes para os trabalhadores. Entretanto, vemos que a flexibilização que vem sendo implementada tem por objetivo atender à demanda de flexibilização da produção (Thoemmes, 2000) e não às necessidades dos trabalhadores. Para Sue (1994:102), até o momento, o que a legislação francesa denomina como tempos «escolhidos» ou tempos atípicos, resulta, na grande parte dos casos, de uma decisão unilateral da empresa.

Do ponto de vista técnico, a flexibilidade é entendida como a habilidade de responder efetivamente a circunstâncias de mudança (Caputo, 1983, apud Salerno, 1989). De acordo com Agostinho (1985, apud Salerno, 1989), a flexibilidade pode assumir diversas formas, entre elas a flexibilidade em preparação, para mudanças de produto, para suportar erros de supervisão e para operações sazonais relativas a flutuações na carga de trabalho. Neste último caso, ela pode assumir a forma de utilização de horas extras, contratos de trabalho para tempos específicos, distribuição não homogênea das horas de trabalho ao longo do ano, polivalência ou multifuncionalidade, podemos ainda incluir, pensando a realidade brasileira, as férias coletivas, os processos de admissão e demissão, entre outros.

Mas, para os trabalhadores, como salienta Sennet (2000), ser flexível significa ser ágil em relação à demanda do capital, estar aberto às mudanças no curto prazo, assumir riscos continuamente, depender cada vez menos de leis e procedimentos formais. Assim, ao invés de maior liberdade, esse novo sistema impõe novas formas de controle, mais difíceis de serem percebidas por serem mais implícitas. Mesmo que alguns trabalhadores aparentemente vivenciem maior grau de liberdade em relação ao tempo, acentua-se o controle por parte da empresa, sendo

6. Entre eles: Blass, 1998; Dal Rosso, 1996; Durand, 2004; Grossin, 1991; Lallement 2003; Sennet, 2000; e Sue, 1994. 
que a vigilância da utilização do tempo está cada vez mais presente, mesmo que o tempo pareça mais desregulamentado. Para Tabboni (2006), em muitos casos a lógica de controle do tempo passa do cronômetro para o computador, sendo que o trabalho fisicamente descentralizado está sob um controle cada vez mais direto.

Assim, vê-se que o processo de flexibilização do tempo de trabalho implementado pelas empresas tem levado os trabalhadores a perderem progressivamente o controle da organização de seus tempos sociais, em função da fragmentação e individualização dos tempos dedicados ao trabalho, que não estão mais de acordo com as outras temporalidades sociais (Mispelblom, 1999). Como salienta Grossin (1991), os sujeitos, em suas vivências temporais cotidianas, têm tido cada vez mais dificuldade em harmonizar as diversas temporalidades sociais. E vale ressaltar que estas novas formas de gestão do tempo de trabalho não significam, por outro lado, o abandono das antigas. Como exemplo, é possível citar a linha de montagem ou a cronometragem que continuam a ser utilizadas tendo como meta a objetivação do tempo do trabalhador (Linhart, 2005).

A intensidade é outra característica do tempo de trabalho que deve ser observada. Durand (2004:267) explicita que o atual processo de intensificação do trabalho se dá não apenas pela maior velocidade na execução dos gestos, mas também pela redução da porosidade do tempo de trabalho. Trata-se de suprimir os tempos denominados pelo capital como mortos, reduzir os tempos de recuperação entre diferentes operações, reorganizar o trabalho prevendo uma atividade enquanto há a recuperação de outra, ou ainda, de fazer trabalhar os diferentes membros do corpo ao mesmo tempo em tarefas diferentes. O que significa que cada minuto deve ser inteiramente ocupado, sem parada e sem descanso, o que é denominado pelos empresários "posto de trabalho eficaz", e significa que o trabalhador deve estar ocupado, pelo menos, $92 \%$ de cada ciclo de um minuto de trabalho.

$\mathrm{O}$ autor frisa ainda que o fluxo tenso ${ }^{7}$ da produção impõe, cada vez mais, uma multiplicidade de intervenções que os trabalhadores devem realizar rapidamente para não romper a continuidade do fluxo produtivo, intensificando progressivamente a tensão e o tempo de trabalho. Para que os trabalhadores aceitem essas mudanças, os empresários também buscam novas formas de gerenciar a força de trabalho. Se no início os capitalistas procuravam neutralizar as iniciativas dos trabalhadores, tentando prescrever todas as tarefas de forma que estes precisassem apenas seguir as normas, ao longo do tempo, foi se observando que esta prescrição total não era viável

7. O termo em francês utilizado pelo autor é "flux tendu" (Durand, 2004). 
e que havia, cada vez mais, um distanciamento entre o trabalho prescrito e o trabalho real realizado pelos trabalhadores. Então, progressivamente, instala-se uma nova forma de organização do trabalho que vai aos poucos mobilizando os trabalhadores (Linhart, 2005). Para Greco Martins (2001), esta nova forma de gestão representa um movimento no sentido de institucionalizar a subjetividade do trabalhador que está sempre presente nas relações de trabalho. Já que não foi possível destruí-la com as formas anteriores, como o taylorismo e o fordismo. Mas isto não significa que o capitalista passe a aceitar que o trabalhador tenha controle sobre seu tempo, o que fica evidente no conjunto de "normas, prescrições, técnicas, instrumentos e organização, de um lado, competência, disponibilidade, saber fazer, compreensão, e interpretação dos objetivos, de outro" (Linhart, 2005:13).

Todas essas mudanças se dão num contexto de crescimento do desemprego, o que tem contribuído para o fortalecimento dos capitalistas e o enfraquecimento dos trabalhadores no processo de negociação coletiva, também sobre o tempo de trabalho. Como veremos de forma mais detalhada no capítulo sobre o caso francês (e também sobre a Volkswagen no Brasil), Thoemmes (2000) salienta que a questão do desemprego na França, ao mesmo tempo em que mobilizou o governo para propor a redução da jornada de trabalho, prejudicou os trabalhadores e seus representantes no processo de negociação coletiva com os empresários. Isto porque o desemprego, ou a sua ameaça, foi utilizado como instrumento de pressão na negociação coletiva, em função do seu poder de modificar a posição/ação dos trabalhadores no sentido da aceitação de diversas formas de flexibilização do tempo de trabalho propostas pelas empresas.

Outra mudança no processo de negociação do tempo de trabalho se refere à relação entre ganhos de produtividade e redução da jornada de trabalho. Husson (1999) observa que no contexto de forte desemprego, a relação entre produtividade e redução da jornada, como ocorrida ao longo da história, deixou de existir. No seu lugar, de acordo com Thoemmes (2000), constitui-se uma nova relação de negociação onde entram emprego, flexibilidade da jornada de trabalho e redução da jornada, no âmbito do discurso patronal. Na prática, a relação se restringe a uma dupla flexibilidade: do tempo de trabalho e da produção. Também Dal Rosso (1996), tendo como foco o Brasil, observam que, apesar dos altos ganhos de produtividade do trabalho nas últimas décadas, pode-se notar que a jornada de trabalho continua muito elevada, além de certa estagnação em seu processo histórico de redução. Assim, se ao longo da história a redução e organização do tempo de trabalho eram tratadas como formas de melhorar as condições de trabalho, após os anos 80, observam-se muitas mudanças. A redução da jornada passa a ser uma variável de ajuste para facilitar a flexibilidade da produção, aumentando a produtividade do 
trabalho, mas não garantindo qualquer forma de divisão destes ganhos e nem mesmo a manutenção dos postos de trabalho. As mudanças dentro das empresas têm implicações notáveis sobre as vivências temporais cotidianas fora dos locais de trabalho.

Vale frisar, entretanto, que tais mudanças não significam o fim da centralidade do tempo de trabalho, mas sim o fim de certa construção social a respeito do tempo de trabalho. Observa-se um processo de desconstrução da ordem temporal vigente até então e que abarca todos os espaços da vida. No que se refere ao tempo de trabalho, não mais a separação entre espaço e tempo de trabalho e de não trabalho, não mais o emprego assalariado, por tempo indeterminado, com local e jornada fixos e remuneração decorrente desta última. Mas, sim, um trabalho sem espaço ou tempo fixos, sem remuneração, jornada, forma de contratação ou garantias determinadas para todos. Para alguns, um tempo de trabalho intenso e flexível, para outros, o desemprego e o desejo de dedicar algum tempo ao trabalho. Por sua vez, tais mudanças afetam não apenas as vivências temporais como também as matrizes discursivas, as práticas coletivas, as percepções e representações simbólicas, contribuindo para a resignificação, seja do tempo de trabalho, seja do tempo de não trabalho (Sennett, 2000)

Ressalta Grossin (1991), ainda, que o estudo das mudanças das vivências temporais cotidianas nas sociedades contemporâneas, nos possibilita levantar as seguintes questões: quais os efeitos da aceleração do ritmo das mudanças e da multiplicação das descontinuidades temporais sobre os modos de vida e da representação do tempo dos indivíduos? Quais os mecanismos pelos quais cada sociedade tenta harmonizar as diferentes temporalidades sociais, e em que medida as tensões entre diferentes modos de temporalidades sociais podem vir a ser fonte de ruptura e de mudanças importantes?

Vale explicitar, também, que a reflexão realizada, neste capítulo, teve como objetivo explicitar as características do arcabouço teórico adotado, o qual possibilitou apreender o tempo de trabalho e de não trabalho de uma maneira ainda pouco presente no meio acadêmico brasileiro. Isto é, voltado a compreender o tempo de trabalho a partir das vivências temporais cotidianas dos trabalhadores, contextualizadas no nível macro-político e micro-organizacional. Por isso mesmo, nos capítulos seguintes, busco analisar duas culturas temporais diferentes: o Brasil, minha preocupação central, que procurei interpretar em diálogo com o caso francês, justamente por ser uma cultura que, em todas as suas instâncias assumiu como essencial a discussão do tempo e do tempo de trabalho. Feito isso, analiso as vivências temporais cotidianas dos trabalhadores, remetidas às determinações mais amplas de uma dada cultura temporal, num dado momento histórico, criando assim uma complementaridade entre o micro e o macro. 


\section{A CONSTRUÇÃO SOCIAL DO TEMPO DE TRABALHO NA FRANÇA: UM OLHAR A PARTIR DOS ANOS 90}

este capítulo, trato da construção social do tempo de trabalho na França, a partir dos anos 1990, considerando três aspectos desta construção: as normas jurídicas, os processos de negociação e as vivências dos trabalhadores. Analiso estes aspectos da realidade francesa, para construir um diálogo com o caso brasileiro e melhor compreender as configurações próprias que resultam da construção social do tempo nesta sociedade. Por serem construções históricas, contêm diversas particularidades, além de traços comuns que transcendem as suas singularidades. Para além das diferenças observadas em cada país, há um movimento mais amplo no sentido da redução dos limites impostos ao capital com relação à gestão do tempo de trabalho.

A opção por demonstrar o caso francês justifica-se também pelo fato de que a temática do tempo de trabalho tem sido amplamente discutida na França, pelos diversos atores sociais governo, empresários e trabalhadores. Tanto estas discussões como a produção de informações e a reflexão realizadas no meio acadêmico estão documentadas e podem ser observadas, não apenas no momento atual, mas também ao longo da história da relação capital e trabalho na sociedade francesa. Ao observar o caso francês, foi possível compreender ainda o processo histórico de construção de limites para a gestão do tempo de trabalho, definidos pelo Estado ou socialmente negociados, até os ano 80, e também a "descontrução" (Thoemmes, 2000) desse processo de limitação, que se inicia em meados dos anos 90 e que culminou na redução da jornada de trabalho de 39 para 35 horas.

Para alcançar os objetivos deste capítulo, foi necessário, então, considerar as diferenças marcantes com relação à construção social do tempo de trabalho na França, em diversos momentos históricos. Assim, inicio o capítulo com o período entre o final dos anos 1970 e meados de 1990, momento marcado por mudanças fundamentais no processo de definição do tempo de 
trabalho. Em seguida, apresento a discussão em torno das 35 horas, entre os anos de 1998 e $2002^{1}$. Na terceira parte do capítulo, são discutidas as mudanças introduzidas na redução do tempo de trabalho - RTT (na França, esta sigla é utilizada tanto nas leis, como nas falas e textos lidos), a partir da eleição em 2002, quando se abriu uma nova etapa de negociação que se prolonga até os dias atuais. Vale ressaltar que durante todo o período analisado, procuro conciliar um enfoque mais amplo, apresentando como as principais mudanças na regulação do tempo de trabalho foram sendo constituídas, com um enfoque mais específico, ilustrando esse movimento a partir de resultados dos processos de negociação em alguns locais de trabalho. Com esta análise, pretendo ampliar a compreensão sobre a relação entre as negociações tal como ocorridas no plano macro-político e no plano micro-organizacional, o que trará novos elementos para pensarmos, posteriormente, o modo pelo qual essa discussão vem ocorrendo na sociedade brasileira e, também, as próprias negociações ocorridas na Volks Anchieta.

Finalizo este capítulo com uma análise sobre como, na França, os trabalhadores vivenciaram a RTT, buscando compreender como essa redução alterou as vivências temporais cotidianas dentro e fora dos locais de trabalho.

\section{1 - O tempo de trabalho na França}

Do ponto de vista das regras jurídicas e do processo de negociação, de acordo com Terssac, Thoemmes e Flautre (2004), dois períodos distinguem a construção do tempo de trabalho na França. Primeiramente, observa-se uma intervenção autoritária e centralizada, até o final dos anos 1970, tendo a discussão, como tema central, a melhora da condição de vida e de traba1ho, bem como a distribuição dos ganhos de produtividade. E a partir deste período, a intervenção do Estado caracteriza-se, segundo os autores, por uma "ação pública negociada", por meio da construção de leis que passaram a ter como meta o incentivo ao processo de negociação. No que se refere ao conteúdo, o tempo de trabalho passa a ser colocado como "moeda de troca" entre a flexibilidade demandada pelas empresas e o emprego necessário à sociedade.

1. É importante ressaltar que tanto nas diversas entrevistas que realizei na França como na bibliografia pesquisada, há uma forte importância dada ao partido que assume o poder, se de "direita" (RPR - Rassemblement pour la République - antigo partido de direita criado nos anos 70 e que se tornou no l'UMP - Union pour un Mouvement Populaire, em 2002), ou de "esquerda", que é o Partido Socialista. E muitas vezes, a mudança de poder é tomada como um marco referencial muito importante no que se refere às mudanças na discussão e negociação do tempo de trabalho. 
No final dos 1970, de acordo com os autores, o Estado redefine sua forma de intervenção em relação à temática, num contexto de fraca pressão sindical pela RTT, à exceção da CFDT (Confederação Francesa Democrática do Trabalho) ${ }^{2}$. Por outro lado, este período já é marcado por forte demanda empresarial no que se refere à redução das limitações impostas à gestão do tempo de trabalho, bem como pelo problema estrutural do desemprego. E é neste contexto que a negociação começa a fazer da construção temporal, no que se refere ao tempo de trabalho, sendo reconhecido o poder de barganha dos setores profissionais e das empresas. Essa segunda etapa de intervenção pública, iniciada no final dos 1970, é dividida pelos autores em quatro momentos que marcam o que eles denominam de "desconstrução" do modo de regulação das regras temporais até então vigentes, como veremos a seguir.

\subsection{1 - A partir dos anos 1980: mudanças na construção do tempo de trabalho}

Até os anos 1980 o Estado buscou proteger o trabalhador ao limitar o poder dos empregadores a partir, principalmente, de quatro grandes leis abrangendo diversos aspectos do tempo de trabalho. O primeiro movimento de limitação da ação empresarial resultou na lei contra o trabalho das crianças, em 1824. O segundo, em 1906, foi a lei que teve como foco o repouso semanal remunerado, limitando o trabalho que antes se desenvolvia por todos os 7 dias da semana. A terceira etapa foi marcada por discussões sobre a limitação da duração do trabalho, com a instauração da jornada de 8 horas em 1919 e, a última, foi a limitação do trabalho semanal, com a definição da duração semanal do trabalho e também do trabalho anual com a instituição das férias pagas, em 1936 (Terssac, Thoemmes e Flautre, 2004). Em 1956, o governo decreta a terceira semana de férias; já a quarta semana de férias será o resultado de negociações coletivas ocorridas entre os anos de 1963 e 1969 (Dares, DP e INSEE, 1997) ${ }^{3}$. Entretanto, vale frisar que apesar da nova lei, foi apenas nos anos 1960 que o tempo de trabalho foi reduzido para 44 horas, e apenas no final dos 70 deu-se a redução para 40 horas.

Em 1978, o lado patronal incita um movimento contra o que vinha sendo implementado pelo Estado, demandando a redução das limitações impostas à gestão do tempo de trabalho, no

2. Confédération Française Démocratique du Travail

3. DARES - Direção de Animação de Pesquisa, de Estudos e de Estatísticas (Direction de l'Animation et de la Recherche des Études et des Statisques), INSEE - Instituto Nacional de Estatística e de Estudos Econômicos (Institut National de la Statistique et des Études Économique) e DP - Direção de Prévision. Este departamento não exsite mais tendo sido integrado aso DGTPE - Direção Geral do Tesouro e da Plítica Econômica, (Direction Générale du Trésor et de la Politique Économique). 
processo de negociação interprofissional. Nesse momento, demandavam aumentar o limite da hora extra para 280 horas anuais, sem a necessidade de autorização da inspeção do trabalho, além de inserir a individualização das durações do trabalho, recusadas pelos trabalhadores e por seus representantes. No início dos anos 1980, a discussão acerca da redução da duração do trabalho foi retomada, ampliando as possibilidades de sua reorganização, já demandada pelo setor patronal, embora sujeito a uma política de geração e manutenção do emprego. Para Thoemmes (1997b) a primeira observação sobre este período refere-se à mudança do lugar ocupado pela temática da redução do tempo de trabalho, transformando-se em um tema não mais discutido em si mesmo, mas relacionado à redução da limitação empresarial para gerenciar o tempo de trabalho que vinha sendo construída até os anos 1980. Para o autor, esta mudança se dá em função de transformações realizadas pelo setor patronal na organização do trabalho dentro das empresas e pela busca de maior liberdade também para reorganizar o tempo de trabalho. Assim, se antes dos anos 80 a RTT tinha como objetivo principal a melhora das condições de trabalho e de vida dos trabalhadores, a partir de então o objetivo principal será a criação de empregos, tanto por parte do Estado como dos sindicatos.

Ao contrário de Thoemmes (1997b), acredito que se uma sociedade define que um de seus principais problemas é a falta de emprego, talvez não se deva considerar que a RTT deixa de ter como objetivo a melhora das condições de vida e de trabalho; afinal, o emprego, nesse caso, é entendido como um dos elementos possibilitadores dessa melhora. Isto não significa, entretanto, deixar de reconhecer que houve uma forte mudança de orientação, que faz da RTT um elemento de troca, portanto, vinculado a outros temas. Isso, porém, não faz com que ela deixe de ter como objetivo a melhora da condição de vida e de trabalho. O maior problema é que os outros temas a ela vinculados nada têm a ver com essa melhora; eles objetivam, como é o caso da reorganização do tempo de trabalho buscando a sua flexibilização, atender a uma demanda patronal voltada a melhorar a produção e aumentar o lucro. Por isso mesmo, geram, na maior parte das vezes, efeitos negativos para o trabalhador, seja no sentido da intensificação do trabalho, seja no sentido da perda do controle e da previsão do tempo de trabalho.

Outra mudança ressaltada pelo autor refere-se à forma da definição das novas regras. A partir de 1982, ela deixa de ser o resultado da ação centralizada do governo e passa a decorrer de amplos processos de negociação coletiva. Desde então, o governo demanda às organizações de trabalhadores e empregadores que iniciem o processo de negociação, abrindo assim a possibilidade para que estes influenciem na definição das modalidades de aplicação 
da RTT. Tais mudanças aparecem no processo de negociação em 1981, resultando em um acordo interprofissional assinado por todas as centrais, exceto a CGT (Confederação Geral do Trabalho $)^{4}$. Nesse acordo estava prevista a RTT de 40 para 39 horas, a generalização da quinta semana de férias, a criação de um contingente anual de hora-extra não submetido à inspeção do trabalho, bem como a continuidade da negociação por setor (Dares, DP e INSEE, 1997). Entretanto, apesar do acordo, as negociações não tiveram continuidade, demonstrando, a meu ver, o desejo dos empresários no sentido de ampliar as formas de gerenciar o tempo de trabalho, como já explicitado em 1978, mas sem que isso significasse passar por um processo de negociação coletiva com os sindicatos.

Em função deste quadro, a lei Auroux de 1982 introduziu a obrigação de negociação anual dentro das empresas, englobando quatro leis, sendo uma delas referente à negociação da duração do trabalho. Nesta lei, havia a obrigação das empresas negociarem, no caso de demanda por parte do movimento sindical, sem que isso significasse a obrigação de se chegar a um acordo. Novamente, diante do reduzido número de negociações incitadas, conforme relata BlochLondon $^{5}$, houve um forte debate dentro do governo resultando na retomada do acordo interprofissional firmado em 1981. A maior inovação apresentada foi a inserção de um princípio de permissão ${ }^{6}$ para as empresas descumprirem a lei sobre tempo de trabalho, através do recurso à negociação coletiva, dando assim um forte poder ao processo negociado. Permitiu ainda a contabilização das horas tendo como referência o ano e não mais a semana, autorizando igualmente a modulação de horário ${ }^{7}$. Como resultado, ao ter o objetivo de possibilitar às empresas uma melhor adaptação às flutuações do mercado, o decreto colocou em questão alguns direitos já adquiridos pelos trabalhadores, como o repouso dominical e os horários coletivos (Askenazy, Bloch-London e Roger, 2004).

4. Confédération Générale du Travail.

5. Entrevista realizada com Catherine Bloch-London - DARES - Ministère de l'Emploi, de la Cohésion Sociale et du Logement, em 2006. Portanto, quando seu nome for citado no texto, sem a referência do ano, trata-se da entrevista e não de alguma publicação.

6. O termo utilizado em francês "dérogation", traduzido literalmente para o português teria o sentido de descumprimento, no sentido de uma falta que deve ser corrigida. Entretanto, neste contexto, o sentido desta palavra é de uma licença ou uma permissão definida por lei, para que as negociações coletivas possam redefinir as regras mesmo que contrárias às já existentes.

7. O funcionamento da modulação é muito parecido com o "banco de horas" no Brasil. Sua forma de organização do tempo de trabalho comporta a realização de uma jornada de trabalho irregular, evitando assim o pagamento de hora-extra. Para ser aplicada na França ela deve ser objeto de negociação coletiva tanto por setor como por empresa, diferentemente do Brasil onde pode haver a negociação individual. Está previsto na legislação o limite máximo de 1607 horas de trabalho por ano, mantidos os limites diários e semanais já citados anteriormente, bem como o limite de 220 horas extras por ano. 
A partir de 1982, como afirmam alguns autores (Freyssinet, 1994; Morin, Terssac e Thoemmes, 1998), toda a política geral de RTT foi abandonada. E se no início ela apareceu ligada à reorganização do tempo de trabalho, a partir de então se percebe que ela passa a ser vista como uma contrapartida à flexibilização demandada pelo setor patronal, invertendo assim a ordem de prioridade. A redução do tempo de trabalho tornou-se facultativa, sendo o objetivo principal harmonizar a organização do tempo de trabalho ao ritmo da produção, cada vez mais inconstante, adaptando o tempo dos individuos, no trabalho e fora deste, ao novo movimento do mercado (Morin, Terssac e Thoemmes, 1998).

Num contexto de mudanças no mercado de consumo bem como de aumento do desemprego estrutural, o início dos anos 1990 marca uma nova etapa do processo de negociação sobre o tempo de trabalho na França. Isto se deu através da lei qüinqüenal de 1993, sobre trabalho, emprego e formação profissional, que ampliou as possibilidades jurídicas de reorganização do tempo de trabalho vinculando redução do tempo de trabalho, compensação salarial e flexibilização ${ }^{8}$. Essa lei incentivou igualmente o trabalho a tempo parcial, reduzindo o custo de contratação e possibilitando a utilização do tempo de trabalho de maneira variável no ano. Permitindo, assim, uma extrema margem de opções e vantagens para o setor patronal, ao vincular a flexibilidade interna e externa do tempo de trabalho em um único dispositivo, isto é, o tempo parcial anualizado ${ }^{9}$ (Thoemmes e Tressac, 1997a). Outro novo modo de organização do tempo de trabalho aparece em 1994, por demanda de empresas que buscavam negociar com os gerentes a não utilização de todos os dias de férias em uma única vez, guardando uma parte para um outro período, quando fosse melhor para a empresa. A partir desta discussão o governo criou a lei sobre a "conta-poupança" - CET ${ }^{10}$ e, em 1998, esta nova regra passa a valer para o conjunto dos trabalhadores.

Como resultado de todas essas negociações e alterações nas leis sobre tempo de trabalho, observa-se uma grande diversidade no que se refere às maneiras de sua organização, de

8. Foram três as leis sobre modulação, a modulação do tipo 1 em 1982, do tipo II em 1987 e do tipo 3, chamada anualização, em 1993 (Dares, DP e INSEE, 1997).

9. Como conseqüência, o tempo parcial passou de 8,6\%, em 1982, para 17,4\%, em 1997, sendo que no caso das mulheres este aumento foi ainda maior passando de $13,5 \%$ para $31 \%$, respectivamente. Ver mais detalhes sobre as regras do trabalho parcial no quadro no final deste capítulo.

10. A Compte épargne-temps - CET, possibilita aos trabalhadores acumular dias de folga remunerados ou realizar uma "poupança" (épargne) em dinheiro, sendo que as regras de conversão devem ser definidas por acordos coletivos. Essa conta é uma poupança que pode ser alimentada por horas resultantes do trabalho em feriados, férias ou de hora-extra. Ver quadro no final deste capítulo. 
forma que o percentual de trabalhadores com horário fixo de trabalho torna-se cada vez mais reduzido $^{11}$. Além disso, se por um lado as negociações apresentaram modulações muito amplas, as reduções do tempo de trabalho a elas relacionadas são muito pequenas, limitadas a meia ou uma hora por semana, e vinculadas ainda, na maior parte dos casos, a uma compensação salarial (Thoemmes e Tressac, 1997a).

Observam igualmente esses autores que, entre os anos de 1984 e 1994, apesar da obrigação legal em matéria de negociação anual sobre o tempo de trabalho, em apenas uma minoria dos casos se chegava a um acordo. E no que se refere ao conteúdo dos acordos pesquisados, em metade deles o tempo de trabalho foi tratado de maneira isolada, sendo que nos outros ele veio acompanhado de temas como formação, saúde, emprego e compensação de salários. E mesmo dentre aqueles que trataram apenas da questão do tempo de trabalho, os temas presentes foram muito diversos, considerando que em muitos casos foram negociados tempos diferentes a depender do setor de trabalho, da função, do sexo, da idade ou da profissão. Como salientam Thoemmes e Terssac (1997a), essas negociações em torno dos dispositivos legais disponíveis serviram para as empresas regularem o tempo de trabalho à demanda do mercado. Isto é, permitiram controlar a variabilidade de fluxo que se exerce no dia ou na semana, via tempo parcial, bem como desenvolver as capacidades de produção da empresa, restituindo os gastos com o maquinário, por meio do trabalho em turnos, no final de semana, no trabalho noturno ou através da modulação.

Do ponto de vista dos resultados, nos anos 1990 o tempo de trabalho estava em torno de 39 horas. Em 1994, apesar dessa média de 39 horas, nas empresas com até 50 trabalhadores, $18 \%$ deles tinham uma duração do trabalho acima de 39 horas, contra 4\% nas empresas com mais de 500. Já em 1997, 12,8\% dos trabalhadores tinham uma duração do trabalho acima de 39 horas. No que se refere ao setor, podemos observar também uma grande disparidade, pois, enquanto na indústria química e naval cerca de $23 \%$ dos trabalhadores tinham uma jornada menor que 38 horas, na indústria automobilística, 68,9\% trabalhavam entre 38 e 39 horas (Dares, DP e ACEMO, 1997) ${ }^{12}$.

11. Quando comparo os anos de 1984 e 1991 (Dares, DP e INSEE, 1997), observo uma redução de 65\% para 52\%. Em 1994, por exemplo, 7,6\% dos estabelecimentos com mais de 10 trabalhadores declaravam ter um acordo sobre modulação, sendo que 3,6\% tinham implementado este modo de reorganização do tempo de trabalho sem negociação, e 47\% declararam ainda utilizar a hora-extra. De acordo com a análise de 68 acordos realizados em 1995, em 1/4 dos documentos constava a negociação vinculando a modulação à criação de empregos. (idem).

12. ACEMO - Activités et Conditions d'Emploi de la Main d'Oeuvre. 


\subsection{2 - A partir de meados dos anos 1990: negociação, redução e flexibilização do tempo de trabalho}

De acordo com a entrevista realizada com Bloch-London, o governo tirou muitas lições do processo de negociação da RTT ocorrido nos anos 80, considerando, sobretudo, que de fato não houve a redução negociada para as 35 horas, nem tampouco a geração de empregos. Em relação a esse último fato, a constatação foi de que a redução de apenas uma hora de trabalho foi facilmente recuperada com o aumento da produtividade. Assim, a idéia do governo de Lionel Jospin, do Partido Socialista, ao ser eleito, foi não a de fazer uma lei que obrigasse as empresas a passarem para 35 horas, mas sim a de criar espaços de negociação com participação dos atores sociais envolvidos. E ainda, de possibilitar que a redução fosse ampla e ocorresse de uma única vez, em cada local de trabalho, reduzindo assim as possibilidades de ser recuperada via ganhos de produtividade.

Em relação ao contexto no qual a lei foi apresentada, efetivamente, embora as principais centrais sindicais já reivindicassem a semana de 35 horas desde 1975, naquele momento, não havia uma demanda explícita e organizada voltada para essa pauta. A questão do emprego acabou por mobilizar a sociedade civil e as diversas organizações, mas a questão da RTT não se incluía dentre os focos principais. Houve diversas mobilizações por parte dos movimentos sociais contra medidas implantadas pelos governos anteriores no sentido da flexibilização dos salários ou das formas de contratação ${ }^{13}$. Mas, apesar dos movimentos sociais e das organizações sindicais não incluírem em sua pauta a RTT como aspecto prioritário, não podemos esquecer que essa era uma das metas previstas no plano de governo de Lionel Jospin, do Partido Socialista, e muito enfatizada na campanha eleitoral de 1998. De forma que o tema da "divisão do trabalho" 14 voltou a ser discutido por toda a sociedade e incentivado pelo governo.

A Lei de 11 de junho de 1996, denominada lei Robien, marcará o retorno da discussão da RTT, via negociação coletiva, no final do governo de Alain Juppé. Essa discussão desdo-

13. Em 1994, houve um grande movimento formado principalmente por jovens escolarizados, obrigando o governo a retirar um projeto que estabelecia um salário $20 \%$ menor do que o mínimo profissional, para essa faixa etária. Soma-se a isso o surgimento de novas organizações que reuniam e mobilizavam desempregados e trabalhadores precarizados, como a AC - Agir Contra o Desemprego (Agir Contre le chômage), movimento surgido por iniciativa principalmente de sindicalistas, desempregados e organizações sem teto. Ainda em 1994, marchas organizadas pela AC percorreram a França por várias semanas e em maio de 1997 acontece a ocupação do Banco da França. As marchas, "contra o desemprego, a precarização e a exclusão", escolhidas como principal meio de expressão, passaram a percorrer outros países europeus, como Espanha e Itália (Borges, 2005).

14. Em francês, a expressão é "partage du travail". 
brou-se até o final de 1997, já no governo de Lionel Jospin, por meio da "Conferência Nacional sobre o Emprego, os Salários e o Tempo de Trabalho". Para Bloch-London, diferentemente de outros momentos, o governo não tinha como preocupação central a questão do tempo livre, mas sim a criação de empregos, como, aliás, pode ser observado no próprio título da Conferência e em toda a discussão acerca das altas taxas de desemprego ${ }^{15}$. A proposta foi a criação de empregos, via reorganização e redução do tempo de trabalho de 39 para 35 horas semanais, ou seu equivalente de 1600 horas anuais. As 35 horas seriam atingidas a partir do ano de 2000 nas empresas com 20 ou mais trabalhadores e de 2002, para as empresas com menos de 20 e também no setor publico; até estas datas, as empresas poderiam negociar, por ramo ou por firma ${ }^{16}$, as formas como se dariam essa redução. Assim, o governo pretendia legitimar as 35 horas, a partir de um vasto processo de negociação dentro e fora das empresas (Askenazy, Bloch-London e Roger, 2004).

Essa negociação baseou-se na isenção, para as empresas, da contribuição de seguridade social dos trabalhadores em troca da criação ou manutenção do emprego. A legislação previa duas possibilidades de negociação, uma "defensiva", voltada para empresas que se preparavam para redução de pessoal, e objetivava a manutenção dos empregos já existentes; e outra mais “ofensiva”, voltada para geração de empregos, com previsão de redução de $10 \%$ do tempo de trabalho e aumento de 6\% no número de empregos (Pepin et alli, 2006) ${ }^{17}$. Seria necessário ainda, que as empresas calculassem a redução da jornada de trabalho do mesmo modo que antes da RTT, ou seja, sem a possibilidade de redefinir o tempo de trabalho efetivo para alcançar a redução da jornada, via redução de pausas, dias feriados, tempos de formação ou troca de roupa. Em função dessa regra, o governo, em 1988 (Waquet, 1998), esclareceu que:

A duração das horas realmente trabalhadas é um período de tempo no qual o empregado fica disponível para o empregador e tem que seguir suas determinações, sem ser permitido dispor

15. No ano da conferência, 1997, a taxa de desemprego era de 12,5\%, a terceira maior da União Européia.

16. As empresas com menos de 50 trabalhadores poderiam ter acesso à ajuda pública, aplicando diretamente o acordo de RTT assinado pelo setor. Dentre as empresas que passaram às 35 horas, $1 / 5$ seguiu este processo (Askenazy, Bloch-London e Roger, 2004).

17. A lei previa que: a jornada de trabalho deveria ser reduzida em pelo menos $10 \%$ de sua duração original; a nova jornada deveria permitir uma semana de 35 horas de trabalho; a redução das horas deveria vir acompanhada da criação de empregos, o equivalente a $6 \%$ ou a manutenção desses mesmos $6 \%$, evitando demissões; o empregador deveria se comprometer a manter por pelo menos dois anos o seu número de empregados, se optasse pelo acordo "ofensivo". As empresas que também contratassem em período parcial - de 18 a 32 horas ou até $80 \%$ da jornada determinada por acordo coletivo, também receberiam abatimento no fundo de seguridade social. 
livremente de seu tempo para a realização de outras atividades. A duração do tempo efetivo trabalhado [...] significa o tempo de fato trabalhado, sem contar o tempo despendido para se vestir ou lanchar, bem como os períodos de inatividade nas fábricas e em outros negócios. [...] Esses períodos podem ser pagos se houver conformidade com a prática e com os acordos coletivos $^{18}$.

Ressalta Freyssinet ${ }^{19}$, que esta definição já existia na Corte de Cassação, mas era utilizada apenas em casos de conflitos mais graves, na ausência de negociação, dado que na grande parte dos casos as definições eram frutos de negociações. Importante salientar que antes da lei Aubry I não havia uma distinção clara entre "tempo de trabalho" e "tempo de trabalho efetivo"; esta era construída via negociação. Os acordos foram incorporando os tempos de pausas ou de troca de roupa ao tempo de trabalho, considerando que eram tempos à disposição do empregador. Todavia, a definição do governo parece ter tido, de fato, um efeito contrário ao pretendido, pois desde então, houve uma onda importante de negociações, incitada por uma parte do setor empresarial contrário à RTT, com o objetivo de contorná-la via redefinição do tempo de trabalho efetivo.

Ainda no que se refere ao setor patronal, para Bloch-London, o governo precisava apresentar contrapartidas concretas, dado que parte dos empresários tinha um forte discurso de que uma RTT sem redução dos salários causaria um aumento nos custos do trabalho, o que, num contexto de competitividade, acabaria por gerar mais desemprego. Assim, o empresariado defendia a redução da limitação na gestão do tempo, introduzindo a flexibilização, contrapartida necessária ao custo gerado pela redução da jornada de trabalho sem redução dos salários (Afsa e Biscourp, 2004). Nesse contexto, o governo ofereceu contrapartidas para os empresários como a exoneração financeira, a possibilidade de moderação salarial (reajustes menores do que a inflação) e de ganhos de produtividade; nesse último caso, os ganhos de produtividade seriam obtidos, de acordo com o governo, ao associar a redução do tempo de trabalho à sua reorganização (Afsa e Biscourp, 2004). De forma que a reorganização e redução do tempo de trabalho ${ }^{20}$ possibilitariam às empresas ganhar em termos de flexibilidade, aos trabalhadores em termos de liberdade e à coletividade em termos de empregos (Dares, DP e INSEE, 1997).

18. Em 1993, esta nova definição sobre "horas efetivamente trabalhadas" foi incluída no Código do Trabalho, através do Artigo L212.4.

19. Entrevista realizada com Jacques Freyssinet do CEE - Centre d'Études de L'Emploi (Centro de Estudos do Emprego), em junho de 2006. Portanto, quando seu nome for citado no texto, sem a referência do ano, trata-se da entrevista e não de alguma publicação.

20. Observa-se que a palavra reorganização aparece sempre antes de redução no documento produzido pelo governo. 
No entanto, mesmo com essas contrapartidas foi significativa a oposição patronal à RTT. Bloch-London, na sua entrevista, ressalta que o patronato sempre foi contra a duração legal do trabalho. O MEDEF (Movimento das Empresas Francesas) ${ }^{21}$, por exemplo, propôs a supressão da duração legal do trabalho, de forma tal que na ausência desta, também não haveria tempo parcial e, sobretudo, hora extra. Para Freyssinet, o ponto fundamental da iniciativa de parte do setor patronal, ao não entrar no processo de negociação e demandar a ajuda financeira, foi o de manifestar-se contra a lei, deixando claro o seu poder e o seu desejo de não ter o estado controlando as relações de trabalho dentro das empresas. Isto porque a ajuda financeira além de prever a não alteração na forma de cálculo da jornada de trabalho, também possibilitaria o controle do governo em relação ao cumprimento do acordo internamente negociado. Dessa forma, o objetivo do MEDEF era levar o governo a renunciar ou a atenuar a segunda fase do processo, que se daria no ano de 2000 , premido pela constatação de que a grande maioria das empresas não havia realizado negociações.

Esta ampliação da possibilidade do capital gerir o tempo de trabalho conforme suas necessidades, com reflexos diretos nos direitos conquistados ao longo das lutas sociais, foi bastante criticada por parte do movimento sindical, entendida como uma degradação das condições de trabalho. No que se refere à forma da RTT, nem todas as centrais partilhavam da mesma idéia, apesar de todas serem a favor da RTT, sem redução de salários. A CGT e a CFDT eram a favor da adoção da RTT pela via legislativa, pois consideravam que um processo de negociação descentralizado traria situações muito desfavoráveis aos trabalhadores, visto que a correlação de forças seria muito desigual. Entretanto, havia uma forte diferença entre essas duas centrais, dado que a CFDT era a única central que aceitava a modulação do tempo de trabalho, desde que houvesse a redução das horas extras bem como a geração de emprego. A CGT-FO (Confederação Geral do Trabalho-Força Operária) ${ }^{22}$, por sua vez, era favorável à negociação por setor. Havia ainda unanimidade em relação ao aumento nominal do salário mínimo proporcional à RTT, entretanto, essa era uma questão que não seria discutida no espaço da negociação coletiva, sendo definida pelo governo ${ }^{23}$ (Askenazy, Bloch-London e Roger, 2004).

21. Mouvement des Entreprises de France.

22. Confédération Générale du Travail - Force Ouvrière.

23. De acordo com Bloch-London, a idéia do governo era não aumentar o salário, mas, ao mesmo tempo, não deixar que este fosse reduzido, optando por manter o nível do salário mínimo - Smic. Num primeiro momento cogitou-se a introdução de dois salários mínimos, um para os trabalhadores com 35 horas e outro para aqueles com 39 horas, mas o que se pôde observar é que no ano de 2005 ainda existiam seis tipos de salários mínimos, variando conforme a data de redução da jornada em determinada empresa. No que se refere aos salários em geral, apesar de em 92\% dos acordos constarem a manutenção dos salários, estavam previstos também dispositivos prevendo o não aumento desses de acordo com a inflação, num espaço de 18 meses (Melchior, 2006). 
Em relação ao processo de negociação, outra mudança da nova lei foi a introdução da figura do "mandatário sindical”, já acordado na negociação interprofissional de 1995 e consagrado na lei Robien de $1996^{24}$. Para Bloch-London foi a CFDT que implementou uma ação mais forte em relação à figura do mandatário, considerando que ela tinha como objetivo conseguir a transformação destes em delegados sindicais. Entretanto, argumenta Bloch-London que a figura do mandatário acabou não acarretando o verdadeiro fortalecimento da presença sindical dentro da empresa.

Finalmente, de forma resumida vemos que no processo de negociação referente à lei Aubry I, foram duas as principais estratégias patronais. Houve empresas que demandaram a ajuda do governo e para tal reduziram a jornada para 35 horas, sem alterar a forma de cálculo e ainda criaram emprego e, por outro lado, houve aquelas que optaram por não demandar a ajuda financeira e, assim fazendo, puderam alterar a forma de cálculo da RTT, além de não ter que gerar empregos. Claro que a situação real é muito mais complexa do que essa divisão em dois grandes grupos. Primeiro porque em cada um desses grupos houve uma diversidade enorme de condutas no que se refere às formas de reorganização do tempo de trabalho e também, porque com a lei Fillon de 2003, as empresas com menos de 20 trabalhadores não precisaram mais reduzir a jornada para 35 horas, de modo a conseguir a ajuda do governo, criando assim um terceiro grupo. É o que veremos com mais detalhe a partir de estudos de caso realizados em empresas específicas.

As empresas que optaram pela ajuda governamental, cerca de 30.000, empregando 10 milhões de trabalhadores, eram, em sua maioria, independentes dos grandes grupos patronais e três quartos delas tinham menos de 50 trabalhadores (Askenazy, Bloch-London e Roger, 2004). Conforme Coutrot (2006), tais empresas apresentam algumas características comuns, tais como a presença de representantes sindicais independentes de correntes e de gerentes que se diziam favoráveis à negociação com os sindicatos e à construção de políticas ativas em favor do emprego. Do outro lado temos os setores ou empresas que optaram pela RTT sem a ajuda pública, como, por exemplo, o acordo da UIMM (União das Indústrias Metalúrgicas) ${ }^{25}$.

24. Até então, para a realização da negociação por setor ou interprofissional era necessária a presença de um delegado sindical. Como a negociação da RTT poderia ocorrer também por empresa, havia o problema da ausência de delegados nas pequenas e médias, sendo criada assim a figura do mandatário, que faria parte das negociações no caso de não haver delegado sindical ou representante eleito pelos trabalhadores (Melchior, 2006: 54). Como resultado, antes de 2000, sete acordos sobre dez, independente do tamanho da empresa, foram negociados por um trabalhador mandatário (Askenazy, Bloch-London e Roger, 2004).

25. Union des Industries et Métiers de la Métallurgie. 
Por meio deste acordo, o setor adotou a estratégia de neutralizar a efetividade da RTT, por meio da redefinição do tempo de trabalho efetivo, da reorganização do tempo de trabalho via o crescimento anual da hora extra acima do máximo previsto e da anualização do tempo de trabalho ${ }^{26}$ (Askenazy, Bloch-London e Roger, 2004).

Outra estratégia utilizada por setores que se colocaram contrários à RTT, foi a tentativa de redefinir a categoria profissional de gerentes, uma vez que a lei previa uma maneira diferente para contabilizar seu tempo de trabalho, via a regra de forfait heure ou jour (ver quadro no final deste capítulo). Neste caso, a ação foi no sentido de redefinir os trabalhadores e funções que faziam parte desta categoria, sendo muitos técnicos redefinidos como gerentes e ficando fora da RTT (Bloch-London, entrevista). Outro acordo típico foi o do setor bancário, onde foram reduzidos os dias feriados. De acordo com a lei, só o dia $1^{\circ}$ de maio é considerado feriado, enquanto nos acordos havia em média entre 8 e 14 dias de feriado pagos como dias de trabalho. Ao descontar os dias feriados, 11 ao total, os bancos, por exemplo, puderam driblar a RTT e reduziram em muito pouco a jornada de trabalho.

\subsubsection{1 - Lei Aubry II - 2000: mudanças de percurso}

A lei Aubry II foi lançada em janeiro de 2000, incluindo em seu conteúdo, como previsto na primeira lei, as principais tendências negociadas nos acordos de RTT. Analisando o seu conteúdo, vemos que há uma mudança radical em relação ao que havia sido proposto, já que a partir desta segunda etapa todas as empresas teriam a ajuda financeira, independentemente de cumprirem ou não as regras, sendo mantida apenas a redução para as 35 horas e o limite de hora extra. De acordo com a avaliação de Bloch-London, a mudança de atitude do governo esteve relacionada à pressão exercida pelos resultados das negociações e à sua avaliação de que ele não teria forças para impor uma segunda lei, nos mesmos moldes que a primeira, levando em conta a correlação de forças existente naquele momento.

Assim, inexistindo a necessidade de contabilizar o tempo de trabalho da mesma maneira que antes da RTT, tornou-se possível a redefinição do tempo de trabalho efetivo, via redução de pausas, do tempo de formação ou de troca de roupa ${ }^{27}$. Já os trabalhadores, conforme Melchior

26. Por exemplo, um acordo da indústria metalúrgica que previa a jornada de trabalho de $38 \mathrm{~h} 30 \mathrm{~min}$, incluindo $1 \mathrm{~h} 45 \mathrm{~min}$ de pausas, passou para as $35 \mathrm{~h}$ descontando a pausa de $1 \mathrm{~h} 45 \mathrm{~min}$, reduzindo assim a jornada de trabalho em apenas $1 \mathrm{~h} 45 \mathrm{~min}$ por mês, ao invés de $3 \mathrm{~h} 30 \mathrm{~min}$, diferença entre $38 \mathrm{~h} 30 \mathrm{~min}$ e $35 \mathrm{~h}$.

27. Em torno de $18 \%$ das empresas que passaram para 35 horas em 2000, modificaram o modo de cálculo do tempo de trabalho, reduzindo as pausas existentes, resultando, portanto, em uma redução do tempo de trabalho de apenas 8\% (Askenazy, Bloch-London e Roger, 2004). 
(2006), diante do discurso das empresas de que o aumento do custo do trabalho poderia levar a um maior número de demissões, acabaram por aceitar as estratégias por elas adotadas. Ficou assim evidente que as centrais não conseguiram dialogar com os trabalhadores, no sentido de alertá-los em relação aos riscos de uma RTT sem aumento de efetivos. Alem disso, havia uma divisão entre as centrais, em que, por exemplo, a posição da CFDT era de validar as propostas das empresas (Melchior, 2006).

Ao final desta etapa, o que pode ser observado é uma grande diversidade de modalidades de aplicação da RTT, desde negociações que praticamente não resultaram em ganho de dias de RTT, até onde ela foi implantada com geração de emprego. De acordo com a Lei Aubry I, por exemplo, os 10\% de redução da jornada de trabalho seriam traduzidos em 22 dias de não trabalho, isto é, de RTT; todavia, enquanto em algumas empresas foram definidos os 22 dias, como no setor público, em outras foram apenas 4 ou 5 dias. Na avaliação de BlochLondon, o maior número de dias de redução foi conquistado nas empresas onde os trabalhadores já tinham melhores condições de trabalho.

Após 2000, observa-se que as formas de RTT foram as mais diversas, podendo ser agrupadas em cinco grandes tipos, conforme Terssac, Thoemmes e Flautre (2004): a) liberação de meia jornada por semana ou uma jornada inteira a cada 15 dias; b) repouso suplementar que poderia se somar ao final de semana, às férias ou ser utilizado separadamente; c) redução cotidiana do tempo de trabalho; d) modulação do tempo de trabalho ou e) "contapoupança". Vale ainda frisar que, em alguns casos, essas diferentes maneiras de RTT foram adotadas simultaneamente para um mesmo trabalhador. Tal diversidade de RTT revela a necessidade de considerar não apenas a quantidade de horas que foram reduzidas, mas também a forma como o tempo de trabalho foi reduzido, considerando ainda sua regularidade e previsibilidade.

Um pequeno balanço do período nos mostra que em 2003, de acordo com Bloch-London, em torno de $70 \%$ dos trabalhadores tinham jornadas de trabalho de 35 horas, ou seu equivalente de 1600 horas por ano, com maior concentração nas empresas médias e grandes. Nas empresas com 500 ou mais trabalhadores, em média, 9 entre 10 trabalhadores apresentavam durações do trabalho de 35 horas, enquanto naquelas com 10 ou menos trabalhadores, essa taxa cai para 2 entre 10 trabalhadores. Em relação ao tempo parcial, 45\% dos trabalhadores que trabalhavam neste regime não tiveram modificação no seu tempo de trabalho e $38 \%$ tiveram uma redução na mesma proporção que a dos trabalhadores a tempo pleno. 
No que se refere ao percentual de redução do tempo de trabalho houve uma grande diferença entre as empresas que passaram às 35 horas antes de 2000, quando a ajuda pública estava vinculada à não alteração na forma de cálculo da jornada de trabalho e à geração de empregos, e aquelas que passaram após esta data. E, dessa forma, apesar da redução de 39 para 35 horas ser de 10,3\%, apenas as empresas que passaram às 35 horas antes de 2000 aplicaram esta redução. No caso das empresas que aplicaram a RTT depois de 2000, a redução foi em torno de $6,4 \%$, e de $8 \%$. E, neste caso, a diferença deve-se à redefinição do tempo de trabalho efetivo, significando a expulsão do tempo de trabalho os tempos de troca de roupa, de formação, os dias feriados ou ainda as pausas.

\section{- Empresas que passaram às 35 horas em 2000}

Em relação às empresas que passaram às 35 horas, apenas no momento da lei Aubry II, em 2000, de acordo Charpentier (et alli, 2005), praticamente todas aquelas que foram pesquisadas ${ }^{28}$ apresentavam um contexto de retração, onde estava ausente um projeto de mudança no qual se incluísse a questão da RTT. Desta forma, a RTT foi compensada, na maior parte dos casos, pela criação de novas formas de flexibilização de usos do tempo, como a redução dos dias de RTT via redefinição do tempo efetivo de trabalho e pouco controle por parte dos trabalhadores em relação ao uso dos dias ganhos com a RTT. Ademais, foi identificada a existência de flexibilidades clandestinas, como o trabalho excedente nos momentos de alta produção.

Assim, a maior diferença em relação às empresas que entraram na RTT, na lei Aubry I, foi a ausência de um projeto capaz de transformar a obrigação da RTT em oportunidade, dentro de um processo mais amplo de mudanças. Além disso, observa-se que, à exceção dos bancos, as outras empresas se localizam, na cadeia produtiva, em lugares onde elas não detêm o controle sobre o mercado, isto é, sobre a demanda ou produção. Assim sendo, para os autores, é muito menos o tamanho da empresa e mais sua posição estratégica em relação ao mercado que acaba por influenciar a existência ou não de projetos englobando a RTT. Observa-se uma fraca, ou mesmo, ausência de criação de empregos, principalmente se pensarmos que, nesses casos, houve redefinição do tempo de trabalho, reduzindo assim o tamanho da RTT e a necessidade de novas contratações que estariam em jogo.

28. Os setores pesquisados foram: comércio, banco, metalúrgico e plástico, abrangendo 6 empresas. Esta pesquisa foi realizada em duas etapas, a primeira entre setembro e dezembro de 2002 e a segunda entre outubro e novembro de 2003. 
Nas empresas que passaram para as 35 horas na lei Aubry I, até o ano 2000, em geral, as regras foram definidas de forma mais coletiva, a partir de uma negociação que buscava um pacto com os trabalhadores, vinculando as mudanças no tempo de trabalho à manutenção da remuneração, criação de emprego e aumento da produtividade. No caso das empresas que negociaram apenas na lei Aubry II, a ausência de projeto tornou mais difícil a vinculação da RTT ao aumento da produtividade, de forma que as mudanças focaram muito mais na tentativa de ter menos perdas com a RTT, gerando um conflito maior com os trabalhadores. Neste caso, o aumento do controle por parte das empresas sobre o tempo de trabalho aparece como central na reorganização, num paradoxo face ao desejo dos trabalhadores de aumentar o controle sobre seu tempo de trabalho.

Como conseqüência, um terço dos trabalhadores pesquisados estima que a passagem para as 35 horas se traduziu em uma intensificação do trabalho, sendo que a metade pensa que seria necessária a realização de uma nova organização do trabalho (Charpentier et alli, 2005). Um terço deles sente que passaram a fazer a mesma quantidade de trabalho em menos tempo; que houve redução de pausas e dos tempos de discussão coletivos; reforço do controle das horas e dificuldade para se adaptar ao aumento da carga de trabalho. Todavia, se pensarmos no tempo fora do local de trabalho, $41 \%$ dos trabalhadores entende que a RTT permitiu recuperar melhor o cansaço oriundo do trabalho. Ou seja, há uma diferença de avaliação quando o foco é o local de trabalho e fora deste, de forma que enquanto a avaliação do tempo de trabalho aparece de forma mais negativa, o aumento do tempo fora do local de trabalho aparece de forma positiva.

Vale ressaltar que o sentimento dos trabalhadores pesquisados é muito diferente em relação à empresa onde ele está alocado, dado à diversidade de formas de reorganização do tempo, mas também da função exercida. Por exemplo, no caso dos trabalhadores dos setores produtivos, $18 \%$ consideram que a nova organização do trabalho foi boa e $28 \%$ sentem que a RTT melhorou a recuperação do cansaço, fora do local de trabalho. Já os trabalhadores administrativos apresentam índices muito maiores de contentamento, $45 \%$ e $66 \%$, respectivamente. A diferença entre a quantidade de dias de RTT entre os gerentes e os trabalhadores produtivos, bem como o controle e a forma de utilizá-los, acentuam ainda mais as diferenças de percepção em relação à RTT.

Outro elemento que tem um papel fundamental no que se refere à vivência e avaliação da RTT é o tempo de trajeto casa-trabalho. Dentre os trabalhadores que levam meia hora para realizar este trajeto, $12 \%$ consideram que o trabalho está mal adaptado à RTT, e esse percentual 
de descontentamento sobe conforme aumenta o tempo de transporte, sendo de $20 \%$ dentre os que fazem este trajeto em uma hora e $40 \%$ entre os que fazem em mais de 1 hora. Por outro lado, $88 \%$ dos que moram próximos à empresa declaram que a RTT permite melhor recuperação do cansaço. Outra variável determinante está relacionada à questão financeira. Nessa pesquisa, $25 \%$ dos entrevistados dizem ter sofrido uma redução da remuneração, em função do não pagamento de hora extra, a partir da introdução da modulação (banco de horas). E mais uma vez a diferença entre as ocupações tem um papel fundamental, pois quanto mais baixa a posição na hierarquia de cargos e salários, mais a redução na remuneração é sentida. Também a questão do gênero, relacionada à profissão, tem um papel fundamental. Enquanto $35 \%$ das mulheres consideram que tiveram perdas em relação à remuneração, apenas 1 homem em cada 6 tem este sentimento.

De acordo com os autores, aqueles que sentiram ter uma redução maior da remuneração são igualmente os que avaliam que a RTT não possibilitou uma melhor qualidade de vida, pois neste caso, "tempo livre sem dinheiro é sinônimo de tempo perdido" (Charpentier et alli, 2005:55) $)^{29}$. E dentre eles, há um percentual maior de trabalhadores que desejam retornar às 39 horas. Há casos em que a questão da redução das pausas e a redefinição do tempo efetivo de trabalho acabaram por gerar um forte descontentamento por parte dos trabalhadores, por se ressentirem da falta de tempo para descansar e conversar. Mas, por outro lado, no caso de empresas em que a polivalência foi utilizada para a substituição de trabalhadores em RTT, a pausa pode ser vista como algo negativo, devido à falta de tempo para realizar todas as tarefas redefinidas pela empresa, em função da polivalência. Diante deste quadro, um dos maiores fatores de descontentamento é justamente a existência de regras muito diferentes para cada grupo de trabalhadores numa mesma empresa.

Um ano após a primeira pesquisa, no final de 2003, foi realizada a segunda fase. De acordo com os autores, dentre os resultados mais presentes estão, o aumento do absenteísmo; o aumento dos acidentes de trabalho; o aumento dos defeitos dos produtos; o aumento do controle sobre os tempos de pausa; bem como um desejo de antecipar a aposentadoria (Charpentier et alli, 2005:56). Ainda enfatizam que diversos fatores podem ser determinantes neste processo, alguns relacionados à questão do tempo de trabalho e outros ao mercado, como o aumento de exigência do cliente; a necessidade de trabalhar de forma mais intensa em função das ausências dos trabalhadores que

29. "Le temps libre sans argent est synonyme de temps perdu". 
estão utilizando seus dias de RTT ou de absenteísmo; ou ainda mudanças mais freqüentes no tipo de produto e de produção. Ao mesmo tempo, muitos trabalhadores explicitam um sentimento de que a vida não mudou muito com a RTT, porque as pressões vindas do mercado já eram sentidas antes mesmo da sua implantação e também porque entendem que o stress e o excesso de trabalho estão muito mais relacionados à falta de organização do trabalho (idem).

\section{- Reticências para entrar nas 35 horas}

No estudo "As reticências para entrar na regra das 35 horas", realizado no ano de 2003, Jorand et alli (2005) examinaram as motivações das empresas que não haviam negociado a RTT para 35 horas até o ano de $2002^{30}$. De acordo com os autores, tais empresas apresentaram características muito diferentes, englobando aquelas que: a) mantiveram a jornada em 39 horas; b) reduziram para 38 ou 37 horas, sem negociar; c) negociaram a redução para 38 horas; d) passaram para as 35 horas sem negociar e sem demandar ajuda do governo e, inclusive algumas que e) cumpriram todos os pré-requisitos para demandar a ajuda governamental, mas não o fizeram.

Os autores ressaltam que foi muito difícil separar as empresas em função da sua jornada de trabalho, dado que a prática de hora extra, mais ou menos oculta, pode levar a empresa a passar formalmente para as 35 horas, mas na realidade estar na mesma situação de uma empresa que permaneceu em 39 horas. A dúvida é ainda maior em função da dificuldade que os pesquisadores encontraram para ouvir os trabalhadores, dado que essa intenção era entendida pelos empresários como uma desconfiança em relação ao que estava sendo conversado, além do receio de perturbar a relação existente. Do mesmo modo, a existência de poucas informações contribuiu para a dificuldade em compreender a duração exata do trabalho, lembrando que estas empresas, ao não demandarem a ajuda pública, não precisaram elaborar dados para controle por parte do governo (Jorand et alli, 2005). Assim, como observam os autores, as motivações das empresas para não terem demandado a ajuda pública podem ser divididas em três grandes questões. Uma delas relaciona-se à oposição frente à redução do tempo de trabalho, outra diz respeito à recusa em negociar com o sindicato e uma terceira à não aceitação do controle governamental ou ainda a dúvida no que diz respeito ao cumprimento do acordo por parte do governo (Jorand et alli, 2005).

30. Esta pesquisa abrangeu 30 empresas com mais de 20 trabalhadores. 
Assim como as empresas que passaram às 35 horas após 2000, como vimos no item anterior, elas também não utilizaram esse momento para repensar o seu modo de organização; sua maior preocupação foi evitar uma forte perturbação nas atividades produtivas, o que explica que a medida mais utilizada tenha sido a redução diária da jornada. Sendo esta fórmula a menos utilizada nos casos das empresas que negociaram a RTT com ajuda pública, principalmente, por ser a que menos interessava aos trabalhadores. Isso porque uma redução pequena diária é menos sentida do que sair mais cedo um dia, ou trabalhar um dia a menos na semana, ou ainda juntar os dias de RTT com as férias.

Também foi observada a ausência da modulação nessas negociações, num contexto onde estudos mostram que ela está presente entre 30 a 50\% dos acordos que foram negociados entre 1996 e 2000, mas que houve igualmente, uma redução da sua aplicação ao longo desses anos. Segundo Jorand (et alli, 2005), a ausência da modulação nas empresas que não haviam negociado a RTT até 2002 pode ser explicada, sobretudo, pelo fato de que aquelas que mais necessitavam da modulação foram as que primeiro optaram para as 35 horas, via negociação. Outro fator, é a preferência dos trabalhadores por realizarem horas-extras antes da modulação e, neste caso, como não houve contra-partida de geração de emprego, e na maior parte dos casos os dias resultantes da RTT foram poucos, a solução mais "simples" para a empresa foi aplicar a redução diária da jornada e o pagamento de hora extra. Além disso, algumas empresas utilizaram também os recursos da sub-contratação e da contratação de temporários, além de ultrapassarem o horário legal de maneira informal com o objetivo de recuperar a RTT. Neste contexto, a reforma implementada pelo governo, em 2003, foi muito bem aceita por essas empresas, mesmo que isso não tenha significado um retorno às 39 horas, pois, em geral, a maior parte já tinha definido a duração do trabalho em 35 horas ou estava em vias de implementação, apesar da forte recorrência à hora extra.

No que se refere à questão da não negociação, de acordo com os autores, isto se deve a dois fatores. Primeiro, à ausência de interlocutores sindicais e de pressão por parte dos trabalhadores, o que possibilitou a manutenção do controle da reorganização do tempo por parte da empresa, e, em segundo lugar, à própria inexperiência em negociar, o desconhecimento da legislação, bem como a necessidade de tempo dedicado a este processo. Nas pequenas empresas, mesmo a presença de conselheiros jurídicos pouco ajudou, pois estes também não tinham todo o conhecimento em relação às novas regras (Jorand et alli, 2005). 
Tais fatos demonstram a complexidade da negociação em função da existência de uma grande quantidade de novas regras e normas. Demonstram também uma cultura de negociação interprofissional e por setor, mesmo que a negociação por empresa venha aumentando desde o final dos anos $1980^{31}$. Assim, a não recorrência à ajuda possibilitou às empresas a ausência de negociação, a não criação de emprego, a definição unilateral da RTT, com a aplicação da redução diária, a recorrência a ultrapassagens informais da jornada legal, bem como a possibilidade de alterar as regras do jogo a qualquer momento.

\subsection{3 - Novas mudanças de percurso: o novo governo}

É importante ressaltar que o processo de negociação continua até os dias de hoje, porque diversos dispositivos alteraram parte do que estava previsto nas leis Aubry I e II, após a eleição do governo de Jacques Chirac, em 2003. Conforme Dockès (2005), pode-se dizer que este governo buscou retornar às 39 horas, mas não de forma explícita e direta, já que se entendia que isto poderia provocar muita resistência por parte dos trabalhadores. Assim, a estratégia escolhida foi realizar etapas sucessivas de pequenas mudanças. Segundo o autor, a divisão de uma grande reforma em pequenas partes obriga aqueles que são contrários a ela ao difícil trabalho de explicação e de reconstrução, no sentido de localizar as partes no todo, tornando assim a oposição muito mais difícil.

A Lei Fillon, de 17 de janeiro de 2003: a) retirou a obrigação das empresas com até 20 trabalhadores de aplicarem a RTT; b) aumentou o limite de hora suplementar de 130 para 180 horas; c) reduziu o adicional de hora extra para 10\% nas empresas com até 20 trabalhadores e $25 \%$ para aquelas com mais de 20 ; d) possibilitou que a "conta-poupança" incluísse o pagamento dos dias trabalhados a mais e não apenas a compensação, via dias de descanso; e e) possibilitou às empresas recorrerem ao repouso no que se refere às quatro primeiras horas extras, no lugar do pagamento do adicional. Outras alterações foram implementadas em 2004, aumentando o limite de hora extra de 180 para 220 horas, e para 130 horas no caso de modulação do horário, podendo ser negociado individualmente um limite superior a este, denominado de "horas escolhidas" 32 (Melchior,2006).

A maior parte destas mudanças teve como objetivo aumentar ainda mais a liberdade para o empregador reorganizar o tempo de trabalho, facilitada ainda pela ampliação do

31. No final desta década foram 10000 acordos por empresa, por ano, aumentando a partir de 1997 com a lei Robien, e triplicando com a primeira lei “Aubry” em 1999 (Askenazy, et alli, 2004).

32. Em francês "heures choisies", ver mais detalhes no quadro no final deste capítulo. 
espaço de acerto individual entre a empresa e o trabalhador. De acordo com Freyssinet, vale ressaltar que tanto a "conta-poupança" como o regime de "horas escolhidas" buscam substituir a negociação coletiva por acertos individuais que não podem ser considerados realmente como negociações individuais. Embora num primeiro momento pudéssemos supor que tais mudanças na legislação poderiam causar um forte processo de renegociação, isso não aconteceu e por vários fatores. Seja porque as mudanças foram consideradas aquém do desejado pelos empresários; seja porque estes não quiseram "arriscar-se" a reabrir o processo de negociação, já que poderia resultar em algo menos vantajoso; ou, ainda, seja pelo reconhecimento de que a RTT já fazia parte da vida das pessoas e que, portanto, seria muito difícil voltar ao patamar anterior.

Ademais, podemos pensar ainda que a renegociação explícita não seria necessária, considerando que diversas negociações já vinham acontecendo de maneira implícita e cotidiana, como vimos anteriormente, diretamente entre a empresa e o trabalhador, sem a presença do movimento sindical. Além disso, vale ressaltar que tais mudanças aconteceram justamente no momento em que a ajuda governamental para as empresas chegou ao fim, incentivando ainda mais as empresas a tentarem outras possibilidades de flexibilização. Isto porque, as empresas que negociaram no contexto da lei Aubry I tiveram como pressuposto a não alteração da forma de contabilizar o tempo de trabalho e, com o fim deste acordo, esta regra também perde a sua validade. Desta forma, as leis, decretos e negociações explícitas, possibilitaram às empresas aumentarem a duração do trabalho, sustentados pela lógica atual, de acordo com Freyssenet, "trabalhar mais para ganhar mais", sem, com isso, atacar frontalmente a duração legal de 35 horas.

Como conseqüência, tais mudanças levaram ao aumento das disparidades entre a condição de trabalho e remuneração entre os trabalhadores das empresas com até 20 trabalhadores e demais trabalhadores de empresas maiores. Por exemplo, um adicional de hora extra de apenas $10 \%$, no caso das pequenas empresas, é muito prejudicial para os trabalhadores, considerando que justamente nestas empresas é que são feitas mais horas extras. Se somarmos essas diferenças às relacionadas ao estatuto diferenciado entre um contrato por tempo determinado e um por tempo indeterminado, temos de fato uma situação de extrema desigualdade. Fazendo um balanço, nota Bloch-London que é difícil falar sobre o regime das 35 horas porque "ela já foi destruída e habilmente reconstruída a partir de uma outra lógica", e que, do ponto de vista estatístico, frisa que as pessoas têm trabalhado, em média, 37 horas. 
No que se refere às negociações ao nível das empresas, sua análise contribui para a compreensão se essas mudanças na lei significaram alterações pontuais de aumento do tempo de trabalho ou se realmente se configurou uma nova tendência. Para tal, utilizei uma pesquisa ${ }^{33}$ que, de acordo com Bloch-London, teve como objetivo compreender se no caso da França estaria acontecendo o mesmo movimento que na Alemanha, onde a negociação da Volkswagen não foi generalizada ou se, ao contrário, estaria acontecendo um movimento em massa das empresas no sentido de renegociarem o tempo de trabalho.

A primeira constatação dos pesquisadores refere-se à dificuldade para encontrar empresas que aceitassem participar da pesquisa, demonstrando, assim, como o assunto da negociação do tempo de trabalho ainda era muito delicado. De uma forma geral, os gerentes tentavam dizer que o que houve foi apenas uma reorganização do tempo de trabalho para se adequarem às mudanças na legislação e não uma verdadeira renegociação. Além disso, tinham o receio de que a presença de um pesquisador pudesse suscitar reações por parte dos trabalhadores focalizando de novo o tema da duração do trabalho. Havia, sobretudo, uma vontade explícita de não comunicar ao exterior o que havia sido renegociado. Ultrapassados esses obstáculos, os pesquisadores chegaram a 16 empresas que haviam realizado a primeira negociação da RTT em momentos diferentes do passado (em 1996 com a Lei Robien, em 1988 com a Aubry I e em 200 com a Aubry II), e que agora estavam em processo de renegociação.

Uma primeira conclusão é que, de uma forma geral, as renegociações indicam um movimento de aumento do tempo de trabalho, mesmo que este não abranja todos os setores da empre$\mathrm{sa}^{34}$. Entretanto, salientam os autores que este movimento não pode ser generalizado para outras empresas, pois o objetivo do estudo foi de analisar apenas aquelas que haviam passado pelo processo de renegociação. No que se refere à amplitude do aumento do tempo de trabalho, enfatizam que ela é totalmente variável. Além disso, esse aumento do tempo de trabalho raramente aparece como o objetivo primeiro da renegociação. Assim, as renegociações foram realizadas abrangendo uma diversidade de temas relacionados à reorganização do tempo de trabalho, como a "conta-popança", o repouso, o vínculo de um aumento do tempo de trabalho a um

33. Esta pesquisa foi realizada entre os meses de fevereiro e junho de 2005 , em 16 empresas que haviam realizado algum tipo de renegociação sobre o tempo de trabalho após as alterações na legislação em 2003. Foram entrevistados gerentes de RH e, num segundo momento, representantes dos trabalhadores.

34. Dentre as 16 empresas pesquisadas, em 7 houve aumento coletivo do tempo de trabalho, em duas delas houve a possibilidade de aumento individual e em três foram os gerentes e coordenadores que tiveram aumento do tempo de trabalho, somando 12 empresas, em 16. 
aumento de salário, a redefinição do tempo de trabalho efetivo, sobretudo no caso das empresas que tinham passado para a RTT na Lei Aubry I (Pepin, et alli, 2006). De acordo com Pepin (et alli, 2006: 71), a estratégia das empresas de não focalizar o debate em torno do aumento do tempo de trabalho tem como objetivo evitar que a renegociação seja vista pelos trabalhadores como uma "regressão social", podendo gerar tensões e conflitos.

Destacam também uma grande diversidade de modos de utilização do tempo de trabalho, resultante de diferentes combinações entre reduções semanais e dias de repouso ${ }^{35}$. Mas, vale ressaltar que os autores fazem referência às horas negociadas nos acordos, entretanto, as horas efetivamente trabalhadas podem variar a depender, por exemplo, da quantidade de horas extras formais ou informais.

No que se refere às motivações das empresas ao demandarem a reabertura do processo de negociação, os autores constatam que essa decisão não foi jamais o resultado de um único determinante, englobando motivações econômicas, organizacionais, jurídicas, simbólicas e sociais, relacionadas à remuneração, ao trabalho ou à vida fora do trabalho. Essas últimas são raramente colocadas como definidoras da renegociação, elas aparecem, na maior parte dos casos, como complementares da discussão principal que, em geral, gira em torno do aumento da remuneração ou da possibilidade do trabalhador escolher seu tempo de trabalho de maneira individual, via "conta-poupança" ou "horas escolhidas". Na prática, são sempre relacionadas ao aumento do tempo de trabalho.

Em relação à motivação econômica, relatam os autores que, apesar de sempre estar presente, na maior parte dos casos, ela convive com outras motivações que servem para reforçar a necessidade de renegociação. Por exemplo, a questão organizacional está muito presente no sentido de poder corrigir os "efeitos negativos" resultantes da primeira negociação, como a dissociação entre os tempos coletivos e individuais, a dificuldade para gerenciar as diversas formas de flexibilidades criadas, entre outras. Assim, a tendência verificada buscou reduzir a diversidade de formas de flexibilização, com a definição de regras mais coletivas, reduzindo a complexidade de gestão da flexibilidade, retornando, em alguns casos, a formas de flexibilização mais "antigas", como o contrato por tempo determinado, o trabalho temporário ou ainda as horas extras (Pepin, et alli, 2006). Ao mesmo tempo, as empresas possibilitam a introdução de certa escolha, por parte dos trabalhadores, entre permanecer com a mesma organização do tem-

35. Como consequência, havia uma variação entre 174 e 228 dias de trabalho por ano e 1432 e 1750 horas, concentrando-se entre 1580 e 1600, ou seja, muito próximo à referência legal 
po de trabalho ou alterá-la, o que demonstra certa contradição com relação ao esforço em ampliar as formas coletivas de organização da duração do trabalho. Questionam os autores se isto não levará as empresas a retomarem o processo de negociação mais tarde.

Outra observação é a ausência da discussão sobre emprego nesses processos de renegociação, confirmando a hipótese de que o emprego só fez parte dos acordos iniciais em função da legislação sobre ajuda financeira, de forma que o fim da ajuda significou o fim da manutenção ou geração de empregos.

\section{2 - Vivências das reduções do tempo de trabalho}

Apesar de já ter sido objeto de discussão ao longo deste capítulo, volto ao tema a fim de apresentar de forma mais detalhada como as mudanças estruturais no tempo de trabalho repercutiram sobre os modos de vida dos trabalhadores, buscando compreender se tais mudanças alteraram ou não, do ponto de vista qualitativo e quantitativo, a maneira como as pessoas vivem o tempo.

Como já vimos nas discussões anteriores, estamos diante de uma grande diversidade de modos de aplicação da RTT, em função da multiplicidade de opções de gestão do tempo de trabalho definidas em lei e negociadas no âmbito das relações de trabalho. Assim, falar sobre os usos que os trabalhadores fizeram do seu tempo liberado está muito relacionado ao modo pelo qual a RTT foi aplicada. Isto é, se ela significou uma pequena redução diária, uma tarde livre por semana, um dia inteiro a cada 15 dias, ou ainda alguns dias de RTT, além de saber se há modulação de horário, "horas escolhidas" ou "conta poupança". Além de, por certo, relacionar-se a diversos determinantes como nível de escolaridade, gênero, renda ou experiência de vida. Finalmente, temos que considerar a questão da remuneração, pois esta é uma variável muito importante na definição das vivências temporais cotidianas, considerando que alguns salários ficaram por um período sem reajuste e algumas remunerações foram reduzidas em função da implantação da modulação, significando o não pagamento de hora extra.

De uma maneira geral, mais da metade dos trabalhadores que tiveram a RTT avaliam positivamente esta mudança. Os dados variam um pouco a depender da pesquisa, tendo a avaliação positiva uma variação que vai de $65 \%$ a $68 \%$. Segundo sondagem do Ifop ${ }^{36}$, realizada no

36. 1'Institut Français d'Opinion Publique. 
ano de 2001, as 35 horas tiveram um reflexo positivo para $65 \%$ dos trabalhadores do setor privado e $64 \%$ no setor publico. Por outro lado, um percentual menor de trabalhadores avaliou que após a RTT sua condição de trabalho havia melhorado, $38 \%$ no setor privado e $40 \%$ no setor público. De acordo com a pesquisa realizada pela Dares, em 2001, 59\% dos trabalhadores pesquisados julgavam que sua vida cotidiana havia melhorado graças à RTT e 13\% que ela havia piorado. Porém, do ponto de vista do trabalho, apenas $25 \%$ afirmavam ter melhorado sua condição de trabalho, $29 \%$ estimavam que ela havia piorado e o restante que não houve modificação. Ou seja, quando se trata de avaliar o que aconteceu especificamente com o seu tempo no local de trabalho, observamos que as avaliações são menos positivas do que quando a análise se refere à vida de uma maneira mais abrangente.

As avaliações diferenciam-se, ainda, se considerarmos o perfil dos trabalhadores. Nesse caso, veremos que dentre aqueles que entendem que sua condição melhorou temos trabalhadores do setor administrativo e gerentes da empresa. Isto porque tais grupos negociaram com maior freqüência a RTT em forma de dias descanso e, ao mesmo tempo, são trabalhadores que, de uma forma geral, têm maior margem de manobra para organizar seu trabalho, mesmo que, no caso dos gerentes, eles continuem a praticar longas jornadas de trabalho. Por outro lado, os que se mostraram insatisfeitos com as mudanças no tempo de trabalho eram, na maior parte, trabalhadores que se encontravam mais abaixo na estrutura de cargos e salários. De uma forma geral, eram menos qualificados e com menores remunerações, podendo ainda estar sujeitos a situações como: ausência de controle sobre o seu tempo de trabalho; ausência de dias ou poucos dias de RTT, em função da redefinição do tempo de trabalho; RTT em forma de descanso diário; forte intensificação do trabalho em função da não contratação ou ainda redução da remuneração, dado que a modulação implica o não pagamento de hora extra.

Ressalta Viard (2001) que a redução do número de horas diárias é a que menos dá ao trabalhador a sensação de redução do tempo de trabalho, sendo que, neste caso, $48 \%$ deles entendem que a redução em nada alterou o seu tempo de trabalho ou de não trabalho (CDFT, 2001, in Viard, 2001). Ainda de acordo com o autor, há dois extremos no que se refere à forma da RTT: de um lado, a maior parte formada por operários qualificados e não qualificados que a têm na forma de redução diária; e, no outro, gerentes que têm uma RTT na forma de semanas de folga, férias suplementares ou ainda metade ou 1 dia de RTT. Soma-se o fato dos gerentes terem um maior controle sobre a organização do seu tempo de trabalho, o que contribui para a sua maior satisfação. É muito provável, ainda, que, mesmo antes da RTT, esse grupo já apresentasse 
um grau maior de satisfação. Outra questão importante é que os trabalhadores, de uma maneira geral, não perceberam as 35 horas como uma demanda própria. No início do processo de negociação, a RTT foi muito mais sentida como algo a que as empresas eram contrárias ou como uma reivindicação sindical ligada ao desemprego, do que como uma demanda dos trabalhadores (Rozès, 1986 in Viard, 2001).

No que se refere à ocupação do tempo liberado, a constatação mais geral é que após a RTT as pessoas passam mais tempo fazendo a mesma coisa, ou seja, o tempo liberado não é utilizado para a realização de atividades diferentes, mas para a dedicação de mais tempo às atividades já realizadas (Maresca, 2004 e Viard 2002). Isso contradiz a idéia de que o aumento do tempo livre levaria as pessoas a se dedicarem a outras atividades como a participação política ou o desenvolvimento intelectual; ou, ainda, a argumentação de que a RTT levaria a uma melhor divisão das tarefas domésticas entre homens e mulheres. Ao final, observou-se que as mulheres continuavam a dedicar muito mais tempo aos filhos do que os homens.

Além disso, de acordo com o argumento governamental referente à "conta-poupança", esta incentivaria as pessoas à auto-gestão do seu tempo, definindo o melhor momento para trabalhar ou para se dedicar às outras atividades, diferentemente do tempo uniforme e imposto para todos. Afinal, conforme previsto na lei, é do trabalhador a decisão de abrir ou não abrir uma "conta-poupança", bem como a quantidade de horas a ser nela depositada ou ainda o momento para utilizá-la. No entanto, pouco tempo depois, observou-se que não foi isso que aconteceu; na prática, não são os trabalhadores que decidem livremente abrir ou não uma conta, muito menos a hora para utilizar o saldo positivo (Terssac, Thoemmes e Flautre, 2004). Na pesquisa realizada por estes autores, com 135 acordos sobre "conta-poupança", no que se refere à diferenciação entre sexos, do total de trabalhadores que abriram uma CET, 20\% eram mulheres, e estas representam $37 \%$ das pessoas que utilizam sua conta para consumi-la em menos de um mês. Por outro lado, $86 \%$ das pessoas que a transformam entre três a seis meses de descanso são homens. Assim, não é difícil formular a hipótese de que as mulheres demandam a utilização da conta muito mais com o objetivo de assegurar a continuidade da atividade doméstica, isto é, para realizar atividades do dia a dia ou ainda para resolver problemas pontuais, do que para realizar novas atividades.

Maresca (2004), analisando a maneira como as pessoas utilizaram o tempo livre ganho com a RTT ${ }^{37}$, observa que as variáveis como nível de qualificação ou remuneração, idade, fun-

37. A classificação realizada pela autora considera: tempo de família; casa; esportes e jogos; viagens; saídas culturais e sociabilidade e engajamento militante. Sendo que a diferença de investimento em cada um desses pólos está relacionada à idade e portanto ao ciclo de vida, ao gênero, à remuneração, ao local de residência, bem como à qualificação. 
ção na empresa ou sexo contribuem para diferentes vivências temporais. Observa a autora que tanto os homens como as mulheres utilizaram o seu tempo livre, ganho com a RTT, muito mais para ampliar o tempo dedicado às atividades habituais do que às novas. Isto é, os homens dedicam mais tempo ao esporte, bricolagem e atividades associativas e as mulheres às atividades de organização da casa e educativas; e, ainda, tanto os homens como as mulheres passam mais tempo com os filhos, mesmo que as mulheres passem um tempo ainda maior.

De acordo com a enquête "Condições de Vida e Aspirações dos Franceses"38, realizada em junho de 2002, após a RTT, 47\% dos trabalhadores franceses passaram a descansar mais, $45 \%$ a se ocupar da família, $41 \%$ a realizar trabalhos de bricolagem e jardinagem, $34 \%$ a receber amigos/família ou visitá-los, 33\% a fazer compras e 31\% passaram a ver mais televisão. Se excluirmos a atividade de receber e visitar amigos, as atividades consideradas como de lazer típico, como passear, viajar, praticar esportes, só aparecem no final lista, com apenas 10 e 20\%.

Se olharmos para o perfil dos entrevistados, veremos que há diferenças importantes. Por exemplo, enquanto no caso dos gerentes, $25 \%$ passam a praticar mais esporte e $27 \%$ a viajar mais, para os classificados como "não gerentes", o aumento é bem menor para estas atividades de lazer. Por outro lado, enquanto no caso dos primeiros, $25 \%$ passam a ver mais televisão, no segundo caso, este número aumenta para $35 \%$. Um outro item que chama atenção é o tempo dedicado às associações, com um aumento de $10 \%$ no geral. Para os moradores da região de Paris este aumento foi de $18 \%$; já para os gerentes de $12 \%$; enquanto que para os não gerentes foi de $8 \%$. Entretanto, não há informações sobre a que tipo de associação cada grupo passou a consagrar maior tempo.

Maresca (2004) observa ainda que uma das mudanças mais marcantes refere-se ao modo de utilização dos dias de férias: passaram a fazer uma substituição de viagens mais curtas no lugar de uma viagem por ano e mais longa. Por exemplo, entre 1994 e 2000, entre os trabalhadores do setor administrativos a taxa passou de 65 para $63 \%$, enquanto para outros trabalhadores, o percentual variou de 48 para $45 \%$. Em relação aos dias de férias, existe também uma redução do número de dias de viagens, que passaram de 19 dias, em 1981, para 16 dias, em 1980, e apenas 10 dias, em $2000^{39}$, mesmo após o aumento de uma semana de férias ocorrido no ano de 1981. Segundo a autora, o que pode explicar a queda do percentual dos trabalhadores que viajam de férias é a redução ou estagnação da remuneração após a RTT. Ainda segundo a pesquisa, $20 \%$ dos trabalha-

38. "Conditions de Vie et Aspirations des Français".

39. Dados da pesquisa INSS e enquête de "déplacements touristiques". 
dores dizem dedicar-se ao tempo de trabalho durante as férias, e ainda, $40 \%$ dos trabalhadores revelam consagrar um determinado tempo ao trabalho no final de semana, sendo esta taxa de $46 \%$ para os homens e $34 \%$ para as mulheres.

Assim, podemos pensar que o aumento a redução do tempo dedicado ao trabalho não conduz, necessariamente, a uma reorganização da estrutura de lazer, dado que esta depende de muitos outros fatores, como por exemplo, a intensidade do tempo de trabalho após a RTT; a transformação da RTT em descanso diário, semanal, mensal ou anual; a governabilidade que os trabalhadores têm em relação à definição dos dias de RTT; a estagnação ou a redução da remuneração, em função da modulação e o não pagamento de hora extra. Como visto, todos esses fatores variam em relação aos atributos pessoais e sociais, como idade, gênero, cultura, hábitos, renda, entre outros.

No caso dos gerentes, por exemplo, 50\% deles puderam determinar seus horários de trabalho e não trabalho, sendo que este percentual é de apenas 5\% no caso dos trabalhadores do setor administrativo e produtivo. E ainda, enquanto $30 \%$ dos gerentes podem formar um "bloco de tempo livre", para o segundo grupo citado, esta possibilidade aparece apenas para $14 \%$. E, com certeza, a sensação de ter mais tempo livre é vivida mais intensamente por aqueles que conseguem juntar dias de não trabalho, do que pelos que entram ou saem do trabalho com 15 minutos de diferença, todos os dias. Em relação ao controle, de acordo com Maresca, a utilização da anualização ou modulação do tempo de trabalho também é outro fator que altera fortemente as percepções dos trabalhadores, considerando que esse modelo foi mais aplicado para aqueles do setor administrativo e produtivo e que, na maior parte dos casos, é a empresa quem define quando e quanto não trabalhar. De forma que os tempos liberados "no último momento não são vividos de maneira positiva" (2004:73), porque este tempo não planejado acaba por se transformar em um tempo de repouso ou de atividades domésticas.

Finalmente, há que se levar também em conta, na sociedade francesa ou dentro de cada grupo específico, como se dá a relação entre os diversos tempos sociais: o tempo de trabalho, o tempo da família, do estudo, do lazer. Afinal, mesmo se consideramos a centralidade do tempo de trabalho, não podemos pensar que os outros tempos exercem um papel unicamente adaptativo. Por exemplo, se pensamos que o tempo de lazer está cada vez mais relacionado ao mercado, isto é, ao gasto monetário, isto significa uma maior dependência do tempo livre ao tempo de trabalho, ou melhor, à remuneração ganha neste tempo. Mas, ao mesmo tempo, uma sociedade com um estado de bem estar sólido e inclusivo, tem um maior poder de possibilitar menor tempo dedicado ao trabalho, mesmo que isto signifique para os trabalhado- 
res uma redução da remuneração. Por outro lado, a ausência de um estado de bem-estar pode pressionar os trabalhadores a dedicarem mais tempo ao trabalho, seja via utilização da hora extra, do trabalho noturno ou, ainda, pela obtenção de uma segunda ocupação. Assim, podemos pensar que uma combinação entre diferentes fatores leva os diversos grupos, nas diversas sociedades, nos diferentes momentos históricos, a demandarem mais ou menos tempo de trabalho, mais ou menos tempo livre.

\section{3 - Considerações finais}

Ao longo deste capítulo, foi possível compreender que a discussão sobre o tempo de trabalho na França passou por diversas mudanças. A análise deste processo histórico explicitou o papel do Estado na construção dos limites para a gestão do tempo de trabalho, movimento que segue até os anos 80 , quando se iniciou o que alguns autores denominaram como desconstrução desse processo. Foi possível perceber também a mudança no conteúdo e na forma da discussão sobre o tempo de trabalho que segue presente até os dias atuais.

O marco principal dessa mudança foi a lei de 1982, quando o poder público definiu a redução da duração do trabalho de 40 para 39 horas, com o objetivo manifesto de atingir as 35 horas, introduzindo a possibilidade da empresa reorganizar o tempo de trabalho. O segundo momento é marcado pela lei de fevereiro de 1986, quando a RTT deixa de ser o objetivo principal e transforma-se numa contrapartida aos novos modos de reorganização do tempo de traba1ho, enquanto vinculada ainda à criação de emprego. O início dos anos 90 marca uma terceira etapa, quando a relação entre emprego e flexibilidade na gestão do tempo de trabalho, passa ao centro da discussão pública, como pode ser visto no debate em torno da lei qüinqüenal de 1993, onde a questão da redução da jornada de trabalho tem um espaço reduzido. A quarta etapa iniciase em 1998 com a discussão sobre a redução do tempo de trabalho de 39 para 35 horas, a partir das negociações em torno das leis Aubry I (1998) e II (2000). E creio ser possível incluir ainda uma quinta etapa, em 2002, marcada por um conjunto de leis que tiveram como objetivo aumentar a duração do trabalho, buscando restabelecer as 39 horas, ainda que sem assumi-lo de uma maneira explícita. De acordo com Freyssenet, a lógica nesse momento passa a ser "trabalhar mais para ganhar mais". 
A construção temporal atual na sociedade francesa tem vinculado três fatores no que se refere ao tempo de trabalho: a redução do tempo de trabalho, a criação de emprego e a redução dos limites impostos ao capital para gerir o tempo do trabalhador. Mostramos neste capítulo que esse processo de construção das mudanças na legislação tem ocorrido a partir de negociações iniciadas pelo governo, o que tem estimulado os demais atores sociais a fazer parte deste processo. Também observamos que, do ponto de vista do conteúdo, a redução do tempo de trabalho deixou de ser um tema discutido em si mesmo para se transformar em moeda de troca, seja pela flexibilização do tempo de trabalho, seja pela criação ou manutenção do emprego. Nesta discussão, dois pontos mereceram maior destaque: a grande diversidade de processos e sobretudo resultados da RTT, levando portanto a vivências totalmente diferentes por parte dos trabalhadores; e o espaço cada vez maior ocupado pela flexibilização do tempo de trabalho.

No que se refere à diversidade, foi possível observar que os processos resultaram em reduções unilaterais -que praticamente não significaram ganho de dias de RTT -, e também em negociações que levaram à geração ou manutenção do emprego. Diferenças que, do meu ponto de vista, foram fruto dos diversos momentos nos quais as empresas ou os setores adotaram a RTT: se antes de 2000, quando a ajuda pública estava vinculada à não alteração na forma de cálculo da jornada de trabalho e à geração de empregos; ou após, quando essas limitações desapareceram. Outro fator que levou a essa grande diversidade está relacionado à decisão do setor ou da empresa em adotar a RTT com a ajuda governamental e, portanto, seguir as regras, ou adotar a RTT sem a ajuda do governo. Vimos que muitos setores e empresas fizeram a passagem para as 35 horas antes de 2000, mas sem recorrer à ajuda governamental o que possibilitou não atender as regras definidas em lei. Dessa forma essas empresas puderam tanto recalcular o tempo efetivo de trabalho como não gerar ou manter empregos.

Um terceiro ponto que, como os outros, não pode ser tomado de maneira isolada, já que influencia e é influenciado pelos fatores que citei anteriormente, está relacionado à correlação de forças existentes entre os diferentes atores sociais - governo, trabalhadores e empregadores. Assim, onde havia maior organização dos trabalhadores, houve maior pressão para a abertura do processo de negociação e para a inclusão das demandas dos trabalhadores. O que resultou em acordos muito diferentes mesmo dentre os setores e empresas que realizam a RTT no mesmo momento, indicando que os melhores acordos foram conquistados justamente naqueles setores ou empresas em que os trabalhadores já tinham melhores condições de trabalho. 
Esta situação explicitou ainda mais a importância de uma mudança na legislação sobre a redução da jornada de trabalho mas, ao mesmo tempo, a sua limitação. Tanto do ponto de vista do seu próprio conteúdo como dos resultados, pois ambos estão diretamente relacionados à correlação de forças existentes na sociedade. As próprias mudanças observadas no intervalo entre as leis Aubry I e II foram fruto da avaliação governamental sobre a correlação de forças desfavorável naquele momento, fazendo com que a ajuda governamental fosse ampliada mesmo para aquelas empresas que não mantiveram ou geraram emprego. Isto porque foram reduzidas as manifestações dos trabalhadores e do movimento sindical a favor da redução da jornada de trabalho, apesar de todos serem a favor.

Essas diferenças no conteúdo das negociações não são evidentes apenas quando comparamos uma empresa a outra mas, igualmente, quando observamos cada uma das empresas. Diferenças na forma de aplicação da RTT que levou a vivências temporais cotidianas totalmente desiguais entre os trabalhadores de uma mesma empresa. Dependendo da função e do cargo, por exemplo, o número de dias de RTT ou mesmo a sua forma de aplicação foram bastante distintos. Assim, gerentes que já tinham maior controle sobre o seu tempo de trabalho passaram ainda a ter controle sobre o momento e o modo de utilizar os dias de RTT. Isso demonstra que a forma de aplicação da RTT manteve as desigualdades já existentes entre setores, empresas ou mesmo funções. O que também nos chama a atenção para o significado das negociações ocorrerem de forma cada vez mais descentralizada, isto é, por empresa, ao mesmo tempo em que é reduzido o número de representantes sindicais nos locais de trabalho.

A RTT manteve as diferenças dentro dos locais de trabalho e, igualmente, as diferenças existentes fora dos locais de trabalho. Assim, ao analisar esses fatores do ponto de vista das vivências temporais cotidianas fica explícito que o aumento do tempo livre por si só, não altera os hábitos e os valores das pessoas. De forma que o tempo livre conquistado foi utilizado, na maior parte das vezes, para se fazer o que já se fazia, sem alterar, inclusive, a divisão sexuada do tempo dedicado ao trabalho doméstico. Assim, as mulheres, por exemplo, demandaram a utilização da "conta popança" muito mais com o objetivo de manter a continuidade da atividade doméstica e de educação dos filhos do que para qualquer outra atividade.

Outro ponto que merece destaque na discussão sobre a redução do tempo de trabalho na França, é o espaço cada vez maior ocupado pela flexibilização. Pois, como já discutido anteriormente, para melhor compreender os impactos da flexibilização no tempo do trabalhador, nos perguntamos quem define quando ele irá trabalhar a mais e a menos. Como vimos, é predomi- 
nantemente o desejo dos empresários que demanda e orienta a flexibilização do tempo dos trabalhadores em função da flexibilização desejada para a produção. Para o trabalhador, como conseqüência, o tempo de trabalho passa a ser diverso, diferente, desigual ao longo do dia, da semana, do mês, do ano ou da vida. Mas, sobretudo, o novo é que seu tempo de trabalho tornase cada vez mais imprevisivel. E se o tempo de trabalho passa a ser mais imprevisível, consequentemente, o mesmo ocorre com o tempo de não trabalho, pois como programar um se o outro pode mudar a qualquer momento e a partir da necessidade do outro?

Todavia, é interessante observar que, tanto no discurso do Estado como em grande parte do discurso do setor patronal, a criação das diferentes formas de flexibilização do tempo do trabalhador na França foi ressaltada como necessidade do mercado, algo que tem vida própria, ou ainda, como uma possibilidade para o trabalhador escolher o seu tempo de trabalho. Aliás, a palavra escolha tem sido muito freqüente nessas discussões, desde a introdução do trabalho a tempo parcial, inicialmente chamado de temps choisir $^{40}$ (Favennec-Héry, 2000). Mas como podemos chamar o tempo parcial de um tempo escolhido, quando $40 \%$ das pessoas que estão nessa situação gostariam de passar para tempo pleno? (Bloch-London, entrevista). Ou ainda na discussão da "conta poupança", que de acordo com a lei, tem por objetivo "permitir ao trabalhador que o deseja" guardar dias de folga remunerados em uma poupança, podendo utilizá-lo em um outro momento. Este novo modo de organização do tempo de trabalho começou a ser discutido justamente a partir da demanda de empresas que buscavam resolver os seus problemas. $\mathrm{O}$ mesmo pode ser visto na lei sobre as "horas escolhidas", definindo que o trabalhador poderia, "individualmente", efetuar mais hora extra do que o previsto em lei ou em acordo coletivo.

E esta mesma discussão foi observada na forma de utilização dos dias de RTT, resultantes da redução do tempo de trabalho para as 35 horas semanais, pois, de acordo com a lei, uma parte desses dias deveria ser escolhida pela empresa e a outra pelo trabalhador. Entretanto, do que pudemos observar nas negociações por empresa, sobretudo as que passaram para as 35 horas sem a ajuda financeira do governo - em muitos casos é a empresa que realmente escolhe quando o trabalhador irá utilizar estes dias, implícita ou explicitamente.

Enfim, a forma como tem se dado a discussão da RTT na França, considerando a participação do diferentes atores sociais, seus argumentos, bem como os diferentes processo de negociação que se desenvolveram ao nível macro e micro, é muito importante para melhor compre-

40. Tempo escolhido. 
ender a realidade brasileira. Além disso, como ressaltado por Grossin (1991), a possibilidade de relativisar a nossa própria cultura temporal é simplesmente olhar para as outras culturas. Assim, a realização desta análise mostrou-se essencial para analisar como as discussões em torno do tema do tempo de trabalho tem se dado, como veremos no capítulo a seguir, considerando algumas indagações: Qual o espaço ocupado pela discussão da redução da jornada de trabalho? E a flexibilização? Como os diversos atores têm participado dessa discussão? Ela tem se dado mais no nível macro-social ou micro, isto é por empresa. 


\section{Quadro resumo: regras vigentes sobre o tempo de trabalho na França}

a) Duração legal, limite de horas e repouso $(1998,2000)$

A duração legal do trabalho ${ }^{1}$ foi definida pela Lei Aubry I (1998) em 35 horas semanais. Ou em 1600 anuais, no caso de anualização, a partir da Lei Aubry II (2000).

O limite legal de horas, a partir da qual "nenhum trabalho efetivo pode ser demandado", é de 10 horas por dia; 48 horas por semana ou 44 horas em média para um período de 12 meses consecutivos. Incluído um repouso diário de 11 horas, no mínimo, e de 24 horas semanal e ainda 20 minutos de pausa quando o trabalho for de 6 horas.

\section{b) Tempo de trabalho efetivo (1998)}

O tempo de trabalho efetivo foi definido pela Lei Aubry I como o período "no qual o assalariado deverá estar à disposição do empregador, tendo como obrigação se conformar às suas diretivas sem poder se consagrar livremente às ocupações pessoais". Assim, "o tempo de refeição e de pausas são considerados como tempo de trabalho efetivo". Por outro lado, salvo negociação em contrário, "não se constitui um tempo de trabalho efetivo os consagrados ao tempo de troca de roupa", a não ser no caso desta troca de roupa estar prevista nas regras de trabalho. E ainda, o tempo de "trajeto profissional para chegar ao lugar de execução do contrato de trabalho não é um tempo de trabalho efetivo" mas, no caso deste trajeto ser maior do que o tempo normal, ele deve ser objeto de uma contrapartida seja sobre a forma de repouso ou financeira, determinada por negociação (Ministère de l'Emploi, de la Cohésion Sociale et du Logemente, 2006)

\section{c) Horas de equivalência:}

As chamadas heures d'équivalence são freqüentes em algumas profissões - como os trabalhadores da saúde, de institutos de beleza, de hotel e refeição- onde os trabalhadores podem estar submetidos à um tempo de trabalho onde estão incluídos tempos em que não há a realização de trabalho. Neste caso a duração legal do trabalho é superior a 35 horas, mas é entendida como equivalente às 35 horas. Estas horas serão remuneradas conforme as negociações coletivas.

\section{d) Horas de sobre aviso:}

As horas astreintes são aquelas quando o trabalhador "sem estar à disposição permanente e imediata do empregador, tem a obrigação de ficar no seu domicílio ou próximo a este, a fim de estar pronto a intervir para efetuar um trabalho". Estas horas, quando não trabalhadas, serão descontadas das durações mínimas de repouso e, quando trabalhadas, serão consideradas como tempo de trabalho efetivo. Suas regras serão definidas por negociação coletiva.

\section{e) Tempo parcial:}

O tempo parcial é definido como sendo aquele inferior à duração legal de 35 horas, em função de norma européia. O numero de hora extra não pode ser superior à décima parte da duração semanal ou mensal contratada e, acima deste "limite" as horas extras devem ser pagas com adicional de $25 \%$. Sendo que o tempo parcial não pode ser modulado. Em 1993, a nova lei possibilitou a utilização do tempo parcial de maneira variável no ano, permitindo assim ampla margem de opções e vantagens, vinculando a flexibilidade interna e externa do tempo de trabalho em um único dispositivo, isto é, o tempo parcial anualizado.

(continua)

1. Vale esclarecer o papel que a lei exerce nas relações de trabalho na sociedade francesa, considerando que ele se diferencia muito do caso da sociedade brasileira. Refiro-me ao fato de que a duração legal do trabalho é uma duração de referência. Assim, não se trata de uma duração mínima, de forma que os trabalhadores podem ser empregados a tempo parcial, nem tampouco máxima, dado que estes podem realizar hora extra, no limite do previsto pela lei ou por convenção coletiva. 


\section{Quadro resumo: regras vigentes sobre o tempo de trabalho na França}

Já em 1998, houve uma importante mudança na lei do trabalho parcial anualizado, onde a exoneração dada às empresas passou a ser vinculada à existência da demanda do trabalhador por este tipo de contrato, buscando assim diferenciar o bom do mau tempo parcial (Favennec-Héry, 2000). Entretanto esta diferenciação foi totalmente abandonada pela nova lei, no ano de 2000.

\section{f) Hora extra - limite e adicionais (1998, 2000, 2003 e 2004).}

De acordo com a lei, é considerado como hora extra, as horas realizadas acima de 36 horas semanais ou 1652 anuais, para as empresas com 20 ou menos trabalhadores ${ }^{2}$ e, para as outras empresas, acima de 35 horas semanais ou 1607 anuais $^{3}$. O limite de horas extras é definido por negociação e, na ausência desta, o limite legal foi definido em 130 horas, na lei Aubry I, 180 pela Lei Fillon e para 220 horas, por um decreto de 2004. Sendo que no caso de aplicação de uma forte modulação de horário, acima dos limites de 31 (mínimo) e 39 (máximo), esse limite reduz para 130 horas. O adicional também deve ser negociado, respeitando um limite mínimo de $10 \%$. Na ausência de negociação, o adicional é de $25 \%$ para as 8 primeiras horas e $50 \%$ para as demais.

\section{g) Horas escolhidas - heures choisies (2005):}

A lei de 31/03/2005 criou uma nova regra, onde o trabalhador, individualmente, mas a partir de regras definidas coletivamente, pode efetuar heures choisies, isto é, pode escolher realizar horas extras acima do limite legal ou convencional, à condição de não exceder o duração máxima do trabalho.

\section{h) Conta poupança - CET (1994, 2005):}

Instituída pela lei de julho de 1994, a Compte épargne-temps - CET, possibilita aos trabalhadores acumular dias de folga remunerados ou realizar uma "poupança" (épargne) em dinheiro, sendo que as regras de conversão devem ser definidas por acordos coletivos. Esta conta é uma poupança que pode ser alimentada por horas resultantes do trabalho em feriados, férias ou de hora-extra. Primeiramente, o tempo de trabalho "depositado" nesta conta poderia ser utilizado somente como repouso compensador, no limite de 5 anos para a estocagem dessas horas trabalhadas a mais e não compensadas. A partir da lei de 31/ 03/2005, essas horas podem ser compensadas como repouso - como licença parental de educação, como ano sabático, para criação de uma empresa. Ou ainda, como tempo de formação fora das horas de trabalho, no limite de 80 horas por ano ${ }^{4}$ (Ministério do Trabalho, 2006), passagem para tempo parcial, mas também convertidas como remuneração (a exceção da $5^{\mathrm{a}}$ semana de férias). Também o limite de 5 anos é eliminado de forma que estas horas a mais, podem ser convertidas no tempo que falta para o trabalhador iniciar a aposentadoria. (Économie et Statistique, 2004).

\section{i) Duração do trabalho para os gerentes - "forfait" (2000 e 2005):}

Em janeiro de 2000, na lei Aubry II, foi criada para os gerentes, uma outra forma de contabilizar o tempo, denominado forfait. De acordo com a explicação dada pelo Ministério do Trabalho (2006), o forfait permite "simplificar a gestão administrativa do pagamento", a partir de uma remuneração sistemática de um numero de hora extra, considerando seu adicional, realizadas regularmente, a partir de uma duração negociada de trabalho, seja em horas ou em dias.

2. Este limite foi fixado pela lei de 31/03/2005, no valor de 1652 horas até o ano de 2008 . Após esta data passa a valer a mesma regra já prevista para as empresas com mais de 20 trabalhadores.

3. A exceção, independente do tamanho da empresa, é o caso de gerentes que utilizam o forfait, como veremos mais adiante.

4. Conforme artigo L.930-1 do Código do Trabalho, previsto na lei de 2004. 


\section{Quadro resumo: regras vigentes sobre o tempo de trabalho na França}

Apesar de mantido o limite de 220 horas extras por ano, de acordo com Dockès (2005), o forfait, via negociação coletiva, pode levar ao trabalho de até $12 \mathrm{~h} 20$ por dia, 57 horas por semana ou 218 dias por ano. Além disso, a partir da lei de março de 2005, os gerentes podem trabalhar acima do forfait diário ou semanal, podendo receber seja na forma de repouso, de ser enviada à CET ou, ainda, na forma de pagamento. Mas este será recebido com adicional. Assim, conforme Freyssinet (2006), os gerentes demandaram à Corte de Cassação a anulação desta lei argumentando que ela viola o limite máximo de duração do trabalho.

Esta regra, a partir de 2005, passa a ser válida também para as “pequenas e médias empresas”, no caso de trabalhadores que, mesmo não sendo gerentes tenham uma duração do trabalho que não possa ser predeterminada e que o trabalhador disponha de uma "real autonomia na organização do emprego do seu tempo de trabalho" (Ministério do Trabalho, 2006).

\section{j) Modulação (1982, 1986,1987):}

O funcionamento da modulação é muito parecido com o "banco de horas" no Brasil. Sua forma de organização do tempo de trabalho comporta a realização de uma jornada de trabalho irregular, evitando assim o pagamento de hora-extra. Para ser aplicada na França ela deve ser objeto de negociação coletiva tanto por setor como por empresa. Está previsto na legislação o limite máximo de 1607 horas por ano, mantidos os limites diários e semanais já citados anteriormente, bem como o limite de 220 horas extras por ano.

\section{h) empresas com 20 trabalhadores ou menos (2005)}

No caso destas empresas as horas extras são contabilizadas somente a partir da $37^{\mathrm{a}}$ hora e até a 39 , sendo a majoração limitada a $10 \%$, e não mais $25 \%$. Provisoriamente, os trabalhadores destas empresas poderão, na ausência de acordos coletivos, abrir uma CET e renunciar a até 10 dias de RTT por ano, tendo como contrapartida um aumento salarial de ao menos 10\%. E ainda, na ausência de delegado sindical, um trabalhador mandatário pode realizar o acordo sobre a criação da CET. 


\section{TEMPO DE TRABALHO: A EXPERIÊNCIA BRASILEIRA RECENTE}

imos nos capítulos anteriores que a sociedade atual passa por uma nova construção temporal e que, no que se refere ao tempo de trabalho, são diversas e profundas as transformações. Tais discussões aportam novos elementos para melhor compreender a construção do tempo de trabalho no Brasil, tanto do ponto de vista macro-político, como micro-organizacional. A análise que realizo, neste capítulo, tem como objetivo apreender o contexto macro social onde se desenvolvem discussões sobre o tempo de trabalho que, por sua vez, influenciam e são influenciadas pelas formas como esse tempo é organizado dentro das empresas. O que possibilitará, mais adiante, realizar uma análise detalhada do contexto micro-organizacional da Volkswagen do ABC, para então estudar as vivências temporais cotidianas dos trabalhadores nesta empresa.

Para tal, neste capítulo, trato da construção social do tempo de trabalho no Brasil, a partir dos anos 1990, considerando os processos de discussão e negociação em torno deste tema e procurando identificar as questões levantadas, as ações implementadas e os argumentos apresentados por trabalhadores, governo e empresários no período compreendido entre 1995 e 2005. Entretanto, para melhor compreender o momento atual, inicio sistematizando brevemente, evidencias recolhidas da literatura sobre como a questão do tempo de trabalho apareceu na esfera pública, expressa nos movimentos de trabalhadores, nas negociações entre sindicatos e empresas, e no espaço político institucional dos debates e iniciativas do Legislativo e do Executivo brasileiros. Desta forma, dou conseqüência ao entendimento, anteriormente expresso, de que a cultura temporal atual é o resultado de construções temporais que foram construídas historicamente e que, para entender o presente, há que se recuar minimamente no processo de sua construção histórica. 


\section{1 - Tempo, trabalho e tempo de trabalho: rastreando elementos importantes da sua construção no Brasil}

Se o trabalho capitalista é uma invenção da modernidade, como vimos anteriormente, como se deu essa invenção no Brasil? Isto é, como se deu o processo de construção social do trabalho e do tempo a ser dedicado a essa atividade? Parto dessas indagações para realizar um rastreamento sobre alguns dos elementos da construção do tempo de trabalho no Brasil e que contribuirá para a compreensão das discussões no momento atual.

Como já discuti anteriormente, a cultura temporal das sociedades industriais teve o tempo do relógio como referência principal, um tempo preciso, abstrato, fracionado, mensurável e universal. Características que se destinaram a orientar os diversos espaços da sociedade, mas principalmente, o espaço do trabalho. De forma que, nessas sociedades, o tempo aparece como um dos principais objetos de disputa entre trabalhadores e capitalistas. No Brasil, veremos que a questão do tempo de trabalho também foi central na história das lutas dos trabalhadores, desde o início do processo de industrialização, sendo um tema catalisador e a partir do qual outras questões subsidiariamente foram sendo colocadas. E foi um processo que envolveu diversos conflitos entre os detentores das terras, do dinheiro e do poder político, que buscavam implantar uma nova concepção de tempo, de trabalho e de tempo de trabalho, e aqueles que tentavam resistir a esse processo.

Leite Lopes (1988) salienta que no início do processo de industrialização no Brasil os trabalhadores se encontravam em uma situação de total desnudamento, não tinham terra e nem instrumentos para produzirem sua subsistência, constituindo-se nas chamadas superpopulações. $\mathrm{O}$ autor sublinha que esse desnudamento abrangia muito mais que a questão econômica, sendo tomado, no amplo sentido, pela separação dos trabalhadores de seus antigos valores, de sua concepção de tempo e dos modos usuais de produção e reprodução social. A citação de Kowarick (1987), reflete muito bem o início do processo de industrialização no Brasil:

\footnotetext{
“(...) a exploração capitalista do trabalho, realizada por meio do assalariamento, não é uma equação que possa ser resolvida de uma maneira simples. Esse processo supõe criar relações sociais de produção que levam ao domínio do capital sobre o trabalhador. É preciso, pois expropriá-lo num duplo sentido: de um lado produzir condições materiais que metamorfoseiam a pessoa em força de trabalho, impedindo sua reprodução autônoma e obrigando-a a se transformar em "mercadoria" que se vende no mercado de trabalho; do outro, é preciso condicioná-lo, no sentido de se
} 
"convencer" a se incorporar no processo produtivo, aceitando a situação de assalariamento ao invés de escolher uma alternativa de vida. O tortuoso processo de produzir força de trabalho, geralmente impregnado de acentuada dose de violência institucional e privada, implica, assim, tanto transformações materiais, em que o acesso da terra é um ponto fundamental, como mudanças culturais e ideológicas que geram no trabalhador a disposição de ingressar na disciplina do processo produtivo" (Kowarick,1987: 113 e 114).

Esta citação estabelece um diálogo com o que vimos em Weber (1989) quando este sublinha que o surgimento de uma nova ética do trabalho não seria absolutamente um produto da natureza ou da violência, sendo seu alcance possível somente com a adoção de um longo processo de educação. Reconhece que o homem não desejava por natureza ganhar cada vez mais dinheiro, mas sim continuar a viver da forma como estava acostumado, trabalhando para ganhar o que sentia ser necessário para viver. O que significa que a invenção do trabalho capitalista, ou do tempo que deveria ser dedicado a esta atividade, não pode ser pensada apenas do ponto de vista econômico, mas sim como fruto de um longo processo de construção social, envolvendo questões sociais e culturais. Ao mesmo tempo, é importante ressaltarmos que os processos de desnudamento nunca são totais, e será a partir das experiências passadas de vida, de relação e produção, que os trabalhadores irão vivenciar o novo mundo, que irão aceitar e recusar certos modos de vida.

Assim, as primeiras gerações de proletários brasileiros foram formadas entre as camadas mais pobres da população, com grande presença de mulheres e crianças, além de uma parte originária do campesinato pobre e também de artesãos, ambos arruinados pela concorrência dos produtos industrializados. E é formado também por imigrantes europeus trazidos para o Brasil no final de 1800. Isso depois de forte pressão dos fazendeiros e dos primeiros industriais que enfatizavam o quanto os trabalhadores brasileiros não gostavam de trabalhar e não queriam aceitar a disciplina do trabalho. Em 1897, o Governo brasileiro, mesmo se referindo à existência de um excesso de trabalhadores, irá buscar trabalhadores na Europa, providenciando a vinda de mais 60.000 imigrantes, constituindo-se um grande exército industrial de reserva (Boris Fausto, 1976). De acordo com Hardman e Leonardi (1991), os trabalhadores europeus trabalharam nas fábricas e nas fazendas em condições de vida e de trabalho semelhantes às de muitos trabalhadores brasileiros que lá estavam, vivendo em alojamentos idênticos, com jornadas entre 13 e até 15 horas por dia, sem direito ao descanso semanal remunerado ou férias, além de forte controle e disciplina. 
Em meados de 1910, a indústria têxtil era o ramo mais industrializado e, assim como ocorrido na Inglaterra, associava em seus primeiros tempos tanto à exploração extensiva como intensiva da força de trabalho. Resultando, na média mais longa da jornada de trabalho, entre 10 a 12 horas; em 8 horas na construção civil, 9 na indústria de chapéu e entre 9 a 11 nas fundições e oficinas mecânicas. Por sua vez, a intensificação do trabalho combinava formas veladas como o aumento da velocidade das máquinas, incentivos materiais e outras mais explícitas como a violência, sendo esta última a mais freqüente (Hardman e Leonardi, 1991).

Nesse contexto, logo os imigrantes também começaram a manifestar seu descontentamento em relação à situação vivenciada, pois a representação que tinham da vinda para o Brasil era de que esta significaria a compra de terras e o trabalho sem patrão. Assim, entre 1900 e 1914, os trabalhadores já tinham iniciado sua organização, realizando diversos congressos e greves onde, de acordo com Silva (1996), o tema da jornada de trabalho de 8 horas ocupava a atenção dos mais importantes atores sociais. Nesse período, conforme inquérito do Departamento Estadual do Trabalho, divulgado em 1912, as jornadas variavam entre 7 horas e meia e 12 horas. Já em 1919, o mesmo órgão divulga que a jornada predominante era de 8 horas.

Os socialistas realizaram seus primeiros congressos nos anos de 1901 e 1902, sendo que em ambos estava presente a questão da redução da jornada de trabalho para 8 horas, a proibição do trabalho de menores de 14 anos, limitação do trabalho das mulheres e do serviço noturno. Mesmo no chamado "congresso pelego" há referências à questão da duração do trabalho, abrangendo os temas da redução da jornada de trabalho para 8 horas, a limitação do trabalho de mulheres e menores e o descanso semanal remunerado. Também no Congresso de 1906, realizado pelos anarquistas, havia a recomendação para os operários lutarem preferencialmente por uma menor jornada de trabalho, ao invés de enfatizarem a luta por maiores salários. A questão do salário seria então resolvida como resultado de um nível mais baixo de desemprego, isto é, se todos tivessem emprego, a questão salarial já seria em parte resolvida (Silva,1996).

Quando observamos as demandas trabalhistas pelo prisma dos movimentos grevistas, também reconhecemos a forte ênfase em relação ao tema da jornada de trabalho. A greve de 1907, por exemplo, teve como reivindicação principal a redução da jornada para 8 horas. Para Boris Fausto (1976), essa greve também deve ser vista como fruto da resolução do congresso de 1906 que havia definido que o movimento sindical "deveria envidar os maiores esforços, de acordo com

1. Este congresso foi assim denominado pelos anarquistas e socialistas por ter sido lançado pelo tenente Mário Hermes, filho do então Presidente da República. 
o método seguido pelos companheiros franceses, para que o operariado do Brasil, no dia 01 de maio de 1907, imponha as 8 horas de trabalho" (1976: 149). No ano de 1912, em outro movimento ocorrido em São Paulo, novamente a reivindicação pela redução da jornada de trabalho para 8 horas estava presente. No que se refere aos resultados, observa Boris Fausto (1976) que neste momento poucas categorias profissionais conquistam essa redução, como o setor sapateiro onde se adotou a jornada de 8 horas e meia.

Segundo Kowarick (1987), neste momento de amplas manifestações dos trabalhadores e redução do processo de imigração, em função da guerra de 1914, há uma mudança radical no discurso empresarial em relação aos trabalhadores brasileiros. Num primeiro momento esses foram representados pelos donos do capital e pelo governo como vagabundos que não sabiam trabalhar e não tinham disciplina. Finda a imigração, o trabalhador brasileiro passa a ser exaltado, ganhando qualidades face aos imigrantes, tachados de "anarquistas e baderneiros". Se antes o governo federal pagava despesas com vinda dos imigrantes para o Brasil, depois de 1914, ele passa a pagar para que os nordestinos e nortistas venham trabalhar em São Paulo. Muda o discurso predominante, que passa a valorizar os trabalhadores nativos, justificando aquilo que eles mesmos enfatizavam como falta de vontade de trabalhar: "quando chegam a São Paulo, mostram, na sua maior parte, pouca ambição e daí uma natural indolência. Verdade é que esta indolência [...] é também em grande parte devido ao seu estado de fraqueza. [...] em pouco tempo tornam-se elementos de trabalho [...]" (Leme, apud Kowarick, 1987:123 e 125). O trabalhador nativo, a partir de então, ganha status de trabalhador superior ao europeu, em função de sua resistência, fidelidade ao compromisso, capacidade de aprender e, sobretudo, pelo espírito de ordem, (Limongi, apud Kowarick 1987:126).

Neste período, o movimento dos trabalhadores continua forte e em 1917 há uma grande mobilização que se inicia em uma empresa de fiação e tecelagem, quando uma resolução patronal prolonga o trabalho noturno. Como resposta, os trabalhadores reivindicam o pagamento de 15 a $20 \%$ como adicional noturno, sendo que ao longo do processo a reivindicação se amplia abrangendo a regulamentação do trabalho da mulher e dos menores. Em seguida, os trabalhadores da Empresa Antártica iniciam uma greve contra o prolongamento da jornada para 9 horas, sem acréscimo de hora extra (Boris Fausto 1976:194). É constituído o Comitê de Defesa Proletária tendo como pauta, entre outros temas, a redução da jornada de trabalho para 8 horas, o pagamento de $50 \%$ para as horas extras, a semana inglesa. Entretanto, ao final desta mobilização foram poucos os trabalhadores que conquistaram a redução da jornada de trabalho. 
Ainda no que se refere ao movimento sindical, Silva (1996) observa que além do tema da redução da jornada de trabalho e do pagamento de adicionais para a hora extra e o trabalho noturno, outro tema muito presente na imprensa operária, era o problema da saúde do trabalhador, sendo enfatizada a relação entre longas jornadas e depressão física e moral. Havendo a preocupação em demonstrar as conseqüências maléficas do tempo de trabalho excessivo, além de estar presente a necessidade de um tempo maior para ser dedicado à família, à cultura, ao "recreio do espírito" e ao amor. De acordo com o autor, também havia a intenção de "mostrar que a diminuição de horas poderia ser benéfica para o próprio sistema, pois contribuiria para alimentar o circuito da acumulação através do aumento do consumo" (Silva, 1996: 76 e 77). Além disso, de acordo com Silva, na imprensa sindical já havia muitas referências de que o desenvolvimento tecnológico ao mesmo tempo em que levaria ao desemprego maior, possibilitaria a redução da jornada de trabalho. Assim, ressaltavam a necessidade da redução da jornada para combater o desemprego, sem, entretanto questionar e apontar uma possível contradição entre tempo dedicado ao trabalho e "bem viver" (1996:76).

Também estava muito presente na imprensa sindical a valorização do trabalho como maneira de se contrapor a uma sociedade que o havia transformado em "maldição e castigo". O trabalho passa a ser mostrado como algo que dignifica o homem, sendo definido como "toda a atividade manual ou mental que aumenta os confortos da vida coletiva, alargando os nossos conhecimentos e as possibilidades humanas de mais progresso, de mais civilização, de mais fraternidade e solidariedade (....)" (Silva, 1996:99).

Silva (1996) salienta que no período entre 1906 e 1932, os empresários se colocaram totalmente contrários à redução da jornada de trabalho, entendendo as reivindicações dos trabalhadores e as leis discutidas no Congresso como limitação ao seu direito de trabalhar e organizar a empresa segundo suas próprias determinações. No que se refere aos projetos de lei sobre a duração do trabalho dos menores e as férias anuais de 15 dias, os argumentos patronais consideravam os custos da produção altos e que havia a necessidade de uma vida moralmente regrada, disciplinada e voltada para o trabalho. Consideravam ainda que precisavam de trabalhadores que tivessem interiorizado a ética do trabalho, disciplinado como modo de vida. Logo, sobre a lei de férias, em 1926 argumentavam: “o que fará o trabalhador braçal com 15 dias de ócio". (Silva, 1996:201).

Cedo o tema da jornada passou a transcender os espaços da luta sindical e a ser parte do debate político institucional. Silva (1996), por exemplo, observa que a questão da redução da 
jornada foi introduzida na Câmara dos Deputados já em 1911, quando um projeto apresentado visava a regulamentação da jornada no comércio em 12 horas. No ano seguinte, uma nova proposta limitava-a em 8 horas e proibia a hora extra; em 1915, outro projeto fixa a jornada em 8 horas com um máximo de 12 e, em 1918, a Comissão de Constituição e Justiça fixa a jornada em 10 horas diárias, podendo-se trabalhar mais horas desde que pagas como extras (Silva,1996)

Muito embora nenhum projeto tenha sido aprovado, diversas discussões ali ocorreram (Silva, 1996). O grupo partidário da intervenção do Estado defendia que a preservação da saúde do trabalhador era razão suficiente para pleitear-se uma redução da jornada de trabalho. Outros demonstravam preocupação com o extremo desequilíbrio de situações entre trabalhadores e patrões, gerando descontentamento por parte dos trabalhadores, como os já acontecidos entre 1917 e 1920. Os liberais entendiam que os próprios trabalhadores não estariam de acordo com a redução da jornada para 8 horas, principalmente no que se refere à limitação de horas extras, sendo a intervenção do Estado um atentado à liberdade do trabalhador "que ficaria impedido de dispor como melhor lhe conviesse da sua força de trabalho, que era propriedade particular dele" (1996:135).

Essa conjuntura de equilíbrio de forças se romperá apenas no inicio do governo Vargas, quando, em 1932, uma lei fixou a jornada de trabalho em 8 horas, além de outras medidas relacionadas à jornada ${ }^{2}$. Em 1949, por exemplo, houve a implantação do repouso semanal remunerado, sendo necessário trabalhar toda a semana anterior, cumprindo integralmente o horário de trabalho para o seu recebimento; incentivava-se, com isso, o trabalhador assíduo e punia-se o faltoso. Evidenciava-se, assim, que já desde esse momento havia uma campanha contra o absenteísmo (Silva, 1996), expressando a necessidade do “desnudamento simbólico", para retomar o argumento de Leite Lopes, daqueles que ainda se recusavam a trabalhar todos os dias da semana.

No local de trabalho estava em jogo o movimento de construção da figura do "trabalhador brasileiro", como bem observa Ramalho (1989), tomando como exemplo da constituição da

2. Dentre as regulamentações relativas à jornada de trabalho, quinze decretos-leis foram colocados em vigor entre os anos de 1932 e 1938, abrangendo diversos setores como bancos, transporte terrestre e ferroviário, serviço público e empresas jornalísticas. Em 1943, a CLT limita a duas as horas extras diárias e define um adicional de 20\%; fixa ainda o direito a férias anuais, sem prejuízo da remuneração. Nos anos 60, nota-se a continuidade de mudanças na legislação no que se refere às categorias profissionais específicas: em 1962, a legislação reduziu a jornada de trabalho dos bancários para seis horas e, em 1967, estabeleceu a jornada de 40 horas para os servidores públicos (Cardoso, 2002) No anexo 1, pode ser observada toda a legislação sobre jornada de trabalho para categorias profissionais específicas. 
Fabrica Nacional de Motores, a FNM, nos anos 40. Para o autor, o projeto político da empresa apresentava uma proposta de formação para seus trabalhadores que se fundamentava na criação de um homem adaptado à nova realidade industrial: "levar o progresso e a ciência para o interior do País e, ao mesmo tempo, valorizar a capacidade do trabalhador brasileiro e o papel do Estado em comandar esse desenvolvimento". Assim, "volta-se para o trabalhador como a expressão máxima das possibilidades de desenvolvimento sócio-econômico" (idem: 42). Mesmo que para alguns trabalhadores ainda faltasse "amor ao trabalho e pelo trabalho" a forma de combater certa displicência estava na disciplina militar, que devia ser utilizada para premiar os operários dignos e castigar os indignos. (Ramalho, 1989: 44, in Discurso do Brigadeiro Guedes Muniz no primeiro Congresso Brasileiro da Indústria, em 1944).

Dentro da empresa, ainda segundo Ramalho, a disponibilidade de tempo dos trabalhadores era total. $\mathrm{O}$ autor sublinha que em diversas falas desses operários aparece a contradição entre as vantagens oferecidas pela empresa para aqueles que moravam nas vilas operárias e o ônus que isso representava dada a interferência direta exercida na forma de controle do seu tempo livre. Morar nas vilas significava que também o tempo livre passava a ser controlado pela fábrica. Além disso, do ponto de vista financeiro, o "serão" significava para o trabalhador a possibilidade de uma vida melhor em função do pagamento de horas extras, considerando a sua baixa remuneração, alem de melhorar a relação com as chefias. Mas o "serão" também era percebido negativamente, dado o cansaço e a redução do tempo disponível para estar com a família.

Leite Lopes (1988), a partir de seu estudo sobre a companhia Paulista de Tecidos, ressalta que a construção de um novo imaginário em relação ao trabalho se colocava para todos que estavam na fábrica: homens, mulheres, velhos e crianças. Todos passam a ser submetidos à forte disciplina do trabalho fabril, de modo que a construção da disciplina e da moral do trabalho era realizada por essa universalização do trabalho fabril. "A imponência dessa moral do trabalho atinge não somente os corpos, mas as coisas, plantas fabris, edifícios, portos, terras, construção e manutenção das casas, transformadas em tantas frentes e fontes de trabalho (...)" (Leite Lopes, 1988:89).

Entretanto, é importante frisarmos que a construção social de uma nova relação com o trabalho e com o tempo dedicado ao trabalho não se restringiu à relação trabalho-capital, extrapolando o espaço do local de trabalho e da legislação trabalhista, abrangendo ainda a música, os programa de rádio, a propaganda comercial, entre outros. Segundo Rocha (2002), tratava-se de construir uma percepção de que o progresso estaria vinculado às virtudes da capacidade de 
trabalho, como podemos observar no documento de comemoração do IV Centenário da Cidade de São Paulo:

"São Paulo nestes quatro séculos de existência mostrou ao mundo a pujança de seu valor. O valor
do homem que produz e anda apressado, consultando o seu relógio que funciona rigorosamente
acertado com os outros dos locais de trabalho, para continuar a contribuir para a nossa grandeza
e a emancipação econômica do Brasil" (Rocha, in material IV Centenário)

De acordo com Rocha (2002), até mesmo a música foi utilizada pelo governo para difundir a nova representação do trabalho e de sua relação com o progresso. De acordo com o autor, neste período, as escolas de samba passaram a ser subvencionadas pelo governo, a partir de 1935, sendo obrigadas a escolherem temas que enfatizassem a relação entre o trabalho, o urbano e o progresso. Também o surgimento do chamado "samba exaltação", esteve relacionado ao incentivo do governo para tirar o samba da "marginalidade" e exaltá-lo como autêntica expressão de brasilidade, daí porque passava a tratar de temas como progresso, desenvolvimento e a alegria do trabalho, deixando assim, de acentuar a vagabundagem. No entanto, como ressalta o autor, a resistência também pode ser observada nas músicas, como é perceptível nos textos de Adoniran Barbosa ou ainda nas novelas de rádio por ele narradas. O sucesso de audiência pode ser entendido, ainda com Rocha, como recusa de parte da sociedade em aceitar o discurso governista que insistia em relacionar trabalho e progresso, trabalho e desenvolvimento, até porque o discurso contrastava em muito com a realidade vivenciada cotidianamente pela maior parte desses trabalhadores.

A ênfase no trabalho pode ser vista também nas propagandas comerciais, como o exemplo da empresa de relógios Hora S.A., que salienta ser o segredo dos paulistas

"não perder tempo! Que cada um de nós tem a sua parcela de responsabilidade quanto ao futuro de São Paulo. O segredo do extraordinário progresso de nossa terra não tem sido outro que o trabalho com todas as suas imposições: pontualidade, divisão e aproveitamento máximo do tempo" (Empresa de Relógios Hora, in Rocha, 2002:10).

Para Lopes (2000), a forte propaganda em relação ao progresso procurava incentivar uma nova relação com o trabalho e, ao mesmo tempo, mascarar as evidentes contradições sociais. Se num primeiro momento a sensação do progresso foi percebida como uma possibilidade de mudança de vida, a realidade logo se evidenciou como algo "absurdamente dura e impessoal" 
(idem:84). Os trabalhadores logo criariam formas de se contrapor a essa realidade, pois, "embora ocorra uma reação de acanhamento ao primeiro contato com a grandiosidade da cidade e da fábrica, os operários decodificam e reelaboram estas circunstâncias impostas numa atitude que intercala fascínio e contrariedade, conformismo e resistência" (idem: 85).

Assim como em outros países, vemos que o processo de construção social do tempo dedicado ao trabalho no Brasil deu-se de maneira conflituosa, não livre de resistências. O processo de "desnudamento" dos trabalhadores, capitaneado por empresários e pelo Estado, incluiu ações que abrangiam amplos espaços da vida em sociedade, não se restringindo ao local de trabalho. Entretanto, o "desnudamento" dos valores e das experiências passadas, diferentemente das condições materiais, nunca é completo. Como salienta Leite Lopes (1988), quando acompanhamos processos de construção social enfrentamos o desafio da interpretação de relações; ainda que extremamente desiguais, estamos diante de relações sociais. Por isso mesmo, há que ter sempre em mente as formas e estratégias de resistências ao processo de dominação. Resistência "que se exerce desde a reação e a resposta ao despotismo da hierarquia até à reinterpretação e reambientação criativas das duras condições de trabalho na fábrica" (Leite Lopes, 1988:32 e 81). Assim, as vivências desse processo de re-construção simbólica do significado do tempo, do trabalho e do tempo de trabalho resultaram tanto em aceitação como em rebeldia, tanto em conflitos de classe abertos como em resistências no âmbito das relações mais cotidianas.

Seguindo essa perspectiva interpretativa, buscarei em seguida compreender como, na sociedade atual, estão sendo reconstruídas a noção, as vivências e as representações sobre o tempo dedicado ao trabalho.

\section{2 - Mudanças no tempo de trabalho a partir dos anos 1990}

Desde o final dos anos 1980 já não há mais, no plano macro-institucional, um movimento de redução da jornada de trabalho no Brasil. Todavia, foram diversas as legislações e negociações que tiveram como foco, ou como conseqüência, a flexibilização e a intensificação do tempo dedicado ao trabalho. Assim sendo, as poucas negociações que resultaram em reduções do tempo de trabalho deram-se primordialmente no plano micro-institucional. No âmbito da empresa; na maior parte dos casos, essas experiências têm andado de braços dados com um movimento de flexibilização da jornada. 
A seguir falarei do contexto macro em relação ao mercado de trabalho no Brasil para, em seguida, discutir de forma mais aprofundada as discussões sobre o tempo de trabalho a partir dos anos 1990 .

\subsection{1 - Anos 1990: contexto de desemprego, estagnação da redução da jornada de trabalho e aumento da hora extra}

Desde a década de 1980 observava-se nos países desenvolvidos um movimento de flexibilização na duração do tempo de trabalho - anualização, banco de dias ou banco de horas, dos períodos de repouso, férias e trabalho nos finais de semana. Em diversos países, como Espanha, Inglaterra, Alemanha e Itália, tal movimento deu-se tanto por iniciativa das empresas, como por forte intervenção estatal, no sentido de alteração na legislação vigente (Promberger e Trinczek, 1996). Na França, como vimos, um movimento diferente foi observado no final dos anos 1990, quando houve um intenso processo de negociação iniciado pelo Estado, abrangendo trabalhadores e empresários, visando a redução da jornada de trabalho para 35 horas. Entretanto, mesmo nesse caso, pode-se reconhecer, como indicado no capitulo anterior, inúmeras iniciativas no sentido de flexibilização do tempo de trabalho, que ganharam maior destaque tanto nas negociações por empresa (Thoemmes, 2000) como, também, nas novas leis definidas pelo novo governo a partir de 2002 .

No caso brasileiro, os anos 1990 foram marcados por um cenário social de fortes transformações políticas e econômicas, tendo como um de seus resultados mais relevantes, a alteração na relação de poder entre os diversos atores sociais, resultando numa maior desigualdade na capacidade de inserção de temas de interesse na agenda nacional. No âmbito governamental, mudanças importantes exprimiram-se na redução do papel do Estado, no intenso processo de privatização, na ênfase na estabilização monetária, bem como na abertura comercial e financeira ao exterior. Os empresários, por sua vez, frente à rápida abertura comercial, optaram por implementar uma reestruturação vigorosa e de caráter defensivo, incluindo ainda um amplo processo de descentralização da atividade produtiva, levando importantes investimentos para áreas com escassa organização sindical.

No que diz respeito às relações trabalhistas, na década de 1990, o governo brasileiro exerceu papel fundamental na desregulamentação da estrutura jurídica trabalhista e no aprofundamento da flexibilização das relações de trabalho. Essa tendência foi acelerada a partir de 1996, com a introdução de um conjunto de medidas que flexibilizam as formas de remuneração, contratação e o tempo de trabalho; que só foram refreadas a partir do inicio do governo Lula, em 
2003. Dentre as mudanças principais no período, como podemos notar no quadro 1 , a seguir, houve a introdução da remuneração variável (1994); a implantação do trabalho em tempo parcial (1998); a suspensão temporária do contrato de trabalho (1996); o trabalho por tempo determinado (1998 e 2001); a liberação do trabalho aos domingos (1999 e 2000); e ainda a suspensão do contrato de trabalho (2001) (Krein 1999).

A rigidez do mercado de trabalho no Brasil foi o principal argumento utilizado pelo governo na defesa dessas alterações; tal inflexibilidade impediria a consecução de alvos governamentais estratégicos como a maior geração de empregos e a maior competitividade das empresas nacionais. Veja-se, por exemplo, o que se argumenta em documento elaborado pela Presidência da República, em 1995, como sendo causas para o desemprego e a informalização do trabalho:

“(...) há evidências de que as pressões de custos decorrentes dos elevados encargos sociais, em um ambiente econômico de competitividade crescente, aliadas a uma rígida legislação trabalhista, estejam contribuindo não apenas para o aumento da rotatividade da mão-de-obra, mas também para o aumento relativo dos ocupados sem carteira assinada"; e ainda que "o ajuste do mercado de trabalho à realidade econômica está se manifestando mais pela informalização do que pelo desemprego" (Brasil, Presidência da República, 1995:10,15).

Propõe-se, entre outros itens, reduzir o custo não-salarial do trabalho e introduzir novas formas de contratação, entendendo que isto "estimulará a geração de mais empregos e reduzirá a informalização do mercado de trabalho" (Brasil, Presidência da República, 1995:25). Todavia, se entendermos por flexibilidade a capacidade de "responder efetivamente a circunstâncias de mudança" (Salerno, 1989), poderíamos dizer que a flexibilização hoje observada, faz parte da realidade brasileira desde muito tempo. Pois mesmo antes dessa nova onda de flexibilização, já havia uma infinidade de possíveis respostas patronais diante das flutuações na carga de trabalho ${ }^{3}$ : hora extra; contrato de trabalho para tempos específicos; trabalho em turnos; compra de férias; trabalho noturno; férias coletivas obrigatórias; redução dos salários e da duração do trabalho ${ }^{4}$; bem como a facilidade nos processos de demissão ${ }^{5}$.

3. De acordo com Salerno (1989), a flexibilidade pode assumir ainda outras formas, entre elas a flexibilidade em preparação do produto, para mudanças de produto e para suportar erros de supervisão.

4. De acordo com a Lei ${ }^{\circ} 4.923$, de dezembro de 1965 , as empresas em face de conjuntura econômica desfavorável, comprovadamente, podem reduzir a jornada e salário de seus funcionários até $25 \%$, não excedente a três meses, prorrogável, nas mesmas condições. Para tanto, deve ser feito um acordo coletivo, com aprovação em assembléia geral da categoria. Não havendo acordo, poderá a empresa submeter o caso à Justiça do Trabalho.

5. No Brasil, a Convenção 158 da OIT foi ratificada no ano de 1996. Entretanto, 10 meses após, foi denunciada pelo Governo, reafirmando, portanto, a possibilidade de demissão sem justa causa. 


\section{QUADRO 1}

As flexibilizações no sistema de relações de trabalho do Brasil

\begin{tabular}{|c|c|}
\hline Temas & INICIATIVAS \\
\hline $\begin{array}{l}\text { Trabalho por tempo determinado } \\
\left.\text { (Lei } \mathrm{n}^{\circ} 9.601 / 98\right)\end{array}$ & $\begin{array}{l}\text { - Desvincula o contrato por tempo determinado da natureza dos serviços } \\
\text { prestados. }\end{array}$ \\
\hline $\begin{array}{l}\text { Denúncia da Convenção } 158 \text { da OIT } \\
\left.\text { (Decreto } \mathrm{n}^{\circ} 2.100 / 96\right)\end{array}$ & - Reafirma a possibilidade de demissão sem justa causa. \\
\hline $\begin{array}{l}\text { Cooperativas profissionais ou de } \\
\text { prestação de serviços } \\
\left(\text { Lei } n^{\circ} 8.949 / 94\right)\end{array}$ & $\begin{array}{l}\text { - Possibilita que trabalhadores se organizem em cooperativas de serviço } \\
\text { e executem o trabalho dentro de uma empresa, sem caracterização de } \\
\text { vínculo empregatício. }\end{array}$ \\
\hline $\begin{array}{l}\text { Trabalho em tempo parcial } \\
\text { (MP 1.709/98) }\end{array}$ & - Jornada de até 25 horas semanais. \\
\hline $\begin{array}{l}\text { Suspensão do contrato de trabalho } \\
\text { (MP 1.726/1998) }\end{array}$ & $\begin{array}{l}\text { - Suspensão do contrato de trabalho, por um período de dois a cinco } \\
\text { meses, vinculada a um processo de qualificação profissional, desde que } \\
\text { negociada entre as partes. }\end{array}$ \\
\hline $\begin{array}{l}\text { Trabalho temporário } \\
\left.\text { (Portaria } n^{\circ} 2 / 96\right)\end{array}$ & $\begin{array}{l}\text { - Amplia a possibilidade de utilização da Lei n }{ }^{\circ} 6.019 / 1974 \text { de contrato } \\
\text { temporário, generalizando a utilização do contrato de trabalho precário. }\end{array}$ \\
\hline $\begin{array}{l}\text { Setor público: demissão } \\
\text { (Lei no } 9.801 / 99 \text { e Lei } \\
\text { Complementar no 96/99) }\end{array}$ & $\begin{array}{l}\text { - Disciplina os limites das despesas com pessoal e estabelece o prazo de } \\
\text { dois anos para as demissões por excesso de pessoal. } \\
\text { - Regulamenta a demissão de servidores públicos estáveis por excesso } \\
\text { de pessoal. }\end{array}$ \\
\hline $\begin{array}{l}\text { Contrato de aprendizagem } \\
\left.\text { (Lei } \mathrm{n}^{\circ} 10.097 / 00\right)\end{array}$ & - Permite a intermediação da mão-de-obra aprendiz. \\
\hline $\begin{array}{l}\text { Trabalho estágio } \\
\text { (MP 2.164/99 e Lei } n^{\circ} 6.494 / 77 \text { ) }\end{array}$ & $\begin{array}{l}\text { - Amplia a hipótese de utilização do estágio, desvincula da formação } \\
\text { acadêmica e profissionalizante. }\end{array}$ \\
\hline $\begin{array}{l}\text { Banco de horas } \\
\left.\text { (Lei }{ }^{\circ} \text { 9.061/98 e MP } 1.709 / 98\right)\end{array}$ & $\begin{array}{l}\text { - Possibilita que a jornada seja organizada anualmente conforme as } \\
\text { flutuações da produção ou serviço. } \\
\text { - Amplia para um ano o prazo de compensação das jornadas semanais } \\
\text { extraordinárias de trabalho. }\end{array}$ \\
\hline $\begin{array}{l}\text { Liberação do trabalho aos domingos } \\
\text { (MP 1.878-64/99) }\end{array}$ & $\begin{array}{l}\text { - Autoriza, a partir de } 9 \text { de novembro de } 1997, \text { o trabalho aos domingos } \\
\text { no comércio varejista em geral, sem a previsão de passar por } \\
\text { negociação coletiva }\end{array}$ \\
\hline $\begin{array}{l}\text { Participação em lucros e resultados } \\
\text { (PLR) (MP 1.029/94), Lei } \mathrm{n}^{\circ} 10.101 \\
\text { a partir de } 19 / 12 / 00 \text {, que reproduz a } \\
\text { MP 1.982-77/2000 } \\
\text { Política salarial } \\
\text { (Plano Real MP 1.053/94) }\end{array}$ & $\begin{array}{l}\text { - Viabiliza o direito de os trabalhadores participarem dos lucros e } \\
\text { resultados da empresa através da negociação. } \\
\text { - Determina que o valor da remuneração, em PLR, não incida sobre os } \\
\text { encargos trabalhistas e não seja incorporado aos salários. } \\
\text { - Elimina a política de reajuste salarial através do Estado. } \\
\text { - Proíbe as cláusulas de reajuste automático de salários. }\end{array}$ \\
\hline $\begin{array}{l}\text { Salário Mínimo } \\
\text { (MP 1.906/97) }\end{array}$ & $\begin{array}{l}\text { - Acaba com o índice de reajuste oficial de correção do Salário Mínimo. } \\
\text { - O seu valor passa a ser definido pelo Poder Executivo sob apreciação } \\
\text { do Congresso Nacional. } \\
\text { - Salário Mínimo Regional/Estadual (1999) }\end{array}$ \\
\hline
\end{tabular}

Fonte: Krein (2003). Elaboração: Calvete (2006). 
Afora isso, há que considerar, ainda, a existência de um amplo mercado de trabalho informal, onde os direitos trabalhistas raramente são cumpridos. Como bem enfatizou Troyano (1991), as possibilidades de flexibilização no Brasil já ocorriam sob diversas formas: salários inferiores ao mínimo legal; trabalho descontínuo; sem carteira assinada; autônomo; terceirização; horas extras; e alta rotatividade. Sendo assim, o que observamos atualmente no Brasil é a intensificação de um processo de flexibilização (Castro, 1997).

E nesse contexto de incidência simultânea de rápida e crescente abertura (comercial e financeira) e de forte reestruturação das empresas, com intensificação da flexibilização, seja da organização do trabalho, seja das relações trabalhistas, há um importante aumento das taxas de desemprego e da informalidade, além da diminuição da média salarial, como podemos observar nas Tabelas 1 a 3, a seguir. Na primeira tabela, contendo os dados para o Brasil, em dez anos observa-se uma redução, em diversos setores da economia, do grau de formalização do trabalho.

Tabela 1

Grau de formalização do trabalho em setores selecionados

Brasil, 19891999

\begin{tabular}{llc}
\hline Setores & $\mathbf{1 9 8 9}$ & Em porcentagem \\
\hline Indústria de transformação & 72,5 & $\mathbf{1 9 9 9}$ \\
Comércio de mercadorias & 40,6 & 62,0 \\
Construção civil & 36,8 & 33,7 \\
Educação & 79,9 & 20,6 \\
Transporte & 60,8 & 75,0 \\
Comunicações & 97,3 & 43,4 \\
Total & $\mathbf{5 1 , 9}$ & 83,5 \\
\hline
\end{tabular}

Fonte: Baltar (2003) apud Calvete, 2006, pp 20.

Nas tabelas seguintes, contendo informações mais detalhadas sobre a região metropolitana de São Paulo, entre os anos de 1989 e 2005, verificamos o aumento das taxas de desemprego aberto e oculto; e um forte aumento do tempo médio de procura de emprego, passando de 04 para 12 semanas. Em relação à qualidade do emprego, há a precarização do mercado de trabalho e a mudança no perfil da ocupação, com o aumento do setor informal, dos autônomos, dos terceirizados e do trabalho doméstico em detrimento dos empregos formais e do assalariamento. E ainda, uma queda do rendimento médio real dos trabalhadores. Já entre os anos de 2004 e 2005 pode-se observar uma situação um pouco diferente, quando as taxas de desemprego apresentam um pequeno declínio, apesar de manterem-se elevadas, e os rendimentos tiveram freada a sua tendência declinante (Calvete, 2006). De forma geral, conforme destacado por diversos autores (Pochmann, 1999, Baltar, 2003 e Dedecca, 2003), o mercado de trabalho no 
Brasil vem se caracterizando pela sua desestruturação e aumento das desigualdades entre os que estão nele inseridos.

\section{Tabela 2}

Evolução do mercado de trabalho na Região Metropolitana de São Paulo - 1989-2005

\begin{tabular}{|c|c|c|c|}
\hline Indicadores & 1989 & 2005 & $\begin{array}{c}\text { Variação } \\
\text { Relativa (\%) }\end{array}$ \\
\hline \multicolumn{4}{|l|}{ Taxa de desemprego (em \% da PEA) } \\
\hline Total & 8,7 & 16,9 & 94,3 \\
\hline Aberto & 6,5 & 10,5 & 61,5 \\
\hline Oculto & 2,2 & 6,4 & 190,9 \\
\hline Precário & 1,5 & 4,8 & 220,0 \\
\hline Desalento & 0,7 & 1,5 & 114,3 \\
\hline \multicolumn{4}{|l|}{ Tempo médio de procura por trabalho } \\
\hline \multicolumn{4}{|l|}{ Proporção de ocupados (em \%) } \\
\hline Setor privado com carteira assinada & 53,0 & 41,6 & $-21,5$ \\
\hline Setor privado sem carteira assinada & 9,1 & 13,8 & 51,6 \\
\hline Autônomos & 15,6 & 21,0 & 34,6 \\
\hline Emprego doméstico & 6,1 & 8,6 & 41,0 \\
\hline \multicolumn{4}{|c|}{ Proporção de assalariados do setor privado (em \%) } \\
\hline Em empresas com até 5 trabalhadores & 8,9 & 12,2 & 37,1 \\
\hline Em empresas com mais de 50 trabalhadores & 53,4 & 49,4 & $-7,5$ \\
\hline $\begin{array}{l}\text { Rendimento médio real dos assalariados } \\
\text { (em R\$ de novembro de 2005) }\end{array}$ & 1.751 & 1.136 & $-35,1$ \\
\hline
\end{tabular}

Fonte: Convênio DIEESE/SEADE, MTE/FAT e convênios regionais. PED - Pesquisa de Emprego e Desemprego apud DIEESE, 2006, pp 5.

\section{Tabela 3}

Distribuição dos postos de trabalho gerados por empresas, segundo formas de contratação Região Metropolitana de São Paulo - 1989-2005

\begin{tabular}{lrc}
\hline \multirow{2}{*}{ Formas de contratação } & \multicolumn{2}{c}{ São Paulo } \\
\cline { 2 - 3 } & $\mathbf{1 9 8 9}$ & $\mathbf{2 0 0 5}$ \\
\hline Contratação padrão & $\mathbf{7 9 , 1}$ & $\mathbf{6 4 , 9}$ \\
Com carteira - setor privado & 67,4 & 55,0 \\
Com carteira - setor público & 6,3 & 3,5 \\
Estatutário & 5,4 & 6,4 \\
Contratação flexibilizada & $\mathbf{2 0 , 9}$ & $\mathbf{3 5 , 1}$ \\
Sem carteira - setor privado & 11,6 & 18,6 \\
Sem carteira - setor público & 0,9 & 1,5 \\
Assalariados terceirizados & 2,4 & 5,3 \\
Autônomos para uma empresa & 6,0 & 9,7 \\
Total de postos de trabalho & $\mathbf{1 0 0 , 0}$ & $\mathbf{1 0 0 , 0}$
\end{tabular}

Fonte: Convênio DIEESE/SEADE, MTE/FAT e convênios regionais. PED - Pesquisa de Emprego e Desemprego apud DIEESE, 2006, pp 18. 
Apesar do problema central desta tese não ser o desemprego, e sim o tempo dedicado ao trabalho, é imperioso observar que essas questões aparecem cada vez mais inter-relacionadas no discurso dos diversos atores sociais, ainda quando abordadas sob prismas diferentes. Assim, se ao longo da história nem sempre a reivindicação dos trabalhadores pela redução da duração do trabalho esteve relacionada ao desemprego, no contexto atual, essa relação aparece de forma muito intensa, como no caso da França, da Volkswagen da Alemanha e como veremos na Volkswagen do Brasil.

Além disso, é importante ressaltar o papel de destaque que o desemprego tem ocupado nos processos de negociação nos últimos anos. Ao mesmo tempo em que aparece como um fator de maior mobilização para a ação sindical, ele se coloca como um elemento limitador desse processo. Tal como já observado por Thoemmes (2000) em relação ao caso francês, no Brasil o desemprego também passou a ser utilizado pelo setor patronal como instrumento de controle e orientação da negociação coletiva, dado o seu poder de modificar a posição e a ação dos trabalhadores e de seus representantes. É o que veremos, de forma mais detalhada, no processo de negociação na Volkswagen do Brasil; ali a flexibilização do tempo de trabalho foi aceita pelos trabalhadores no momento em que a empresa ameaçou com demissões. Aceita como moeda de troca pela manutenção do emprego. Portanto, no contexto atual de crescimento estrutural do desemprego, observamos que as negociações institucionais e coletivas sobre o tempo de trabalho têm tido como resultados, a flexibilização e o aumento do tempo dedicado trabalho, ao invés da sua redução.

Do ponto de vista formal, a duração da jornada de trabalho tem o seu limite inalterado desde a Constituição de 1988, data da última alteração na legislação, quando sua duração passou de 48 para 44 horas semanais. O que demonstra que as mudanças conquistadas e implementadas no governo de Vargas, só conseguiram ser refeitas quando da conquista da redemocratização no Brasil, pois até então, o foco era a própria reconquista de direitos políticos básicos. Demonstra também, a importância do tema da jornada de trabalho, que no processo de redemocratização logo reaparece na cena política. Esta mudança na legislação foi fruto de diversas mobilizações realizadas pelos trabalhadores a partir de meados dos anos 80, a exemplo do ano de 1985 quando algumas categorias, sobretudo os metalúrgicos e químicos de São Paulo, conquistaram reduções do tempo de trabalho de 48 horas para 44 ou 42 horas semanais.

O contexto em que se formula essa reivindicação é marcado por mudanças no processo de organização do trabalho dentro das empresas e, no plano macro, já se notavam indícios de retração do mercado de trabalho e crescimento do desemprego, a partir da estagnação das taxas 
de crescimento econômico. Entretanto, apesar do objetivo principal da reivindicação de redução do tempo de trabalho ser a criação de empregos, o que se verificou, após a redução da jornada em 1988, foi um intenso crescimento da quantidade de horas extras realizadas. Na Região Metropolitana de São Paulo, por exemplo, 27\% de assalariados trabalhavam além da duração legal, sendo que após a alteração na legislação este percentual aumenta, passando para 39\%; e permanecerá em torno de $40 \%$ até os dias atuais, como vemos no Gráfico (1), a seguir. Isso significa que, num primeiro momento, os empresários mantiveram a jornada diária de trabalho igual a existente antes da redução da jornada de trabalho, transformando, portanto, parte da jornada anterior, em hora extra. O que demonstra que esses trabalhadores não tiveram, na prática, uma redução da jornada de trabalho. No ano seguinte, há uma queda da proporção de trabalhadores que realizaram hora extra, mas o que vemos nos anos posteriores é a retomada de uma jornada efetiva de trabalho maior, quando o nível de hora extra volta a crescer, permanecendo em patamares elevados até os dias atuais.

A utilização do expediente da hora extra de forma transitória, até que as firmas pudessem contratar novos trabalhadores ou automatizar ainda mais a produção, já era esperada pelo movimento sindical, porém, o que deveria ser uma solução transitória acabou se configurando em um novo patamar de hora extra (Dal Rosso,1996 e Calvete, 2006). Importante ressaltar neste processo, a confluência de interesses diferentes, mas complementares, no que se refere à realização

\section{Gráfico 1}

Proporção de assalariados que trabalharam além da jornada legal semanal na Região Metropolitana de São Paulo

1985-2005

(em \%)

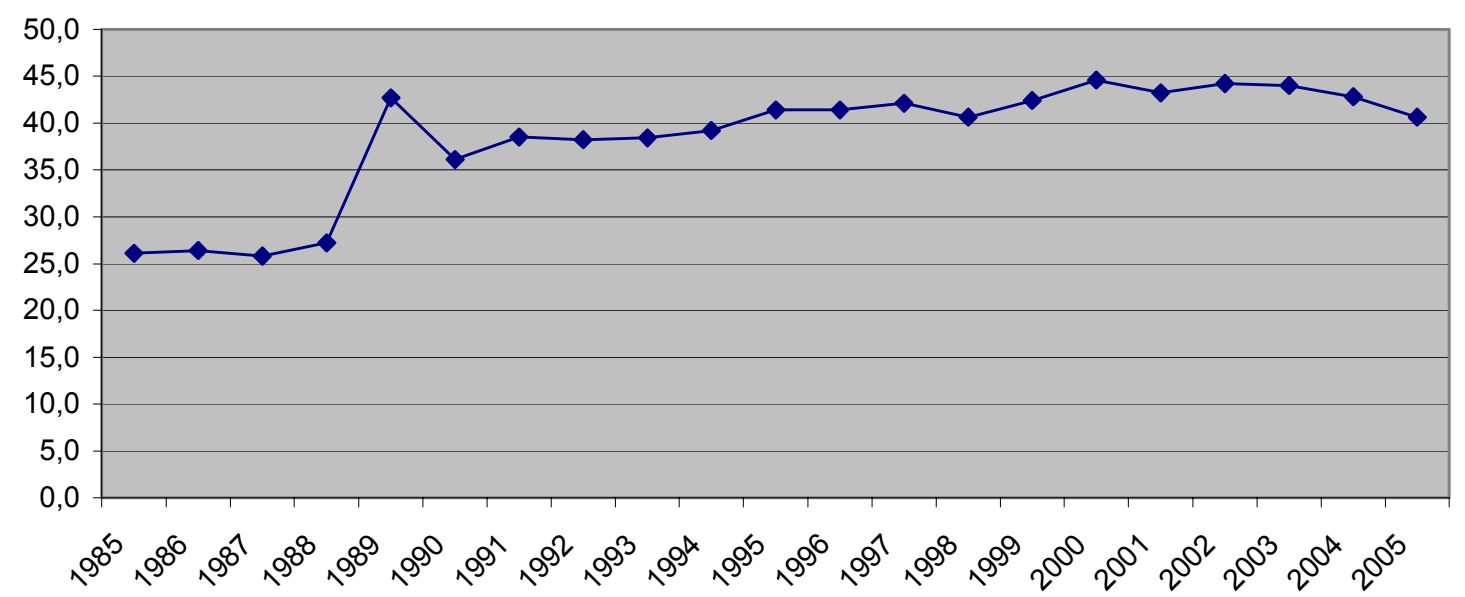

Fonte: Convênio DIEESE/SEADE, MTE/FAT e convênios regionais. PED - Pesquisa de Emprego e Desemprego apud DIEESE, 2006, pp. 
de hora extra. Se para o setor patronal é mais barato e prático pagar hora extra do que contratar um novo trabalhador e depois demiti-lo, para o trabalhador, em função da baixa remuneração, a hora extra significa uma possibilidade individual de ganho maior. Dessa forma, a ação sindical tem encontrado resistência, tanto da parte dos empregadores, como dos próprios trabalhadores no sentido da limitação da utilização das horas extras.

Assim, vemos que o forte crescimento do número de trabalhadores que recorrem a esse expediente, desde 1988, abrange todos os setores da economia e Estados da federação pesquisados pela PED. Na tabela a seguir, podemos observar que é nas atividades ligadas ao comércio, à construção civil e ao emprego doméstico - onde estão os mais baixos salários -, que notamos o maior percentual de assalariados que trabalham além da jornada legal.

Tabela 4

Proporção de assalariados que trabalharam mais que a jornada legal, segundo setores de atividade econômica

Regiões Metropolitanas e Distrito Federal - 2004/2005

\begin{tabular}{|c|c|c|c|c|c|c|}
\hline \multirow{2}{*}{$\begin{array}{l}\text { Regiões Metropolitanas } \\
\text { e Distrito Federal }\end{array}$} & \multicolumn{2}{|c|}{ Indústria } & \multicolumn{2}{|c|}{ Comércio } & \multicolumn{2}{|c|}{ Serviços } \\
\hline & 2004 & 2005 & 2004 & 2005 & 2004 & 2005 \\
\hline São Paulo & 42,4 & 38,8 & 59,1 & 56,6 & 38,0 & 36,5 \\
\hline Porto Alegre & 29,1 & 26,2 & 50,6 & 51,6 & 28,8 & 27,6 \\
\hline Belo Horizonte & 36,8 & 37,9 & 51,8 & 51,9 & 27,2 & 27,6 \\
\hline Salvador & 44,8 & 48,9 & 60,6 & 64,3 & 31,4 & 32,5 \\
\hline Recife & 61,2 & 59,0 & 72,0 & 71,6 & 39,1 & 39,4 \\
\hline Distrito Federal & 43,0 & 40,3 & 67,2 & 65,1 & 20,8 & 20,4 \\
\hline
\end{tabular}

Fonte: Convênio DIEESE/SEADE, MTE/FAT e convênios regionais. PED - Pesquisa de Emprego e Desemprego apud DIEESE, 2006, pp 21.

Calvete (2006), ao analisar os dados da PED por tamanho de empresa, cor, sexo, grau de escolaridade e faixa etária, conclui que os trabalhadores em situações mais vulneráveis - baixos salários e com menor qualificação -, apresentam a maior proporção de realização de hora extra. Ressalta o autor que, quando a comparação é por sexo, em todas as regiões pesquisadas os homens fazem mais hora extra do que as mulheres; provavelmente visto que nesta pesquisa estão computados apenas os tempos de trabalho remunerados. E ainda: 
"quando o corte é por cor, é entre os negros que se encontra o maior percentual de trabalhadores fazendo horas extras; quando o corte é por escolaridade, é justamente entre os trabalhadores de menor nível de instrução que se encontra o maior percentual; por setor de atividade, os maiores percentuais encontram-se nos setores de mais baixo salário médio (comércio, empregados domésticos e construção civil); e, quando a análise é por tamanho de empresa, são os trabalhadores nas microempresas que têm maior probabilidade de fazer horas extras; quando a análise é por faixa de renda, são nas faixas de renda mais baixas que se encontram percentuais maiores de trabalhadores fazendo horas extras “(2006: 112).

Assim, apesar da jornada de trabalho oficial ser de 44 horas semanais, podemos ver na tabela 5, a seguir, a jornada efetivamente trabalhada - a partir dos dados da PNAD, que considera outras categorias além dos assalariados no setor formal da economia - pelos trabalhadores do setor formal e informal e não a jornada contratual. E vemos que o número de trabalhadores que têm uma jornada efetiva maior do que 44 horas é muito representativo no setor privado, tanto para os trabalhadores com carteira como sem carteira.

Se considerarmos os dados da Rais - que engloba apenas os trabalhadores empregados e com registro formal -, verificamos que $68,3 \%$ têm jornadas contratuais de 44 horas semanais e aproximadamente $20 \%$ dos trabalhadores têm jornada de 40 horas semanais, incluindo, nesse último grupo, os funcionários públicos que têm como limite máximo para jornada contratual, justamente as 40 horas semanais (DIEESE, 2006).

Tabela 5

Jornada semanal normalmente realizada por assalariados Brasil, 2005

\begin{tabular}{l|c|c|c|c}
\hline $\begin{array}{l}\text { Jornada de } \\
\text { trabalho } \\
\text { semanal } \\
\text { (horas) }\end{array}$ & $\begin{array}{c}\text { Assalariados do } \\
\text { setor privado } \\
\text { com carteira }\end{array}$ & $\begin{array}{c}\text { Assalariados do } \\
\text { setor privado } \\
\text { sem carteira }\end{array}$ & $\begin{array}{c}\text { Funcionários } \\
\text { públicos } \\
\text { celetistas }\end{array}$ & $\begin{array}{c}\text { Funcionários } \\
\text { públicos } \\
\text { estatutários }\end{array}$ \\
\hline Até 39 & 2.138 .273 & 3.290 .071 & 559.740 & 1.914 .331 \\
40 & 6.776 .753 & 3.285 .846 & 947.750 & 2.425 .727 \\
De 41 a 43 & 516.900 & 190.438 & 27.742 & 44.197 \\
44 & 5.349 .860 & 1.234 .650 & 101.524 & 178.647 \\
De 45 a 48 & 6.260 .983 & 2.589 .415 & 160.283 & 414.436 \\
De 49 e mais & 4.108 .680 & 2.786 .262 & 94.793 & 258.489 \\
Total & $\mathbf{2 5 . 1 5 1 . 4 4 9}$ & $\mathbf{1 3 . 4 6 6 . 6 8 2}$ & $\mathbf{1 . 8 9 1 . 8 3 2}$ & $\mathbf{5 . 2 3 5 . 8 2 7}$ \\
\hline
\end{tabular}

Fonte: IBGE. PNAD

Nota: Somente assalariados com declaração de jornada. 
Mas além das altas taxas de trabalhadores que trabalham além da jornada legal, há ainda forte pressão patronal no sentido de aumentar a jornada de trabalho em setores onde os trabalhadores já conquistaram jornadas inferiores ao previsto em lei, como no setor bancário, e também, em diversas categorias profissionais. Ao analisar as informações contidas no banco de dados de greves do DIEESE, observo uma diversidade de categorias que tiveram a "manutenção da jornada" como ponto de pauta de reivindicações das greves, motivados, principalmente, pela iniciativa patronal de aumentar a jornada de trabalho; mas também de reduzir a jornada e os salários, como possibilitados pela legislação. Verifica-se, igualmente, pressão pela redução do número de equipes em turnos de revezamento, que têm jornada garantida por lei de 36 horas e é muito comum no setor industrial, como forma de atingir a ampliação das jornadas semanais médias (DIEESE, 2000).

Desse modo, a partir dos anos 90, no contexto de uma das maiores crises de emprego da história (Prado, 2000), além de não ter havido a redução da jornada de trabalho, tem sido forte a pressão pelo aumento do tempo a ser dedicado ao trabalho - ao considerarmos conjuntamente as tendências da jornada de trabalho e da realização de hora-extra -, e pela flexibilização. Tratarei disso no item subseqüente.

\subsection{2 - Anos 1990: a intensificação da flexibilização do tempo de trabalho}

No que se refere à flexibilização do tempo de trabalho, uma das principais alterações ocorreu no ano de 1998, com a aprovação pelo Congresso Nacional do Projeto de Lei de 1996, criando a anualização do tempo de trabalho, chamado "banco de horas". Essa mudança significou a ampliação do prazo para a compensação das horas trabalhadas acima da duração legal de 44 horas, que era semanal, para um ano ${ }^{6}$. Com esta medida, o governo brasileiro atende aos interesses dos empresários que já vinham, desde o início dos anos 1990, solicitando às entidades sindicais a negociação da flexibilização da jornada (Cardoso, 1998a e 1999b; e DIEESE, 2002). Já em 1999, foram registrados diversos acordos negociados sobre o «banco de horas» (SACC-DIEESE) ${ }^{7}$. Uma única proposta do governo que poderia ter criado empregos

6. A Lei 9.601, de 21 de janeiro de 1998, trata em seu artigo $6^{\circ}$ de uma alteração ao artigo 59 da CLT, parágrafo $2^{\circ}$, dando a este uma nova redação, possibilitando o não pagamento das horas trabalhadas em excesso, se as mesmas forem compensadas com a diminuição das horas trabalhadas em outro dia, devendo ser compensadas dentro de 120 dias no máximo, de forma que não exceda à soma das jornadas semanais de trabalho previstas, nem seja ultrapassado o limite máximo de dez horas diárias de trabalho. Em seguida, foi editada a Medida Provisória 1.709, de 6 de agosto de 1998, que alterou esse período de compensação para um ano.

7. Sistema de Acompanhamento de Contratações Coletivas - DIEESE 
e colocado limites ao tempo dedicado ao trabalho, acabou não sendo implantada. Trata-se do limite de 120 horas extraordinárias no período de um ano, prevista no Projeto de Lei que criou o banco de horas. Entretanto, ao final do processo de negociação esse dispositivo não foi aprovado pelo Congresso nacional. Quanto à forma de negociação do banco de horas, de acordo com essa lei, ela seria coletiva. No entanto, no ano de 2000, nova alteração na legislação legaliza também as negociações individuais realizadas diretamente entre a empresa e os trabalhadores. No quadro 2, a seguir, há um resumo da legislação vigente sobre a jornada de trabalho no Brasil.

QUADRO 2

Legislação sobre jornada de trabalho no Brasil

\begin{tabular}{|c|c|c|c|c|}
\hline Temas & $\begin{array}{c}\text { CLT e Constituição } \\
\text { Federal }\end{array}$ & $\begin{array}{c}\text { Lei } 9.601 \\
\text { de } 21 / 01 / 96\end{array}$ & $\begin{array}{c}\text { MP 2.164-41 } \\
\text { (versão de } \\
\text { 24/08/01) }\end{array}$ & $\begin{array}{c}\text { Orientação } \\
\text { Jurisprudencial } \\
\mathbf{n}^{\circ} 182(\text { de 08/11/00) }\end{array}$ \\
\hline Jornada Diária & $\begin{array}{l}8 \text { horas e } 6 \text { para } \\
\text { turnos ininterruptos }\end{array}$ & $\begin{array}{l}8 \text { horas e } 6 \text { para } \\
\text { turnos ininterruptos }\end{array}$ & $\begin{array}{l}8 \text { horas e } 6 \text { para } \\
\text { turnos ininterruptos }\end{array}$ & Não altera \\
\hline Jornada Semanal & 44 horas $(\mathrm{CF})$ & 44 horas & 44 horas & Não altera \\
\hline \multirow[t]{2}{*}{ Horas Extras } & Adicional: $50 \%$ & Adicional: $50 \%$ & Adicional: $50 \%$ & \\
\hline & Limite: $2 \mathrm{~h} / \mathrm{dia}$ & Limite: $2 \mathrm{~h} / \mathrm{dia}(1)$ & Limite: $2 \mathrm{~h} / \mathrm{dia}$ & Não altera \\
\hline Prazo para compensação & Semanal & 120 dias & 12 meses & Não altera \\
\hline $\begin{array}{l}\text { Forma de implantação } \\
\text { da alteração da Jornada }\end{array}$ & Acordo Coletivo & Acordo Coletivo & Acordo Coletivo & $\begin{array}{l}\text { Vale o acordo indi- } \\
\text { vidual, à exceção da } \\
\text { existência de normas } \\
\text { coletivas em sentido } \\
\text { contrário }\end{array}$ \\
\hline
\end{tabular}

Fonte: Consolidação das Leis do Trabalho - Artigo 59 -Constituição Federal de 1988 -Capítulo II , artigo $7^{\circ}$ - Lei nº 9.601 de 21.01 .98 ,Medida Provisória 2164-41, de 24.08.01 e Orientação Jurisprudencial n 182, de 08.11.00.

Elaboração: DIEESE.

(1) No projeto de Lei 1.724, de 1996, sobre "Contrato de Trabalho por Tempo Determinado", enviado ao Congresso pelo Poder Executivo, havia o limite de 120 horas extraordinárias no período de um ano. No documento final, entretanto, esta limitação não estava prevista.

Assim, sem perder de vista o jogo de interesses que permeiam as discussões em relação à organização do trabalho, as mudanças na legislação, tais como a flexibilização do tempo de trabalho, ou ainda a ausência de limitação da hora-extra, devem ser vistas também como respostas à forte pressão exercida pelo setor patronal junto à esfera de governo. E quando observamos os argumentos empresariais em relação à jornada de trabalho ${ }^{8}$, duas direções principais ficam evidentes.

8. O material empírico de base para tal foi obtido por entrevistas que realizei no ano 2000 para a elaboração do vídeo «Jornada de trabalho: a visão dos empresários», que faz parte do Kit «A negociação da jornada de trabalho por meio do banco de horas» (Cardoso et alli, 2002). Tais entrevistas contaram com a participação de representantes empresariais que recobriam diferentes ramos de atividade: do setor industrial (como a Volkswagen, a Scania, a Mahle Metal Leve e a Basf), ao setor do comércio (como o Carrefour) e aos serviços (através da Federação Brasileira do Bancos - FEBRABAN). 
Uma delas diz respeito à busca do total controle sobre o tempo do trabalhador: ao invés de uma jornada de trabalho fixa, fazê-la flexível e totalmente dependente da demanda por produção. Ou seja, o empresário busca transferir para os trabalhadores os custos de uma redução da produção causados por fatores sobre os quais estes não têm qualquer governabilidade. Confluindo para a intenção anterior, os empregadores entrevistados também enfatizaram o interesse da empresa em funcionar " 24 horas por dia, 07 dias por semana". Aliadas à busca pelo total controle do tempo de trabalho, pela possibilidade de suspender o trabalho quando há uma redução da demanda, estão intimamente ligadas ao desejo empresarial de ter os trabalhadores no local de trabalho ou à disposição da empresa mesmo que fora do local, sem nenhuma restrição durante a maior parte do tempo. Assim, defende-se que "A jornada dos bancos deve acompanhar a jornada dos demais segmentos que hoje trabalham sábado, domingo, até dez horas da noite, até meia noite" (Febraban); num mesmo sentido, um representante do setor industrial ressalta, "nós precisamos buscar alguma alternativa que nos permita trabalhar 24 horas por dia, 7 dias por semana" (Mahle), ou ainda, "4 turnos de 6 horas (...) de forma que você terá a fábrica trabalhando 24 horas por dia" (Volks). Pouco importa se é através do banco de horas, da contratação de trabalhadores a tempo parcial, da realização de hora extra, do aumento da jornada normal ou de turno. O importante parece ser a utilização do capital fixo 24 horas por dia e, de preferência, a um menor custo monetário e político possível. Como já fora analisado por Offe (1997), o interesse em controlar cada vez mais a jornada do trabalhador está relacionado à possibilidade de utilizar a força de trabalho conforme o surgimento descontínuo de trabalho, sem ter que pagar salários nos períodos de tempo em que esta não seria usada por razões empresariais e organizacionais.

Alves Silva (2001), analisando o tema do "tempo à disposição do empregador" sob o prisma do direito do trabalho, ressalta que se o empregador resolve, em função dos seus interesses, reduzir a jornada de trabalho em um dia específico, o trabalhador não deveria ter a sua remuneração alterada. Pois, nesse caso "seria o empregado assumindo os riscos do empreendimento" (2001:2), já que o empregador, quando dispensa o trabalhador da sua jornada normal, busca, com a flexibilização desta, via banco de horas, "liberar-se de salários e encargos" (idem). E frisa ainda, no que se refere à possibilidade do trabalhador em relação ao uso desse tempo liberado em função do interesse do empregador: 


\section{Tabela 6}

Distribuição anual das greves, segundo temas de reivindicações selecionados

Brasil 1990-2006 (1)

\begin{tabular}{lcccccccc}
\hline Tema & Adicional & Auxílio & $\begin{array}{c}\text { Direito } \\
(2)\end{array}$ & Emprego & Jornada & $\begin{array}{c}\text { Adicional de } \\
\text { hora extra (3) }\end{array}$ & $\begin{array}{c}\text { Relações } \\
\text { de trabalho }\end{array}$ & Remuneração \\
\hline 1990 & 4,9 & 13,8 & 17,0 & 11,5 & 3,7 & 1,5 & 10,3 & 84,9 \\
1991 & 4,1 & 13,0 & 20,8 & 9,4 & 2,8 & 1,2 & 10,0 & 84,5 \\
1992 & 5,4 & 9,4 & 29,9 & 12,1 & 2,7 & 2,2 & 10,6 & 68,9 \\
1993 & 9,2 & 14,4 & 33,7 & 13,4 & 4,5 & 2,2 & 16,0 & 57,5 \\
1994 & 7,7 & 17,5 & 22,4 & 12,0 & 4,5 & 3,0 & 13,3 & 74,3 \\
1995 & 6,8 & 25,7 & 42,1 & 13,8 & 5,7 & 3,4 & 15,7 & 56,2 \\
1996 & 5,3 & 16,3 & 55,8 & 10,0 & 13,4 & 2,3 & 8,5 & 44,6 \\
1997 & 6,8 & 17,2 & 51,0 & 14,7 & 4,9 & 3,5 & 13,1 & 41,9 \\
1998 & 9,9 & 18,7 & 59,7 & 19,4 & 5,6 & 5,0 & 14,9 & 30,2 \\
1999 & 14,0 & 23,7 & 49,2 & 29,2 & 10,1 & 6,7 & 21,5 & 38,9 \\
2000 & 14,8 & 22,1 & 45,8 & 17,3 & 11,6 & 6,7 & 22,6 & 44,3 \\
2001 & 6,0 & 16,4 & 40,2 & 15,2 & 8,6 & 3,1 & 19,0 & 49,3 \\
2002 & 17,1 & 17,4 & 35,5 & 23,0 & 6,3 & 5,9 & 27,3 & 43,4 \\
2003 & 11,2 & 19,1 & 28,2 & 20,6 & 10,0 & 4,4 & 28,5 & 56,8 \\
2004 & 14,6 & 25,8 & 35,4 & 24,8 & 11,9 & 3,6 & 34,8 & 64,6 \\
2005 & 14,4 & 25,1 & 23,4 & 22,7 & 13,4 & 4,0 & 36,1 & 64,2 \\
2006 & 16,9 & 30,3 & 27,5 & 24,1 & 15,9 & 5,9 & 42,5 & 64,7 \\
\hline
\end{tabular}

Fonte: DIEESE.

1) Dados em percentuais, não consolidados, sujeitos a alterações.

2) Neste grupo «Direito», estão incluídas as greves por descumprimento de acordo ou convenção coletiva por parte do setor patronal.

3) Reivindicação de aumento do percentual pago pelo trabalho extraordinário ou contra irregularidades praticadas no pagamento desse adicional.

“... como o empregado poderia se sentir a vontade para, antecipadamente, destinar diferentemente o uso de um tempo que ele não sabe se terá. Pois só lhe será permitido, se, e somente se, os serviços naquele dia assim o permitirem, especialmente se estamos tratando de estabelecimentos de movimentação inconstante" (Alves Silva, 2001: 2).

Do ponto de vista do Movimento Sindical, mesmo tendo as ações do governo e dos empresários voltadas para a flexibilização e para a ampliação do tempo que os trabalhadores estão à disposição para o trabalho, a atuação continua sendo no sentido da limitação ou redução da duração do tempo de trabalho. Como veremos, tais ações desenvolvem-se tanto pela via das negociações setoriais ou por empresa, nos locais de trabalho, como pela via da luta por mudanças na legislação, mediante a elaboração de propostas mais abrangentes que culminaram na criação de uma campanha nacional pela redução do tempo de trabalho. Assim, já no final de 1995, 
vemos um primeiro ensaio de retomada da discussão sobre a redução do tempo de trabalho por parte das centrais sindicais - Central Única dos Trabalhadores (CUT) e Força Sindical -, transformando-se em propostas de redução da duração do trabalho de 44 para 36 horas semanais, em troca da redução dos salários em 5\%, bem como de redução de encargos e renúncia físcal. Nesse mesmo ano, as duas centrais realizaram uma campanha de negociação coletiva abrangendo todos os metalúrgicos do Estado de São Paulo, incluindo a reivindicação sobre a redução da duração do trabalho, o que refletiu no aumento do percentual de greves sobre a jornada no ano de 1996, conforme observado na tabela 6.

O tema "jornada de trabalho" volta a ser destaque nos anos de 1999 e 2000, e, novamente em 2003, mantendo-se em alta até o ano 2006, apesar do forte movimento de queda no número geral de greves, conforme destacado pela tabela 7. Nos demais anos, esse tema apareceu sempre em percentuais inferiores a 10\%. A reivindicação de maior destaque tem sido aquelas que tratam da questão da "remuneração", seguida de "direito", com forte aumento a partir de 1995, mas que nos últimos anos perde força. Num sentido contrário, há de se destacar o aumento significativo das reivindicações relacionadas ao adicional de hora extra, motivadas, na sua maior parte, pela ação empresarial no sentido de redução do valor pago. Vemos ainda um aumento das greves sobre "emprego", sobretudo a partir de 1999.

Quando olhamos para os diversos conteúdos das greves classificadas como "jornada de trabalho" (tabela 7), retomo o ano de 1996, onde das 167 greves ocorridas, 141 tiveram como uma de suas reivindicações a redução da jornada para 40 horas semanais ${ }^{9}$. Chama também a atenção, o número de greves realizadas nos dois anos anteriores a 1996, mesmo em menor quantidade, estando também presente a reivindicação da "redução da duração do trabalho". Depois de um período de queda no número de greves, entre 1992 e 1993, momento marcado por forte recessão, já no final deste último ano, vemos uma retomada das greves com o tema da jornada de trabalho voltando a estar presente. Também vale ressaltar que entre os anos de 2003 a 2006 há um pequeno aumento das greves sobre o tema da "jornada de trabalho" com reivindicação sobre "redução da jornada de trabalho" e, em 2006 sobre "extinção da hora-extra" podendo demonstrar reflexos da Campanha Nacional pela redução da jornada, limitação da hora extra e do banco de horas, lançada no ano de 2004.

9. Considerando sua relação com a campanha de negociação coletiva dos metalúrgicos do Estado de São Paulo, que tinha na sua pauta a reivindicação da redução da duração do trabalho, vale ressaltar, então, dois pontos relevantes: trata-se, na sua grande maioria, de greves por empresa, no setor metalúrgico; e como trata-se de uma campanha de data-base, essas greves englobam ainda outras reivindicações. 
Tabela 7

Total anual e distribuição das greves segundo reivindicações selecionadas Brasil - 1990-2006 (1)

\begin{tabular}{|c|c|c|c|c|c|c|c|c|c|c|c|}
\hline \multirow{3}{*}{ Ano } & \multirow{3}{*}{$\begin{array}{c}\text { Total de } \\
\text { greves }[\mathrm{A}]\end{array}$} & \multicolumn{10}{|c|}{ Reivindicações relativas a jornada } \\
\hline & & \multicolumn{2}{|c|}{$\begin{array}{l}\text { Total de greves } \\
\text { sobre jornada }[\mathrm{B}]\end{array}$} & \multicolumn{2}{|c|}{$\begin{array}{l}\text { Manutenção de } \\
\text { jornada }\end{array}$} & \multicolumn{2}{|c|}{$\begin{array}{l}\text { Redução de } \\
\text { jornada }\end{array}$} & \multicolumn{2}{|c|}{$\begin{array}{c}\text { Extinção de } \\
\text { horas extras (2) }\end{array}$} & \multicolumn{2}{|c|}{$\begin{array}{c}\text { Não- } \\
\text { flexibilização } \\
\text { de jornada }\end{array}$} \\
\hline & & $\mathrm{n}^{\mathrm{o}}$ & $\begin{array}{c}\% \\
\text { sobre } \\
{[\mathrm{B}]}\end{array}$ & $\mathrm{n}^{\mathrm{o}}$ & $\begin{array}{c}\% \\
\text { sobre } \\
{[\mathrm{B}]}\end{array}$ & $\mathrm{n}^{\mathrm{o}}$ & $\begin{array}{c}\% \\
\text { sobre } \\
{[\mathrm{B}]}\end{array}$ & $\mathrm{n}^{\mathrm{o}}$ & $\begin{array}{c}\% \\
\text { sobre } \\
{[\mathrm{B}]}\end{array}$ & $\mathrm{n}^{\mathrm{o}}$ & $\begin{array}{c}\% \\
\text { sobre } \\
{[\mathrm{B}]}\end{array}$ \\
\hline 1990 & 1.789 & 66 & 3,7 & 4 & 6,1 & 40 & 60,6 & 1 & 1,5 & 0 & 0,0 \\
\hline 1991 & 1.054 & 29 & 2,8 & 3 & 10,3 & 12 & 41,4 & 0 & 0,0 & 0 & 0,0 \\
\hline 1992 & 556 & 15 & 2,7 & 1 & 6,7 & 8 & 53,3 & 0 & 0,0 & 0 & 0,0 \\
\hline 1993 & 644 & 29 & 4,5 & 2 & 6,9 & 11 & 37,9 & 1 & 3,4 & 0 & 0,0 \\
\hline 1994 & 1.043 & 47 & 4,5 & 3 & 6,4 & 23 & 48,9 & 8 & 17,0 & 1 & 2,1 \\
\hline 1995 & 1.056 & 60 & 5,7 & 7 & 11,7 & 30 & 50,0 & 7 & 11,7 & 0 & 0,0 \\
\hline 1996 & 1.242 & 167 & 13,4 & 1 & 0,6 & 141 & 84,4 & 1 & 0,6 & 0 & 0,0 \\
\hline 1997 & 633 & 31 & 4,9 & 2 & 6,5 & 13 & 41,9 & 0 & 0,0 & 1 & 3,2 \\
\hline 1998 & 536 & 30 & 5,6 & 12 & 40,0 & 9 & 30,0 & 3 & 10,0 & 1 & 3,3 \\
\hline 1999 & 507 & 51 & 10,1 & 15 & 29,4 & 17 & 33,3 & 5 & 9,8 & 4 & 7,8 \\
\hline 2000 & 526 & 61 & 11,6 & 2 & 3,3 & 42 & 68,9 & 2 & 3,3 & 4 & 6,6 \\
\hline 2001 & 420 & 36 & 8,6 & 5 & 13,9 & 19 & 52,8 & 3 & 8,3 & 0 & 0,0 \\
\hline 2002 & 304 & 19 & 6,3 & 3 & 15,8 & 7 & 36,8 & 3 & 15,8 & 1 & 5,3 \\
\hline 2003 & 340 & 34 & 10,0 & 6 & 17,6 & 18 & 52,9 & 2 & 5,9 & 2 & 5,9 \\
\hline 2004 & 302 & 36 & 11,9 & 1 & 2,8 & 14 & 38,9 & 4 & 11,1 & 2 & 5,6 \\
\hline 2005 & 299 & 40 & 13,4 & 1 & 2,5 & 16 & 40,0 & 5 & 12,5 & 7 & 17,5 \\
\hline 2006 & 320 & 51 & 15,9 & 3 & 5,9 & 9 & 17,6 & 16 & 31,4 & 2 & 3,9 \\
\hline
\end{tabular}

Fonte: DIEESE

(1) Dados não consolidados, sujeitos a alterações.

(2) Inclui redução do número de horas extras.

Sobre as greves voltadas à temática da "manutenção da jornada", seu ponto alto está nos anos de 1998 e 1999; essas greves têm um caráter mais propriamente reativo, seja em face à tentativa patronal de aumentar a jornada de trabalho, seja ainda almejando redução na jornada, acompanhada de redução nos salários, como previsto na legislação e já comentado neste capítulo. As reivindicações em torno da flexibilização da jornada começam a aparecer no ano de 1997, mesmo que de forma tímida, antes mesmo de implementada a legislação sobre banco de horas. Já em 1999 e 2000, após a mudança na legislação, observamos um pequeno aumento no percentual 
dessas greves, sobretudo em 2005. Vale ressaltar que são poucas as greves que tiveram como reivindicação a extinção da hora extra ou mesmo a sua limitação, a exceção do ano de 2006, sendo mais freqüente a reivindicação pelo aumento ou contra a tentativa patronal em reduzir o adicional de hora extra.

Os dados anteriores deixam patente que os anos 1990 foram marcados pela dificuldade das organizações sindicais inserirem temas na agenda dos processos negociais. Além da redução do tempo de trabalho, outros temas como a discussão acerca dos processos de inovação tecnológica, das políticas de qualificação e treinamento, do trabalho temporário e da terceirização - todos esses aspectos chaves das mudanças técnico-organizacionais que estavam em curso e que alteravam substancialmente o ambiente das empresas - foram ficando de fora da pauta negocial. E, como veremos de forma mais detalhada a partir do exemplo da Volkswagen, a alteração no tempo de trabalho não se deu apenas a partir de mudanças na jornada de trabalho, mas resultou também, do próprio processo de inovação técnico-organizacional. Entretanto, o foco da negociação entre trabalhadores e empresários, na maior parte das vezes, dizia respeito à extensão e à flexibilização da jornada de trabalho, deixando de lado os reflexos que a transformação na organização do trabalho acabou produzindo.

É importante ressaltar, ainda, que a dificuldade para inserir esses temas no processo de negociação coletiva vem de longa data, e não começou nos anos 1990. Bresciani (1994) ressalta que desde os anos 1980 esses temas, sobretudo no que se refere às mudanças tecnológicas e organizacionais ${ }^{10}$, já estavam sendo discutidas pelo movimento sindical. Mesmo assim, como também avaliado por Cardoso (1998a), as ações e reações dos trabalhadores não conseguiram se transformar em efetiva influência no curso dos processos de inovação, tal como foram sendo definidos pelas empresas. Nos raros casos de cláusulas negociadas sobre essa temática, elas apenas prevêem a comunicação ao sindicato quando da implantação de alguma inovação, como é o caso da Volkswagen, ou treinamento ao trabalhador atingido por esse processo (DIEESE, 1993, Bresciani, 1994 e Cardoso, 1998a).

A novidade dos anos 1990 é o caráter de equilíbrio instável que adquirem as negociações, dado que o empresariado logrou excluir ou flexibilizar direitos já conquistados durante a década

10. O autor ressalta que essa temática esteve presente nos congressos de algumas centrais sindicais, como a CUT, sendo que esta criou, em 1985, a Comissão Nacional de Tecnologia e Automação (CNTA), na qual faziam-se presentes preocupações com a intensificação do ritmo de trabalho, da qualificação do trabalhador e do emprego (Bresciani, 1994). 
anterior. Dentre eles, muitos estão vinculados ao tempo dedicado ao trabalho, como licenças maternidade e paternidade, aviso prévio, trabalho temporário, adicional de hora extra ou adicional noturno.

Observando-se especificamente a negociação sobre o tempo de trabalho, dos 96 instrumentos normativos do SACC/DIEESE ${ }^{11}$, em 2002, 34\% contêm cláusulas que asseguram jornadas reduzidas para categorias diferenciadas, como pessoal administrativo, e $12 \%$ definem jornada inferior a 44 horas semanais para o conjunto dos trabalhadores. Houve ainda uma pequena redução do número de acordos coletivos, garantindo a redução do tempo de trabalho, entre os anos de 1996 e 2002 (DIEESE, 2005). Como já ressaltamos anteriormente, dentre as categorias profissionais que conquistaram a redução da jornada de trabalho, a maioria foi obtida em acordos coletivos realizados por empresa e não em convenções coletivas, sendo, portanto, de abrangência restrita. Dentre as reduções conquistadas, a maior parte delas altera a jornada de 44 horas semanais para 42 horas $^{12}$. Finalmente, no ano de 1999, há um aumento significativo dos acordos sobre a flexibilização do tempo de trabalho, após a implantação legal do sistema de banco de horas, aprovado em 1998 (idem).

No que refere ao processo de negociação específico do "banco de horas", vale ressaltar que, mesmo no caso em que as entidades sindicais conseguiram realizar acordos coletivos - pois a lei passou a aceitar também as negociações diretas entre empregadores e trabalhadores -, elas têm enfrentado diversas dificuldades. Seja para evitar a implantação do banco de horas, seja para negociar regras para a sua utilização que sejam favoráveis aos trabalhadores. Isto se deve a vários fatores, dentre os quais se destacam: o fato de que tal negociação foi realizada de forma descentralizada,

11. Sistema de Acompanhamento de Contratações Coletivas (SACC), que contempla negociações paradigmáticas no Brasil, em níveis regional, setorial ou nacional. No total, acompanha 98 acordos e convenções coletivas, abrangendo 30 categorias em 14 unidades da federação.

12. Alguns exemplos de acordos com redução da jornada de trabalho, conforme o SACC: Trabalhadores nas indústrias PETROFLEX, Pernambuco; Klabin, Lages; COELBA, Bahia; CEMIG, Minas Gerais; CELPA, Pará; COSANPA, Pará; Itaipu, Paraná; CEDAE, Rio de janeiro; CAERN, Rio Grande do Norte; TELEMIG Celular S/A, Minas Gerais; TELEMAR Norte Leste S/A, Minas Gerais; Telefônica Empresas S/A, São Paulo; Trabalhadores em Empresas de Processamento de Dados de Pernambuco; Trabalhadores em Empresas de Processamento de Dados do Rio de Janeiro; Aeroviários, em âmbito nacional; Trabalhadores no Transporte Rodoviário do Município do Rio de Janeiro; Metroviários de São Paulo; Trabalhadores na Indústria de Alimentação Nestlé de São Paulo; Metalúrgicos da Empresa Samarco, Espírito Santo; Metalúrgicos da ACESITA, Minas Gerais; Enfermeiros, Paraná; Condutores de Veículo Urbano, São Paulo; Trabalhadores da Indústria Farmacêutica do Estado de São Paulo; Trabalhadores da Indústria B.S Colway, do Paraná. Além desses casos, o Sindicato dos Metalúrgicos de São Paulo fechou acordo com 230 empresas, que beneficiam 40.596 empregados, e, entre elas, encontram-se: Arno S/A, Bicicletas Caloi S/A, Bicicletas Monark S/A e Philips do Brasil S/A (DIEESE, 2006). 
mediante acordos por empresa e não através de convenções coletivas; a inexistência de regras legais para a sua utilização; a pouca penetração do movimento sindical dentro dos locais de trabalho; e ao contexto de forte desemprego, que pressiona os trabalhadores a aceitarem piores condições de trabalho.

Assim, desde a instituição do "banco de horas" os trabalhadores têm enfrentado diversos problemas, entre eles a falta de controle sobre as horas trabalhadas a mais (saldo positivo no banco), e sobre as horas trabalhadas a menos (saldo negativo). Há ainda a dificuldade de utilizar horas positivas, já que a solicitação quase sempre vem acompanhada da negativa empresarial, argumentando que a produção não pode parar. São também comuns os casos de trabalhadores que, em função de demanda da própria empresa, acumulam grande saldo positivo no banco de horas e, ao final, a empresa alega que ele não pode ficar muito tempo longe da empresa. (Cardoso et alli, 2004). Além disso, na maior parte dos acordos negociados, uma hora trabalhada a mais equivale a uma hora trabalhada a menos ${ }^{13}$.

Enfim, esse é um tema que tem dividido muito a opinião dos dirigentes sindicais ${ }^{14}$. Alguns entendem que vale negociá-lo se o acordo contiver cláusulas de contrapartida, tais como a garantia de emprego, a redução da jornada de trabalho ou a redução do número de horas extras. Para outros, os riscos decorrentes da implantação do banco de horas são muito maiores do que as oportunidades, uma vez que a elevação da jornada semanal e a intensificação que a acompanha podem levar ao surgimento de doenças profissionais, ao stress, e ao aumento do número de acidentes de trabalho. Além disso, há a redução da remuneração do trabalhador em função do fim do adicional de hora extra, bem como a dificuldade de planejamento por parte do trabalhador do seu tempo livre, ficando sempre a mercê da demanda da empresa. Finalmente, no que se refere à hora extra, os sindicalistas entrevistados entendem que os trabalhadores preferem a sua realização ao "banco de horas" (DIEESE, 2000), assunto ao qual voltarei adiante, quando discutir as experiências dos trabalhadores da Volkswagen do ABC.

13. Ou seja, quando o trabalhador trabalha uma hora a mais em um dia, ele irá receber, no mínimo, 50\% de adicional de hora-extra. Com a implantação do banco de horas, se ele trabalha uma hora a mais e um dia, e compensa essa hora em 12 meses, como prevê a legislação, ele irá descansar apenas 1 hora, e não 1h30. Há casos de acordos, como veremos na Volkswagen onde os trabalhadores conquistaram para cada 1 hora trabalhada, 2 descansadas.

14. As informações empíricas utilizadas em seguida fazem parte de uma pesquisa realizada pelo DIEESE, CNM e metalúrgicos do $\mathrm{ABC}$, com base em entrevistas com dirigentes sindicais das seguintes montadoras: Agrale/RS, Fiat/Betim - MG, Ford/São Bernardo do Campo (SBC) - SP, GM/São José dos Campos - SP, Mercedes Benz/ SBC, Scania/SBC, Toyota/SBC, Honda/Sumaré, Mercedes Benz/Juiz de Fora -MG, Toyota/Indaiatuba SP, Volks/Taubaté Volks/Resende - RJ e Volks/Anchieta SP. O período pesquisado compreendeu os anos de 1995 a 2000. Agradeço às instituições promotoras da pesquisa pela possibilidade de acesso a estes dados. 
Outra questão importante que discuto de forma mais detalhada no capítulo sobre a Volkswagen, é que o banco de horas tem gerado forte intensificação do trabalho. Primeiramente, porque o tempo na empresa passa a significar, na maior parte dos casos, um tempo de alta demanda e máxima produção, pois nos momentos de desaceleração o trabalhador ficará em casa para compensar as horas a mais no banco, para tirar férias individuais ou coletivas. Em segundo lugar, porque em paralelo à flexibilização, há forte pressão patronal para eliminar os tempos de descanso do trabalhador, significativamente, chamados pelo jargão gerencial de tempos mortos.

No plano nacional, a partir de 2003 as Centrais Sindicais ${ }^{15}$ iniciam uma campanha nacional intitulada «Reduzir a Jornada de Trabalho é Gerar Empregos», tendo como foco principal, a redução da jornada de trabalho para 40 horas por semana, englobando ainda a questão da limitação da utilização da hora extra e do banco de horas. Entretanto, já em 2001, a CUT e o DIEESE criaram um sítio na Internet ${ }^{16}$ com diversas informações sobre o tempo de trabalho no Brasil e no mundo. Essa discussão foi ganhando fôlego ao longo dos anos de 2001 e $2002^{17}$, até que em 2003 todas as Centrais se reúnem e participam de um seminário para a construção do planejamento da "Campanha Nacional pela Redução da Jornada de Trabalho, sem Redução dos Salários".

No início de 2004, o movimento sindical decide ampliar o espaço de discussão da campanha para outros atores sociais e faz o lançamento oficial da campanha na Assembléia Legislativa de São Paulo. Inicia um abaixo-assinado com os dizeres Reduzir a Jornada é Gerar Empregos, visando defender a tramitação, em caráter emergencial, da Proposta de Emenda Constitucional 393/01, de autoria do senador Paulo Paim (PT-RS) e do deputado federal Inácio Arruda (PC do B-CE), que prevê a redução da jornada de trabalho sem redução do salário. Em 2005, no Fórum Social Mundial, o Comando da Campanha Nacional decidiu construir um diálogo internacional tendo como objetivo melhor compreender a situação da jornada de trabalho em vários países, além de dar continuidade à divulgação da campanha no Brasil, lançando uma cartilha, além do sítio da campanha na Internet.

No que se refere ao foco da campanha, vemos que, mais uma vez, a reivindicação por parte do movimento sindical vincula, principalmente, a redução da jornada de trabalho à geração

15. Além da CUT e da Força Sindical, fazem parte a CAT (Central Autônoma dos Trabalhadores), a CGT (Confederação Geral dos Trabalhadores), a CGTB (Central Geral dos Trabalhadores) e a SDS (Social Democracia Sindical).

16. O nome do sítio é www.tempolivre.com.br

17. Em 2002 houve o lançamento do sitio no Fórum Social Mundial - RS e, no ano seguinte, em 2003, foi realizada uma mesa de trabalho, no Fórum Social Mundial. E ainda, em novembro de 2003, a campanha foi apresentada na Mesa de Trabalho-Fórum Social Brasileiro, em Minas Gerais. 
de empregos e não ao aumento do tempo livre. Aliás, no Brasil, a reivindicação pela redução da jornada de trabalho esteve, na maior parte das vezes, vinculada a outra demanda: à questão da saúde, ao tempo para as mulheres cuidarem da casa e dos filhos, para as crianças irem à escola ou ainda à necessidade de um tempo maior de repouso entre duas jornadas de trabalho. Vimos que, no início de 1900, nos primeiros congressos dos trabalhadores, a questão do tempo livre apareceu de forma mais evidente, mas, ao mesmo tempo, as greves normalmente foram iniciadas a partir de demandas que vinculavam a redução da jornada de trabalho ao pagamento de horas extras. Depois, já nos anos de 1985 e 1986, num contexto de crescimento do desemprego, a demanda pela criação de novos postos de trabalho orientou o movimento de greve realizado pelos sindicatos metalúrgicos, como veremos de forma mais detalhada ao analisarmos o caso dos trabalhadores da Volkswagen. Nos dois exemplos citados, em momentos históricos diferentes, vimos que estava presente a preocupação a respeito da necessidade de mais tempo livre, mas este não era o foco, nem dos trabalhadores e nem tampouco dos governantes.

Assim, no contexto atual, o mesmo pode ser observado na campanha nacional pela redução da jornada de trabalho. Ao longo do processo de construção dessa campanha ${ }^{18}$, muitas vezes os dirigentes responsáveis, frisavam que ela não poderia dar muita importância ao aumento do tempo livre, pois o que os trabalhadores querem e necessitam, na realidade, é ter um tempo a ser dedicado ao trabalho. Neste sentido, a demanda pela redução do tempo de trabalho aparece muito mais ligada à necessidade de dividir o tempo de trabalho para todos, do que à necessidade de menos tempo de trabalho.

Dentre os diversos fatores que nos ajudam a compreender o reduzido espaço ocupado pela discussão sobre o tempo livre, temos a própria constituição e composição do mercado de trabalho, como vimos anteriormente. No caso brasileiro, mesmo nos momentos em que o mercado de trabalho incorporou maior número de pessoas, ainda assim, uma grande parte da população permanecia excluída do mercado formal. Como resultado, sempre houve forte demanda dos trabalhadores por uma ocupação regular, para terem um tempo de trabalho garantido e remunerado. Agregue-se a isso a ausência de um estado de bem estar, que garantisse direitos mínimos ao

18. Como dito anteriormente, o DIEESE assessorou as Centrais Sindicais na organização dessa Campanha. Como uma das assessoras que participou desse processo, pude acompanhar todo o seu desenvolvimento até agosto de 2006. A ausência de referências bibliográficas sobre esse processo deve-se à inexistência de avaliação documentada, tanto do ponto de vista das Centrais como do DIEESE, e do próprio meio acadêmico. 
cidadão, além dos níveis muito baixos de remuneração; sem contar o valor do trabalho na sociedade brasileira. Todos esses, acredito, são fatores que nos ajudam a compreender a demanda pelo tempo de trabalho e não pelo tempo livre.

No que se refere ao desenvolvimento e resultados da campanha, até o presente ela não se traduziu em um amplo e efetivo processo de discussão. Primeiramente, porque foi difícil ao movimento sindical assegurar a mobilização dos trabalhadores. Diversas razões podem ser aventadas para explicá-lo: seja porque não é uma tarefa fácil conseguir realizar uma campanha nacional em torno da temática do tempo de trabalho; seja porque dentre as categorias com uma história de maior organização e mobilização, a maior parte já conquistou uma jornada de trabalho menor do que o previsto na legislação; seja ainda porque para as outras categorias, como muitas vezes explicitado pelos próprios trabalhadores, a preocupação central é emprego e salários e não redução do tempo de trabalho.

Além disso, outra questão que não pode ser desconsiderada diz respeito à dificuldade por parte do movimento sindical em superar as divergências internas em relação à demanda apresentada. Vale lembrar que a campanha tinha como mote não apenas a redução da jornada de trabalho, sem redução de salários, mas também a limitação da hora extra e do banco de horas. A campanha envolvia a participação de todas as centrais, fato que potencializa a ação por um lado, mas que, por outro lado, dificulta a tomada de decisão coletiva e a manutenção dessa demanda como preferencial na agenda de ações a serem conduzidas pelas centrais, uma vez que cada uma carrega consigo outras demandas tidas como prioritárias. A verticalização das decisões pode ser outro problema, já que o foco da campanha traz uma preocupação com a política de emprego do país, o que, à primeira vista, pode parecer aos trabalhadores empregados, algo distante, de muito mais interesse para os trabalhadores desempregados. Entretanto, e tomando como exemplo os processos de negociação ocorridos em outros países, um fator que parece ter sido decisivo para esse resultado, foi a mudança radical no contexto político enquanto a campanha buscava se fortalecer. No início do primeiro mandato do Governo Lula, as reformas sindical e trabalhista foram colocadas como prioridades de governo, gerando a compreensão por parte das Centrais Sindicais de que o ambiente se apresentava favorável à conquista da redução da jornada de trabalho.

Assim, as centrais sindicais procuraram o engajamento do governo na campanha, a partir do entendimento e da experiência de que, assim como ocorrido na França, o alcance da 
redução da jornada de trabalho para todos os trabalhadores seria conquistado se houvessem mudanças na legislação. Porém, a partir do momento em que o governo viu-se envolvido na crise política, abandonou as discussões das reformas, e, face ao cenário bastante conturbado, a campanha pela redução da jornada de trabalho perdeu fôlego. Como resultado, a campanha se viu sem o apoio dos trabalhadores, sem o apoio do governo, e, consequentemente, não conseguiu inserir este tema na pauta negocial com os empresários, que se posicionam totalmente contrários à redução da jornada de trabalho.

É nítida, portanto, a dificuldade que movimento sindical tem encontrado para pautar a agenda social e política em relação a esta temática, mesmo com forte vinculação entre a questão da redução da jornada de trabalho e a geração de emprego ${ }^{19}$, um dos principais problemas vividos pela sociedade brasileira. Assim, a discussão sobre a jornada de trabalho, no caso do Brasil, tem se concentrado muito mais em torno da sua flexibilização, no sentido de diminuir as limitações impostas à gestão do tempo de trabalho por parte do empresariado. O que tem significado a perda de direitos historicamente conquistados pelos trabalhadores, limitando também, a própria discussão sobre a redução do tempo de trabalho, o aumento do tempo livre, bem como a própria geração de empregos. Por sua vez, a discussão sobre a redução do tempo de trabalho tem se dado unicamente de forma localizada e em categorias com forte organização sindical, como é o caso dos trabalhadores da Volkswagen. Mas, mesmo nesses casos, as negociações sobre redução do tempo de trabalho têm sido vinculadas à sua flexibilização, normalmente a partir dos acordos de banco de horas.

\section{3 - Considerações finais}

Analisar a construção temporal no Brasil, a partir das discussões travadas nos capítulos anteriores, nos fornece elementos para compreensão de como o tempo de trabalho veio a ocupar um lugar importante na sociedade brasileira, e entender também, os contornos da

19. De acordo com os cálculos realizados pelo DIEESE para essa campanha, a redução do tempo de trabalho no Brasil de 44 para 40 horas semanais poderia gerar 1.800.000 novos empregos, considerando que 18 milhões de pessoas têm contrato de trabalho de 44 horas. Somando a redução do tempo de trabalho à limitação das horas extras, estíma-se a geração de mais 1 milhão de postos de trabalho, já que, no país, são realizadas 41 milhões de horas extras por semana (Cardoso et alli, 2005). 
discussão atual sobre o tempo de trabalho. Vimos que, no Brasil, a invenção do trabalho capitalista, assim como em outros países, foi um longo processo, marcado pela disputa de interesses, visões de mundo, num contexto onde a correlação de forças foi sempre muito desigual. Tal processo não pode ser pensado apenas do ponto de vista econômico, mas também envolve questões sociais e culturais. Por isso mesmo, há ênfase e valorização do trabalho, do progresso, das cidades e do tempo cada vez maior a ser dedicado ao trabalho. Ao mesmo tempo, reforça-se a marginalização da malandragem, do não trabalho; além da vinculação entre a pobreza - na qual está inserida a grande parte dos brasileiros -, e a preguiça, o ócio, a não aceitação do trabalho como definido pelo capital e pelo Estado. Valorizações e desmerecimentos realizados a partir de diversas ações e nos mais diferentes espaços; via legislação, discurso, propaganda, música e mesmo a violência.

Assim, a discussão e as lutas sindicais em relação ao tempo de trabalho nascem neste contexto. Um contexto de extrema desigualdade quanto à possibilidade e à forma de inserção no mercado de trabalho. Entender esse processo ajuda a compreendermos por que, no Brasil, na maior parte das vezes, a demanda pela redução da jornada de trabalho tem estado relacionada à demanda pelo emprego; e ainda, porque, sobretudo a partir dos anos 30, outras questões foram ganhando maior destaque na agenda sindical, como a inflação, a ditadura, o emprego. Desse modo, quando a reivindicação por redução da jornada de trabalho volta à cena política em 1985 , após o movimento sindical ter reconquistado o direito à negociação coletiva, já se notavam indícios de retração do mercado de trabalho, crescimento do desemprego e estagnação das taxas de crescimento econômico. Em 1988, a sociedade brasileira conquista a redução da jornada para 44 horas semanais. Mas, apesar do objetivo manifesto da redução da jornada ter sido a criação de empregos, verificou- se o crescimento da quantidade de hora extra realizada pelos trabalhadores e não a geração de empregos.

Nas empresas, como veremos com mais detalhes no capítulo sobre a Volkswagen - um dos centros por onde se irradia a reivindicação dos trabalhadores pela redução da jornada de trabalho para 40 horas -, o momento é marcado pela reestruturação tecnológica e organizacional. Inovações que, por sua vez, têm forte impacto não apenas no emprego, mas também no tempo de trabalho, sobretudo pela via da sua intensificação. E apesar de parte do movimento sindical ter investido na reflexão sobre o tema da inovação, tendo inclusive a preocupação com seu reflexo na intensificação do tempo de trabalho, ele não conseguiu se transformar em tema da pauta de negociação coletiva (DIEESE 1993, Bresciani 1994). Isso não chegou a ocorrer nem 
mesmo naquelas categorias, como os metalúrgicos do $\mathrm{ABC}$, em que houve forte investimento no processo de reflexão e discussão com os trabalhadores (Cardoso, 1998a). Assim, na maior parte das vezes, a negociação sobre o tempo de trabalho ficou muito mais focada na questão da sua extensão, ficando de fora a discussão da sua intensificação.

A partir dos anos 90, a negociação sobre o tempo de trabalho restringiu-se à questão da flexibilização, tendo em vista a dificuldade que o movimento sindical encontrou para voltar a inserir o tema da redução da duração do trabalho na pauta nacional. Assim, a Campanha Nacional pela redução da duração do trabalho, iniciada pelas centrais sindicais no ano de 2003, apesar de tomar a questão do emprego como ponto de partida, num contexto de forte desemprego, não teve força suficiente para construir uma reivindicação a nível nacional, sobre o tempo de trabalho, ficando restrita a negociações coletivas localizadas. Como frisado, foram diversos os motivos para a não transformação da demanda sindical em discussão nacional, dentre as quais se sobressaem a dificuldade de mobilização sindical em torno do tema, a ausência de apoio por parte do Governo e ainda o fato dos empresários serem totalmente contrários à redução da jornada de trabalho.

Apesar de contrários à redução da jornada, o empresariado apresenta todo o seu interesse a favor da flexibilização, exercendo forte pressão para flexibilização dos direitos trabalhistas, entre eles o tempo de trabalho, num contexto mais amplo de continuidade no processo de reestruturação tecnológica e organizacional das empresas. Esta pressão encontrou eco nas diretrizes governamentais, que também tinham como meta flexibilizar os direitos trabalhistas, a partir do diagnóstico de que esses direitos se constituíam em obstáculos à competitividade das empresas nacionais, frente à abertura comercial e financeira.

A confluência de idéias e interesses entre governo e empresários culminou em diversas mudanças no sentido de desregulamentação da estrutura jurídica trabalhista brasileira, e do conseqüente aprofundamento da flexibilização das relações de trabalho. No que se refere especificamente ao tempo de trabalho, a mudança mais importante foi a implantação do banco de horas, anualizando o tempo de trabalho. Tal mudança, como destacado ao longo deste texto, soma-se às diversas outras modalidades de flexibilização há muito existentes na sociedade brasileira, reforçando uma tendência ao desequilíbrio de forças que quase sempre resulta em prejuízo financeiro ou de qualidade de vida para os trabalhadores.

Como resultado, a sociedade brasileira se caracteriza por uma realidade de extremos: por um lado, uma quantidade cada vez menor de trabalhadores formalmente empregados, reali- 
zando mais hora-extra e estando cada vez mais à disposição do empregador; por outro lado, muitos trabalhadores desempregados e à procura de um tempo a ser dedicado ao trabalho. Nesse contexto de desequilíbrio a redução do tempo de trabalho poderia ter estado presente na discussão nacional, mas acabou ficando restrita a algumas negociações por empresa, mais precisamente, naquelas onde há forte organização sindical, como foi o caso da Volkswagen $\mathrm{ABC}$, que analisaremos em seguida.

Fazendo um diálogo com o que foi observado com respeito à sociedade francesa em torno da discussão do tempo de trabalho, vemos que há alguns traços comuns e outros muito particulares à cultura temporal de cada sociedade. A grande diferença fica por conta da ação governamental. No caso francês, o Partido Socialista tinha o tema da redução da jornada de trabalho como um dos focos principais, desde a sua plataforma de governo. Pois, como vimos, não havia naquele momento, uma forte mobilização dos trabalhadores em torno desse tema, o que permaneceu ao longo de todo o processo de negociação das 35 horas. Já no caso do Brasil, o tema da redução da jornada de trabalho esteve praticamente ausente da pauta governamental. No caso do movimento sindical, vimos que houve certa mobilização, sobretudo após a eleição do Presidente Lula, faltando, entretanto, tanto a âncora da mobilização dos trabalhadores, quanto o apoio do governo, sem, os quais, o tema não teve força para entrar na pauta de discussão com o setor patronal.

Frente as dificuldades apresentadas pelo movimento sindical e as diferenças de atitude entre os dois governos, francês e brasileiro, chama a atenção a semelhança da ação empresarial no sentido de recuperar o controle sobre o tempo dos trabalhadores, tanto dentro como fora do local de trabalho, resgatando espaços perdidos diante do acúmulo de avanços de cada uma das sociedades ao longo da história. O que tem significado, nos dois países, a flexibilização, cada vez maior, do tempo de trabalho. Uma flexibilização definida a partir das necessidades da produção e não dos trabalhadores. 
ANEXO 1

Leis que regulam a jornada de trabalho para categorias ou casos específicos no Brasil

\begin{tabular}{|c|c|c|}
\hline Leis & Categorias ou casos específicos & Jornada de trabalho \\
\hline $\begin{array}{l}\text { Constituição Federal } \\
- \text { Art. } 7^{\circ}\end{array}$ & Turno ininterrupto de revezamento. & 6h diárias. \\
\hline${\text { Lei }{ }^{\circ} \quad 8.270 / 91}$ & $\begin{array}{l}\text { Funcionário Público em Regime } \\
\text { Jurídico Único (RJU). }\end{array}$ & 40h semanais. \\
\hline CLT - art. 224. & $\begin{array}{l}\text { Bancários e Funcionários da Caixa Econômica } \\
\text { Federal, se aplicam também aos empregados } \\
\text { em portaria, limpeza, telefonista, contínuos e } \\
\text { serventes empregados em banco. }\end{array}$ & $6 \mathrm{~h}$ diárias e $30 \mathrm{~h}$ semanais. \\
\hline CLT - art. 227 & $\begin{array}{l}\text { Empregados nos serviços de telefonia, telegrafia } \\
\text { submarina e subfluvial, de radiotelegrafia } \\
\text { e radiotelefonia. }\end{array}$ & $\begin{array}{l}\text { Duração máxima de } 6 \text { h contínuas de } \\
\text { trabalho e de } 36 \mathrm{~h} \text { por semana. Para } \\
\text { empregados sujeitos a horários va- } \\
\text { riáveis, fica estabelecida a jornada } \\
\text { máxima de } 7 \mathrm{~h} \text { diárias. }\end{array}$ \\
\hline CLT - art. 234 & Operadores cinematográficos. & $6 \mathrm{~h}$ diárias. \\
\hline CLT - art. 293 & Empregados em minas de subsolo. & $6 \mathrm{~h}$ diárias e $36 \mathrm{~h}$ semanais. \\
\hline CLT - art. 303 e 304 & Jornalistas profissionais. & 5h diárias, prorrogável para $7 \mathrm{~h}$. \\
\hline CLT - art. 432 & Trabalho aprendiz. & $\begin{array}{l}\text { Não excederá } 6 \text { h diárias, sendo } \\
\text { vedadas prorrogação e compensação } \\
\text { da jornada. Porém o limite poderá } \\
\text { ser prorrogado para } 8 \mathrm{~h} \text { para os } \\
\text { aprendizes que já tiverem completado } \\
\text { o ensino fundamental. }\end{array}$ \\
\hline $\begin{array}{l}\text { Lei } n^{\circ} 3.270 \\
\text { de } 30.09 .1975\end{array}$ & Cabineiros de elevador. & 6 horas diárias. \\
\hline
\end{tabular}

Elaboração: Calvete (2006). 


\section{TEMPO}

Quem teve a idéia de cortar o tempo em fatias,

a que se deu o nome de ano,

foi um indivíduo genial.

Industrializou a esperança

fazendo-a funcionar no limite da exaustão.

Doze meses dão para qualquer ser humano

se cansar e entregar os pontos.

Aí entra o milagre da renovação e tudo começa outra vez

com outro número e outra vontade de acreditar

que daqui para adiante vai ser diferente

(Carlos Drummond de Andrade)

\section{PARTE II}

\section{CONFIGURAÇÕES DE DISCURSOS SOBRE AS VIVÊNCIAS TEMPORAIS COTIDIANAS NO CONTEXTO DA VOLKSWAGEN DO ABC}

4. A construção de um objeto de estudo: vivências temporais cotidianas

5. O contexto da pesquisa: o tempo de trabalho na Volkswagen do $A B C$

6. Vivências dos tempos no local de trabalho

7. Vivências dos tempos nos turnos de revezamento e trabalho noturno

8. Jovens: transições entre tempos dentro e fora da empresa

9. Tempos de trabalho e de não trabalho: vivências a partir de uma perspectiva de gênero

10. Vivências temporais cotidianas fora do local de trabalho 


\section{A CONSTRUÇÃO DE UM OBJETO DE ESTUDO: VIVÊNCIAS TEMPORAIS COTIDIANAS}

este capítulo, apresento o percurso de análise do tempo de trabalho e de não trabalho, construída a partir dos discursos dos trabalhadores sobre suas vivências temporais cotidianas. Vivências essas contextualizadas tanto ao nível macro, no que se refere às mudanças que vêm ocorrendo no tempo e no trabalho na sociedade atual, como ao nível micro, das transformações que têm se dado nos locais de trabalho.

Para apresentar esse percurso, este capítulo está estruturado da seguinte forma: primeiro apresento a perspectiva metodológica adotada, um estudo de tipo qualitativo, de um caso, a partir do local de trabalho, analisando discursos sobre vivências, contextualizados por rigorosa análise. Em seguida, abordo o contexto da pesquisa, discutindo os motivos que me levaram a escolher a Volkswagen do ABC e a observar o fenômeno no período compreendido entre os anos de 1995 e 2005. Na terceira parte, indico os procedimentos metodológicos utilizados para coleta de dados, relatando como a pesquisa foi realizada. O modo de tratamento analítico do material empírico recolhido será detalhado na quarta parte. Finalmente, apresento os sujeitos empíricos desta pesquisa coletivamente, além do perfil de cada trabalhador entrevistado.

\section{1 - Perspectiva metodológica}

No Brasil, os estudos já realizados com respeito ao tema do tempo de trabalho, em sua maioria, caracterizaram-se por uma abordagem de tipo macro-econômico e focalizada na negociação coletiva ou institucional ${ }^{1}$. Em minha própria dissertação de mestrado, por exemplo, tive

1. Mesmo assim, as reflexões não são muitas, entre elas: Dal Rosso (1996), Silva (1996) e Calvete (2006), sendo que este último tem como foco principal a discussão macro-econômica da redução da jornada de trabalho. 
a oportunidade de focalizar os processos de negociação e seus resultados, deixando à margem as vivências e experiências dos trabalhadores. Com esse procedimento, na maior parte das vezes, os diversos tempos sociais não dialogam, pois o pesquisador observa apenas o tempo de trabalho, como se ele fosse o único tempo ou o determinante de todos os outros tempos sociais. Discute-se a quantidade de tempo dedicada ao trabalho, as regras vigentes, como elas surgiram e se alteraram ao longo na história, mas não como esse tempo é vivenciado cotidianamente e como tais vivências podem levar a mudanças na negociação ou mesmo na legislação.

A partir da orientação teórica apresentada anteriormente, fica claro que além das pessoas incorporarem uma temporalidade institucional e social - estando submetidas a um tempo possível de ser cronometrado e medido objetivamente, definindo os momentos de trabalho, de não trabalho, de acordar, dormir, de comer, de descansar - elas vivenciam e representam subjetivamente tais temporalidades. Desse modo, uma parte do tempo dedicado ao trabalho é mensurável - pelo calendário, relógio de ponto, expressando-se em horas, minutos e segundos -, mas existe outra dimensão que não é possível ser contabilizada, e que se refere às vivências temporais cotidianas de cada um, de cada grupo, em cada sociedade, em cada momento histórico.

Assim, ao empreender esse olhar a minha intenção foi a de buscar romper com um ponto de vista que busca dar conta apenas dos efeitos e resultados mais visíveis do tempo, penetrando no que Lopes (2000) denomina de historicidade dos seus condicionamentos. Por isso mesmo, busquei compreender os significados e as representações construídas pelos diferentes atores sociais que, por sua vez, foram remetidas às determinações mais amplas de uma dada cultura temporal, num dado momento histórico. Para tal, realizei uma abordagem predominantemente qualitativa, tendo como fonte de análise principal as falas dos trabalhadores sem, contudo, me restringir a elas, colocando-as diante de outras, presentes tanto dentro do local de trabalho como fora dele. As narrativas discursivas dos sujeitos foram compreendidas como um processo de "elaboração/reelaboração dos fatos, e numa organização do enredo que não se limita à descrição ipsis litteris do que aconteceu. Revela a atitude ativa de alguém que é ator, co-autor e platéia dos eventos que estão sendo narrados", sendo o relato, ele mesmo, uma construção (Lopes, 2000:95). Do ponto de vista da análise, esse método significou um esforço concentrado no sentido de interpretar e hierarquizar os significados atribuídos pelos sujeitos, submetendo-os, sempre que possível, às falas de outros atores bem como à contextualização mais ampla.

Desta forma, concordo com Tedesco quando argumenta que "o desafio acadêmico está em estruturar metodologias e teorias que promovam o diálogo epistemológico entre o micro e o 
macro e que dêem conta das várias modalidades que a vida social hoje apresenta (...)" (2002:204, in Tedesco 1999). Ou ainda, com Demazière (1995), quando salienta que a análise sociológica de uma determinada realidade deve abarcar diversas dimensões: a forma como a construção de um conceito se institucionaliza nas políticas do Estado, isto é, o que passa a ser reconhecido institucionalmente; o seu reconhecimento social; bem como a situação subjetiva e de identidade dos indivíduos. E o mais importante, como se dá a relação entre essas dimensões dado que, apesar de separadas analiticamente, estão totalmente imbricadas no mundo real, havendo uma influência mútua entre as estruturas e as práticas sociais.

A partir desse olhar, analisei como os tempos dedicados ao trabalho e ao não trabalho foram socialmente construídos, articulando as histórias individuais ao contexto coletivo e social do local de trabalho e da sociedade. Construí a análise vinculando as vivências cotidianas individuais dos trabalhadores aos processos de negociação coletiva no local de trabalho, por sua vez influenciadas e influenciando as estruturas e os valores presentes na sociedade atual.

Para tal, defini como locus de análise o espaço do local de trabalho. Nele os empresários definem mudanças na organização e gestão da produção e do trabalho que afetam diretamente o tempo de trabalho. Enquanto que os trabalhadores e seus representantes pressionam, ou não, para que tais mudanças sejam objeto de negociação. Tais mudanças, por sua vez, influenciam as vivências cotidianas dos trabalhadores tanto no local de trabalho como para além deste e, ao mesmo tempo, recebem influências externas ao cotidiano de trabalho. Para melhor acompanhar as vivências temporais cotidianas no local de trabalho, o desenho metodológico centrou-se na escolha de um estudo de caso. Assim fazendo, busquei melhor compreender este fenômeno social, por meio do detalhamento das relações dentro das organizações e também entre os indivíduos e as organizações, bem como das relações que são estabelecidas entre esses e os meios nos quais estão inseridos. Pude, então, observar uma relação recíproca de influência entre as construções temporais no âmbito do espaço fabril e as realidades para além deste espaço, isso porque os atores que em determinados momentos então dentro da fábrica, em outros, estão nos demais espaços por onde também constroem e reconstroem suas necessidades, valores, interesses e projetos políticos.

Escolher um estudo de caso, em um local de trabalho, para estudar as vivências temporais cotidianas, justifica-se ainda pela existência de um processo de substituição dos princípios da organização fordista do trabalho por novos conceitos de produção, alterando totalmente o tempo dentro do local de trabalho. As mudanças implementadas têm como objetivo o desenvol- 
vimento de uma capacidade de resposta efetiva e rápida às circunstâncias de mudanças, (Caputto, 1983, apud Salerno, 1989), criando assim um fluxo tenso e intenso que abrange todos os setores da empresa (Durand, 2004). Entretanto, em cada local de trabalho tais mudanças têm sido realizadas de uma maneira específica, daí a necessidade de compreender como se deu este processo em um local particular, pois como salienta Leite,

"... mesmo que possamos identificar um caminho comum, a realidade não está determinada aprioristicamente a trilhar caminhos irreversíveis, mas está antes aberta a conflitos, contradições, acidentes e acontecimentos não previstos de antemão, os quais são capazes de moldá-la de formas diferentes, ainda que circunscritas ao interior de um universo de possibilidades" (Leite, 2003:24).

\section{2 - $O$ contexto da pesquisa: o caso Volkswagen do ABC}

A partir dessa perspectiva, o passo seguinte foi definir o local de trabalho que seria objeto de estudo. Em alguns setores e empresas houve uma transformação mais intensa, em outros, mais pontual; em alguns casos essas mudanças foram negociadas, em outros não; em alguns gerou mais desemprego e em outros não; em alguns o tempo de trabalho foi mais modificado, em outros menos. Diante dessa multiplicidade de opções, escolhi a Volkswagen visto que, como documentado por Rodrigues $(2002)^{2}$, foi a empresa montadora que, na década de 1990, apresentou o maior número de negociações sobre jornada de trabalho. Enquanto nas outras empresas o tema mais freqüente foi a Participação nos Lucros e Resultados - PLR, abrangendo $27 \%$ da amostra, seguido do tema da jornada, $26 \%$ do total, na Volks o tema mais presente nos acordos foi o da jornada de trabalho.

A Volkswagen está inserida no setor metalúrgico, constituído por fábricas montadoras e de autopeças, que têm presença considerável na economia brasileira. Segundo estimam a Associação Nacional dos Fabricantes de Veículos Automotores (Anfavea) e o Sindicato dos Fabricantes de Autopeças (Sindipeças), o setor fatura mais de 15\% do valor da produção total da indústria de transformação do país. Além disso, é um segmento importante na geração de renda, na criação de empregos - diretos e secundários -, na produção de máquinas e equipamentos, nas atividades de serviços aos veículos, assim como tem peso no conjunto dos investimentos industriais por ser demandante de bens de capital e de insumos básicos. Sua importância está igual-

2. As empresas pesquisadas por Rodrigues foram: Volkswagen, Mercedes-Benz, Scania, Toyota e Ford. 
mente no fato de estar em um dos setores mais dinâmicos da economia mundial, sendo representante dos avanços tecnológicos e das inovações de toda ordem, principalmente nos últimos trinta anos (DIEESE,2002).

Minha escolha considerou, igualmente, o fato de já haver um razoável conhecimento acumulado sobre esse setor, com consistentes e sólidas análises teóricas em relação às diversas mudanças ali ocorridas, tanto no que se refere aos processos de inovação técnico-organizacional quanto aos de negociação ${ }^{3}$. Isso me possibilitou, a partir da análise da bibliografia já existente, uma abordagem muito mais focada na questão específica das vivências e representações dos trabalhadores, ainda pouco presente nos estudos que se debruçaram seja sobre o setor, seja sobre esta Empresa, seja sobre o tema do tempo de trabalho e de não trabalho.

Ao escolher a unidade da Volkswagen localizada no ABC, encontrei características particularmente adequadas à realização da pesquisa, tais como:

- a planta escolhida tem uma importância estratégica tanto na história da Volkswagen no Brasil como na do setor;

- por ser uma planta antiga, são quase 50 anos de existência, poderemos analisar, a partir da fala dos trabalhadores, dirigentes sindicais e dos gerentes, a construção social do tempo dedicado ao trabalho ao longo da sua história, que se confunde com a história da automobilística brasileira, comparando períodos diferentes, ao mesmo tempo em que teremos a possibilidade de analisar as vivências e representações dos trabalhadores com menos tempo de trabalho e mais jovens;

- do ponto de vista quantitativo, na planta temos mais de 14 mil trabalhadores;

- o Sindicato e a Comissão de Fábrica, por sua força no cotidiano das relações de trabalho, constituem-se como importantes interlocutores e pressionam pela abertura de diversos processos de negociação;

- os trabalhadores têm participação ativa nesse processo;

- do ponto de vista da negociação coletiva, nos últimos anos e principalmente a partir de 1995, há uma intensificação desse processo no que se refere à discussão de temas relacionados ao tempo dedicado ao trabalho, como a redução da jornada de trabalho, o banco de horas e o banco de dias.

3. A bibliografia referente ao setor é muito ampla, abrangendo teóricos de diversas áreas. Dentre as referências utilizadas neste trabalho temos: Arbix (1995), Barbosa (2002), Brandão (1991), Bresciani, (1994 e 1997), Castro (1995), Hirata (1993), Gitahy, e Bresciani, (1998), Leite (1997 e 2003), Rodrigues (2002), Salerno (1995), além de trabalhos que já realizei como Cardoso, (1993 e 1998a) e Bresciani e Cardoso (1999). 
O contexto histórico que analiso compreende os anos entre 1995 e 2005, dado se tratar de um período particularmente denso em termos de mudanças direta ou indiretamente relacionadas ao tempo de trabalho. Entre o final de 1994 e início de 1995 temos o fim de dois importantes eventos; a parceria entre a Volkswagen e Ford - Autolatina, (Bresciani e Cardoso, 1999) e a Câmara Setorial Automotiva, iniciada em 1991. De acordo com depoimentos dos diretores do Sindicato dos Metalúrgicos do $\mathrm{ABC}^{4}$, ao final desses processos, a retomada da luta pela redução da jornada de trabalho, sem redução de salário, parecia afigurar-se como um dos caminhos mais importantes para responder politicamente ao problema do desemprego. Não sem razão, já no final de 1995 temos a negociação sobre a redução da jornada efetiva semanal de 42 para 40 horas e o primeiro acordo de banco de horas (Blass, 1998), o banco de dias e a chamada "jornada alemã", negociada no final de 2001 (Barbosa, 2002). A mera enumeração desses fatos deixa entrever a importância desta Empresa e, nela, desta unidade de produção, para elucidarmos o tema que interessa aqui focalizar.

\section{3 - Procedimentos metodológicos}

O processo de construção dos resultados desta pesquisa teve três etapas metodológicas distintas: a) pesquisa e análise bibliográfica para a elaboração do arcabouço teórico e para a contextualização dos modos de construção social do tempo e do tempo de trabalho na França e no Brasil; b) análise das negociações coletivas sobre o tempo de trabalho no Brasil e em particular no contexto da Volkswagen do Brasil a partir de material documental e de entrevistas com representantes institucionais da Empresa e dos trabalhadores; e, c) análise das vivências temporais cotidianas dos trabalhadores a partir da realização de entrevistas.

No que se refere à construção do arcabouço teórico, esta foi uma etapa inicial do trabalho que teve continuidade durante todo o processo de elaboração da tese, inclusive no período de atividades na França. Teve como foco principal as discussões relacionadas à temática da construção social, das representações simbólicas, das vivências temporais cotidianas e da subjetividade; da construção histórico- social do tempo de trabalho e de não trabalho; e da relação entre as diversas inovações tecnológicas e organizacionais e o tempo de trabalho.

4. Entrevistas realizadas no ano de 1997, no mestrado. Para mais detalhes, ver Cardoso (1998a). 
A segunda etapa, que também se estendeu ao longo de toda a pesquisa, teve como objetivo conhecer o contexto das interações sociais desenvolvidas na Volkswagen do ABC, sendo realizada tanto pela análise bibliográfica como pela realização de entrevistas com representantes da Empresa e dos trabalhadores. Primeiramente, realizei uma análise bibliográfica para compreender a maneira como se articularam as diversas inovações tecnológicas e organizacionais, por um lado, e o tempo de trabalho, por outro; tal articulação precisava ser descrita tendo em vista o modo especifico como este processo se deu dentro da Volkswagen. É digno de nota que nenhuma das obras pesquisadas concentrava seu interesse nessa relação entre os processos de inovação e o tempo de trabalho. Em seguida, realizei um levantamento das negociações com respeito ao tempo de trabalho na Empresa, desde meados dos anos 1990 até o ano de 2005, tendo como objetivo perceber como o tempo de trabalho foi sendo (re)negociado. Analisei não apenas as negociações relacionadas diretamente ao tempo de trabalho como também aquelas que acarretaram mudanças no tempo de trabalho, como as relacionadas à PLR, às células de produção e ao Plano de Cargos e Salários (PCS).

Ainda como forma de compreender as mudanças e sua relação com o tempo de trabalho, e também a história da negociação sobre o tema, realizei entrevistas semi-diretivas e gravadas com técnicos do DIEESE, alocados no Sindicato dos metalúrgicos do ABC. Em seguida, foram também realizadas entrevistas com representantes institucionais envolvidos diretamente neste processo, incluindo gerentes das áreas de Recursos Humanos e Relações Trabalhistas, membros das comissões de fábrica e diretores sindicais.

$\mathrm{Na}$ terceira etapa - de análise das vivências temporais cotidianas dos trabalhadores -, previ o uso de três tipos diferentes e complementares de fontes de pesquisa: a) a observação direta, que buscaria entender como os trabalhadores vivenciavam as normas de utilização do tempo no espaço fabril, a partir das condições impostas pela empresa, como as mudanças técnico-organizacionais, as horas de trabalho, o ritmo e a intensidade; b) entrevistas semi-diretivas e gravadas com os trabalhadores nas quais busquei recolher os seus discursos sobre as vivências cotidianas e as suas representações em relação às situações e normas de utilização do tempo; c) aplicação de diários de usos do tempo ${ }^{5}$, com a finalidade de entender quanto tempo os trabalhadores dedicam a cada uma das atividades, dentro e fora da jornada de trabalho.

5. De forma resumida, podemos dizer que o diário de usos do tempo (ver anexo 2) é uma agenda onde as pessoas devem anotar todas as suas atividade durante um dia inteiro, informando o horário de início e de fim, sendo o intervalo de tempo a cada 30 minutos. As questões que fazem parte do diário são: a) atividade principal desenvolvida, b) atividade secundária, c) com que a atividade é exercida, d) para quem a atividade é desenvolvida e f) lugar em que a atividade é desenvolvida. Para mais detalhes, ver em anexo um diário de usos do tempo. 
Como veremos no decorrer deste texto, não foi possível realizar a observação direta de modo sistemático visto que a empresa, após muitas tentativas, apenas permitiu a minha entrada para a realização das entrevistas e não para visitas sistemáticas e prolongadas à fábrica. A observação que pude desenvolver foi, assim, assistemática e restrita aos momentos em que colhia entrevistas. Estas, por sua vez, nem sempre se realizaram na unidade da Volkswagen. Elas abrangeram grupos diferenciados, que selecionei de modo a representar a necessária presença de todo o leque de diversidade que caracteriza o coletivo de trabalhadores na Volkswagen, de modo a poder contemplar indivíduos com vivências diferentes em relação ao tempo dedicado ao traba1ho. Assumi que duas seriam as fontes principais de diferenciação dessas vivências: a) a natureza do engajamento profissional na Empresa, expressa tanto na ocupação ali desempenhada, como no setor de atuação e tempo de contrato; b) o perfil do trabalhador, expresso por características como sexo, idade, e posição no ciclo de vida. Tendo em mente essas fontes de diferenciação procurei compor a minha amostra de casos a entrevistar.

Além das entrevistas, também empreguei o diário de usos do tempo com a finalidade de entender como os trabalhadores utilizam o seu tempo, dentro e fora da jornada de trabalho, ou seja, o que fazem e quanto tempo dura cada atividade. No que se refere à forma de preenchimento, a idéia inicial era de que os trabalhadores levassem os diários para casa e depois devolvessem, devidamente preenchidos. Entretanto, essa maneira não se mostrou eficaz; os quatro primeiros trabalhadores entrevistados não o fizeram e tive que reencontrá-los para preencher os diários juntamente com os mesmos. Esta mudança acarretou uma forte transformação no conteúdo das respostas e na natureza da informação que obtive. Isso porque, se num primeiro momento o alvo da coleta seria a captura dos tempos e das atividades no momento da sua realização, sob esta nova sistemática passei a dispor de um outro tipo de material empírico, os discursos e lembranças desses trabalhadores em relação ao tempo e às atividades realizadas nos dias anteriores. Vale ainda frisar que, por razões de exigüidade de tempo, não foi possível explorar, neste trabalho, todas as possibilidades abertas por esta técnica de pesquisa e pelos dados produzidos a partir dela; não obstante eles tenham sido de grande valia para elucidar práticas de grupos desses trabalhadores, como se verá no curso da tese.

Quanto ao modo de realização das entrevistas, é importante detalhar que as primeiras seriam realizadas os gerentes da Empresa e depois com dirigentes sindicais. Essa primeira seleção dos sujeitos teve como objetivo conhecer melhor a fábrica para compreender, do ponto de vista destes sujeitos, quais tinham sido, nos últimos dez anos, as mudanças na organiza- 
ção do trabalho que tiveram impacto no tempo de trabalho. Também considerei essas primeiras entrevistas como uma etapa necessária para conhecer os processos de negociação referentes à temática do tempo, bem como o perfil dos trabalhadores, para poder, então, definir mais precisamente quais seriam os entrevistados. A dificuldade em iniciar o contato com a Empresa me fez alterar esse andamento e iniciar as entrevistas com alguns dirigentes sindicais, optando pelos mais antigos da Volkswagen, que participaram de todo o processo de negociação, desde os anos 1990, envolvendo a questão do tempo de trabalho. Em seguida, ainda sem uma resposta da Empresa, iniciei as entrevistas com os dirigentes da Comissão de Fábrica (CF) e do Comitê Sindical de Empresa (CSE). Esses dirigentes ${ }^{6}$ foram selecionados em função do setor que representavam e também do tempo na função de dirigente sindical. Em cada entrevista demandei ainda a indicação de dois outros trabalhadores do setor, considerando as diferenças de perfis.

Durante as entrevistas, tive a oportunidade de voltar à Volks e visitar alguns setores da fábrica, sendo acompanhada por um dos dirigentes. Essa visita foi realizada sem o conhecimento da Empresa, pois até o momento eu não havia recebido nenhuma resposta, apesar dos constantes contatos. Foi muito proveitoso rever a fábrica, considerando que a última visita que realizara havia sido no ano de 2002, e que a primeira tivera lugar em 1998. Além de observar as mudanças nos processos de trabalho, principalmente comparando as três linhas na montagem final e as duas linhas na estamparia, foi possível olhar os trabalhadores nos seus postos de trabalho e falar com alguns da montagem final, onde passei a maior parte do tempo, conseguindo me apresentar e obter o telefone de vários deles para posterior contato. Em sua maioria, os trabalhadores contatados não foram indicados pelo dirigente que me acompanhava, mas escolhidos em função das diversas funções, idades e sexos.

Ainda sem retorno da Empresa, dei andamento à etapa seguinte com a realização das entrevistas com os trabalhadores, totalizando, nesta etapa, 16 entrevistas. Para estas conversas, alguns trabalhadores foram indicados pelos dirigentes sindicais, outros contatados durante a minha visita e outros indicados pelos próprios trabalhadores entrevistados. A continuidade das entrevistas ocorreu dentro da Empresa, quando esta me respondeu. Neste momento, demandei a realização de entrevistas com dois trabalhadores de cada setor - abrangendo as diferenças de

6. Sobre a composição da CF e do CES vale a pena dizer que existe uma oposição sindical. Como a minha entrada no sindicato foi através dos dirigentes que fazem parte da situação, eu demorei um pouco para conseguir entrar em contato com dirigentes e trabalhadores da oposição. 
sexo, idade, setor, função, turno de trabalho e tempo de casa; com cinco gerentes, abrangendo alguns setores da empresa, bem como a realização de visitas.

Ao final, consegui realizar duas entrevistas com os gerentes das áreas de relações trabalhistas e de recursos humanos. Embora em número reduzido, a relevância dessas entrevistas está no fato desses sujeitos pertencerem a setores cruciais para o meu estudo, porque responsáveis pela gestão dos trabalhadores (recursos humanos) e pela discussão do processo de negociação sobre o tempo de trabalho (relações trabalhistas). A solicitação de visitas, porém, como já disse anteriormente, não foi aceita.

Assim, dentro da Empresa, realizei mais 14 entrevistas com trabalhadores. Ao contrário das entrevistas realizadas fora da Empresa, dentro desta o tempo definido para a conversa era de, no máximo, uma hora, com a justificativa de que os trabalhadores não poderiam ficar muito tempo fora da sua área de trabalho. Vale ressaltar que nem todas as entrevistas planejadas pela Empresa foram realizadas, pois a Volks interrompeu o processo alegando o fato de estar acontecendo paralisações de trabalhadores, não sendo assim completada a meta de duas pessoas por setor.

No curso dessas entrevistas definidas pela empresa, dois fatos me chamaram atenção: primeiro, o fato de todos os trabalhadores eram ou horistas do I turno (entre $6 \mathrm{~h}$ e $14 \mathrm{~h} 55$ ) ou horalistas (trabalhador horista, mas que trabalha no turno do mensalista) ou, ainda, mensalistas (entre $8 \mathrm{~h}$ e $17 \mathrm{~h}$ ), não tendo nenhum trabalhador do II ou III turno. E também o fato de a quase totalidade desses entrevistados, 12 em 14, ser formada por trabalhadores não alocados em linhas de produção, mas vindos das áreas de qualidade ou ainda líderes, monitores ou encarregados.

Sobre a minha necessidade de entrevistar trabalhadores de todos os turnos, fui informada de que além do primeiro turno abranger a maior parte dos trabalhadores, o segundo turno começa o trabalho às $15 \mathrm{~h}$, horário muito próximo da saída do setor administrativo (às $17 \mathrm{~h}$ ), dificultando a minha permanência na empresa. Isso implicou a realização de mais entrevistas fora da Empresa, com trabalhadores dos outros turnos.

Além dessas, ainda ocorreram interferências de alguns funcionários no decorrer desse processo. Durante a entrevista com um responsável pela qualidade do setor, por exemplo, perguntei como ele havia sido contatado pela empresa. Obtive a resposta de que ele havia recebido um e-mail solicitando a seleção de um funcionário para ser entrevistado. Como considerou muito difícil tirar algum trabalhador da linha, foi pessoalmente responder à entrevista. Além dele mesmo, também indicou um outro funcionário da mesma área responsável pela qualidade, 
mas nenhum da linha de produção, como tinha sido solicitado. Isto, logo depois dele ter comentado que não havia problemas de falta de trabalhadores nas linhas.

Realizei ainda entrevistas com o médico do trabalho do sindicato, para compreender a relação entre tempo de trabalho e saúde, sobretudo na Volks; e com uma formadora sindical, para saber como a temática do tempo do trabalho estava sendo tratada pelo sindicato dos metalúrgicos do $\mathrm{ABC}$.

No total, foram feitas 40 entrevistas com trabalhadores, sendo que destas, 14 foram realizadas no sindicato, 14 na empresa, 7 na casa dos trabalhadores, 3 em faculdades, 1 num bar e outra no metrô. Em relação aos dirigentes e membros da CF ou do CSE, foram 12 entrevistas, além de mais uma com o médico do trabalho, uma com a formadora sindical, e mais duas entrevistas com os gerentes da empresa. Para a realização destas entrevistas, foram elaborados 3 roteiros diferentes e especialmente orientados para: a) dirigentes membros da executiva do sindicato, b) representantes membros da CF e do CES, c) gerentes da empresa, e d) trabalhadores, sendo que neste último havia duas partes específicas, uma para trabalhadores de empresas terceiras e outra para aposentados. Tais roteiros são apresentados nos anexos à tese.

\section{4 - As configurações de discursos}

De posse das entrevistas, e após transcrevê-las e revisá-las, iniciei uma etapa de leitura detalhada do material para analisar como as narrativas discursivas dos trabalhadores expressavam vivências cotidianas e representações sobre o tempo dentro do local de trabalho e fora deste, bem como se e o modo pelo qual deixavam entrever as suas inter-relações. Essa análise teve como foco levantar os elementos que organizavam essas narrativas no que se refere aos diversos tempos sociais e suas inter-relações, considerando as seguintes questões: Como os entrevistados falavam do tempo? Que aspectos foram mais explicitados? Quais os aspectos do tempo dentro do local de trabalho que levam a maior assincronia com respeito a outros tempos sociais? Quais são as equações temporais realizadas pelos trabalhadores para organizarem esses diversos tempos? Como os atributos pessoais e sociais influenciam as vivências cotidianas e as representações dos tempos sociais - como as relações de gênero, de geração, as trajetórias de vida, trajetórias ocupacionais, a situação atual na empresa, a escolaridade, ou a situação familiar, por exemplo. Que configurações de discursos ficaram mais explicitadas? 
É importante ressaltar que os indivíduos não foram primariamente agrupados por suas características de perfil, mas sim por suas narrativas discursivas sobre as vivências temporais cotidianas. Foram agrupados em função da similitude ou da diferença de seus discursos, pelo modo como construíam as suas percepções sobre a vivência do tempo, pelo modo como as enunciavam, como falavam delas e como, ao fazê-lo, se aproximavam ou se distanciam uns com respeito aos outros, em seus modos de dizer. Veremos que o modo de falar do vivido encontra contrapartidas analiticamente interessantes em certas características sociais (perfil, tipo de inserção da fábrica, características pessoais, situação familiar). Busquei levantar principalmente a fala do tempo, as dimensões do vivido com respeito ao tempo que se destacam no discurso de cada entrevistado e como essas dimensões se combinam com outras formas de falar sobre o tempo, também presentes, mas secundárias.

A partir desse levantamento, pude perceber, no que se refere ao tempo dentro da fábrica, que havia configurações de discursos similares, enquanto outras se diferenciavam muito claramente. Algumas delas se aproximavam de forma muito evidente, como as narrativas discursivas daqueles que trabalham em linhas de produção. E neste caso, a diferença entre aqueles que trabalham em uma das linhas e os que não trabalham era tão forte que outras questões, como a idade, o sexo, o tempo de casa, ou a situação familiar, não apareciam de forma marcante como elementos ordenadores da confluência nos discursos. Ou seja, estar na linha com mais ou menos idade, mulher ou homem, casado ou solteiro, não pareciam variáveis relevantes. Ao mesmo tempo esse grupo possuía um perfil comum: eram mais velhos, com mais tempo de casa, menor escolaridade e salários mais baixos. Já para aqueles trabalhadores que estão fora das linhas, outras normas de usos do tempo no local de trabalho apareceram com mais força, mesmo assim, nenhuma delas foi tão marcante como o tempo imposto da linha. Em comum a todos os trabalhadores, dentro do local de trabalho, transparecia a vivência de um tempo controlado, intensificado e flexibilizado.

As definições no local de trabalho, e seus elos com o tempo de trabalho, têm também impactos diretos no tempo fora da fábrica. Algumas vezes em função do cansaço, outras em função da total dessincronização entre as diversas temporalidades sociais, sobretudo quando se trata do trabalho em turnos de revezamento e do trabalho noturno. Daí a necessidade de focalizar uma segunda configuração de discursos relativa à vivência dos turnos de trabalho e sua capacidade de total desorganização em relação aos outros tempos sociais. Demonstrando as diversas equações temporais realizadas pelos trabalhadores para buscar certa harmonização entre esses tempos. 
Outras configurações foram, posteriormente, construídas em torno de novas singularidades, como o que se observava entre os jovens e as mulheres. As relações de geração e de gênero que se tecem na Volkswagen e, é claro, as inter-relações com a sociedade como um todo, também possibilitam vivências temporais cotidianas muito específicas sobre o tempo dentro e fora da Empresa. No caso dos jovens, a questão da transição marcava uma singularidade muito forte em relação às outras gerações. Transições já realizadas, entre a casa e a escola, entre esta e o trabalho na Volks, mas, sobretudo, e daí a maior diferença em relação às outras gerações, uma expectativa futura de transição para um trabalho melhor. E esta expectativa de tempos melhores leva a vivências do tempo presente - dentro e fora da fábrica - totalmente diferentes das outras gerações, de forma que o tempo de trabalho, estudo e descanso, ocupa praticamente as 24 horas desses jovens, independente do sexo. Mas vale ainda frisar que não é apenas o fato de serem jovens, mas de morarem com os pais, de não serem casados ou terem filhos que possibilita tais vivências cotidianas. Assim, para este grupo, o que chama atenção nos discursos é a transição entre tempos muito diferentes.

Mas se o sexo não marca fortemente as experiências dos jovens com respeito ao tempo, no caso das pessoas mais velhas, a condição de sexo e as relações de gênero apresentam importância fundamental para compreendermos as vivências dos diferentes tempos sociais, sobretudo ao pensar suas inter-relações. Assim, no caso das mulheres, além do tempo no local de trabalho receber a pressão da gestão fabril e institucionalizada, explicitada por quase todos os trabalhadores da Volks, há ainda a pressão exercida pelos próprios trabalhadores, que são homens em sua grande maioria. Neste contexto, os discursos das mulheres explicitam a necessidade de provar para as chefias e para os trabalhadores que elas também entendem de carro, que elas também podem realizar o trabalho demandado e que elas têm um diploma que vale tanto quanto o dos homens. E este tempo no local de trabalho é pressionado ainda pelo tempo fora da fábrica, isto é, pelas tarefas relacionadas à casa e ao cuidados dos filhos. Assim, constituindo-se vivências dos tempos sociais muito particulares, caracterizadas pela forte pressão e dificuldade para harmonizar os diferentes tempos sociais dentro e fora do local de trabalho.

Finalmente, se inicio a análise do trabalho de campo a partir do local de trabalho, termino com a discussão sobre as vivências temporais cotidianas fora da fábrica. Mesmo que no decorrer de toda a análise fiquem evidentes as inter-relações entre os diversos tempos sociais, sobretudo ao tratar do trabalho noturno, das relações de geração e gênero, no último capítulo retomo a totalidade dos entrevistados para perceber, sobretudo, qual o sentimento que têm em 
relação ao tempo na vida. Busco levantar o que fazem fora do local de trabalho, o que gostariam de fazer, e o que dizem que fariam, caso a jornada de trabalho fosse reduzida. E, nesse caso, veremos que este tempo fora da Empresa, que também é ocupado por atividades ainda relacionadas ao trabalho, é explicitado como um tempo curto, insuficiente, corrido e um tempo de cansaço. O que, aliás, caracteriza a atual cultura temporal das sociedades contemporâneas.

\section{5 - Os sujeitos empíricos da pesquisa}

Foram realizadas 40 entrevistas com os trabalhadores da Volks, sendo que 2 deles eram aposentados e 1 era trabalhador de uma empresa terceira.

\subsection{1 - Características pessoais e sociais do grupo}

Este grupo que analiso é composto por 8 mulheres e 32 homens (20\% de mulheres), sendo 2 indicadas pelo sindicato, 2 pela empresa, 2 outras por contato direto durante minha visita à fábrica e mais 2 indicadas pelas próprias entrevistadas. Por sua vez, dentre os homens entrevistados, 12 foram indicados pela empresa, 13 pelo sindicato e 8 por contato direto durante minha visita à fábrica. De acordo com as informações concedidas pela Volks para o ano de 2005, o percentual de mulheres na Empresa está em torno de 9\%, sendo 1300 mulheres e 14 mil homens. Esta composição reflete e explica a grande dificuldade que tive para entrevistar as trabalhadoras mulheres, mesmo tendo feito a demanda tanto para o sindicato como para a empresa, como veremos de forma mais detalhada nos capítulos seguintes.

Quanto à idade, dentre os trabalhadores pesquisados, vemos uma pequena concentração na faixa entre 41 e 45 anos. Se utilizarmos faixas mais amplas, entre 21 a 30, 31 a 40, 41 e 50 e acima de 50 , teremos $35 \%, 33 \%, 28 \%$ e $3 \%$ respectivamente. De acordo com informações concedidas pela empresa, a faixa entre 20 e 30 anos tem $13 \%$ dos trabalhadores, entre 31 e $40,41 \%$, entre 41 e $50,36 \%$ e acima de 50 anos, 10\% (Quadro 1).

De acordo com os trabalhadores entrevistados, há dois movimentos fortes ocorrendo na empresa em relação à idade dos trabalhadores. Um deles explica os baixos percentuais de trabalhadores acima de 50 anos, considerando a saída dos já aposentados, de forma mais intensa a partir de 1998, em função da abertura de PDV's orientados prioritariamente para os trabalhadores já aposentados e próximos da aposentadoria. Por sua vez, o alto índice de trabalhadores na faixa entre 41 e 50, comparado ao tempo de casa, como veremos adiante, deve-se a uma menor 
rotatividade desses trabalhadores, se comparamos com outros setores ou a outras empresas no Brasil. Na Volks, a experiência dos trabalhadores era entrar na empresa, levar os filhos e depois aposentar-se. Por outro lado, a empresa, a partir de meados dos 90 , tem reduzido muito as vagas no Senai, por onde entravam a maior parte dos jovens, o que explica a informação concedida por esta de apenas $13 \%$ de trabalhadores entre 20 e 30 anos.

\section{Quadro 1}

Distribuição dos entrevistados segundo faixas etárias

\begin{tabular}{|l|c|c|}
\hline Idade & Nos $^{\text {Abs. }}$ & $\mathbf{( \% )}$ \\
\hline 21 a 25 & 6 & 15,0 \\
26 a 30 & 8 & 20,0 \\
31 a 35 & 7 & 18,0 \\
36 a 40 & 6 & 15,0 \\
41 a 45 & 9 & 23,0 \\
46 a 50 & 2 & 5,0 \\
Acima de 50 & 2 & 2,0 \\
\hline
\end{tabular}

No que se refere à situação familiar, praticamente metade dos meus entrevistados eram trabalhadores que vieram de outros estados, ou descendentes de famílias que fizerem este trajeto anteriormente. A maior parte veio do Nordeste, seguidos de Minas e apenas um do Sul do país, sendo que algumas famílias também vieram do litoral e do interior do Estado de São Paulo. Alguns chegaram primeiro e depois buscaram suas famílias; outros vieram justamente porque já havia alguém da família em São Paulo e, em muitos casos, esta pessoa já trabalhando na Volks. Em relação à situação conjugal, 12 são solteiros, sendo a maior parte com idade até 26 anos e, dentre estes, alguns moram sozinhos. 25 são casados e a maior parte tem filhos, havendo 3 pessoas separadas.

Dentre os trabalhadores casados, 14 homens relatam que suas esposam não trabalham fora de casa, e alguns explicitam que elas trabalhavam antes do casamento ou antes do nascimento do primeiro filho. Por outro lado, 10 entrevistados e uma entrevistada dizem que suas companheiras trabalham. Nestes dois subgrupos há uma pequena diferença na idade média, para o primeiro, a idade média é de 39 anos e para o segundo, composto por famílias onde marido e 
mulher trabalham fora de casa, a idade média é de 36 anos. Entretanto, a diferença maior entre esses dois subgrupos refere-se à quantidade de filhos. Assim, no subgrupo onde as esposas não trabalham a média é de dois filhos por casal, no segundo subgrupo, a média é menor, sendo que cinco casais não têm filhos, quatro têm 1 apenas e dois casais têm dois filhos.

\section{Quadro 2}

Distribuição dos entrevistados segundo grau de escolaridade

\begin{tabular}{|l|c|c|}
\hline Formação & $\mathbf{N}^{\text {so }}$ Abs. & (\%) \\
\hline 1 grau & 3 & 8 \\
2 grau & 10 & 25 \\
3 grau completo & 7 & 18 \\
3 grau (em curso) & 12 & 30 \\
3 grau (parado) & 2 & 5 \\
pós-graduação & 1 & 3 \\
Sem informação & 5 & 13 \\
\hline
\end{tabular}

Por fim, no quadro 2, vemos a distribuição dos entrevistados de acordo com a formação escolar. Dos 40 trabalhadores entrevistados, 12 estão cursando a faculdade. Dentre estes, a maior parte é representada por trabalhadores solteiros, com até 30 anos e do sexo masculino. Dentre os trabalhadores que já concluíram o $3^{\circ}$ grau, quase todos têm entre 31 e 42 anos e são casados, tendo feito o curso entre os anos de 98 e 2004, momento em que a empresa começou a pressionar os trabalhadores para cursarem a faculdade, vinculando a isto, mudanças de função ou setor.

\subsection{2 - O Grupo de acordo com a situação na empresa}

No que se refere ao setor de trabalho, vemos que 30\% dos entrevistados trabalham na montagem final. Mas isto não significa que todos estejam em uma das linhas de montagem, como veremos adiante, pois muitos estão em outros subsetores como a logística, a pré-montagem ou a oficina de reparos, por exemplo. De acordo com os dados fornecidos pela Empresa, os trabalhadores estão divididos da seguinte forma: 19\% na armação, 9\% na estamparia, 12\% na ferramentaria e manutenção, $25 \%$ na montagem final, $13 \%$ na pintura e $20 \%$ na usinagem. 
Quadro 3

Distribuição dos entrevistados segundo o setor

\begin{tabular}{|l|c|c|}
\hline \multicolumn{1}{|c|}{ Setor $^{7}$} & Nos $^{\text {Abs. }}$ & $\mathbf{( \% )}$ \\
\hline Armação (Alas 2 e 4) & 4 & 10 \\
Estamparia (Ala 1) & 6 & 15 \\
Ferramentaria (Ala 8) & 3 & 8 \\
Montagem Final (Ala 14) & 12 & 30 \\
Pintura (Ala 13) & 5 & 13 \\
Usinagem (Ala 5) & 6 & 15 \\
Engenharia & 2 & 5 \\
Administrativo & 2 & 5 \\
\hline
\end{tabular}

Já no que se refere ao posto ocupado, do total de trabalhadores entrevistados, $28 \%$ trabalham diretamente na linha e outros $20 \%$, como dito anteriormente, apesar de trabalharem na produção, não estão pressionados diretamente pelo tempo da linha. É importante ressaltar que a divisão que elaborei não é a mesma feita pela Empresa, onde os trabalhadores são classificados como produtivos ou improdutivos (como a ferramentaria e a manutenção), ou ainda como qualificados, não qualificados ou semi-qualificados. Isto porque, a minha classificação teve como ponto de partida as diferenças encontradas nas narrativas discursivas no que se refere às vivências do tempo dentro da Empresa.

\section{Quadro 4}

Distribuição dos entrevistados segundo posto ocupado

\begin{tabular}{|l|c|c|}
\hline Posto ocupado & Nos $^{\text {Abs. }}$ & (\%) \\
\hline Linha & 11 & 28 \\
Produção & 08 & 20 \\
Qualidade & 07 & 18 \\
Qualificados & 09 & 23 \\
Administrativo & 2 & 5 \\
Líderes & 3 & 8 \\
\hline
\end{tabular}

7. Ver no final deste texto como o fluxo de produção na Volkswagen do ABC passa pelos diversos setores. 
Uma observação importante refere-se ao surgimento de novas funções, a partir do final dos anos 90, como os monitores e líderes, que trabalham nas células, substituindo os antigos encarregados. Mas, diferentemente dos antigos encarregados, os trabalhadores não são lideres ou monitores, mas estão temporariamente nestas funções e para tal recebem um adicional temporário de 7 a $10 \%$, mantendo assim o mesmo salário base. Houve também a criação de diversas funções ligadas ao trabalho com a qualidade, em que os próprios trabalhadores têm a tarefa de realizar treinamentos com os outros trabalhadores e fazer o controle de produção, das faltas, horas extras, gasto, defeitos, entre outros. Tais funções aparecem a partir de 1999.

Sobre o tempo de casa, como já disse anteriormente, essa é uma das características que mais diferenciam os trabalhadores da Volks de outros. No quadro 5 vemos que o grupo mais significativo é o dos trabalhadores que têm entre 06 e 10 anos de casa, com $28 \%$. Se ampliarmos esta faixa para cada 10 anos, os trabalhadores com até 10 anos de casa significariam $43 \%$.

Finalmente, em relação ao horário de trabalho, conforme o quadro 6, vemos que mais da metade dos entrevistados trabalham no I turno. De acordo com as informações da empresa, $49 \%$ dos trabalhadores estão no I turno, $28 \%$ no II, $10 \%$ no III turno, também chamado péquebrado, e 13\% são horalistas, isto é, trabalhadores horistas que trabalham no horário do mensalista. Os mensalistas, que não foram o foco da minha pesquisa, representam $22 \%$ dos trabalhadores.

\section{Quadro 5}

Distribuição dos entrevistados segundo tempo de casa

\begin{tabular}{|l|c|r|}
\hline Tempo de casa & Nos $^{\text {Abs. }}$ & (\%) \\
\hline Acima 26 & 2 & 5 \\
21 a 25 & 6 & 15 \\
16 a 20 & 8 & 20 \\
11 a 15 & 7 & 18 \\
6 a 10 & 11 & 28 \\
Até 5 & 6 & 15 \\
\hline
\end{tabular}




\section{Quadro 6}

Distribuição dos entrevistados segundo horário de trabalho

\begin{tabular}{|l|c|c|}
\hline \multicolumn{1}{|c|}{ Horário de trabalho } & Nos Abs. & (\%) \\
\hline I turno (6:00 às 14:55) & 23 & 58 \\
II turno (14:55 às 23:36) & 6 & 15 \\
III turno (22:15 - 06:00) & 3 & 8 \\
Horalista (08:00 às 17:00) & 5 & 13 \\
Mensalista (08:00 às 17:00) & 3 & 8 \\
\hline
\end{tabular}

Em relação ao III turno, apesar de ter entrevistado apenas 3 trabalhadores deste horário, muitos dos que hoje estão no I e no II já passaram pelo III horário ou o pé-quebrado. Isto porque, como já vimos no capítulo sobre a Volks, os turnos de trabalho passaram a ser fixos apenas desde o ano de 1999, sendo que antes eles variavam a cada 15 ou 45 dias.

Finalmente, apresento o fluxo de produção da Volkswagen, para facilitar a compreensão sobre da dimensão da Empresa bem como os elos entre os diversos setores e um quadro com o perfil de cada trabalhador entrevistado, considerando: sexo, idade, situação familiar, situação na empresa e data e local da entrevista. Sobre o quadro contendo o perfil dos trabalhadores, ressalto que, além de não utilizar os nomes verdadeiros dos entrevistados, no quadro 1, a seguir, optei por não incluir nem mesmo os nomes fictícios, buscando assim preservar e proteger ao máximo os informantes. Sobretudo porque estudo uma única Empresa e muitos dos entrevistados foram definidos pela própria Volkswagen. Desta forma, o quadro pretende mostrar a diversidade de trabalhadores na Empresa e que, por sua vez, foram entrevistados. 
Fluxo de Produção Volkswagen do ABC - São Paulo

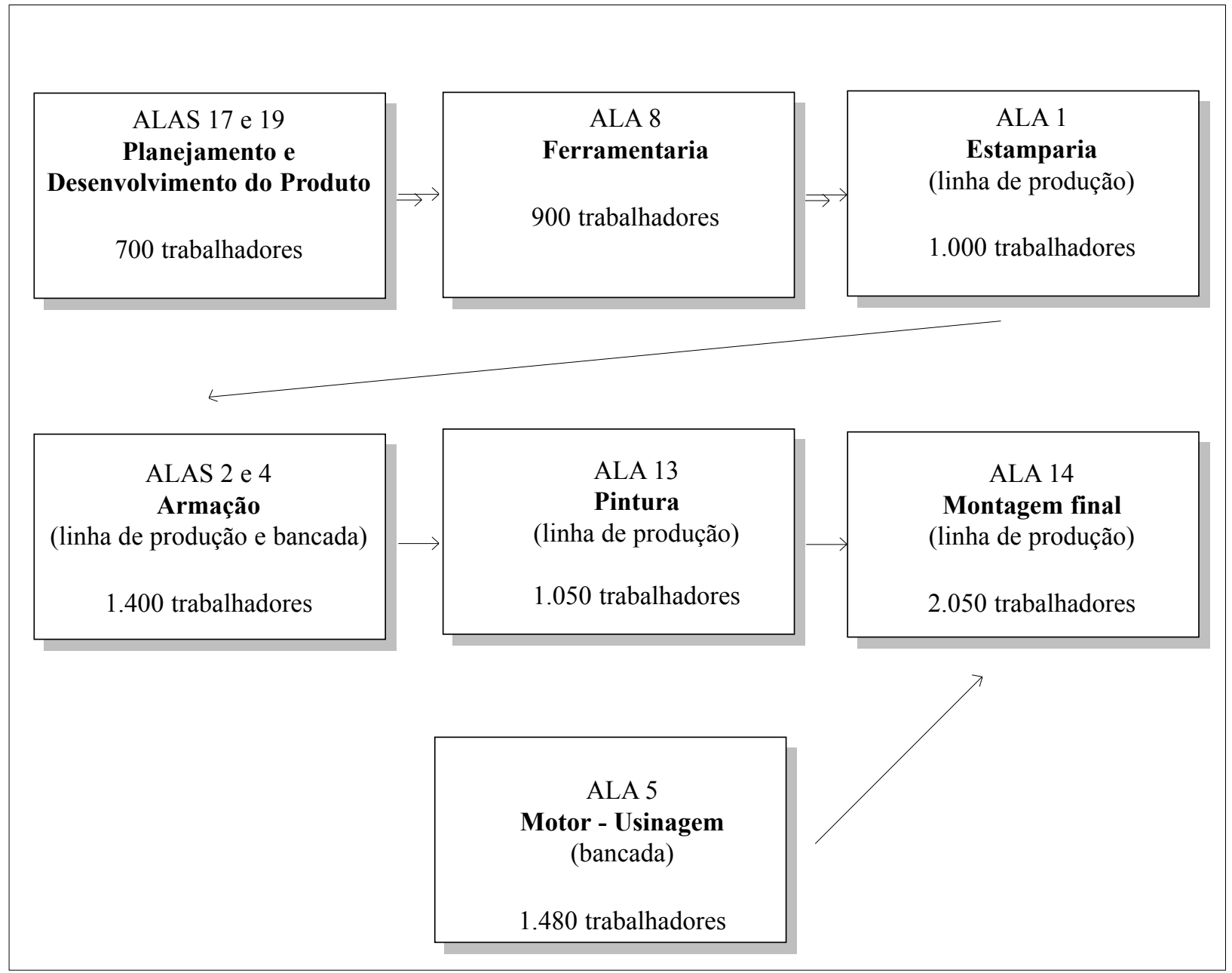

Nota: As informações sobre o número de trabalhadores foram fornecidas pelo Sindicato, antes do último PDV, que teve início em novembro de 2006. 
Quadro 1 - Perfil dos entrevistados na Volkswagen do ABC - São Paulo

1 - Mulher, 21 anos, mora com a família, solteira e não tem filhos. Cursa Engenharia e faz estágio na Empresa. Está há 6 anos na Volkswagen, é horista, no I turno. Trabalha na montagem final (Ala 14), na linha do Gol (montagem da bateria). A entrevista foi realizada em maio de 2005, no sindicato, tendo sido contatada na minha visita à Empresa.

2 - Mulher, 21 anos, solteira e mora com a família. Cursa Engenharia. Na Volkswagen há 5 anos, é horista, no I turno. Trabalha na produção (não diretamente na linha), na montagem final (Ala 14), na linha do Pólo (controle de toques - perto de parafusos). Indicada pela Empresa, a entrevista foi realizada na Volkswagen, em junho de 2005.

3 - Mulher, 21 anos, solteira e mora com a família. Cursa Física e Alemão. Na Volkswagen há 5 anos, é horista, no I turno. Trabalha em uma área da qualidade, na pintura (Ala 13), no setor administrativo. Indicada por um dirigente sindical, a entrevista foi realizada na faculdade, em julho de 2005.

4 - Mulher, 23 anos, solteira e mora com a família. Acabou seu curso de Engenharia, no ano de 2000. Na Volkswagen há 7 anos, é horista, no I turno. Trabalha em uma função qualificada, no setor de medição de peças, na Ala 3. Indicada pela Empresa, a entrevista foi realizada na Volkswagen, em junho de 2005.

5 - Mulher, 28 anos, casada, grávida e mora com o esposo, que também trabalha fora. Concluiu a pósgraduação em Educação lattu senso, em 2004. Na Volkswagen há 5 anos, é mensalista e trabalha na área administrativa, na função de secretária. Indicada pela Empresa, a entrevista foi realizada na Volkswagen, em junho de 2005.

6 - Mulher, 42 anos, mora com a filha de 16 anos. Estudou até o $2^{\circ}$ grau. Há 21 anos na Volkswagen, é horista, no II turno. Trabalha na linha do Gol (montagem das portas), na montagem final (Ala 14). É militante do Sindicato, sendo indicada por um dirigente sindical para a entrevista, que se realizou em agosto de 2005, no Sindicato.

7 - Mulher, 44 anos, separada, mora com a filha de 11 anos. Estudou até o $2^{\circ}$ grau. Na Volkswagen há 21 anos, é horista, no I turno. Assim, como Joice, trabalha na linha do Gol (montagem das portas), na montagem final (Ala 14). Foi contactada na minha visita à Empresa, sendo a entrevista realizada no Sindicato, em maio de 2005.

8 - Mulher, 45 anos, solteira e mora sozinha. Estudou até o $2^{\circ}$ grau. Na Volkswagen há 21 anos, é horista, no I turno. Trabalha na produção (não diretamente na linha), na pré-montagem da montagem final (Ala 14). Indicada para ser entrevistada por outra trabalhadora, a entrevista ocorreu na sua casa, em maio de 2005.

9 - Homem, 21 anos, solteiro e mora com a família de sua irmã. Parou o curso de Administração e atualmente faz um curso técnico de radiologia. Ele trabalha, há 1 ano, em uma empresa terceirizada, dentro da Volkswagen. É horista, no I turno. Trabalha na produção (não diretamente na linha), na logística da montagem final (Ala 14). Foi contatado em minha visita à Empresa e a entrevista realizou-se no metrô, em maio de 2005.

10 - Homem, 21 anos, solteiro e mora sozinho. Cursa Administração e Inglês. Na Volkswagen há 5 anos, é horista, no III turno. Trabalha em uma função qualificada, como ferramenteiro na manutenção de estampas, na estamparia (Ala 1). É militante e foi indicado por um dirigente sindical, sendo a entrevista realizada no Sindicato, em julho de 2005.

11 - Homem, 26 anos, solteiro e mora com a família. Faz faculdade de Direito. Está na Volkswagen há 5 anos, é horista, no I turno. Trabalha na produção (não diretamente na linha), como frentista do posto de gasolina, na estamparia (Ala 1). É militante e foi indicado por um dirigente sindical para a entrevista, que se realizou no Sindicato, em maio de 2005. 
Quadro 1 - Perfil dos entrevistados na Volkswagen do ABC - São Paulo

12 - Homem, 28 anos, mora sozinho, solteiro e concluiu o $2^{\circ}$ grau. Há 8 anos na Volkswagen, é horista, no II turno. Trabalha em uma das linhas, na pintura (Ala 13), na parte de vedação. Ele trabalha ainda com vendas de carros. É militante e foi indicado por um dirigente sindical para a entrevista, que foi realizada no Sindicato, em julho de 2005.

13 - Homem, 29 anos, casado, tem uma filha de 7 anos e mora com a família. A esposa também trabalha fora. Estudou até o $2^{\circ}$ grau. Na Volkswagen há 10 anos, é horista, no II turno. Trabalha na produção (não diretamente na linha), na área de logística (operando empilhadeiras), montagem final (Ala 14). Militante do Sindicato, sua indicação para a entrevista partiu de um dirigente sindical e foi realizada no Sindicato, em maio de 2005.

14 - Homem, 30 anos, casado e não tem filhos. Mora com a esposa, que também trabalha fora e estuda. Ele cursa Administração e faz curso de Inglês. Está há 11 anos na Volkswagen, é horista, no I turno. Trabalha na linha da Gol (montagem de portas), na montagem final (Ala 14). Foi entrevistado em maio de 2005, em um bar, tendo sido contatatado na minha visita à Empresa.

15 - Homem, 30 anos, casado e tem dois filhos: de 6 e 10 anos. Mora com a família e sua esposa não trabalha fora. Cursa Tecnologia de Produção. Está na Volkswagen há 10 anos, é horista, no I turno. Trabalha em uma área da qualidade, na estamparia (Ala 1), já tendo sido monitor. Militante do Sindicato, sendo indicado pela Empresa. Sua entrevista foi realizada na Volkswagen, em junho de 2005.

16 - Homem, 30 anos, noivo e mora com a família, sendo que sua noiva trabalha fora. Está cursando Sistema de Informação. Na Volkswagen há 8 anos, é horista, no I turno. Trabalha em uma área da qualidade, com o controle do trabalho dos líderes e encarregados, montagem final (Ala 14). Foi indicado pela Empresa, sendo a entrevista realizada na própria Volkswagen, julho de 2005.

17 - Homem, 30 anos, solteiro e mora sozinho. Concluiu o curso de Comunicação e atualmente faz curso de Inglês. Há 13 anos na Volkswagen, é horista no I turno. Trabalha em uma área qualificada, na ferramentaria (Ala 8), sendo líder desde 2002. Indicado pela Empresa, a entrevista se realizou no mesmo local, em junho de 2005.

18 - Homem, 32 anos, casado e tem uma filha de 3 anos. Mora com a família e sua esposa trabalhava fora até o casamento. Concluiu o curso de Administração em 2003. Está na Volkswagen há 10 anos, é horista, no I turno. Trabalha em uma área da qualidade, no controle administrativo, na usinagem (Ala 5). Indicado pela Empresa, onde a entrevista foi realizada, em julho de 2005.

19 - Homem, 34 anos, casado, tem 2 filhos de 11 anos, mora com a família e sua esposa; também trabalha fora. Parou de estudar Administração. Na Volkswagen há 11 anos, é horista, no I turno. Trabalha em uma área da qualidade, na usinagem (Ala 5), no controle/avaliação. Indicado pela Empresa, local onde foi realizada a entrevista, em julho de 2005.

20 -Homem, 34 anos, casado e mora com a família. Tem um filho e a esposa trabalhava fora até o casamento. Estudou até o $2^{\circ}$ grau Técnico. Está na Volkswagen há 12 nos, é horista, no I turno. Trabalha em uma área da qualidade, na armação (Ala 4), onde é monitor desde 2004. É militante e foi indicado pela Empresa, onde foi realizada a entrevista, em junho de 2005.

21 - Homem, 34 anos, solteiro e mora com a família. Concluiu o curso de Administração. Está na Volkswagen há 20 anos, é mensalista. Trabalha na área Administrativa, na Ala 21, na área de logística de peças para concessionárias. Indicado por uma amiga minha, a entrevista ocorreu na casa do entrevistado, em maio de 2005.

22 - Homem, 34 anos, casado, não tem filhos e mora com a esposa, que está desempregada. Está cursando Tecnologia. Há 18 anos na Volkswagen, é horalista (horista que trabalha no mesmo horário 
Quadro 1 - Perfil dos entrevistados na Volkswagen do ABC - São Paulo

que o mensalista). Trabalha em uma função qualificada, na Ala 17, como mecânico montador de protótipo. Foi indicado pela Empresa, local no qual se realizou a entrevista, em junho de 2005.

23 - Homem, 35 anos, casado, tem dois filhos de 6 e 9 anos e mora com a família. A esposa não trabalha fora. Está na Volkswagen há 12 anos, é horista, no III turno. Trabalha na produção (não diretamente na linha), na pintura (Ala 13), no reparo de veículos. É militante e sua indicação partiu de um dirigente sindical, sendo a entrevista realizada no Sindicato, em agosto de 2005.

24 - Homem, 35 anos, casado, tem uma filha de 2 anos e mora com a família. Sua esposa também trabalha fora. Concluiu o curso de Administração em 2003. Há 13 anos na Volkswagen, é horista, no I turno. Trabalha em uma área da qualidade, com a formação dos trabalhadores, na armação (Ala 2). Foi indicado pela Empresa, sendo a entrevista realizada na Volkswagen, em junho de 2005.

25 - Homem, 36 anos, casado, tem uma filha de 9 anos e mora com a família. Sua esposa também trabalha fora. Estudou até o $2^{\circ}$ grau. Na Volkswagen há 8 anos, é horista, no I turno. Trabalha na produção (não diretamente linha), na armação (Ala 4), na armação de carroceria do Fox. Ele foi indicado pelo irmão, que também trabalha na Volkswagen, sendo a entrevista realizada na sua casa, em maio de 2005.

26 - Homem, 36 anos, casado e mora com a esposa, que também trabalha fora. Há 16 anos na Volkswagen, é horista, no II turno. Trabalha em uma área da qualidade, na pintura (Ala 13), como controlador estatístico. É militante e foi indicado por um dirigente sindical, sendo a entrevista realizada no Sindicato, em julho de 2005.

27 - Homem, 38 anos, casado e tem 2 filhos: de 7 e 12 anos. Sua esposa estuda. Há 10 anos na empresa, é horista, no III turno. Trabalha em uma das linhas, na pintura, (Ala 13), na preparação do veículo para o banho. Militante, foi indicado por um dirigente sindical para a entrevista, que foi realizada no Sindicato, em agosto de 2005.

28 - Homem, 38 anos, separado e tem 3 filhos: 2 com 13 anos e 1 com 15 anos de idade, que moram com a mãe. Cursa o terceiro ano de Ciências Sociais. Está na Volkswagen há 8 anos, é horista, no I turno. Trabalha na produção (não diretamente na linha), na montagem final (Ala 14), como reparador na oficina. É militante e foi indicado por outro trabalhador. A entrevista foi realizada na faculdade, em julho de 2005.

29 - Homem, 40 anos, casado e tem três filhos: de 13, 15 e 16 anos. Sua esposa não trabalha fora. Estudou até o $2^{\circ}$ grau. Está na Volkswagen há 25 anos, é horista no I turno. Trabalha em uma função qualificada, sendo ferramenteiro. Gerson optou por entra no projeto auto-visão, a partir de 2003. Indicado por um dirigente sindical, a entrevista foi realizou no Sindicato, em maio de 2005.

30 - Homem, 40 anos, casado, tem um filho de 16 anos e sua esposa não trabalha fora. Concluiu o curso de Administração em 2003. Na Volkswagen há 20 anos, é horista no I turno. Trabalha na estamparia (Ala 1) e atualmente é líder. Indicado pela Empresa, a entrevista foi realizada a mesma, em junho de 2005.

31 - Homem, 41 anos, casado, tem dois filhos: de 15 e 7 anos. Sua esposa não trabalha fora. Está cursando Administração de Empresas. Na Volkswagen há 14 anos, é mensalista, trabalha na área Administrativa, com especificação de auditoria. Foi indicado por um dirigente sindical, e a entrevista foi realizada na sua faculdade, em maio de 2005.

32 - Homem, 41 anos, casado, tem um filho de 14 anos e sua esposa também trabalha fora. Concluiu o curso de Tecnologia em 2000. Na Volkswagen há 20 anos, é horalista (horista que trabalha no 
Quadro 1 - Perfil dos entrevistados na Volkswagen do ABC - São Paulo

mesmo horário que mensalista). Trabalha na estamparia (Ala 1), sendo encarregado na da sala de medidas. Foi indicado pela Empresa, sendo a entrevista realizada na Volkswagen, em junho de 2005 .

33 - Homem, 42 anos, casado e tem 2 filhos: de 16 e 18 anos. Mora com a família e sua esposa não trabalha fora. Estudou até o $2^{\circ}$ grau técnico. Está na Volkswagen há 10 anos, é horista, no I turno. Trabalha na armação (Ala 2), na linha da armação de carroceria da Kombi. Ele foi monitor entre 2000 e 2004. Militante sindical, foi indicado por um outro trabalhador, sendo a entrevista realizada na casa do entrevistado, em maio de 2005.

34 - Homem, 42 anos, casado, tem dois filhos: de 6 e 12 anos, mora com a família e sua esposa não trabalha fora. Concluiu a faculdade em Eletrônica, no ano de 2003. Há 18 anos na Volkswagen, é horalista (horista que trabalha no mesmo horário que mensalista). Trabalha em uma função qualificada, na usinagem (Ala 5), como prático de laboratório. Foi indicado pela Empresa, onde se realizou a entrevista, em maio de 2005.

35 - Homem, 43 anos, separado e casado novamente. Tem 3 filhos: de 6, 11 e 13 anos, mora com a família e sua esposa atual trabalhava fora. Na Volkswagen há 20 anos, é horista, no II turno. Trabalha em uma das linhas, na montagem final (Ala 14), no retoque de pintura. Foi indicado por um dirigente sindical para a entrevista, que se realizou no Sindicato, em agosto de 2005.

36 - Homem, 43 anos, divorciado, casado novamente, não tem filhos e mora com a esposa. Sua esposa trabalha fora e os dois são professores de dança de salão. Estudou até o $2^{\circ}$ grau. Há 29 anos na Volkswagen, é horista no I turno. Trabalha em uma função qualificada, na ferramentaria (Ala 8), no setor 1382. Indicado pela Empresa, a entrevista foi realizada na Volkswagen, em junho de 2005.

37 - Homem, 49 anos, casado, não tem filhos e mora com a esposa, que não trabalha fora. Estudou até o $2^{\circ}$ grau. Está na Volkswagen há 25 anos, é horista, no II turno. Trabalha na montagem final (Ala 14), na linha do Fox e do Pólo, na montagem das correias. É militante e foi indicado por um dirigente sindical para entrevista, que se realizou no Sindicato, em julho de 2005.

38 - Homem, 51 anos, casado, tem 2 filhos, de 21 e 24 anos e mora com a família. A esposa também trabalha fora. Estudou até o $2^{\circ}$ grau. Há 25 anos na Volkswagen, é horista, no I turno. Trabalha na linha da estamparia (Ala 1). Foi indicado por um dirigente sindical e a entrevista se realizou no Sindicato, em maio de 2005.

39 - Homem, 60 anos, casado, tem dois filhos: de 24 e 34 anos e mora com a família. A esposa não trabalha fora. Concluiu curso técnico. Trabalhou durante 29 anos na Volkswagen. Trabalhou em uma função qualificada, na usinagem (Ala 5), na sala de medidas. Desde 1996 se aposentou e não trabalha mais na Volkswagen. Foi indicado para ser entrevistado por outro trabalhador e a entrevista foi realizada na sua casa, em maio de 2005.

40 - Homem, 62 anos, casado, tem dois filhos: de 22 e 25 anos, mora com a família e sua esposa não trabalha fora. Fez o curso técnico no Senai dentro da Empresa. Trabalhou durante 22 anos na Volkswagen. Trabalhou em uma função qualificada, na usinagem (Ala 5), na sala de medidas. Desde 1998 se aposentou e não trabalha mais na Volkswagen. Foi indicado pelo seu filho, que trabalha na Empresa, e a entrevista foi realizada na sua casa, em maio de 2005. 


\section{O CONTEXTO DA PESQUISA: O TEMPO DE TRABALHO NA VOLKSWAGEN DO ABC}

esta pesquisa, tenho como locus de análise o espaço do local de trabalho da Volkswagen do ABC. Um dos espaços privilegiados onde se expressa o conflito entre os empresários, que buscam objetivar, entre outros, o tempo comprado dos trabalhadores e, por outro lado, onde os trabalhadores tentam se reapropriar subjetivamente do seu tempo. E esse conflito, que é permanente, irá se configurar de diferentes formas, a cada momento histórico. Assim, ao olharmos para a história da Volkswagen no Brasil, considerando o seu desenvolvimento geral e as mudanças ocorridas no tempo de trabalho, veremos que é possível dividi-la em quatro grandes momentos.

Trato, neste capítulo, desses quatro momentos da história da Volkswagen, dedicando maior atenção para o quarto momento, pós 1995, por ser o foco da análise desta tese. No primeiro momento, entre os anos 1950 e final dos 1970, observo o movimento de expansão tanto da produção e do emprego como do tempo de trabalho. No segundo momento, entre o final dos anos de 1970 e meados dos anos de 1980, o foco está na retomada das lutas sindicais, principalmente, nas reivindicações voltadas para a redução da jornada de trabalho. Já no terceiro período, entre 1986 e 1995, enfoco o processo de mudanças na organização do trabalho e da flexibilização não declarada e não negociada do tempo de trabalho. A discussão do quarto período, entre 1995 e 2005, foi dividida na seguinte estrutura: primeiramente, localizo as mudanças ocorridas no contexto macro, bem como as mudanças mais gerais que se desenvolveram na Volkswagen, sobretudo, após o fim da Autolatina e da Câmara Setorial. Em seguida, observo com mais detalhes as negociações que foram desenvolvidas dentro da Volkswagen do ABC, no momento em que a Empresa ameaça fechar esta unidade. Estas negociações são estudadas a partir dos reflexos provocados no tempo de trabalho, com atenção especial às mudanças implementadas no próprio tempo de trabalho, como as diversas formas de flexibilização adotadas. 


\section{1 - Dos anos 50 ao final dos 70: expansão da produção, do emprego e do tempo no trabalho}

Este primeiro momento da história da Volkswagen inicia-se com sua instalação no Brasil, em 1953, e se estende até final dos anos 1970. É caracterizado por um movimento de expansão da Empresa, que, por sua vez, acompanhava o próprio crescimento do setor automobilístico no Brasil. Um momento, portanto, de expansão da produção, do emprego e do tempo no traba1ho. Desde os anos 20 registramos a presença de montadoras automobilísticas no Brasil. As primeiras a se estabelecerem no país foram a Ford, em 1919, e a General Motors (GM), em 1925. Entretanto, foi a partir da década de 1950 que o setor cresceu e começou a adquirir a complexidade atual, com a instalação de diversas empresas no estado de São Paulo, entre elas a Volkswagen. Mas não foi apenas a Volkswagen ${ }^{1}$ que nasceu durante esse período, pois medidas governamentais na forma de incentivos oficiais acompanharam e estimularam o rápido avanço das montadoras no Brasil, assim como investimentos em infra-estrutura e indústrias de base (Bresciani, 1997).

Em 1953, a Volkswagen localizava-se no bairro Ipiranga, em São Paulo, montando os seus primeiros veículos Kombi e VW Sedan, conhecido como fusca (Diário Grande ABC, 2003). Em 1957, quando instala a fábrica Anchieta, no ABC, a Volkswagen passa a assumir seu papel entre as pioneiras do "boom" de industrialização ocorrido no pós-guerra. Um dos símbolos da evolução industrial do país, a planta Anchieta, se caracterizou pelo gigantismo. No pico da produção dos anos 80, chegou a ter 38 mil trabalhadores; num total de 45 mil, se considerarmos todas as plantas da Volkswagen no Brasil. A fábrica Anchieta é estruturada em prédios de grande porte em geral correspondendo a uma "Ala”, como são denominados os departamentos produtivos. Com estruturas de gestão segmentadas, ressaltando duas macro-áreas - a armação/montagem/pintura (ou B\&A, body and assembly) e a área correspondente à força motriz (ou PTO, powertrain, que inclui motores e câmbio) -, além da ferramentaria, engenharia e do setor administrativo.

Entre início e meados dos anos 1960, a indústria automotiva passou por dificuldades com o declínio da economia do país, acompanhada de uma capacidade produtiva acima do potencial de absorção pelo mercado, além da recessão e do golpe de Estado. A partir de 1967, o

1. Entre elas a Toyota, em São Bernardo do Campo (SBC), 1959; Willys, 1952; Mercedes-Benz, em SBC, 1956; Scania, SBC, 1957; Simca, 1958; GM, em São José dos Campos (SJC), 1959; Karmann Ghia, em SBC, 1960 e Ford, em SBC, 1969 (DIEESE, 2002). 
setor passou por uma reconfiguração através de processos de fusão e aquisição entre Empresas, a partir do qual Volkswagen, Ford e GM solidificaram suas posições no mercado brasileiro. No final dos anos 1970, novas Empresas e plantas foram instaladas no Brasil ${ }^{2}$, consolidando o processo de recuperação do setor. Em relação à gestão do trabalho, de acordo com Salerno (1989), no período entre os anos 1950 ao final dos 1970, num contexto de mercado ainda pouco competitivo, as empresas automobilísticas tinham suas estratégias marcadas pela redução do custo do trabalho, controle de preços, repressão aos Sindicatos, compressão dos salários, alta rotatividade e intensificação e extensão da jornada de trabalho. Nos relatos de José, trabalhador aposentado na Volkswagen desde 1968, ou ainda Gomes, dirigente sindical também aposentado, fica explícita a extensão da jornada de trabalho.

\footnotetext{
"Quando eu entrei fazia 2 horários, me lembro como se fosse hoje, trabalhava das $6 \mathrm{~h} 00$ as $4 \mathrm{~h} 30$, que hoje mudou muitos os horários, era 48 horas até mais, hoje eu nem sei quanto que é deve ser 39,40 horas. Então diminuiu bastante, naquele tempo não, era das $6 \mathrm{~h} 00$ as $16 \mathrm{~h} 24 \mathrm{e}$ das $16 \mathrm{~h} 24$ as 2h20 da manha" (José).

“A grande reivindicação era salário e redução da jornada do trabalho. Que para falar para você, eu entrei na fábrica, 1974, trabalhávamos 48 horas semanais. Eu saí agora [aposentou] em 2003, trabalhando 40 horas semanais. Isso significou uma redução em 30 anos de 8 horas por semana que não é pouca coisa, esse foi uma conquista palpável" (Gomes ).
}

Mas não era apenas a jornada de trabalho contratada que era longa, pois a esta se somavam as horas extras que, em função da pressão da Empresa, os trabalhadores se viam obrigados a cumprir, como vemos na fala de José:

"Então eu trabalhava das $16 \mathrm{~h} 24$ as $6 \mathrm{~h}$ direto. Ou às vezes que eu entrava às $6 \mathrm{~h}$, eles pediam para ficar até às $18 \mathrm{~h}$. Teve época que ficou apertado, você era praticamente obrigado a fazer isso daí. O pessoal que não colaborava era visto de outra maneira. Você vê que muita gente foi mandada embora, porque às vezes o cara não fazia o que a chefia queria”. (José)

Somado a este contexto, havia ainda a própria situação de muitos trabalhadores que relatam terem chegado à São Paulo sem dinheiro, tendo ainda a responsabilidade com a família

2. Como a Ford, em Taubaté - SP, 1974; Fiat, em Betim - MG, 1976; Mercedes-Benz, em Campinas - SP, 1978; Volvo, em Curitiba - PR, 1979 e a Agrale, com plantas em Caxias do Sul - RS e duas em Manaus - AM, no ano de 1983 (DIEESE, 2002). 
que ficou na terra de origem. Entrar na Volkswagen significava uma perspectiva de mudança radical na vida: um tempo de trabalho regular, um salário garantido, uma carteira de trabalho e um tempo de trabalho contínuo. Assim, vemos que do ponto de vista do tempo de trabalho, este período foi marcado pela sua expansão, seja pela longa jornada de trabalho contratada, como também pela forte demanda pela realização de hora extra.

\section{2 - Anos 80: o início da luta pela redução da jornada}

Um segundo momento, abrangendo o final dos anos 1970 e seguindo até meados dos 1980, se caracteriza pelo grau de conflito mais acentuado entre Empresa e Sindicato, no contexto da reafirmação do movimento sindical ${ }^{3}$ como ator político. O foco da reivindicação abrangia a questão da negociação direta com o setor patronal, o reajuste salarial, a organização no local de trabalho e a redução da jornada de trabalho.

Do ponto de vista econômico, este período é marcado pela recessão dos anos 80, depois de um crescimento da produção brasileira de veículos automotivos, até atingir o pico no ano de 1980. Essa crise teve como conseqüência, a queda da produção, diminuição das vendas, rebaixamento do nível de emprego e pouco investimento em termos de expansão de sua capacidade (Bresciani, 1997). Provocou ainda uma alteração no enfoque adotado pelas montadoras para o mercado externo.

Neste contexto, a Volkswagen inicia alguns processos de mudanças tanto do ponto de vista tecnológico como organizacional, considerando que, de acordo com Barbosa (2002), as mudanças implementadas até este momento não chegaram a produzir alterações significativas na configuração da estrutura produtiva. Em relação às inovações tecnológicas, de acordo com o autor, as mudanças que ocorrem neste período são: a introdução dos equipamentos de comando numérico computadorizado na ferramentaria e manufatura e a instalação da primeira estação de solda automática. Já no que se refere à mudança organizacional, a Empresa implementa, na campanha "Juntos para o Futuro", um programa de Círculos de Controle de

3. O surgimento do chamado "novo sindicalismo", tendo como berço os metalúrgicos do $\mathrm{ABC}$, coloca em xeque o modelo de relações industriais vigente no país desde meados dos anos 30. Na relação trabalho/capital, esse momento é marcado pela resistência do setor patronal em negociar diretamente com os trabalhadores, resultando, na maior parte das vezes, na intervenção do Estado através da Justiça do Trabalho. Essa ação é alterada quando os metalúrgicos passam a pressionar o setor patronal através de paralisações, forçando a negociação direta, sendo que, a partir daí, vemos novas demandas e conquistas surgirem nas negociações coletivas neste setor. (Cardoso, 1998b). 
Qualidade - CCQ, com objetivo de envolver os trabalhadores na busca de soluções voltadas para a melhoria da qualidade do produto e do processo produtivo.

Este programa não teve uma duração muito longa, com encerramento em meados dos anos 80. Para Barbosa (2002), a implantação dos CCQ's era vista com desconfiança pelo Sindicato, em função da recusa da Empresa em discutir este processo, numa relação já desgastada com o recente episódio da Volkswagen tentar implantar uma Comissão de Fábrica, em 1981 -, à revelia do Sindicato que se encontrava sob intervenção do regime militar. Sobre o período em questão, Arlindo, um dos dirigentes sindicais entrevistados, ressalta que, “... foi um período muito confuso, pois os trabalhadores não sabiam quem os representavam, se era a Comissão de Fábrica ou o CCQ”.

E apesar da ação sindical contrária ao CCQ, de acordo com Mendes, antigo representante dos trabalhadores, “ o CCQ nunca deixou de existir por conta de uma ação sindical..., no geral sempre que a fábrica chamou, a peãozada sempre participou, como hoje participa do tal $\mathrm{PMC}^{2}$, dos planos de sugestões”. Ainda ressalta que a participação nesses programas, sobretudo nos CCQ'S, significou, para os trabalhadores, a possibilidade de ser reconhecido pela Empresa além de fazer um trabalho diferente, durante alguns períodos, saindo, portanto da pressão das linhas de produção.

Diante dessas inovações, de acordo com Barbosa (2002), a posição do Sindicato foi de reivindicar contrapartidas para o aumento de produtividade, no sentido de manutenção dos empregos, redução da jornada de trabalho e aumento da remuneração, bem como o acesso a informações sobre os processos que estavam sendo implementados. Segundo o autor, a conquista da Comissão de Fábrica, no início dos anos 80, foi fundamental para viabilizar as demandas da época. Como citado anteriormente, no ano de 1980, a Volkswagen implanta, unilateralmente, um sistema de representação dos trabalhadores, em meio a uma intervenção do governo no Sindicato de São Bernardo, como forma de combater uma “comissão clandestina", já existente na Volkswagen desde os anos 70. Após muita negociação, contando inclusive com a participação do Sindicato dos metalúrgicos - IG Metall, em 1982, foi acordada a existência de uma Comissão de Fábrica ${ }^{4}$ eleita pelos trabalhadores nas plantas Anchieta, Ipiranga e Taubaté ${ }^{5}$ (Barbosa, 2002). Ainda no que se refere ao alcance dessas contrapartidas, na revisão do estatuto da Comissão de

4. No estatuto elaborado pela Volks estava definido que o Sistema de Representação seria constituído por 17 membros (sete horistas sindicalizados, sete não sindicalizados e três mensalistas), com estabilidade e liberação parcial de jornada. Neste estatuto estava previsto ainda que a Empresa teria a prerrogativa de alterar as disposições do documento, enquanto as propostas dos trabalhadores só entrariam em vigor se aprovados pela Volks. Além disso, não havia nenhuma referência à entidade sindical.

5. No caso da Volks Resende, São Carlos e Pinhais, a Comissão de Fábrica foi conquistada, em 1999, em função do acordo coletivo celebrado entre a Volks e os respectivos Sindicatos no âmbito do Mercosul. 
Fábrica, em 1985, foi inserida uma cláusula garantindo o acesso do Sindicato às informações sobre as mudanças tecnológicas e organizacionais (Bresciani e Cardoso, 1999).

A redução da jornada de trabalho também aparece, nesse momento, como uma das reivindicações de contrapartida, apesar de já fazer parte da pauta do Sindicato desde 1976. No início de 1985 esta reivindicação foi ampliada para toda a categoria metalúrgica, com a demanda de uma jornada de 40 horas e aumento do adicional de horas extras para 200\%, desencadeando um amplo movimento grevista, envolvendo os metalúrgicos e químicos do Estado de São Paulo, com duração, na Volkswagen, de 53 dias. Entre 1985 e 1986, a jornada de trabalho, na Volkswagen, foi reduzida para 44 horas semanais.

Mas, se por um lado, os trabalhadores conquistaram a redução da jornada de trabalho, por outro, a Volkswagen inicia uma pressão para reduzir as pausas e expulsar do tempo de trabalho aqueles tempos nos quais os trabalhadores não estivessem produzindo diretamente. Neste caso, a Empresa retirou 5 minutos diários entre o início oficial da jornada de trabalho e o início do funcionamento da linha, utilizados pelos trabalhadores para caminharem entre o vestiário e o setor ou ainda preparar o que fosse necessário para rodar a linha, como nos relata Mendes.

“... 06h05 era o horário que começava rodar a linha. Porque esses cinco minutos era o tempo que eu tinha para chegar do vestiário até o meu setor, colocar os meus equipamentos de proteção, acertar as minhas ferramentas, verificar a máquina e aí que eu iria começar a trabalhar. [...] Era uma hora de almoço, e fazia o horário normal e nesse caso não tinha os cinco minutos de tolerância porque supunha que a parte de equipamento e de ferramenta já estava tudo visto na parte da manhã”. (Mendes)

Da mesma forma, as pausas não regulamentadas, as chamadas pausas marrons, foram foco de disputa já a partir de 1986.

“... não ia se ter mais as paradas de café, mas as pessoas podiam fazer o café individualmente. Então, se eu adiantasse a minha produção, se tivesse alguém para segurar ou tivesse uma parada de linha eu sairia e teria o café à disposição. Mas em algumas áreas deu 6 horas da manhã, a chefia ia lá e catava as garrafas de café, jogava tudo fora para não deixar café na área. Então, tudo isso foi cortado esse negócio de cinco minutos pra se higienizar, parada de café cortada, basicamente tudo, claro que isso sim foi cortado num primeiro momento, mas gradativamente foi se ajustando; até hoje você ainda tem na maioria das áreas" (Mendes). 
Vemos, então, que, desde a segunda metade dos anos 80, existia uma disputa declarada pelo tempo de trabalho na Volkswagen do ABC. Por um lado os trabalhadores buscavam a redução da jornada de trabalho e o aumento do adicional de hora extra, mas não a sua limitação. Por outro, a Empresa buscou ocupar ao máximo o tempo contido na jornada de trabalho, reduzindo pausas ou expulsando tempos considerados não produtivos. Entretanto, não vemos uma discussão sobre a natureza das mudanças organizacionais, que já começam neste período e que irão se aprofundar a partir da criação da Autolatina com fortes impactos no tempo de trabalho. Como bem salienta Bresciani (1997), nesse período a Empresa não teve problemas para implementar as modificações no processo de trabalho, "seja porque o estatuto facultava apenas a informação, seja porque a comissão não desenvolveu políticas que pudessem questionar os processos objetivamente" (1997:77). Salienta ainda que a Comissão focava a discussão na introdução dos robôs quando eram as mudanças organizacionais que tinham maiores efeitos sobre os trabalhadores, tanto sobre a organização e conseqüente racionalização do trabalho, como sobre o nível de emprego na fábrica, que se torna decrescente a partir dos anos 80 .

\section{3 - Meados dos 80 a meados dos 90: a flexibilização não-declarada e não negociada do tempo de trabalho}

O ano de 1987 marca o início do terceiro período, quando o sistema Volkswagen passou por um choque de culturas resultante da fusão com a Ford, no processo de formação da Autolatina (DIEESE, 1987). Por sua vez, o fim da Autolatina, em 1995, é justificado pela própria Volkswagen como decorrente da abertura das importações e do reaquecimento do mercado interno (Volkswagen, 1998). Do ponto de vista macro, após um período de retração do mercado, a indústria automotiva volta a ocupar um lugar de destaque nos dispositivos governamentais, com políticas específicas direcionadas para o setor, tais como a implantação das Câmaras Setoriais e do Regime Automotivo. As conseqüências foram recordes de produção e produtividade, investimentos em novas fábricas e intenso processo de transformação do setor.

Com a instalação da Câmara Setorial Automotiva ${ }^{6}$, envolvendo Estado, trabalhadores e seus representantes e empresários, caberia aos diversos atores do complexo automotivo elabo-

6. A Câmara Setorial teria como um de seus efeitos substituir o controle de preços realizado pelo CIP, organismo interministerial que discutia basicamente a estrutura de preços de determinados produtos, visando o controle da inflação, o que incluía os veículos. Essas decisões eram discutidas, unicamente, pelo governo federal junto aos empresários das montadoras e autopeças. 
rar um diagnóstico sobre os seus problemas principais, bem como um conjunto de proposições comuns e um programa de médio e longo prazo para a recuperação do setor. Este processo resultou em dois acordos, em 1992 e 1993, que possibilitaram respostas econômicas e políticas rápidas, eliminando-se assim as pressões sobre o setor ${ }^{7}$. Vale ressaltar que na Câmara Automotiva a questão da redução da jornada de trabalho não esteve presente nas negociações tripartites, porque o foco parecia estar na geração de emprego via o crescimento do setor, já que se avaliava que havia muita demanda reprimida. Assim, foi discutido o aumento do adicional de hora extra, em função da retomada e aumento da produção e conseqüente pressão da Empresa para a realização de trabalho no final de semana, como vemos na fala de Edgar:

\begin{abstract}
"Neste momento que havia necessidade de produção o que fez o Sindicato? Tirou do capital o que pôde. Domingo, hora extra era 200\%, sábado era 100\%”. Mas quando acabou o acordo a produção voltou a reduzir a Empresa começou a falar em mais reestruturação, em demissão, em redução de jornada e salário e, neste momento, “...o Sindicato muda a sua estratégia, demanda a redução ou eliminação de hora extra e a estabilidade no emprego. Então, são dois momentos, dois tempos". (Edgar)
\end{abstract}

Neste contexto de crescimento as montadoras passaram a adotar estratégias que abrangiam a diversificação de modelos, rapidez no lançamento de novos tipos e ampliação dos modelos de carros populares, redução dos tempos de projeto e fabricação dos novos produtos, redução de estoques, ampliação do controle gerencial sobre a produção e o aumento da qualidade (DIEESE, 2002). Todas essas mudanças geraram forte impacto no rendimento do trabalho, resultante tanto de processos de intensificação ${ }^{8}$ do trabalho como do aumento da produtividade. Assim, apesar da produção recuperar-se a partir de 1992, o número total de trabalhadores em montadoras de veículos passou de 138 mil, em 1990, para 94 mil, em 2001 (DIEESE, 2002).

7. Como resultado destas negociações, o nível de emprego se estabilizou, sendo os planos de demissão suspensos, os salários evoluíram nas montadoras do Estado de São Paulo, havendo ainda desempenho positivo na arrecadação do Estado. Além disso, a produção foi retomada, atingindo o patamar de 1.073 .761 veículos produzidos no país, semelhante à produção de 1988 (em 90 foram 914.366). "As Empresas também viram seu nível de produtividade aumentar de 7,7 veículos/trabalhador em 1990 para 14,8 veículos/trabalhador, em 1994" (DIEESE, 2006: 2). Entretanto, nem todas as metas foram atingidas, pois enquanto as de produção foram superadas, não houve, ampliação do nível de emprego no setor metalúrgico como um todo. (Bresciani e Benites, 1995:92 e Arbix, 1995).

8. De acordo com Coriat (1979, apud Salerno 1989), chamamos de intensificação do trabalho quando dada uma tecnologia constante, um mesmo número de trabalhadores produz ao mesmo tempo uma quantidade maior de produtos, acentuando o ritmo de trabalho e reduzindo as porosidades e tempo mortos na produção. Já o aumento da produtividade ocorre quando, dentro de um mesmo ritmo de trabalho, a mesma quantidade de trabalhadores produz uma quantidade maior. 
A formação da Autolatina, em 1987, marca a introdução e o aprofundamento de diversas inovações tecnológicas e organizacionais com o início do processo de desverticalização da produção. A Empresa reduziu o número de fornecedores, exigindo ainda a qualidade garantida e o sistema just in time e, na organização da produção interna, implementou a redistribuição da produção dentro das fábricas e igualmente o just in time. Começou também a implantação de programas de "qualidade total" e de "garantia da qualidade" que, sob o discurso da melhoria contínua, buscava, entre outros, a padronização dos processos e a obtenção da ISO9000. Tais programas acabaram por alterar as condições de execução das tarefas e do tempo de trabalho, em função da incorporação de novas atividades, sejam elas operatórias (como no caso da TPM - manutenção produtiva total) ou gerenciais (como no CEP - controle estatístico de processos) (DIEESE, 1999).

No que se refere às mudanças organizacionais, a partir deste período houve muitas transformações que intensificaram o tempo de trabalho em toda a fábrica, como a introdução do just in time. Sobre isso, a fala de Arlindo nos elucida o que acontecia na logística: “... não ter estoque na linha significa que eu estou o tempo todo trazendo peças para a linha...”. A fala de Beto também reforça essa intensificação: "se de repente o trabalhador [da linha] podia advertir que o estoque estava acabando e ficar parado até que o estoque viesse novamente, isso não acontece mais".

Assim, um dos primeiros reflexos da introdução do just in time, foi a redução das pausas para abastecimento de materiais, interna ou externa, levando a forte reorganização nos setores, para dar conta de um fluxo de trabalho cada vez mais intenso e bem mais vulnerável (Durant, 2004). O just in time acaba transformando todos os setores da Empresa, além de fornecedores externos, em partes de uma grande linha de produção, em que cada setor é, ao mesmo tempo, cliente e fornecedor dos setores a montante e a jusante, num contexto de ausência ou de redução significativa dos estoques. Durant (2004) ressalta que, para os trabalhadores, isto significa atenção e responsabilidade redobradas, pois qualquer problema em um dos setores pode significar a parada de toda a produção da fábrica. Assim, o fim dos estoques cria um estresse e um sentimento de insegurança permanentes em cada local de trabalho, acabando por pressionar e desestabilizar os trabalhadores.

Ainda de acordo com Durant (2004), o just in time além de reduzir a imobilização do capital investido, em função da ausência de estoques, pressiona e ao mesmo tempo possibilita que sejam percebidos os pontos de estrangulamento ao longo do processo, com a conseqüente 
redução do desperdício. Significa, portanto, ainda conforme o autor, mudanças no conteúdo do trabalho, nos ritmos, nas condições de intervenção sobre o objeto de trabalho, na relação entre os trabalhadores e, finalmente, na percepção que estes passam a ter sobre o tempo de trabalho. Além disso, a necessidade de manter em funcionamento o fluxo leva os trabalhadores a naturalizar as pressões, pois eles se engajam para manter o fluxo em funcionamento, visto como uma demanda da organização do trabalho e não do capitalista.

No que se refere à introdução de mais trabalho, vemos que as atividades de manutenção e também as de controle de qualidade passam a ser inseridas no trabalho na linha, como forma de manter a coerência do modelo de fluxo intenso. A manutenção passa a acontecer ao longo do processo, reduzindo a possibilidade de rompimento do fluxo e atuando na identificação de problemas ao longo da linha, fato que aumenta a tensão e responsabilidade sobre o trabalhador. Dentre as atividades ligadas à qualidade, com a Autolatina iniciou-se a implantação do Controle do Processo Estatístico (CEP), com forte resistência dos trabalhadores. Isto porque, houve a incorporação das tarefas relativas ao CEP, mas não houve, por outro lado, alteração nos padrões de tempo, ficando evidente a disputa pelo tempo de trabalho. Na fala de Arlindo, vemos claramente essa disputa: de um lado a Empresa insere novas tarefas e busca manter o tempo padrão, por outro, os trabalhadores tentam driblar a cronometragem, no intuito de aumentar esse tempo padrão. Mas é importante ressaltar que esta luta aparece muito mais como iniciativas individuais dos trabalhadores do que parte da pauta de reivindicações do Sindicato.

“E perguntávamos, mas o que vocês querem? A gente monta o carro, 25 minutos pra montar o veículo, você [Empresa] quer que eu monte em 20 e ainda quer que eu dê qualidade que vocês precisam, então não tem lógica, se você falasse que é 25 e você vai fazer em 30 para fazer bem feito. E foi justamente nesse controle de tempo da engenharia industrial, e o pessoal da carta CEP da área qualidade que surgiu o carimbo. Começou a surgir o carimbo para dizer que você precisa fazer a qualidade, se não fizer nós vamos saber que foi você que não fez. E daí nós começamos a fazer outras questões de embate contra isso, 'tudo bem, você quer fazer com qualidade nós vamos fazer. Então, quando vinham medir, ao invés de 20 minutos a gente levava 30, principalmente nas funções mais complicadas demorava mais'. [...] essa foi uma luta que se deu até 2 ou 3 anos no início dos anos 90, essa grande luta pelo tempo, porque tem isso até hoje, mas hoje os dois lados estão mais maduros". (Arlindo)

Essas novas tarefas relacionadas à qualidade trouxeram não apenas a intensificação do trabalho, mas, também, maior responsabilidade e pressão individual sobre os trabalhadores, 
pois a Empresa passa a ter a possibilidade de identificar o trabalhador que produziu fora do padrão.

Se no período anterior tivemos a implementação dos CCQ's, já no início dos 90 a Empresa cria o Programa de Melhoria Contínua - $\mathrm{PMC}^{2}$, onde os trabalhadores não tinham mais a mesma participação. Mesmo assim, como no caso dos CCQ's, a implantação do PMC muitas vezes implicou em um aumento do tempo de trabalho, como podemos ler no documento elaborado pela Volkswagen, na discussão sobre os objetivos do programa: "combater o desperdício; aumentar a produtividade e melhorar a qualidade dos produtos com a eliminação de refugo e retrabalho", frisando ainda que "O Programa evita também parar a produção para promover alterações - muitas delas são feitas nos fins-de-semana" (Revista Volkswagen, 1998:27). Para Durant (2004) assim como Linhart (2005), se num primeiro momento a participação nessas equipes de sugestão e solução de problemas tem como objetivo a melhoria permanente, aos poucos, essa participação vai possibilitando e conduzindo os trabalhadores ao sentimento de fazerem parte dos objetivos da Empresa, num processo de interiorização desses objetivos e de suas obrigações, passando a utilizar todos os seus conhecimentos para atingi-los.

A Empresa inicia ainda um amplo programa de terceirização, abrangendo mais de 7000 trabalhadores $^{9}$, dos setores de chicote, tapeçaria e banco. Do ponto de vista da automação na Autolatina, de uma forma geral, Salerno (1995) avalia que até o início dos anos 90 não era algo generalizado, podendo ser observadas algumas ilhas de automação ${ }^{10}$. E se eram poucas as mudanças tecnológicas, noto que elas estavam ausentes do processo de negociação durante todo o período analisado, não aparecendo, igualmente, nos discursos dos sindicalistas ao serem questionados sobre as mudanças no tempo de trabalho.

No que se refere ao tempo de trabalho este período marca a flexibilização não-declara$\mathrm{da}^{11}$. Isto é, uma flexibilização implícita e indireta, fruto do processo de inovação tecnológica

9. Estes trabalhadores foram realocados em outros setores e não mandados embora em função do acordo de 1991, que garantia ainda a discussão prévia entre Empresa e Comissão de Fábrica e Sindicato, gerando uma série de consultas, estudos e protocolos específicos, muito embora a pressão da Volks por maior agilidade no processo de decisão tenha se tornado um aspecto constante (Barbosa, 2002).

10. Como, por exemplo, a instalação de prensas, sistemas de pintura, alguns robôs de pontos de solda, sistema de transporte flexível com veículos guiados automatizados, associados com a montagem de carroceria, sistema de Armazenamento de Busca Automática (ABA), algumas ferramentas da máquina CNC, instalações CAD/CAM, teste de motor auxiliado por computador, sistemas de informatização da informação, além de investimento na automação do escritório.

11. Estamos utilizando a tipologia elaborada por Bresciani (1994) para compreender a ação sindical. Neste caso estou considerando a ação da Empresa. 
e organizacional, como vimos anteriormente. Mas também vemos uma flexibilização direta, prevista na legislação, possibilitando o trabalho em períodos flexíveis, com utilização de horas extras, trabalhos em turnos, trabalho noturno, imposição de férias coletivas, compensação compulsória dos feriados, transferência de trabalhadores entre setores e também entre fábricas (Salerno, 1995).

Uma flexibilização do tempo de trabalho que, talvez por não ser declarada e ainda fazer parte da legislação, muitas vezes nem chegou a ser reivindicada pelos representantes dos trabalhadores como objeto de negociação. Movimento muito diferente do que caracteriza o momento seguinte, a partir de meados dos anos 90, marcado por uma flexibilização negociada da jornada de trabalho. Além disso, o fato das mudanças organizacionais serem temas novos para o Sindicato pode ter contribuído para o escasso processo de negociação com a Empresa, o que não significa que não estivessem sendo discutidas. Como vemos na fala de Arlindo, tais mudanças foram

“criando uma discussão muito grande no chão da fábrica e todos se perguntando o que era isso, então para nós foi muito difícil porque a gente não sabia o que era, hoje todos os trabalhadores usam e sabem o que significa. A gente sabia que era para redução dos postos de trabalho". (Arlindo)

Ainda no que se refere ao tempo de trabalho, se a redução da jornada se deu entre os anos de 1985 e 1986, paralelamente, a Empresa continuou a pressionar para o maior controle do tempo de trabalho e pela redução de algumas pausas coletivas. Há uma diferença muito grande ao comparar as décadas de 80 e de 90 , pois se passou do "improviso" para uma leitura e gestão do tempo muito mais detalhada e complexa, por parte da Empresa, como fica evidenciado na fala de Beto:

\footnotetext{
"Havia muito de improviso. Claro que havia norma de tempos, mas havia mais espaço para [o encarregado] de um setor improvisar em termos de folgas ou mesmo de pausa. E que a partir dos anos 90, intensificou-se a leitura do tempo de trabalho e a identificação de todo o tempo morto da jornada de trabalho e ai a identificação de pausas, paradas para café. Dai os estudos de tempo e de produtividade identificaram que nesses pontos havia uma possibilidade de ganhos de produtividade." (Beto)
}

E como ressaltado por Linhart (2005), a cronometragem é algo constante nas Empresas justamente porque as inovações, tanto tecnológicas como organizacionais, possibilitam a redução 
do tempo necessário para a realização de cada tarefa, daí a necessidade, de acordo com essa lógica gerencial, de se recalcular o tempo efetivamente despendido numa dada atividade ou processo. Se somarmos a estas mudanças, a redução das pausas coletivas, a introdução de tarefas adicionais relacionadas seja à primeira manutenção, seja ao controle de qualidade, temos uma mudança radical no tempo de trabalho.

Ao questionar os dirigentes sindicais sobre como essas mudanças foram vivenciadas pelos trabalhadores, vemos, na fala de Beto, que "Como elas foram acontecendo lentamente, os impactos também acabaram sendo lentamente absorvidos". Arlindo diz que o trabalhador foi "acostumando" com essas mudanças, além de entender que não teria outra possibilidade, já que a Empresa precisaria aumentar a sua competitividade, para que ele pudesse manter seu emprego. "Se fosse para voltar ao que era antes, o trabalhador rejeitava. Porque se perguntassem para mim, se eu queria estar trabalhando conforme eu vejo a área hoje, ou voltar a 1988, eu ia falar que gostaria que continuasse do jeito que está”. Além disso, considera que

\begin{abstract}
"hoje essas coisas já estão mais assimiladas pelos trabalhadores, teve também uma rotatividade grande, tem muita gente nova, daquele pessoal antigo uma boa parte se aposentou, uma parte também que estava muito insatisfeito com essas mudanças, a oportunidade que teve de pegar pacotes, PDV, e foram embora, foram cuidar da vida. Então entrou muita gente nova que se adaptou melhor com essas mudanças" (Beto).
\end{abstract}

Mendes, que além de ter sido representante pela CF foi também membro da CIPA ${ }^{12}$, ressalta, em sua fala, que todas as mudanças foram "aumentando drasticamente a intensidade do trabalho e mesmo com todos os movimentos por redução de jornada o trabalhador se sente mais cansado". Na fala de Mendes, vemos ainda a relação entre a questão da saúde e o aumento da quantidade de tarefas e de responsabilidade do trabalhador com a nova ênfase para a qualidade dos produtos:

Até porque a Empresa, com essa questão de implantação de conceito de qualidade, ISO, essas coisas, então o trabalhador, hoje ele é exigido não só para produzir, mas também ele produz; ele inspeciona, então ele vê toda a parte se a peça que ele está fazendo tem qualidade; ele anota, ele é responsável, a partir do momento que ele anota, põe o nome dele, ele é responsável e ainda quando tem as auditorias, ele tem que conhecer pelo menos algumas normas, normas de qualidade, algumas normas de segurança, todas essas besteiras que surgiram aí, o trabalhador, ele é exigido

12. CIPA - Comissão Interna de Prevenção de Acidentes. 
nisso daí, $5 \mathrm{~S}^{13}$, tudo isso daí. [...] O numero de LER aumenta porque o esforço dele, às vezes se ele estivesse trabalhando tranqüilo, por uma peça numa boa, dar risada, conversar, talvez a peça não ia acarretar em problema nenhum, mas só o fato de ter que fazer, correr para ver se aquilo que ele está fazendo, então ele monta, então...é uma seqüência muito complicada". (Mendes)

Tais fatores acabaram por gerar um ambiente de trabalho muito mais tenso, levando ao aumento das licenças causadas por doenças, acidentes e também ao aumento do stress.

\section{4 - A partir de meados dos anos 1990: redução e flexibilização negociada e legal do tempo de trabalho}

O quarto momento, objeto central desta pesquisa, tem como característica principal o intenso processo de negociação sobre a redução e flexibilização da jornada de trabalho, com forte participação tanto da matriz da Empresa na Alemanha como do Comitê Mundial dos Trabalhadores da Volkswagen. Este período é também marcado por um movimento de discussão sobre a planta do $\mathrm{ABC}$, que resultou na fabricação de novos modelos, bem como em uma nova etapa de inovação tecnológica e organizacional, afetando diretamente o tempo de trabalho. Na realidade, este momento caracteriza-se muito mais por mudanças tecnológicas, em função do novo produto Pólo e depois do Fox, do que organizacionais, diferentemente, do observado no momento anterior.

No contexto mais geral, a partir da segunda metade dos 90, novas fábricas do setor automotivo foram instaladas no país, marcando o aprofundamento da descentralização geográfica deste setor. Entre elas temos mais três plantas da Volkswagen: em 1996, nas cidades de São Carlos - SP (motores) e de Resende - RJ (caminhões) e, em 1999, a Volkswagen-Audi, em São José dos Pinhais - PR, todas fora da região do ABC paulista ${ }^{14}$. Estas instalações apresentam um movimento de abandono de antigas áreas industriais ${ }^{15}$, marcadas por maior tradição sindical,

13. O Método 5S é uma das várias ferramentas utilizadas para implementar Sistemas de Qualidade. Os cinco conceitos surgiram no Japão, e cada um deles começa com a letra "S": (1) seiri - senso de utilização; (2) seiton - senso de arrumação; (3) seiso - senso de limpeza; (4) seiketsu - senso de saúde e higiene; (5) shitsuke - senso de auto-disciplina.

14. O mesmo movimento pode ser observado em outras plantas: Honda, em Sumaré - SP, 1997; Chrysler, Curitiba - PR, 1998; Navistar, dentro da planta da Agrale, Caxias do Sul - RS, 1998; Renault, São José dos Pinhais - PR, 1998; Toyota, Indaiatuba - SP, 1998; Mercedes-Benz, em Juiz de Fora - MG, 1999 (DIEESE, 2002). Sobre esta discussão são interessantes os textos de Rodríguez-Pose, A. \& Arbix, G. (1999) e, sobre a questão específica da Volks no Sul Fluminense, ver Ramalho. J.R. (1999).

15. De acordo com estudo elaborado pelo DIEESE (2002) as fábricas do ABC paulista, em 1975, eram responsáveis por cerca de $75 \%$ da produção brasileira, em 1991, passou para $45 \%$ e, em 1995, para 42\%, ao mesmo tempo em que se observa o crescimento de 436 mil para 675 mil veículos, no mesmo período. 
como é o caso do ABC (os denominados “brownfield”), para locais com pouca ou frágil organização sindical ("greenfields").

Na segunda metade dos anos 90, o processo de expansão da Volkswagen no Brasil, de acordo com Bresciani e Cardoso (1999), apresentou três grandes movimentos:

- a instalação da nova fábrica de automóveis em São José dos Pinhais, no Estado do Paraná, bem como da fábrica de motores de São Carlos, no interior do Estado de São Paulo;

- a retomada da condução autônoma de operações produtivas no setor de veículos comerciais, com a implantação da fábrica de Resende no conceito do "consórcio modular";

- a transformação das tradicionais plantas Anchieta e Taubaté, através de mudanças organizacionais e tecnológicas, e da transferência de atividades produtivas (como a produção de motores), levando a uma progressiva redução do quadro de funcionários destas duas fábricas, intensificação do trabalho e aumento da produtividade.

E mesmo ameaçada pelo crescimento da Fiat e da General Motors, a Volkswagen segue entre as maiores empresas privadas brasileiras, com cinco fábricas de veículos no Brasil. Depois de chegar ao ápice com quase 45 mil trabalhadores, no início dos anos 80, o grupo Volkswagen passou, em fins de 1997, a operar com cerca de 30.775 pessoas. Um ano após, este número foi reduzido para 28 mil, em decorrência do acordo que contemplou a abertura de um programa de demissões voluntárias e que alcançou quase 10\% do contingente (Bresciani e Cardoso, 1999). $\mathrm{Na}$ Volkswagen do ABC, o número de trabalhadores passou de 19.740, em 1997, para 18.641, em 1999; 16.690, em 2001; 14.500, em 2003; e 12.065, em 2006.

A partir do ano de 2002, conforme nos relata Horta (2003), novas mudanças podem ser observadas na planta Anchieta, na linha de produção do Pólo, que mais tarde será também a linha do Fox. Entre elas, o autor observou a implantação de "perceptrom" "16, equipamento instalado no final da operação de montagem que evita o retrabalho na linha. A nova linha Pólo trabalha com $65 \%$ de automação e dispõe de áreas 100\% robotizadas, controladas por terminais de computadores. Exige atenção contínua e qualificação específica dos trabalhadores, $25 \%$ são

16. O perceptron é um equipamento usado para fazer o controle dimensional a laser de todas as peças que saem da unidade, evitando que aquelas que apresentam imperfeições sigam adiante. 
engenheiros ou tecnólogos que ainda estão estudando. O tempo de treinamento necessário para assumir qualquer função na linha é de 45 horas. Na análise das entrevistas com os trabalhadores, veremos que após o primeiro treinamento, as novas pessoas ingressaram nas linhas do Pólo e do Fox passaram a ser treinadas pelos próprios trabalhadores.

O autor observa também a ausência do inspetor de qualidade, a presença do sistema "Audit" (que avalia a qualidade), uma estrutura celular de produção e um conceito de grupos semi-autônomos. Em relação aos grupos de trabalho, veremos nos capítulos seguintes que eles estão longe de poderem ser caracterizados como semi-autônomos, uma vez que o trabalho em células parece ter ficado restrito à existência de grupos que seguem a definição dos líderes e gerentes, ainda com a figura do monitor responsável pela comunicação e controle do trabalho. Horta ressalta ainda o forte uso da linguagem do cliente fornecedor, o uso do Kanban e de outras técnicas que permitem respostas rápidas, ciclo de ajustes curtos e com qualidade. Por outro lado, verifica Horta que a existência de estoques revela que o modelo "enxuto" do Pólo não segue o modelo estrito do just in time. No que se refere ao tempo de montagem, nesta nova linha houve uma redução de 12 para 8 horas na montagem de cada veículo.

A produção do Pólo e, a partir de 2005, do Fox, alteraram não apenas a área da montagem final, mas também de diversos outros setores, como a estamparia e a pintura, por exemplo. Rogério, representante sindical da pintura, relata que com a vinda desses novos carros foi construída uma nova linha praticamente semi-automatizada no que se refere à pintura da parte externa do carro. Ressalta que, no caso da pintura, o fato da linha ser mais automatizada não implica a necessidade de ter um número menor de trabalhadores, "muito pelo contrário", já que embora haja uma redução do número de trabalhadores na linha, há um aumento na reparação e na correção.

A fabricação desses novos modelos gerou, portanto, um conjunto amplo de novas alterações técnico-organizacionais: um alto índice de automação, fim do retrabalho, estrutura celular de produção, grupos de trabalho, just in time, entre outras. Mudanças que alteram totalmente o tempo padrão da produção e que têm como objetivo transformar, cada vez mais, os tempos alocados em tempos impostos. Assim, ao mesmo tempo em que a Empresa fala sobre grupos semi-autônomos, as novas tecnologias implantadas simplificam as tarefas e impõe novos ritmos de trabalho dos quais é muito mais difícil escapar, como veremos nos capítulos seguintes. 


\subsection{1 - Mudanças na gestão do trabalho}

De acordo com o gerente de recursos humanos, entrevistado para esta pesquisa, em função do acordo de estabilidade no emprego e conseqüente retenção dos trabalhadores na Empresa, houve aumento da idade média dos trabalhadores, como vemos em sua fala: "Então, acarreta isso, os empregados ficam mais velhos e não deixam os postos para os mais jovens”. É interessante observar que, para o gerente da Empresa, o fator que impede a entrada de novos trabalhadores não está relacionado à opção desta em reduzir a produção na fábrica do $\mathrm{ABC}$, mas sim aos trabalhadores mais velhos protegidos pelo acordo de estabilidade.

Em relação ao processo de admissão, o gerente ressalta que hoje em dia ele é feito pelo processo formal, "Então, aquele caminho tradicional que era mais comum no passado: eis aqui meu cunhado, eis aqui minha filha, ele foi verdadeiro no passado, eu sou de uma época aqui em que se admitia por fila, o escritório admitia mil pessoas em um dia". Ele nos relata ainda que praticamente não está havendo mais contratações, a não ser pela admissão dos alunos vindos do Senai. Mais tarde veremos que uma das demandas da Empresa no processo de negociação de 2006 foi justamente o término da contratação compulsória de aprendizes do Senai.

No que se refere à formação, se no passado era a Volkswagen que formava os trabalhadores, o gerente de recursos humanos ressalta que a "função social da Empresa" não é mais a mesma. Hoje em dia, a maior parte dos trabalhadores tem o primeiro grau completo e, desde 1986, a Empresa só admite trabalhador com segundo grau completo. Da mesma forma, as fábricas novas já nasceram com esta demanda, onde já existem muitos engenheiros trabalhando como operários,

"E o que você faz com esse jovem, com esses engenheiros que não são absorvidos, eles vão trabalhar como produtores de veículo, é assim que funciona. Aqui então nós começamos a mudar as exigências, ou seja, se o mercado tem disponível, você coloca como perfil mínimo o curso colegial completo. Então, aquele dever que a Empresa tinha de dar o curso supletivo, com o tempo fomos vendo que isso não é função da Empresa, o mercado já pode dar pra você. Eu tenho pessoas que eu já pego prontas". (gerente de RH)

Nos dias atuais, como o mercado já oferece trabalhadores com alta escolarização, em tese já preparados para o mercado de trabalho, então não apenas deixa de ser "função da Empresa" como ela ainda pode elevar a exigência de escolaridade para a contratação. 
“...o cara tem que ser alfabetizado, ele tem que saber se expressar, para participar dos grupos que a gente chama de $\mathrm{PMC}^{2}$, para propor melhorias. Então, é exigência que a pessoa evolua naturalmente, não por benesses da Empresa, mas como uma característica dele mesmo..... Você tem que ser multifuncional, tem que encarar numa boa fazer várias atividades, aprender que não é um coisa ruim pra você, é uma coisa boa, essa educação para os novos tempos...”. (gerente de RH)

$\mathrm{Na}$ fala anterior, vemos que a demanda não é apenas por uma formação escolar mais elevada, pois não é esta que irá ensinar a ser multifuncional ou a saber participar dos grupos de trabalho. Ainda no que se refere à formação, pergunto se a Empresa tem demandado aos trabalhadores mais velhos que voltem a estudar, a que o gerente de RH responde que retomar a faculdade "passou a ser uma coisa natural". Isto também porque em muitos casos a Empresa condicionava a promoção ao curso superior, "Então a gente falava assim: nós temos essa vaga, estou te promovendo, mas assina aqui um termo de compromisso em que você tem três anos pra terminar o curso". O gerente de RH diz ainda que "eles tinham consciência prática e experiência plena para exercer a atividade, mas não tinham a condição escolar", então, a leitura que faz é que o trabalhador "simplesmente pagou uma dívida que ele tinha". E desta forma acabou não gerando nenhuma expectativa em relação a uma nova promoção.

Como veremos nas falas dos trabalhadores, nos capítulos seguintes, esta relação entre a nova formação e a expectativa de mudar de função está muito presente, sobretudo entre aqueles trabalhadores que estão na linha e buscam uma chance para sair da produção direta. Neste caso, há uma grande reclamação em relação à dificuldade de conseguir uma bolsa da Volkswagen ou ainda ao não reconhecimento da nova formação. Em relação às bolsas, o gerente de RH relata que hoje há uma quantidade menor justamente porque o mercado já está oferecendo trabalhadores formados; em função disso, no momento atual há 200 trabalhadores que estão com bolsas.

A demanda por trabalhadores mais qualificados alterou não apenas o processo de admissão, mas também o de demissão, como podemos ver no perfil dos trabalhadores desligados da Volkswagen do ABC e Taubaté, em janeiro de 1998, no Plano de Demissão Voluntária - PDV, que atingiu 4.062 trabalhadores ${ }^{17}$. Neste PDV houve o desligamento de um contin-

17. Conforme pesquisa do DIEESE junto aos trabalhadores que aderiram ao PDV, verificou-se que: a) o tempo médio na Volks era de 20 anos, e $82 \%$ eram já aposentados; b) 94\% tinham inserção direta no processo produtivo (trabalhadores horistas); c) o salário mais freqüente era de R $\$ 6,57$ por hora (R $\$ 1.200,00$ por mês); d) 44\% apresentavam alguma doença profissional; e) 95\% eram sócios do Sindicato; f) 44\% possuíam escolaridade inferior a oito anos e $24 \%$ tinham o primeiro grau completo, enquanto $12 \%$ possuíam de 8 a 10 anos de escolaridade formal, e 14\% haviam completado o segundo grau. 
gente caracterizado basicamente pelo alto tempo de casa, em geral já aposentados, vinculados à produção e com algum histórico de doença profissional, além de ter escolaridade formal limitada ao primeiro grau. Já em relação ao PDV de 2003, o gerente de RH ressalta que também saíram muitos trabalhadores novos em função de ter sido oferecida uma indenização alta independentemente do tempo de casa. "Por exemplo, no setor de RH, todos foram embora". Ainda em relação aos processos de demisão, vale ressaltar que apesar da constante redução de pessoal nas montadoras, a partir do início dos anos 1990, nota-se uma nova postura por parte das empresas, como no caso da Volkswagen; no lugar da demissão sem justa causa, planos de demissão voluntária, planos de aposentadoria sem reposição de pessoal ou terceirizações negociadas. Isto porque,

No novo modelo gerencial, todos os funcionários (diretos e indiretos) devem se envolver e participar como "colaboradores" do sucesso do negócio, e não apenas como "os músculos em ação" do período fordista. Neste contexto, as Empresas procuram adotar políticas de demissão que minimizem os seus efeitos negativos sobre o trabalho participativo dos funcionários que permanecem na Empresa. (DIEESE,1999).

Mesmo assim, é importante ressaltar que a iniciativa não tem sido da Empresa e sim dos próprios trabalhadores e de seus representantes, como ocorreu nas negociações na Volkswagen, o que demonstra ser esta a lógica válida nas fábricas que possuem uma forte organização no local de trabalho.

Finalmente, pergunto ao gerente de RH qual a reclamação mais comum dos trabalhadores, e a resposta é que a principal tem sido a "insegurança em relação ao futuro e ao seu emprego"; é a "questão de sobrevivência como profissional", sendo que ela suplanta até as questões de ordem de remuneração. Uma segunda questão é o que ele chama de "relacionamento".

"Talvez o que as pessoas vão reclamar muito é saudades da velha Volkswagen. Do paternalismo, da tutela, porque a Volkswagen não é mais uma Empresa social. Ela ficou malvada, ela tirou nosso brinquedo do final do ano. As pessoas não têm mais amor. $\mathrm{O}$ empregado não vem mais trabalhar de uniforme. No passado os empregados vinham de uniforme, vinham no ônibus vestidos com o uniforme da Volkswagen. [...]. É complicado, porque ele passa a ser mais mercenário, vamos dizer assim. Ele não faz isso pela Empresa . Ele faz por ele mesmo. Quando a pessoa tem uma relação ruim, ou seja, não tem nenhum vínculo afetivo com o trabalho, ou porque the causa algum prazer, alguma satisfação, isso passa a ser ruim. [...] Ninguém veste mais a camisa... Então 
ele está em um churrasco, em uma festa, o cara fala do carro e ele mesmo malha o próprio produto dele. Ou ele mesmo não tem um produto da própria marca, ou seja, nem ele próprio mais acredita". (gerente de RH)

Esta fala é importante para termos claro o momento de fortes transformações implementadas pela Empresa e sentidas pelos trabalhadores: não ter mais um papel social; não ser mais uma mãe; tirar o presente dos filhos dos trabalhadores no final do ano; não realizar mais a formação dos trabalhadores, reduzir a quantidade de bolsas de estudos, abrir planos de demissão. Por outro lado, a Empresa se espanta com a reação dos trabalhadores de não terem mais tanto orgulho por estar na Volkswagen, de falarem mal dos carros, de não vestirem mais a camisa da Empresa, de terem uma relação não mais sentimental, mas puramente "mercenária" com a Empresa. Ou seja, a Empresa muda a relação com o trabalhador, mas quer que este permaneça como antes, com a mesma relação "afetiva com o trabalho".

Assim, vemos que todo o investimento na participação dos trabalhadores seja via CCQ's, PMC, planos de sugestão, trabalho em célula, buscando internalizar os objetivos da Empresa, não têm sido suficientes para minimizarem os efeitos negativos do processo de transformação que passa a Volkswagen, levando os trabalhadores a não vestirem mais a camisa da Empresa.

\subsection{2 - As negociações coletivas na segunda metade dos anos 1990}

Antes de olharmos para as negociações coletivas ocorridas na Volkswagen do ABC, apresentarei, rapidamente, como está estruturado este processo e quem são os atores envolvidos, dado que a organização sindical na Volkswagen apresenta uma estrutura bastante complexa, fruto da própria estrutura sindical vigente no país. Um dos principais aspectos que demarcam esta estrutura é a pluralidade de correntes sindicais que representam os trabalhadores da Volkswagen. Nesse contexto, a Central Única dos Trabalhadores (CUT) está presente nas fábricas mais tradicionais (ABC e Taubaté) e tenta se organizar com a criação do Sindicato Automotivo de Resende, configurando disputa intersindical, já que a entidade que representa e negocia oficialmente com a Volkswagen Resende é o Sindicato de Volta Redonda, filiado à Força Sindical (após ter permanecido por longo tempo na CUT). A Força Sindical está presente também na fábrica de Pinhais, através do Sindicato de Curitiba. Por fim, a SDS (Central da Social-Democracia Sindical), está na unidade de São Carlos. Entre as disputas e tanta diversidade na representação, somente a partir de 1998, essas entidades procuram se articular em âmbito nacional. 
No caso da Volkswagen do $\mathrm{ABC}$, é o Sindicato dos Metalúrgicos do $\mathrm{ABC}$ que negocia com a Empresa, através do Comitê Sindical de Empresa (CSE) formado por 25 diretores do Sindicato, e do Sistema Único de Representação (SUR), que engloba e Comissão de Fábrica e CIPA, com 25 membros. A partir dos anos 90, há ainda forte participação do Comitê Mundial dos Trabalhadores da Volkswagen. Por fim, vale ressaltar que estamos falando de um Sindicato ${ }^{18}$ que tem uma história de ação muito relevante e que, mesmo no contexto de redução do número absoluto de trabalhadores, apresenta uma alta taxa de sindicalização, mantendo um movimento ascendente, como já observado por Leite (1997). Em 2005, a taxa de sindicalização era de $53,8 \%$ no setor metalúrgico do $\mathrm{ABC}, 70 \%$ nas empresas montadoras da região e $80 \%$ na Volkswagen do ABC.

No quadro 1, a seguir, sintetizo os principais momentos de negociação e mudanças relevantes ocorridos entre 1995 e 2005. É importante ressaltar o fato de que em todos os anos a questão da jornada de trabalho esteve presente nas negociações.

\subsubsection{1 - A manutenção da Planta do ABC}

De um ponto de vista mais amplo, os metalúrgicos do $\mathrm{ABC}$ adotaram diversas estratégias, a partir de 1995, como a constituição da Câmara Regional do ABC e, em 1998, a formação do Grupo de Trabalho do Setor Automotivo para discutir o desenvolvimento local ${ }^{19}$. No caso específico da Volkswagen ABC, desde 1995 há iniciativas do Sindicato e da CF de discutir o futuro da planta. Neste mesmo ano, acontece um workshop e abre-se um processo de discussão

18. O Sindicato foi fundado em 1933, congregando os metalúrgicos de toda a região do ABC. Em 1959, a entidade se desmembrou, sendo fundados o Sindicato dos Metalúrgicos de São Bernardo do Campo e o de Diadema e o Sindicato dos Metalúrgicos de Santo André, até a reunificação de 1993, quando foi criado o Sindicato dos Metalúrgicos do ABC.

19. A Câmara Regional do $\mathrm{ABC}$, que além dos metalúrgicos do $\mathrm{ABC}$ participavam outros Sindicatos, ONG's, Empresas, governo do Estado de São Paulo e as sete prefeituras municipais, esteve voltada à negociação de políticas públicas regionais, tendo como um dos focos principais a questão do emprego na região (Bresciani, 1999a). Este fórum multipartite desenvolveu uma série de acordos visando fortalecer a competitividade da região, incluindo a criação de novos modelos de financiamento para pequenas e médias Empresas, o desenvolvimento de programas de requalificação profissional, e a formação do Pólo Tecnológico do $\mathrm{ABC}$, além de medidas voltadas à melhoria da infra-estrutura e das políticas sociais (Bresciani e Cardoso, 1999). O Grupo de Trabalho do Setor Automotivo local deveria se concentrar nos temas: custo do trabalho e benefícios, infraestrutura regional, desenvolvimento tecnológico e estrutura tributária. Porém, ao contrário de seu correspondente GT Petroquímico-Plástico, responsável pela modernização do complexo petroquímico no Grande $\mathrm{ABC}$, o GT Automotivo não teve muito impacto entre 1998 e 2006, não produzindo qualquer impacto regional. Neste período emerge também a proposta dos trabalhadores para incentivo à renovação da frota nacional de veículos (Sindicato dos Metalúrgicos do ABC, 1998). 
Quadro 1 - Principais Negociações na Volkswagen do Brasil - 1995 a 2005

\begin{tabular}{|c|c|c|}
\hline Tema do Acordo & Abrangência e Vigência & Conteúdo \\
\hline $\begin{array}{l}\text { Redução da jornada } \\
\text { anual e flexibilização } \\
\text { da jornada }\end{array}$ & ABC e Taubaté (1996) & $\begin{array}{l}\text { - redução da jornada de trabalho para } 42 \\
\text { horas semanais } \\
\text { - jornada máxima } 44 \text { horas } \\
\text { - incorporação do descanso semanal } \\
\text { remunerado } \\
\text { - banco de horas }\end{array}$ \\
\hline $\begin{array}{l}\text { Nova estrutura de } \\
\text { cargos e salários } \\
\text { (a partir de 1995) }\end{array}$ & ABC e Taubaté & $\begin{array}{l}\text { - } \text { reequilíbrio da tabela salarial } \\
\text { - } \text { e reagrupr número de salários diferenciados } \\
\text { - novos critérios de promoção } \\
\text { - multifunção }\end{array}$ \\
\hline $\begin{array}{l}\text { Células e trabalho } \\
\text { em grupos }\end{array}$ & $\begin{array}{l}\text { ABC e Taubaté } \\
\text { (a partir de 1996) }\end{array}$ & $\begin{array}{l}\text { - constituição de segmentos produtivos } \\
\text { ("células") }\end{array}$ \\
\hline $\begin{array}{l}\text { Participação nos } \\
\text { resultados }\end{array}$ & $\begin{array}{l}\text { ABC e Taubaté } \\
(1995 \text { - negociação } \\
\text { anual) }\end{array}$ & $\begin{array}{l}\text { - estabelecimento de valores, indicadores, } \\
\text { regras e metas, entre elas o absenteísmo. }\end{array}$ \\
\hline $\begin{array}{l}\text { Novos Investimentos } \\
\text { e Jornada Flexível }\end{array}$ & $\begin{array}{l}\text { ABC e Taubaté } \\
\text { (1997 a 98) }\end{array}$ & $\begin{array}{l}\text { - criação do banco de dias } \\
\text { - compromisso de produzir modelo PQ24 } \\
\text { (Pólo) na Volks do ABC e Taubaté } \\
\text { - debate sobre fábrica de transmissões } \\
\text { - programa de demissão voluntária }\end{array}$ \\
\hline $\begin{array}{l}\text { Redução da jornada } \\
\text { e rendimento anual }\end{array}$ & $\begin{array}{l}\text { ABC e Taubaté } \\
\text { (98 a 2000) }\end{array}$ & $\begin{array}{l}\text { - redução da jornada de trabalho para } \\
40 \text { horas semanais } \\
\text { - jornada flexível - "semana Volks" }\end{array}$ \\
\hline $\begin{array}{l}\text { Flexibilização da } \\
\text { jornada }\end{array}$ & $A B C(2000)$ & $\begin{array}{l}\text { - recusa dos trabalhadores em renovar } \\
\text { acordo sobre jornada de quatro dias } \\
\text { e banco de horas }\end{array}$ \\
\hline $\begin{array}{l}\text { Novos Investimentos } \\
\text { e Jornada Flexível }\end{array}$ & ABC e Taubaté (2001) & $\begin{array}{l}\text { - jornada de quatro dias } \\
\text { - programa de demissão voluntária } \\
\text { - banco de horas } \\
\text { - } \text { terceirização de alguns setores } \\
\text { - compromisso investir } 500 \text { milhões no Pólo; } \\
\text { - produzir no ABC o modelo Pólo Sedan; } \\
\text { - produzir no ABC o modelo Tupi (Fox), } \\
\quad \text { caso a Volks decida produzi-lo no Brasil. }\end{array}$ \\
\hline $\begin{array}{l}\text { Jornada Flexível e } \\
\text { Garantia de Emprego }\end{array}$ & $\begin{array}{l}\text { ABC e Taubaté (2002, } \\
\text { prorrogado a cada } 2 \\
\text { anos, até } 2006)\end{array}$ & $\begin{array}{l}\text { - jornada de quatro dias } \\
\text { - banco de horas } \\
\text { - garantia de emprego até novembro } 2006\end{array}$ \\
\hline $\begin{array}{l}\text { Limitação da } \\
\text { hora extra }\end{array}$ & $\begin{array}{l}\text { Federação Estadual } \\
\text { dos Metalúrgicos } \\
\text { (2003 a 2005) }\end{array}$ & $\begin{array}{l}\text { - o primeiro acordo de limitação da } \\
\text { hora extra }\end{array}$ \\
\hline
\end{tabular}


sobre o programa de reestruturação, cujas prioridades selecionadas para o debate com a Empresa foram: o desenvolvimento de novos produtos, a redução da jornada e manutenção do nível de emprego. No ano seguinte, as discussões prosseguiram na conferência mundial dos trabalhadores da Volkswagen, na Alemanha, onde a Empresa explicitou sua intenção de desverticalizar e descentralizar as atividades desenvolvidas na planta do ABC (Barbosa, 2002). Além disso, o movimento por parte da Empresa de construção de novas fábricas era visto pelo Sindicato como um forte indicativo de enxugamento das plantas antigas (idem:101). Assim, relata Edgar:

"Teve uma mudança que ela foi provocada por nós. A gente vendo essa fábrica aqui totalmente
velha e os rumores que aconteciam no mundo Volkswagen de que esta planta era arcaica,
improdutiva, que não tinha mais condições, não só a planta mas a própria logística da região. [...]
E nós começamos a provocar a fábrica e dizíamos "vamos chamar o urso para dançar"”. (Edgar)

Além disso, pelos relatos de Edgar, vemos que o IG Metall da Alemanha e a CF da Volkswagen alemã alertaram os metalúrgicos do $\mathrm{ABC}$ : "se vocês não se mexerem eles vão fechar essa planta, tudo caminha para isso”. Edgar ainda faz questão de dizer que “...nós queremos a mudança, em primeiro lugar, porque nós aceitamos o desafio para modernizar a fábrica, para trazer produto novo, vender carro para a Europa." Assim, conforme o documento elaborado pelo DIEESE, já no ano de 1997 o Sindicato pautava nas reuniões com a direção da Volkswagen uma série de itens na tentativa de aumentar os níveis de produção e competitividade da Empresa, garantindo assim o emprego e a renda dos trabalhadores. Dentre as medidas, estão:

“... transformação dos processos produtivos (investimento em equipamentos, organização do trabalho, gestão da produção, relação com fornecedores e clientes), projetos de longo prazo (modelos para os próximos 10 anos, capacidade produtiva e investimentos, mercado, projetos para as demais plantas, política de preços), finanças, gestão a planta (conceito e projeto das unidades de negócio, agilização de processos) e recursos humanos (programa de capacitação profissional, política de remuneração, entre outros)" (DIEESE, 2006).

Desta forma, veremos que a discussão da manutenção da planta do ABC está presente em todo o período analisado, sendo inclusive utilizada como pressão e moeda de troca pela Empresa. Isto porque, no contexto de crescente insegurança em relação ao desemprego, muitas vezes os trabalhadores aceitam as mudanças propostas pela Empresa como forma de garantir o emprego. 
A seguir, apresento algumas negociações sobre mudanças na organização e gestão do trabalho que tiveram forte impacto no tempo de trabalho, de acordo com os relatos dos dirigentes e também dos trabalhadores entrevistados, como veremos nos capítulos seguintes. Entre eles: a redução das pausas individuais e coletivas, a multitarefa, a flexibilização da jornada de trabalho, o maior controle do tempo, a redução dos prazos para a produção, a pressão pela redução do absenteísmo, o aumento do ritmo de trabalho, a competição entre as células, a redução do pagamento da hora extra, o aumento do tempo livre definido pela Empresa.

\subsubsection{2 - A multifunção e o trabalho intenso em cada função (PCS)}

As discussões sobre o Plano de Cargos e Salários (PCS) foram iniciadas na época da Autolatina, resultando no acordo de 1995. Esta negociação foi demandada pelos trabalhadores que nos últimos anos vinham realizando diversas greves setoriais com reivindicações sobre equiparação salarial e desvio de função. Este acordo, além de reduzir os níveis salariais, permitiu um maior grau de multifuncionalidade na produção, por meio do reagrupamento e da redefinição de uma série de funções. Assim, apesar dos dirigentes dizerem que sempre houve a possibilidade da Empresa demandar a multifuncionalidade dos trabalhadores, a partir deste momento há a sua “institucionalização" e intensificação.

Vemos, nos relatos dos entrevistados, que a maior mudança se deu nas áreas de trabalho qualificado, como na ferramentaria. Neste setor, de fato houve uma maior complexidade na realização das tarefas e intensificação do tempo de trabalho, pois se antes um fresador de protótipo, por exemplo, poderia ficar um tempo sem trabalho ao longo da sua jornada, quando classificado como ferramenteiro, passa a ter de realizar todas as tarefas. Isto teve como conseqüência a redução das pausas durante a jornada de trabalho, a redução de pessoal e dos prazos. Aprender novas funções foi algo que afetou a área qualificada, na produção a necessidade de qualificação parece não ter sido tão intensa, como vemos na fala de Beto: "no geral, quando era para atender demandas setoriais havia uma necessidade de qualificação muito pequena, geralmente, os trabalhadores já estavam qualificados para fazer aquele trabalho". Mas este dirigente faz questão de frisar que “...a coisa da mobilidade sempre foi um tema muito difícil da Volks, em termos até de uma relação emocional do trabalhador com seu posto de trabalho, com seu setor, então havia uma resistência muita grande em se transferir para outro...” (Beto).

Os dirigentes trazem também a questão do tempo para explicar um dos motivos de os trabalhadores não gostarem de mudanças de setor. No novo local, embora precisem de um tempo 
para apreender a função, eles precisam começar a desempenhar $100 \%$ do trabalho mesmo sem conhecê-lo direito. Esta situação acaba gerando mais tensão para o trabalhador e, de alguma forma, mais trabalho.

\footnotetext{
"Tem um tempo pra você conhecer e ir sabendo o jeito mais fácil, mais leve, que te prejudica menos. Normalmente a atividade que você pega no começo, você só falta morrer, você chega em casa arrebentado, moído, quebrado, doendo tudo. Porque assim você desenvolve um esforço às vezes desnecessário, mais porque você não tem ainda os macetes daquele serviço...”(Mendes).
}

E mais do que isso, há ainda um tempo de deslocamento entre o setor de origem e o novo setor que, na maior parte das vezes, não é respeitado pela hierarquia, ou seja, mais um tempo de trabalho que a Empresa busca caracterizar como de não trabalho.

\begin{abstract}
"Você tem um tempo até chegar ao setor que você foi designado e depois você tem um tempo pra sair antes do seu horário, para se dirigir para o seu local de trabalho de origem, para poder chegar dentro do horário, na qual você sairia da sua própria linha. Para ir ao vestiário tomar o seu banho, se trocar e poder pegar o ônibus, nem isso é respeitado. Você começa e o encarregado quer saber porque você atrasou, porque você não está lá as seis da manhã, mas você diz que a sua jornada começa às seis dentro do meu setor original" (Rogério).
\end{abstract}

\title{
5.4.2.3 - A meta de absenteísmo (PLR)
}

Em 1995 houve a primeira negociação de PLR - Participação nos Lucros e Resultados, quando a Empresa passou a pressionar a entidade sindical para a negociação em torno das metas de produção, qualidade e absenteísmo, como vemos no relato de Arlindo:

"Produção e qualidade hoje a discussão é mais tranqüila, porque a gente consegue acompanhar o mix de produção, então a gente chega no meio do ano e gente já tem mais ou menos a perspectiva da produção do ano, então as coisas ficam mais fáceis". (Arlindo)

E sobre o absenteísmo, este mesmo entrevistado relata como um ponto de conflito, pois o Sindicato só aceitaria discuti-lo se ele fosse coletivo e, sobretudo, vinculado às questões sobre saúde. Por outro lado, a fábrica tentava associá-lo ao desempenho individual ou mesmo setorial. Entretanto, na fala de Marcos observamos que mesmo o absenteísmo sendo coletivo, acabou gerando problemas, porque havia uma cobrança muito grande entre os trabalhadores. Como relata Marcos, quando, por exemplo, um trabalhador faltava poderia ouvir de outro: “...seu sacana você fica faltando, o nosso absenteísmo vai para lá. A fábrica chegou a colocar na entrada dos refeitórios 
como estava o absenteísmo dela. Então o cara ia almoçar e via lá: está faltando 0,1 para a gente estourar, e de produção a mesma coisa". Durand (2004) nos ajuda a compreender este processo de produção caracterizado pelo fluxo intenso. Segundo o autor, para que este não pare, a coerção não vem apenas da hierarquia, mas igualmente de diversos outros setores, inclusive dos próprios trabalhadores, de forma que os atrasos, as faltas, a fadiga ou as fracas performances não são mais criticadas apenas pelo chefe, mas também pelo grupo.

Desde 1998 foi excluída a meta de "assiduidade" e "qualidade Audit de veículos", sendo mantida apenas a de volume de produção (acordo de 1998). Mesmo assim, Marcos nos conta que a Empresa passou a buscar outras formas para tentar combater o absenteísmo e "quando ela percebe que tem uma pessoa absenteísta ela pára de pagar o atestado médico da pessoa”. Edgar também diz que a busca em reduzir o absenteísmo, que na Volkswagen está em torno de 3 a 5\%, aparece principalmente no final da década de 90 , num contexto de incertezas que os trabalhadores passaram a viver e "...foi colocando no trabalhador um certo medo, e a própria fábrica trabalhando no sentido de reduzir o absenteísmo, por exemplo, pegando exemplos de pessoas, falsificação de atestados, e ela indo para cima, e não perdoando". E ainda, se considerarmos a questão da multifuncionalidade, como vimos anteriormente, as faltas podem ser mais bem geridas com a sua implantação, além da criação da figura do monitor (Durant, 2004), como veremos no item a seguir.

\subsubsection{4 - As células de produção - maior controle, menos pausas e maior competição}

No ano de 1996, para surpresa do Sindicato, a Empresa publica no quadro de avisos que seriam implantadas células de produção, a partir de janeiro de 1997, tendo em vista a necessidade de se modernizar para ganhar competitividade. Após muita pressão, o Sindicato conseguiu o compromisso da Empresa em constituir um grupo de trabalho para discutir este projeto, culminado em um acordo, em março de 1998. Em termos de concepção, os grupos deveriam contar certo grau de autonomia visando a solução de problemas, racionalização de processos, desenvolvimento de atividades de manutenção e logística e ampliação da garantia de qualidade. Do ponto de vista dos impactos em relação ao tempo de trabalho, as conversas com os dirigentes sindicais e também com os trabalhadores, evidenciam que a implantação das células trouxe um aumento do ritmo e da intensificação do tempo do trabalho, em função de três pontos principais.

O primeiro deles é a maior aproximação entre os trabalhadores e a hierarquia. Se, por um lado, isto poderia ser positivo, por outro, acabou por se configurar em maior controle e pressão sobre os trabalhadores em relação a diversos aspectos, entre eles, o tempo de trabalho. Podemos 
perceber a disputa pelo tempo de forma muito explícita, apesar de individual, por exemplo, na intenção de driblar o monitor ou o líder, como vemos na fala de Arlindo:

“Teve mudança porque ficaram todos mais próximos, um chefe que você nunca via hoje está lá do lado. Antes você dormia dentro do veículo, hoje eles pegam pesado nisso. Então, antes era muito solto porque o chefe não via, ele ficava lá longe. [...] Hoje, com a célula ficou mais difícil, então você tem que controlar teu tempo trabalhando, senão ele te dá mais serviço. Então o próprio trabalhador tem que controlar o seu tempo para não mostrar para o líder de célula, para o monitor. Para este não perceber essa coisa que se pode fazer tão rápido" (Arlindo).

O segundo aspecto está relacionado à redução das pausas coletivas. Para manter o fluxo contínuo da linha, uma das tarefas dos monitores de células seria a substituição dos trabalhadores quando estes necessitassem um intervalo. Mas, de acordo com a fala dos dirigentes e dos trabalhadores entrevistados, essa substituição não tem sido eficaz. Isto porque, na maior parte das vezes, o monitor substitui, durante o dia todo, um único ausente, seja em função de falta, férias, compensação de banco de horas ou doenças do trabalho.

"A fábrica inseriu essa política de monitores, e esse monitor tem $60 \%$ do tempo dele fora da produção. Então, essa pessoa está aí pra fazer a substituição, pra eliminar essa parada do café coletivo, então, a fábrica falava o que? Nós vamos colocar o monitor pra ir revezando cada um dos trabalhadores, pra não ter que parar a linha. Na maioria das áreas isso não dá certo, porque você pega uma área com 22 trabalhadores, mesmo sete minutos cada um, quer dizer que o último trabalhador que vai tomar café já quase na hora do almoço, não tem cabimento isso" (Mendes).

Além do maior controle e da redução das pausas coletivas, outra conseqüência negativa em relação ao tempo de trabalho foi a competição entre as células. No setor da estamparia, por exemplo, a Empresa passou a incentivar a competição entre as células, por meio da distribuição de prêmios, objetivando o aumento do ritmo de trabalho e da produtividade, como relata Nunes:

“... o encarregado falava assim: se vocês fizerem tanto de produção, eu libero vocês 10 minutos mais cedo. [...] Só que o que acontece? Na outra turma o encarregado falava: a turma anterior fez tanto de produção, por que vocês não conseguem fazer? Então o que acontece? Isso passava a ser um padrão" (Nunes).

$\mathrm{Na}$ fala anterior vemos que a competição entre grupos de trabalho não é algo recente, mas algo que foi se alterando ao longo do tempo. Se antes havia a troca entre aumento do ritmo de 
trabalho por mais tempo livre, hoje a troca é entre aumento do ritmo de trabalho por um prêmio. No relato de Nunes também observamos que a introdução das células significou uma redução da hierarquia na Empresa e a conseqüente redução de custo com salários ${ }^{20}$. Entretanto, entendo que, além destes, há mais um fator relevante não comentado pelos dirigentes: aquele que passa à função de monitor não é também um trabalhador? Portanto, um monitor é alguém que conhece profundamente os outros trabalhadores e as estratégias empregadas para driblar as normas de tempo da Empresa, entre tantas outras.

Finalmente, devemos observar, baseados nos conceitos de Durant (2004), que a probabilidade de conseguir a manutenção do fluxo contínuo de trabalho passa a ser resultado de uma ação muito mais coletiva do que individual. Entretanto, essa eficácia suplementar, fruto do trabalho coletivo, não é paga aos trabalhadores. E mais do que isso, se retomamos a discussão da PLR, a flexibilidade da remuneração combinada a outras mudanças, como a flexibilização do tempo de trabalho, possibilita à Empresa remunerar apenas os tempos "produtores de valor" (idem).

\subsection{3 - Jornada de trabalho: redução, flexibilização e intensificação}

De acordo com os dirigentes dos metalúrgicos do $\mathrm{ABC}^{21}$, ao final do Acordo da Câmara Setorial "ficou mais difícil para o Sindicato dar uma resposta mais abrangente e direta para a questão do desemprego, então a atitude foi incluir na campanha de 1996, o item sobre a redução da jornada de trabalho sem redução de salário". Assim, neste mesmo ano, no acordo com o SINFAVEA ${ }^{22}$, ficou prevista a redução da jornada de trabalho para 43 horas semanais, em 1996, e 42, em 1997, vinculada à sua flexibilização, via banco de horas ${ }^{23}$. Em relação à remuneração, esta foi mantida, além da incorporação do valor referente ao Descanso Semanal Remunerado.

20. Nunes ressalta que o monitor é um trabalhador horista e ganha apenas um adicional de função de 7\%, mas realiza um serviço que no passado era do encarregado que, por sua vez, ganhava um salário bem mais alto do que o monitor. Além disso, hoje "O monitor ocupa o lugar [do trabalhador], coisa que o encarregado não fazia antigamente...".

21. Entrevistas realizadas pela autora no ano de 1997, para a realização do mestrado (Cardoso, 1998a).

22. Nesta negociação o SINFAVEA - Sindicato dos Fabricantes de Veículos Automotores - representava apenas as Empresas que estavam presentes na negociação e não o conjunto filiado ao Sindicato, sendo que as Empresas que estavam ausentes não assinaram o acordo de redução, aliás, nem mesmo as plantas que estavam representadas não assinaram o acordo, assim, a redução passou a valer para a Volkswagen Anchieta e Taubaté, mas não para Resende ou São Carlos.

23. Na Volkswagen, a jornada poderia variar entre 36 e 44 horas. As horas trabalhadas acima de 42 e até 44 horas (horistas) e acima de 40 e até 44 horas (mensalistas), passariam a ser lançadas no banco de horas. Já as horas trabalhadas acima de 44 horas semanais continuariam a ser pagas como extra. Da mesma forma, as horas trabalhadas entre 36 e 42 horas, para os horistas e 36 até 40, para os mensalistas, também iriam para o banco de horas, como horas devedoras. 
De acordo com um dos negociadores patronais deste período ${ }^{24}$, na Volkswagen a demanda sindical era apenas para a redução da jornada, entretanto, "como forma de barganha nós acabamos aceitando a redução da jornada de trabalho, nós setor Empresarial, desde que houvesse a possibilidade de uma flexibilização, e essa foi traduzida depois num sistema de banco de horas".

Após essa negociação, os dirigentes sindicais relatam que não houve equilíbrio na administração do banco de horas, porque, na maior parte das vezes, era a Empresa que definia o tempo de trabalho, a mais e a menos. Os trabalhadores tiveram muita dificuldade para utilizálo, gerando muito descontentamento. Nunes entende ainda que se o banco de horas "funcionasse de forma equilibrada, poderia ser muito interessante para os trabalhadores que, no lugar de pegar um atestado médico poderiam, quando necessitassem, pegar um banco de horas". Relata que os trabalhadores também ficaram incomodados com a manutenção da lógica que existia por parte de muitas gerências, de sempre demandarem a hora extra para os mesmos trabalhadores. E neste caso,

\footnotetext{
"Aquela pessoa que devia [banco de horas], vê aquele cara que não devia, que tinha saldo [positivo], e a chefia sempre chamava ele para fazer hora extra, ao invés dele chamar aquele que devia, para pagar banco de horas. Aqueles que a gente chama lá de peixinho, que ficava dentro do aquário, então gera ciúmes, gera conflito entre os trabalhadores" (Nunes).
}

Para melhor entender a aceitação do banco de horas pelos trabalhadores, é importante compreender a relação entre este e a hora extra, uma das formas mais antigas de flexibilização do tempo de trabalho. No caso da hora extra a troca se dá entre mais tempo de trabalho por maior remuneração, já com o banco de horas a troca é entre mais tempo de trabalho, em um momento, por mais tempo de não trabalho, em outro. Assim, há duas grandes questões em jogo: o fim da possibilidade de aumento individual da remuneração e a determinação de quem define o tempo de trabalho e de não trabalho, isto é, o controle sobre o tempo.

Todos os dirigentes entrevistados foram unânimes em dizer que a hora extra era muito comum na Volkswagen até o final dos anos 90, quando a Empresa começou a criar uma política de controle e eliminação desta. E frisam que em alguns setores os trabalhadores sempre fizeram mais horas extras, como a manutenção ou a ferramentaria, por exemplo, lembrando que são nestes setores da produção, em que os salários são mais altos, que os trabalhadores mais recla-

24. Conforme já visto na nota 8 , do capítulo 2 , estas entrevistas foram realizadas pela autora em 2000, abrangendo representantes do setor industrial, como a Volkswagen, a Scania, a Mahle Metal Leve e a Basf; do setor do comércio através do Carrefour e da Federação Brasileira do Bancos - FEBRABAN. 
maram quando da implantação do banco de horas. Para Edgar, que trabalhava na ferramentaria, neste setor os trabalhadores fazem muita hora extra por hábito.

“Porque é um hábito e não é todo mundo, mas quem faz, é um hábito, vira um hábito, a pessoa fazer. Faz mesmo para ter propriedades, ter veículos. [...] Acho que muito ali, acho que ele entende que ele dando um bem estar para a família, dando carro para o filho, dando uma casa boa, ter casa na praia, mesmo que ele não desfrute, então ele fazendo o pé de meia. Porque quando ele sair da Empresa, ele esteja tranqüilo...” (Edgar).

O mesmo acontecendo com a área de manutenção, que abrange 15 a 20\% dos horistas,

“... e quando veio essa coisa de banco de horas foi a área que mais chiou porque o pessoal não queria trocar tempo de trabalho por tempo de descanso depois. Trabalho agora e depois descansa. Não, trabalhou e quer receber a hora cheia e ai o banco de horas desse pessoal em pouco tempo explodiu, chegou a ter pessoas, em pouco tempo, com mil horas extras no banco e ai acabava sendo um instrumento de pressão para romper o acordo e receber as horas extras. ["']. O pessoal poderia se fosse gozar aquelas horas tirar 2 meses de férias e viajar. Mas essa cultura mesmo de trabalho $\mathrm{X}$ dinheiro, o próprio sistema estimula isso, então faz com que, muita vezes, uma boa parte dos trabalhadores não valorize o tempo de descanso ..." (Beto).

Se existem grupos de trabalhadores que fazem horas extras, temos também aqueles que gostam menos de fazê-las, como é relatado por Nunes. "O pessoal mais jovem, normalmente foge um pouco da hora extra, não todos, mas não deixa de fazer, todos fazem, porque é algo extra que você assumir”. O que ocorreu a partir de meados dos anos 1990 é que ao Sindicato, há muito tempo, interessava ter alguma forma de controle da hora extra, eliminando ou ao menos limitando a sua realização. Ao mesmo tempo a Empresa começa a ter um discurso de redução da hora extra, para a redução de custo, vinculada à flexibilização do tempo de trabalho, como vemos na fala de Mendes:

“...coincidiu 2 interesses tá certo? O nosso era fazer o controle das horas extras certo? O interesse da Empresa era a questão da flexibilidade da jornada, então houve toda uma construção que terminou virando nesse monstrinho que é hoje o sistema de banco de horas, que na verdade não tem controle de horas extras nenhum né? (...) nos próprios, enquanto sindicalistas, enquanto dirigentes, não tem controle absolutamente nenhum, nenhum, nenhum, quer dizer o controle continua sendo da fábrica , e ela faz o que quer e o que bem entende ..." (Mendes ). 
Do ponto de vista da Empresa, o antigo gerente de relações trabalhistas, observa que as vantagens da implementação do banco de horas foram muitas, a começar por uma redução de custo, na medida em que a empresa praticamente não paga mais horas extras. Além disso, salienta que o banco não permite mais que os chefes de produção escondam "más administrações", pois antes se houvesse "algum problema durante a semana aí ele escalonava o pessoal para fazer hora extra no sábado e isso [o problema] ficava mascarado". Além disso, o banco também contribui para "que a Empresa não perca bons profissionais treinados", pois em momentos de queda da produção não há a necessidade de demitir um trabalhador em que a Empresa já tenha investido em treinamento. Com isso, também há uma redução do “custo indenizatório", já que menos pessoas são demitidas. Permite ainda uma "flexibilidade entre as áreas da companhia" que depende da demanda por um ou outro produto (antigo gerente de relações trabalhistas). Tais argumentos também podem ser verificados nas falas de representantes empresariais de outros setores, principalmente, no que eles chamam de "efeito colateral" do banco de horas, que é a redução drástica da necessidade de horas extras, em função da explicitação dos problemas e, conseqüentemente, de uma forte redução de custos.

Em 1997, num contexto de queda nas vendas da Volkswagen na ordem de $40 \%$ e perda de faturamento, 6.500 trabalhadores foram ameaçados pela Empresa de perderem o emprego na planta do ABC (Barbosa, 2002). Além disso, a Empresa demanda uma outra forma de flexibilização do tempo de trabalho com a implementação do "banco de dias". A lógica deste instrumento de flexibilização era o trabalhador deixar de trabalhar alguns dias em que não havia condições técnicas da Empresa produzir e depois compensar estes dias, na relação de um dia não trabalhado, um dia a ser trabalhado. Após a negociação, o acordo resultou, além da introdução do "banco de dias": na garantia de emprego durante um ano; no compromisso da Empresa em produzir o Novo Pólo na planta do ABC; e na abertura do Programa de Demissão Voluntária, abrangendo 3.600 trabalhadores (a maioria deles aposentados).

O "banco de dias" não foi aplicado em todos os setores da Empresa, mas principalmente naqueles onde estavam ocorrendo mudanças na produção, como em toda a cadeia da Kombi e no momento da implementação da linha do Pólo. O que, de acordo com os dirigentes, acabou gerando uma quantidade de horas negativas muito grande para os trabalhadores e, conseqüentemente, um forte foco de descontentamento e reivindicação por parte dos desses. Por isso mesmo, o Sindicato conseguiu que a Empresa desconsiderasse essas horas, já que as faltas não foram por culpa ou desejo dos trabalhadores, mas sim por necessidade da Empresa. Mas como veremos nas falas dos 
trabalhadores, no capítulo 6, muitos não sabem que este acordo "caducou" e ainda reclamam da grande quantidade de horas negativas que têm em função deste banco.

\subsubsection{1 - Flexibilização do tempo de trabalho, via "semana Volkswagen"}

O acordo fechado, no final de 1998, também aconteceu num período de crise financeira da Empresa, causada pela deterioração da sua posição em função da queda de vendas iniciada em outubro do ano anterior ${ }^{25}$, além do avanço da Fiat e da GM sobre uma parte do mercado ocupada pela Volkswagen, conforme Barbosa (2002). Neste contexto, segundo a Empresa, o banco de horas e o "banco de dias" deixam de ser suficientes para contornar a queda das vendas, sendo o modelo da "jornada alemã", também chamada como "semana Volkswagen" ou "semana de 4 dias", apresentado como a solução possível.

Esta forma de flexibilização do tempo de trabalho já havia sido implantada pela Volkswagen na Alemanha, no final do ano de 1993, quando a Empresa anunciou a demissão de 30.000 trabalhadores. Neste caso, a proposta da Empresa era de reduzir a jornada de trabalho de $36 \mathrm{~h}$ para 28,8h, sendo 7,2 horas de segunda a quinta e, na mesma proporção, os salários ${ }^{26}$. No Brasil, a Volkswagen também propõe a adoção da "semana Volkswagen", permitindo assim a flexibilidade da jornada entre quatro e cinco dias da semana ${ }^{27}$, com redução dos salários em $20 \%$, nos moldes do acordo realizado na Alemanha. Esta proposta foi recusada pelos trabalhadores

25. De um patamar superior a 50 mil unidades produzidas e vendidas antes da crise, a Volkswagen sofre queda superior a $25 \%$ nos meses seguintes. O nível de veículos por empregado desce de 22 para 17,5 entre outubro/ 97 e abril/98.

26. Ao final deste processo de negociação, foi fechado um acordo com validade de 2 anos. Com a semana de 4 dias, podendo a jornada de trabalho variar entre 28,8 e 35 horas, sendo as horas extras compensadas por repouso e não mais remuneradas. A remuneração mensal foi mantida e a anual bruta foi reduzida em $16 \%$ (Thoemmes e Labit, 1995). Em 1995, este acordo foi renovado, tendo a Volkswagen demandado que o sábado passasse a ser um dia de trabalho normal e que houvesse o aumento da jornada de trabalho em 3 horas mensais, em função da supressão de uma parte das pausas, levando a outra forte mobilização por parte dos trabalhadores até a Empresa desistir dessas ações. No acordo final, foi definida a jornada de trabalho de 30 horas semanais, no lugar das 28,8 horas, bem como a possibilidade desta variar entre 18,8 horas e 38,8. E o sábado, apesar de não passar a ser um dia normal de trabalho, teve o seu adicional reduzido de 50 para 30\% (Thoemmes, 2001). Vale ressaltar, ainda, que na Volkswagen da Alemanha, a jornada de trabalho era de 40 horas em 1978 e após 3 grandes mobilizações dos trabalhadores - em 1984, 1987 e 1990, a jornada de trabalho chegou a 36 horas. Em 1995, no contexto da rediscussão da adoção da semana Volkswagen, a jornada foi reduzida de 36 para 35 horas (Thoemmes e Labit, 1995). Desde a negociação de 1984 que a Empresa conseguiu incluir a flexibilização do tempo de trabalho, podendo a jornada variar entre 37 e 40 horas. Conforme a jornada de trabalho foi reduzindo, o mesmo foi acontecendo com os limites de variação desta (idem).

27. Para melhor entendermos a relação entre o banco de horas e a semana Volkswagen, com estes dois acordos o trabalhador poderia trabalhar uma semana de 4 dias, isto é, 32 horas (semana Volkswagen), ou 5 dias, somando 40 horas semanais. Neste último caso, isto é, na semana cheia, a jornada de trabalho poderia ser entre 36 e 42 horas, aplicando-se assim o banco de horas. 
em assembléia, iniciando-se um novo processo de negociação que resultou em um acordo fechado entre a Volkswagen e Sindicatos do ABC e Taubaté, com vigência até julho de 2000, estabelecendo: a) jornada reduzida "semana Volkswagen"; b) redução da jornada efetiva semanal de 42 para 40 horas; c) desligamento de funcionários já aposentados ou que se aposentem; d) manutenção de um programa de demissões voluntárias nos próximos cinco anos; e e) sinalização, mas não garantia, de novos investimentos para as fábricas do $\mathrm{ABC}$ e Taubaté.

No relato de Beto vemos que uma parcela dos trabalhadores achou interessante a oportunidade de trabalhar por 4 dias e folgar 3, mas que, por outro lado, houve muita pressão para voltar a trabalhar a semana cheia, porque apesar de não ter havido a redução da remuneração mensal, havia uma redução de $15 \%$ na PLR. Pergunto se em algum momento houve a sensação dos trabalhadores de que teria ocorrido uma intensificação do trabalho, no sentido de produzir em quatro dias o que seria normalmente feito em cinco. A esta questão Edgar responde que a oposição bateu muito neste ponto, "o cara tá trabalhando o dobro". Mas considera que isso a Empresa não poderia ter feito, já que o Sindicato tem o conhecimento e o acompanhamento da produção, "Por que, porque quem controla a velocidade da linha somos nós, e a produção a gente conhece a gente sabe o quanto é produzido..., a gente sabe quanto sai no final da linha durante os 4 dias e quanto sai em 5 dias".

Por outro lado, Edgar explicita em seu relato que este "acordo era muito difícil de ser administrado", e que o fato dos trabalhadores aceitarem a "semana Volkswagen" pode estar muito mais relacionado ao receio de perder o emprego, do que ao desejo de ter mais tempo livre e redução na remuneração. É isto que veremos de forma mais explícita nos anos de 2000 e 2001.

\subsubsection{2 - A explicitação do descontentamento}

Em 2000, no momento da renovação do acordo, a continuidade do banco de horas e da "semana Volkswagen" foi rejeitada por $40 \%$ dos trabalhadores, em assembléia, o que evidencia o descontentamento em relação a essas duas formas de flexibilização do tempo de trabalho. A conseqüência disso podemos ver na fala de Mendes:

\footnotetext{
"Sem esses 2 acordos a fábrica começou a fazer uma política de pressão, então assim ela iniciou, nós já estávamos adentrando a campanha salarial e ela começou uma política que a gente denominou de política de terrorismo. Era, juntava lá de 20 a 30 trabalhadores apresentavam lá uma transparência tá certo, explicando a disputa de mercado no setor automobilístico de que a Fiat com menos gente produz mais, que a GM com menos gente produz mais e que não sei que lá,
} 
a produtividade lá é não sei quantos carro ano/homem e assim ia. Que a necessidade da Volkswagen, as alternativas que tem redução de salário, demissão de 3000 trabalhadores e tal, e tal e tal, e foi na peãozada." (Mendes).

Sem a renovação do acordo, em 2001, mais uma vez a Volkswagen anuncia a existência de trabalhadores "excedentes" - 3.000 trabalhadores. Isso força a abertura de um novo processo de negociação, que tem como objetivo retomar os acordos de flexibilização da jornada e introduzir um sistema de rotatividade de pessoal em torno de 5\% ao mês (Barbosa, 2002). Em novembro de 2001, a Volkswagen prometeu investir R\$ 1 bilhão, mas condicionou o investimento à redução de $15 \%$ na jornada e salários dos trabalhadores. Em seguida a este anúncio, os trabalhadores aprovaram a abertura das negociações informando que estavam dispostos a negociar se a Volkswagen: a) apontasse para uma melhoria no mecanismo de recomposição do salário (para o caso da "semana Volkswagen"; b) se comprometesse com novos investimentos nas plantas do ABC e Taubaté e c) garantisse o emprego por cinco anos. Neste momento vemos claramente como a flexibilização do tempo de trabalho foi utilizada como moeda de troca para o alcance de objetivos que os trabalhadores julgavam muito mais importantes, isto é, a garantia de emprego, com a possibilitada de produção de um novo modelo. Mas sem esquecer a questão da remuneração, pois outro prérequisito seria repensar a forma de recomposição do salário (antes 15\% da PLR anual) em função da "semana Volkswagen".

Três fatores são apontados por Beto, em seu relato, para a recusa dos trabalhadores em renovar estes acordos de flexibilização da jornada de trabalho: a "cultura" do trabalhador que prefere trabalhar mais para ganhar mais; a oposição sindical enfatizar a questão da perda da renda em função do acordo; e, finalmente, o contexto de melhora da economia. De acordo com o dirigente, esta melhora da conjuntura gerou certa segurança nos trabalhadores em relação ao futuro, o que neste caso significava a não necessidade de abrir mão da remuneração, seja via redução do pagamento da hora extra, com o banco de horas, ou da PLR, com a semana Volkswagen.

\footnotetext{
"Tem a ver com essa coisa que a gente falava: trabalho mais para ganhar mais. Então na medida em que tanto o banco de horas como a semana de 4 dias limitava essa possibilidade e, de outro lado, um discurso permanente da oposição procurando mostrar isso como uma coisa negativa, que reduzia, que os trabalhadores estariam perdendo renda, enfim. ... Depois da crise de 97, 98 e mesmo da crise de 2000, começo de 2001, superada, houve uma retomada da produção, semana
} 
de 5 dias, o pessoal trabalhando em semana cheia, enfim, então essa certa, uma segurança de que agora a coisa estava bem e que agora não precisava mais disso..." (Beto).

A estes três fatores podemos incluir a dificuldade dos trabalhadores, sobretudo aqueles da produção, em utilizar o banco de horas de acordo com suas necessidades. Marcos resume bem a situação ao dizer que todos os mecanismos de flexibilização do tempo de trabalho foram implantados em momentos de "...faca no pescoço, ou faz isso ou tem o pior, que é demissão. Então acabou tendo que fazer. Então, momentaneamente o pessoal ficava com aquilo lá e tinha que engolir aquilo lá, mas no decorrer do tempo começaram: isso aqui não serve".

Para o gerente de recursos humanos, os trabalhadores rejeitaram renovar o acordo porque esqueceram dos problemas que a Empresa já havia passado.

É uma característica, me parece, do nosso jeito de ser como brasileiro: nós temos a memória curta e lembramos da dificuldade quando nós estamos passando por ela, depois nós esquecemos. As pessoas lamentaram, elas reclamaram do acordo da semana Volkswagen pelo lado amargo dele, e no momento da decisão, eles tinham como prioridade se livrar daquela questão amarga e não pensaram que o amargo trazia como remédio. O que é ruim do ponto de vista da composição de uma história, de você gerar credibilidade naqueles que vão decidir sobre o negócio, que vão entender que as decisões vão ser sempre circunstanciais e não por uma lógica, por um conceito, não é. Mas foi o que aconteceu, eles não aceitaram, apesar de nós alertarmos da segurança que aquilo poderia trazer, e depois diante de uma nova crise eles se reposicionaram, com muito sacrifício com muita dificuldade, mas se reposicionaram. Acho que falta na gente isso: essa estabilidade, essa maior firmeza de propósito. (gerente de $\mathrm{RH}$ )

Quando o gerente fala que após "uma nova crise os trabalhadores se reposicionaram", ele esta se referindo à resposta que a Empresa deu a recusa dos trabalhadores, como vimos, ao anunciar a demissão de cerca de 3000 trabalhadores. Assim, após um longo processo de negociação, envolvendo a matriz na Alemanha bem como o Comitê Internacional de Trabalhadores na Volkswagen, o acordo fechado garantiu: a) reversão das demissões; b) abertura de outro programa de demissão voluntária; c) mudanças na recomposição salarial dado a "semana Volkswagen", abrangendo 1/3 do reajuste da data-base e parte da PLR; d) criação de nova tabela salarial para os novos trabalhadores; e) aumento no transporte; f) retomada do banco de horas e g) terceirização de duas áreas - embalagens e montagem de peça, com cerca de 900 trabalhadores com o aproveitamento em outros setores. No ano seguinte, foi conquistada a garantia de emprego, por dois anos, prorrogável por mais dois anos, isto é, até 2006. 
Em 2003, houve a negociação da convenção coletiva limitando a realização da hora extra, tendo sido negociada no âmbito da Federação Estadual dos Metalúrgicos da CUT. Neste contexto, como os trabalhadores tinham garantido o emprego até 2006, a estratégia da Empresa foi terceirizar alguns setores e paralelamente abrir novos planos de demissão voluntária, além da criação do projeto Autovisão ${ }^{28}$. Assim, a partir desse momento, a negociação passou a ser não mais entre a garantia de emprego e a flexibilização do tempo de trabalho, mas entre a produção de novos veículos e a dispensa dos trabalhadores via PDV's, buscando assim dar continuidade à redução desta planta, mesmo com a garantia de emprego.

Entre meados de 2002 e inicio de 2003, por exemplo, houve uma extensa negociação entre a Empresa e os trabalhadores, pois esta vinculada à produção do novo projeto, o VW 249 Tupi (Fox), à terceirização de alguns setores - como a logística e a ala 21. Em meados de junho de 2003, num contexto de queda nas vendas na ordem de 15,6\% a Empresa anuncia mais um corte, desta vez seriam de 3933 vagas, sendo 1923 na planta do ABC e 2010 em Taubaté. E como havia o acordo de estabilidade, a Volkswagen propõe a transferência destes trabalhadores, denominados como "excedentes" para a Autovisão (Diário do Grande ABC, 22/6/2003) e a abertura de outro PDV com 15 salários extras, sendo recusada a proposta na assembléia dos trabalhadores (Diário São Paulo, 16/09/2003). Após mais um processo de negociação, com a ida dos dirigentes à Alemanha para conhecer o projeto Autovisão, o acordo previa a possibilidade dos trabalhadores escolherem entre aderir ao $\mathrm{PDV}^{29}$, ir para o projeto Autovisão, onde permaneceriam recendo salários até 2006, ou ficar em casa até o fim do acordo. (Valor Econômico, 10/03/2004).

Em 2004 a questão da hora extra volta à pauta, pois a Volkswagen queria ampliar o limite da hora extra, negociado em 2003, em função do aumento da produção. Os trabalhadores aceitaram essa ampliação e, em troca, conquistaram o aumento do adicional de hora extra. Neste ano, enquanto a Volkswagen na Alemanha anunciava um plano para demitir 5 mil trabalhadores no mundo todo, tendo como objetivo a redução de custos na ordem de 2 bilhões, até 2005 (Valor Econômico, 10/03/2004), no Brasil, a Empresa registrava um volume recorde de produção, foram 682.912 unidades no ano de 2004, passando a deter $31 \%$ da produção nacional (Diário do Grande ABC, 03/05/2005).

28. O projeto Autovisão engloba uma empresa especializada na recolocação de trabalhadores no mercado de trabalho e também o CFE - Centro de Formação e Estudos, como nos moldes da empresa criada na Alemanha, pela Volkswagen.

29. Aberto para toda a fábrica e composto por 20 salários adicionais, mais $40 \%$ do salário por ano de trabalho e não mais a proposta da Empresa de 15 salários. 
Além dessas novas negociações, e apesar dos trabalhadores terem aceitado retomar a flexibilização do tempo de trabalho, em 2001, podemos observar, pela fala de Gerson que na "semana Volkswagen" o trabalhador ainda reclamava da redução da PLR e que também ainda havia problemas na administração do banco de horas: "Mesmo hoje o trabalhador quando ele necessita do banco de horas, a Empresa não quer conceder”. E que a área produtiva é onde há o maior problema para administrar o banco, principalmente "com a falta de pessoas que nós temos hoje”, (2005). Mas que, por outro lado, quando o trabalhador “...começa a pensar que está ruim, ele lembra na estabilidade que ele tem". Hoje o trabalhador entende melhor que estes acordos de flexibilidade do tempo de trabalho foram "... meios que se achou para manter o nível de emprego". Nunes também diz que no setor da estamparia os trabalhadores continuam a ter problemas para utilizar o banco de horas quando necessitam "O trabalhador ele não gosta porque, ele não pode usar quando ele quer (...) Porque por estar muito enxuta a produção, um trabalhador que falta, outro que está de férias, outro que por algum motivo está fazendo um curso, já sacrifica os demais".

É por este motivo que os trabalhadores, no início de agosto de 2005, fizeram várias assembléias para discutir os problemas do banco de horas, principalmente porque a Empresa estava chamando para "pagar" o banco de horas ${ }^{30}$ em um sábado após o feriado na sexta feira, gerando forte descontentamento por parte dos trabalhadores. De acordo com Rogério, a proposta do Sindicato era que apenas os trabalhadores que estivessem devendo banco de horas fossem trabalhar "Porque a produção não roda só com esse pessoal que está devendo, porque é uma minoria". Outras mobilizações ocorreram a partir de maio de 2005 tendo como reivindicação principal a contratação de 350 trabalhadores, em função do aumento da sobrecarga e do ritmo de trabalho em diversas áreas. Esta foi uma disputa muito forte, pois desde o começo a Volkswagen deixou claro que não iria contratar novos trabalhadores, mas sim transferir alguns de setor, resolvendo assim os problemas que ela definiu como pontuais ${ }^{31}$. Ao final, não houve nenhuma contratação na planta do $\mathrm{ABC}^{32}$.

30. Quando a Volkswagen chama individualmente o trabalhador que deve banco de horas, ele pode se recusar a ir na primeira convocação, mas na segunda ele não tem opção, senão há desconto no salário.

31. Após 2 meses com diversas paralisações pontuais, a Empresa distribuiu cartas de advertência para os trabalhadores e transferiu alguns para a manutenção da Ala 1 e para a montagem final. Em seguida, como os trabalhadores decidiram não aceitar a transferência, a Volkswagen enviou cartas de advertência para os trabalhadores que não aceitaram a transferência de setor. Além disso, alguns diretores do Sindicato foram suspensos entre 1 e 30 dias.

32. Ainda no ano de 2005 foi aberto outro PDV, desta vez direcionado para os 600 trabalhadores do projeto Autovisão, já previsto no acordo de 2003 (Diário do Grande ABC, 31/05/2005). 


\subsubsection{3- Fim da estabilidade no emprego e manutenção da flexibilização do tempo de trabalho}

A última negociação coletiva ocorreu no ano de 2006, quando, mais uma vez, a Empresa iniciou este processo anunciando a demissão de aproximadamente 6000 trabalhadores nas plantas do ABC, Taubaté e Curitiba. Estas demissões ocorreriam a partir de novembro de 2006 - com o fim da vigência de aplicação do acordo de estabilidade no emprego e de flexibilidade do tempo de trabalho -, estendendo-se até 2008. Recorde-se que já em 2005, no momento em que realizei a entrevista com o gerente de negociações trabalhistas, ele frisou que não havia nenhuma possibilidade de renovação do acordo de estabilidade no emprego, "Pra mim, garantia de emprego se dá pela viabilidade do negócio e não por decreto". Mas, por outro lado, ele entende que deveria ser negociado um banco de horas "mais flexível", no sentido de "trabalhar mais com a folga e não com adicional, como é o nosso caso (...). Esse me parece o melhor caminho".

Além das demissões a Empresa anunciou mudanças na remuneração e no tempo de trabalho. No que se refere a este último tópico, a Empresa propôs alterações no banco de horas de forma que as horas trabalhadas a mais, até 200 horas, seriam creditadas no banco sem nenhum adicional; as horas trabalhadas entre 201 e 400, também seriam creditadas no banco de horas e os trabalhadores receberiam o adicional de 50\%; e acima de 400 horas, estas seriam pagas como hora extra, no balanço anual do banco. A Empresa propôs ainda a eliminação das pausas na área da pintura, do tempo livre dos representantes da CIPA e a extensão da organização do tempo de trabalho da produção do Pólo para as outras áreas ${ }^{33}$.

Também apresentou o conceito de "retrabalho por falta de qualidade". Isto é, no caso de haver a necessidade de retrabalho em função da falta de qualidade, o trabalhador "responsável pelo erro" deveria trabalhar por mais 2 horas para a execução do retrabalho, mas sem receber por estas horas trabalhadas. Isso evidentemente significaria, para o trabalhador, o aumento do tempo de trabalho em duas horas diárias sem o respectivo aumento da sua remuneração ${ }^{34}$, ou seja, trabalho não remunerado.

33. Esta jornada é composta por uma folga fixa aos domingos e outra alternada na semana, de forma que apenas a cada 42 dias o trabalhador consegue folgar sábado e domingo seguidamente.

34. O plano de reestruturação completo proposto pela Empresa aos representantes dos trabalhadores compõe-se de: Redução do efetivo: desligamento de funcionários entre 2006 e 2008 (um total de 5.773, sendo 3.672 na Anchieta, 1.401 na planta de São José dos Pinhais e 700 em Taubaté); possibilidade de negociação de incentivos; concessão de 3 meses de plano médico; verbas rescisórias;

Conceito de retrabalho: permanência do empregado em caso de falta de qualidade; extensão obrigatória da jornada diária em $2 \mathrm{~h}$, limitadas a $8 \mathrm{~h}$, em caso de falta de qualidade; crédito para horas do banco somente para os não geradores do retrabalho; 
Então, mais uma vez, este processo de negociação foi iniciado pela ameaça da Empresa em demitir os trabalhadores, além do discurso de que iria fechar a planta do $\mathrm{ABC}$, tendo a Empresa, no final de agosto, entregue 1.800 cartas de demissão. Em assembléia, os trabalhadores decidem entrar em greve por tempo indeterminado. E após mais de 4 meses de negociação, com mobilizações e greves, chegou-se a um acordo coletivo. Neste, ficou previsto um plano de demissão voluntária ${ }^{35}$ para atingir 3.100 trabalhadores até 2008 , com mudanças no banco de horas, além de outras no que se refere às questões salariais. Por outro lado, como moeda de troca, fez parte deste acordo a definição sobre a produção de dois novos modelos na fábrica do $\mathrm{ABC}$.

Finalmente, além da Empresa já ter manifestado explicitamente o desejo de ter um banco de horas mais flexível, o gerente de negociações trabalhistas também aponta para essa possibilidade ao dizer que na Volkswagen, em Curitiba, há horários móveis para as atividades administrativas, como, por exemplo, um "horário recheio" em que todos os trabalhadores devem estar na Empresa, sendo a entrada e a saída, porém, definidas pelos próprios trabalhadores. E que "viu" nos jornais que a Volkswagen, na Alemanha, pensa em "colocar três dias funcionando dez horas e flexibilizar quinta e sexta, trabalhando três dias e com dois dias não trabalhados", e que a Empresa estaria funcionando 7 dias por semana. Para o Brasil "pra frente, teria alguma tendência de funcionar 24 horas por dia", futuramente. Mas para isso, ressalta que:

Plano médico: aumento da contribuição de 1\% para 3\%; fábrica mantém pagamento de 1/3 das consultas; Sistema de banco de horas: crédito até o limite de 200h, sem pagamento adicional; de $201 \mathrm{~h}$ até $400 \mathrm{~h}$, pagamento dos adicionais; acima de 400h, pagamento de horas extras; Introdução de Consórcio Modular: estabelecer acordo que permita implementar o conceito de consórcio modular, bem como a regulamentação das terceirizações;

Jornada: introdução de jornada 6X2 para as áreas de manutenção e retrabalho; possibilidade de estabelecimento da jornada Polo (fixa aos domingos, alternadas nos dias da semana);

Nova tabela salarial: $35 \%$ inferior a atual, inclusive no teto; empregados atuais não serão paradigmas para os novos; salário inicial conforme salário base da categoria;

Reajuste anual de salário: incorporação de $85 \%$ do INPC (15\% utilizado para pagamento de remuneração variável, condicionada à indicadores de resultado); não concessão de aumento real; regras válidas para 2006 e 2007;

PLR: adequação dos valores às práticas de mercado; estabelecimento de indicadores individuais, departamentais e da planta;

Novos conceitos: término da contratação compulsória de aprendizes; eliminação do tempo livre para cipeiros; transferência de 40 funcionários da área Pós-Venda para Vinhedo (DIEESE, 2006).

35. Este programa de desligamento prevê o adicional de 1,4 a 0,3 salários por ano de trabalho, a depender da data em que o trabalhador entre no plano. 
"Sem dúvida primeiro nós temos um grande obstáculo que é a legislação, nós precisamos de flexibilidades que garantam a fábrica funcionando 24 horas, sete dias por semana. Não estou falando que o trabalhador tem que trabalhar sete dias por semana, mas a fábrica operando dessa forma é uma necessidade da produção, para ocupar o máximo da capacidade instalada que é o que se faz no mundo. Nesse aspecto, a nossa legislação ainda é muito restritiva, e quando você faz, você faz de uma forma muito cara, mas sem dúvida esse é o ideal..., não compensa você instalar uma estamparia imaginando que você vai trabalhar somente cinco dias, você consegue reduzir o investimento trabalhando sete dias na semana, 24 horas por dia, isso seria o mais adequado" (atual gerente de negociações trabalhistas).

Neste caso, mudar a legislação está relacionado à demanda da Empresa em ter turnos ininterruptos de trabalho que não sejam caracterizados como tal, já que de acordo com a legislação, os turnos devem ter a duração de 6 horas, isto é, 36 horas por semana. Quando perguntado sobre a possibilidade de redução da jornada de trabalho, responde: "40 horas me parece um patamar adequado". De fato, conforme Veltz, (2000), há uma tendência ao funcionamento continuo dos sistemas e, quanto mais as Empresas se automatizam maior é o capital empregado e maior o interesse em fazer funcionar as máquinas 24 horas. Daí as exigências maiores em relação aos trabalhadores e também em relação aos fornecedores, de forma que há uma diversificação de horários, mas, ao mesmo tempo, um aumento do controle do tempo para que a fábrica funcione 24 horas ininterruptamente.

\section{5 - Considerações finais}

Neste capítulo, apresentei e discuti o contexto da Volkswagen do $\mathrm{ABC}$, tendo como objetivo compreender o local de trabalho em que os sujeitos entrevistados vivenciam cotidianamente seus tempos de trabalho. Para tal, estudei algumas mudanças ocorridas no tempo de trabalho e sua relação com as transformações mais amplas realizadas pela Empresa, tendo como foco principal o período entre os anos de 1995 e 2005.

Analisar a Volkswagen do ABC, aportou elementos para melhor compreender os inúmeros fatores que podem alterar o tempo de trabalho; assim, se num primeiro momento se poderia pensar que apenas as mudanças diretas na jornada de trabalho poderiam impactá-lo, a análise do caso evidencia que diversos outros elementos precisam também ser considerados. São muitas as mudanças que afetam o tempo de trabalho, algumas de forma mais ou menos explícita; mais ou 
menos direta; mais ou menos intensa. Algumas inovações são mais recentes, outras mais antigas; algumas foram objeto de negociação, outras não; algumas foram reivindicadas coletivamente, outras apenas no âmbito individual. Algumas, ainda, são de ordem política, outras tecnológicas, organizacionais ou administrativas, mas muitas tiveram forte impacto sobre o tempo de trabalho, no sentido da sua intensificação.

Este estudo contribuiu ainda para o entendimento dos processos de negociação coletiva em torno da temática do tempo de trabalho, levantando quais os temas passíveis de negociação e os que nem sequer são colocados em discussão pelo setor patronal, no Brasil. Também foi possível identificar os temas que constroem a pauta sindical; os que, embora presentes na ação do dia a dia, não conseguem se transformar em ponto de negociação coletiva com o setor patronal, e as questões que sequer chegam a ser cogitadas pelo movimento sindical. Esses elementos foram imprescindíveis tanto na compreenção das vivências temporais cotidianas dos trabalhadores que serão analisadas nos capítulos seguintes, como na percepção do processo de negociação em torno do tempo de trabalho no Brasil.

Há mudanças que têm impactos diretos e explícitos no tempo de trabalho e que, na maior parte das vezes, são objeto de demanda sindical por negociação: como a redução da jornada de trabalho, hora extra, pausas e flexibilização do tempo de trabalho. Há ainda mudanças que afetam o tempo de trabalho, mas de forma menos explícita e muito mais indireta. Estas, por sua vez, podem ser divididas em dois grupos: mudanças que não foram objeto de negociação coletiva, como a maior parte das mudanças tecnológicas e algumas organizacionais, entre elas a implantação do just in time, por exemplo. E mudanças que foram objeto de negociação, no qual, entretanto, a questão do tempo de trabalho não esteve presente. Vale dizer, o tema foi objeto de demanda sindical e de negociação coletiva, mas o foco não foi a questão do tempo de trabalho, como vimos, por exemplo, no caso do PCS ou das células de produção.

No caso estudado da Volkswagen do ABC é muito dificil definir a alteração que tenha afetado mais fortemente o tempo de trabalho e, consequentemente, as vivências dos outros tempos socias. Mas, observando os anos 1990, entendo que uma das mudanças mais importantes durante o processo de negociação coletiva foi a decisão da Volkswagen de reduzir o tamanho da planta do $\mathrm{ABC}$, ameaçando, inclusive, fechá-la. Essas alterações impactaram diretamente a negociação, o emprego e o tempo de trabalho; deixando alguns sem tempo a ser dedicado ao trabalho, no caso daqueles que saíram nos inúmeros planos de demissão voluntária, e outros com um tempo de trabalho totalmente flexibilizado e intensi- 
ficado, já que os trabalhadores aceitaram as mudanças propostas pela Empresa em troca da manutenção do emprego.

Mas isto não significa que o processo de mudanças no tempo de trabalho, bem como a disputa em torno dele tenham começado nesse momento, pois como pudemos observar, desde os anos 1980 há discussões dentro da Volkswagen em torno dessa temática. Assim, já a partir desse momento, paralelamente às reduções da jornada de trabalho pressionadas pelos trabalhadores e seus representantes, foram diversas as inovações adotadas pela empresa e que tiveram como objetivo, ou consequência, a intensificação do tempo de trabalho: a redução dos intervalos individuais e coletivos, as mudanças tecnológicas e organizacionais, como o just in time/ kanban ou a introdução de atividades de manutenção ou controle de qualidade ao longo da linha. Algumas mudanças implementadas alteraram o tempo- padrão da produção e, consequentemente, a relação do trabalhador com o seu tempo de trabalho e com seu tempo de não trabalho, dada a relação direta existente entre eles.

A ação por parte do movimento sindical dentro da Volkswagen, ao longo dos anos 80, buscou discutir algumas dessas mudanças e, sobretudo, reivindicar contrapartidas para o aumento de produtividade resultante dessas inovações. Entre essas contrapartidas estavam a redução da jornada de trabalho e a manutenção do emprego. Entretanto, vimos que poucas vezes o movimento sindical questionou a natureza em si das mudanças, focando muito mais nas suas consequências. Por outro lado, raras foram as vezes em que a Empresa aceitou que essas inovações fossem discutidas no espaço da negociação coletiva. Os casos da implantação das células de produção e do PCS são um dos poucos exemplos em que os trabalhadores e o Sindicato conseguiram forçar a Empresa a negociar uma mudança, inicialmente, implantada unilateralmente. Por outro lado, são exemplos também de negociação coletiva cujo foco não esteve na questão do tempo de trabalho, mas na questão dos monitores: quem seriam, a remuneração, a forma de eleição, o seu papel, entre outros pontos.

A partir de 1995 houve mudanças no processo de negociação dos temas relacionados ao tempo de trabalho, sendo que as alterações na jornada de trabalho, pretendidas pela Empresa, foram ficando cada vez mais explícitas e diretas. Isto porque, entre meados dos anos 1980 e 1990, observamos uma flexibilização não-declarada do tempo dedicado ao trabalho que não foi objeto de negociação. Uma flexibilização e intensificação resultando tanto do aprofundamento do processo de inovação tecnológica e organizacional como da utilização da legislação existente que em muito possibilitava a flexibilização do tempo de trabalho. Já no período entre 1995 e 
2005 vimos um forte processo de negociação em torno do tema do tempo de trabalho, o que incluiu discutir a redução da jornada de trabalho e sua flexibilização via, o banco de horas, o banco de dias e a "semana Volkswagen".

Neste momento, enquanto a Empresa buscava simultaneamente flexibilizar o tempo de trabalho e reduzir os gastos com a hora extra, a demanda do Sindicato era pela manutenção da planta do $\mathrm{ABC}$ - o que, do ponto de vista deste ator, significava a renovação da Empresa, a produção de novos produtos, a manutenção dos empregos e a redução da jornada de trabalho. Assim, já a partir de 1996, as negociações explicitam uma troca entre flexibilização e consequente redução de custos, por um lado e redução do tempo de trabalho, por outro. Já a partir do ano seguinte, a questão do emprego passa a ser o foco principal da negociação, assim como já fora observado por Thoemmes (2001) para o caso da Volkswagen na Alemanha. Os trabalhadores foram aceitando as flexibilizações como forma de garantir os seus empregos.

No entanto, em 2000, quando a situação econômica inicia um processo de recuperação que deixa os trabalhadores mais tranquilos em relação ao emprego, estes explicitam o descontentamento em relação a flexibilização do tempo de trabalho, que já se manifestava informalmente no cotidiano do trabalho. Sendo, então, rejeitada a renovação dos acordos de banco de horas e da "semana Volkswagen". Entretanto, quando a Empresa anuncia novas demissões, os trabalhadores retomam a negociação e acabam por aceitar a renovação do acordo, vinculada à manutenção do emprego. E esse precesso se repetirá até o ano de 2006, última negociação que acompanhei.

Assim, ao iniciar os processos de negociação coletiva a partir da ameaça de desemprego, a Empresa reforça e amplia a desigualdade entre as partes neste processo, possibilitando um resultado muito mais favorável aos seus interesses e objetivos. Entre eles a demissão de trabalhadores a baixo custo, o aumento do tempo de trabalho sem aumento da remuneração, a flexibilização do tempo de trabalho, bem como a redução dos salários dos trabalhadores. Se num primeiro momento os trabalhadores aceitaram tais reduções de direitos com vistas à conquista da garantia de emprego, isto não aconteceu na última negociação coletiva. Em 2006, além de não ser renovado o acordo de garantia de emprego, a Empresa manteve e ampliou ainda mais a flexibilização do tempo de trabalho, fatos que demonstram o desequilíbrio na correlação.

Para o futuro, a intenção explicitada pela Empresa é de funcionar 24 horas por dia, para o maior aproveitamento da sua capacidade instalada, com a total flexibilização do tempo de trabalho. Isto é, ter os trabalhadores com ampla disposição de tempo para Empresa, sem que isto 
signifique o pagamento de hora extra e muito menos a caracterização do trabalho como turnos de revezemanento. O que significa que a Volkswagen continuará a pressionar por mudanças na legislação que possibilitem a ampliação das regras de flexibilização do tempo de trabalho e também o trabalho em turnos.

Finalmente, vimos que nessa nova organização e gestão do trabalho, como explicita Durand (2004), a pressão em relação ao tempo permanece no coração da atividade do trabalho. Alguns autores falam ainda do trabalho na "urgência" e também no aumento do tempo "informal" dedicado ao trabalho graças aos "instrumentos nômades" como telefone, computador, fax, entre outros. Resta saber o que representam tais mudanças no âmbito das vivências temporais cotidianas, como veremos adiante. 


\section{VIVÊNCIAS DOS TEMPOS NO LOCAL DE TRABALHO}

este capítulo, tenho como objetivo analisar as narrativas discursivas dos trabalhadores da Volkswagen do ABC para buscar compreender como vivenciam cotidianamente o tempo de trabalho, no local de trabalho, e que representações criam a partir dessas vivências. A intenção é perceber como as situações do local de trabalho - artefatos tecnológicos, mudanças na organização do trabalho, na gestão das pessoas ou na jornada de trabalho - são vivenciadas e experimentadas cotidianamente pelos trabalhadores e quais desses elementos são por eles considerados como os principais definidores do tempo de trabalho. E retomando a discussão realizada por Grossin (1991), quais são as principais características do enquadramento do tempo de trabalho dentro da Volkswagen do ABC.

Veremos que os artefatos técnicos, como a linha de produção, as mudanças organizacionais, de gestão ou administrativas, em muito têm influenciado as vivências cotidianas dos trabalhadores no que se refere ao tempo de trabalho e de não trabalho. Tais mudanças podem ser divididas em dois grandes grupos, se temos como referência a vivência do tempo de trabalho: as mudanças ocorridas na organização do trabalho (mudanças organizacionais, usos e gestão de pessoal, mudanças administrativas) e mudanças diretas no tempo de trabalho. E nesses casos, mesmo que praticamente todos os trabalhadores tenham passado por várias dessas mudanças, os relatos explicitam vivências totalmente diferentes.

Assim, visando evidenciar as especificidades dos fatores na vivência dos trabalhadores e na construção de representações sobre o tempo de trabalho e de não trabalho, este capítulo foi organizado em cinco grandes blocos. No primeiro, analiso as narrativas discursivas sobre o tempo de trabalho daqueles trabalhadores que estão na linha de produção ou muito próximos dela, considerando que na análise das narrativas, o primeiro fato que saltou aos olhos foi a freqüência com que os trabalhadores sugerem que trabalhar mais ou menos próximo da linha de 
produção cria condições muito diferentes no que se refere às vivências do tempo, tanto no espaço da fábrica como fora desta.

Num segundo momento, o foco passa a ser as mudanças na organização e gestão do trabalho e seus impactos sobre o tempo de trabalho, assim definidas pelos trabalhadores tanto da linha como fora desta. Em seguida, analisarei como estes trabalhadores vivenciaram as diversas mudanças ocorridas diretamente no tempo de trabalho: a redução da pausas coletivas e individuais, a redução da jornada de trabalho, as antigas formas de flexibilização do tempo de trabalho, ou a hora extra, bem como a implantação de novas formas de flexibilização do tempo de trabalho como o banco de horas, o banco de dias e a "semana Volks". Além desses três grandes blocos, falarei ainda sobre os tempos dedicados ao trabalho, dentro do local de trabalho, mas que por ocorreram fora da jornada oficial, não são considerados como tempo de trabalho, não sendo, portanto, remunerados.

\section{1 - Sob o império da linha de produção: vivências dos tempos impostos no local de trabalho}

Mas o que significa, nos dias atuais e na Volkswagen do ABC, trabalhar em uma linha de produção? Quais os discursos que emergem desta vivência e quais representações do tempo de trabalho são construídas a partir delas?

Nas diversas conversas com os trabalhadores observei que muitos, ao serem perguntados sobre o seu tempo no local de trabalho, faziam referência à linha de produção. E esta aparecia de maneira muito forte mesmo quando o assunto não estava relacionado diretamente à jornada de trabalho, como pode ser visto na fala de Renato, sobre a constituição da Comissão de Fábrica, nos anos 80 .

\footnotetext{
"Quando implantaram a Comissão de Fábrica lá na Volkswagen, o Lula falou o seguinte: 'procura aqueles caras que não trabalham na linha para ser representante, porque eles vão ter tempo, como motorista, um conferente'. Até isso o cara pensou. Quando eu entrei lá, o cara tinha tirado 2 horas [redução da jornada de trabalho], aí foi mudando, os caras foram brigando e conseguiram". (Renato)
}

Nesta fala observamos que a questão central era pensar quais os trabalhadores que, no seu tempo de trabalho, poderiam ter um tempo livre para atuarem na Comissão de Fábrica; e neste caso, eram justamente os trabalhadores da linha os que exemplificavam a falta de tempo 
livre. Isto é, para os trabalhadores, o tempo de trabalho na linha significa um ritmo imposto que afeta tanto o ritmo de trabalho como, até mesmo, os intervalos. Um ritmo intenso, contínuo, repetitivo, minuciosamente controlado e, muitas vezes, causador de desconforto, dor e doença. E esse ritmo desconsidera ainda necessidades básicas dos trabalhadores, como beber água, ir ao banheiro, aliviar as dores, o cansaço, além da vontade de conversar com os outros trabalhadores ou ainda as diferentes disposições ao longo do dia. Joice, ao ser perguntada se há um momento do dia em que ela tenha mais ou menos energia para trabalhar, responde: “... não há muita opção quando você está na linha. [...] Você tem que estar ali, não pode diminuir porque a linha não diminui, então o ritmo é o mesmo, independente de você."

E dessa forma o tempo de trabalho na linha leva a uma vivência cotidiana muito forte, nova e que causa "susto", quando os trabalhadores têm que enfrentá-la pela primeira vez, como podemos ver não apenas nos discursos de trabalhadores que já foram da linha; mas também no discurso de trabalhadores que vieram do Senai; tanto nos que entraram há mais tempo na Empresa como naqueles contratados há menos tempo. Rogério, que veio do Senai e hoje está trabalhando na qualidade, relata que a sua entrada na Volkswagen foi muito "estranha". Além de começar a trabalhar em regime de turnos de revezamento, ele foi para a linha de montagem, do que decorre, no seu discurso, a necessidade de explicitar as estratégias individuais e coletivas que foi obrigado a construir para "suportar" a nova situação. Seja criando músicas ("650 câmbios por dia, monta mais um pouquinho") ou brincadeiras com os outros trabalhadores.

"Eu brincava comigo mesmo, montando, eu ficava estipulando desafios, coisa de louco né? Pensava: 'já que eu tenho que fazer, vamos tornar esse trabalho estimulante'. Então a gente estipulava o tempo de montagem para algumas outras operações e ficava imaginado: 'vamos ver se eu consigo trabalhar mais', aí o dia ia passando".(Rogério - qualidade)

Aldo, hoje na linha de montagem final, nos relata ainda o quanto o seu trabalho na linha, em meados dos anos 80, influenciou a sua vida fora da Empresa. Além de um trabalho intenso e repetitivo, frisa também que eram dois turnos diferentes, 15 dias de manhã e 15 à tarde.

\footnotetext{
"Nessa época a Volkswagen produzia 400, 500 carros por turma, então você não tinha tempo para conversar, não tinha tempo para tomar café, não tinha tempo para ir ao banheiro, não tinha tempo para nada, você saía dali arrasado. Chegava em casa, eu não vou falar que era estressado para não brigar, não, chegava cansado mesmo, não tinha mais ânimo para nada. Era chegar, tomar um banho, sentar no sofá, assistir televisão ali e acordar no outro dia para a mesma coisa". (Aldo linha de montagem final)
} 
Os dois últimos relatos nos possibilitam um paralelo bastante interessante com o contexto apresentado no filme "A Classe Operária vai ao Paraíso"1. Este filme relata o cotidiano de operários, dentro e fora da fábrica, vivendo as angústias e a dor do controle exercido numa linha de produção, bem como as estratégias criadas por eles para trabalhar mais rápido e aumentar sua produção e, ao mesmo tempo, para que o tempo passasse mais rápido, assim como apresentado por Rogério. Da mesma forma, a fala de Aldo, assim como o filme, explicita quanto o tempo de trabalho e todo desgaste ali vivido em nome da produção, podem influenciar o tempo de não trabalho. Tanto na ficção quanto na vida real, o resultado, ao fim da jornada de trabalho, acaba sendo o estresse, o desânimo, com interferência direta na saúde e nas vivências temporais cotidianas.

Mas apesar do trabalho na linha não considerar os sujeitos e suas necessidades, estes reclamam e buscam, formal ou informalmente, resolver os incômodos e sofrimentos causados por este tipo de trabalho. Isso obriga a Empresa a buscar cotidianamente respostas às reivindicações e pressões dos trabalhadores e de seus representantes. É por isso também que não podemos dizer que exista uma única vivência do tempo na linha de produção. Podemos perceber que além das diferenças resultantes da existência de diversas linhas, as falas dos trabalhadores explicitam ainda que cada um pode vivenciar o mesmo tempo de trabalho, em uma mesma linha, de maneiras totalmente diferentes. Se mais não fosse, como salientado por Grossin (1991), porque seus mundos não se restringem ao tempo presente, ao tempo de trabalho e ao tempo da linha, mas são bem mais amplos do que estes.

\subsection{1 - As vivências nas diferentes linhas}

A experiência do trabalho imposto pela linha de produção muda na mesma medida em que mudam as características da linha. Essas diferenças podem ser percebidas mais objetivamente, quando analisadas por perspectivas diferentes, como pela observação das alterações ocorridas nas mesmas linhas ao longo do tempo; nos diversos turnos de trabalho; nos diversos setores (como no setor de pintura, de estamparia ou da montagem final); e subsetores (como a montagem da porta e a da bateria, por exemplo); pelos diferentes processos de produção em um mesmo setor (como é o caso da montagem final onde há as linhas da Kombi; do Gol, Saveiro e Santana e a do Pólo e do Fox). Enfim, são diversas as características da organização do trabalho

1. "A Classe operária vai ao paraíso". Direção: Elio Petri. Itália: Euro International Film, 1971. 
que influenciam, em maior ou menor medida, as experiências dos trabalhadores em relação ao trabalho e ao tempo, tanto na linha como fora desta.

Assim, após o "susto" da entrada, os trabalhadores vão experimentando o trabalho e o tempo de trabalho nas diversas linhas e setores, o que me levou à necessidade de distinguir os discursos sobre as vivências do tempo de trabalho na linha hoje e em tempos passados. Como a maior parte dos trabalhadores tem muitos anos de casa, há vários relatos sobre a passagem por diversos espaços de trabalho dentro da Volkswagen. Vagner, um dos mais velhos trabalhadores entrevistados e que atualmente está na linha do Pólo, nos conta a sua experiência desde que entrou na Volkswagen, em 1980, frisando a diferença entre os diversos momentos na Empresa. Sua fala nos traz elementos para melhor compreender o que significa estar hoje na linha e o que isso significou em tempos passados e, mais do que isso, como o fato de ter a experiência da linha no passado torna diferente a vivência presente e a sua percepção desta. Ou seja, se objetivamente a linha no presente é a mesma, subjetivamente os trabalhadores constroem representações do trabalho e do tempo de trabalho muito diferentes, a partir de suas experiências vividas.

“[...] hoje, às vezes esses jovens que estão saindo do Senai, eles ficam reclamando de tudo. Eu falo: 'se vocês tivessem entrado aqui na minha época, vocês não tinham trabalhado nenhum dia'. Só agüentava o pessoal que vinha de fora mesmo, pessoal da roça mesmo. Mas naquela época eles nem exigiam que você tivesse muito estudo, porque eles sabiam que não agüentava. Mas hoje já ta diferente, né, hoje tem uma exigência muito grande pra entrar lá.[...] você tinha que trabalhar agachado, por isso que muita gente naquela época tinha problema de coluna, né, e era na base da marreta, não tinha máquina. Era aquela correria toda, ...e quem ficou daquela época até agora vê que a diferença é muito grande, né” (Vagner - linha do Pólo).

Vagner nos remete, a partir da sua experiência, às diversas características do tempo e do trabalho na linha. Considerava como um trabalho para o pessoal da "roça", quase sem estudo, diferente do pessoal que hoje sai do Senai, filhos de metalúrgicos e que logo vão fazer um curso superior, nova exigência da Empresa. Diz que era um trabalho duro, na marreta, com muitas pessoas e poucas máquinas; pouco espaço, problemas de saúde por trabalhar em posições não cômodas e também por estar exposto ao barulho, além de muita discussão e correria. Em seguida, ele compara com a linha do Pólo, uma das mais recentes e "modernas":

"Então, primeiro que você vai trabalhar na altura que você quer. Quando você vai colocar uma peça embaixo dele assim, ele fica na altura certa, se é pra abaixar também ele baixa, naquele 
espaço ele sobe e desce, e você também. Tem o privilégio também, mas é assim; se caso precisar, então também você assim, quando não dá pra segurar o serviço, que tava com um problema ou então precisava ir no banheiro rapidinho e não tem quem ficar no lugar, você tinha que segurar e tudo. Agora não, agora é uma linha que você puxa [um dispositivo] e que ela [a linha] pára. Eles não querem né, mas quando necessário, se for um caso de necessidade, um caso que ta caindo o serviço, né, pode puxar, né. Só não pode é demorar muito tempo". (Vagner)

Mas, mesmo se considerarmos apenas o tempo presente, veremos que as diferenças se mostram, igualmente, entre as linhas em cada um dos setores da Empresa. Renato, que trabalha na linha da estamparia, lança luz sobre estas diferenças ao falar a respeito de alguns trabalhadores da montagem final que foram "emprestados" para a estamparia e depois não quiseram mais voltar para sua linha de origem. Explicitando, assim, as diferenças entre linhas de diversos setores.

"Porque lá [montagem final] é linha, corrido, você não tem tempo nem de tomar água. Eu trabalhei lá 1 dia, bebedouro aqui, não dá tempo, senão o carro vai embora e você tem que fazer. Você fala assim: 'o serviço é esse, você vai colocar esses três parafusos aqui, está aqui a maquininha, três parafusos'. Mas se você for apertar três parafusos, em um minuto, um minuto e meio, é moleza, agora, um atrás do outro, quando você termina aqui, o outro já está chegando, é diferente. No outro dia você está que não agüenta”. (Renato)

E há diferenças ainda se considerarmos as diversas linhas dentro de um mesmo setor. Ao comentarem sobre o trabalho na montagem final, por exemplo, todos que passaram pela linha da Kombi foram unânimes em dizer que ela é muito "dura", que o trabalho é "muito pesado" e "muito grosseiro". "Eu tenho histórico muito bom para estar indo para um serviço que eu iria fisicamente me desgastar mais", é a fala de Anderson a respeito do momento em que a Empresa o "mandou" para a linha da Kombi, tendo nela permanecido apenas um dia. Em relação às duas outras linhas da montagem final, nas quais Anderson já trabalhou, ele diz preferir a do Gol, já que na do Pólo e do Fox, as novas linhas, não há um mínimo de tempo livre.

"Eu acho que aquilo ali é serviço escravo. [...] Aquilo ali para mim, é um absurdo. Aquilo ali é um descaso humano. A linha é tão otimizada, o processo é tão enxuto, tão otimizado o processo que você não tem tempo para tomar água. A liderança tem outra maneira de agir e os próprios funcionários que estão lá, é característica deles é tão... Às vezes se torna até arrogante, porque eles fazem de tudo para que não pare o processo. Mesmo que o funcionário não esteja conseguindo executar sua tarefa, eles ajudam, são os braços direitos dos encarregados. Eu acho isso um absurdo". (Anderson) 
$\mathrm{Na}$ mesma direção se exprime Vagner ao dizer que muitos trabalhadores reclamam de sair da linha do Gol, porque nas novas linhas, do Pólo e do Fox, eles não conseguem produzir nenhum tempo livre, além do intervalo coletivo determinado pela Empresa, que é cada vez menor:

\footnotetext{
"Porque o Gol, a vantagem que eles tavam acostumados, lá faltando uma hora pra refeição ou pra ir embora já acelera todo mundo e atropela todo mundo. [...] O Pólo é uma linha moderna só que você não consegue adiantar [o trabalho], cada espaço que ele tem é aquela quantidade de carro, né...”. (Vagner)
}

E como enfatiza Sato (1997:06), “a busca de controle é uma estratégia criada informalmente pelos trabalhadores para lidarem com as demandas de trabalho que ameaçam o seu bem estar" e, neste caso, a nova linha significa a perda da capacidade dos trabalhadores criarem um tempo livre que não tenha sido previsto pela empresa. Afinal, o controle do trabalho e do tempo de trabalho é importante tanto para os trabalhadores como para as empresas, transformando-se assim em objeto de disputa nos locais de trabalho, de forma explícita ou implícita.

Luana, que atualmente trabalha na montagem das portas do Gol, também discorre sobre a sua preferência em trabalhar nessa linha, mesmo depois de ter feito o treinamento para trabalhar na nova linha do Pólo. Ela relata que ficava muito isolada na linha do Pólo, que os grupos se fechavam e não havia muito contato com as pessoas dos outros grupos, pois eles ficavam muito distantes fisicamente. Além disso, questiona se o trabalho no Pólo é realmente mais leve:

\footnotetext{
"Era um trabalho mais pesado, porque tinha que colocar o eixo e mesmo o dispositivo requer força. Eu fiquei lá por um ano dizendo, para mim mesma: 'eu tenho que me adaptar à nova realidade, é nova mudança, é uma nova linha"”. (Luana)
}

Mas ela não agüentou e hoje trabalha na linha do Gol. Joice, que trabalha no II turno, disse que havia acabado de ser mandada novamente para trabalhar na linha do Pólo e do Fox, mas que também prefere a do Gol.

"Não sei se é porque eu estou há mais tempo. [...] A linha do Pólo tem uma forma, não sei se porque ainda é começo, tem umas operações lá que eu acho que até o jeito de montar está mais difícil, poderia dar uma ajeitada para ficar mais fácil. Às vezes você está fazendo uma coisa aqui, você sai daqui tem que ir lá na outra peça, lá embaixo, você anda muito". (Joice) 
Assim, vemos que dentre os trabalhadores que já passaram pelas linhas na montagem final, muitos dizem preferir a linha do Gol por diferentes motivos. E é interessante observar que Anderson, que prefere a linha do Gol, assim como Vagner, que prefere a do Pólo e do Fox, explicitam a mesma percepção de redução do tempo livre nessas últimas, ou melhor, que esta linha torna mais difícil a possibilidade dos trabalhadores criarem tempos livres dentro do tempo de trabalho. Tais falas explicitam talvez a maior diferença, no que se refere ao tempo de trabalho, entre as velhas linhas e as novas linhas, já que estas submetem o trabalhador a um novo tipo de tempo imposto.

Vimos ainda que outros fatores influenciam as vivências dos trabalhadores nas diferentes linhas, como o esforço físico, pois tanto Luana como Joice dizem que na linha do Pólo o trabalho é duro e mais difícil, o mesmo dito por Anderson, mas em relação à linha da Kombi. E há também o sentimento de isolamento em relação aos colegas, explicitado por Luana, ao dizer que nas novas linhas fisicamente as pessoas ficam mais distantes dificultando a conversa entre os trabalhadores, aumentando ainda mais o chamado tempo produtivo. Assim, além da experiência de uma vivência do passado, como citada por Vagner, esses são outros elementos importantes que diferenciam o modo pelo quais os trabalhadores representam as suas vivências nas linhas de produção.

Temos ainda de observar em que parte de uma mesma linha o trabalhador está. Por exemplo, o caso de Tamara, que trabalhava na colocação de vidros da linha do Gol, considerava o trabalho nessa parte muito repetitivo, quando foi para a montagem da bateria, nessa mesma linha e onde está até hoje, diz que a mudança foi muito boa e que o trabalho agora é "bem mais interessante e menos monótono ”. Este sentimento em relação à qualidade do tempo de trabalho também aparece quando os trabalhadores falam sobre o revezamento de funções, isto é, sobre o fato de trabalharem em linhas, setores ou funções diferentes. Joice, por exemplo, diz que gosta muito de trocar de "tarefa" porque assim "o tempo passa mais rápido".

"Se você fica meses após meses na mesma tarefa, chega uma hora que parece que a hora demora, o tempo não passa. Agora se você está sempre mudando de operação, então é... O dia que você pega uma coisa nova para fazer, a hora passa que você nem vê, porque você está aprendendo, você está quebrando a cabeça, você está naquela correria, a hora passa, você fala: 'Nossa! Já é hora da janta?', dali a pouco: 'Nossa! já é hora de ir embora'”. (Joice)

Nesta fala, assim como na de Tamara, evidencia-se a relação direta entre o sentimento que os trabalhadores têm do trabalho e do tempo de trabalho. Vemos que se o trabalho é sentido 
e vivido como algo repetitivo, o tempo não passa nunca; por outro lado, se há a necessidade de pensar para realizá-lo, ele pode se tornar interessante e o tempo passará mais rápido. Ou seja, a duração em si de uma atividade deixa de ser algo sentido de maneira uniforme e vai depender do trabalho que se realiza. Como salienta Hassard (1989), o "sentimento do tempo varia segundo o tipo de trabalho efetuado", de forma que para romper a monotonia do tempo de trabalho são diversas as estratégias a que os trabalhadores recorrem: demandar a mudança de setor ou aceitar uma solicitação de mudança são algumas delas.

Além disso, é interessante observar que tão pouco há uma idéia absoluta sobre a preferência da linha, pois cada um pode olhá-la a partir de um ponto de vista específico, ressaltando, em alguns momentos, pontos positivos e, em outros, negativos. Assim, se a linha do Pólo aparece como positiva, no sentido de um trabalhador não atropelar o outro, da posição física ser mais confortável, ela também pode ser representada como negativa, do ponto de vista do trabalhador que não consegue "adiantar" o seu serviço, tanto para ter uma pausa maior como para poder sair mais cedo.

Finalmente, os trabalhadores ressaltam as diversas vivências em função do trabalho nos diferentes turnos. Por exemplo, de acordo com Vagner, que está no II turno na linha do Fox e do Pólo, seu trabalho é muito melhor e mais "sossegado", porque nesse horário há "menos chefias supervisionando", há "menos gente trabalhando" e "menor produção". Emerson, que trabalha na ferramentaria, faz esta mesma observação ao diferenciar o seu tempo de trabalho, enquanto estava no I turno e agora, que está no III. A partir dessas colocações é possível entender o turno como uma das variáveis mais importantes na produção das vivências cotidianas pelos sujeitos, em relação ao tempo no local de trabalho e fora deste. É por esse motivo que o capítulo seguinte será dedicado unicamente a esta discussão.

É interessante analisarmos ainda, como contraponto às falas dos que estão na linha, e para melhor aclarar as especificidades dessas vivências, o que dizem os trabalhadores que estão na produção, mas não diretamente em uma das linhas. Embora não necessariamente sob a imposição direta destas, muitos iniciam o trabalho em uma das linhas e diversas vezes voltam a ela e, desta forma, quando demandados a falar sobre o trabalho presente, fazem uma comparação com o trabalho no passado, sendo unânimes em dizer que o atual é melhor por diversos motivos.

Felix, que antes trabalhava na linha de montagem final e que atualmente está na logística, em uma empresa "terceira", diz que agora o seu trabalho é muito melhor porque ele tem contato com compradores e há uma maior responsabilidade. Também Robson, que trabalha com 
empilhadeiras que abastecem as linhas, ressalta que seu trabalho hoje requer maior responsabilidade e que, apesar do seu trabalho também ser muito corrido e a Empresa pressionar para terceirizá-lo, mesmo assim ele prefere o trabalho atual. Odilson, que hoje trabalha na reparação de veículos fora da linha, mas que já foi reparador na linha, disse que a diferença entre esses dois trabalhos é muito grande. Na linha a reparação se faz "correndo", para seguir o ritmo desta, sendo, portanto, um reparo muito mais pontual; já na oficina, o trabalho é "parado" e mais detalhado.

Para Lúcio, que é reparador de veículos na oficina, mas que em momentos de maior demanda "migra" para a linha de montagem final, essas duas experiências, no momento presente, são assim definidas:

\footnotetext{
"Veja bem, trabalhar na oficina é bom, onde você aprende bastante, você vê uma série de coisas. É interessante, é gostoso, você tem um pouco mais de liberdade, porque você fica mais à vontade para lá e para cá. Porém, a cobrança é muito maior. [...] Então a vantagem da linha qual que é? Não tem uma cobrança. A cobrança que pode ter, a cobrança que tem na linha é a seguinte, se você fizer alguma coisinha errada o cara vem e fala: 'olha, o serviço não está saindo muito legal, dá para você dar uma melhoradinha e tudo mais'. Mas, pronto. Só isso. O importante da linha é que você esteja lá...”. (Lúcio)
}

Por diferentes motivos, todos os trabalhadores que já passaram por uma das linhas dizem preferir o trabalho atual, mesmo que muitas vezes estejam próximos de uma das linhas. Talvez por sentirem que o trabalho demanda maior responsabilidade, possibilita maior liberdade, é mais interessante, mesmo sendo mais controlado e corrido, pois "É corrido mas você faz seu tempo, não sendo como a linha". É o sentimento de ausência de liberdade na linha, que aparece com mais freqüência, como já citado por Lúcio e também por Robson “... você ficar 8 horas na linha, você depender dos outros para ir ao banheiro", ou ainda Edgar, falando do seu irmão que trabalha na linha:

\footnotetext{
"Uma vez eu fui tentar conversar com meu irmão, não dava. Meu irmão faz um carro, pula outro. Linha é determinado, é calculado, é um carro a cada..., tem um tempo determinado, calculado tudo certinho, perdeu um carro, dançou." (Edgar)
}

Ou seja, estar fora da linha não significa que o tempo de trabalho seja tranqüilo, sem correria ou que o trabalho não seja cansativo ou repetitivo, como podemos observar na fala de Eliana, mas sim que há outros fatores que também pressionam. 
“...eu não trabalho diretamente na linha, eu até costumo brincar com o pessoal, eu estou fora da linha e estou atordoada que nem o pessoal da linha. O pessoal (da linha) praticamente não respira, está com o bebedouro do lado deles, se ele parar para beber água o carro vai passar e ele não vai fazer. Então está um ritmo muito acelerado". (Eliana)

Assim, vimos que a vivência do tempo na linha é muito marcante para os trabalhadores, de forma que mesmo um pequeno distanciamento desta, já possibilita vivências diferentes do trabalho e do tempo de trabalho. Com efeito, a linha, um dos mais importantes artefatos tecnológicos, símbolo da "era fordista", continua a afetar fortemente a vivência do tempo de trabalho daqueles que estão diretamente a ela submetidos. Além disso, é importante ainda ressaltar que as diferenças entre estar ou não na linha são também explicitadas quando analisamos as falas dos trabalhadores no que se refere às mudanças na organização do trabalho e do tempo de trabalho. Esses dados evidenciam que a vivência de uma mesma mudança organizacional ocorre de maneira totalmente diferente quando comparamos os trabalhadores da linha e os de fora desta. Como no caso da hora extra, da redução das pausas coletivas, da implantação da multitarefa ou do banco de horas.

Há, por outro lado, mudanças organizacionais que são muito mais sentidas pelos trabalhadores que estão fora da linha, como a redução de prazos e a pressão para a padronização dos produtos. Há ainda mudanças que, por sua vez, são vivenciadas e representadas de maneira diferente, mas que guardam uma relação muito menor com o fato do trabalhador estar ou não na linha, como a flexibilização da jornada de trabalho via "semana Volks". Neste caso, o que marca esta diferença são outras características e atributos pessoais como o fato de ser jovem, estar estudando, ter outro trabalho fora da Volkswagen ou maiores salários.

A seguir, analiso as vivências e representações dos trabalhadores entrevistados em relação às mudanças em relação à organização do tempo de trabalho e do trabalho.

\section{2 - Mudanças na organização do trabalho sentidas como intensificação do tempo de trabalho}

Como vimos, no capítulo sobre a Volkswagen, algumas mudanças na organização e gestão dos usos do trabalho tiveram forte impacto para o tempo de trabalho, tais como o just in time, a introdução de tarefas de qualidade e manutenção na linha, da multitarefa via o novo PCS, das células de produção, da redução do tempo de desenvolvimento e produção, das metas de produ- 
ção e absenteísmo em função da PLR, entre outras. Todas essas mudanças foram apontadas pelos dirigentes sindicais como fatores de impacto sobre o tempo de trabalho. No caso dos trabalhadores, como veremos a seguir, pouco se fala da introdução do just in time, e muito se fala da multitarefa, como uma das mudanças que mais intensificaram o trabalho.

\subsection{1 - A multitarefa e o trabalho intenso em cada uma delas}

Dentre as diversas mudanças na organização do trabalho que foram implantadas pela empresa e que tiveram impactos sobre o tempo de trabalho, de acordo com as falas dos trabalhadores, uma delas foi a introdução do revezamento de função, institucionalizado no acordo sobre PCS, no ano de 1995. No discurso da Empresa, essa nova forma de organizar o tempo de trabalho teve como objetivo responder às reivindicações dos trabalhadores em relação aos problemas de saúde, ocasionados pelo trabalho repetitivo. De forma que o trabalhador não ficasse, todos os dias, exposto à mesma tarefa, principalmente, se repetitiva e prejudicial à saúde.

O problema é que, se por um lado o trabalhador passa a não ficar exposto ao mesmo trabalho prejudicial, todos os dias, por outro lado ele pode estar exposto ao trabalho intenso. Isto porque a Empresa, para viabilizar o aumento da produção em um setor sem a contratação de mais trabalhadores, desloca trabalhadores de outros setores onde o ritmo de trabalho é mais tranqüilo. Assim, o resultado pode ser a exposição ao trabalho intenso, todos os dias, mas em setores ou funções diferentes. E se essas mudanças, no curto prazo podem atenuar uma dor na coluna, por exemplo, no médio prazo, pode trazer outros problemas de saúde. Isto porque o trabalhador sempre estará, em um setor ou função onde a demanda esteja em alta, de forma que o trabalho será sempre mais intenso.

Os trabalhadores que mais reclamam disso são aqueles alocados em uma das linhas, mas, igualmente, os que trabalham na produção direta, isto é, pré-montagem, oficina e armação. Já Alcio, que trabalha na qualidade, e não faz "rodízio de função", entende que a multitarefa

“... traz grandes benefícios para os montadores por quê? Porque quando ele faz esse rodízio de operações, ele evita problema de saúde. Agora, também traz mais qualificação para ele. O montador se torna uma pessoa mais versátil, ele conhece mais o problema, ele não fica focado apenas no que a gente sempre brinca, 'apertar o parafuso', não, ele começa a conhecer que o processo é complexo. [...] Agora, o importante é o treinamento....”. (Alcio) 
E perguntado se os trabalhadores têm treinamento,

"Tem, geralmente tem. Às vezes quem faz o próprio treinamento são os monitores, o grupo que recebe essas pessoas, eles fazem um treinamento com a pessoa e dão um suporte para ela, até ela pegar prática. Só que a gente, quando fala em qualidade, a gente tem que tomar cuidado, porque pode, talvez, comprometer um pouco a qualidade". (Alcio)

Ou seja, treinar os trabalhadores que vêm de outras áreas é mais uma tarefa para os que dizem já estar com o trabalho corrido. Eliana, que trabalha no final da linha, nos fala sobre este assunto, ressaltando que de fato há um grande problema quando a Volkswagen coloca a linha para rodar mais rápido, como a do Pólo que passou a rodar a 1,15', e traz pessoas de outras áreas:

“...só que as pessoas não têm experiência e não têm treinamento. Então eles acabam, coitados, sofrendo pra caramba. E as outras pessoas que já estão lá, também sofrem porque tem que ajudar eles, então é meio complicado. Os supervisores, os gerentes, não querem saber, põe o pessoal para trabalhar, ele quer a quantidade de carros que tem para aquelas pessoas, independente de saber ou não". (Eliana)

As duas falas anteriores, tanto de Alcio que é a favor da multifunção como de Eliana que é contrária a esta, frisam a questão do comprometimento com a qualidade do trabalho. O resultado da multitarefa, quando não há treinamento, e parece ser este o caso, pode ser a redução da qualidade do produto, na maior parte das vezes. De qualquer forma, como salienta Elaine, o importante é a quantidade que é produzida. Além de acarretar, do ponto de vista do trabalhador, uma intensificação do trabalho para aqueles que precisam treinar o trabalhador que chega, assim como para este que ainda não domina a função a ponto de trabalhar com menos esforço. Como dizem Luana e Joice, trabalhar em uma linha onde você já conhece o serviço, ou as pessoas, possibilita que você "adiante" um pouco o serviço para "dar uma corrida ao banheiro".

Lúcio ressalta ainda que, nos casos como o seu, que trabalha na oficina e às vezes é enviado para trabalhar na linha, cria-se ainda um problema em relação ao salário, pois às vezes ele realiza uma função na qual os trabalhadores do setor ganham menos do que ele. Além disso, as mudanças constantes de setor também acarretam problemas com as férias, porque se o trabalhador já as tiver organizado no setor de origem, ao ser transferido haverá a necessidade de novamente demandar e negociar suas férias no novo setor. 
Além dessas questões, vemos que há ainda aquelas relacionadas aos sentimentos dos trabalhadores, como diz Luana: "Porque é assim, tem uns serviços que são bons e uns que são ruins. Você acha que de manhã, às 6h00, mal humorada, alguém vai feliz da vida fazer um serviço que não seja bom?". Ou ainda, como ressalta Edgar ao dizer que os trabalhadores se sentem inúteis ao serem "jogados” de um setor para outro.

"A grande verdade é a seguinte, se você é uma pessoa que você é importante no setor, se você faz falta no setor, dificilmente você sai. Só que, por outro lado, também há o lado da chefia, tem chefe que não gosta de peão, tem chefe que quer se vingar do cara". (Edgar)

Edgar, apesar de dizer que não é contra o revezamento, relata que quando foi "trocado" teve "uma sensação de ser inútil" e, ao ser perguntado se ele não poderia pensar o contrário, isto é, que a mudança de setor poderia significar a valorização do trabalho, responde:

\footnotetext{
"Não, pelo seguinte, se a coisa fosse bem clara, que você não é idiota, ninguém é idiota, quando você vai: 'olha você vai porque você vai ser importante lá'. Mas não, o que acontece é a mesma coisa quando vêem outras pessoas para o nosso setor. Quando vem outras pessoas para o nosso setor, só vem tranqueiras. Então, isso, de repente, é um mal da própria chefia, é uma cultura que a própria chefia implantou: 'olha eu preciso de 10 homens no Gol', ele pega os piores homens que tem e manda para o Gol.” (Edgar)
}

Como resultado, Carlinhos entende que a rotatividade de tarefas deixou o trabalho muito "mais intenso":

[...] porque antigamente você trabalhava em 1 posto, hoje você trabalha em 3, 4 postos, aquele rodízio que você faz, então a pessoa fica desgostosa, dá problema no ombro. [...] É tendinite, bursite, coluna, dor na coluna". (Carlinhos)

Assim, vemos que o chamado revezamento de função, multitarefa ou multifunção, tem sido um artefato gerencial muito utilizado pela Volkswagen para possibilitar a estratégia adotada de manter um mínimo de trabalhadores na Empresa. Para tal, ela busca ocupar de maneira produtiva todo o tempo do trabalhador; assim, o setor onde há maior demanda é onde estarão os trabalhadores. Além disso, como bem salienta Grossin (1991), para a empresa, a expansão das tarefas possibilita aumento de produtividade, economia para a empresa, aumento da carga de trabalho para o trabalhador e a redução do número de trabalhadores empregados. Grossin ressal- 
ta ainda que a rotação de postos pode romper a rotina de trabalhar sempre no mesmo lugar, o que não significa, necessariamente, uma melhora em relação aos tempos impostos, pois o trabalhador pode ser apenas mudado de uma linha para outra. Durand (2004) também entende que a multitarefa significa, na maior parte das vezes, a ampliação das atividades e não o seu aprofundamento, o que não elimina ou diminui a monotonia do tempo de trabalho. Isto nos ajuda a compreender porque os trabalhadores da Volkswagen colocam-se contra esta forma de organização e ressaltam a intensificação do tempo de trabalho.

\subsection{2 - A redução dos prazos}

Além do revezamento de função, outro fator citado pelos trabalhadores e que acaba por contribuir para a intensificação do tempo de trabalho é a redução dos prazos para a realização das tarefas. Esta mudança é muito citada tanto por trabalhadores do setor administrativo, da qualidade e da ferramentaria como pelos líderes. Muitos falam ainda sobre um forte aumento da "pressão" por parte da hierarquia em função do aumento da responsabilidade, por qualidade, maior controle, aumento da quantidade de tarefas, entre outros. E muitos ressaltam que a redução de pessoal, somada à pressão pela redução dos prazos é totalmente incompatível com a pressão pela melhoria da qualidade dos produtos.

Manolo e Luiza, ambos do setor administrativo, falam que a redução dos prazos tem gerado, ao mesmo tempo, intensificação do trabalho e redução da qualidade. Luiza, diz que desde 2003 ela tem de atender vários gerentes ao mesmo tempo, tornando o seu trabalho muito desgastante, “... e hoje, com essa atividade que você atende várias pessoas, várias áreas, você nunca sabe qual é o teu dia de amanhã, você tem uma programação, mas ela muda completamente". Ela não reclama dessa situação, apenas diz que o problema é a qualidade do serviço prestado, “... porque às vezes você não tem tempo de rever aquilo que você fez. Muitas vezes você faz e entrega, porque não dá tempo, a gente não tem tempo para isso".

Para Manolo, que trabalha com peças defeituosas:

"Antes do just in time, você tinha um estoque maior de peça, então para você fazer um ajuste não é necessário você correr tanto. Porque geralmente se você fizer uma variação do inventário, mas você tinha estoque para suprir, agora não, é estoque zero. Então quando dá um problema assim, você tem que resolver o mais rápido possível essas coisas, você não pode perder muito tempo para resolver". (Manolo) 
Mauro, encarregado da ferramentaria, relata que os prazos têm ficado cada vez mais apertados.

"Para você ter uma idéia, antes a gente fazia um carro, que é chamado DKN, não muito tempo, quando eu cheguei aqui de 99 para 2000, demorava 1 ano. Em 2002 nós fazíamos em 6 meses, agora a gente está fazendo em $1 \frac{1}{2}$ mês para 2 meses e a tendência é diminuir cada vez mais.... [...] Nós estamos brincando de fazer carro, brincando assim, brincando com o tempo. Até a hora que não vai dar, a hora que não der, aí a gente vê o que acontece". (Mauro)

Para Gerson, também da ferramentaria, o fato dos prazos estarem cada vez mais curtos acaba por influenciar o próprio desejo e o incentivo para trabalhar, pois não há mais tempo para fazer um produto com qualidade.

"Então hoje você está fazendo um serviço e amanhã você tem que entregar aquele outro, aí te tira desse e te põe naquele, então você nunca faz aquilo que você gostaria de fazer". (Gerson)

Márcio, também da ferramentaria, fala que antes era mais gostoso trabalhar:

“...se você quer dar um pouco mais de qualidade, o serviço atrasa. [...] antigamente tinha-se pouco dinheiro, pouca verba [o setor] e um prazo enorme. Hoje em dia não aumentou muito o dinheiro, mas o prazo é curtíssimo, eles estão achando que é pastelaria, o pastel virou, está pronto. Então aí complica um pouco. Então, às vezes, você trabalha de uma forma estafante, é pressão, pressão". (Márcio)

Além disso, a redução dos prazos, somada à redução do número de trabalhadores no setor, acabou por demandar a realização de muitas horas-extras, alterando a vida fora do local de trabalho; esse foi um dos motivos que incentivou Gerson a entrar no projeto Auto-visão ${ }^{2}$ e sair da ferramentaria. Devemos lembrar ainda que o setor da ferramentaria passou pelo processo de terceirização de alguns subsetores, o que, de acordo com os trabalhadores, também tem influenciado fortemente na falta de qualidade dos produtos. O que, somado à falta de tempo para "refazer" as peças que vêm de fora, tem tido como resultado a intensificação do trabalho e produtos com menor qualidade, acabando por influenciar toda a produção do carro, como veremos na fala de Márcio:

2. Como já vimos, o projeto Autovisão engloba uma empresa especializada na recolocação de trabalhadores no mercado de trabalho; e também o CFE - Centro de Formação e Estudos, como nos moldes da empresa criada na Alemanha, pela Volkswagen. 
"Mas esse discurso de qualidade é para inglês ver, porque é assim, não tem como você fazer um serviço bem, caprichado, se tem alguém te apertando. A pessoa não vai dar aquele fino trato, porque senão não dá tempo, então por isso que eu falo que a qualidade cai. Aí depois começam as reclamações: 'ah vocês não fizeram'. Não deu tempo... [...] É a mesma coisa, corre, corre, corre, passa as ferramentas para a ala 5, aí chega na ala 5 agora, está dando problema, agora estão querendo matar meio mundo, porque não está saindo a peça. Tudo isso é questão de correria, stress, acúmulo". (Márcio)

Assim vimos que se por um lado o trabalho na linha impõe um ritmo determinado, contínuo e repetitivo, também as mudanças organizacionais e gerenciais podem, igualmente, impor um ritmo de trabalho intenso. De acordo com o gerente de $\mathrm{RH}$, ao comparar o trabalho da linha e da ferramentaria, "O revólver na cabeça é igual".

“...quem dá o trabalho pra ele [ferramenteiro] é a linha, ele tem que seguir a batida do remo, na ferramentaria. Eu diria que extremo não é bem o cara da ferramentaria e sim o cara da engenharia. Se bem que tem a ver porque ferramentaria também trabalha com projetos e os projetos têm tempo e data. Eles trabalham sobre pressão. Por isso que é uma das áreas que mais faz hora extra na companhia é a ferramentaria. Porque eles têm tempo de projeto. Porque é assim, eu preciso entregar esse carro em tal época, então eles falam o tempo é x, então uma das áreas que é mais controladas por projeto é a ferramentaria. Só que atividade dele, não sei se é isso que você quer dizer, ela não é padronizada, é diferente de um cara, que não é repetitiva, a ferramentaria é um trabalho mais artesanal....". (Gerente de RH)

E este aumento de tarefas é ainda por ele explicitado, ao citar a fala dos trabalhadores: "A sensação que eu tenho é que eu sou mais escravo, que eu estou trabalhando mais do que no passado". Relata que de fato há menos pessoas para realizar o mesmo trabalho, "Mas você tem que fazer diferente". Desta forma, ele entende que cabe ao supervisor de unidade, no caso do setor administrativo ou do líder na produção “... rever essas atividades, programar seus recursos de acordo com as suas atividades. Ou seja, a administração da escassez é a virtude de qualquer líder, de qualquer lugar. O cara tem que lidar com isso".

Ao comentar sobre o seu próprio tempo de trabalho, o gerente de RH também comenta sobre o acúmulo de trabalho e de seus reflexos sobre as vivências dos outros tempos sociais, para além do espaço da fábrica:

"Eu tenho um problema sério de tempo. Eu trabalho uma média de doze a catorze horas por dia. Gerir o tempo é complicado. [...] Eu tenho que fazer as coisas de forma alternadas. É complicado. 
Fica assim qual é a época boa? Chego a conclusão que não tem época. Você tem que se programar, fazer uma coisa assim, por agenda mesmo. Eu me comprometo que na quarta-feira, do jeito que está ir embora em tal hora, programar coisas. Eu tenho uma filha que gosta de tocar, eu vou gravar junto, ir junto. Terça-feira é dia de ir ao cinema. Você tem que passar a tratar as coisas pessoais de uma maneira profissional. Você precisa fazer isso. Agendar coisas para você conseguir espaço e fazer com que as outras pessoas entendam isso. Porque é comum sete horas da noite as pessoas ligarem aqui e marcar reuniões para começar às seis horas da tarde, como se fosse absolutamente normal. Então você tem que disciplinar". (gerente de RH)

Por fim, em função da enorme demanda de trabalho e da falta de trabalhadores, os ferramenteiros reclamam que é impossível planejar as férias, pois elas sempre têm de estar vinculadas aos momentos onde há menor demanda de trabalho: "se tem serviço você não sai de férias; se não tem serviço, você sai de férias". De forma que mesmo o tempo de não trabalho, acaba sendo totalmente determinado pela Empresa. E esse problema das férias não ocorre apenas no setor da ferramentaria, como nos conta Odilson, que é reparador de veículo no III turno. Ele diz que as últimas duas férias ele não conseguiu sair na mesma data que seus filhos, em função de mudanças definidas pela empresa, de última hora.

Assim, frisam os trabalhadores que esta redução dos prazos ocorre num contexto de redução também do número de trabalhadores. E, apesar dos trabalhadores na linha fazerem referência a este fato, são os que estão na produção, na qualidade, os ferramenteiros e trabalhadores da manutenção que enfatizam mais esta questão e a conseqüente intensificação do tempo de trabalho. É importante ressaltar que a maior reclamação dos trabalhadores jovens que saem do Senai é justamente a dificuldade que encontram para passar para as chamadas funções qualificadas, isto é, para a ferramentaria e a manutenção.

\footnotetext{
"Isso [redução do numero de trabalhadores] já faz tempo, desde que ela começou com projeto de reestruturação para reduzir o quadro de funcionários, ela saiu de 24.200, 24.500, um negócio assim, hoje está 12 mil e poucos empregados, mantendo o mesmo nível de produção. [...] esse último acordo mesmo, que a gente conseguiu a estabilidade de trabalho até 2006, não foi de graça, foi a custo de terceirização de áreas, foi a custo de demissões [PDV]. (Edgar).
}

Manolo, que trabalha no setor administrativo, fala ainda da relação entre a redução de pessoal no seu grupo, que trabalha com "especificação e auditoria", e a redução da qualidade do serviço realizado. Esta relação entre a redução do número de trabalhadores e a redução da qualidade do serviço será ainda citada por outros trabalhadores de diversos setores da Empresa, 
demonstrando que este não é um evento localizado. No seu caso, se em 1990 o grupo era composto por 40 pessoas, em 2005 são apenas 9.

"Só o que acontece? O serviço, a gente consegue fazer, mas perdeu muito a qualidade do que era feito antes. A gente pegava uma peça para fazer analise, a gente tinha mais tempo, tinha mais tranqüilidade para fazer. Hoje não. Hoje é tudo no sufoco, está sempre atrasado, está sempre”. (Manolo)

No caso da ferramentaria, com a implantação do PCS diversas funções foram reagrupadas em uma única, denominada "ferramenteiro", de forma que os trabalhadores passaram a fazer todos os trabalhos que antes eram divididos entre diversas funções. Tal mudança, a princípio, poderia ter sido positiva para o trabalhador que deixaria de ter uma visão fragmentada do trabalho, passando a conhecer e a desempenhar outras funções. Mas, como a intenção principal da empresa não era essa, e sim ocupar ao máximo o tempo dos trabalhadores empregados, ao mesmo tempo em que reduzia o número de funcionários no setor, isso acabou por significar forte intensificação do trabalho com a redução dos tempos de não trabalho. Logo, o que poderia ser vivenciado de maneira positiva acabou sendo muito criticado pelos trabalhadores.

Assim, vemos que, num contexto de redução do número de trabalhadores, a maior parte das reclamações dizem respeito à redução dos prazos para realização das tarefas e ao aumento da pressão por maior responsabilidade e pela qualidade do serviço ou trabalho realizado. E estas reclamações são feitas por trabalhadores de todos os setores da empresa que ainda frisam que essa redução de pessoal, somada à pressão pela redução dos prazos é totalmente incompatível com a pressão pela qualidade.

\section{3 - Mudanças na organização do tempo de trabalho}

Trabalho, a seguir, com alguns itens da organização do tempo de trabalho que foram destacados nas narrativas discursivas. E, como já vimos anteriormente, essas mudanças se deram a partir da redução das pausas individuais e coletivas, da redução da jornada, da extensão do tempo produtivo e da flexibilização do tempo de trabalho - via trabalho em turnos, noturno, hora extra, banco de horas, banco de dias e "semana Volks". 


\subsection{1 - Redução da jornada de trabalho e extensão do tempo produtivo de trabalho}

Desde meados dos anos 80 a Volkswagen tem buscado a redução das pausas coletivas e também individuais de trabalho, ao mesmo tempo em que os trabalhadores pressionam pela redução da jornada de trabalho. Renato e Joice, ambos militantes no Sindicato, fazem referência às reduções na jornada de trabalho, em 1985 e 1995, mas também às reduções das pausas, principalmente, a partir de meados dos 90. De acordo com Renato, na estamparia eram dois intervalos de 10 minutos, um às $09 \mathrm{~h}$ e outro às $14 \mathrm{~h} 30$, isto quando eles saiam da Empresa às 16h30. Após a redução da jornada, em 1985, a Empresa aproveitou para excluir um intervalo e reduzir o outro. Flávio, que trabalha na linha da estamparia, relata ainda que depois da redução da jornada de trabalho em 1995, houve uma redução do horário do almoço em 5 minutos por dia, sendo agora de 55 minutos.

Joice, que na época da redução da jornada de trabalho trabalhava na tapeçaria, ao ser perguntada se sentiu as reduções na jornada, responde:

"Lógico, a gente sente, é muito bom você chegar em casa, a gente que trabalha, a gente chegar em casa 10 minutos mais cedo, a coisa já muda, 10 minutos você já fala: 'Nossa cheguei 10 minutos mais cedo, imagina 1 hora, 2 horas, é muito"”. (Joice)

Ao mesmo tempo ela faz questão de relacionar a discussão da jornada de trabalho à época em que começou a trabalhar na Volkswagen, em 1984:

"Na época a data base, acho que era em novembro, aí teve uma greve, nós ficamos mais de 30 dias parados. Não foi aquela grave que nem nos anos 80. ["'] Mas foi difícil, 84, 85, 86, todos esses anos eram lutas pela jornada de trabalho, sem redução de salário". (Joice)

Diferentemente de Joice, Lúcio diz que ele não "viu" a redução da jornada de trabalho de 42 para 40 horas, ocorrida em 1995, e que muitos trabalhadores tiveram a impressão de que houve redução nos salários:

"Por que a pessoa faz essa leitura hoje? Porque a todo o momento o salário vem caindo e você continua trabalhando. E a redução da jornada, se reduziu a jornada de trabalho, mas a linha continua numa velocidade bem elevada, e a produção começa a aumentar [e o salário não]". (Lúcio)

Vivian, trabalhadora qualificada, diz que não sentiu, mas que, com certeza, os que trabalham na linha sentiram. Robson, que utilizou as horas resultantes da redução de 44 para 42, e 
depois para 40, para dormir mais, pois o horário de entrada foi adiantado, explicita a sensação de que “então, não fiz nada de especial”. Para Jorge, que atualmente é monitor:

"Como a redução da jornada de trabalho foi assim gradativamente, não sente. [...] Aí a gente até falava vamos fazer isso, aquilo, aquilo outro, no final não faz é nada. [...] Não, e olha que reduziu muito! 4 horas. É aquilo que nós falamos, o que você acha que você faria? No final eu acho que não faz nada. Hoje a faculdade eu vou fazer à tarde, para mim fica uma maravilha, porque eu vou entrar às $17 \mathrm{~h} 00$ sair às $20 \mathrm{~h} 30,21 \mathrm{~h} 30$ eu estou em casa. Então vai dar para descansar bem mesmo. Chegar em casa, estudar alguma coisa, então vai ficar ótimo, agora, se eu estivesse naquele horário, já não daria”. (Jorge)

Esses relatos sobre os sentimentos em relação às reduções na jornada de trabalho nos indicam que, na maior parte das vezes, para estes trabalhadores, as horas resultantes dessas reduções gradativas foram utilizadas para dormir e descansar mais. Muitas vezes o descanso ganho parece não ser muito sentido no momento. Esta sensação é dada à intensificação do trabalho, tendo como um dos fatores, a redução das pausas coletivas, relatada pelos trabalhadores. O que nos ajuda a compreender porque alguns deles têm a sensação de que não fizeram nada com as horas livres que foram ganhas.

Ao mesmo tempo em que houve a redução da jornada de trabalho, pressionada pelos trabalhadores e por seus representantes, a Empresa, por seu lado, vem buscando reduzir as pausas individuais e também as coletivas, para transformar todos os tempos do trabalhador, dentro da empresa, em um tempo produtivo. E esta redução das pausas é sentida de forma diferente entre os trabalhadores, principalmente, em relação ao lugar que ocupam na produção (na linha, mais próximos ou mais distantes dela).

Assim, os trabalhadores da linha, diante dos incômodos causados pela falta de tempo, reclamam e buscam, formal ou informalmente; individual ou coletivamente, resolver o problema, levando a Empresa a introduzir mudanças na organização do trabalho, visando atender também às suas reivindicações. Uma das mudanças implementadas pela Volkswagen foi a criação da figura do monitor, dentro da discussão sobre as células de produção, que teria como uma de suas funções substituir, pontualmente, um trabalhador no momento em que este necessitasse. Entretanto, como "falta gente na linha", o monitor raramente consegue substituir o trabalhador em um momento específico. Isto porque ele acaba por ocupar o lugar de um trabalhador, durante toda a jornada de trabalho, seja por alguém ter faltado ou por pressão do aumento da produção. E para Lucas, que está na linha da pintura, os trabalhadores faltam porque o ritmo da linha é 
muito acelerado e o trabalhador não agüenta, “...rotina, todo dia, todo dia aquele mesmo ritmo ali, tanto que é difícil mesmo".

E como a figura do monitor parece não ter resolvido a questão da falta de tempo livre na linha, e a Empresa procura reduzir as pausas coletivas, os trabalhadores continuam a buscar resolver esse incômodo da falta de tempo livre na jornada de trabalho. Pois, como salienta Grossin (1991: 28), apesar das empresas buscarem eliminar os tempos próprios dos trabalhadores e substituí-los por tempos impostos, seja pela mecanização e por novas formas de organização do tempo e do trabalho, de forma que "o trabalhador se esvazie do seu próprio tempo", ao mesmo tempo o trabalhador tenta, de alguma maneira, impor também o seu ritmo, composto por acelerações e atrasos que ele decide, em função de suas necessidades e possibilidades. Por outro lado, Sato (1997: 150) ressalta, na sua discussão sobre trabalho prescrito e trabalho real, que muitas vezes as formas observadas de resistência dos trabalhadores "não chegam a se conformar em uma ação intencional e coletivamente elaborada", sendo uma "resistência menos visível, menos explícita". E, como veremos a seguir, na Volkswagen há tanto resistências individuais como coletivas, tanto as que são feitas de forma silenciosa como as que buscam visibilidade.

No que se refere à resistência cotidiana contra o tempo imposto, há o exemplo de Joice, que estava na linha do Pólo, ao falar sobre a ida ao banheiro:

\footnotetext{
"Olha o banheiro, na verdade, quem teria que fazer isso era o monitor, mas como hoje, essa falta de mão de obra, faz com que todos estejam trabalhando na linha, ninguém fica fora da linha. [...] Mas tem vezes também que se você trabalha, vamos supor, eu trabalho, tem eu e o meu colega, aí eu adianto o meu serviço, aí eu falo para ele: 'eu vou ao banheiro, se aquele carro chegar aqui e eu não estiver aqui, você faz ele para mim?'. Aí ele pega e já adianta o dele também. Ele vai corre, adianta o dele também, para que, se o carro chegar, ele poder me ajudar". (Joice)
}

Já Otelo, diz explicitar o incômodo em relação ao momento em que ele precisa ir ao banheiro e o encarregado não pode substituí-lo,

“...você tem que ficar segurando ou então a gente, que tem mais um pouco de consciência, abandona a linha lá, né, abandona o setor e vai no banheiro e aí passam cinco, sete, oito carros sem fazer. Porque o certo é que tivesse trabalhador disponível pra qualquer trabalhador que fosse no banheiro, ir no médico, alguma doença, ele sair de imediato, não pode ficar esperando.” (Otelo)

Mas os trabalhadores buscam também resolver a falta de tempo livre e a conseqüente intensificação do trabalho, de forma explícita e coletiva, como aconteceu no mês de agosto de 
2005, quando os trabalhadores fizeram diversas mobilizações tendo como reivindicação principal a contratação de mais trabalhadores, argumentando que o trabalho estava muito intenso e "não dava tempo para nada". Desta forma, os trabalhadores que estão nas linhas demonstram que o sentimento que têm em relação ao tempo de trabalho está muito relacionado ao tempo de não trabalho (pausas), dentro da jornada. São essas pausas que possibilitam aos trabalhadores atenderem às suas necessidades mais básicas como repousar, conversar, tomar água ou ir ao banheiro. É o que já vimos nas falas de Anderson e Vagner, Joice, Flávio, Otelo..... E como nos conta Luana, em relação ao seu intervalo de 7 minutos.

\footnotetext{
"Então, o banheiro, tem serviços que dá para dar uma adiantada, então nesse espaço de tempo, você corre, vai no banheiro, inclusive o nosso fica mais próximo ao setor e faz ali o xixi rapidinho porque se for para fazer outra coisa não dá e fica assim nesse sufoco. É tudo muito corrido, é muito estressante, por isso mesmo porque as coisas básicas têm que fazer naquela correria. $\mathrm{E}$ a gente se adapta tanto a essa vida, que não sabe fazer diferente, não sabe fazer com tranqüilidade, só sabe fazer correndo". (Luana)
}

Além da redução das pausas, Flávio diz que o trabalho na linha da estamparia tem ficado cada vez mais intenso, porque os tempos entre uma tarefa e outra estão cada vez mais curtos. Ele nos explica que no seu grupo são

“... seis linhas de produção de prensas..., enquanto você está produzindo um tipo de peça, a outra linha de prensa já está sendo preparada, pronto o material da sua linha de prensa, você não tem um minuto de descanso, você tem imediatamente que trocar de linha e começar a rodar aquela outra linha, que estava sendo preparada". (Flávio)

Já para os trabalhadores que estão na produção, mas não diretamente na linha, como Lara e Carlinhos, a redução das pausas coletivas foi menos sentida. Isto porque frisam ter maior liberdade, já que não há uma linha que volta a funcionar, automaticamente, ao final do intervalo. Lara relata que, apesar do intervalo oficial ser de 10 minutos, como ela não está na linha diretamente, ela sempre permanece por mais tempo na linha para ter tempo suficiente para tomar café e ir ao banheiro. Pelo mesmo motivo, ela relata que sempre consegue adiantar o seu serviço e acabar o trabalho mais cedo, às $14 \mathrm{~h} 15 \mathrm{~min}$ e não às $14 \mathrm{~h} 55 \mathrm{~min}$.

Também os trabalhadores que estão mais distantes da produção direta, não têm reclamação sobre os intervalos. Márcio, ferramenteiro, diz que “... como a gente tem um serviço, tem 
prazo de entrega, então você mais ou menos faz o seu tempo. Então, seu eu ficar 15 minutos tomando café, não vai afetar tanto o dia a dia do meu serviço". E nesses casos a questão do banheiro nem chega a ser citada por esses trabalhadores, demonstrando que no caso deles esse tempo não é um problema. Ou seja, a questão da liberdade (citada muitas vezes) e da maior autonomia (palavra não citada) parece ser o grande diferencial no que se refere ao tempo de não trabalho (pausas), dentro da jornada de trabalho, para os que estão na linha ou fora desta, como podemos ver na fala de Rogério, que trabalha na qualidade.

“...na usinagem [que não é linha], não vai das $6 \mathrm{~h} 00$ às $11 \mathrm{~h} 00$ direto. E cada um faz o seu volume, ele sabe o objetivo que ele tem que atender, ele sabe que se ele parar um pouquinho não vai prejudicar, desde que ele saiba administrar o trabalho dele. Então o pessoal faz um pouquinho de peças, às vezes pára para comer um lanche". (Rogério)

Assim, como pudemos perceber nos relatos anteriores, a redução da duração e da quantidade de pausas, parece ser muito mais sentida pelos trabalhadores do que a própria redução da jornada de trabalho, principalmente, para os que estão na linha ou na produção; sobretudo, porque eles não têm liberdade para gerar o seu tempo de trabalho e de não trabalho dentro da jornada.

Além disso, as ressalvas em relação aos monitores - que não conseguem substituir momentaneamente os trabalhadores, para que estes possam ir ao banheiro -, explicitam tanto um ritmo de trabalho mais intenso como uma forte redução das pausas. E esta é uma questão amplamente reclamada pelos trabalhadores, bem como debatida e negociada pelos sindicalistas com a Volkswagen. Como salienta um dos diretores sindicais, o tempo de intervalo não deve ser para o trabalhador ir ao banheiro. Ele considera, que, em primeiro lugar, é impossível marcar hora para as necessidades fisiológicas e, em segundo, que 7 ou 10 minutos são insuficientes para descansar, tomar café e ir ao banheiro. Assim, a pausa é vista pelo Sindicato como o momento para o trabalhador descansar. Por isso há demanda pelo monitor de célula, para que este tenha como uma de suas tarefas substituir o trabalhador no momento em que este precisa parar, mantendo assim o fluxo contínuo da linha.

\subsection{2 - Flexibilizações dos tempos de trabalho}

Retomando o que foi discutido sobre a flexibilização do tempo de trabalho na França, a questão principal é perguntar quem decide sobre a flexibilização. Afinal, como bem salientado 
por Grossin (1991), se nos perguntarmos se preferimos a flexibilidade à rigidez poucos dirão que esta última é a melhor, mas a questão seguinte é saber quem decide. E se considerarmos os casos nos quais são os trabalhadores que decidem a hora de entrar e sair, ou o dia para trabalhar ou não, podemos dizer que é a primeira vez que os desejos dos trabalhadores são considerados: sua condição física, sua disposição psicológica, seu humor, seu gosto pela mudança, suas obrigações familiares, seu transporte. Mas são raros os casos nos quais são os trabalhadores a decidir, como veremos nos itens a seguir que tratam da flexibilidade adotada pela empresa via banco de horas, banco de dias e "semana Volks".

\subsubsection{1 - Banco de horas e hora extra}

Para a maior parte dos trabalhadores entrevistados e que estão na linha, a flexibilização do tempo de trabalho, via a implantação do banco de horas, "não é ruim". Mas apesar de considerálo um "bom" instrumento, poucos dizem utilizá-lo e, quando utilizado, relatam que é para resolver problemas emergenciais. Para outros, como Otelo, o banco de horas tem um lado bom e outro ruim,

“...em termos financeiros, de salário, foi ruim porque você não recebe. Só que num ponto também eu acho que foi bom, porque deu uma brecada nas horas extras. Eu não concordo muito também com hora extra, porque eu acho que o que prevalece é você conviver dentro do seu orçamento mensal. Se você faz muita hora extra, você acaba se acostumando a fazer hora extra, quanto mais você faz, mais você quer fazer, então você acaba entrando nessa. E quando acaba a hora extra o neguinho fica endividado, já vi muitos exemplos". (Otelo)

Assim como Joice, Lucas, Aldo e Otelo, todos trabalhadores de uma das linhas, quando perguntados se conseguem utilizar o saldo positivo no banco de horas, respondem que normalmente é difícil. É o que podemos ver na fala de Otelo, ao enfatizar que para conseguir não trabalhar quando ele precisa, a negociação direta com o encarregado não é suficiente, necessitando o emprego de outras ações.

\footnotetext{
"Nem sempre, porque às vezes você não consegue. Eu consigo, quando tem. Porque ultimamente a gente só trabalha devendo, mas quando tinha, eu conseguia porque não chegava lá para pedir hora para encarregado, eu faltava, e no outro dia eu chegava lá e falava: 'oh, bota no banco de horas aí porque não deu para mim vir tal dia'. E aí ele não ia ter como negar, porque se eu tenho hora positiva, ele ia ter que colocar. E se ele falasse que não ia colocar, eu falava: 'Vou chamar a
} 
representação e eles vão fazer você colocar...'. Então assim, nem todas as vezes que você quer, você consegue. Porque eu já vi vários exemplos, pessoal que tem banco de horas, vai lá para a chefia $\mathrm{e}$ fala: 'vou ficar em banco de horas amanhã porque preciso', e o encarregado falar para ele que amanhã não dá porque geralmente não dá, mas se o cara falta, eles ajeitam lá e tem que dar”. (Otelo)

Tais falas nos remetem às dos dirigentes, vistas no capitulo sobre a Volkswagen, em que diversas vezes foram frisadas as dificuldades manifestadas pelos trabalhadores, tanto da linha como da produção, em conseguir utilizar o banco no momento em que necessitam. Mas se eles não conseguem utilizá-lo quando querem, por outro lado, eles têm de usar o banco de horas quando a Empresa determina, seja para trabalhar menos como mais, o que acaba gerando muito descontentamento. Tamara e Anderson, trabalhadores mais jovens e que estão nas linhas de montagem, se colocaram explicitamente contra o banco, porque entendem que os trabalhadores ficam com horas negativas em função de problemas ou programações da Empresa. E depois, justamente por terem saldo negativo, são obrigados a realizarem hora extra quando a Volkswagen determina, alterando totalmente o planejamento pessoal, como o lazer ou o estudo. Tamara, que está devendo 26 horas, porque em um determinado momento a Volkswagen determinou que ficasse em casa em função de mudanças na linha, entende que o banco às vezes ajuda, mas que, por outro lado, o trabalhador fica totalmente "dependente" da Volkswagen. A mesma opinião é compartilhada por Anderson, pois para ele o banco de horas

“...acabou onerando o funcionário. Porque o funcionário, como eu te falei, ele está devendo horas, sem ter opção de estar devendo ou não. O funcionário não tem a opção de optar por banco negativo ou positivo, que acaba fazendo ele seguir as normas da Empresa, o que ela propõe, em termos de estar pagando essas horas, sem um prévio planejamento. Quer dizer, aumentou a demanda de mercado, a fábrica convoca, você tem que ir, sendo que pode ser um dia que você pode estar usando para outra coisa ou ter programado alguma coisa...". (Anderson)

Assim, vemos que se poucos trabalhadores da linha colocam-se explicitamente contra o banco de horas, praticamente, todos relatam a dificuldade em utilizá-lo quando necessitam. Já, dentre os trabalhadores da produção, mas que estão fora das linhas, a maior parte é contra. Seja pela dificuldade em utilizá-lo "pois a resposta era sempre de que a Empresa precisava produzir”, mas, principalmente, por terem um saldo negativo grande, em função das necessidades da Empresa de que eles não trabalhassem em determinados momentos, o que os obrigava a trabalhar quando a Empresa demanda. Já os trabalhadores que estão mais distantes da linha, à exce- 
ção dos ferramenteiros que também encontram dificuldades para folgar quando querem, os trabalhadores da qualidade, administrativos, os líderes e encarregados, entendem que o banco de horas é um instrumento "interessante" e não têm reclamação. Mas é muito importante ressaltar que a maior parte relata que só utiliza suas horas positivas quando tiram suas férias, como é o caso de Mauro, encarregado na ferramentaria, que nas férias passadas teve 22 dias a mais, em função da compensação do banco de horas.

Gustavo, que é líder, e Alcio que trabalha na qualidade, também dizem que não utilizam o banco de horas, mas por outros motivos. Dizem que preferem resolver seus problemas particulares fora do horário de trabalho para não ficarem devendo nada para a Empresa. Isto demonstra que para compreendermos os motivos que levam o trabalhador a gostar ou não do banco de horas, a utilizá-lo ou não, também temos de considerar os valores e hábitos de cada um e não apenas as condições mais objetivas encontradas em cada um dos setores.

\footnotetext{
"Eu acho, é que eu sou uma pessoa de criação, eu sou uma pessoa que aprendi com os meus pais, nunca dever a ninguém. Então, por incrível que pareça e por mais engraçado que possa parecer, até um banco de horas, que você tem um saldo negativo, me incomoda, porque é uma coisa que eu devo". (Gustavo)
}

É interessante notar igualmente que poucos trabalhadores fizeram referência à questão da remuneração, isto é, ao não pagamento da hora extra, já que as duas primeiras horas extras vão para o banco e o trabalhador só recebe o adicional.

Finalmente, nas falas analisadas vimos que há diferenças de percepção em relação ao banco de horas, dependendo do setor em que os trabalhadores estão alocados, ou seja, varia em relação à proximidade ou distanciamento da linha de produção. A diferença fundamental está no fato de que os trabalhadores da linha e da produção são chamados para pagarem as suas horas negativas aos sábados (isso porque não há possibilidade dos trabalhadores de um turno continuarem na linha, no momento em que chegam os de outro turno, diferentemente das áreas onde não há linhas). Soma-se a isso, o fato da Empresa ter parado a produção em muitos momentos em que as linhas estavam sendo reestruturadas, obrigando assim os trabalhadores a ficarem em casa (mesmo que uma parte dessas horas negativas tenha ido para o banco de dias e mais tarde desconsideradas pela Empresa, como vimos no capitulo da Volks). Já outros trabalhadores que estão mais distantes da linha, como os lideres ou os do setor administrativos, relatam que conseguem utilizar as horas positivas somando-as aos dias de férias. Já no caso dos ferramenteiros e 
também dos trabalhadores da manutenção, em função da redução do número de funcionários nestes dois setores, eles não conseguem nem usar as horas positivas e nem tirar férias no momento em que necessitam, mesmo sendo estes os dois setores onde há um maior número de horas extras durante a semana.

Alguns trabalhadores, ao serem perguntados sobre o banco de horas, fazem uma relação direta tanto com a questão da hora extra quanto com a multitarefa, como o caso de Lúcio, que é reparador de veículo. Ele diz que no seu setor está ocorrendo muita demanda por hora extra porque muitos reparadores estão sendo "mandados" para a linha de montagem final, de forma que os reparadores que ficam têm que fazer muita hora extra para realizar o serviço demandado. Ao mesmo tempo, Lúcio entende que com o banco de horas a Volkswagen tem reduzido muito os seus custos, ao deixar de pagar uma parte do adicional de hora extra o que, para os trabalhadores, tem significado uma redução da remuneração.

Aliás, não apenas nas falas dos trabalhadores, mas também na dos dirigentes sindicais ou gerentes da Volkswagen, há sempre uma relação direta entre o banco de horas e hora extra, mesmo que seja a partir de perspectivas muito diferentes. Para a Volkswagen, como foi falado pelo gerente de RH, o banco de horas teve como "efeito colateral" a possibilidade de identificar os setores onde havia problemas de produção que tinham como conseqüência a realização de muita hora extra, formalizando a sua demanda, que antes ocorria em função de "acertos" diretos entre o chefe e o trabalhador.

“[O banco de horas] nos parece ser uma coisa boa em relação ao que nós tínhamos no passado, em que isso era tratado de uma maneira informal. Quer dizer, os acordos de 'não venho hoje, venho amanhã', eles eram informais. O banco de horas é uma maneira de tratar isso formalmente. Ou seja, eu faço com que o gestor tenha pleno controle e o empregado também. [...] Então, o que era no passado um benefício de apenas algumas categorias, isso passou a ser para nós uma forma mais democrática. E a outra, um meio também de combater a questão das horas extras, que nós tínhamos a fábrica de hora extra. Então, as vezes a hora extra provocada também pelo próprio empregado, aquele que nós falamos que quer acabar a reforma da casa dele e ajustava com o chefe e falava: 'você me escala para a hora extra'. E durante o dia ele estendia de alguma forma para poder ficar. No final do dia, ele tinha a sua hora extra. Existia isso, existia como em qualquer outra empresa. Então o banco de horas faz com que isso seja um pouco mais disciplinado". (Gerente de RH)

E muitos trabalhadores relatam o quanto, nos anos 80, eles trabalhavam muito além da jornada de trabalho normal, como nos relata Lara, sobre a época em que ela trabalhava na mon- 
tagem do chicote, na metade dos anos 80 , quando havia muita pressão para a realização de hora extra.

"Chegavam para você e falavam assim, eu falo porque eu cansei de ver ela [encarregada], com o papel na mão: 'você vem amanhã?' Não perguntava se você tinha um casamento, se você tinha um aniversário, ela falava: 'você vem'? Eu falava: 'eu não'. Aí, uma vez a encarregada disse: 'você vai ser mandada embora', e então eu respondi: 'se eu tiver que ser mandada embora, vou ser mandada embora, mas que eu não faço hora extra, eu não faço"”. (Lara)

É interessante observar que o fato de realizar hora extra está relacionado não apenas à forte demanda por parte da Empresa, mas também aos interesses e momentos da vida dos trabalhadores fora do local de trabalho. Assim, são vários os que relatam que fizeram muita hora extra no momento em que casaram, que quiseram comprar uma casa ou trocar de carro. Mas, por outro lado, há trabalhadores que relatam que, apesar da forte demanda, nunca fizeram muita hora extra porque entendem que esta atrapalha muito a vida fora do local de trabalho ou, ainda, porque o próprio trabalho já os deixava, ou os deixa, muito cansados. Mas frisam ainda que há uma grande diferença entre fazer hora extra e ganhar mais dinheiro, e gostar de trabalhar a mais,

"Tem aquele que briga com o chefe porque não tem hora extra, mas são raros, não é assim a grande maioria, todos eles gostam de ficar em casa. Agora, para você ficar em casa, ter um lazer, você tem que ter dinheiro, então fica uma coisa sabe? Eu já vi amigos meus aqui, o cara não saía daqui de dentro, não saía, não saía, um dia a Volkswagen não quer mais você, até logo. Passou 2 meses, ele morreu. O que ele aproveitou da vida? Nada, só trabalhou a vida inteira. Aí aproveitou? ‘eu tenho 2 casas, tenho casa em Santos', e daí, vai levar para o buraco? Não vai”. (Eron)

E, de acordo com as falas, a forte demanda por hora extra continuou depois dos anos 80 . Alguns dizem que foi mais forte até 97, com a produção do Gol, outros até 98, quando acabaram os turnos de revezamento; outros entre 95 e 2000; ou no ano de 2001, em função da produção do Pólo, ou ainda em 2004 com a produção do Fox. Mas que houve uma forte redução da hora extra após a negociação do acordo limitando a realização desta, em 2003. Diante desse acordo vemos que apenas um dos trabalhadores entrevistados colocou-se frontalmente contrário à limitação da hora extra, negociada entre o Sindicato e a Empresa, enquanto os outros parecem concordar e entender a necessidade dessa limitação. Aqui também a questão do medo do desemprego exer- 
ce um papel fundamental, pois o discurso do Sindicato sempre foi de que os trabalhadores não deveriam fazer hora extra, pois isso pressionaria a Volkswagen a contratar mais trabalhadores. Assim, perguntado se nos últimos tempos tem havido muita hora extra, Carlinhos responde: "A Comissão de Fábrica, não quer que a gente faça mais hora extra. Por quê? Para contratar mais gente, para ter mais mão de obra, só que a Empresa não quer”.

Além disso, observa-se uma mudança no próprio discurso da Volkswagen, a partir de meados dos anos 90, que passou a defender a não realização da hora extra como forma de reduzir os custos. Alguns trabalhadores que estão no setor administrativo e outros que trabalham com a qualidade frisam que a Empresa "não permite" mais a realização de tanta hora extra. Alcio e Gilson, que trabalham com sistemas de controles coletivos e individuais das horas realizadas a mais ou a menos, por trabalhador ou por grupo de trabalho, relatam o aumento do número de programas que têm esse objeto de controle das horas. Demonstrando assim o interesse da Empresa em controlar as horas que estão sendo realizadas para reduzir os gastos com o pagamento de horas extras, sendo que a implantação do banco de horas em muito contribui para esta redução.

Entretanto, Lara, Carlinhos e Lúcio, que estão na produção, entendem que a Volkswagen não irá contratar, porque ainda há muitos trabalhadores que fazem hora extra, mesmo que limitado ao acordado. Vagner, Otelo e Renata, que trabalham em uma das linhas, falam a partir de um ponto de vista mais coletivo, e entendem que os trabalhadores precisam se unir para acabar com a hora extra, pois "se um fala que não irá e o outro diz que irá, não adianta nada". Ao mesmo tempo, Anderson entende que a Empresa não precisa mais utilizar tanta hora extra, já que há o banco de horas. Como muitas pessoas ficam com horas negativas, em função de problemas na produção, isto significa que muitos terão horas para serem trabalhadas a mais, quando a Volkswagen precisar. E Lúcio ainda ressalta,

"A Volkswagen, ela fez uma experiência interessante, ela chamou o pessoal para trabalhar numa sexta e no sábado [julho de 2005]. O Sindicato fez uma pressão para o pessoal não vir. Vem quem está devendo horas, quem está devendo horas vem no sábado, que ela convoca, quem está devendo vem pagar no sábado. Então ela faz uma experiência, ela chega lá, ela faz uma pressão assim, convoca as pessoas para virem e chama pessoas que não estão devendo [banco de horas]. Essas pessoas que não estão devendo, vêm para ganhar hora extra. Se ela [Volks] chega e vê um grande número de gente fazendo hora extra, qual o pensamento que ela tem? Para que eu vou contratar gente? Não, não contrato ninguém, se eu chamo e o pessoal vem. Esse é um embate entre o Sindicato, entre a Comissão de Fábrica e a Empresa". (Lúcio) 


\title{
6.3.2.2 - "Semana Volks"
}

A "semana Volks" é uma outra forma de flexibilização do tempo de trabalho, utilizado pela empresa e refere-se a uma semana de trabalho de segunda a quinta, o que implica a redução de $15 \%$ na PLR $^{3}$. Mais da metade dos trabalhadores entrevistados apresenta muitas críticas em relação à mudança no tempo de trabalho, sendo a questão da redução da PLR o grande motivo explicitado. Marcos, que trabalha na qualidade, e que também é contra o banco de horas, pois prefere receber a hora extra realizada, explica porque prefere a semana "normal":

\begin{abstract}
"Porque a semana reduzida a gente perde, e o intuito da gente aqui é ganhar dinheiro. Ninguém é relógio, a gente trabalha por querer ganhar grana. Então você fica em casa e sabendo que você não está recebendo, e às vezes você não tem o que fazer, porque você já está programado para isso, e às vezes vem assim, fica um dia perdido. Isso é ruim porque acaba sendo 150 reais a menos". (Marcos)
\end{abstract}

$\mathrm{Na}$ fala de Marcos, e também na de outros trabalhadores, além da questão mais objetiva da redução da remuneração, transparece o que foi sendo socialmente construído e representado em relação ao trabalho: trabalhar de segunda a sexta e folgar no final de semana. Como veremos também nas narrativas discursivas de Carlinhos e Robson, que trabalham na produção.

\begin{abstract}
"Trabalhar de sexta-feira é uma coisa de rotina seu, todo o dia. Agora se for analisar assim, se tem fim de semana para você ficar em casa, sábado e domingo, por que eu vou ficar sexta-feira em casa? Quer dizer, reduz as horas, reduz o seu dinheiro, que é o mais importante. É dinheiro. [...] Sem dinheiro você não faz nada, então eu prefiro trabalhar na sexta-feira, a semana cheia, porque é uma coisa de rotina". (Carlinhos).

"Eu não gosto não [da "semana Volks"]. Assim, é bom para descansar, mas só que você acostuma entendeu, você fica assim, puxa, você não trabalha, você fica meio sabe? Mas você vai na casa da mãe, ela fala: 'hoje você não foi trabalhar?'A té eles acostumar que..., pensa que você está faltando entendeu. Então tem gente que gosta. Para mim, como minha esposa trabalha, para mim ficar fazendo em casa o que? Para mim tem que ser de segunda a sexta. Sábado e domingo descansando está bom não é?”. (Robson)
\end{abstract}

Essas falas são muito interessantes, pois poderíamos dizer que há certa contradição se compararmos com os discursos dos trabalhadores que não reclamavam e não reclamam de ter

3. Participação nos Lucros ou Resultados. 
que trabalhar no sábado. Mas a grande diferença é que no caso da extensão do tempo de trabalho via hora extra, isso significa um ganho a mais, mesmo com a implantação do banco de horas. Já no caso da "semana Volks", a redução do tempo de trabalho vem acompanhada de uma redução da remuneração, através da PLR, mesmo que o salário mensal não seja alterado. De forma que, assim como vimos ocorrer com os trabalhadores franceses, tempo livre sem dinheiro tem o significado de tempo perdido. Além disso, para alguns, como a folga na sexta não era algo "certo", pois sempre dependia do mercado, isso os impedia de trabalhar em outro local, de forma que a sexta-feira livre foi muitas vezes adjetivada como "perdida" ou "ociosa", mesmo para aqueles que disseram estar cansados, sem tempo para ficar com a família ou passear.

Mas há também aqueles que dizem gostar da "semana Volks", apesar de representarem a menor parte dentre os trabalhadores pesquisados. Neste caso, há muitos jovens, estudantes, trabalhadores que têm um outro emprego fora da Volkswagen e ainda os que têm os salários mais altos na empresa. Na maior parte das vezes a justificativa apresentada para gostar da "semana Volks" é o fato de ter mais tempo livre, ou melhor, ter a sexta-feira para fazer tudo o que não foi possível durante a semana, como estudar, por exemplo. Já para outros, a sexta-feira livre também foi muito boa para descansar, viajar e ficar mais tempo com a família, como relata Gilson, que é líder.

“... porque você sempre tem uma coisa para resolver, e essa sexta-feira você reservava ela. Se tinha alguma coisa para resolver, você ia, não perdia hora de trabalho, não te causava problemas com banco de horas, para mim foi excelente. [...] Eu até brinquei com o pessoal: 'a gente precisa fazer uma greve, um movimento para ficar em casa sexta-feira, porque já estava acostumado'. [...] Depois do que eu já vivenciei, eu gostaria de ficar em casa sim. Você teria a chance de estar fazendo várias coisas, estar estudando, alguma coisa. É um dia a mais que você ganha na vida, eu penso assim". (Gilson)

Mas, assim como ocorre em relação à aceitação do banco de horas, Lucas, que trabalha na linha e tem um outro trabalho fora, ressalta a relação direta entre aceitar a "semana Volks" e não haver demissões na Empresa: “... foi muito interessante porque a gente evitou bastante demissão aqui na Volkswagen. E era uma maravilha, porque a gente trabalhava de segunda a quinta e ficava em casa de sexta, sábado e domingo". E Lucas ainda ressalta que optaria por continuar com a "semana Volks", mesmo com a redução da PLR "se fosse também pra abrir mais vagas no mercado e fosse mesmo pra evitar demissão, né”. Porque é melhor você trabalhar de segunda a quinta do que você ser demitido". (Lucas) 
Ou seja, a questão da demissão exerce sempre pressão direta para que os trabalhadores aceitem ou não uma mudança implementada pela empresa. Por outro lado, é interessante notar que Edgar, que trabalha na produção, disse que não gostaria de retomar a "semana Volks" alegando um motivo muito próximo ao de Lucas, mas a partir de uma perspectiva totalmente diferente, como podemos notar:

“A Semana Volkswagen, ela não é boa. Primeiro que ela te abre a perspectiva de que o mercado
não vai bem, é sinal de que o mercado não vai bem. E quando ela coloca a Semana Volkswagen,
primeiro tem o PLR, você perde no PLR. Porque o PLR compensa aquele dia, você recebe o teu
pagamento integral, porém diminui no teu PLR. E você fica sempre com uma pulga atrás da
orelha: 'quando é que o mercado vai melhorar? Será que o mês que vem o mercado vai aquecer
novamente? O que está acontecendo? A Volkswagen perdeu o mercado? Esse mês ela ficou em $3^{\circ}$
lugar?' Todo esse tipo de coisa a gente procura acompanhar para ficar sempre atualizado". (Edgar)

Finalmente, se compararmos as duas formas recentes de flexibilização do tempo de trabalho, isto é, o banco de horas e a "semana Volks", podemos observar que há uma menor aceitação em relação a esta última. Mesmo que, no limite, a maior parte dos trabalhadores já tenha explicitado que prefere não ter nenhuma dessas formas de flexibilização, sobretudo, porque ambas implicam a redução da remuneração (seja da hora extra ou da PLR), mas também em função da falta de autonomia para decidirem quando trabalhar a mais ou a menos. Duas questões que, por sua vez, alteram totalmente as vivências das outras temporalidades sociais fora do local de trabalho: ou seja, a renda e o controle do tempo.

\section{4 - Tempos dentro do local de trabalho como tempos de não trabalho}

Há ainda uma outra questão a ser analisada que se refere ao tempo que o trabalhador está dentro da fábrica, além do tempo que compõe a jornada de trabalho, e que não é considerado como tempo de trabalho. Os trabalhadores entrevistados da Volkswagen, por exemplo, ficam em torno de $09 \mathrm{~h} 30$ à $10 \mathrm{~h}$ dentro da Empresa. Destas, 8 horas referem-se à jornada de trabalho, sendo, portanto remuneradas; mas há ainda entre $1 \mathrm{~h} 30$ e $2 \mathrm{hs}$, que não são consideradas como tempo de trabalho. Neste tempo temos 55 minutos referentes ao intervalo de almoço, mais 30 minutos antes da jornada de trabalho (ônibus da Empresa chega sempre antes), e 30 minutos depois da jornada, (tempo a espera do mesmo). Nesses 30 minutos, antes e depois da jornada, os 
trabalhadores irão, obrigatoriamente, caminhar dentro da Volkswagen entre a portaria e os setores e trocarem de roupa ${ }^{4}$.

Este tempo adicional à jornada e não remunerado, tanto é utilizado por alguns trabalhadores para bater papo e tomar café como para já começar a trabalhar quando chegam aos setores, mesmo antes do início "formal" da jornada de trabalho. Aldo, que trabalha na linha, ressalta que nesses 30 minutos, entre a chegada do ônibus e a linha começar a rodar, já existe trabalho sendo realizado:

"Sempre teve, todas as vezes que o funcionário chega no local de trabalho dele, ele tem... se o horário de trabalho dele é às $15 \mathrm{~h} 00,14 \mathrm{~h} 55$, ele tem chegar pelo menos 10 a 15 minutos antes, para ele preparar as peças que ele vai usar, pelo menos para começar, então ele já começa trabalhando, ele não fica esperando dar a hora para ir”. (Aldo)

Vale lembrar que na fala de um dos dirigentes sindicais foi dito que a empresa tirou 5 minutos que os trabalhadores tinham para preparar a linha, dado que esta começava a rodar apenas às 6 h05 no período da manhã. Quando pergunto a Aldo se os trabalhadores não reclamam desses 30 minutos antes e depois da jornada de trabalho, ele responde:

"Não. Mas hoje em dia estão reclamando, eles estão abrindo processo. Eu conheço umas duas pessoas que já ganharam. Eu mesmo ganhei porque quando eu abri, já entrou com tudo isso aí, o tempo que eu chegava, quanto tempo eu gastava até chegar ao setor, se eu já chegava trabalhando, na audiência o juiz pega tudo isso. [...] Eles fazem as perguntas quando você vai lá: 'o que você faz, que horas você saí de casa, que horas você entra no ônibus, que horas você desce do ônibus, que horas você passa a sua carteirinha, o que você faz quando você entra dentro da Empresa', tudo isso eles juntam tudo". (Aldo)

Lúcio fala ainda sobre o tempo de deslocamento e sobre os processos abertos por trabalhadores contra a Empresa:

“...eu até soube de casos que a pessoa processou a Empresa por caminhar todo esse tempo até chegar ao local. Eu soube de pessoas que já abriram processo por..., chama até de caminhante. Porque a pessoa caminhava. Porque antes o ônibus levava você até próximo ao local de trabalho, o ônibus parava fora da Empresa, você saía e já tinha os ônibus lá perto, que já levava você a cada setor". (Lúcio)

4. Duas observações. A troca de roupa não é realizada pelos trabalhadores do setor administrativo. No que se refere ao transporte interno, a empresa tirou os micro-ônibus que levavam os trabalhadores aos seus respectivos setores, sendo mantidos apenas para aqueles que trabalham na Ala 17, que é a mais distante. 
Ao analisar a legislação atual sobre a jornada de trabalho, e seu significado de "tempo à disposição do empregador" veremos que já há muitos casos de trabalhadores que, a partir de ações implementadas na Justiça do Trabalho, conquistaram que esse tempo seja considerado como parte da jornada de trabalho. Não apenas esse tempo, mas o que tem sido discutido ultimamente engloba ainda o tempo que os trabalhadores utilizam para caminharem entre os seus locais de trabalho e o restaurante. São ainda decisões pontuais, entretanto, esse movimento demonstra que a definição do tempo de trabalho é uma construção social em constante mudança. Claro que, como o resultado de correlações de forças, uma mudança demora certo tempo para se estabelecer, para criar uma nova ordem social (Sue, 1994).

Felix, da logística, relata que ele deve contar o estoque uns 15 minutos antes da linha começar a rodar. Por outro lado, Rogério, que trabalha com qualidade na usinagem, onde não há linha, entende que o tempo entre às 5h20, quando chega na Volkswagen até às $6 \mathrm{~h}$, quando inicia a jornada de trabalho, é um tempo de entrosamento do grupo.

"É rotineiro que a gente chegue, a gente tem uma mesa parecida com essa, em volta do nosso trabalho, que a gente se reúne com o pessoal, coloca lá o café, toma café, brinca um com outro, fala de futebol. Então eu vejo como um tempo de descontração, até necessário para estar envolvendo o grupo no trabalho, estar todo mundo mais entrosado, porque depois começa a trabalhar, embora às vezes a gente conversa (sobre trabalho), mas aí já é mais difícil, então é um tempo, vamos dizer assim, de entrosamento. [...] Eu nunca ouvi de ninguém que está trabalhando aqui falar que esse tempo deveria ser para receber, mas depois que saem é comum você ouvir algumas pessoas falarem, tem gente que abre processo, querendo receber esse tempo. [...] Eu já vi gente que se aposentou, aí abre o processo dizendo que ele já começa a trabalhar antes das 6 h00, que às vezes ele chega, começa a discutir trabalho com algum colega, só que na prática, sinceramente, eu não vejo". (Rogério)

Uma observação merece destaque no que se refere, sobretudo, aos 30 minutos antes e depois da jornada. Falo do duplo papel que esse tempo pode cumprir. Um deles é de ser realmente um tempo de trabalho não remunerado e o outro, como visto no discurso de Rogério, é de cumprir o papel das pausas, cada vez mais reduzidas, de ser um tempo de conversa, de descontração, possibilitando maior conhecimento dos colegas e entrosamento entre o grupo. A diferença é que as pausas, durante a jornada de trabalho, ainda são consideradas como tempo de trabalho e são, portanto, são remuneradas.

A outra é que, como já vimos anteriormente, a questão do que é socialmente definido como tempo de trabalho e, em contraposição tempo de não trabalho, exerce um papel funda- 
mental na vivência do trabalhador e na sua percepção sobre esta. É o que veremos claramente no diálogo a seguir, onde Eron, que trabalha na qualidade, tenta me explicar que as atividades que ele realiza antes da sua jornada formal não é um trabalho:

"Eron: Chego 5h25, 5h30.

Ana: E aí o que você faz?

Eron: Eu chego, vou para a produção, passo na produção, vejo tudo o que está produzindo. Porque devido ao trabalho da auditoria, a gente procura sempre estar vendo os problemas que podem ocorrer.

Ana: Mas a sua jornada começa a que horas?

Eron: Às 6 h00.

Ana: Mas então antes da tua jornada você já está trabalhando?

Eron: Eu passo só olhando, também não estou já trabalhando. Eu passo olhando, vendo se tem algum problema, sento junto com os lideres, é onde eles passam os trabalhos.

Ana: Isso a que horas?

Eron: Isso antes das 6h00. A gente conversa, a gente bate um papo.

Ana: E vocês ficam até que horas conversando?

Eron: Mais ou menos umas 10 ou 5 para as 6 h00. Aí eu vou lá, tomo um café, uns 10 minutos, às 6 h00 eu já começo a luta.

Ana: Agora esse tempo aqui, anterior, que você está conversando com os lideres, você não recebe por essas horas?

Eron: Não. Não é bem um trabalho.

Ana: É o que?

Eron: É a comunicação que você tem com eles.

Ana: E a comunicação é o que?

Eron: Praticamente se trabalha, mas isso é da gente, é da pessoa, nem todos fazem isso. A gente faz isso diariamente, a gente vai lá conversar". (Eron - qualidade)

Por sua vez, Gilson e Mauro, líder e encarregado, explicitam que iniciam e/ou terminam o trabalho antes ou depois da jornada. Mauro diz que tem de "passar" o serviço para o responsável da tarde, e que, portanto, essa é sua prática diária, mas ressalta: "tudo num tempo saudável, 15 a 20 minutinhos". Por outro lado, o responsável da tarde começa a trabalhar antes da sua jornada, para poder "pegar o serviço". Mas ele nos conta ainda que no banco de horas só entram aquelas horas que somarem mais do que 30 minutos no dia. Isto significa que neste caso há entre 10 e 15 minutos, por dia, de um tempo de trabalho não remunerado. Se pensarmos em um mês, teríamos, no mínimo, umas 4 horas de trabalho a mais, não remuneradas. 
Vale ainda sublinhar que, como já vimos anteriormente, esta não parece ser uma discussão forte entre os trabalhadores, nem mesmo entre estes e o Sindicato. Joice, uma militante do Sindicato, perguntada sobre esses 30 minutos, antes e depois da jornada de trabalho, responde que este tempo não é remunerado e que "É uma boa pergunta, eu nunca vi ninguém reclamar, eu vou começar a pensar nisso".

\section{5 - Considerações finais}

Ao longo deste capítulo analisei como os trabalhadores da Volkswagen do ABC vivenciam cotidianamente seus tempos de trabalho, no local de trabalho, e que representações são criadas a partir de tais vivências. Ou seja, como têm sido as vivências temporais cotidianas dos trabalhadores, em meio aos artefatos tecnológicos, às mudanças na organização do trabalho, na gestão das pessoas, ou na jornada de trabalho, discutidos no capítulo sobre a Volkswagen.

No processo de análise das narrativas discursivas, o primeiro fato que chamou atenção foi a freqüência com que os trabalhadores ressaltaram que trabalhar mais ou menos próximo da linha de produção cria condições muito diferentes no que se refere às vivências do tempo, tanto no espaço da fábrica como fora desta. Estar ou não na linha, ter ou não o seu tempo submetido à imposição desta, possibilita vivências totalmente diferentes, demonstrando que o artefato tecnológico que caracterizou a fábrica fordista, é ainda hoje um grande definidor do tempo de trabalho. Não falo da mesma linha de produção dos anos 1980 ou 1990, com certeza, mas de uma nova linha que, ao mesmo tempo em que mantêm as conhecidas formas de submissão do tempo do trabalhador, ganha inovações que possibilitam novas formas de submissão.

A análise das narrativas discursivas explicitou ainda que, no limite, todos os trabalhadores, independentemente do setor, estão e se sentem de alguma forma pressionados pelo ritmo da linha de produção. Não apenas porque o objetivo da empresa é produzir carros e para isto todos devem passar pela linha de montagem final, mas, sobretudo, porque as novas formas de organização do trabalho acabaram por gerar uma forte dependência entre os diversos setores, gerando um fluxo cada vez mais tenso, intenso e contínuo, que abrange toda a fábrica e ainda os fornecedores externos (Durand, 2004). Mas, ainda que todos de alguma forma estejam pressionados pela linha, seus discursos explicitam vivências muito diferentes em relação ao tempo de traba1ho. Isto porque em outras funções ou setores há outros artefatos tecnológicos ou gerenciais que 
operam como instrumentos de pressão, como os evidenciados pelos trabalhadores da ferramentaria, da qualidade ou do setor administrativo. Vimos nas falas dos trabalhadores que alguns deles, muitas vezes, recorrem à comparação com a linha para falar sobre o seu próprio tempo de trabalho, principalmente, quando o assunto diz respeito às pausas individuais e coletivas ou à questão da liberdade e controle do trabalho e do tempo.

Também foi possível verificar que a maneira como cada trabalhador vivencia uma mudança tecnológica ou organizacional depende da sua história e da sua expectativa dentro e fora do local de trabalho, dos seus valores em relação ao trabalho, dos seus atributos sociais e pessoais. Os trabalhadores mais jovens e que estão estudando, por exemplo, são os que mais disseram ter gostado da "semana Volks", quando tiveram uma redução do tempo de trabalho e da remuneração.

Assim, para os trabalhadores que estão na linha, o tempo vivenciado tem como características principais a imposição, intensidade, continuidade, repetição e o extremo controle. Causando desconforto, dor e doença. Sobretudo porque este tempo imposto desconsidera ainda as necessidades mais básicas dos trabalhadores. Num sentido contrário, os trabalhadores que estão fora da linha dizem que, apesar de também ser um tempo muito corrido, é possível fazer o seu tempo, ter um intervalo de descanso e, sobretudo, não depender de ninguém para ir ao banheiro. E estes trabalhadores explicitam ainda diversas mudanças que têm ocorrido e que têm afetado diretamente seus tempos na fábrica e também fora desta. De forma que, se por um lado o trabalho na linha impõe um ritmo determinado, contínuo e repetitivo, por outro, também as mudanças organizacionais e gerenciais acabam por impor um ritmo de trabalho cada vez mais alucinante.

Como conseqüência, dois setores (a linha e a ferramentaria), que antes representavam na produção extremos no que se refere à autonomia em relação ao tempo, hoje em dia, em função das mudanças na organização do trabalho impostas pela Volkswagen, têm se aproximado bastante. E esta aproximação, vale ressaltar, não se dá porque os trabalhadores da linha passam a ter maior liberdade em relação ao tempo, mas porque os ferramenteiros passam a ter menor liberdade e autonomia. O que demonstra que em alguns setores onde os trabalhadores eram mais donos do seu tempo, isso tem sido alterado, transformando muitos tempos alocados em tempos impostos.

Em relação aos trabalhadores da linha, vale ressaltar, ainda, que as diferenças aparecem mesmo entre os trabalhadores que estão alocados em uma mesma linha de produção. Antes da análise destas entrevistas, o recorte metodológico desta etapa da pesquisa selecionava apenas os trabalhadores que estavam ou não em uma linha, mas diante da análise das narrativas discursivas 
foi possível perceber as inúmeras diferenças que ocorrem entre as linhas e refazer a abordagem dos dados. Esse processo foi importante também para deixar claro o quanto não há idéias absolutas sobre as linhas. Existe a linha no passado e a mesma linha no presente, por exemplo, a linha do Gol. Mas mesmo nessa linha no presente, os trabalhadores relatam vivências diferentes das vividas no passado, dependendo da história de cada um dentro da empresa: para quem é mais velho e já teve outras experiências na linha mais antiga ou para os mais jovens que acabaram de sair do Senai. Tema que voltarei a enfocar no capítulo 8, ao olhar especificamente para as diferentes gerações presentes na empresa. Há ainda as diferentes linhas nos diversos setores e, neste caso, estar na linha da montagem final é uma experiência distinta de estar na da estamparia ou ainda na da pintura. É necessário salientar, também, as diferenças em cada função numa mesma linha de produção, além de diferenças em relação ao turno de trabalho, o que será discutido de forma mais aprofundada no capítulo 7 .

Além destas, foram explicitadas as diferenças nas linhas mais novas, como a do Pólo e do Fox, sobretudo a dificuldade para os trabalhadores criarem tempos de não trabalho, durante o tempo imposto da linha. Isto, porque devemos lembrar que uma das maiores reclamações dos trabalhadores que estão em uma das linhas é justamente a falta de tempo livre para ir ao banheiro, tomar café ou descansar um pouco. De forma que as linhas mais "modernas", assim denominadas pelos próprios trabalhadores, ao invés de atender necessidades básicas do trabalhador, são pensadas e estruturadas, cada vez mais, com o objetivo de atender os interesses da Empresa, qual seja, o de transformar todos os tempos em tempos produtivos.

Vale ressaltar, entretanto, que nos relatos dos dirigentes sindicais, no capítulo sobre a Volkswagen, nenhum deles fez qualquer ressalva em relação a essa maior dificuldade dos trabalhadores em criarem tempos de não trabalho nas novas linhas. O que se discute coletivamente é a velocidade da linha, mas não a lógica da linha em si mesma. Além disso, como também enfatizado pelos dirigentes, havia a necessidade de "modernizar" a fábrica antiga que estava sendo ameaçada de fechar.

Sobre as mudanças na organização do trabalho, as novas formas de usos e gestão da força de trabalho, as narrativas discursivas dos trabalhadores demonstram que estas foram vivenciadas de maneiras muito diferentes, também a depender do trabalhador estar ou não em uma das linhas. Nem todas foram citadas por todos os trabalhadores, algumas, como vimos, foram citadas pelos dirigentes, mas não pelos trabalhadores. Algumas foram aplicadas apenas em determinados setores; outras, apesar de terem sido aplicadas em todos, foram sentidas de 
maneiras diferentes pelos trabalhadores; e algumas ainda não foram sentidas como tendo alterado o tempo de trabalho.

Os trabalhadores do setor administrativo, sobretudo os ferramenteiros, ressaltaram, por exemplo, a contradição de medidas simultâneas como o aumento da pressão sobre a redução dos prazos e o aumento da pressão sobre a qualidade, e num contexto de redução do número de trabalhadores. Vemos, em muitas falas, que esses trabalhadores consideram que, para a empresa, o importante é a quantidade e não a qualidade dos produtos. A multitarefa, por sua vez, aparece como a mudança mais criticada pelos trabalhadores da produção, tanto aqueles que estão em uma das linhas como os que são chamados para exercerem, por um tempo, o trabalho nas linhas. Já no caso dos ferramenteiros, a terceirização é muito mais citada como tendo intensificado o trabalho, pois ela tem causado muito retrabalho em função do aumento das peças com defeito.

Ou ainda, a questão do just in time que, embora tenha sido muito citada pelos dirigentes como tendo intensificado o trabalho em quase todos os setores, foi citada apenas por um trabalhador. Podemos pensar que isso se deve ao fato de ser uma mudança organizacional mais antiga - apesar de provocar impactos até os dias atuais -, mas também pelo fato do just in time não ter sido objeto de negociação. Não gerando, portanto, um espaço de debate em relação ao tema, sobretudo no que se refere aos impactos diretos para o tempo de trabalho.

No que se refere às mudanças que ocorreram diretamente no tempo de trabalho, vimos, no capítulo sobre a Volkswagen, que ocorreram a partir de uma diversidade de eventos, tais como: a redução das pausas individuais e coletivas, a redução da jornada, da extensão do tempo produtivo e da flexibilização do tempo de trabalho - via trabalho em turnos, noturno, hora extra, banco de horas, banco de dias e "semana Volks". E nesse caso, mesmo que praticamente todos os trabalhadores tenham passado por essas mudanças, os relatos explicitaram vivências temporais cotidianas totalmente diferentes. E mais uma vez, estar ou não submetido ao império de uma linha de produção cria condições totalmente diferentes para que os trabalhadores experimentem as mudanças tanto na organização do trabalho como na do tempo de trabalho.

Ao compararmos as duas formas recentes de flexibilização do tempo de trabalho, isto é, o banco de horas e a "semana Volks", podemos observar que há uma menor aceitação em relação a esta última, independente do setor ou função do trabalhador. Mesmo que, no limite, a maior parte dos trabalhadores já tenha explicitado que prefere não ter nenhuma dessas formas de flexibilização. Sobretudo, porque ambas implicam a redução da remuneração (seja da hora 
extra ou da PLR), mas também em função da falta de autonomia para decidirem quando trabalhar a mais ou a menos. Duas questões que, por sua vez, alteram totalmente as vivências das outras temporalidades sociais fora do local de trabalho, ou seja, a renda e o controle do tempo. Neste caso, os trabalhadores da linha e os mais jovens que estudam reclamam muito mais do banco de horas. Esses mesmos trabalhadores mais jovens, estudantes; aqueles que têm outro emprego fora da Volkswagen; e ainda aqueles com salários mais altos na Empresa, são os que mais gostam da "semana Volks".

Vimos, ainda, que os trabalhadores ressaltam muito mais a redução dos intervalos individuais e coletivos - a partir da ênfase dada à ineficácia da adoção dos monitores depois da implantação das células, do que a própria redução da jornada de trabalho, geralmente utilizada para recuperar a falta de tempo para dormir. Isto porque, dada a redução cada vez maior do número de trabalhadores, os líderes acabam por assumir o lugar de um único trabalhador no lugar de substituir, pontualmente, cada trabalhador que precise sair da linha.

De forma resumida, para os trabalhadores que não estão na linha, a redução dos prazos, somada à pressão pela qualidade, num contexto de redução do número de trabalhadores é o mais explicitado como tendo modificado o tempo de trabalho. E para os trabalhadores da linha é a combinação do banco de horas com a multitarefa que tem levado à extrema intensificação do tempo de trabalho. Pois, como já discutido anteriormente, a combinação dessas mudanças leva o trabalhador a estar sempre no momento - em função do banco de horas -, e no espaço - dada a multitarefa -, onde há maior demanda de produção. 


\section{VIVÊNCIAS DOS TEMPOS NOS TURNOS DE REVEZAMENTO E NO TRABALHO NOTURNO}

0

turno de trabalho é um outro elemento a balizar fortemente as vivências dos trabalhadores no que diz respeito aos tempos sociais (Grossin, 1991) ${ }^{1}$. Com a discussão realizada no capítulo anterior, pudemos perceber que a organização do horário de trabalho em horários atípicos como os turnos de revezamento e o trabalho noturno - são as formas que mais desorganizam o tempo fora do local de trabalho, já que exigem uma equação temporal pessoal e familiar capaz de acomodar, da melhor maneira possível, os diversos tempos sociais. Desta forma, a análise das vivências temporais cotidianas é de extrema importância para melhor compreendermos a dessincronização dos tempos sociais.

Foi essa constatação sobre a necessidade de reacomodação da vida dos trabalhadores que me instigou a construir a reflexão deste capítulo, cujo foco principal é compreender como ocorrem as vivências temporais cotidianas, por meio da análise das narrativas discursivas dos trabalhadores que já trabalharam ou que trabalham em um desses horários alternativos. Para tal, partindo do pressuposto de que esses tempos desorganizam a vida dos trabalhadores, busquei responder às seguintes questões: como esses trabalhadores reorganizam o tempo fora da fábrica, a fim de manter suas relações sociais com a família, com os amigos e com a sociedade em geral? Porque os trabalhadores optam por horários como o pé-quebrado e o III turno? Porque desistem desses horários? Há diferenças no trabalho desses horários, em relação ao trabalho de I e II turnos? É um tempo de trabalho mais tranqüilo ou de maior pressão?

Para buscar responder a essas questões, observo as falas dos trabalhadores com respeito às experiências nos turnos de revezamento e no período noturno (também chamado III turno e

1. A discussão do trabalho em turnos ou noturno não é algo novo, já tendo sido, inclusive, objeto de diversas discussões teóricas e empíricas, como, por exemplo: Silva, (1987), Rurenfrantz et alli (1989), Guimarães (1990) e Fischer, (2003). 
pé-quebrado) ${ }^{2}$, que, por sua vez, explicitam três categorias distintas de vivências, dentro e fora do local de trabalho, a partir das quais organizei este capítulo. Primeiro analiso as falas dos trabalhadores sobre as vivências na época do turno de revezamento, no qual os trabalhadores não tinham como escolher o horário de trabalho; trato, em seguida, das narrativas daqueles que já trabalharam no III horário ou no pé-quebrado, mas que, por algum motivo, desistiram desse horário. Finalmente, discuto as experiências daqueles que atualmente trabalham no período noturno, buscando compreender as suas motivações para lá permanecerem e as formas encontradas para gerir os tempos fora da fábrica.

\section{1 - Na época dos turnos de revezamento}

$\mathrm{Na}$ Volkswagen Anchieta, o trabalho em turnos de revezamento teve vigência até o ano de 1999. Até então, os trabalhadores ficavam 15 dias em cada um dos três turnos, no caso do regime de $6 \mathrm{X} 1$, e 45 dias em cada turno, no caso do regime $5 \mathrm{X} 2$, onde são apenas dois turnos. Nas falas de todos os trabalhadores que vivenciaram os turnos de revezamento foram apontados diversos pontos negativos sobre o trabalho nesses horários. Busquei então esclarecer, durante minha conversa com o gerente de negociações trabalhistas da Volkswagen, se o fim do revezamento tinha sido uma demanda dos trabalhadores ou uma iniciativa da empresa.

\footnotetext{
"Não, não, na verdade foi uma junção de fatores. A nossa legislação é uma legislação bastante ultrapassada, infelizmente ela não confere bastante segurança para quem administra pessoas. E nesta insegurança, o revezamento de turnos poderia classificar, alguns juízes vinham classificando, como turnos ininterruptos. O que não faz nenhum sentido do ponto de vista lógico; até mesmo por parte do sindicato, nós nunca tivemos demanda desse tipo. [...] ...até pelo entendimento da companhia de ser melhor a administração concentrando os empregados, nós concentramos. Hoje, eles trabalham em turnos fixos". (Gerente de negociações trabalhistas)
}

2. Há vários tipos de turnos na Volkswagen. Para o que nos interessa é importante saber que o setor da estamparia funciona 6 X1, com 3 turnos: I- 6:00 às 13:34, II - 13:34 às 22:12 e III - 22:12 às 6:00, somando 1.108 trabalhadores. 5X2, com 2 turnos: I- 06:00 às 14:55 e II - 14:55 às 23:36, com 7.179 trabalhadores e o pé- quebrado, no horário entre 22:15 e 6:00, com apenas 257 trabalhadores. Além dos horalistas que, como já falado, têm a mesma jornada que os horistas, isto é, entre 8:00 e 17:00, abrangendo 257 trabalhadores. Essas informações são referentes à maio de 2005. 
Na resposta do gerente, vemos que a preocupação da empresa era com a possibilidade do turno de revezamento ser classificado como turno ininterrupto, dado que, após a Constituição Federal de 1988, estes teriam uma duração de 6 horas diárias e não de 8 horas. Mas, independentemente da intenção da empresa, o fato é que todos os trabalhadores que falaram sobre esta questão, concordam com esta decisão, uma vez que declararam não ter gostado de trabalhar na época que havia o revezamento. Todos foram unânimes em avaliar a experiência de revezamento como negativa, "muito ruim", porque até questões básicas como dormir e se alimentar ficavam totalmente "bagunçadas". Isto porque se construía um abismo muito grande entre os horários individuais e sociais, como veremos nas falas de Márcio e Eron, a seguir:

"É muito desgastante. Porque é assim, quando você está acostumado com um período, você muda, aí seu corpo estranha porque o seu horário de dormir é diferente, comer em horário diferente, você mexeu com todo o seu metabolismo. Aí a hora que você está acostumado com aquilo, aí muda de novo". (Márcio)

"O pior era quando você estava de manhã e ia para a noite, praticamente você chegava em casa, cadê o sono? Você estava de manhã, até você acostumar, demorava três, quatro dias para você acostumar. Para a noite, era pior, porque chegava a noite começava a dar sono, dava 3h00, 4h00 da manhã, que sono! Ia lá tomava um café para ver se acordava, aí você agüentava e ia embora". (Eron)

O desgaste fica explícito na dificuldade que esses trabalhadores relatam terem sentido para se acostumar com horários tão diferentes e, sobretudo, com as mudanças freqüentes. Essa questão era tão relevante na época do revezamento que a própria Empresa chegou a fazer pesquisas para saber como os trabalhadores se mantinham acordados durante a noite, como indica o relato a seguir:

"E coisas assim de perguntar para o empregado: 'como que você faz para se manter acordado durante o trabalho'. Coisas assim, as pessoas falam o famoso café, muito café, alguns falam assim: 'tem dias que eu tenho que bater a cabeça na máquina pra cada momento ter uma reação física, pra poder ficar desperto'. [...] Esses dias eu vi também uma reportagem que as funções administrativas, muitos confessaram que conseguem, de alguma forma, cochilar durante a noite, porque não é o trabalho que manda nele, ele que manda no trabalho. Então os famosos tomadores de conta, que seria: o vigia do estacionamento, o guarda, o porteiro, o recepcionista, o zelador. [...] Agora o trabalhador aqui, onde você tem uma linha de produção, principalmente nas máquinas, ele não manda, a máquina que dá o comando" (gerente de RH). 
Desgaste que aparece tanto no tempo dentro da fábrica como fora desta, alterando as 24 horas dos trabalhadores e também daqueles que estão à sua volta. Por isso Eron nos fala sobre seu tempo de não trabalho, frisando que o final de semana era totalmente dedicado à família: "A vida da gente praticamente era o final de semana. A semana se adequava à fábrica e o final de semana $\mathrm{a}$ gente sempre fazia uma festinha, ia passear, ia para a praia, sempre foi assim a vida da gente".

Entretanto, mesmo o tempo dedicado à vida, como alude Eron, poderia estar comprometido. Como relata Robson, quando estava em casa não tinha disposição para fazer nada; acordava, ficava esperando chegar a hora para ir trabalhar e às vezes cochilava novamente. No relato do gerente de $\mathrm{RH}$, a seguir, vemos que as reclamações dos trabalhadores também se referiam à dificuldade de relacionamento com a família:

\begin{abstract}
"Muitos reclamavam que de manhã, quando eles chegavam, o filho passava em cima da barriga dele, ele queria dormir e o filho queria brincar. Porque era a hora que o filho estava acordado. E também a relação com a mulher, a hora de fazer o almoço, o jantar, ele [trabalhador] acaba interferindo na rotina da casa. [...] Isso era complicado e acabava causando rupturas às vezes com a família. (Gerente de $\mathrm{RH}$ )
\end{abstract}

O fato de trabalhar em turnos de revezamento implica dormir enquanto a maioria das pessoas está acordada. Isso não apenas altera a quantidade do tempo dedicado às outras atividades fora do local de trabalho, como interfere também na qualidade do tempo em que o trabalhador está disponível para as pessoas e para as outras atividades. Esse tempo atípico de trabalho não concorre apenas com o tempo a ser dedicado à família, mas também ao estudo, como nos explica Marcos, em seu relato sobre a difícil equação entre o tempo do trabalho em turnos de revezamento e o tempo da escola. Ele afirma que havia pouquíssimo tempo para dormir, pois logo precisava ir para a escola. Nesse caso, é evidente que a qualidade do tempo dedicado ao estudo não seria o mesmo, caso ele estivesse descansado.

"Era complicadíssimo por que quando você acostuma a almoçar e jantar num horário, você trocar é duríssimo. E eu, além de chegar, quando eu trabalhava à noite chegava 1 h09 da manhã, eu acordava as 7 h para ir para a escola. Então eu saía daqui [Volkswagen] 1h09, chegava em casa 2h30, 7h já estava na escola, na época eu fazia o colégio, então era pauleira" (Marcos).

No que se refere às relações com amigos ou namorados, Robson, que entrou na Volkswagen na época dos turnos de revezamento, considera que o pior horário era o II turno, 
sobretudo, na sexta feira e no final de semana. Ele diz que raramente conseguia sair com a sua namorada porque chegava em casa muito tarde. Hoje ele ainda trabalha no II turno, mas em regime fixo, e continua a não gostar desse horário, pois tem a sensação de que não há tempo para fazer muita coisa, daí preferir trabalhar pela manhã ou à noite,

"Eu não gosto. Porque eu gosto de um futebol à noite, eu gosto de sair num shopping. Então para mim assim, que nem eu chego em casa à meia- noite, ai durmo, aí acordo 10h, então eu faço um negocinho, eu almoço, eu já tenho que ir para a empresa. Ai para mim, sabe, depois do almoço eu trabalhar, eu prefiro acordar mais cedo de manhã, às $5 \mathrm{~h}$ para entrar as 6 . Eu já estou o que? Sete anos já no turno só de dia. Então me acostumei. Tem gente que não gosta. Para descansar é melhor o das 15:00, das 15:00 as 23:30 [II turno], lógico, você acorda as 10h, você está descansado, mas eu não gosto. Agora das 10 às 6 [III turno] eu podia encarar de novo. Já gostaria entendeu" (Robson).

Como no caso de Robson, Gilson nos conta que o trabalho em turnos de revezamento foi um dos elementos que contribuiu para a dificuldade que enfrentou ao entrar na Volkswagen,

\footnotetext{
"Mas assim, fui trabalhando. No começo eu confesso, eu sofri muito. [...] Eu não estava me adaptando muito naquela situação, não estava gostando. Eu não sei, acho que era mais eu mesmo não estar acostumado com aquilo, e o ritmo. Eu nunca havia trabalhado em três turnos, era sempre um turno fixo" (Gilson).
}

Vemos que ao responder sobre o trabalho em turnos de revezamento todos os entrevistados avaliam a experiência como negativa, tanto em função de problemas de adaptação, no que se refere ao sono e à alimentação, como também no que se refere à diferença entre os seus horários e os da família e dos amigos. Esses relatos também evidenciam que os diversos tempos sociais concorriam entre si, tornando impossível a sua harmonização. Os piores horários identificados nas falas são o III e o II turnos, mas, o que é mais fortemente rejeitado nas entrevistas é o incômodo causado pelos períodos de transição entre um turno e outro. Além disso, essas percepções negativas dos entrevistados sobre suas vivências temporais contribuem para a nossa compreensão sobre o fato dos trabalhadores terem aprovado a decisão da Volkswagen em transformar o turno de revezamento em fixo. 


\section{2 - Vivências do trabalho noturno, em tempos passados}

Após o fim dos turnos de revezamento, em 1999, os trabalhadores fizeram suas opções em relação ao turno que gostariam de trabalhar, em uma pesquisa realizada pela Empresa. Alguns deles optaram pelo III turno ou pelo "pé-quebrado". Aldo, por exemplo, diz não ter ficado incomodado com o trabalho no "pé-quebrado", apontando como único problema a menor opção de transporte. Vagner, que já trabalhou tanto no I como no III turnos, considera este último como o pior horário: "você perde o dia inteirinho, praticamente para dormir" e, dessa forma, mesmo com a vantagem do adicional declara: "para mim não vale a pena”. Por outro lado, ele considera o II turno, em que está atualmente, o melhor de todos. Em relação ao tempo fora do local de trabalho, comenta que o interessante é não precisar acordar cedo e, conseqüentemente, poder dormir mais tarde, além de ter tempo para desenvolver outras atividades durante o dia, como ir ao mercado ou ao banco. E no que se refere ao tempo de trabalho, entende que o II horário é o mais sossegado, pois há menos chefias para "pegar no pé", de forma que ele "tem mais liberdade" para trabalhar.

Lucas relata que foi para o III turno em função do adicional noturno e que ali ficou apenas por três anos, "tempo suficiente para pagar a casa", porque não gostou desse horário. Depois disso escolheu o II turno, para poder se dedicar a outro trabalho no período matutino. Já Flávio, que trabalhou no II e no III horários, relata que achou "horrível" tanto um como outro. No caso do II, o motivo alegado para não gostar foi o mesmo mencionado por Robson: "não dava tempo durante o dia para fazer nada". Hoje diz que está satisfeito trabalhando no I horário. É interessante notar que embora haja uma unanimidade nas falas dos trabalhadores em relação à rejeição aos turnos de revezamento, depois que esses turnos passam a ser fixos, vemos declarações de preferência por um ou outro turno e por motivos diferentes. Algumas vezes, porém, encontramos o mesmo motivo para justificar diferentes escolhas de turnos, como é o caso de Lara e Joice. A primeira diz preferir o I turno para ficar com a filha à tarde, e Joice, ao contrário, que prefere o II turno, para ficar com a filha pela manhã. Isto é, essas escolhas são fruto de equações temporais pessoais que retratam diferentes vivências cotidianas.

Saulo, que trabalhou durante 2 anos no período noturno, Wilson e Álvaro ${ }^{3}$, que ficaram apenas 6 meses, foram unânimes em rejeitar a experiência, qualificando o trabalho como "muito

3. Esses três trabalhadores: Saulo, Wilson e Álvaro, hoje são representantes sindicais, pela oposição sindical, e já trabalharam no III turno, em tempos passados, antes de serem membros da Comissão de Fábrica ou do Comitê Sindical de Empresa. 
ruim". Por isso mesmo, logo que puderam, solicitaram a transferência para outros horários, alegando problemas tanto fora como dentro da fábrica. Saulo conta que embora a mudança tenha sido uma demanda da Empresa, na época ele a considerou como "uma boa oportunidade para resolver os problemas financeiros". Mas, ao final, sentiu que isto não ocorreu: “... achei também, como ele [Wilson] falou, que as coisas fossem melhorando e não vejo que melhorou coisa nenhuma, porque você acaba entrando em dívidas maiores, você passa a se privar de uma série de coisas". Indago a quais privações ele se refere,

"Familiar, a parte de lazer. Eu mesmo tenho uma dificuldade muito grande de dormir durante o dia, porque moro de frente para uma escola, que tem $1^{\circ}, 2^{\circ}$ e $3^{\circ}$, como diz na fábrica, turno. Então fico parecendo aquele bonequinho do Tom e Jerry, coloco o travesseiro e fico pulando na cama. Então para mim não me fez bem, acho que a minha saúde é mais importante do que outras coisas. Porque você sente, a médio e longo prazo, você vai sentindo" (Saulo).

Tanto o caso de Wilson como o de Saulo foram demandas da Empresa, mas o de Álvaro foi uma escolha. Todos, porém, dizem ter aceitado ou demandado a ida para o "pé-quebrado" em função do adicional do trabalho noturno, de $25 \%$. Entretanto, contam que rapidamente perceberam que não seria possível continuar neste turno, permanecendo por apenas 6 meses.

\footnotetext{
"Meu caso, eu trabalhei 6 meses porque estava precisando de soldador à noite. Aí pediram para mim ir lá colaborar, eu fui, fiquei 6 meses, depois saí, não agüentava. [...] É que nem o caso dele [Saulo], não dormia durante o dia, até dinheiro eu ia tirar no caixa eletrônico, esquecia o dinheiro lá. Para mim a noite foi feita para dormir ou para a balada mesmo, menos para trabalhar" (Wilson).

“Terrível, não foi legal não. No início eu chegava de manhã, não conseguia dormir, eu ia ter sono só à tarde. Eu comecei a inverter, chegava em casa não ia dormir, eu andava, saía, às vezes ficava acordado fazendo alguma coisa, e comecei a dormir 1h00, $2 \mathrm{~h} 00$ da tarde, aí eu já dormia direto até as $8 \mathrm{~h} 00$, já acordava no horário praticamente de ir trabalhar. Me adaptei dessa forma, mas eu acho que você perde muito em relação a estilo de vida, vamos dizer assim. Você passa a ter menos contato com a família, lazer como ele falou, acho que a saúde. Quem não consegue se adaptar fica debilitado, você fica mais frágil no sentido de pegar um resfriado, esse tipo de coisa.”(Álvaro).
}

Álvaro, além de ter falado sobre a dificuldade em relação ao sono, do risco em relação à saúde, frisa a menor convivência com a família e demonstra como os trabalhadores vão mudando os hábitos para tentar se adaptar ao novo tempo, para buscar reacomodar todos os 
tempos sociais. Mas, se ainda é possível a adaptação individual, isto é, com o seu próprio tempo de sono, é muito mais difícil em relação às outras pessoas, que têm uma vivência temporal cotidiana tão diferente. E Álvaro relata ainda que "o seu rendimento profissional também cai, quando você não se adapta", ou seja, a falta de sono lhe causava muita indisposição o que acabava por interferir e comprometer a "qualidade do trabalho".

Saulo, que não trabalha em uma das linhas, também fala a respeito da falta de disposição dos trabalhadores no III turno, em comparação aos outros turnos, reportando-se aos diferentes ritmos pessoais ao longo da jornada.

“... na parte da manhã, você tem uma disposição melhor porque você já vem descansado [...]. Na parte da tarde, depois do almoço, você já vem com uma preguiça, um pouco mais indisposto. Você faz a produção, mas com aquele esforço maior mesmo. Se você trabalha num horário que você não se adapta, é que nem o Álvaro, a dificuldade termina sendo um esforço dobrado" (Saulo).

Álvaro também comenta: “eu acho que acaba até trabalhando um pouquinho mais" porque “eu passo a trabalhar dobrado, eu vou trabalhar forçado, porque eu não dormi direito”. E no caso dos trabalhadores que estão em uma das linhas de produção, há ainda o risco do ritmo da linha aumentar, quando há atrasos de produção, seja no I ou no II turnos, algo que era comum na linha de montagem de funilaria, como relatado por Wilson.

“... lá você acelera a linha na hora de ir embora porque de manhã, roda normal, aí à tarde sempre tem algum atraso, alguma coisa, aí eles querem tirar a produção que atrasou. [...] Cada encarregado lá tem uma produção a ser tirada, então você tem o tempo, divide, um tanto de carro por hora, só que se deu problema na primeira hora, então na segunda hora vão ter que sair os carros, que eram para ter sido feitos na primeira. [...] A gente da Comissão tem que estar em cima para colocar mais pessoas, se a gente não está, eles tentam tirar com o mesmo numero de pessoas, acelera a linha. Então a gente tem que estar acompanhando para eles colocarem mais pessoas, para tirar a produção" (Wilson).

Ao final da análise dos discursos destes trabalhadores que escolheram ir para o III turno ou "pé-quebrado", vimos que nem todos os trabalhadores vivenciaram os mesmos horários de trabalho da mesma forma, isto porque, há uma maneira pessoal de cada um se acomodar aos enquadramentos temporais aos quais estão inseridos (Grossin, 1991). Neste grupo, apenas Aldo nos diz que a sua ida para o III turno não lhe trouxe problemas. Para 
alguns trabalhadores o maior problema é estar no II turno, porque se tem a impressão de que o tempo livre durante a manhã passa muito rápido e "não dá tempo de fazer nada", sendo que alguns trabalhadores chamam esse horário de "o turno dos preguiçosos". Já nos casos de Wagner, Lucas, Wilson, Saulo e Álvaro, a redução do convívio com a família, tanto no que se refere à quantidade do tempo dedicado como à sua qualidade, acabou não conferindo um sentido para se manter nesses horários atípicos de trabalho, mesmo com o adicional de $25 \%$. Além disso, a dificuldade para dormir, bem como a questão da saúde, acabaram, do mesmo modo, se sobrepondo à possibilidade de aumento na remuneração.

Mas o que há em comum, é que praticamente todos ressaltam que foram para o horário de trabalho noturno ou aceitaram a solicitação da Empresa, em função do adicional, entendendo que com ele poderiam resolver problemas financeiros vindos de fora do local de trabalho. Da mesma forma, quando da desistência, é a dificuldade de adaptação, seja em relação ao sono, à alimentação, à saúde, ou à falta de contato com a família - todos fatores igualmente vindos de fora do local de trabalho -, que levam o trabalhador a buscar sair deste turno.

\section{3 - Vivências do trabalho noturno, no tempo presente}

A questão do adicional noturno também é mencionada pelos trabalhadores que em 2005 estavam no III turno ou no "pé-quebrado", como no caso de Otelo. Ele relata que foi para o "péquebrado", na ala da pintura, porque precisava pagar a compra da casa.

\footnotetext{
"Porque teve um momento que eu precisava aumentar um pouco a renda familiar. É porque eu comprei a casa e aí começou a apertar as coisas. E foi financiado pela Caixa e veio uma dívida que eu não tinha como pagar. Aí essa dívida começou a atrapalhar um pouco o meu orçamento, então para dar uma equilibrada, eu pedi para ir para o "pé-quebrado"” (Otelo).
}

No início menciona que pretendia ficar apenas seis meses, mas que já está há dois anos, “...eu acabei gostando e não quis mais voltar”, já que não teve problemas com a mudança de horário. Afirma que para ele ainda é interessante trabalhar à noite e, após uma risada, responde: "Não sei se é bem interessante porque tem os seus pontos positivos e os negativos, mas eu acho que ainda prevalece, no momento, para mim é interessante." No que se refere ao tempo dentro a Volkswagen, Otelo, que já trabalhou nos três turnos, entende que "quem trabalha na linha de 
produção o ritmo não muda". Isto é, mesmo sendo diferente a quantidade de carros que deve ser produzida, o número de pessoas será proporcional, logo, o ritmo de trabalho será o mesmo. A mesma idéia é expressa por Ângelo, ao comparar o trabalho na linha e fora desta,

“[...] Mas, a gente que trabalha em linha de produção, não tem essa de você: 'vou parar um pouquinho'. Se você parar um pouquinho, o carro vai embora. [...] A questão do ritmo da linha, o ritmo é o mesmo. E a noite, é claro que na pintura, na [Ala] 13, quando não tem representante à noite aí a chefia aproveita e faz acelerar mais" (Ângelo).

Ou seja, mais uma vez a diferença entre trabalhar em uma das linhas de produção ou em outros setores é explicitada pelos trabalhadores, mesmo quando o foco é a questão do turno de trabalho. Se em outros setores o ritmo pode variar em função da disposição dos trabalhadores, não que isto seja a regra, na linha ele pode até ser mais intenso, em função da redução do número de representantes sindicais. Por outro lado, Otelo entende que "em termos de pressão, de chefia" também na linha ocorre o mesmo que nos outros setores, isto é, o trabalho é mais tranqüilo. Não porque o ritmo seja menor, mas porque há menos pressão da "chefia".

“Tipo, de manhã tem um movimento muito grande porque é chefia, é visita, são um monte de coisas que acontecem. Quando é à tarde, é um pouco mais leviana. Já quando é a noite não tem ninguém, são os próprios trabalhadores ali, e nem gerente passa na área às vezes, então é sossegado...”(Otelo).

Em relação ao tempo fora da Empresa, nem todos têm o mesmo ritmo, mas Otelo nos conta como, normalmente, é seu dia. Ele chega à casa em torno de $07 \mathrm{~h}$ da manhã, toma café e vai dormir até as $12 \mathrm{~h}$, quando levanta para levar a filha à escola. Volta para casa, assiste o jornal e dorme de novo até às $18 \mathrm{~h}$, quando vai buscar a filha. Depois, às $20 \mathrm{~h} 30$, vai para o trabalho. No que se refere à alimentação, ele relata que apenas toma café quando chega em casa, de manhã, e depois janta na fábrica, as $22 \mathrm{~h}$. "E às vezes, quando tem alguma coisa para participar eu levanto mais cedo, não tem stress assim", mas faz questão de frisar que, diferentemente de Ângelo, "não me acorda a não ser por um problema sério. Tem um irmão que está precisando urgente? É doença? Tudo bem, até que eu permito ainda [...] Senão eu fico bravo, fico mal humorado". Ainda no que se refere ao tempo fora do local de trabalho, 
“Em relação ao convívio com a família, para mim não mudou nada. Pelo contrário, quando trabalhava durante o dia, não tinha esse tempo de estar levando o filho para a escola, buscando o filho na escola. Hoje eu já tenho mais esse contato, aliás o convívio com a família, para mim, está até maior do que antes" (Otelo).

Entretanto, mesmo Otelo tendo falado que após a sua ida para o trabalho noturno ele passou a ter mais tempo para estar com a família, quando pergunto sobre qual a atividade que ele considera mais importante, no final de semana, ele responde:

"Não sei especificar assim o mais importante. Acho que o mais importante é o convívio com a família, porque o convívio na família, esse pouco tempo que eu fico com a família aqui, eu acho que é o mais importante. A pesar de que é pouco tempo, que é um tempo que você pode ver que é, eu durmo, então é um tempo um pouco restrito. Mas esse pouco tempo, eu acho que é o mais importante" (Otelo).

Otelo ressalta ainda que geralmente, durante a semana, fica pouco tempo com a sua esposa, pois ela estuda e sai de casa às $18 \mathrm{~h} 50$, lembrando que ele acorda por volta de $18 \mathrm{~h}$, voltando às $22 \mathrm{~h} 40$, quando ele já não está mais em casa. Também Orlando me conta que foi uma escolha ir para o III turno em função do adicional, já estando nele há dois anos, justamente por não ter sentido dificuldade para se adaptar, sobretudo no que se refere ao sono, que ele considera o mais importante. Isto porque conta que já viu vários casos nos quais os trabalhadores tiveram muita dificuldade para se adaptar em função de problemas com o sono e depois, dentro do local de trabalho, ocorreram diversos problemas como acidentes ou doenças. Assim, Orlando considera que "agressivo" para a sua saúde era não conseguir dormir cedo e ter que acordar as $4 \mathrm{~h} 30$ da manhã, quando trabalhava no I turno. Por isso, a sua maior surpresa foi a boa adaptação, já que depois de um mês ele diz não ter sentido mais nenhuma dificuldade.

No que se refere ao seu tempo fora da Empresa, ele também relata que durante a semana não almoça, pois quando chega em casa toma um café, fazendo o mesmo quando acorda, e depois janta na Empresa. Orlando, do mesmo modo que Otelo, ao ser questionado sobre o que mais gosta de fazer na vida, relata que gostaria de ter mais tempo para se dedicar à família.

\footnotetext{
"Olha, hoje eu diria que está meio fora do que eu gosto. Eu gostaria de estar ampliando alguma coisa para estar próximo à minha família. Assim, no gostar de uma maneira forte. [...] Eu sinto até ai uma falta porque eu fico pouco tempo, então seria ai o que eu queria estar fazendo, ter mais tempo. [...] Fui envolvido aí com horário de trabalho, envolvendo outras coisas que a gente faz no dia-a-dia voltado a ele [trabalho]" (Orlando).
} 
E no seu caso é importante lembrar que há ainda um tempo dedicado ao trabalho com venda de carros, que ocupa algumas tardes na semana e o domingo pela manhã. Ainda no que se refere à família, Orlando conta que alterou o horário da escola dos filhos para que eles estudassem pela manhã, já que à tarde seria mais livre para ele. Mas há ainda a preocupação com a família.

“... de deixar o lar à noite por ser o homem da casa. E aí você enfrenta, você pensa de uma certa forma, seja de dia ou de noite tudo está exposto à vida. Mas você pensa assim, à noite é diferente. Vou sair na hora de estar agasalhando o sono, ou então a fortaleza da família, vou estar saindo. É preocupação. Vou deixar o meu lar assim de uma certa forma exposto e vou trabalhar, vou a luta" (Orlando).

No que diz respeito ao tempo no local de trabalho, ele entende que, além da questão do adicional, há outros pontos positivos em trabalhar no III turno, como a existência de uma pressão menor por parte da "chefia", como já comentado por Otelo. Também aponta a possibilidade de ter maior liberdade no trabalho, uma vez que o gerente conversa sobre o que será realizado e "então, cada um sabe das suas obrigações".

"Durante o dia é gerente, é visitante, é encarregado que tem em toda esquina, mesmo não sendo o seu. Então quer dizer, você fica intimidado. Fica porque você está ali no meio de todos, você está agindo, está fazendo a sua operação. Está, mas daí fica aquilo: 'aquele me conhece, sabe que eu estou dando conta do recado e até mais'. Aí passa um outro e você se sente, querendo ou não querendo, parece uma pressão. O outro passa lá e fala: ele parou, por que será que aquele funcionário está parado?" (Orlando).

Emerson, o mais novo dentre os trabalhadores que hoje estão no III turno, no momento da nossa conversa estava há apenas três meses no "pé-quebrado". Disse ter feito esta opção "Primeiro por causa do adicional noturno, pra falar a verdade. Porque eu tinha muitas contas pra pagar. [..] Aí, eu indo para o III turno daria uns R\$ 600,00 a mais. Aí, eu falei: ‘já dá pra equilibrar’”. Perguntado sobre seu processo de adaptação, ele responde:

"Bastante gente falava: 'ah, é difícil adaptar'. Eu fiquei até meio receoso, mas eu estava precisando no momento, então eu falei: 'tenho que ir'. Mas eu acho que me adaptei fácil. Todo mundo fala que tem muita dificuldade nos primeiros meses, eu acho que me adaptei fácil” (Emerson).

Em seguida, reporta-se ao trabalho no III turno para explicitar o que mais gostou com a mudança de horário: 
"Uma coisa que eu gostei bastante foi o ritmo de trabalho e a forma de trabalho no período noturno. Que nem a ferramentaria, é uma área muito técnica, você precisa de muito tempo pra ganhar experiência, e a gente estava no período da manhã, tinha muita gente com experiência. A gente tinha chegado, tudo novo, a gente ficava meio descartado, as pessoas não tinham confiança na gente, e não passavam serviço, a gente não tinha como aprender. [...] À noite, porque o número de pessoas é menor, e o serviço é o mesmo, então, você é obrigado, chega uma hora que você tem que fazer alguma coisa. É legal porque às vezes você pega uma pessoa que está interessada em te ensinar. É diferente de manhã, que você ia começar a fazer alguma coisa, e como tinha mais gente, um cara mais experiente vinha: 'dá isso aqui que você não vai saber fazer', e fazia no seu lugar. Aí o que você ia fazer? Limpar uma ferramenta, varrer o chão, porque não tinha nada pra fazer, ficar parado também não pode. Eu estou gostando bastante" (Emerson).

Este relato de Emerson retoma o que foi falado pelos outros trabalhadores, no capítulo anterior, sobre o trabalho na ferramentaria estar muito corrido, em função da redução do número de trabalhadores e ainda da redução dos prazos. Vemos nesse relato que, pela manhã, não há tempo para incluir mais uma tarefa para os trabalhadores que lá estão, isto é, ensinar aos mais novos. Já à noite, como os trabalhadores dizem ser um horário mais tranqüilo, além de ter menos gente para trabalhar, há tempo para ensinar e aprender a trabalhar. Emerson também ressalta que outra diferença é a existência de uma quantidade menor de "chefias". O que tem como conseqüência, como já citado por Otelo, além de um trabalho mais tranqüilo, maior liberdade.

\footnotetext{
"Então, até a relação com a gente é diferente, porque nenhum pode ficar em cima o tempo todo. Que nem os encarregados da manhã, estão sempre passando pra ver o serviço, então [à noite] ele tem que confiar nele [trabalhador], tem que ter uma relação de confiança melhor. Então na hora da entrada no turno ele já passa o serviço que a gente tem que fazer, aí tem diferentes tipos de serviços. [...] Então é legal porque chega à noite, no caso, e eles já passam o serviço, aí chega um e já sabe o que tem pra fazer, já vai pra lá" (Otelo).
}

No que se refere ao seu tempo fora do local de trabalho, Otelo diz que geralmente dorme entre $7 \mathrm{~h}$ e $12 \mathrm{~h}$, ou então até as $14 \mathrm{~h}$. Acorda, vai para a faculdade que começa às $16 \mathrm{~h}$ e termina às 19h. Para Emerson, o único problema relatado acontecia no sábado, antes de entrar de férias da faculdade, porque não tinha tempo para dormir quando voltava do trabalho.

"Eu estava num ritmo meio louco, porque eu saía no sábado da firma, 6h da manhã, e aí eu fazia um curso de inglês das $8 \mathrm{~h}$ às $10 \mathrm{~h}$, e $11 \mathrm{~h}$ eu tinha que estar na faculdade. Aí eu ia $11 \mathrm{~h}$ pra faculdade, saía da faculdade 4h30 da tarde, aí eu ia dormir. Então, eu estava num ritmo meio louco" (Emerson). 
Quando questiono se houve algo negativo nesta mudança para o “pé-quebrado”, Emerson responde que o sono, ou melhor, a diferença entre dormir durante o dia e à noite, foi um problema. "Você descansa, mas você dormir durante a noite, nem que seja uma quantidade menos de sono, mas você aproveita mais, durante o dia é meio difícil, você acaba acordando com facilidade, o sol batendo na cara, é meio ruim. Mas acho que só". E em seguida menciona: "Depois que eu comecei a trabalhar [no "pé-quebrado"], sem perceber várias vezes eu me pego na televisão, quando eu vou olhar no relógio já são 3 h30, 4h00, o sono não veio ainda". Antes de termos iniciado a nossa conversa sobre o horário de trabalho, havia perguntado se ele gostaria de fazer alguma outra atividade e ele conta que gostaria de ir a shows, mas que por estar trabalhando à noite, e também em função da faculdade, isso não é mais possível.

Apesar de todos os pontos positivos ressaltados durante toda a nossa conversa, sobretudo em relação ao trabalho, Emerson, ao falar sobre os seus planos para o futuro, inicia dizendo que pretende voltar para o horário da manhã, no final de 2005. "Porque no dia a gente tem mais informações, a gente tem contato com mais pessoas e eu prefiro mesmo trabalhar no horário do dia, eu acho que descanso melhor". O que nos leva a pensar que o fato dele estar tendo uma experiência de forte aprendizado no “"pé-quebrado"”, algo que ainda não havia ocorrido, poderia estar influenciando positivamente a sua vivência deste regime de trabalho, mesmo com problemas de sono ou de alimentação. De forma que a boa adaptação ao novo horário de trabalho e de não trabalho poderia estar muito mais relacionada à melhor vivência em relação ao trabalho, em si, do que ao tempo de trabalho. Mesmo assim, apesar de toda a experiência positiva, ele pretende voltar para o horário da manhã, assim que resolver seu problema financeiro, o que o levou ao trabalho noturno.

Ângelo, que já havia trabalhado no "pé-quebrado" entre os anos de 1994 e 1996, é o único que relata não ter escolhido ir para este turno, apesar de ter deixado claro, quando abordado pelo encarregado, que ele aceitaria qualquer horário de trabalho. Assim, relata que ao final do seu mandato de representante sindical, em 2004, a Empresa o mandou para o III turno. "É claro que naquele momento eu estava saindo da representação, estavam entrando os meninos que a gente tinha defendido a chapa, com certeza iam ter muito contato comigo de dia. Então para a Empresa, naquele momento, era me jogar no III, me isolar lá no III". Mas para ele o trabalho à noite é tranqüilo e também a temperatura do ambiente é muito mais agradável, pois durante o dia é muito quente. Além disso, a mudança não teria acarretado qualquer problema dentro ou fora do seu tempo de trabalho, seja com a família, seja com o sono. 
"É tranqüilo. Até porque eu tenho o dia todo para sair, às vezes eu gosto de participar de reunião, às vezes eu vou na fábrica, eu gosto de ir ao banco, eu gosto de fazer um passeio. Eu não sou aquele cara que dou a vida para dormir, eu não sou assim. Na minha casa, por exemplo, o pessoal pode ligar na minha casa e me chamar porque eu não tenho nenhum problema. ['”] No meu caso, por exemplo, hoje não porque meus filhos já vão para a escola, mas antes, quando eu trabalhava no III turno, eu levava o menino de manhã, chegava em casa e dormia de novo, 5h00 da tarde ia pegar. Eu ia, pegava, tornava a dormir, tornava a voltar, não tinha grandes problemas. Quando eu era da representação, a mesma coisa, eu estava na fábrica à noite, fazia assembléia, ia para casa, voltava, fazia assembléia às 2 horas, voltava para casa, dormia de novo" (Ângelo).

É interessante notar que Ângelo faz referência à linha de montagem, ressaltando o sentimento de estar "preso" a ela durante o dia todo. Por outro lado, trabalhando à noite, há a sensação de ter o dia todo livre, como vemos em sua fala a seguir.

“... E você tem o tempo todo, é o contrário do dia, de dia você fica preso, vai para casa, você começa a assistir novela, mas de dia você está preso. Quando eu era da representação [dos trabalhadores], daí era diferente, daí tinha espaço para sair, ir ao Sindicato, ir no banco. Mas quando você está na linha não tem como, você está preso, não tem esse negócio de sair ali” (Ângelo).

Vimos que, dentre os trabalhadores entrevistados e que atualmente estão no III turno ou no "pé-quebrado", à exceção de Ângelo, todos dizem ter escolhido trabalhar nesses horários atípicos em função do adicional noturno. Ao serem indagados se continuariam no trabalho noturno caso não houvesse o adicional, ainda à exceção de Ângelo, todos afirmam que mudariam de horário. Emerson deixa claro que ao acabar com suas dívidas pretende voltar para o I turno, o que demonstra que mesmo buscando harmonizar os tempos, o adicional não compensa o distanciamento das pessoas.

\section{4 - Considerações finais}

Como vimos nos discursos sobre as vivências dos trabalhadores entrevistados que já trabalharam ou ainda trabalham no III turno ou no "pé-quebrado", na maior parte das vezes, a ida para esses horários é uma solução individual para resolver problemas financeiros. Assim como ocorre na hora extra, como bem salientado pelo gerente de $\mathrm{RH}$ : 
"Porque é uma forma de aumentar a renda dele, ou por hora-extra ou pelo trabalho noturno, que têm formas de remuneração diferenciadas. Então, alguns fazem isso por uma etapa da vida é tem lá uma minoria de pessoas que biologicamente gostam de trabalhar à noite" (gerente de RH).

Como salienta Lallement (2003), decidir por trabalhar à noite é uma coisa, e viver cotidianamente este trabalho é uma outra, muito diferente. Assim, vemos que uma vez iniciado o trabalho nesses horários, parecem ficar claras as diferenças em relação aos outros turnos, tanto no que se refere à organização do trabalho como à desorganização da vida. $\mathrm{Na}$ fábrica, os trabalhadores falam sobre uma pressão menor, possibilitando assim uma experiência positiva do trabalho e do tempo de trabalho. Se na discussão sobre os trabalhadores que vivenciaram o trabalho na linha de produção vimos que a questão da pressão é recorrentemente citada de maneira negativa, no caso dos que estão no III turno ou no "pé-quebrado", o mesmo acontece, mas de maneira positiva: à noite há menor pressão e o trabalho é mais tranqüilo.

A menor pressão é por eles explicada, na maior parte das vezes, pela redução da presença da "chefia". Se durante o dia "é gerente, é visitante, é encarregado que tem em toda a esquina", à noite há menos “chefias” passando, verificando e pressionando para a realização do serviço. Assim, no trabalho noturno os trabalhadores relatam que há uma relação de confiança com os encarregados e líderes, porque estes conversam com os trabalhadores sobre o serviço que deverá ser realizado, para depois cada qual dar "conta do seu serviço". Neste caso, a mudança no tempo de trabalho acaba por possibilitar não apenas melhor remuneração, inicialmente pretendida pelos trabalhadores que optaram pelo trabalho noturno, mas também, outro tipo de vivência do próprio trabalho.

Um trabalho mais "tranqüilo", "sossegado", "livre”, responsável, com “menor pressão" e ainda com tempo suficiente para que os mais experientes ensinem os mais novos. De alguma forma, mesmo que a palavra autonomia não tenha sido citada por qualquer trabalhador, arriscaria dizer que o que os agrada é justamente a margem de autonomia que podem exercer em relação ao seu trabalho. Assim, ainda que individual e pontualmente, os trabalhadores acabam por amenizar problemas associados à remuneração insuficiente ou à pressão excessiva no trabalho. E é interessante observar que uma situação muito parecida foi relatada por Lallement (2003), em um espaço profissional totalmente diferente do que estudo, o das enfermeiras que trabalham à noite. Essas trabalhadoras relataram que o trabalho noturno possibilitava uma pressão menor das chefias, uma autonomia muito maior no trabalho, além de maior solidariedade entre as trabalhadoras.

Mas isso não acontece com os trabalhadores que estão em uma das linhas de produção. Nelas, como salientam Otelo e Ângelo, embora haja uma redução da pressão da chefia e do 
movimento existente no turno da manhã, o ritmo da linha se mantém inalterado, podendo até mesmo aumentar, quando há atrasos de produção. Neste caso, os gerentes aproveitam a presença igualmente reduzida de representantes sindicais, para compensar os atrasos, aumentando o ritmo de trabalho dos que estão no "pé-quebrado" ou III turno.

Entretanto, é importante perceber que para os entrevistados que dizem não ter tido uma boa adaptação ao trabalho noturno, sobretudo em função de problemas com o sono e a alimentação, o trabalho pode, ao contrário, ser vivido como "um trabalho dobrado", sendo assim muito mais cansativo e desgastante. Nesse caso, o que os trabalhadores mais relatam é a falta de disposição, tanto para o tempo de trabalho como para o tempo de não trabalho. No tempo de trabalho ressaltam a queda do "rendimento profissional", da "qualidade do trabalho", do aumento do cansaço, do mau humor e de casos de acidentes e doenças do trabalho.

Nos momentos de não trabalho, fazem referência à alteração na quantidade e na qualidade do tempo dedicados às atividades fora do local da fábrica, com a família, com os amigos, aos outros momentos de lazer e à dificuldade de acomodar todos os tempos sociais. Para os que não se acostumam com o III horário, os discursos enfatizam as vantagens do I e do II turnos. Nesse caso, o desgaste em relação ao tempo dentro e fora da Empresa não compensa o adicional de $25 \%$, motivação inicial para a escolha do horário da noite, nem tampouco a menor pressão vivida no trabalho noturno.

Isso se aplica àqueles que fizeram a opção por trabalhar no "pé-quebrado" ou III turno, a partir do momento em que foram introduzidos os turnos fixos. Isso porque, no período anterior, os trabalhadores não tinham opção; logo, não é sem razão, que todos falam dessa experiência como algo muito negativo. Negativo em função da dificuldade para se acostumar às freqüentes mudanças de horário, seja em função do sono ou da alimentação, mas também do convívio com a família, amigos e namorados. Talvez a frase de Eron resuma bem o sentimento desses trabalhadores: "A vida da gente praticamente era o final de semana".

E mesmo dentre os que relataram não ter tido problemas de adaptação no III turno ou no "pé-quebrado", praticamente todos dizem que mudariam de horário, caso não houvesse o adicional noturno. Emerson, como vimos, logo que acabar de resolver seus problemas financeiros pretende voltar para o I turno, por considerar muito negativo o distanciamento em relação às pessoas. Já Otelo e Orlando, mesmo explicitando o desejo de ficar mais tempo com a família, dizem que permanecerão no horário. Nestes casos, o desejo/necessidade de maior remuneração parece compensar o pouco tempo dedicado à família. 
Desta forma, vimos que, na maior parte das vezes, a entrada e a saída no III turno, ou no "pé-quebrado" deve-se à vida fora do local de trabalho. De forma que a possibilidade de ter uma remuneração maior, vinda de necessidades de fora do local de trabalho, é o ponto principal para a demanda ou a aceitação para ingressar no trabalho noturno. Ao mesmo tempo, é a dificuldade de adaptação, bem como são as mudanças na quantidade e na qualidade do tempo dedicado aos outros tempos sociais, que os pressiona para a mudança de horário. Nesse caso, falo do tempo dedicado ao sono, ao estudo, à alimentação, à família, aos amigos ou aos namorados.

E é interessante notar ainda que, mesmo no caso dos trabalhadores que mencionam alguma melhoria na condição de trabalho - como a menor pressão, o trabalho mais tranqüilo, mais livre, com tempo para ensinar e aprender -, esta não é citada como um fator motivador seja para a entrada, permanência ou saída do trabalho noturno. Vimos que é a comparação entre os elementos positivos e negativos vindos de fora da vida no trabalho, que leva à decisão do trabalhador estar ou não no trabalho noturno. 


\section{JOVENS:TRANSIÇÕES ENTRE TEMPOS DENTRO E FORA DA EMPRESA}

ara alguns autores que têm como discussão principal a questão das vivências temporais e os tempos sociais ${ }^{1}$, a idade, assim como o sexo, aparece como uma dimensão social importante para a compreensão da organização temporal de uma sociedade. Afinal, essas dimensões são fundantes e organizadoras das sociedades nos diferentes momentos históricos e nas diferentes culturas, sendo que sua análise em muito contribui para o entendimento da articulação entre os tempos individuais e os tempos sociais. Assim, neste capítulo, o foco de análise será uma configuração construída a partir de narrativas discursivas comuns sobre os tempos sociais de trabalhadores jovens que trabalham na Volkswagen.

Esses trabalhadores foram selecionados em função da similitude dos discursos pelos quais constroem as percepções das vivências dos tempos. Veremos que é um modo de falar do vivido relacionado a uma certa situação social, como o perfil individual, o tipo de inserção na fábrica, entre outros. Eles são jovens que vivem com os pais e estudam e esta é uma diferença fundamental em relação a outros jovens que, por exemplo, são chefes de família e/ou têm filhos. Assim, o problema não é dividir o tempo entre escola e trabalho, mas como o fazem, dado que ainda vivem com os pais. E ainda, neste caso, a palavra chave para este grupo é a transição entre as diferentes fases da vida adulta. Ou seja, trata-se muito mais da construção da autonomia do que propriamente da questão da idade.

Esta análise foi construída em três partes. Uma primeira busca definir o que é ser jovem na Volkswagen, considerando sua especificidade. Na segunda parte, falarei de transições que já foram vivenciadas por esses jovens - entre a casa e a escola, e também entre a escola e o primei-

1. Como já analisado, entre os autores temos Bessin (2000), Grossin, (1974), Mercure, (1995) e, como veremos neste capítulo, Leccardi (2005). 
ro trabalho. Em seguida, tratarei do tempo presente e do tempo futuro. Como estes tempos são vivenciados e como fica explícita a expectativa de uma segunda transição que pode se dar com o fim da faculdade e o início de uma nova função; ou com o fim da faculdade e o reconhecimento deste fato por parte da empresa; ou ainda o fim da faculdade e um novo trabalho fora da Volkswagen. Assim, o presente para esses jovens não é apenas uma ponte entre o passado e o futuro, mas é o momento que os prepara para o futuro. De forma que o tempo presente e futuro parecem se sobrepor num mesmo momento, tal a sua inter-relação (Leccardi, 2005). Nessa segunda parte, trarei ainda das falas e situações de trabalhadores de outras gerações, a fim de contribuir para a compreensão das experiências dos jovens.

\section{1 - Ser jovem na Volkswagen, no tempo presente}

Inicio então pelo questionamento do que é ser jovem na Volkswagen, no momento presente, lembrando o contexto em que esses trabalhadores entraram na Empresa. Afinal, a transição que esses trabalhadores já vivenciaram e a que ainda esperam vivenciar estão totalmente relacionadas às mudanças ocorridas no nível micro da empresa, que foram muitas. Além, é claro, do contexto macro de mudanças na sociedade brasileira e no mundo do trabalho. De acordo com Pessanha e Morel (1991), as transformações no processo produtivo, bem como na gestão da força de trabalho, constituem as bases para a produção de novas experiências e sistemas de diferenciação do coletivo de trabalhadores. Há, portanto, uma relação direta entre os marcos externos que, por sua vez, se combinam com os diferentes processos de socialização vivenciados dentro da fábrica, assim como as novas formas de recrutamento ou formação que geram trabalhadores com um novo perfil e experiências distintas daqueles que já trabalhavam na Empresa.

Os sete jovens entrevistados - quatro mulheres e três homens, com idades entre 21 e 26 anos -, têm entre cinco a sete ${ }^{2}$ anos de trabalho na Volkswagen, isto é, passaram a fazer parte do quadro da empresa mais ou menos em 2000, momento de importantes discussões e negociações sobre a flexibilização do tempo de trabalho. Nesse ano, lembramos que os trabalhadores se recusaram a renovar o acordo sobre a «semana Volkswagen» e o banco de horas. Entretanto, em 2003, eles acabaram por aceitar a renovação desse acordo, depois que a

2. Este é o menor tempo de casa da minha amostra, sendo que estes dados estão na apresentação dos participantes. 
empresa anunciou cerca de três mil demissões. Apesar de nenhum desses jovens trabalhadores ter recebido uma carta de demissão, eles iniciam o trabalho na Volkswagen, em um momento onde as discussões sobre tempo de trabalho aparecem extremamente vinculadas à manutenção do emprego, num contexto de maior instabilidade deste, considerando que desde 1995 a empresa havia anunciado sua intenção de fechar a planta do ABC. De um ponto de vista coletivo, podemos dizer que esses trabalhadores, assim como aqueles que entraram um pouco antes, vivenciaram um momento de forte transição da empresa. Qual seja, a passagem de uma empresa com investimento na formação dos trabalhadores e empregos até certo ponto estáveis, sobretudo se compararmos o tempo médio de trabalho dos trabalhadores de dentro e fora da Volkswagen, para outra, que, entre tantas outras mudanças, tem reduzido o investimento na formação interna e o número de trabalhadores, tornando o emprego muito mais instável.

À exceção de Félix e Flávio, que tiveram outras experiências profissionais anteriores, todos os outros entraram na empresa pelo Senai, localizado dentro da própria empresa, o que só era permitido a filhos e irmãos de trabalhadores. Até 1990, não era permitido o ingresso de mulheres por esta via. Isto significa que quase todos os trabalhadores homens vieram de famílias metalúrgicas com um de seus membros trabalhando na própria Volkswagen. Tal situação configura um perfil de socialização do trabalho muito específico: emprego em uma grande empresa, até certo ponto estável, bem remunerado com um sindicato forte e onde os pais se formaram para o trabalho e se aposentaram. Por conta disto, observa-se uma socialização consistente devido ao fato de que esses pais (sim, porque são sempre pais e não mães que trabalharam na empresa), viveram, em média, entre quinze e vinte anos dentro da empresa até a aposentadoria ${ }^{3}$. Desta forma, podemos dizer que estes jovens passaram por uma socialização que antecipa o ser operário, o que não é comum na sociedade brasileira, onde as pessoas têm poucos anos de casa e raras vezes há a possibilidade de pais e filhos trabalharem juntos numa mesma empresa.

Nessa situação, ao final do curso no Senai, a passagem para o trabalho na Volkswagen está garantida para todos os alunos. E para onde vão esses jovens, uma vez dentro da empresa? Atualmente, os sete trabalhadores do conjunto estudado, à exceção de Vivian que entrou na inspeção, entraram em uma das linhas de produção. Émerson foi para a ferramentaria há dois anos. Tamara está trabalhando na linha, na montagem da bateria. Giulia, que atualmente está na

3. Não há nenhum caso de pai que ainda esteja na Volkswagen. Isso possivelmente resulta da pressão da empresa para a saída dos trabalhadores já aposentados (via PDV). Apenas para ilustrar, no PDV realizado no ano de 1999, o tempo médio na Volkswagen era de vinte anos e $82 \%$ dos incluídos eram trabalhadores já aposentados que continuavam a trabalhar na empresa. 
parte administrativa do setor da pintura e Eliana, que hoje trabalha no controle de aperto de parafusos, apesar de não estarem diretamente na linha, relatam que quando há um aumento da produção são solicitadas a retornar à linha. Félix, que trabalha numa empresa terceira, está na logística, sendo responsável pela compra de materiais e Flávio trabalha como frentista no posto de gasolina, no final da linha de montagem.

Assim, vemos que esses trabalhadores têm pouca experiência profissional e a maior parte está em áreas onde o trabalho não é considerado qualificado. Fora da fábrica, no seu dia-adia, todos continuam a estudar, são solteiros, não têm filhos e moram com os pais. Essas são as situações sociais comuns que influenciarão vivências similares em relação ao tempo de trabalho e de não trabalho, que se manifestam, por sua vez, através de um modo específico de falar do tempo vivido. A seguir, apresento uma análise de suas vivências tanto no que se refere à transição que já experimentaram - entre a escola (Senai) e o trabalho, e a outra, que eles têm a expectativa de vivenciar no tempo futuro, entre a escola atual (faculdade) e um novo trabalho.

\section{2 - O tempo passado: uma primeira transição entre tempo de estudo e tempo de trabalho}

Um primeiro traço evidenciado nos discursos, se refere à vivência da passagem do tempo de estudo para o de trabalho, que neste caso significou o fim do curso do Senai e início do trabalho na Volkswagen. Para muitos essa transição foi avaliada como "terrível" porque significou um choque entre o imaginário e o real. Ou seja, muito diferente de uma transição imaginada por mim como tranqüila, em função de dois fatos que se complementam, já citados anteriormente. Primeiro, no que se refere à passagem do Senai para a Volkswagen, como praticamente todos são filhos de antigos trabalhadores na empresa, isto deveria significar que a realidade da Volkswagen não era totalmente desconhecida. Segundo, por estudarem em uma unidade do Senai, localizada dentro da empresa, onde o conteúdo desta formação guarda uma relação direta com o trabalho a ser realizado na Volkswagen, seria esperado que o trabalho já fosse conhecido. De forma que o conjunto desses fatores deveria levar a uma transição fácil entre o tempo de estudo e o de trabalho. Entretanto, não foi isso que apareceu nas falas dos entrevistados, que sublinham, ao contrário, vivências difíceis e descontínuas expressas em palavras como "susto" e "choque". 
Para melhor compreendermos o paradoxo da transição como um "choque", devemos considerar a relação entre esse tempo passado vivido em uma "família de metalúrgico", o tempo presente, num contexto de fortes mudanças na empresa e no mundo do trabalho, e um tempo futuro de incertezas em relação ao emprego. Nesse sentido, veremos que o sentimento de susto dos trabalhadores parece estar muito mais relacionado à passagem do tempo de estudo no Senai para o tempo de trabalho na linha, do que à transição de tempo de estudo para o tempo de trabalho qualificado, para o qual os alunos do Senai costumavam ser formados, como veremos adiante. Isto é, um choque entre a expectativa de um tipo de trabalho e a realização de outro. Pois como já vimos, trabalhadores mais velhos também relataram que foi difícil começar a trabalhar em uma das linhas de produção e essa mesma avaliação também surge nos relatados das mulheres, como veremos no capítulo a seguir. Mas a diferença fundamental, é que os trabalhadores mais antigos não tinham conhecimento do que era o trabalho na Volkswagen, ao contrário dos jovens que estudaram no Senai dentro na empresa.

O tempo presente trouxe para esses jovens uma Volkswagen, e também um Senai, diferentes do esperado. De acordo com Emerson, por exemplo, há uma divisão de épocas. Até 1999, o SENAI era voltado para o aluno, para formar o ferramenteiro, o mecânico. Ia-se ao teatro, à Bienal, havia incentivo ao esporte. A partir de 2000, como vemos na fala de Emerson:

“eles [o Senai] estão formando aluno voltado para a produção. Eles já colocam na cabeça assim: olha, vocês estão se formando aqui pra trabalhar na produção. Então mecânica vocês não precisam aprender muito, só noções básicas" (Emerson).

Podemos notar que essa mudança qualitativa e quantitativa, pois houve ainda uma redução do tempo de estudo passando de três para dois anos, vem acompanhada por uma pressão da empresa no sentido de acabar com o Senai dentro da fábrica. É bom lembrar que uma das demandas da empresa na negociação de 2006 foi o término do contrato compulsório de aprendizes.

Se num primeiro momento, esse processo poderia parecer uma contradição, já que no momento em que a Volkswagen mais demanda formação é quando menos investe, na realidade, há um movimento para externalizar os custos não relacionados diretamente à produção. Mais do que isso, como se evidencia na fala do gerente de $\mathrm{RH}$, a empresa vê como desnecessário o investimento porque hoje o mercado já oferece trabalhadores com alta escolaridade. Logo, não apenas a Volkswagen não precisa mais investir na formação - considerando que houve redução do número de cursos no Senai, redução das turmas nos cursos que se mantêm e redução 
do número de bolsas para as instituições externas à Volkswagen - como pode, igualmente, aumentar o pré-requisito escolar para novas contratações.

Flávio, que fez o Senai fora da Volkswagen, questiona essa estratégia da empresa, pois, se por um lado ela aumenta a exigência na hora da contratação, por outro, nem o trabalho exige tudo o que se demanda e nem a empresa oferece contrapartida para o que demandou dos trabalhadores.

\begin{abstract}
"O que mais me incomoda é a questão do valor que o empregado tem. Eles [Volkswagen] te pedem tanto para você entrar, perdem que eu digo é você tem que ter curso de nível técnico. Quando eu entrei era no mínimo um ano de experiência na função, $2^{\circ}$ grau completo, de preferência grau técnico e ter pelo menos um curso no Senai. Imagina, e você não podia ter mais que 40 anos, era uma exigência grande que poucas pessoas conseguiam alcançar. [...] Muitas vezes a gente diz, o que você faz aqui, 50 mil pessoas fazem lá fora também fazem. Então se você não quiser trabalhar, você pede as suas contas e a Empresa coloca outra pessoa no seu lugar. Então você sai de lá imaginando: 'eu sou um lixo, eu não tenho valor nenhum aqui dentro'. Porque te pedem tanto para você entrar, mas o serviço que você desempenha lá, qualquer pessoa aqui fora consegue fazer, então você se sente meio alienado em relação ao trabalho". (Flávio)
\end{abstract}

O gerente de RH, ao falar do novo perfil do Senai, relata que este passou a formar "profissionais universais". No passado se prendia mais à ferramentaria, funções mais críticas. "Hoje acaba que eles acabam trabalhando onde tem vaga, porque não dá pra você escolher muito”. E hoje há em torno de 200 aprendizes estudando, sendo formados 60 a 70 alunos por ano, todos absorvidos pela empresa. Quando pergunto se ainda há expectativas para os jovens que entram no Senai irem para as áreas qualificadas, ele responde:

“... nós tivemos que corrigir o procedimento de seleção de aprendizes. No passado, nós pegávamos, como qualquer escola faz, você fazia um teste e você pegava sempre os melhores. Então hoje, no processo seletivo, nós passamos a escolher outras características, às vezes a afinidade com o trabalho, a gente não pega os melhores intelectualmente $[. .$.$] ... porque ele chega no final ele se$ frustra, tá bom, você vai trabalhar agora em uma linha de montagem. Ele diz: 'eu não, eu quero ser engenheiro, eu quero ir pra engenharia'. E o nosso curso não é de aprendiz pra engenharia, é mecânico geral. [...] Nós temos algumas disciplinas que formam uma pessoa para a indústria automobilística, não um profissional especializado como era no passado, formava, por exemplo, um ferramenteiro, formava um torneiro mecânico. Hoje nós somos mais um profissional generalizado. Então, tem que se adequar o perfil de quem se forma pra que depois ele continue. O sucesso da nossa escolinha são aqueles que ficam na empresa. Porque se ele ficar e depois disser arrumei um emprego melhor fora, será um investimento desnecessário" (Gerente de RH). 
Ou seja, as possibilidades são poucas. A fala do RH revela um pouco da nova estratégia da Volkswagen em relação ao Senai, ou seja, em relação à formação de seus empregados. A forma de seleção dos alunos foi alterada para que os formados, ao final do processo formativo, não saiam da empresa, mas também não pressionem para trabalhar em setores considerados qualificados. Na realidade, como vimos anteriormente, o objetivo final é acabar com a contratação de alunos do Senai e, em seguida, fechá-lo.

Desta forma, vê-se que a empresa marcha em direção a práticas que a eximem de bancar, como antes, parte dos custos de formação de seus trabalhadores. E num contexto de altas taxas de desemprego, ela sabe que os trabalhadores irão procurar fazer a formação por conta própria, que é, justamente, o que tem ocorrido. Essa não é uma realidade apenas da Volkswagen, mas está cada vez mais presente na sociedade atual, para jovens e não apenas para estes. "A continuidade biográfica torna-se, assim, fruto da capacidade individual de construir e reconstruir, sempre de novo, molduras de sentido, narrativas sempre novas, a despeito da moldura temporal presentificada" (Leccardi,2005:06). Mas a autora ressalta que nem todos os jovens têm a mesma possibilidade de construir individualmente seu presente, em relação ao projeto de futuro, pois tanto a capacidade financeira, como as familiares ou cognitivas são muito diferenciadas.

Os jovens, por sua vez, relatam que já sabiam, a partir de 2000, que poucos seriam efetivados, seja na ferramentaria ou na manutenção. Entretanto, a expectativa de tempos futuros dentro da empresa parece ter se mantido a mesma, apesar das mudanças nas condições objetivas.

\footnotetext{
"Porque a gente sabia que ia acabar indo pra produção, mas a gente não sabia realmente como era assim, o ritmo de trabalho. Que nem, eu peguei uma linha de montagem, né, comecei a trabalhar em linha de montagem, então você fica meio chocado assim, né. Porque você estudou mecânica, estudou outra coisa e acaba caindo numa linha de montagem. Eu acho que você não aplica nada do que você estudou, aí você fica.... Tem muita gente que não agüenta, pede a conta, teve até uns amigos meus que pediram a conta, não agüentou trabalhar" (Emerson).
}

Desta forma, no caso de Emerson, o choque foi começar a trabalhar na linha, em função da decepção de não utilizar o que havia estudado, do ritmo de trabalho e da falta de autonomia em relação a seu tempo. Vemos que o tempo também é um elemento marcante quando se compara o trabalho na linha ou em outros setores, como na ferramentaria.

"Levaram a gente para a produção, foi quando comecei a conhecer a realidade do que era uma produção, do que era trabalhar ali 8 horas por dia mesmo. Porque na ferramentaria você tem o seu 
serviço, mas você administra o seu tempo, como fazer ele e tudo. Na produção não é, tem um tempo determinado para fazer aquela operação, não interessa o que vai acontecer ou não, tem que fazer" (Emerson).

Para Eliana, o início do trabalho na Volkswagen foi terrível porque houve uma diferença enorme entre o que foi dito no Senai e a realidade que ela enfrentou no trabalho. Primeiro porque no Senai diziam que mesmo você estando na linha você teria condição de mudar aquilo que entendesse estar errado.

"Então eu cheguei lá com aquela mentalidade, mas eu vi que não tinha nada a ver com aquilo. Eles falavam que, por exemplo, parava na sua hora de café, você ia lá e pegava uma vassoura, ia varrer o chão, que assim você mostrava para o seu líder que você tinha um diferencial dos outros, aí que você ia conseguir coisas melhores. Tem outra pessoa precisando de ajuda, você ia lá e ajudava, você estava mostrando para o seu líder que aquilo é diferente" (Eliana).

Com o tempo a entrevistada disse que não foi isso o que ela vivenciou, que não foi possível mudar nada do que ela entendia estar errado, e que no fundo ela não tinha o seu trabalho reconhecido. Aliás, como veremos mais adiante, o reconhecimento, ou a falta deste, são sentimentos muito freqüentes entre esses trabalhadores. Ainda de acordo com Eliana, o choque foi tão grande que ela resolveu voltar ao Senai para conversar com alguns professores sobre a necessidade de esclarecer a situação real que os alunos iriam enfrentar. Ela disse que hoje em dia as pessoas já sabem que sairão do Senai para a linha, apesar disso, continuam a se referir às possibilidades de mudanças e de progredir na empresa, mesmo sendo isso cada vez mais raro. À Eliana, que ganhou o prêmio de melhor aluna do Senai da fábrica Anchieta, foi oferecido um plano de carreira no qual estava previsto que ela trabalharia na linha e nas áreas técnicas para depois ser líder, ganhando, para isso, uma bolsa de estudos e outra de idioma. Todavia, já no ano seguinte, em 2003, ela foi obrigada a voltar para a produção quando houve aumento de demanda, trabalhando no controle de aperto de parafusos, e nunca mais falaram sobre seu plano de carreira.

Esses relatos reafirmam que trabalhar na linha acarreta uma conjunção de vivências negativas do ponto de vista pessoal que, no caso dos jovens entrevistados, significa não poder administrar seu próprio tempo, não utilizar os conhecimentos adquiridos, ter um salário menor, sentir que seu trabalho não é reconhecido. Para as trabalhadoras, entrar na linha apresentou ainda um outro problema: confrontar-se com um mundo masculino. De acordo com Eliana e 
Tamara, quando elas foram trabalhar na linha a quase totalidade dos colegas eram homens ${ }^{4}$ e, como veremos de forma mais detalhada no capítulo seguinte, essa realidade acabou por dificultar, ainda mais, a vivência do trabalho na linha.

Assim, se muitas vezes é a forma de inserção incerta no mercado de trabalho que causa angústias e sofrimentos em muitos jovens na nossa sociedade (Guimarães, 2006), esse não foi o caso dos jovens que ingressaram no Senai, pois havia segurança em relação à entrada no mercado de trabalho, isto é, na Volkswagen. De forma que a transição entre o tempo de estudo e o tempo de trabalho foi vivenciado como continuidade e certeza de que esta passagem iria acontecer. Mas, do ponto de vista do trabalho realizado, houve um forte estranhamento entre a expectativa e a realização.

Finalmente, ressalto que as mudanças ocorridas no local de trabalho influenciam não apenas as vivências dos jovens dentro da empresa. De acordo com o debate sobre a transição dos jovens para a vida adulta, uma das bases dessa transição, são justamente os processos que transcorrem no âmbito do trabalho, desde a entrada até a forma de permanência no mercado de trabalho (Guimarães, 2006). Por sua vez, essas mudanças influenciam as condições para outras transições - como a saída da casa dos pais ou a constituição de uma nova família. Desta forma, as mudanças que vêm sendo implementadas pela Volkswagen têm levado à experiências, tanto dentro como fora do local de trabalho, muito diferentes do vivenciado pelos pais desses jovens.

\section{3 - Tempos presentes: a expectativa de uma segunda transição}

Vimos que a transição do tempo de estudo, no Senai, para o tempo de trabalho, na linha, foi sentida como um choque pelos jovens entrevistados. Por outro lado, a expectativa de uma possível transição entre o atual tempo dedicado ao estudo na faculdade e um novo trabalho tem sido vivenciada de maneira muito positiva. Parece indicar que a possibilidade de realização de uma expectativa, até então frustrada, de vivência de um outro tipo de trabalho, dotado de maior autonomia em relação ao tempo, maior salário e maior reconhecimento, decorrentes da qualificação, tivesse sido postergada e transferida para essa possível segunda transição. Dessa maneira, o fim da faculdade significa a possibilidade de entrada em outro trabalho, em outra função,

4. De acordo com os dados fornecidos pela Empresa, os setores onde há maior concentração de mulheres são a engenharia e o setor administrativo. 
ou, no limite, em outra empresa, caso a Volkswagen não reconheça a nova formação, como no relato de Elaine, ao falar sobre a relação entre o seu curso e o seu trabalho.

“Está vinculado ao meu trabalho, mas é algo que eu quero, quero ser uma engenheira, eu não faço pela empresa e sim porque.... É assim, eu penso que é assim, eu me formando engenheira, eu não conseguindo nada aqui dentro, eu tenho chances de ir para o mercado lá fora e conseguir alguma coisa, eu não faço só pela empresa" (Elaine).

Para realizar essa possibilidade, os jovens trabalhadores ocupam praticamente todo seu tempo com o trabalho e a faculdade, de forma que o tempo livre é apenas residual, restringindose a uma parte do sábado, ao domingo e às férias, quando estas também não são dedicadas ao estudo. Além de permanecerem dentro da empresa em torno de dez horas por dia, dedicam, em média, mais quatro horas diárias ao estudo durante a semana. Se somarmos ainda 1h30min de transporte, isso perfaz uma jornada média de 15h30min de tempo ocupado, ou do que eu chamo de tempo dedicado direta e indiretamente ao trabalho. Como eles dizem dormir só quatro a cinco horas por noite, isso significa que teriam apenas três horas livres para o cuidado com a higiene, a alimentação e todo o mais que queiram fazer. Essa falta de tempo é expressa na fala de Tamara, "O meu dia é assim, de segunda a sexta. No começo, eu juro para você que eu sentava e chorava. Chegava em casa e falava para a minha mãe que eu não ia agüentar: 'mãe eu vou desistir, não dá. E meu pai e minha mãe sempre ajudando".

Mas ao mesmo tempo em que essa vivência de estudo e de trabalho ocupando a quase totalidade das 24 horas seja muito valorizada, há também outras falas que valorizam vivências diferentes, como estar com amigos, namorados, família; poder passear, viajar e descansar. E mais uma vez a questão do tempo, ou da falta deste, é citada, principalmente quando se pergunta se eles têm feito o que mais gostam. Conforme Leccardi (2005), no caso dos jovens, a identidade pessoal é construída em relação à projeção de si no tempo futuro, no sentido do que se quer ser, de forma que a falta de tempo presente para atividades prazeirosas ou julgadas importantes, acaba adquirindo um sentido diferente, quando se projeta um futuro determinado. Assim, as experiências do presente ganham um novo significado a partir da perspectiva de tempos futuros e melhores. Talvez por isso os trabalhadores mais velhos optem por não voltar a estudar, pois, em sua perspectiva de futuro, diferentemente dos jovens dificilmente um diploma seria um passaporte para um trabalho mais qualificado. 
Pessanha e Morel (1991:75 e 76) ressaltam que a partir do momento em que a CSN (Companhia Siderúrgica Nacional) passou a dar maior ênfase a títulos escolares, tanto para a entrada na empresa como para as promoções, passou a haver uma divisão entre aqueles trabalhadores que estavam na empresa há mais tempo e aqueles que chegaram depois das mudanças. Afinal, os primeiros haviam passado pela experiência de uma "política de valorização do mérito e da dedicação à empresa, qualidade do bom trabalhador" e que, por sua vez, encontrava eco “nos próprios valores dos operários, como, por exemplo, o peso conferido ao trabalho, a importância atribuída à ascensão pelo esforço individual e o orgulho profissional". Para estes mais antigos, de acordo com os autores, as novas exigências foram compreendidas como desqualificação de seu saber, gerando um conflito de gerações, o que significou não necessariamente uma oposição entre operários de diferentes faixas etárias, mas sim entre trabalhadores com perfis diferentes.

No caso da Volkswagen, as falas dos trabalhadores não mostram o conflito entre gerações causado, em geral, pela crescente importância dada à formação escolar, por parte das empresas. No que se refere à formação dos trabalhadores, podemos falar de três tipos de perfis diferentes, que não se resumem à questão da idade, como bem salientado pelos autores. Um primeiro grupo abarca trabalhadores que estão, em média, há 17 anos na empresa, apresentam grande variedade de idade (têm entre 28 e 51 anos), estão concentrados na produção direta, têm até o segundo grau e alguns cursos técnicos (no caso dos homens) realizados na empresa. Nesse grupo, os trabalhadores não voltaram a estudar e dizem que nem pretendem, mas, em nenhum momento fazem críticas à empresa, no sentido desta estar valorizando mais os títulos formais ou de não serem reconhecidos; também não há qualquer referência a outros trabalhadores com maior escolaridade ou ainda alguma expressão do desejo de mudar de função.

Um outro grupo é formado por trabalhadores que têm entre 30 e 40 anos de idade, com 14 anos, em média, de tempo na empresa, que já fizeram ou estão terminando o curso superior. Todos, sem exceção, não trabalham na produção direta, mas na inspeção da qualidade, na ferramentaria, no administrativo, ou ainda são líderes e encarregados. Pelo relato do gerente de RH, no capítulo sobre a Volkswagen, vimos que a Empresa chegou a provocar alguns trabalhadores para que voltassem a estudar. Para instigá-los, foram criadas novas funções vinculadas à necessidade de curso superior, ou ainda, a possibilidade de mudança de função se o trabalhador se comprometesse a voltar a estudar. Neste grupo também não há qualquer reclamação da empresa, no sentido de não serem reconhecidos, possivelmente por já estarem fora da produção. 
Mas, por outro lado, alguns reclamam do fato de terem voltado a estudar. Afinal, têm família, filhos, são mais velhos e muitos já haviam parado de estudar há algum tempo, o que acabou por complicar a relação entre o tempo de trabalho, de estudo e aquele dedicado à família. Assim, alguns trabalhadores, mesmo sofrendo pressão da empresa para voltar a estudar, optaram por não fazê-lo, em função da dificuldade em conciliar os tempos e as necessidades vindas de dentro e fora do local de trabalho. Esse é o caso de Gilson, que não conseguiu obter a bolsa de estudos da Volkswagen e parou de fazer o curso de Administração de Empresas.

\begin{abstract}
"Escola é investimento. Hoje prefiro estar investindo na casa, do que lá [Volkswagen]. E se eu voltar a estudar, acabar o que tenho que fazer, o que for exigência, eu não vou ter retorno. Acabo daqui a três anos a escola, um pouquinho mais na frente eu saio [da Volkswagen] não tem retorno. Eu já ganho graças a Deus o suficiente para dizer que está bom. Se eu passar a encarregado vou ter aumento de salário, ai compensaria. [...] Se a fábrica falar, independente de ser promovido, ou não, eu tenho que ter a faculdade, eu estou numa função, eu vou" (Gilson).
\end{abstract}

Esta fala explicita a expectativa em relação aos tempos futuros e do espaço ocupado pelo estudo no projeto de vida, muito diferente do que vemos nos jovens que constituem um terceiro perfil. São trabalhadores que estão há menos tempo na empresa, em sua maior parte fora da produção direta, que reclamam da falta de reconhecimento por parte da empresa e que têm grande expectativa de que a faculdade abra um novo caminho. Todos, apesar de já terem ingressado no mercado de trabalho optaram pela continuidade da formação escolar, existindo, portanto, uma sobreposição entre os tempos dedicados ao trabalho e ao estudo e não uma substituição (Guimarães, 2006, 178). As escolhas dos cursos, como veremos, estão relacionadas às perspectivas de melhoria do emprego dentro da Volkswagen.

Assim, Emerson faz administração ${ }^{5}$, Tamara, Vivian e Eliana, engenharia, Giulia está no curso de física e Flávio, no de direito. Tamara ainda faz um estágio na empresa na área de inspeção, Giulia curso de alemão e Emerson de inglês. Vivian e Eliana disseram que se tivessem

5. É interessante observar que a Fundação Santo André, onde muitos trabalhadores pesquisados estudam, planeja quase todos os cursos com horários diferentes dos habituais dos cursos superiores, de modo a ajustar-se ao tempo disponível para o estudo dos trabalhadores das empresas montadoras em regime de turnos. Nesse sentido, o modo de alocação e usos do tempo na empresa acaba por afetar, também, o planejamento do tempo de instituições de ensino que atendem a seus trabalhadores. Assim, se a organização da produção já influenciava o espaço ao redor da empresa, sobretudo com a relação do just in time e os fornecedores, tendo impactos nas estradas e portos, neste caso, vemos que a organização da empresa influencia para além do planejamento de instituições relacionadas diretamente ao seu processo de trabalho. 
uma redução da jornada de trabalho dedicariam esse tempo ganho a um curso de inglês. A exceção é um trabalhador de uma das empresas terceiras, dentro da Volkswagen, que atualmente faz um curso técnico de radiologia, depois de ter iniciado os estudo em uma faculdade de administração que abandonou por falta de recursos.

Emerson, que estuda administração, diz que gostaria de ter feito ciências sociais, pois adora a vida política e sindical, tal como seu pai que era militante. Acreditando que o curso de administração lhe daria mais chance de sair da linha de montagem, acabou optando por ele. No momento, trabalhando na ferramentaria, diz que o curso não tem nada a ver com o seu trabalho, apesar de estar adorando fazê-lo. Na realidade, ele entende que do ponto de vista do aprendizado para o trabalho é o próprio trabalho que o possibilita e não um curso universitário. Tamara também diz que irá se formar em engenharia, mas que gostaria de ter feito engenharia ambiental. Acabou optando pela primeira para ter mais chances dentro da Volkswagen ou então montar seu próprio negócio. Flávio, que estudou no Senai fora da Volkswagen, atualmente cursa direito, e nos fala também de sua preocupação em relação ao mercado, neste caso, fora da Volkswagen, pois considera que dentro suas chances são muito reduzidas.

\footnotetext{
"Porque é uma área em que você não depende do mercado, nas empresas, hoje, você está muito fadado ao mercado. Se o mercado está bom, você contrata; se o mercado está fraco, você demite. Como advogado ou como profissional liberal você não depende do mercado, você tem uma margem, talvez, restrita de trabalho, mas você sempre vai ter trabalho, então você não fica sempre à ercê da oferta de emprego, que às vezes, a própria economia te sujeita" (Flávio).
}

Giulia, que faz faculdade de física, também um curso mais distante do seu trabalho, diz: "a gente sabe a situação lá dentro [Volkswagen] hoje, que não é a mesma que antigamente. Tem muita gente que se forma e que está na linha esperando". Por isso resolveu fazer um curso superior e pensa poder utilizá-lo fora da Volkswagen, se necessário. Isso não significa que Giulia não tenha expectativas de continuar a trabalhar na Volkswagen. Ao mesmo tempo em que cria uma alternativa para sair da empresa, ela constrói pontes para ali permanecer, como, por exemplo, fazendo há quatro anos um curso de alemão, de forma que dar aula seria uma segunda renda e não a substituição daquela recebida na Volkswagen.

Vivian, também estudante de engenharia e que trabalha fora da linha na medição de peças, diz que o curso tem muita relação com seu trabalho e que contribuirá para que ela continue a "subir" na empresa. O que nos indica que, mesmo para aqueles que já estão fora da linha, 
ou que já entraram em um setor considerado qualificado, também o curso superior é visto como uma possibilidade de progredir. Félix, que trabalha na empresa terceira, é o único que não explicita alguma expectativa de relacionar a sua formação em técnico de radiologia com o seu trabalho atual. Na realidade, ele faz uma total distinção e diz que no começo escolheu esse curso apenas para conseguir um emprego melhor; com o passar do tempo passou a gostar e agora pensa em fazer uma especialização na área. Nessa perspectiva, o futuro é pensado por esses jovens como o espaço para a construção de um projeto de vida e, ao mesmo tempo, a definição de si, como salienta Leccardi $(2005,10)$, pois, “projetando que coisa se fará no futuro, projeta-se também, paralelamente, quem se será".

As falas dos entrevistados parecem indicar que a escolha do curso está totalmente relacionada à perspectiva de emprego, seja para a melhora deste ou para a obtenção de outro, fora da Volkswagen. Em nenhuma das respostas deste grupo houve menção ao estudo como algo em si mesmo, ao contrário, em alguns casos fica explícito o abandono da opção por um curso que gostariam de ter estudado, em função da expectativa em relação ao emprego. O estudo é visto como um meio para conseguir algum outro trabalho, apesar de não se ter uma definição clara de que trabalho seria, uma vez que as mudanças introduzidas pela empresa têm levado a processos de desconstrução e reconstrução de sonhos e de expectativas de cada um ao longo das vivências no Senai, na Volkswagen ou na faculdade. Em algumas falas podemos perceber claramente que as atuais vivências no trabalho vão destruindo algumas expectativas como, por exemplo, não trabalhar na linha, entrar direto na ferramentaria, na manutenção ou, ainda, de ser líder.

Nesse sentido, segundo o relato de Emerson, como há muitos comentários prevendo que a área de ferramentaria será terceirizada, o sonho daqueles que terminam seus estudos no Senai é ir para a manutenção ou ser líder, pois o salário é muito melhor ${ }^{6}$. Mas, como a fala de Giulia indica, a pressão e a cobrança cada vez maiores sobre o líder, parecem ter alterado esse quadro. Se antes o sonho de Giulia, como o de muitos, era ser líder de célula, não importasse o setor, hoje ela já mudou de idéia e prefere ir para outra área.

Outro fator que também contribui para a incerteza é a preocupação com o emprego, que não se resume ao tempo futuro, pois no presente a insegurança também é explicitada para além da discussão sobre a formação. Giulia, por exemplo, mostra preocupação com o emprego ao

6. Em relação ao Grau 6, por exemplo, que é o recebido na produção, a diferença é de 11 reais para 24 reais, a hora, isto é, pouco mais do que o dobro. 
avaliar que os trabalhadores que estão na fábrica há mais tempo têm uma visão diferente daqueles que vieram do Senai mais recentemente.

“... porque peãozada velha, você [Empresa] muda alguma coisa no trabalho deles, eles chamam atenção, não quer nem saber. E o pessoal do Senai não, já é mais maleável, trabalha, não reclama muito. Ainda assim tem seus focos de problemas. [...] Quando precisar de um corte, eles [Senai] estão numa situação melhor. Eles vão mandar embora quem reclama, porque convém pra eles" (Giulia).

Aqui a questão da geração fica explícita, quando Giulia faz referência a "eles”, como "peãozada velha" mas, por outro lado, o pessoal do Senai como sendo mais maleável, que não reclama e que, por isso, tem menor risco, no seu entender, de serem mandados embora. Pessanha e Morel (1991:81), no texto sobre as gerações operárias, frisam que algumas das mudanças implementadas pelas empresas, sobretudo aquelas que representaram perda de direito já adquirido, como as pausas, por exemplo, enfrentavam forte resistência por parte dos mais velhos, enquanto "os trabalhadores mais jovens, que não conheceram os velhos costumes", cumpriam mais facilmente as novas regras. O que também pode ser visto no relato de Mendes, que foi representante sindical, ao falar sobre a diferença entre os trabalhadores da "jovem guarda" e da "velha guarda", no que se refere à aceitação da multitarefa que, como já vimos, provoca uma intensificação do trabalho. Reforça ainda que a aceitação dos mais jovens os coloca em situação de vantagem frente às decisões de demissão da Volkswagen.

"Mais aí eles [Empresa] jogaram bastante pesado na política de versatilidade, isso faz parte da avaliação da pessoa também. Então, normalmente é um dos itens que pega, principalmente os trabalhadores, vamos dizer assim, os mais da velha guarda. Já os da jovem-guarda acha que estão abafando, trabalhando em tudo que é lugar. E de fato esse que trabalha em tudo quanto é lugar, eles tem um ponto de vantagem a mais mesmo em relação aos outros, principalmente quando de uma redução no volume de produção de alguma área, porque aí quando a chefia tem que tirar alguém, tira aquele que consideram menos versátil’. (Mendes)

Flávio também mostra sua preocupação com o emprego ao ser perguntado sobre as mudanças tecnológicas ocorridas na estamparia, setor onde trabalha.

7. Maior em relação à mesma função, dado que a empresa há muito tempo busca implementar uma nova tabela salarial, com salários $10 \%$ inferiores à tabela antiga. 
"A mudança tecnológica que existe no setor, ela sempre, ela vem acompanhada com uma certa dose de insatisfação dos trabalhadores. Porque todo o investimento que é feito na estamparia, é feito no sentido de diminuir postos de trabalho. Com a questão de robotização de linhas, então você substituiu o homem por um robô. Um que coloque a chapa dentro da prensa, a prensa consiga bater essa peça automaticamente e outro robô retira essa peça de dentro da prensa e coloque direto na próxima prensa. Só nessa operação, você eliminou aí, se for uma peça grande, oito trabalhadores. Se for uma peça menor, você economizou três trabalhadores” (Flávio).

Mesmo assim, a preocupação com o emprego irá aparecer de forma muito mais forte nas falas dos trabalhadores mais velhos que têm como expectativa que a próxima transição se dê diretamente entre o tempo de trabalho na Volkswagen e o tempo da aposentadoria. Além disso, a estratégia da empresa tem sido incentivar as pessoas já aposentadas ou próximas deste momento, a entrar nos processos de demissão chamados voluntários. Mauro, por exemplo, que trabalha na ferramentaria, disse que em 98 conseguiu escapar do PDV (Plano de Demissão Voluntária) e o fez porque entende que a empresa é fantástica, no sentido de ter um bom salário, convênio médico e outros benefícios, e que os colegas que saíram, hoje estão trabalhando por menos da metade do salário da Volkswagen.

Assim, como já verificado por Sochaczewski (1998) numa pesquisa em que compara trabalhadores com mais e menos idade, os mais velhos estão em situação muito mais vulnerável do que os mais jovens. Também no caso da Volkswagen, vemos que os trabalhadores mais velhos, além de estarem próximos da aposentadoria, estão, em muitos casos, vendo suas funções desaparecerem em virtude das diferentes mudanças tecnológicas e organizacionais. Em geral, possuem menor escolaridade, salários maiores ${ }^{7}$, além de estarem mais próximos do Sindicato. Neste último caso, apenas um dos jovens trabalhadores diz estar próximo do Sindicato, pretendendo até vir a se tornar um representante sindical, quando acabar a faculdade. Trata-se de Edson, cujo pai foi militante sindical na Volkswagen.

É bastante evidente que a vivência do tempo presente influencia as perspectivas de tempos futuros. Assim, quando os jovens foram perguntados sobre os planos futuros, apesar de ter sido feita uma pergunta ampla, considerando todos os aspectos da vida ${ }^{8}$, a maior parte das respostas fazia referência direta aos planos de estudo e só depois aos de trabalho ${ }^{9}$. E

8. Como pode ser visto nos roteiros, anexo 1, a questão era formulada para que as pessoas falassem sobre os planos futuros. Se elas perguntavam sobre qual aspecto, eu respondia que sobre todos aqueles que elas julgassem importantes, considerando um tempo de 5 a 10 anos.

9. Claro que não podemos desconsiderar que praticamente toda a segunda parte da entrevista, isto é, antes da pergunta sobre o futuro, tratava, sobretudo, do tempo de trabalho (conforme anexo 1). 
dentro destes planos, como vimos, a permanência na Volkswagen não apareceu como um horizonte certo. Isto é, o futuro na Volkswagen é visto como incerto, seja em função da dúvida em relação ao reconhecimento do estudo pela Empresa, o que no entendimento dos entrevistados significa tirá-los da produção; ou pelo desejo de construir uma outra possibilidade fora desta empresa.

De uma forma geral, poucos falam de planos para o médio prazo e mais uma vez a questão da idade é um grande diferenciador. Os mais jovens falam um pouco mais a respeito de planos para o futuro, como um tempo de expectativa e em construção: sair ou ficar na empresa, abrir um negócio próprio, casar, ter filhos, estudar mais. Tamara, que tem 21 anos, por exemplo, fala sobre muitos planos a partir de um diálogo entre o que ela gostaria de fazer no futuro e o que parece ser possível de ser realizado no curto prazo.

“O meu futuro é assim, eu vou me formar em engenharia, que é o que eu preciso, não realmente o que eu gosto. O que eu realmente gosto é engenharia ambiental, voltada à indústria, mas eu não sei se vou fazer isso porque os meus planos não são... Eu vou trabalhar aqui por um tempo, mas eu quero ter o meu próprio negócio.[...] Eu gostaria de abrir uma auto peças para automóveis. Eu quero ter o meu próprio negócio e não aqui, em Minas. Eu penso em estudar, me formar, ter a minha independência, me auto estabelecer, conseguir abrir o meu negócio. Se eu não conseguir, continuar estudando, não pretendo parar, sempre me renovando. [...] Não ter patrão, ter seu horário, ter a sua maneira de ser, viver de uma maneira tranqüila, que é o que todo mundo quer, sombra e água fresca, quando envelhecer, eu não vou ser diferente”. (Tamara)

Para os que estão mais próximos da aposentadoria é quase um tempo de transição, sendo que os planos são pensados para depois da saída da empresa. Isto é, eles não falam sobre qualquer plano dentro da empresa, mas apenas em realizar a transição do tempo de trabalho para um de não trabalho. Para os que estão a um tempo médio para a aposentadoria, entre cinco e sete anos, por exemplo, esse parece ser um tempo de espera da aposentadoria para, então, se pensar em fazer algo diferente. Nesse caso, o tempo de espera é também vivido como um tempo de muita angústia, tempo de medo. Medo de perder o emprego na Volkswagen e não conseguir outro, pois citam parentes que estão desempregados e casos de trabalhadores que ao sair da Volkswagen passam a ganhar muito menos. Luana e Joice, apesar de estarem mais distantes da aposentadoria, ao serem questionadas sobre os planos para o futuro, também frisam que pretendem trabalhar na Volkswagen até a aposentadoria.

"Eu pretendo trabalhar até me aposentar na Volkswagen. Não quero sair de lá em hipótese alguma. 
Hoje eu já penso, não tem nem como eu sair de lá porque para mim, aqui fora, não consigo mais nada. Eu tiro pela minha irmã, está desempregada, ela é bem mais jovem do que eu, tem estudo, curso superior, ela está batalhando aí e não está fácil. Então esses 5, 6 anos eu quero trabalhar na Volkswagen, depois que eu me aposentar, aí vai depender da minha filha”. (Joice)

$\mathrm{Na}$ fala de Joice, que é muito próxima da de Luana, alguns sentimentos são explicitados. Primeiro que seu futuro e também da família, aparece como dependente da permanência na empresa, demonstrando um certo medo em relação aos tempos futuros. Apresenta dúvidas, também, em relação ao futuro da filha. Disse ter ficado muito triste quando sua filha não conseguiu entrar no Senai da Volkswagen, porque sabe que "o mercado de trabalho está muito difícil”. Gustavo, para quem ainda faltam cerca de treze anos para se aposentar, diz que agora sua preocupação é com o filho, sua faculdade e seu trabalho. Ressalta que irá sugerir ao filho trabalhar na Volkswagen, fato bastante recorrente entre os trabalhadores com filhos. Portanto, é importante ressaltar que nessa discussão sobre os tempos futuros, em meio a uma conjuntura de incertezas e grande preocupação em relação ao trabalho, a questão do tempo de estudo aparece com grande destaque. É uma alternativa que amplia as possibilidades de construção de uma transição para um trabalho melhor, seja na Volkswagen ou mesmo fora dela, ou ainda para o próprio ingresso no mercado de trabalho, como no caso dos filhos.

\section{4 - Considerações finais}

Neste capítulo, vimos que há um conjunto de narrativas discursivas comuns sobre as vivências dos tempos de trabalho e de não trabalho, vindas dos jovens trabalhadores entrevistados na Volkswagen. São pessoas que a partir de determinadas situações sociais constroem vivências similares em relação às vivências temporais cotidianas tanto no que se refere aos tempos de trabalho e não trabalho, e que se manifestam através de um modo específico de falar do tempo vivido. Esse falar sobre o tempo aponta para experiências de transição no percurso da vida entre a casa e a escola e entre a escola e a entrada no mercado de trabalho. Explicita ainda, no tempo presente, expectativas de novas transições no tempo futuro, neste caso, entre o fim do tempo dedicado à faculdade e o início de um novo trabalho.

A construção dessas expectativas em relação ao tempo futuro traz em seu bojo tanto a frustração e decepção em relação à transição passada, quanto esperança no que se refere a uma 
possível transição futura. Logo, as transições são aqui pensadas quando a estrutura da vida precedente está, ou foi, substituída por uma nova fase, como pontos que ligam dois períodos da vida, duas vivências temporais diferentes.

Vimos que esses jovens experimentaram a transição para o primeiro emprego como continuidade - já que tinham o emprego na Volkswagen garantido, e, ao mesmo tempo, como ruptura, no que se refere à vivência desse processo, um choque entre a expectativa de um trabalho e a realização de outro. Assim, se essa transição era avaliada, antes da realização das entrevistas, como uma passagem tranqüila, justamente por ter como característica principal a continuidade, não foi o que se verificou.

$\mathrm{Na}$ análise das falas deste grupo, ficou evidenciado que, mesmo esses jovens tendo passado por um processo de socialização antecipado pela família bem como pelos estudos no Senai ou, talvez, justamente em função dessa socialização, essa transição foi caracterizada por um processo de ruptura: afinal, esses trabalhadores foram socializados para um outro tipo de trabalho, diferente do que encontraram quando entraram na Volkswagen. Importa dizer que muitos trabalhadores mais velhos, homens e mulheres, também dizem ter levado esse mesmo "susto" causado pelo desconhecimento da Empresa. Para os jovens, entretanto, o processo de socialização anterior acabou apresentando uma Volkswagen diferente daquela que encontraram ao iniciar o trabalho.

Isto porque esses jovens entraram no Senai, e depois na empresa, no momento em que esta passava por uma forte mudança, como vimos anteriormente. Entre as mudanças implementadas, destacam-se a redução do investimento na formação interna, a implementação de uma significativa política de redução do número de trabalhadores, caracterizando uma situação micro, em meio ao contexto macro da sociedade, de instabilidade crescente no emprego.

A partir dessa situação, os jovens acabam por adiar a realização do projeto de ter um trabalho dotado de maior autonomia em relação ao tempo, maior salário, maior reconhecimento, para o futuro, para uma possível segunda transição. Nesse caso, não é mais o fim do curso do Senai que possibilita o trabalho desejado, mas o final da faculdade. E, sobretudo, não há certeza sobre sucesso. Apesar disso, os jovens acabam por dedicar quase todo seu tempo ao estudo e ao trabalho, mesmo que isso signifique a falta de tempo para outras atividades que dizem apreciar muito. Assim, "o tempo cotidiano é cuidadosamente investido e desfrutado de modo análogo ao dinheiro; é programado, e seu uso, racionalizado" (Leccardi, 2005:36), e com isso, postergam não apenas a realização do trabalho desejado, como também o prazer de vivenciar aquilo as outras temporalidades sociais. 
Esta estratégia é construída pelos jovens como forma de enfrentar as transformações pelas quais passam a empresa e o mercado de trabalho e, mais do que para enfrentá-las, para, de certo modo, controlá-las, sem perder de vista o projeto futuro. De acordo com Leccardi, $(2005 ; 50)$,

“... o resultado desses importantes processos de reestruturação da relação entre jovens, tempo biográfico e tempo social não se reduz à absolutização do presente imediato e à glorificação do aqui e agora. As identidades não se conjugam apenas no presente. [...] O futuro é relacionado, assim, com a abertura potencial - o futuro constitui, hoje mais do que nunca, o espaço do devir possível - mas, ao mesmo tempo, com uma indeterminação expressa, com freqüência cada vez maior, como insegurança".

Como já discutido de um ponto de vista teórico, apesar da idéia de futuro não ser mais portadora indiscutível da certeza, do progresso, da melhora em relação ao passado e ao próprio presente, isso não significa que as incertezas geradas levem à vivencia unicamente do presente. Logo, mesmo que o futuro fuja do controle desses jovens, eles buscam criar condições para assegurar o seu projeto. Mas, como salienta Leccardi (2005: 51), não são todos os jovens que apresentam as mesmas condições para driblar esse futuro incerto. No extremo, estão os jovens com mínimas condições para programar o futuro e, neste caso, a "incerteza do futuro significa, então, disponibilidade diante do acidental, do fortuito - do acaso. Para esses jovens, o futuro, fora de controle, pode ser somente anulado, apagado para dar lugar a um presente sem fascínio". (idem: 51).

O caso de Felix é o que mais se diferencia dessa perspectiva. Trabalhando em uma empresa terceira, onde tem uma remuneração inferior ao da Volkswagen, e ainda tendo que dividir as despesas em casa, foi obrigado a deixar a faculdade de administração e começar um curso técnico em radiologia. Mas não é apenas a condição atual que o orienta, pois ele entende que a sua perspectiva de crescimento na empresa onde trabalha é muito pequena, e que o salário "não é assim tão bom". Neste caso, a escolha do curso técnico pode trazer outras possibilidades muito diferentes dos jovens que hoje estão na faculdade e dentro da Volkswagen.

Outro sentimento é externado pelos jovens que dizem gostar de trabalhar na Empresa, geralmente, em função do nível de conquista da categoria - salário, seguro saúde, PLR, transporte -, apesar da falta de reconhecimento que enfrentam. Mas, ao mesmo tempo, alimentam a esperança de um reconhecimento futuro. É preciso notar, entretanto, que mesmo entre eles há 
diferenças. Flávio, por exemplo, que não fez o Senai na Volkswagen, relata que escolheu o curso de direito, que não tem nenhuma relação com seu trabalho, por entender que não terá muitas oportunidades dentro da empresa. Todos os outros trabalhadores disseram que, apesar da falta de certeza, acham que podem vir a ser reconhecidos pela empresa e, conseqüentemente, migrar para áreas qualificadas.

No caso dos trabalhadores mais velhos, vimos que o futuro é pensado a partir de outras condições e de outras perspectivas em relação ao tempo de trabalho dentro e fora da fábrica. Vimos que há um grupo de trabalhadores - entre 30 e 40 anos, casados, alguns com filhos, já formados ou que estão no final do curso, que já saíram da área produtiva -, que também explicitam planos relacionados ao emprego, no sentido de se manter na Volkswagen. Nesses casos, fica evidente uma dificuldade maior do que para os jovens para harmonizar os tempos dedicados ao estudo e ao trabalho, já que despendem ainda tempo e recursos financeiros com a família.

Vimos, além disso, um outro perfil de trabalhadores - com mais idade, mais tempo de casa, que atualmente não estudam e trabalham na produção. As narrativas desse grupo não demonstram perspectivas de tempos melhores em relação ao trabalho. Para esses, voltar a estudar não faz sentido. Neste caso, o melhor futuro é entendido como a possibilidade de se manter na Volkswagen até a aposentadoria. Essa perspectiva não é explicitada apenas por trabalhadores que estão a um ou dois anos da aposentadoria, isto é, muito próximos da transição do tempo de trabalho para um tempo de não trabalho, mas também, por aqueles que estão a dez, doze anos de completar o tempo para aposentadoria. Nesses casos, quando são perguntados sobre os planos futuros, falam apenas sobre o tempo após a aposentadoria, como se o tempo até lá fosse só um tempo de espera, no que se refere à própria vida. E se têm planos futuros, antes da aposentadoria, estes se referem aos filhos, a quem desejam que estudem, entrem na Volkswagen, consigam um "bom" emprego.

Desse modo, a maior diferença entre os jovens e os trabalhadores de outras gerações, aparece mais fortemente quando olhamos a vivência presente do tempo de trabalho, em comparação à expectativa de um tempo futuro. Assim, mesmo que o tempo presente seja muito similar ao de outros trabalhadores, a expectativa de um futuro melhor possibilita aos jovens um outro sentido para o presente e, portanto, uma outra vivência e representação deste. 
Mas mesmo o tempo presente, na inter-relação entre o tempo dentro e fora do local de trabalho, guarda as suas especificidades ao compararmos as vivências temporais cotidianas das diferentes gerações. Como vimos no capítulo 6, sobre o tempo dentro do local de trabalho, não há muita reclamação dos trabalhadores mais velhos em relação à realização de hora extra ou em relação ao banco de horas - no que se refere à questão do tempo e não da remuneração. Já para os jovens, tanto a hora extra como a compensação das horas negativas do banco de horas, que são definidas pela Empresa para ocorrerem no sábado, são fortemente criticadas. Num mesmo sentido, também o são por alguns adultos que estudam, pois há uma sobreposição entre o tempo de trabalho e o tempo de estudo.

Mas a grande diferença se manifesta em relação à "semana Volkswagen", isto é, a semana de quatro dias. À exceção de Felix, que não teme essa experiência na empresa terceira, todos os outros jovens julgam que ela foi muito positiva e que, se pudessem escolher, optariam pela semana Volkswagen, mesmo com redução da remuneração. De forma que estes jovens, dadas as suas condições atuais e expectativas em relação ao futuro, não hesitam em escolher menos trabalho, mesmo que isso signifique menor remuneração, ao invés de mais tempo dedicado ao trabalho e maior remuneração.

Finalmente, pudemos observar que todos vivenciam fortemente o tempo dedicado ao trabalho tanto no presente como nos planos futuros. Entretanto, quando perguntados sobre o que é mais importante na vida, apenas dois jovens apontam para o trabalho: Felix, que trabalha na empresa terceira e Tamara com um discurso que enfatiza a questão da independência. Dois outros fazem questão, inclusive, de dizer que trabalham porque precisam e não porque gostam. Por outro lado, nenhum deles tem em mente uma vida sem espaço ou tempo para o trabalho. Sochaczewski (1998) ${ }^{10}$, havia concluído que tanto trabalhadores mais velhos como os jovens «herdeiros», julgavam ser o trabalho a atividade mais importante na vida. Já os jovens «recémchegados», consideravam que o tempo dedicado ao estudo, à família ou à igreja eram os mais importantes. No caso de minha análise, realizada dez anos depois e tratando praticamente só com jovens «herdeiros», vê-se que as vivências dos «recém chegados» de dez anos atrás se generalizaram para a juventude atual.

10. A autora dividiu os entrevistados em três grupos: os mais velhos que trabalhavam há muitos anos na mesma empresa; os «herdeiros» - jovens, filhos de pais metalúrgicos que haviam começado a trabalhar na mesma empresa que seus pais e os «recém-chegados» - jovens que haviam entrado na empresa há pouco tempo e provenientes de famílias sem tradição operária. 
Ou seja, muitos jovens dizem não ser o trabalho a atividade mais importante de suas vidas, mesmo que ele ocupe grande parte delas, tanto no tempo presente como na perspectiva de tempos futuros. Guimarães (2006), também ressalta, a partir de dados de pesquisa atitudinal de $2003^{11}$, que apenas $6 \%$ dos entrevistados responderam que o tempo dedicado ao trabalho era o mais importante, salientando a homogeneidade do grupo: jovens que já tinham ou estavam em um emprego regular e notadamente formado por rapazes mais escolarizados de 18 a 20 anos. Isto é, um perfil muito próximo ao dos jovens da Volkswagen. Mas Guimarães observa, por outro lado, que quando a questão era sobre os problemas mais urgentes, a questão do emprego ganhava um grande destaque.

11. Este foi um survey: Perfil da Juventude Brasileira, que entrevistou uma amostra de 3.501 jovens, entre novembro e dezembro de 2003. 


\section{TEMPOS DE TRABALHO E DE NÃO TRABALHO: VIVÊNCIAS A PARTIR DE UMA PERSPECTIVA DE GÊNERO}

O

utra dimensão marcante que confere sentido e especifica uma configuração de discursos com relação ao tempo é a perspectiva da relação social de gênero. E como uma relação social, esta tem um significado de contradição, antagonismo, luta pelo poder, mas, ao mesmo tempo, de recusa em considerar os sistemas dominantes como totalmente determinados (Kergoat, 1986). Esta relação de gênero corta transversalmente alguns discursos de representantes sindicais, homens ou mulheres, líderes, gerentes da Empresa, trabalhadores e trabalhadoras, referentes aos temas ligados ao tempo de trabalho e não trabalho, tal a sua força na produção dos relatos. Além disso, ao olharmos as vivências temporais cotidianas das mulheres que trabalham na Volkswagen, fica ainda mais evidente o caráter indissociável entre o trabalho profissional e o trabalho realizado em casa, a produção e a reprodução, o trabalho e a família (Hirata, 1996). E é justamente a análise desse conjunto que possibilita repensar a divisão entre tempo de trabalho e tempo de não trabalho, onde este último deixa de ter o mesmo significado que tempo fora do local de trabalho.

Desta forma, neste capítulo estarei realizando uma análise sobre as vivências temporais cotidianas dos tempos de trabalho e de não trabalho, a partir de uma perspectiva de gênero, tendo como foco principal as falas das trabalhadoras sobre as suas vivências do tempo dentro e fora da fábrica. Para tal, à vista dos discursos dessas trabalhadoras, foram construídos cinco grupos de mulheres com experiências diferentes em relação aos diversos tempos sociais. Para formar os grupos, considerei diversos aspectos além do sexo, como a idade, a situação familiar, a escolaridade e a função exercida na Empresa. Analiso, ainda, as narrativas de dirigentes sindicais, gerentes da Empresa e trabalhadores, a respeito das visões que têm sobre as vivências das mulheres, explicitando ainda, as suas próprias representações e valores sobre o papel e o espaço ocupado por homens e mulheres, tanto dentro da fábrica como fora desta. 


\section{1 - As mulheres na Volkswagen}

Uma primeira observação, sobre as mulheres na Volkswagen, refere-se à grande dificuldade que tive para alcançar e ouvir as trabalhadoras mulheres, mesmo tendo feito a demanda para o Sindicato e para a Volkswagen. Ao todo entrevistei 8 mulheres, o que significou $20 \%$ dos casos, abaixo do programado inicialmente, em torno de $30 \%$ da amostra, mas acima do percentual de mulheres que trabalham na Volkswagen. Em parte esta dificuldade foi explicada pela Empresa devido à quantidade reduzida de mulheres, algo em torno de $9 \%$, sendo 1300 mulheres e 14 mil homens. No setor produtivo, foco da pesquisa, esse número está em torno de 400 mulheres, de acordo com informações do gerente de RH, para o ano de 2006. Lembrando que na produção, os dois únicos setores nos quais se empregavam mais abundantemente mulheres, o chicote e a tapeçaria, foram terceirizados no final dos anos 90.

“... hoje nós temos apenas 400 operárias aqui na fábrica (setor produtivo). Pro sociólogo é fácil explicar. No passado a indústria automobilística era muito verticalizada, então quando ela precisava ter boa parte dos recursos ela mesmo fazia, a parte grande das mulheres estava no chicotes.[...] Nós tínhamos uma legião de mulheres que trabalhavam na montagem de bancos e chicotes. Com o tempo a própria pressão econômica faz com que isso seja passado pra fornecedores. [...] Então, nós perdemos algumas ocupações, porque pra mexer com chicote tinha que ser mãos de mulheres, vamos dizer assim. Então a parte física propiciava essa vantagem de destreza maior, porque facilitava. E o inverso agora é verdadeiro, você tem as vezes comando de máquinas que são universais, você precisa as vezes mais de um cérebro do que a parte física que não interfere tanto" (gerente de RH).

A fala do gerente de RH nos revela que a presença da mulher, no caso da Volkswagen, se concentrava naqueles setores que não faziam parte do foco da empresa que passou a ser montar carros $^{1}$, sendo que no processo de desverticalização tais setores, considerados os menos importantes no processo produtivo, foram terceirizados. Assim, podemos falar que a Volkswagen sempre foi uma fábrica de predominância masculina, tanto do ponto de vista quantitativo, como em relação à qualidade dos postos de trabalho, onde os homens ocupavam os principais setores da produção.

E em função dessa redução cada vez maior do número de mulheres na Empresa, Mônica, a única mulher dirigente sindical, explicita que “A gente está tendo muito problema lá na fábrica até

1. Tendo como exemplo extremo, o consórcio modular na Volkswagen em Resende- RJ. 
em questões de saúde sabe? Tem o ambulatório, mas não tem médico especializado. [...] A gente tem alguns direitos que foram tirados por não ter mulher”. Mônica relata ainda, que são poucas as mulheres que têm entrado na Volkswagen. A "Fábrica reduziu muito, mulher na Volks hoje está entrando somente pelo Senai para a área de produção e área técnica, tirando escritório né, pois neste setor há muitas mulheres".

Um exemplo interessante que explicita bem a diferença no tratamento entre homens e mulheres é o fato de que, até o início dos anos 1990, as mulheres não podiam fazer o curso do Senai dentro da Empresa, ficando as vagas reservadas apenas para os filhos e irmãos de trabalhadores. Em relação à terceirização dos setores de maior presença feminina, apesar de não ter havido uma política de demissão dessas trabalhadoras ${ }^{2}$, posteriormente elas foram saindo via PDV's e mesmo pela aposentadoria.

E por fim, outro motivo alegado pelos dirigentes que contribuiu para a dificuldade em contatar mulheres para serem entrevistas, é o distanciamento destas em relação à entidade sindical. Como ressalta Mônica, “A categoria nossa da parte das mulheres é muito desunida. A gente [Sindicato] precisa vim com outra filosofia para tentar unir, para ver se a gente ganha o espaço que a gente, né, merece”. Ela nos fala igualmente sobre a dificuldade da ação sindical, não apenas porque as mulheres estão distantes do Sindicato, mas também porque este não conhece bem a realidade das trabalhadoras. Destaca que a Empresa é muito grande, que as mulheres são poucas e espalhadas e que em cada setor elas "devem ter problemas específicos". No seu relato, a dirigente explicita as dificuldades de participação e a necessidade de construir alternativas para envolver as trabalhadoras com a organização sindical.

"Eu penso em fazer uma pesquisa para saber qual é o problema delas, nunca foi feito. (...) Um questionário, isso eu vou tentar puxar aqui com o nome das sócias, a princípio para falar: o que você acha que tem que melhorar? O que você acha que não tem? Tem que partir daí né? Para a gente poder identificar as pessoas" (Mônica).

Assim, o que fica explícito é que se as mulheres estão distantes da entidade sindical, esta, por sua vez, também está longe das mulheres. Dada a ausência de falas dos dirigentes em relação ao trabalho das mulheres na Volkswagen, além da existência de apenas uma mulher atuando como representante do Sindicato, num grupo de 42 representantes.

2. Em função do acordo sobre terceirização, negociado entre a Empresa e o Sindicato, como já vimos anteriormente. 
A seguir, apresento a análise sobre as vivências temporais cotidianas, tendo como foco principal as falas das trabalhadoras sobre as suas vivências do tempo dentro e fora da fábrica, considerando o gênero, a geração, a situação familiar, a formação e a função exercida na Empresa.

\section{2 - Vivências das trabalhadoras nos tempos de trabalho e de não trabalho}

Nas narrativas discursivas das trabalhadoras veremos que as relações de gênero não podem ser consideradas de maneira isolada, mas sim em relação direta com os diferentes momentos do percurso da vida ${ }^{3}$, com a situação familiar, a formação e a função exercida na Empresa, num contexto de imbricação de múltiplas relações sociais, como as de gênero, geração e também de exploração (Kergoat, 1996). Isto porque, apesar dessas narrativas apresentarem recorrências em relação às vivências desses tempos, observa-se que para além da condição do sexo, outras relações e situações nos ajudam a compreender, entre outras questões: como as mulheres vivenciam os diversos tempos sociais? O que significa ser jovem, considerando as relações de gênero? Qual a relação entre casar e ter filhos e estar no mercado de trabalho? Homens e mulheres vivenciam estas situações da mesma forma? E, neste caso, como ficam os tempos dedicados ao trabalho profissional e ao estudo? Que representações são explicitadas pelos homens, sendo eles trabalhadores, dirigentes ou gerentes, no que se refere às experiências de tempo de trabalho das mulheres?

\subsection{1 - Giulia, Viviane, Eliana e Tamara}

Nos discursos de Giulia, Viviane, Eliana e Tamara, onde relatam suas vivências temporais cotidianas, observei que há pouca diferença quando comparadas a dos jovens, da mesma idade, como já apresentado anteriormente. Tanto no que se refere aos usos do tempo em relação às vivências no tempo presente, como também, em relação às perspectivas para os tempos futuros. Isto porque, outras características como ser jovem, morar com a família, cursar o nível superior, ser solteiras e não ter filhos, acabam influenciando fortemente essas vivências, de forma que tanto os jovens como as jovens vivenciam os tempos de trabalho e de não trabalho de

3. Aqui, "parcours de vie" tem um significado que considera fortemente a idéia de historicidade, sendo que a sociologia dos percursos de vida tem como foco de análise as relações entre os tempos individuais e os tempos sociais, considerando ainda a questão geracional e, portanto, a relação entre os diferentes momentos dos percursos de vida, através de análises de trajetórias biográficas (Bessin, 2000). 
uma maneira muito similar. Do ponto de vista quantitativo suas 24 horas são basicamente ocupadas com o tempo de trabalho, o tempo dedicado ao estudo e o tempo de repouso, sendo que o tempo de lazer é algo totalmente marginal, ao mesmo tempo em que muito desejado.

Entretanto, apesar da aproximação dos discursos, no caso das jovens há algumas especificidades nas suas experiências cotidianas em relação aos tempos sociais. Fora da fábrica, por exemplo, foi relatado um tratamento diferenciado em relação aos filhos e às filhas; estas nem sempre foram incentivadas a entrar na Volkswagen, mesmo no caso do pai já trabalhar na Empresa. Podemos pensar ainda, que talvez seja por isso mesmo, isto é, por saber que a grande maioria dos trabalhadores dentro da Volkswagen são homens e que o trabalho é muito "duro". Aliás, é interessante lembrarmos que dentre todos os que vêm de uma família metalúrgica é sempre o pai e não a mãe que trabalhou na Volkswagen, como no caso de Tamara, que atualmente está na linha do Gol.

\begin{abstract}
"Quando chegou a idade dele [irmão] fazer a prova, ele fez, não passou no Senai da Volks, que era o grande sonho do meu pai, que ele passasse. Aí na minha [vez] fui lá, quietinha, fiz a prova, passei. Foi bom e não foi. Porque ele não gostou muito, mulher trabalhando...né? Mas aí o tempo foi passando, ele viu que não tinha nada a ver, gosto do que faço, é uma vida corrida, no começo foi difícil" (Tamara).
\end{abstract}

E se o pai muitas vezes serve como referência do trabalho profissional, do que se quer ser, a mãe (ou outras mulheres da família), algumas vezes serve como referência do que não se quer ser, no sentido de uma experiência a ser evitada. Por isso a grande importância dada ao tempo dedicado à escola, como tempos que possibilitam a construção de um presente e um futuro diferente do da mãe, que de acordo com o relato de Tamara, sempre dependeu do seu pai.

"Hoje eu estudo por isso, porque eu pretendo ter um futuro, eu pretendo ser diferente. Então eu penso assim, não sei se porque a minha família foi muito complicada, as minhas primas serem mães muito novas, primos serem pais muito novos, então eu penso assim: eu quero ser diferente, eu quero uma realidade diferente. Eu quero dizer assim: eu estou casando porque eu quero, eu vou morar aonde eu quero, eu sou sustentada com o meu dinheiro, não dependo de um marido, eu quero isso. Eu não sei se porque os nossos pais são muito antigos, então minha mãe é totalmente dependente do meu pai. Às vezes eu falo: 'mãe você não tem vontade de fazer uma coisa diferente, que você fale: eu vou fazer e não quero saber do seu pai?’ [...] Então é isso que eu não quero, eu quero ter a minha independência, eu quero ser uma pessoa auto- suficiente, então eu considero a escola o mais importante" (Tamara). 
Também a Empresa ofereceu um tratamento desigual para os jovens e as jovens, ao proibir, até os anos 90, a entrada de mulheres para estudar no Senai, dentro da Volkswagen. Vivian relata que na sua turma do Senai, em 1996, havia 220 meninos e 20 meninas, sendo que esta já era a sétima turma com admissão de meninas. Menciona ainda que "As primeiras meninas, acho que foi no ano de 93, tinha duas meninas formadas, então já tinha bastante meninas". Mônica, representante sindical, está na fábrica há 12 anos, e nos conta que ela entrou aos 14 anos, pelo Senai, sendo a segunda mulher a entrar na Volkswagen através desta instituição.

“... porque antes não podia entrar mulher, era norma da fábrica, entrou antes de mim, foi feito teste aí eu fui a segunda, passamos por várias dificuldades porque era uma coisa nova, mecânica para mulher. A adaptação foi um pouco difícil a princípio, mas depois a gente foi acostumando e graças a Deus a gente abriu esse leque. Hoje não tem mais essa cota. Quando eu entrei, podia entrar duas [mulheres], era limitado. Hoje não, hoje se passar tudo mulher, pode entrar” (Mônica).

O gerente de $\mathrm{RH}$ entende que a própria abertura do Senai para as mulheres acabou por contribuir para reduzir a resistência dos pais, e que hoje ela praticamente não existe.

"E os próprios pais têm colocado as filhas como operárias, assim, não é bem operários, faz uma função que tradicionalmente seria ocupada por um homem. E aqui dentro nós acabamos com isso. A gente percebe que eles mesmos vão se aceitando e tem outra cabeça que talvez os mais velhos: 'Puxa, uma mulher trabalhando na operação? ' Sim, uma mulher trabalhando na operação. Em São Carlos, onde é a nossa fábrica de motores, lá tem muitas mulheres que trabalham em um posto que seria tradicionalmente de um homem" (gerente de RH).

Já dentro da Empresa, não foi fácil a vivência de um tempo de trabalho num local onde a quase totalidade era, e é, constituída por homens, tanto no que concerne aos colegas de trabalho, à gerência, como à entidade sindical. Como já vimos na discussão sobre as gerações, para os jovens a transição do Senai para o trabalho na Volkswagen foi vivenciada como um "susto", porque a expectativa alimentada era de trabalhar em uma área qualificada; e, no caso das mulheres, ir para a produção significou uma dificuldade ainda maior, pelo fato de trabalharem praticamente com homens, como nos relata Eliana, que trabalha no final da linha do Pólo.

"Eu montava a parte de ar condicionado e tapete. Então era uma área que só tinha eu de mulher, então já era outro ponto bem difícil de se lidar. [...] Porque no começo, os homens têm certo receio de conversar com você porque eles pensam que vão estar dando em cima de você. Depois, 
quando você começa a pegar amizade, tem aquele ponto de você dar liberdade demais e acabar com o respeito. Então, é muito difícil você lidar com isso; você dá liberdade demais é perigoso, você não dá liberdade, você é chata. No começo foi meio difícil lidar, mas assim, hoje eu trabalho também só com homem, mas me dou super bem com eles" (Eliana).

E a fala de Tamara também explicita bem as dificuldades vividas pelas mulheres, não só de adaptação, mas de construção e manutenção das relações com demais trabalhadores da Empresa: “... trabalhar só com homens você não tem muito que falar, quando tem, você tem que falar meio assim, porque peão é uma coisa terrível, você tem que ir meio devagar. Com a menina não, a gente vai, a gente brinca". Na sua fala é interessante observar a referência aos homens como peões, como se ela mesma não fizesse parte dessa mesma categoria. E é ainda importante salientar que estas duas situações relatadas pelas jovens trabalhadoras - o não incentivo da família e a dificuldade de trabalhar num setor predominantemente composto por homens -, também o foram pelas trabalhadoras de mais idade, como veremos adiante.

Ainda fora da fábrica, muitas vezes o convívio com um mundo constituído na sua maior parte por homens, se dá também no tempo de estudo. De forma que, muitas vezes, este tempo também é vivenciado como um momento de prova; de mostrar aos outros, ou seja, aos homens, a sua capacidade, como podemos notar na fala de Tamara, ao ser questionada sobre o que mais gosta de fazer.

\footnotetext{
"Conhecer sobre ele [carro]. Eu acho assim, não sei se eu comecei a gostar quando comecei a conversar com os meus amigos. Eu cheguei na faculdade, eu olhei dentro da sala, eu sou a única mulher. Os cursos que eu fiz, todos praticamente, eu era a única mulher. Fiz um curso de desenho e projetos, que eu estudava com 42 homens. Então chegar na sala e os caras olharem para você: o que ela está fazendo aqui, ela caiu de pára-quedas? [...] O fato dos homens ficarem um pouco; você é menina, você entende disso! Mas por que mulher não pode entender, tem alguma coisa? Acho que eu fui gostando, fui gostando, o meu namorado também curte muito essas coisas, então uni o útil ao agradável, acabei curtindo esse mundo, dos carros mesmo, é o que eu gosto (Tamara).
}

Dentro da Empresa, o tempo de trabalho, tanto quanto o tempo da pausa, não é vivenciado da mesma maneira por homens e mulheres, como nos conta Tamara, quando questionada sobre o tempo para ir ao banheiro. Já havíamos discutido, anteriormente, que a questão das pausas nas linhas de produção tem sido um problema cada vez maior para os trabalhadores da Volkswagen. Vemos, entretanto, que no caso das mulheres, a dificuldade de parar o tempo de trabalho, quan- 
do necessário, pode ser vivenciada de forma ainda mais onerosa e constrangedora, quando as mulheres têm que explicitar a situação de estarem menstruadas, em meio a um universo machista. Outro reflexo relatado por Tamara, diz respeito a mudanças de hábito, como a própria redução da ida ao banheiro limitando-a aos momentos de extrema necessidade.

“... eu falo para você que eu me adaptei a não ir ao banheiro nesse período, falo para você que eu não tenho vontade de ir ao banheiro, são raras às vezes, basicamente nos dias que eu estou menstruada. Nessa semana, a gente entra, tem o monitor, a gente entra num acordo com ele, a cara vermelha, mas: 'Marcelo eu preciso ir'. Ele entra em desespero; ele fala: 'calma que a gente vai dar um jeito"” (Tamara).

Finalmente, no que diz respeito às expectativas em relação ao tempo futuro, de uma forma geral, como já discutido anteriormente, este é pensado de maneira muito similar pelos jovens do sexo masculino e feminino. No que se refere ao tempo fora do local de trabalho, os estudos aparecem de forma muito evidente; se formar e continuar a dedicar um tempo ao estudo, seja um curso de línguas ou uma pós-graduação. E em relação ao tempo dedicado à família, estes jovens até citam a questão do casamento e de ter filhos, mas é algo realmente marginal nas suas falas. Em relação ao tempo de trabalho, como já vimos, a expectativa é de que sejam reconhecidas pela Empresa, de que tenham a oportunidade de trabalhar em outras áreas, e caso não seja possível, então, sair da Volkswagen.

\subsection{2 - Luiza}

"Meu nome é Luiza, tenho 28 anos, estou gestante de 8 meses, sou casada, meu marido é engenheiro mecânico na Empresa ABB, fica em Guarulhos, na unidade da Guarulhos".

$\mathrm{Na}$ fala de Luiza, vemos que ela se apresenta e ao mesmo tempo apresenta seu marido, dizendo qual a sua profissão. E o mais interessante é que ela foi a única que se apresentou desta maneira, sendo que os homens, já que não há nenhum outro caso de mulher casada entrevistada, ao se apresentarem, não falaram da profissão de suas respectivas esposas.

Luiza apresenta uma vivência temporal cotidiana muito diferente dos tempos sociais, tanto no que se refere ao tempo de trabalho como o de não trabalho. Como vimos em sua fala, ela trabalha como secretária, é casada, está grávida do seu primeiro filho, e, diferentemente do grupo anterior, já dedica um tempo à família e tende a aumentar este tempo, como ela mesma 
ressalta, com o nascimento do filho. Mas esta situação - casar e ficar grávida -, não a levou a não dedicar menos tempo ao trabalho, como explicita, ao ser perguntada sobre o que mais gosta de fazer na vida.

"Eu gosto muito de trabalhar, eu até brinco com meu marido: você não casou com uma mulher
para ficar em casa e cuidar de filhos, obviamente que eu não digo que eu vou ficar aqui o resto da
minha vida, mesmo que eu saia daqui um dia, eu vou fazer outra coisa, eu não sou uma pessoa de
ficar em casa. Então assim, eu dou muito valor a vir trabalhar, mas também dou muito valor a
estar com a minha família (...)" (Luiza).

Assim, é importante ressaltar que Luiza se difere dos vários casos relatados por trabalhadores em relação às esposas que pararam de trabalhar, em função do casamento ou do nascimento do filho. Como no caso da esposa de José Egito, que parou de trabalhar no momento do casamento, mesmo antes que o primeiro filho nascesse. Mas ele relata que no futuro ela deve voltar a trabalhar fora de casa, quando a segunda filha crescer.

"Nós já tínhamos planejado isso. [...] Primeiro nós pensamos o seguinte: vamos ter um filho,
vamos ficar 5 anos sem ter filho para que? Para curtir nós dois. Aí tivemos a primeira menina. Aí
pensamos, vamos dar um tempo de mais ou menos 5 anos para o segundo, que é mais ou menos
o tempo da gente poder ajudar ela, no futuro, numa faculdade. Aí demos um tempo de 5 anos, aí
veio o menino. Aí agora, estamos dando um tempo para ele crescer com ela [mãe] porque nós
pensamos que essa primeira fase da criança, de 1 até 5 anos, é muito importante estar com a mãe,
ter a atenção da mãe, dos pais, não ficar numa creche, acho que não é legal" (Luiza).

Muitas vezes, as esposas nem começaram a trabalhar, como relatam Donizete, Gerson e Edgar. "Porque não teve necessidade. A gente dentro de um padrão que a gente achou que estava bom para a gente, deu para a gente viver até hoje, está dando para viver, graças a Deus" (Gerson). “Eu entrei na Volkswagen, aí a Volkswagen já proporciona uma condição melhor, então já dá para a gente manter a família tranqüila" (Edgar) e sua esposa complementa: "É nasceu a Carina, fui cuidar dela e estou em casa até hoje". Donizete também relata que sua esposa nunca trabalhou fora de casa por falta de necessidade. Primeiro porque a família dela tinha um alto padrão de vida e depois porque quando se casaram, mesmo ele não tendo conseguido manter o mesmo padrão, foi uma opção ela não trabalhar.

"Foi basicamente uma opção. Ela, quando eu conheci, em termos de padrão de vida, duas famílias bem opostas, ela tinha um padrão de vida bem melhor em relação ao que eu tinha, se fosse 
comparar. Ela tem 3 irmãos, a única filha, então ela tinha uma condição muito melhor do que a minha. Então, eu comecei a trabalhar, eu consegui, não dar um padrão, eu diria assim, algo bom. E a caminho vieram os filhos cedo, então tinha aquela questão de trabalhar, tinha que deixar, então foi uma opção" (Donizete).

Nas falas anteriores de trabalhadores da Volkswagen sobre suas respectivas esposas, vemos que se todos são conscientes do papel fundamental da família, no que se refere à função de reprodução da força de trabalho, a maioria deles não pode conceber outro modelo de mulher senão o que a define parando de trabalhar ao casar ou ao ter filhos (Kergoat, 1986). Em muitos, as mulheres nem entram no mercado de trabalho, como relatado por Donizete e outros trabalhadores, porque o salário recebido por eles é suficiente para manter toda a família, como se o trabalho profissional tivesse como único objetivo e conseqüência o recebimento de uma remuneração. De acordo com Lipietz (1996), na geração dos seus pais era totalmente admissível que o "chefe da família" tivesse um trabalho profissional que lhe proporcionasse uma remuneração suficiente, enquanto a mulher assumia o papel, reconhecido socialmente, de dona de casa. O que vimos é que esta relação continua valendo, mesmo nos dias de hoje, nas falas dos entrevistados na Volkswagen.

Já no caso de Luiza, a gravidez não significou sair do trabalho, mas sim abrir mão, mesmo que provisoriamente, do tempo dedicado ao estudo, já que antes da gravidez ela fazia pós-graduação, na área de pedagogia, e curso de inglês. Digo provisoriamente, pois ao falar sobre o seu tempo futuro vemos que há projetos tanto para voltar a dedicar tempo ao estudo como para ter mais filhos. É interessante notar que parte dos seus projetos se assemelha aos dos trabalhadores mais novos, como o desejo de continuar a dedicar um tempo ao estudo e ainda vincular este a uma possível mudança no trabalho.

“[...] Hoje eu moro num apartamento, ele é nosso, mas eu quero morar numa casa, não sei se em São Paulo. [...]. Profissionalmente falando, quero fazer outras coisas, quero continuar nessa área de educação, estou gostando muito, talvez não continuar na área secretarial porque isso te limita, uma vez que você está na educação, então se eu continuar nessa área de educação, provavelmente, buscar uma nova oportunidade na área de RH. [...] Então assim, quero fazer outros cursos, então agora como eu estou nessa fase de bebe, é o que eu vou realmente pensar durante essa minha licença, os cursos que eu quero fazer, o que eu vou fazer quando eu voltar e já estar preparada para tal e já começar a fazer [...]. Pretendemos, não a curto prazo, mas pretendemos assim 3 filhos, a gente quer uma família meio grande, mas não sei, é alguma coisa que a gente pretende" (Luiza). 
Em relação à sua vivência do tempo e do trabalho dentro da Empresa, a grande diferença em relação às outras mulheres entrevistadas é que ela está na área administrativa, em uma função socialmente ocupada por mulheres, sendo secretária. O que possibilita uma vivência do tempo de trabalho sem a discriminação vinda de outros trabalhadores, ou mesmo da gerência, em função da sua condição de mulher. Afinal, ela ocupa uma função considerada feminina, ou melhor, uma função que sempre foi ocupada por mulheres. Assim, na sua fala, não aparece nenhuma reclamação ou observação que faça referência a algum tipo de discriminação nem, tampouco, qualquer questionamento sobre o fato dos gerentes serem homens e as secretárias mulheres, situação que não se limita à Volkswagen.

Mas esta é uma situação muito específica, pois mesmo em áreas técnicas, como a sala de medidas, onde Mônica trabalhava até ser liberada para atuar como representante sindical, também há mais homens do que mulheres. Eram 37 homens e 8 mulheres, até o PDV ocorrido em 2003, hoje são 13 homens e apenas ela de mulher. Dessa forma, além de já haver um número muito reduzido de mulheres, na área produtiva e técnica, as últimas demissões afetaram fortemente as mulheres, de acordo com a representante.

"Que toda a vez que a fábrica ia ter uma redução, a mulher ainda tem muito preconceito na área industrial. [...] Que você é mulher, então você pode ser sustentada. Vai por esse princípio. Então, toda a sua formação, toda a sua dedicação. Isso foi, sabe, me incomodando um pouco" (Mônica).

Nesse contexto, Mônica diz que a maior reclamação das trabalhadoras neste setor é a dificuldade para terem o diploma de engenharia e o trabalho reconhecidos. E isso ocorre não apenas na sala de medidas onde ela trabalhava, mas também em outras salas ou outros setores técnicos.

"O maior incômodo, é o seguinte: é o que eu falei, é o preconceito. [...] quando você vai para uma área técnica, eles sempre tentam inferiorizar o serviço que você vai fazer. [...] Você estudou engenharia, você fez tecnologia, então você pensa em trabalhar num projeto, uma coisa assim. Eles sempre, a mulher, tentam jogar para a parte de escritório, para a parte do arquivo, serviços que são menos reconhecidos. Isso é a maior reclamação. Hoje a gente tem uma supervisora só, na fábrica inteira, nós não temos nenhuma gerente. Então, assim, os cargos e as promoções para a mulher é muito difícil porque eles acabam minando a mulher. $\mathrm{Na}$ área técnica, a reclamação é maior porque na última demissão que teve, foi praticamente extinta quase todas as mulheres da área técnica (Mônica). 
Na sua narrativa, vê-se que há dois valores diferentes, um dado para a formação dos homens e as oportunidades que dela decorrem e outro dado para a mesma formação realizada pela mulher, e as dificuldades de oportunidade na carreira a despeito da formação. O resultado é um longo processo de discriminação que vai da entrada na empresa até as possibilidades de movimentação e promoção na carreira. Desta forma, se as mulheres estão, salvo algumas exceções, limitadas às áreas de escritório ou arquivos, por exemplo, como é possível, em algum momento, chegar à supervisora técnica?

\subsection{3 - Lara: vivências cotidianas do tempo fora da Volkswagen}

É interessante observar que ao analisar a vivência cotidiana do tempo no local de trabalho de Lara, pude perceber o quanto esta é semelhante às vivências de Joice e Luana. Todas entraram na Volkswagen na mesma época e iniciaram o trabalho no setor do chicote, setor constituído praticamente por mulheres. Depois, quando da terceirização destes setores, todas foram para áreas onde a quase totalidade era de homens, causando, assim, diversos problemas de adaptação. Entretanto, quando pensamos a relação entre os tempos dentro da fábrica e fora desta ou quando analisamos com mais atenção para este último, vemos diferenças muito grandes entre elas. Sobretudo porque Lara tem 45 anos, é solteira, não tem filhos e mora sozinha. De acordo com a fala de Lara, ela vai à casa da irmã, com quem já morou anteriormente, todos os dias e seus sobrinhos também sempre freqüentam sua casa. Relata, inclusive, ter viajado com um dos sobrinhos nas suas últimas férias. Vemos nas falas de Lara, que o tempo dedicado à família da irmã é vivenciado como um tempo de lazer, mais como uma opção do que como uma obrigação. Não se refere a esse tempo como a um tempo dedicado a uma tarefa que tivesse sido designada para ser realizada diariamente.

No que se refere ao tempo dedicado às tarefas da casa, Lara enfatiza que faz tudo sozinha, uma vez que não tem ninguém para dividir essas tarefas e por morar numa casa muito pequena. Mas, em seguida, ressalta que mesmo se tivesse um marido ela não tem certeza de que ele iria ajudá-la, pois sente que são poucos aqueles que colaboram. De fato, dentre os entrevistados que perguntei se ajudavam em casa, uma minoria respondeu positivamente e tais respostas não tinham muita relação com o fato da esposa trabalhar ou não, ou de terem filhos ou não. Desta forma, poder-se-ia interrogar se a divisão ou não das tarefas da casa não estaria menos relacionada a questões mais objetivas, como o fato de ambos trabalharem fora ou terem filhos, e mais ao papel que foi sendo construído no que se refere ao espaço a ser ocupado por homens e mulheres. 
O que nos remete à discussão, já realizada, sobre um dos argumentos para a redução da jornada de trabalho na França, de que a queda drástica no tempo de trabalho levaria a uma divisão menos desigual entre os sexos no que se refere ao trabalho com a casa ou os filhos. Porém, o resultado final não foi esse, demonstrando que para resolver essa relação tão desigual não basta alterar as condições objetivas, como a quantidade de tempo trabalhado. Também Seifert (1997), ao retomar esse argumento no contexto da discussão da redução da jornada de trabalho na Volkswagen na Alemanha, chega à mesma conclusão. Assim, ao analisar os dados da sua pesquisa, o autor percebe que, no geral, as mulheres demonstram maior satisfação do que os homens em relação à redução do tempo de trabalho ${ }^{4}$. Isto porque, mais da metade relata que esta redução permitiu melhor conciliar vida pessoal e profissional, o que leva o autor a concluir que as mulheres se sentem mais satisfeitas justamente porque há um acúmulo do tempo dedicado ao trabalho na empresa e na casa. Já no caso dos homens, que socialmente devem manter a família, a redução da remuneração acabou pesando mais do que o aumento do tempo livre.

O estudo de Seifert (1997) demonstra também que se o motivo mais forte da aceitação do acordo ${ }^{5}$ foi a garantia de emprego, no caso das mulheres este motivo foi ainda muito mais citado, explicitando que elas se sentem mais ameaçadas pelo desemprego do que os homens. Finalmente, em relação à forma como o tempo livre foi ocupado, novas diferenças foram observadas, quando comparados homens e mulheres. Ambos dedicam mais tempo à família. Em seguida, no caso das mulheres temos: ficar em casa, fazer compras para a casa, lavar e passar roupa. Para os homens: bricolagem, ficar em casa, praticar esporte e encontrar amigos. Assim, conclui o autor que a redução da jornada de trabalho não contribuiu para reduzir "os modelos sexuados de utilização do tempo", e, em alguns casos até reforçou, uma vez que as pessoas passaram a dedicar mais tempo ao que já faziam. O que já era muito desigual.

Retomando a discussão sobre a Volkswagen no Brasil, vemos o caso de Anderson, que exemplifica bem a divisão desigual dos tempos dedicados às tarefas domésticas. Clarisse, sua esposa, trabalha e faz faculdade, voltando para casa às $23 \mathrm{~h} 30$. Ele, por usa vez, chega em torno de $18 \mathrm{~h}$. No sábado, ele vai ao curso de inglês e na volta fica lendo revistas ou trabalha na internet, enquanto isso, Clarisse vai limpar a casa "sozinha e lava a roupa também, e ela passa

4. Devemos lembrar que, como já discutido no capítulo sobre a França, na redução da jornada de trabalho que ocorreu na Volkswagen houve ainda uma redução anual na remuneração, mas em percentual menor que a redução da jornada de trabalho, além da garantia da manutenção do emprego.

5. Sendo a resposta tipo mais citada: " a redução da jornada de trabalho permite a garantia de emprego". 
[roupa] no domingo". Pergunto por que apenas a sua esposa cuida da casa e ele me responde que não tem tempo. Então indago se ele não tem mais tempo livre do que ela, já que na semana é ela quem chega mais tarde, e pergunto ainda como ele vê essa situação e se ela não reclama:

\footnotetext{
"Eu não acho certo, mas não é meu hábito também estar ajudando. Eu ajudo em coisas bem supérfluas mesmo, jogar uma água na calçada, na escada, isso é de praxe meu e pegar o lixo da casa, isso é uma coisa que eu faço. Agora, além disso, só se for, se eu estiver com muita disposição para mim estar varrendo uma sacada ou coisa parecida, mas nada além do que isso. [...] Ela não reclama" (Anderson).
}

Na sua fala, Anderson exemplifica o que havia sido dito por Lara, isto é, que não seria o fato dela ter um marido que significaria uma divisão das tarefas da casa. Mas também explicita que a questão da geração parece ter menos peso do que a relação de gênero, já que tanto Anderson, como sua esposa, pertencem ao que pode ser denominado de nova geração. Assim, o caso de Clarisse demonstra que o aumento da taxa de atividade profissional para as mulheres não pode "mascarar" a persistência da extrema desigualdade entre homens e mulheres tanto no que se refere à própria atividade profissional como também às atividades domésticas (Chabaud, 1986) . Ou seja, a mulher não passou a dedicar um tempo ao trabalho profissional por ter antes se liberado do tempo dedicado ao trabalho doméstico, mas sim, somou esses dois tempos, reduzindo e/ou comprimindo os outros tempos sociais.

Em relação ao tempo dedicado ao estudo, Lara nos conta que não acabou o $2^{\circ}$ grau. Num primeiro momento podemos pensar que o fato dela não ter continuado a estudar não tem muita relação com a questão de gênero e muito mais com a geração. Isto porque, dentre os trabalhadores mais velhos, que entraram na Empresa na época em que não havia exigência de escolaridade, muitos acabaram por estudar apenas até o $2^{\circ}$ grau. Entretanto, ao analisar um pouco mais atentamente, vemos que há uma diferença entre as mulheres e os homens desta geração, dado que estes fizeram além do primário e ginásio na Volkswagen, também cursos técnicos no Senai. O que não é o caso das mulheres com mais idade que entrevistei, pois não apenas Lara, mas também Joice e Luana têm apenas o segundo grau.

Finalmente, no que se refere aos tempos futuros, para Lara, a aposentadoria é pensada como um tempo de total liberdade, e para a sua realização, ela pretende mudar e construir uma casa em Florianópolis. Planos totalmente diferentes, como veremos, de Joice e Luana que têm filhas. 
"Uma coisa que eu quero fazer é assim, se eu quiser viajar, eu viajo, sem aquela obrigação, eu não quero ter mais obrigação de nada, não quero viver em função do relógio. Isso aí, eu acho que me irrita, me incomoda, tanto que quando eu estou de férias, eu não quero saber do relógio, eu não quero saber do horário. Eu gosto de dormir a hora que eu tenho vontade, 2h00, e 3 h00 da manhã, acordar a hora que eu tenho vontade meio dia, 1 h00 da tarde, então eu não quero horário" (Lara).

\subsection{4 - Joice e Luana Lara: vivências cotidianas do tempo fora da Volkswagen}

Diferentemente de Lara, nos casos de Joice e Luana, nem toda a vivência do tempo dedicado à família é explicitada como um tempo de lazer, pois muitas atividades têm um sentido de obrigação. Joice tem uma filha de 16 anos e Luana uma de 11 anos. Ambas foram casadas com trabalhadores da Volkswagen, mas atualmente estão separadas, o que significa que não podem dividir com os respectivos maridos as tarefas domésticas e o cuidado com as filhas. Entretanto, como já vimos no exemplo de Anderson, se elas estivessem casadas o tempo utilizado com estas tarefas não necessariamente seria reduzido em função da ajuda dos maridos.

Mas tanto Joice como Luana estão separadas. Este fato nos leva a questionar, quanto tempo os seus ex-maridos dedicam às filhas. Luana não citou o ex-marido durante toda a entrevista e Joice diz que o seu voltou para o Piauí. Ademais, se olharmos para os dois casos de trabalhadores entrevistados que dizem terem se separado e que têm filhos, em ambos os casos os filhos ficaram com as esposas e, de acordo com Lúcio, que tem três filhos, ele fica com os seus apenas a cada 15 dias. Por outro lado, ambas têm irmãs que moram com elas e que ajudam no cuidado com a casa e com as filhas. No caso de Luana, após o nascimento da sua filha elas decidiram que a irmã cuidaria da casa e da filha, porque ela não conseguia arranjar emprego, enquanto Luana continuaria a trabalhar na Volkswagen.

"Só que é assim, ela me tirou também esse prazer de cuidar da casa porque ela faz tudo isso, então não sobra para mim. Como somos 3 pessoas, e a minha irmã é uma pessoa muito organizada, também eu fico assim, sem ter muito que fazer [...]. E inclusive eu até já falei para você, tinha falado para você que eu estou numa posição meio privilegiada porque a minha irmã faz tudo isso por mim"(Luana).

Na sua narrativa, Luana deixa entrever certo incômodo pelo fato de "não sobrar nada" para ela fazer no que se refere ao cuidado da filha e da casa. E o interessante é que nesse caso essas tarefas são citadas como algo prazeroso, talvez, justamente por ela não ter a obrigação de 
fazê-las sempre. Ao mesmo tempo, pode demonstrar um sentimento de culpa, no sentido de não estar cumprindo um papel que lhe foi socialmente definido, isto é, cuidar da casa e dos filhos, mesmo que no seu lugar tenha uma outra mulher que cumpre este papel. Luana fala ainda que sua situação é "meio privilegiada" e provavelmente esta percepção pode ser fruto da comparação que faz em relação à vida das outras trabalhadoras que estão na mesma situação que ela, isto é, trabalham fora de casa e têm filhos. Já no caso de Joice, além dela e a irmã terem filhas, ambas dedicam um tempo ao trabalho fora de casa. Vale lembrar que inicialmente Joice tinha se negado a dar entrevistas, alegando que sua vida estava "muito corrida, não sobrando tempo para nada".

Como visto no caso de Luiza, o casamento e o nascimento das filhas não significaram, para Joice e Luana, o fim do tempo de trabalho fora de casa. Joice quando se casou ainda não trabalhava e Luana quando conheceu o marido já trabalhava na Empresa. Mas não é apenas o casamento, o nascimento dos filhos ou o trabalho do marido na Volkswagen que leva a mulher a não dedicar ou a parar de dedicar um tempo ao trabalho fora de casa. Como na maior parte das vezes, as esposas dos trabalhadores da Volkswagen entrevistados têm empregos com salários inferiores aos dos maridos, isto acaba sendo mais um motivo para que esta abra mão deste tempo em função de outras necessidades da família. Como nos relata Carlinhos, ao me contar que sua esposa havia voltado a trabalhar depois de 9 anos,

\footnotetext{
"Ela saiu também, quando a minha filha fez 2 anos, ela pediu para ir embora para a gente comprar esse terreno aqui, ela pegar a indenização dela, para a gente comprar esse terreno aqui, hoje é minha casa. Aí nós falamos: eu trabalho, você cuida da menina, pega dinheiro da empresa, compra o terreno, eu moro com a minha mãe aqui do lado, aí eu comprei esse terreno aqui, através da demissão dela" (Carlinhos).
}

Ou ainda no caso da esposa de Roberto que saiu do seu trabalho para cuidar do pai que estava doente “...daí ela parou de trabalhar para poder ficar com ele, só que pouco tempo depois ele faleceu e daí ela decidiu voltar a trabalhar. Mas engravidou e então decidiu esperar a filha nascer e crescer para retornar". E esta decisão também pode ser tomada em relação à prioridade para dedicar tempo à formação, como vemos no relato de Anderson: “(...) Nós fizemos o planejamento da seguinte maneira: eu me formei primeiro, quer dizer, teoricamente eu teria me formado o ano passado, que esse ano eu estou realizando o meu estágio para conclusão do meu curso e ela então prestou vestibular". As falas demonstram bem a enorme dificuldade que as 
mulheres encontram para entrar no mercado de trabalho e lá permanecerem a partir do momento em que se casam.

No que se refere aos tempos futuros, vemos que as expectativas de Lara, Joice e Luana são muito próximas no que se refere ao tempo de trabalho. Esperam ficar na Volkswagen até a aposentadoria, pois consideram muito difícil conseguir um outro emprego fora, sobretudo em função da pouca formação. E, como já vimos, essa expectativa em relação ao futuro não difere muito dos trabalhadores da mesma geração que elas. Entretanto, quando falam sobre os planos para depois da aposentadoria, apresentam expectativas muito diferentes se comparamos Lara, por um lado, e Joice e Luana, que têm filhas, por outro. Pois, no caso destas, o tempo futuro está fortemente vinculado ao das filhas.

“(...) pretendo trabalhar até me aposentar na Volkswagen, não quero sair de lá em hipótese alguma. Hoje eu já penso, não tem nem como eu sair de lá porque para mim, aqui fora, não consigo mais nada. Eu tiro pela minha irmã, está desempregada, ela é bem mais jovem do que eu, tem estudo, curso superior, ela está batalhando aí e não está fácil. Então esses 5, 6 anos eu quero trabalhar na Volks, depois que eu me aposentar, aí vai depender da minha filha. É que nem eu falo para você, hoje eu vivo mais a vida dela do que a minha. Mas se ela estiver bem, estabilizada, eu vou ficar aqui com ela, porque eu não pretendo deixar ela, mesmo que ela esteja vivendo a vida dela, mas eu quero estar por perto, senão, eu vou embora, pego ela e vamos embora" (Joice).

\subsection{5 - Lara, Joice e Luana - vivência dos tempos e dos trabalhos dentro da Volkswagen}

Lara, Joice e Luana, fazem parte de uma mesma geração, tendo entre 41 e 45 anos. As três trabalhadoras entraram na Volkswagen no mesmo ano, em 1984, e todas foram para o setor de chicote. Para entrar na Empresa Joice encontrou certa resistência do marido, assim como já vimos no relato da jovem Tamara que também enfrentou o pai para trabalhar na Empresa. Ela relata que sua chegada a São Paulo foi muito difícil: "Não conhecia ninguém aqui, deixei pai e mãe lá. Nós somos em 8 irmãos, deixei meus irmãos todos, então foi difícil mesmo. Aí quando eu fiz 18 anos, eu falei: 'vou trabalhar'. Nesta época seu marido trabalhava na Volkswagen,

\footnotetext{
"Aí um dia ele chegou em casa e falou que a Volks ia contratar mulheres. Eu pensei, nem falei para ele porque ele não queria que eu trabalhasse mais: 'amanhã vou dar uma passada lá'. Aí saí cedinho, fui para a portaria, cheguei lá estava realmente contratando mulheres, nesse dia contratou 70 mulheres e eu entrei junto" (Joice).
} 
E o marido também foi contra a sua participação nas atividades grevistas ocorridas dentro da Empresa. “... ele brigava comigo quando eu falava: 'hoje a gente foi na ala 21 tirar um pessoal que furou a greve'. Ele brigava: 'você é maluca, não pode fazer isso, você vai perder o emprego"”. Ou seja, se a Empresa já não era entendida, pelo seu marido, como um espaço para ela, muito menos o Sindicato e as ações políticas a ele relacionadas, poderiam ser pensados como um espaço para as mulheres.

Para essas mulheres que entraram no setor produtivo nos anos 1980, entendo que houve dois momentos fortes de transição. O primeiro momento foi a entrada na Empresa, caracterizado pelo choque com a Volkswagen e com o setor do chicote, principalmente com o ritmo acelerado, com as péssimas condições de trabalho, com a grande quantidade de pessoas ou ainda com a difícil relação com a "chefia", como relatado pelas próprias trabalhadoras. O segundo momento foi a transição entre a saída dos dois setores que empregavam praticamente apenas mulheres - o chicote e a tapeçaria - e a entrada em outros setores predominantemente masculinos como as linhas de produção.

Em relação à primeira transição, entre o tempo fora da Volkswagen e o início do trabalho, Joana diz que ao entrar "Na montagem do chicote. Era um setor só de mulheres. Tinha um ou outro homem, mas eram só mulheres”. Luana lembra: “Quando eu entrei, entrei direto para um setor chamado chicote, é onde era confeccionada toda a fiação do carro. Esse não foi um dos primeiros, mas logo ele [também] foi terceirizado. E do chicote, terceirizou, aí foram remanejando o pessoal e eu fui parar na linha das portas”. E como relatado por Lara:

\footnotetext{
"Eu entrei no setor de chicote, aí fiquei uns 5 anos lá. Aí diz que o chicote ia acabar, jogaram eu para a tapeçaria, aí fiquei lá até acabar a tapeçaria. [...] Foi fogo. Aí foi acabando, foram jogando o pessoal aí da tapeçaria, fui para a pré-montagem, que eu estou até hoje. [...] O chicote, porque eu quando entrei lá, eu me horrorizei, você está acostumada a trabalhar num lugar calmo com pouca..., quando eu entrei lá, era assustador, era gente demais, eu chegava e falava: 'não vou ficar'. Era horrível. Então, para mim, o primeiro dia, eu me apavorei, te juro por Deus, eu falei: 'gente, a hora que a gente for almoçar - a menina que troca comigo, hoje é até grande amiga-, eu falei: "é agora, vamos correr desse povo"” (Lara).
}

Lara nos conta ainda que na tapeçaria, setor para onde ela foi "jogada", após a terceirização do chicote, o trabalho não era muito diferente, isto é, não era muito melhor.

\footnotetext{
"Muita quantidade, era muita gente na área, era muito serviço, trabalhar com aquelas prensas, eu tinha pavor de machucar minha mão, como eu vi muitas meninas machucarem a mão,
} 
ficar presa. [...] nunca vi tanta mulher. [...] Fui ponta de linha, ponta de linha era você pegar o serviço, arrumar, tinha aquele arames, você se arranhava toda, separar por cor, guardar" (Lara).

Ao comparar os dois setores, Lara diz que no chicote o trabalho era mais sujo, mas mesmo assim entende que era melhor que o da tapeçaria, pois neste último setor as trabalhadoras não tinham liberdade. Ademais, relata que havia um grande esforço físico em função da necessidade de ir buscar o material "empurrando um carrinho e era um trabalho muito manual onde todas saiam com as mãos machucadas de cortar espuma com a tesoura". Aliás, vale ressaltar que Lara, Joice e Luana dizem ter problemas na coluna, resultantes do tempo de trabalho nos setores de chicote e tapeçaria. Lara, inclusive tem restrição médica e não pode trabalhar em todos os setores.

Também na tapeçaria, Lara nos conta que havia "muita disputa entre as mulheres mais velhas e as mais novas", demonstrando que não necessariamente trabalhar em um setor onde só tenha mulheres torna o tempo de trabalho mais prazeroso ou menos opressivo. Afinal, estamos falando de pessoas que ao mesmo tempo estão inseridas em relações de opressão entre sexos, mas também de exploração entre classes (Kergoat, 1986).

"As meninas, as mais velhas queriam mandar. Ela era assim, por exemplo, estava para dar a hora de ir embora, você tinha que esperar, eu como não tinha lugar para ficar, ficava esperando. Tinha que esperar dar a hora para correr, porque a líder fica olhando, te juro por Deus, você não podia nem atender um telefone. Quando ela te chamava para atender o telefone na gaiola, gaiola é a cabine, aí falavam assim: 'nossa, morreu alguém”” (Lara).

Com a terceirização desses setores algumas trabalhadoras foram trabalhar em uma das linhas, como Joice e Luana. Também foram transferidas para a pré-montagem, como é o caso de Lara. Sobre a transição para a linha, Joana faz questão de frisar que a diferença

\footnotetext{
"Foi grande também. Foi muito grande porque na linha, nessa época não trabalhavam mulheres, era nossa! A gente tinha pavor, a gente falava que aquilo era para homem. [...] Eram pouquíssimas mulheres. Aí eu fui, enfrentei dificuldade. [...] Era um setor muito machista, até o encarregado. Ele me colocou num serviço bem..., eu parafusava lâmina do pára-choque, essa peça vai dentro do pára-choque, era muito forte o tranco que a máquina dava, se não segurasse firme, ela torcia. Aí eu falei para ele: 'nossa, não tem um serviço mais leve, isso aqui é serviço para homem, não dá para mim trabalhar aqui'. Ele falou: 'se quiser é esse daí, porque não tem serviço para mulher aqui'. Aí eu pensei: 'ah é, então é aqui mesmo que eu vou ficar, se o homem pode fazer eu
} 
também vou fazer, ele vai ver se eu não vou conseguir, ele vai me engolir, vou ficar é aqui'. Aí fiquei lá" (Joana).

É interessante observar que no discurso de Joana transparecem duas dificuldades. Uma delas é a realização de trabalhos considerados duros e pesados, como também é relatado por Mônica:

“... na produção existe muito a reclamação [por parte das mulheres] do serviço mais pesado. Mas aí não tem como você descaracterizar, porque quando você está na produção, você é igual a todo mundo. Então, acho que na produção é menos preconceito do que na área técnica. E na produção não tem como escolher serviço melhor, é tudo igual, então não existe opção" (Mônica).

A outra dificuldade que transparece na fala de Joana é a resistência dos homens em relação à chegada das mulheres no seu espaço. Assim, devemos pensar o que significa para as mulheres chegarem a um espaço masculino, mas também o que significou para estes homens a chegada das mulheres, tanto no Senai, na área produtiva, como também na área técnica.

Roberto, representante sindical na área da pintura, nos fala sobre o trabalho das mulheres na produção, ressaltando que na pintura, assim como relatado por Nunes, representante da estamparia, não há mulheres na linha de produção, sendo que as últimas se aposentaram recentemente. Ao ser questionado sobre os motivos da ausência de mulheres na linha da pintura, ele diz que a fábrica começou a levar as jovens vindas do Senai para as áreas de retoque e retrabalho e que, neste caso, a experiência foi muito bem aceita, do ponto de vista do trabalho realizado. Porém, apesar do trabalho ter sido bem aceito, ainda há discriminação dos trabalhadores em relação à presença das mulheres na produção.

\footnotetext{
"Porque não é prática da Empresa. Vamos dizer assim: o que veio, as mulheres conseguiram seu espaço dentro da produção, [...] a fábrica percebeu que a mulher tem um tato mais apurado, uma preocupação maior no trabalho voltado também para a produção. Então começaram, fizeram uma experiência de como a mulher, como é que vai ser a adaptação da mulher numa linha de produção e dentro da área de pintura. E foi muito bem aceito. Foi muito bem aceito. Primeiro porque tem que quebrar certos dogmas lá, principalmente o dogma machista, dos trabalhadores da linha" (Roberto).
}

Roberto entende que a idade é outro motivo que dificulta a ida das jovens vindas do Senai para as linhas de produção: "Mas, sempre quando as mulheres vêm e as mulheres são 
novas porque são crianças". Entretanto, não podemos esquecer que os jovens que vêm do Senai e vão trabalhar na produção têm a mesma idade, isto é, 18 anos. Ou seja, no caso dos meninos a idade não é vista como um empecilho para o trabalho na produção, já no caso das meninas, isso é um dificultador. Além disso, frisa a questão de ser um espaço machista.

"Uma coisa é o machismo. Em duas vias é ele. O homem ele não quer a mulher na linha e quando a mulher está na linha ele não deixa ela pegar um serviço muito pesado. [...] Ele não deixa a mulher pegar no muito pesado. E quando a mulher chega e fala assim, identifica esse tipo de coisa e tenta não fazer certas coisas tem um outro grupo que trabalha contrário: já que está na linha tem que se molhar. Entrou na chuva vai ter que se molhar junto com os outros. Então começa a cobrar [o trabalho da mulher] também.” (Roberto).

Roberto salienta ainda que a cobrança não é apenas da parte dos outros trabalhadores mas também da chefia.

"Só que a pressão maior é por parte da chefia. A chefia chega para as mulheres e fala assim: olha, vocês estão aqui e usa justamente aquilo que a sociedade, o preconceito da sociedade, joga contra elas. Falam assim: se vocês tem que produzir $100 \%$ que é o que é pedido para vocês, no caso de vocês [mulheres], vocês têm que produzir 110 porque além de provar que vocês são capazes vocês têm que provar para os outros que vocês não deixam nada a desejar. Então utiliza até de uma forma sacana a produção da mulher em si. A relação delas para com os representantes, falam assim: não vocês não têm que chegar perto [do sindicato], porque vocês são capacitadas, vocês vêm do Senai, vocês têm uma qualificação de estudo maior. E vamos dizer assim, a fábrica pode entender que vocês têm mais condições de crescer do que o homem que ali está porque vocês não aceitam fazer esse trabalho" (Roberto).

E diz que a atuação sindical frente a esse tratamento desigual em relação à mulher não é fácil, porque o dirigente deve chegar na hora certa e no local certo "... porque se você chegar depois não adianta. E quem nos avisa é um trabalhador homem que avisa, mas quando a gente vai abordar, que a gente chega com cuidado com a mulher e tudo, ela dificilmente se abre".

Assim, vemos que além da dificuldade das trabalhadoras em relação ao tempo dentro do trabalho em função da maior pressão por parte da gerência, há ainda o preconceito dos trabalhadores, exercendo igualmente um outro tipo de pressão. Neste sentido, se já havíamos discutido anteriormente que a experiência da pressão tem sido uma característica forte da vivência do tempo de trabalho na Volkswagen, seja em função do ritmo da linha, da redução do número de 
trabalhadores ou da redução dos prazos, no caso das mulheres, elas sofrem ainda estas pressões. A mulher é pressionada para mostrar, seja para os próprios colegas de trabalho como para a gerência, que elas podem realizar um trabalho, na realidade, um trabalho melhor.

\section{3 - Considerações finais}

Tratar das vivências dos tempos de trabalho e de não trabalho trouxe para esta pesquisa a perspectiva de gênero, outra dimensão marcante nos discursos sobre as vivências e representações desses tempos. Esta perspectiva apresenta novos elementos para a discussão sobre a inexistência de uma identificação clara entre tempo de trabalho e tempo no local de trabalho, por um lado, e tempo de não trabalho e tempo fora do local de trabalho, por outro. Daí a necessidade de não separar esses tempos, mas, ao contrário, analisar a inter-relação existente entre eles, considerando, sobretudo, que são as mesmas pessoas que vivenciam esses tempos.

No decorrer deste capítulo vimos que as mulheres mais jovens apresentam uma vivência e uma representação similares do tempo, em relação aos homens mais jovens. Essas jovens formam um grupo homogêneo tanto no que se refere aos tempos dentro como fora do local de trabalho. Isto, porque as outras características pessoais e sociais dessas jovens acabam por influenciar fortemente suas vivências. Entretanto, nas narrativas discursivas dessas trabalhadoras, pudemos observar ainda diversas especificidades tanto no que se refere ao tempo antes da entrada na Volkswagen, como ao tempo de trabalho na Empresa. Neste caso, este grupo de jovens tem experiências muito próximas às das mulheres com mais idade.

No grupo de mulheres com mais idade essas experiências se diferenciam em alguns aspectos. No caso de Luiza, que exerce uma função socialmente ocupada por mulheres, a vivência do tempo é muito diferente tanto dentro como fora da empresa. Não é por acaso que esta é a trabalhadora que menos explicita um tratamento discriminatório dentro da empresa, afinal, ela não ocupa, diferentemente das outras trabalhadoras, o espaço dos homens. Um outro tipo de vivência foi verificado no caso de Lara que, do ponto de vista da vivência cotidiana do tempo de trabalho, parece ter experiência similar às de Joice e Luana. As três entraram na Volkswagen em um dos poucos setores predominantemente formado por mulheres. Entretanto, quando considero também o tempo de não trabalho de Lara, a diferença em relação às outras duas trabalhadoras torna-se muito grande, já que seu tempo de dedicação às filhas é maior, o que altera não apenas 
sua vivência e representação do tempo presente como também do tempo futuro. Nesse sentido, Luana e Joice apresentam experiências semelhantes quanto ao tempo fora do local de trabalho.

A partir da análise dessas narrativas discursivas, bem como das falas dos trabalhadores, gerentes e representantes sindicais, pudemos observar que, apesar das transformações ao longo do tempo, ainda estamos, predominantemente, diante de relações de gênero muito desiguais, hierárquicas, assimétricas, antagônicas e discriminatórias. Isso tanto no que se refere aos tempos na família, como na escola ou na fábrica. Essa desigualdade nas relações de gênero ocorre em todas as faixas etárias das mulheres entrevistadas, tanto as mulheres com mais idade como as mais novas relatam a relutância dos maridos ou dois pais em deixá-las trabalhar fora de casa.

Esta situação começou a se transformar com a abertura do Senai para as mulheres, a partir do início dos anos 1990. Mas, embora essa abertura tenha tornado possível uma formação técnica igual para homens e mulheres e, com isso, a admissão de mulheres nos setores considerados mais qualificados, não significou, entretanto, tantos avanços do ponto de vista da discriminação em relação ao gênero, já que ainda é enorme a dificuldade para entrar em uma área de trabalho qualificado. No âmbito da educação formal, as mulheres também relatam a dificuldade para freqüentar um curso universitário como o de engenharia, por exemplo, em que a maior parte dos alunos é formada por homens. Neste contexto, é constante a necessidade das mulheres terem de provar que também podem gostar e entender de carros.

Voltando nossa reflexão para o contexto interno da Volkswagen, também é importante pensar sobre a seguinte questão: como se dão as relações de gênero, num espaço marcado por relações de exploração? No caso das mulheres em que o casamento ou a chegada dos filhos não significou o abandono do tempo de trabalho profissional, o tempo dedicado ao trabalho doméstico permaneceu inalterado. E essa é uma diferença fundamental quando comparamos as mulheres nas diferentes situações familiares, pois para aquelas que ainda moram com os pais, não há relatos de um tempo dedicado às tarefas da casa. Isso não significa, por outro lado, que essas últimas tenham mais tempo livre, pois nesse caso, há o tempo dedicado ao estudo que inclui a semana, o final de semana e ainda o tempo de férias.

Para todas as mulheres que foram para as áreas produtivas, independentemente da idade, começar a trabalhar na Volkswagen foi relatado como uma experiência difícil, não apenas em função das condições de trabalho, mas por ser uma fábrica predominantemente masculina. A maior parte dos trabalhadores são homens, os gerentes são homens e também os representantes sindicais. No que se refere ao trabalho, nos anos 80 as mulheres iam, predominantemente, para 
setores que não eram considerados importantes pela empresa e que foram depois terceirizados. Mesmo atualmente, quando a maior parte dos alunos do Senai são mandados diretamente para a linha, algumas meninas são encaminhadas para setores burocráticos, considerados de menor importância, pois a linha continua sendo vista como espaço de trabalho para homens.

Ficou evidenciado ainda, nos relatos das trabalhadoras, que ocupar um território masculino, além de gerar dificuldades para construir amizades, cria a necessidade de provar a capacidade de realizar um trabalho, até então, feito apenas por homens. Mesmo entre as mulheres com formação superior e que atuam nas áreas técnicas, como Mônica, fica explícita a necessidade de provar, tanto para os trabalhadores como para os gerentes, que o diploma adquirido tem o mesmo valor social que o dos homens. De acordo com Hirata e Kergoat (2003), "o valor distingue o trabalho masculino do trabalho feminino: produção vale mais que reprodução, produção masculina vale mais que produção feminina (mesmo quando uma e outra são idênticas)". E esse valor diferenciado que é conferido socialmente, "induz a uma hierarquia social", definindo os que são superiores e inferiores.

Assim, se por um lado tanto homens e mulheres ressaltam algumas qualidades do trabalho realizado pela mulher - a delicadeza, a destreza, o cuidado, a atenção, o capricho - ao mesmo tempo, vemos que tais qualidades são entendidas como naturais, como características inatas das mulheres. Por sua vez, essas características atribuídas não têm o mesmo valor social que o conhecimento científico, adquirido na escola. Esse sim, entendido como o resultado do investimento, do esforço das pessoas e não como um atributo natural. Mesmo nos casos em que as mulheres passam a dedicar também um tempo ao estudo, ao final, o título acadêmico, muitas vezes, tem um valor social menor que o dos homens.

É importante ressaltar, ainda, que as diferenças de valor são conferidas socialmente tanto por homens como pelas próprias mulheres, mesmo por aquelas que buscam questioná-lo, como é o caso de Mônica que atua como representante sindical. Afinal, todos passamos pelo mesmo processo de socialização. No caso de Mônica, essa contradição fica explícita em suas falas, quando, primeiramente, ela ressalta o fato de que os gerentes inferiorizam o trabalho da mulher no setor técnico e a coloca em setores menos reconhecidos. Em seguida, ao buscar justificar a importância do trabalho da mulher, no seu setor, ela acaba contradizendo essa idéia anterior: também valoriza apenas as características tidas como naturais das mulheres, no lugar de valorizar o conhecimento técnico adquirido, como podemos ver no trecho a seguir. 
"Porque minha área, inclusive, para mulher trabalhar é muito boa, porque é uma área delicada; é de serviço, sabe? Que você tem que ter muito cuidado porque é tudo medida pequena; trabalha com micro. Então é uma área que a mulher é muito boa; mas na fábrica a gente tem muito preconceito ainda" (Mônica).

É interessante notar que essa diferenciação do trabalho realizado pelas mulheres aparece pressuposta em vários relatos, inclusive dos trabalhadores. Quando perguntei a Gustavo, líder de outra sala de medidas no setor da estamparia, como era o perfil dos trabalhadores nesse setor, ele responde fazendo a mesma consideração que Mônica. Demonstrando que apenas uma parte do conhecimento adquirido pelas mulheres é enfatizada, aquela que socialmente tem um valor menor.

"Mas, o trabalho que nós fazemos, o trabalho feminino, no caso, ele é melhor porque a mulher é mais meticulosa, ela é mais paciente. [...] Ela está junto com os outros, mas a gente percebe que o trabalho dado para elas tem um resultado, não melhor, mais bem elaborado do que quando você pede para uma outra pessoa fazer. Porque elas pensam mais, elas têm mais calma, capricham um pouco mais. O resultado, às vezes é o mesmo, mas a apresentação do trabalho, ele é mais bonito" (Gustavo).

Finalmente, vale ressaltar a importância que o tempo dedicado ao trabalho, fora de casa, tem para as mulheres. Tanto as mais jovens como as mais velhas dizem gostar do trabalho, sentimento que fica representado pela fala de Joana: "Uma coisa que eu gosto e faço com prazer é o meu trabalho, adoro trabalhar". Assim, apesar de toda desigualdade existente, de toda discriminação, desde a entrada no Senai até a ocupação dos espaços na Empresa, os tempos dedicados ao trabalho e também ao estudo são vivenciados como algo que possibilita a independência, não apenas financeira. Portanto, um tempo de trabalho que possibilita criar os filhos, manter a casa e, mais do que isto, que possibilita o prazer, as amizades e a satisfação. 


\section{VIVÊNCIAS TEMPORAIS COTIDIANAS FORA DO LOCAL DE TRABALHO}

este capítulo final da análise do trabalho de campo, tenho como objetivo estudar as configurações do discurso a respeito das vivências temporais cotidianas fora do local de trabalho, isto é, fora do espaço da Volkswagen. Nos capítulos anteriores analisei as vivências do tempo fora da fábrica, a partir dos recortes das vivências dos trabalhadores no trabalho em turnos e no trabalho noturno, dos jovens e também das mulheres. Agora, a intenção é analisar o conjunto dos trabalhadores, a partir de suas narrativas discursivas, considerando algumas indagações: o que os trabalhadores dizem que têm feito fora da Volkswagen? Quanto tempo dedicam aos diversos tempos sociais, isto é, à família, aos amigos, ao lazer, ao estudo? Quais são as equações temporais realizadas para harmonizarem os diversos tempos sociais? Quais tempos são privilegiados? Há ainda algum tempo dedicado ao trabalho profissional, mesmo fora do local de trabalho? O que os trabalhadores dizem que não têm feito e por quais motivos? Quais atividades julgam mais importantes na vida? Quais sentimentos e representações expressam em relação ao tempo?

O texto foi dividido em três grandes blocos, além das considerações finais. Começo a discussão a partir da última questão, isto é, sobre o sentimento mais explicitado nas narrativas discursivas, em relação ao tempo. Em seguida, para nos ajudar a compreender o porquê desses sentimentos, apresento uma discussão em torno da relação entre o que as pessoas dizem fazer da vida, quando não estão na Volkswagen; o que gostariam de fazer a mais na vida; e o que fariam no caso de uma possível redução da jornada de trabalho. A terceira parte terá a finalidade de analisar se há atividades relacionadas ao trabalho profissional que se desenvolvam fora da Volkswagen, mesmo que indiretamente. 


\section{1 - O sentimento de falta de tempo e as equações temporais cotidianas}

Como já explorei nos capítulos anteriores, as sociedades contemporâneas caracterizamse por um tempo urgente, acelerado e de mudanças contínuas (Bessin, 1999 e Chesneaux, 1996), gerando extremo mal estar nas pessoas, em função da dificuldade crescente em harmonizar a multiplicidade de temporalidades sociais existentes. Assim, quando analiso as narrativas discursivas dos trabalhadores da Volkswagen, observo que os sentimentos de falta de tempo, de vida muito "corrida", "agitada" ou "acelerada" e o conseqüente cansaço proveniente desse ritmo são muito explicitados, independentemente da idade, sexo ou função na empresa. Esses sentimentos valem tanto para o tempo dentro do local de trabalho, como já vimos nos capítulos anteriores, como para o tempo fora deste espaço. Neste sentido, alguns trabalhadores fazem uma relação direta entre estes tempos, como Luíza, que relata ainda não ter tido tempo para organizar a casa para a chegada de seu filho, apesar de já estar grávida de 8 meses, porque "o trabalho aqui [na Volkswagen], te exige bastante tempo, bastante carga horária". Ou Junior, que se reporta à "correria do serviço" para explicar o porquê de não fazer o que gosta no final de semana: "É mais tempo no serviço do que no lazer, né".

Marcos diz ainda que gostaria de começar a montar um negócio próprio, mas que é impossível, pois ele tem a sensação de que dedica todo o seu tempo para o trabalho dentro da Volkswagen, e que não sobra fôlego para ainda pensar em seu próprio negócio, mesmo expressando certa dúvida em relação à manutenção do seu emprego:

“Às vezes eu saio daqui [Volkswagen], começa a bater aquela canseira. Se eu tivesse um pouco mais de tempo eu ia atrás disso [negócio próprio], de poder sair para ver o mercado, fazer umas pesquisas, aluguel, sei lá, procurar alguma coisa para eu estar fazendo à parte, fora da fábrica, me calçar um pouco mais. Porque a gente não sabe o dia de amanhã, então é bom poder montar um negocinho para mim. A gente praticamente ocupa o nosso tempo todo aqui na fábrica, fica full time aqui, e quando a gente sai, sai às vezes com a cabeça voltada aqui ainda. Então não tenho muito tempo para pensar em praticamente nada..." (Marcos).

Um tempo cansativo no local de trabalho e um tempo fora da fábrica vivenciado como "muito curto", insuficiente para descansar e vivenciar todas as outras temporalidades sociais. É interessante perceber que a sensação explicitada pelos trabalhadores é de que utilizam a maior parte de seu tempo para o trabalho dentro da Empresa. Quando comparados aos trabalhadores de outras empresas, entretanto, os da Volkswagen tem uma jornada de trabalho menor, em torno 
de 40 horas semanais, e utilizam menos tempo no transporte. Mesmo assim, observamos que é forte a sensação de falta de tempo, o que demonstra que as vivências dos tempos guardam uma relação com a quantidade, mas também com a qualidade, isto é, com a forma como se vivencia cada hora do dia.

Também foi possível notar que o trabalho causa cansaço às pessoas para além do espaço da fábrica, pois, como já relatado, é um trabalho repetitivo, monótono, sem autonomia, que desconsidera as necessidades dos trabalhadores, as diferentes disposições ao longo do dia; porque, na linha, o tempo é imposto e o ritmo intenso. Outros falam ainda da intensificação do trabalho em função da redução do número de trabalhadores. Como nos relata Edgar - que não trabalha na linha, mas está na produção:

\footnotetext{
"Realmente, na fábrica, o quadro reduziu demais, hoje você não trabalha por 2, você trabalha por 3,4 . O setor mesmo que eu trabalho, para a produção que a gente faz hoje, antigamente eram 7 pessoas, hoje nós estamos em 3 e estamos produzindo. E isto vai cansando cada vez mais, daí quando saio do trabalho não consigo pensar em fazer mais nada. Tenho que descansar para o dia seguinte, que será igualzinho" (Edgar).
}

Essa sensação também é reiterada pela esposa de Edgar que faz questão de dizer que seu marido, nesses últimos tempos, "anda chegando muito cansado em casa, não tem ânimo para nada, chega, senta no sofá e fica".

A intensificação é conseqüência da redução da quantidade e da duração das pausas, bem como da implementação da rotatividade de tarefas. Da redução dos prazos, do aumento da pressão pela maior responsabilidade, pela demanda de qualidade, pelo crescimento do controle e da quantidade de tarefas, entre outros procedimentos. Ou seja, um trabalho tenso e intenso que é imposto, independente do setor, e que traz, como conseqüência, os sentimentos de cansaço, stress, falta de ânimo e de coragem. Sentimentos esses manifestados, principalmente, quando os trabalhadores são perguntados sobre o que gostariam de fazer "a mais na vida". Muitas vezes a resposta é, simplesmente, descansar ou dormir.

Assim, há um sentimento de que o trabalho é cansativo porque intenso, de que o trabalho ocupa o dia todo, gera falta de ânimo e de coragem, outros sentimentos muito explicitados pelos trabalhadores. É muito presente também a sensação de que falta tempo para a vivência das outras temporalidades sociais, entre elas o tempo a ser dedicado à família, tanto do ponto de vista quantitativo, como no que se refere à qualidade do tempo que despendem em casa. $\mathrm{A}$ 
pouca quantidade de tempo de dedicação à família é mencionada, principalmente, por trabalhadores que estudam, mas também pelos trabalhadores que não estão estudando. Nos relatos dos primeiros, ficam evidenciados os problemas com a família em função dessa falta de tempo.

Vemos que a família age com movimentos contraditórios: possibilita aos seus membros a dedicação ao tempo de trabalho ou ao estudo, mas também os pressiona em função do pouco tempo dedicado a ela. Ao mesmo tempo em que pressiona, direta ou indiretamente, por uma renda maior - normalmente obtida com a hora extra, o trabalho noturno ou outro emprego -, a família também cobra mais atenção, mais tempo livre, como vemos, por exemplo, nas falas de Otelo.

\footnotetext{
"Até falei outro dia para a minha menina: 'o papai tem que fazer essa correria, mas no sentido de que eu tenho vontade de estar mais próximo de vocês, mas tenho necessidade de estar preocupado com vocês amanhã'. É nesse sentido. Então fica dividido os horários e tal, e pra você entender o porquê do pai da outra ficar mais tempo, ou então porque ele tem tempo de levar a filha no cinema e às vezes eu não tenho. Eu faço essa cobertura do cinema depois. Vou correr atrás primeiro de garantir um outro lado e depois eu tiro o lado do cinema. Para mim hoje não está sendo permitido" (Otelo).
}

De acordo com Grossin (1991) a família é um dos espaços privilegiados para se estudar as vivências temporais, porque é ela que busca harmonizar os tempos dos diversos integrantes, que amortece o mal estar que os tempos exteriores a ela podem causar, mas que também possibilita que seus membros vivenciem esses tempos externos. Ao falar sobre a hierarquização dessas diversas temporalidades sociais, ressalta que normalmente é o tempo de trabalho, justamente por suas características - como a rigidez, a pontualidade, a coerção e a regularidade - que acaba se sobrepondo a outros tempos sociais, sobretudo ao tempo de lazer.

Assim, veremos que as escolhas feitas pelos trabalhadores - afinal o dia só tem 24 horas -, refletem valores, hábitos, necessidades e expectativas em relação aos tempos presentes e futuros dos próprios trabalhadores e de suas famílias. Essa combinação de valores, hábitos e necessidades informa, por exemplo, a partir de qual momento o tempo livre é mais importante do que uma renda maior, como vimos também na discussão sobre a "semana Volks". Essas escolhas, denominadas por Grossin (1991) de equações temporais pessoais, são feitas cotidianamente e definem as prioridades do trabalhador, entre as diversas temporalidades que concorrem entre si, como veremos nas narrativas discursivas a seguir. 
“...podia tirar, tipo assim, sábado. Às vezes não ir para a igreja, não participar da comunidade para ficar. Ou não ir para a quadra também bater uma bola que eu gosto, para ficar com eles [família]. Mas aí eu também ia me privar de uma coisa que eu também gosto de fazer, então tem aqueles dois lados" (Otelo).

"Eu gosto de tocar [bateria] também. Eu já tive banda na minha adolescência, hoje eu não toco mais, só de vez em quando. [...] Na época que eu parei, eu tive que fazer uma escolha: trabalhando, estudando, família, eu não tinha tempo mais. Nem com essa agenda aqui [diário de usos do tempo que ele estava preenchendo ${ }^{1}$ ] eu ia conseguir encaixar tanta coisa. Então eu tive que fazer uma escolha" (Rogério).

Assim, a família tem um papel muito importante na vivência dos tempos dos trabalhadores entrevistados, não apenas no que diz respeito ao tempo presente, mas também ao passado e futuro. Pois é ela que orienta, de acordo com os discursos dos trabalhadores, a decisão do que fazer no tempo livre, seja nas férias ou nos finais de semana. No que diz respeito aos tempos passados, foi a família igualmente que possibilitou, na maior parte das vezes, a vinda dos trabalhadores com mais idade para São Paulo; a entrada na Volkswagen, bem como a socialização antecipada vivida pelos jovens, filhos de metalúrgicos.

"Eu vim trazida pela necessidade. Primeiro veio um irmão e uma irmã. Inclusive essa irmã, o primeiro emprego dela foi na Volkswagen. Sempre com muita dificuldade, sonhava numa vida melhor e tinha a minha irmã aqui, que já servia para mim como referencia.[...] Eu vi que a vida dela estava melhorando e cresceu aquela ilusão, até que naquela época não seria uma ilusão, era uma realidade. A vida, aqui, oferecia grandes oportunidades. A minha irmã arrumou para mim [emprego na Volkswagen]" (Luana).

No que se refere ao tempo futuro é a família, ainda, que exerce forte influência, principalmente sobre aqueles que já estão próximos da aposentadoria, pois muitos relatam que irão retornar à terra natal, onde ainda estão as suas famílias. De forma que presente ou ausente, a família é sempre citada. A sua ausência também é muito sentida por aqueles que têm famílias fora de São Paulo, como nos relata Joice. Ela nos diz que, nos finais de semana, enquanto os vizinhos dedicam o tempo às visitas aos parentes, ela, sua irmã e as filhas, acabam indo para o shopping, na falta da família para visitar.

1. Diário de usos do tempo (Anexo 2), como já exposto no capítulo metodológico, é uma agenda que foi preenchida pelos trabalhadores na hora das entrevistas, com todas as atividades realizadas por eles durante um dia. 
Mas não são apenas os tempos dedicados ao trabalho e à família que entram em conflito e concorrem entre si. Há igualmente a concorrência entre o tempo de trabalho e o tempo de lazer; o tempo de trabalho e o tempo de estudo; o tempo de estudo e o tempo de descanso, entre outros. Pois se para os trabalhadores com mais idade é o pouco tempo com a família o que mais causa incômodo, para os mais jovens, é o pouco tempo dedicado ao lazer, às viagens e aos namorados que são mais explicitados. E como salienta Grossin (1991), na maior parte das vezes esses tempos são sobrepostos, se interpenetram, são hierarquizados mas, poucas vezes, harmonizados.

A seguir, analiso, de forma mais detalhada, o que os trabalhadores relatam que fazem da vida; o que gostariam de fazer e o que fariam, no caso de uma redução da jornada de trabalho.

\section{2 - Vivências temporais cotidianas}

Mas o que fazem os trabalhadores fora da empresa, quando se observa a semana, o final de semana ou mesmo as férias? Fazem o que gostariam? O que fariam, no caso de uma redução da jornada de trabalho? Investiriam esse tempo ganho para fazer mais do que já fazem? Vislumbrariam a possibilidade de novas atividades? Descansariam mais, já que dizem estar cansados? Ou dedicariam mais tempo à família, já que alegam dispor de pouco tempo para esse convívio?

No que se refere ao que fazem os trabalhadores entrevistados, vê-se que aqueles que estudam, especialmente os jovens, mas não apenas eles, não têm muito tempo para fazer outra coisa além de dormir, já que o tempo de estudo se estende pelo sábado e muitas vezes pelo domingo. $\mathrm{O}$ mesmo ocorre com os trabalhadores (todos homens e mais velhos) que têm outro trabalho. E para os mais velhos e que estudam, fica explícita a quase impossibilidade de ter um tempo a ser dedicado à família. No caso dos mais jovens, é interessante observar que estes dedicam mais tempo aos estudos do que os mais velhos, porque para os primeiros não há tempo a ser dedicado à família, principalmente, nos finais de semana.

Dentre os que não estudam ou não têm outro trabalho, durante a semana alguns participam de atividades no Sindicato (os mais velhos), ficam com os filhos, assistem televisão, poucos praticam algum tipo de exercício e também poucos homens relatam dedicar um tempo às tarefas da casa. Quando analiso as respostas dadas nos diários de usos do tempo, a televisão ocupa um importante espaço entre os trabalhadores entrevistados, sobretudo entre os mais velhos e aqueles que não estudam. Um contraste muito forte quando olhamos para a quase ausên- 
cia de tempo dedicado à leitura por prazer e não à leitura relativa ao estudo. Apenas dois trabalhadores relataram ter a leitura em sua prática cotidiana. Ouvir rádio, principalmente, notícias, aparece como uma prática cotidiana dos homens mais velhos.

As atividades culturais estão praticamente ausentes, como ir a museus, shows, teatros ou cinemas, mesmo no final de semana. O namoro também é citado como tempo dedicado à descontração por vários trabalhadores mais jovens, além dos passeios e da conversa com os amigos que aparecem com certa freqüência. Outro dado que chama atenção é a ausência de dedicação de tempo às atividades políticas entre os jovens. A participação é pequena mesmo quando olhamos para o conjunto dos entrevistados com mais idade; alguns relatam o tempo dedicado ao Sindicato e apenas um ao movimento social do bairro. O tempo dedicado à igreja está um pouco mais presente, tanto na semana como no final de semana.

Outro aspecto analisado diz respeito ao tempo dedicado ao trabalho doméstico, demonstrando, como já visto anteriormente, a diferença entre os papéis socialmente atribuídos e vivenciados por homens e mulheres no âmbito do espaço da vida privada. Isto, porque a maior parte dos (poucos) homens que declararam executar atividades domésticas, está relacionada ao cuidado com animais e com serviços de reforma da casa - o que é muito comum, pois os próprios trabalhadores dizem construir e reformar as suas casas. Ou a atividades como lavar o quintal e colocar o lixo na rua ou, no limite, lavar a louça. Já no caso das mulheres, esse tempo é dedicado a preparar a comida, arrumar a cozinha, o resto da casa e ainda lavar roupas. No que diz respeito ao cuidado com as crianças, também aqui aparecem diferenças, pois no caso dos poucos homens que citaram este tempo, a maioria está relacionada com o transporte para escola. É ainda importante ressaltar a quase ausência de jovens quando o assunto é o cuidado com a casa e com as crianças. Demonstrando, como já vimos, que o fato de morarem com a família possibilita uma vivência temporal cotidiana muito diferente.

Assim, no final de semana, há tempos dedicados a uma enorme variedade de atividades: ao estudo, ao segundo trabalho, às compras para a casa, à organização da casa, à família, ao esporte, à igreja, ao passeio, ao churrasco, ao encontro com os amigos ou namorados. Para os homens, o final de semana é ainda um tempo dedicado ao futebol e à cerveja com os amigos. Para muitos, o final de semana é o tempo para se fazer tudo o que não foi feito durante a semana: "Só sobra o fim de semana, né. Aliás, até a semana passada só sobrava o domingo, porque aqui [faculdade] a gente tem aula de sábado à tarde. De manhã eu fazia inglês, aí eu terminei agora o inglês. Aí, fazia aula aqui à tarde, aí depois ia pra casa ter alemão". 
Um tempo para fazer tudo o que não foi feito na semana, inclusive relaxar. E muitos relatam que principalmente o domingo é um dia mais "sossegado", "tranqüilo", de "descanso", para "tirar o stress da semana", é dia de "não ter hora", de dormir mais "...eu durmo até o corpo reclamar de dor nas costas e acordar" (Fábio).

"O domingo é quando eu posso descansar e fazer uma coisa diferente, eu vou num shopping ou num parque, vou jogar RPG que a gente [ela e o namorado] gosta. É um dia de esquecer das coisas. Pra na segunda lembrar de novo. [...] Eu queria aproveitar melhor. Poxa, todo mundo no sábado faz alguma coisa, eu tenho que estudar" (Giulia).

Essas falas demonstram que o tempo liberado da jornada de trabalho, na maior parte das vezes, ainda comporta diversas obrigações familiares ou sociais, como salienta Bacal (1988), restando de fato pouco tempo livre. Vale lembrar ainda que em muitos casos o sábado é dedicado ao trabalho dentro da empresa em função da hora extra ou da compensação do banco de horas.

No caso de Aldo e Gerson, o final de semana é dedicado à ida ao sítio com a família e, ambos ressaltam que, se pudessem, nem voltariam para São Paulo. Entretanto, Aldo, diferentemente de Gerson, não optaria pela "semana Volks", que significou não trabalhar na sexta-feira. Em sua explicação vemos a preocupação em planejar suas atividades, considerando não apenas o tempo, mas também o aspecto financeiro:

"Eu também posso pensar que seja bom [a "semana Volks"]. Mas tem o outro lado que não é bom. O que adianta eu ir para o sítio e chegar no final do ano não ter aquilo que você mais quer, que é um valor mais alto [em função da redução da PLR]. Então, eu prefiro trabalhar e no final do ano eu vou para o sítio; não tem problema não ir todo o final de semana" (Aldo).

Ao serem perguntados sobre as atividades mais importantes na semana, a principal resposta foi o trabalho. Assim, expressar uma sensação de cansaço como conseqüência do trabalho não significa, como se poderia imaginar, que os trabalhadores não gostem desta atividade. Alguns frisam que o trabalho é a atividade mais importante durante a semana, outros fazem questão de explicitar que apreciam o trabalho, como é o caso de Carlinhos, Joice, Luana e Fábio. Mas o que demonstram gostar, sobretudo aqueles que trabalham em uma das linhas, é de trabalhar na Volkswagen e não exatamente do trabalho que exercem. O que gostam é de ter um trabalho em uma grande Empresa que oferece transporte, alimentação, seguro saúde; além das 
amizades que são feitas. Como também já vimos, o trabalho é o que possibilita a sobrevivência da família tanto no momento presente, como no futuro e, no caso das mulheres com mais idade, separadas e com filhos, isso adquire uma importância ainda maior.

\begin{abstract}
"A única coisa que não morre dentro de mim é a vontade de trabalhar. Esse meu compromisso que eu tenho com o meu trabalho, para mim é fundamental, eu não me vejo faltando, eu não me vejo chegando atrasada, isso, para mim, é tudo. Meu trabalho é tudo. E isso, até pela minha filha eu falei: se eu não tivesse esse salário, esse trabalho, hoje eu não poderia oferecer uma educação para a minha filha, que é o que eu mais me preocupo. Aliás deixo de me preocupar comigo, que é um erro, porque se eu quisesse um emprego teria que voltar a estudar, porque eu só fiz até o $2^{\circ}$ grau. E eu não me preocupo com isso, eu me preocupo em trabalhar para oferecer uma educação melhor para a minha filha, talvez eu queira me realizar na minha filha, o que é um erro também" (Luana).
\end{abstract}

Outros dizem, entretanto, que em tempos passados eles gostavam mais do trabalho na Volkswagen, e que hoje ele "não é mais o mesmo" como é o caso de alguns ferramenteiros. Outros mencionam que gostam apenas do trabalho que têm fora da Volkswagen, como Márcio e Gerson. Há ainda aqueles que fazem questão de dizer que não gostam de trabalhar, mas que o fazem porque precisam, como Giulia e Fábio: "Não é trabalhar. Ah, é sair com os amigos, o pessoal, se divertir, programas assim....". Além de explicitarem o tempo de trabalho como uma das vivências temporais mais importantes, os trabalhadores também ressaltam os tempos dedicados ao estudo - para os mais jovens, e à família - para aqueles com mais idade. Para os jovens, o estudo vem primeiro e depois o trabalho.

Já no final de semana, os tempos dedicados à família e também ao lazer são considerados os mais importantes. Muitos explicam esta prioridade enfatizando que durante a semana não têm tempo para estar com a família, com os amigos ou passeando. Acrescentam, ainda, que julgam essas as atividades mais importantes para o final de semana. Tal é o caso de Otelo: "esse pouco tempo que eu fico com a família aqui, eu acho que é o mais importante. Apesar de que é pouco tempo, que é um tempo que você pode ver que é, eu durmo, então é um tempo um pouco restrito; mas esse pouco tempo, eu acho que é o mais importante".

Em relação ao que os trabalhadores gostariam de fazer a mais na vida, viajar aparece, de longe, como aquilo de que mais gostariam; e, muitas vezes, viajar está relacionado à possibilidade de rever a família. Gostariam ainda de voltar a estudar; dedicar mais tempo à família e ao esporte. Para aqueles com mais idade, o esporte aparece sempre vinculado diretamente à solu- 
ção de problemas de saúde, resultantes do trabalho na Volkswagen. Mas alguns dizem ainda que não gostariam de fazer nada a mais. Seja por explicitarem que a vida atual está boa e que são felizes, seja, no outro extremo, por estarem muito cansados ou desanimados para pensar em fazer mais alguma coisa da vida.

Quando instigados a imaginar o que fariam no caso de uma redução na jornada de trabalho, em duas horas diárias ${ }^{2}$, é interessante observar que "viajar" desaparece totalmente das respostas, embora tenha sido a escolha que mais aparece como resposta para a pergunta sobre o que gostariam de fazer a mais na vida. Mas o que leva a uma diferença tão grande entre o que gostariam de fazer e o que fariam?

De acordo com as narrativas dos trabalhadores esta situação está relacionada a uma combinação de fatores, como, por exemplo, o fato da redução da jornada de trabalho ocorrer durante a semana, enquanto as viagens, normalmente, acontecem no final de semana, nos feriados ou nas férias. Entretanto, posso pensar que a saída na sexta-feira, duas horas mais cedo, também poderia ser utilizada para viajar. Outro fator a ser considerado é a necessidade não apenas de mais tempo livre como também de mais dinheiro para viajar, como nos relata Edgar, logo depois de dizer “... a minha vida é monótona, uma rotina. [...] Se eu pudesse, de vez em quando, a gente ia lá no interior, como a gente tem uma casinha lá né? E devido ao pedágio muito alto, não dá para ir".

Também vemos esse mesmo fator expresso na narrativa de Vagner, ao justificar o motivo de não viajar para a praia aos finais de semana, apesar de gostar muito. Relata ainda que suas viagens se restringem aos lugares onde há parentes para não gastar com estadia, por exemplo.

\begin{abstract}
"Ah porque... Eu também não tenho parente num lugar assim [praia]. E também ir e voltar no mesmo dia, né. Mas às vezes, de vez em quando, quando eu saio é pra cidades da Grande São Paulo. Eu tenho uns parentes que moram em Osasco, de vez em quando eu vou ali. Tem uns que moram em São Mateus. Esses lugares de vez em quando eu vou. Mas assim fora da Grande São Paulo é difícil eu sair" (Vagner).
\end{abstract}

As viagens dependem ainda da possibilidade de harmonizar o aumento do tempo livre com o tempo do outro, da esposa ou esposo, como nos lembra Rogério ao dizer que sua esposa

2. Neste caso, não estou tratando do que realmente as pessoas passaram a fazer com a redução da jornada de trabalho, mas apenas o que disseram que fariam no caso de uma possível redução (ver no Anexo 1 - Roteiro das entrevistas). 
trabalha aos sábados, o que dificultaria viajar aos finais de semana. Esse aspecto retoma a discussão de Grossin (1991) para quem as equações temporais devem levar em conta uma diversidade de fatores, entre eles, as pessoas que estão à volta. Isso também se confirma nos comentários dos trabalhadores sobre a "semana Volks", pois muitos relatam que a sexta-feira livre "não era assim tão interessante", uma vez que a família ou os amigos nem sempre estavam em casa ou estavam trabalhando.

Assim, os trabalhadores dizem que gostariam de viajar mais, mas quando perguntados, mais especificamente, sobre o que fariam com a redução da jornada e conseqüente aumento do tempo livre, são as atividades mais urgentes que são explicitadas, como estudar ou descansar ou praticar algum esporte. Algumas poucas pessoas disseram que ficariam mais tempo com a família, que trabalhariam mais - no segundo emprego -, ou ainda que passeariam mais.

Descansar, portanto, é muito mais citado no caso de uma possível redução da jornada, do que quando perguntados sobre o que desejariam fazer a mais. Joice, Luana, Rogério e Eron contam que, no caso de uma redução da jornada de trabalho, ficariam mais tempo com as suas respectivas filhas. No caso de Luana, é interessante observar que no momento em que fiz a pergunta sobre o que ela faria, ela respondeu: "todo planejamento deve levar em consideração a questão do salário", partindo do pressuposto de que a redução da jornada viria acompanhada de redução do salário e que, portanto, ela não poderia fazer nada de diferente. Entretanto, quando esclareço que o salário seria mantido, mesmo assim, ela fala novamente que não faria nada de novo e que dedicaria mais tempo à filha.

Em relação ao esporte, vale ressaltar que praticamente todas as pessoas que falaram que dedicariam as horas ganhas com a redução da jornada de trabalho nessa atividade são homens. Renato diz que faria natação em função do seu problema de coluna, mas afirma não ter tempo para fazer. Entretanto, quando olho para o seu diário de usos de tempo, vejo que ele chega em casa em torno de $16 \mathrm{~h}$, e vai dormir às $21 \mathrm{~h}$, e nessas cinco horas permanece em casa, quando não participa de alguma atividade no Sindicato.

Alguns dizem que não fariam nada no caso de uma redução na jornada. Vagner, por exemplo, perguntado se gostaria de fazer alguma outra atividade durante a semana, responde: “Ah, acho que ta bom, né. Também se quiser fazer alguma coisa não tem tempo né”. Entretanto, ao questioná-lo sobre o que faria caso tivesse uma redução da jornada de trabalho, diz que “ficaria em casa mesmo". É interessante observar que tanto Luana, como Vagner e Renato, tornam explícito que não é apenas a existência ou não de mais tempo livre que leva as pessoas a 
se dedicarem a outras atividades, mas há também o desejo, os valores, a motivação. Todos se mostraram, ao longo das entrevistas, muito desanimados com a vida.

No que se fere ao tempo dedicado ao estudo, vemos que tem grande importância, pois é citado tanto em resposta ao que gostariam de fazer a mais quanto ao que fariam com a redução da jornada de trabalho. A diferença é que entre os trabalhadores com mais idade isso significaria, na maior parte das vezes, voltar a estudar e, entre os mais jovens, incluir um curso de línguas ao tempo já dedicado ao estudo. Siron, Eliana, Vivian, Álcio, Rogério e Tamara disseram que gostariam ou que fariam um curso de inglês, sendo que Tamara faz questão de frisar que não seria por desejo, mas por necessidade. Gustavo, ao responder sobre o que gostaria, afirma: “Eu preciso voltar a estudar um idioma, comecei e parei, mas ultimamente eu ando sem ânimo e sem coragem. O que preciso é criar vontade e voltar a fazer isso". Otelo diz que teria "um monte de objetivos", mas que primeiro faria um curso de informática para “obter novos conhecimentos", esclarecendo que não teria nada a ver com seu trabalho. Isto logo depois de dizer que tem pouco tempo para ficar com a família, que muitas vezes é cobrado por isso e que considera o tempo com a família o mais importante.

Fica evidente que, na maior parte dos casos, quem já estuda, diz que estudaria mais; quem tem outro trabalho, diz que dedicaria mais tempo ao mesmo; as mulheres, por sua vez, informam que ficariam mais tempo com os filhos. Repete-se aqui, o que já vimos sobre a redução da jornada de trabalho ocorrida na França e na Volkswagen da Alemanha. Também lá os trabalhadores utilizaram o tempo livre, ganho com a redução do tempo de trabalho, muito mais para ampliar o tempo dedicado às atividades habituais, do que às novas, mantendo ainda os modelos sexuados de utilização do tempo. Assim, viajar, o que realmente seria o novo, fica, na maior parte dos casos, restrito às férias.

Mas o que fazem nas férias, isto é, no seu tempo livre? Todos viajam? Quem define esse momento de não trabalho? É possível conciliar esse tempo de não trabalho com o dos filhos, namorados, maridos e esposas?

Muitos dizem que nas férias vão para os estados onde têm família, já que os trabalhadores mais velhos ainda têm os pais que moram fora de São Paulo e também alguns mais jovens têm pais que, após a aposentadoria, mudaram de São Paulo. Entre os casados, nem todos conseguem viajar todos os anos, uma vez que a viagem é mais cara, pois inclui o casal e os filhos. Nesses casos, normalmente, é realizada a cada dois ou três anos. Em geral, poucos mencionam viajar desde o início ao fim das férias, sendo que a maior parte diz viajar durante 8 ou 15 dias. 
Para alguns é um tempo para "esquecer um pouco das coisas", da "vida agitada". Em contrapartida, para outros as férias são dedicadas ao estudo, uma estratégia delineada pela necessidade de usar o tempo e/ou a remuneração ganha nas férias com este fim: “As últimas férias a gente não viajou por causa da faculdade. A gente estava um pouco apertado, a gente acabou ficando por aqui mesmo". A remuneração e o tempo das férias podem ser utilizados, ainda, para a reforma ou a compra da casa, como foram os casos de Vagner, Edgar, Carlinhos e Gilson.

Outra dificuldade, como salientado por Junior, Álcio e Rogério, é que nem sempre ou "quase nunca" é possível conciliar as férias com as respectivas esposas e namoradas, pois nem eles e nem elas têm autonomia para definir os seus tempos de não trabalho, isto é, sair de férias no momento em que desejam ou necessitam. Já Otelo diz que não tem problema e que ele sempre consegue tirar férias, em julho, para poder viajar com seus filhos. Odilson, por outro lado, diz que, nas últimas duas férias, ele não conseguiu sair na mesma data que seus filhos.

"No final do ano passado, bem antes até que fiz um projeto de sair numa data e fui surpreendido e tive que sair em data diferente. [...] Houve marcação, eu teria que estar saindo numa data que não tinha nada a ver com o que eu tinha intenção. Eu pretendia sair favorável no final do ano. [...] Tive que sair em meados de outubro, de setembro para outubro, que estava totalmente fora de tudo" (Odilson).

Quando pergunto qual a justificativa dada pela Empresa, ele responde:

"Eu não quis entrar em por que. Vou falar em cima dessa passada, essa passada foi ficando, acumulando e a Empresa chegou no final do ano e disse: 'tem que sair todo mundo'. Então aí começa agendar as datas de férias para que não atrapalhe o ciclo de produção. Aí entra nós, você, ou fulano tem férias agressivas que já está estourando, está quase próxima da outra, sempre tem, sempre fica umas férias comendo a outra, aí então tem que ficar reagendando" (Odilson).

Também os ferramenteiros entrevistados reclamam dizendo que é impossível planejar as férias porque a Empresa sempre os pressiona a que tirem nos momentos de menor demanda por trabalho: "se tem serviço você não sai de férias; se não tem serviço, você sai de férias". Lúcio cita ainda que um dos problemas da multitarefa, isto é, de ficar mudando de setor, é a dificuldade em ajustar o calendário das férias. Isto porque quando o trabalhador já programou as férias no seu setor de origem e é levado para trabalhar em outro setor, em que precisa demandar as férias novamente, o que é sempre mais complicado. 
Fábio, que é estudante, diz que não tem problemas para marcar as suas férias, pois o acordo coletivo define que os estudantes têm prioridade. Por outro lado, Giulia, também estudante, diz que normalmente viaja para a casa dos pais, mas que, nas últimas férias, ela não conseguiu conciliá-las com as da escola, porque "quem é mais velho no setor sempre escolhe primeiro, tem os privilégios".

No que se refere à duração, vale lembrar que eles têm férias coletivas, portanto obrigatórias, entre o Natal e o Ano Novo. Para aqueles que conseguem emendar e logo em seguida tirar as férias individuais, isto significa ter os 30 dias corridos de férias; mas, para os que não conseguem, significa que em outra época do ano eles terão apenas 20 dias. Talvez esse seja mais um dos motivos para os trabalhadores terem dito que viajam somente entre 8 e 15 dias. Além disso, as férias podem ficar mais curtas, porque os trabalhadores podem vender para a Empresa 10 dias das férias, apesar de nenhum deles ter mencionado esse fato. Alguns líderes dizem que utilizam as horas positivas do banco de horas quando tiram férias, como no caso de Mauro, que contou ter tirado nas férias passadas 22 dias a mais, em função do saldo no banco de horas. Mas, por outro lado, nenhum outro trabalhador relatou que emenda os dias de banco de horas aos dias de férias. O que demonstra a diferença de autonomia para utilizar o banco de horas e, por isso mesmo, são os trabalhadores da produção aqueles que mais reclamaram sobre a dificuldade em usar as horas positivas do banco.

Vemos assim que esse tempo de não trabalho nem sempre é vivido no momento e da forma como os trabalhadores gostariam. Muitas vezes é a Empresa que determina o momento e, por isso, há a dificuldade de conciliar os tempos de não trabalho na fábrica com as férias da faculdade, dos filhos ou das esposas que trabalham fora. Em outros casos, tanto o tempo como a remuneração das férias ficam comprometidos seja com a escola, com a reforma ou compra da casa. Fica difícil harmonizar não apenas o tempo, mas também o dinheiro referente às férias.

\section{3 - Tempos dedicados ao trabalho profissional, fora do local de trabalho}

Algumas atividades relacionadas ao trabalho profissional, mas realizadas fora do local de trabalho e, por isso, não contratadas ou remuneradas, podem contribuir para a sensação de "vida corrida", cansaço ou "falta de tempo". Essa sensação não diminui mesmo que os trabalhadores da Volkswagen tenham conquistado a redução da jornada de trabalho de 44 para 40 horas. Como já discutido no capítulo teórico, tais atividades englobam o tempo dedicado ao desloca- 
mento entre casa e trabalho e o tempo dedicado às atividades de qualificação. Mas há também aquele tempo no qual os trabalhadores buscam soluções e sugestões para o processo de trabalho, principalmente, a partir da ênfase dada pela Empresa à participação dos trabalhadores e ao aumento da responsabilidade. Tudo isto contribui para que permaneçam com a mente no trabalho mesmo quando estão distantes deste. Assim, se esses tempos não podem ser nomeados como tempos de trabalho, não podem, por outro lado, ser entendidos como tempos livres, nos quais os sujeitos poderiam fazer o que quisessem. Veremos, de forma um pouco mais detalhada, como essas atividades aparecem nos discursos dos entrevistados e quais são as representações sobre esses tempos dedicados ao trabalho profissional.

\subsection{1 - Tempo dedicado ao transporte}

O tempo dedicado ao transporte é um tempo não reconhecido socialmente como um tempo de trabalho e nem um tempo à disposição do empregador, portanto, ele não é remunerado. Isto resulta da construção social que definiu primeiro que o trabalho contido em uma jornada de trabalho significa tempo à disposição do empregador e, depois, determinou o próprio significado de "tempo a disposição do empregador". Definição esta que, como todas as outras, também vai sendo modificada ao longo do tempo ${ }^{3}$. Mudanças que, por sua vez, foram fruto de percepções individuais e coletivas que entraram em conflito com a definição do que é tempo à disposição ou não do empregador.

Em meio a essas discussões e definições sociais, é interessante analisarmos as narrativas discursivas dos trabalhadores onde, veremos, aparecem representações muito diferentes, que explicitam diversas concepções de trabalho e de tempo de trabalho e não apenas as socialmente predominantes. Anderson, Joice e Otelo, que trabalham em uma das linhas, consideram o tempo de transporte como um tempo de trabalho,

“...porque a partir do momento que você se levanta para ir trabalhar e você pega o ônibus da firma, psicologicamente você já está trabalhando. Quer dizer, todo aquele clima, todo aquele ambiente, já faz o seu cérebro, quer dizer, já está te conduzindo ao trabalho. Então eu acho que

3. O que já gerou mudanças, como o enunciado 90 do Tribunal Superior do Trabalho que passou a definir "O tempo despendido pelo empregado, em condução fornecida pelo empregador, até o local do trabalho de difícil acesso, ou não servido por transporte regular público, e para o seu retorno, é computável na jornada de trabalho". Assim como também vimos as decisões sobre considerar o tempo utilizado para caminhar entre o portão da empresa e o local de trabalho, ou ainda as atuais discussões em torno do tempo despendido entre o local de trabalho e o refeitório. 
mesmo você estando descansado, estando no ônibus, numa posição confortável, mas creio eu, para mim já se caracteriza como trabalho" (Anderson).

Joice complementa enfatizando a questão de ter o tempo certo para fazer cada etapa da preparação para o trabalho, por isso também o considera como um tempo de trabalho: “...1h10 eu entro no chuveiro, tenho horário de sair; 1 h40 já vou para o ponto, o ponto é um pouco longe. Para mim quando eu levanto do sofá, falo: ‘vou tomar banho', para mim acabou, já é trabalho". Para Otelo, é a questão da obrigatoriedade que mais caracteriza este tempo como de trabalho, pois ele não se sente livre para fazer o que quiser. Lúcio, ao ser perguntado sobre o tempo entre a chegada na fábrica e o início da jornada de trabalho, isto é, entre $5 \mathrm{~h} 30$ e $6 \mathrm{~h}$, diz: "Na verdade, eu quando acordo, eu já me sinto já, não deveria ser assim, mas eu já me sinto como se eu estivesse lá [Volkswagen] porque eu já estou mentalmente preparado para aquilo que eu vou fazer".

Por outro lado, Rogério entende esse tempo como um tempo de descanso ou, quando vai de carro, um tempo de transição. Ao ser questionado se durante este tempo de transporte ele poderia fazer outra coisa, responde: "se eu tivesse mais disposição, eu poderia usar esse tempo, por exemplo, para ler, apesar de que está escuro, acenderia a lanterninha do ônibus. Só que mesmo no tempo da faculdade eu nunca consegui, eu sempre dormia nesse tempo...".

Fábio e Jorge, da produção e da qualidade, respectivamente, entendem este como um tempo livre, já que dormem e descansam no ônibus da Volkswagen, sem compromisso. Contrariamente, quando questionados sobre como classificariam esse tempo se utilizassem o transporte público, dizem que, nesse caso, classificariam esse tempo como um tempo de trabalho. Alguns trabalhadores relatam que às vezes vão de carro para a Empresa para "não perder tempo", para poder dormir até mais tarde ou para chegar em casa mais cedo.

Álcio também não entende esse tempo como um tempo de trabalho, embora diga que o tempo no transporte poderia ser mais bem aproveitado. Em relação à utilização de transporte público, vemos que esse tempo é também considerado como um tempo perdido.

“É um tempo perdido porque, eu tenho a possibilidade, por exemplo, de voltar para casa com o ônibus da empresa, mas existem pessoas que pegam metrô, que pegam duas, três conduções, e a gente sabe que o trânsito é caótico. Então as pessoas poderiam aproveitar de uma forma mais produtiva, mas não, acabam perdendo tempo tomando condução" (Álcio). 
Na narrativa discursiva de Luiza, a seguir, é muito interessante observar a explicitação do diálogo interno entre o significado do trabalho e do tempo de transporte socialmente construídos, e o que ela vivencia cotidianamente. Quando perguntada sobre como classificaria o tempo de transporte, ela também diz que é tempo perdido. Depois, quando questionada sobre a relação desse tempo com o trabalho, Luiza responde:

"Ele não deixa de ser. Você está voltando do teu trabalho, mas eu não considero como sendo um exercício, eu não acho, eu não considero como sendo um trabalho. Obviamente que quando eu chego na minha casa, eu falo: 'acabei de chegar do trabalho'. Obviamente que quando você chega, toca o telefone, alguém te liga: 'mas eu acabei de chegar do trabalho'. Ou seja, eu sai do trabalho a $1 \frac{1}{2}$ hora atrás, mas eu continuo no trabalho. É uma diferença, mas ao mesmo tempo, em exercício não, mas de certa forma sim, então é complicado te colocar isso" (Luiza).

Assim, vemos que as falas anteriores, na maior parte das vezes, revelam que a classificação do tempo de transporte não é exata e pode ter muitas variações. A fala de Luiza é a que mais explicita essa relação entre o que é social e institucionalmente definido como tempo de trabalho - e neste caso o tempo de transporte não está incluído -, e o sentimento de cada um a partir de suas vivências temporais cotidianas. Assim, como vimos nas discussões anteriores, é justamente nas vivências, experiências e representações que podemos encontrar, além do que é conservação, o novo e a criação, isto é, não há o tempo de transporte, mas sim tempos de transporte. Demonstrando certo conflito, como salienta Grossin (1991), entre o tempo vivido e o tempo institucionalizado.

\subsection{2 - Tempo dedicado ao estudo}

No que se refere ao tempo dedicado ao estudo, vemos que muitos trabalhadores ou estão dedicando um tempo a essa atividade ou já dedicaram num passado recente. Apesar dos trabalhadores da Volkswagen terem conquistado uma jornada de trabalho de 40 horas, trabalhar e estudar significa, na maior parte dos casos, sair de casa as 5:h da manhã e voltar após as $22 \mathrm{~h}$. Como conseqüência, os trabalhadores com mais idade aludem à extrema dificuldade de estudar e vivenciar as outras temporalidades sociais, isto é, o tempo com os filhos, namorados, famílias ou amigos, tanto durante a semana como no final de semana, como relata Manolo, 
"No final de semana o importante é você estar com a família, principalmente nesse período que eu estou estudando. Porque durante a semana, por exemplo, eu vejo meu filho de manhã, a hora que eu estou saindo, ele acorda o mesmo horário que eu para ir para a escola, minha filha não vejo, porque ela estuda a noite. Eu saio do emprego, vou para casa, dá tempo de tomar um banho, tomar um lanche e voltar. Chega à noite, muitas vezes eles estão dormindo. Então, final de semana é para a gente ter tempo de conversar, saber como que os meninos estão na escola, dar carinho, conselho. No final de semana, às vezes eu fico na garagem trancado dentro do carro, não dá 10 minutos um bate na porta para falar alguma coisa, não dá para concentrar, eu prefiro vir na faculdade..." (Manolo).

E este sentimento de falta de tempo em relação aos filhos, em função do tempo que foi dedicado ao estudo, é algo referido mesmo por aqueles que já terminaram a faculdade, demonstrando como essa é uma vivência forte e angustiante. Tal é o caso de Ronaldo, quando diz que o mais importante para ele na semana é o tempo que ele fica com a filha,

“...porque quando ela nasceu, eu estava na faculdade. Aí, ela me viu crescendo no meio dos livros. Embora a faculdade não era tão rígida, eu estudei aqui na Fundação. Mas eu sempre gostei de me dedicar ao que eu faço, então eu gostava de pegar as coisas, gostava de fazer. Então ela cresceu me vendo no meio de livros..." (Ronaldo).

É possível observar que o fato de voltar a estudar altera a vivência do tempo, tanto do ponto de vista quantitativo como qualitativo, em muito contribuindo para a sensação de "vida corrida" que discuti anteriormente. Considerando que o dia continua tendo uma duração de 24 horas e que o salário recebido se mantém, significa que o tempo e a renda antes dedicados às outras atividades serão reduzidos, afetando as vivências dos diversos tempos sociais. Afinal, como vimos, é justamente no momento em que a Empresa está exigindo cada vez mais que os trabalhadores voltem a estudar, que ela tem cortado os cursos antes oferecidos pelo Senai e também reduzido o número de bolsas de estudo. Não sem razão, alguns trabalhadores, mesmo sob tal pressão, optam por não estudar, premidos por outras demandas vindas de fora do local de trabalho. Tal recusa explicita a necessidade e a dificuldade de repensar a vida toda para incluir um "novo" tempo que traz uma despesa financeira adicional. Evidencia as equações temporais que são feitas considerando tanto o tempo presente como o futuro, tanto as perspectivas dentro como fora da Empresa, como vimos na discussão sobre as gerações.

Outros trabalhadores, como vimos, apesar de não estarem estudando, relatam que pretendem voltar a estudar, quando perguntados sobre o que gostariam de fazer, ou o que fariam, no caso da redução da jornada de trabalho, como é o caso de Jorge: 
"Eu comento com a minha esposa, porque eu estou sendo literalmente atropelado. Antes, vamos dizer, há uns 5 anos atrás, 4 anos atrás, eu com esses 2 [cursos] técnicos que eu tinha, e vários cursos do Senai, para efeito de Volkswagen, eu tinha um currículo muito bom, mediante aos outros que trabalhavam a minha volta. Hoje, isso já não quer dizer nada, então o estudo que eu tinha, já está num nível, vamos dizer assim, abaixo dos outros" (Jorge).

E pensando ainda no tempo presente, pergunto a Jorge se a Empresa exerce algum tipo de pressão para ele voltar a estudar.

"Não. É assim, eu exerço o cargo de monitor na empresa. E alguns líderes não me pressionaram em nada. Eles aconselharam, que seria bom que eu fizesse uma faculdade, até mesmo para um eventual crescimento meu na empresa. Que não teria como eu crescer mais se não tivesse uma faculdade. Mas, pressão a Empresa não faz não. Ela até ajuda, se for fazer um curso que ela vê que pode ser usado para ela aqui, ela ajuda até, mas pressão não" (Jorge).

A fala anterior faz a conexão entre o tempo presente, onde o estudo faz falta e o tempo futuro, que pode vir a abrir portas, tanto dentro como fora da Volkswagen. Reporta-se, também, à pressão por parte da Empresa, em alguns setores, para que os trabalhadores voltem a estudar. Como vimos, a Empresa transferiu alguns trabalhadores da produção direta para trabalharem com qualidade e esses são os mais pressionados para voltar ao estudo.

Assim, o estudo aparece já ocupando um tempo dos trabalhadores ou, muitas vezes, como uma preocupação ou como uma possibilidade. Como isso altera totalmente as vivências temporais cotidianas, sobretudo nos caso dos trabalhadores mais velhos e que já constituíram família, voltar a estudar significa uma equação temporal para inclusão de mais este tempo, numa vida já considerada corrida e sem tempo.

\subsection{3 - Ainda pensando no trabalho}

A sensação de falta de tempo pode estar, igualmente, relacionada ao fato de alguns trabalhadores mencionarem que ficam com o "trabalho na cabeça", mesmo fora da jornada de trabalho. Não estou falando da hora extra, como é o caso de Márcio que diz já ter, em 5 meses, 68 horas positivas, nem do trabalho levado para casa, pois, como salienta Luiza, se antes as pessoas do setor administrativo levavam trabalho para fazer em casa, hoje "ele vai é na cuca".

Trata-se do "pensar no trabalho", que se expressa seja na contínua busca de soluções para os problemas que são enfrentados, nas sugestões para a melhoria da produção, estimulados 
pelos programas de sugestão muito presentes na Empresa, seja em função da maior responsabilidade em relação à qualidade do produto ou, ainda, na preocupação cotidiana em não perder o emprego.

"Eu trabalho para não ser demitido, como eu estava falando para você, eu procurei estudar, no meu dia a dia, minhas avaliações, eu nunca tive um S, eu nunca tive um I, minhas avaliações sempre foram nota B e E. Então, para mim, é muito importante esse emprego, eu procuro valorizar muito esse emprego, por tudo. Isso que eu estou te falando, essas estruturas que ela dá, esse respaldo que ela dá...”. (Edgar)

Anderson, trabalhador da linha da montagem final, ao mesmo tempo em que diz não ver perspectiva de ser efetivado no estágio dentro da Volkswagen, pois sente que a Empresa não dá as mesmas oportunidades para todos, muitas vezes demonstra certa expectativa quando afirma que no final de semana o mais importante são as coisas que "agregam valor" ao seu conhecimento: “... eu estou na busca, almejo uma coisa melhor dentro da empresa, sempre trabalhei na produção, então quer dizer, eu procuro me aperfeiçoar, pegando os livros, lendo coisas que me interessam e fazendo o meu curso de inglês...". Neste sentido, sua fala explicita que boa parte do seu dia é dedicada ao investimento pessoal, relacionado ao trabalho, pois as atividades sempre são mencionadas como algo que pode contribuir para o seu desenvolvimento profissional.

Em relação às sugestões, Carlinhos relata que antes eles tinham um tempo dentro da Empresa para discutir os problemas da área e pensar em sugestões:

"hoje você tem que trazer de casa a sugestão. [...] Porque o tempo para a Empresa é muito grande, porque ela quer melhoria em pouco tempo, que dá resultado para ela em pouco tempo. O tempo que a gente faz a melhoria, ela está ganhando" (Carlinhos).

Tamara diz que nem sempre consegue separar o tempo de trabalho e de não trabalho e que, muitas vezes, leva problemas e preocupações do trabalho para casa.

“...muitas vezes o stress do trabalho eu levo para casa, minha mãe que sabe, coitadinha, sofre. Às vezes é difícil com o meu namorado, ele fala: espera aí que eu não fiz nada, calma, e olha que eu nem estava lá. Hoje ele é mais acostumado, peço desculpa. [...] Dependendo do problema que eu tenho, eu já cheguei a sonhar, ter pesadelo com os problemas que eu tive na linha, igual, montar bateria errada" (Tamara). 
De acordo com Marcos, que trabalha na qualidade, a pressão da Empresa tem sido muito forte, a ponto de mencionar que chega a ir para casa "meio perturbado" e fica pensando em como deveria agir no dia seguinte.

\begin{abstract}
"Existem muitos desafios na vida, não posso achar que está bom do jeito que está, tenho que procurar sempre melhorar. Então, às vezes eu saio daqui pensando, o que eu vou fazer amanhã, para até mesmo melhorar a palestra que eu vou fazer amanhã. Quando eu não tenho palestra, para ajudar a minha equipe de trabalho, o que vou fazer amanhã para eu sobressair sobre os meus concorrentes [outros trabalhadores], de uma forma positiva? Então a gente fica aí com esse pensamento, a gente acaba, lógico, tem toda a nossa vida social lá fora, família que a gente também tem que pensar" (Marcos).
\end{abstract}

Relata ainda que embora tenha mudado de função, não teve alteração de salário. É interessante notar que, como solução para esse desvio de função, levanta a possibilidade de "trabalhar melhor ainda".

\begin{abstract}
"Eu ganho como funileiro (grau B), apesar de estar fazendo trabalho 7 anos fora [da funilaria]. Ainda não tive esse reconhecimento financeiramente. A gente vai trabalhando para que isso aconteça, eu mais ou menos o que dizem, fora de função, mas para mim está sendo muito bom, não tenho o que reclamar. Estou trabalhando cada dia, tentando ser o melhor no mundo naquilo que eu faço, que não existe outra alternativa, a gente tem que procurar ser assim. Mas eu sei que as coisas acontecerão, pode ser que demore, pode ser que não, mas eu estou trabalhando para que isso aconteça o mais cedo possível" (Marcos).
\end{abstract}

Edgar lembra que quando foi monitor, a família não agüentava mais ouvi-lo falar sempre a mesma coisa e "eu acho que a minha cabeça ia ficar branquinha, era terrível, eu carregava um fardo muito pesado...”. Nessa entrevista, a esposa de Edgar, também presente, comenta que ele passou a ficar mais cansado, com disposição apenas para ver televisão. Nunes, atualmente representante dos trabalhadores, explicita:

"Eu acho que a jornada não se limita nas 8 horas diárias. Eu acho que ela envolve muito mais, porque você fica 8 horas vivendo isso, você até conseguir tirar isso da cabeça, demora. Eu imagino mas não estudo isso. (...) Mas eu imagino que para o cara deixar pelo menos sair daquele "click"; ele trabalhou das 8 as 5 ele vai pelo menos até umas 8 horas da noite naquilo carregado dentro dele, para depois ele se desligar. Isso vai depender do que ele vê na TV, porque se ele vê na TV falando alguma coisa relacionada ao trabalho, daí ele volta para aquele mundo dele. Acaba voltando.(...) Ele tem a Empresa a ponto dele andar no meio da rua com uma camisa com um 
símbolo da empresa. Então é. O processo de cooptação em uma Empresa tão grande faz com que a jornada do cara seja a própria vida dele. Complicado isso. Bastante complicado e difícil você combater" (Nunes).

Gomes, antigo dirigente sindical, hoje aposentado, entende que o trabalhador não faz a separação entre o tempo que ele está dentro da Empresa e fora dela, sobretudo em função da preocupação em não perder o emprego, em poder continuar a sobreviver.

\footnotetext{
"Isso porque infelizmente, o trabalho não é meio de vida é meio de morte. E as pessoas vivem no reino da necessidade. A pessoa trabalha numa fábrica dessa, ele está preocupado, ele vai para casa e ele leva o trabalho, e ele está preocupado com o emprego, está preocupado. (...) ... perder o emprego, ela não tem outro emprego, não vai arrumar outro emprego. Não porque ela é incompetente, porque não tem emprego. Isso leva que ele viva nesse dilema, se preocupe em perder o emprego, se submeta a trabalhar fazer uma jornada dupla na fábrica, tripla porque leva, vai para não perder o emprego e manter" (Gomes).
}

Essas narrativas nos relevam que quanto maior a pressão pela redução dos prazos ou pela qualidade dos produtos, maior o controle, maior a responsabilidade, maior o desejo de se destacar, de sair da produção, maior o receio de perder o emprego. Fatores que levam os trabalhadores a continuarem a pensar e a se preocupar com o trabalho profissional, mesmo estando distantes do local de trabalho.

\section{4 - Considerações finais}

Ao analisar as narrativas discursivas sobre as vivências temporais cotidianas fora do local de trabalho, fica explícito que o fluxo tenso e intenso, característica principal do tempo dentro da fábrica, se estende para fora da fábrica. O que nos ajuda a compreender como os trabalhadores entrevistados, inclusive os que têm uma jornada de trabalho menor que a prevista em lei, explicitam, tão fortemente, que o tempo de trabalho ocupa quase as 24 horas do dia. E a entender quais os fatores que resultam nessa sensação de que a vida é corrida, de que não há tempo para se fazer mais nada além de trabalhar. Como já salientado por Sue (1994) e Mercure (1995), nas sociedades contemporâneas onde são diversos os tempos sociais, quanto mais o tempo contido na jornada de trabalho é reduzido, mais o tempo liberado é ocupado por outros tempos sociais. 
Sem dúvida a vida fora do local de trabalho exerce grande influência sobre o tempo no local de trabalho, como já vimos nos capítulos anteriores; mas, para aqueles que ainda estão empregados, de fato, o tempo fora da fábrica é ainda tomado por diversas atividades relacionadas ao trabalho profissional. E, ainda, se o tempo dentro da Volkswagen é vivenciado como intenso e pressionado, o tempo fora será um tempo onde o corpo e a mente estão cansados. Isto é, o que pressiona não é apenas a quantidade de horas vivenciadas dentro da fábrica - que, como vimos, não se restringe ao tempo da jornada de trabalho, mas significa em torno de $9 \mathrm{~h} 30$ a $10 \mathrm{~h}$, além da hora extra - mas também às características desse tempo. Intenso, repetitivo, pressionado, receoso.

O tempo fora do local de trabalho é curto para vivenciar todas as outras temporalidades sociais. É grande a angústia explicitada diante da falta de tempo para a família, no caso daqueles com mais idade; da falta de tempo para passear, ressaltado com mais vigor pelos mais jovens; das barreiras para a inclusão do tempo de estudo, conforme dizem os casados e com filhos; das dificuldades em conciliar o tempo dedicado ao trabalho doméstico e ao trabalho profissional, no caso das mulheres com mais idade. O que implica equações temporais cotidianas que são implementadas visando harmonizar todos os tempos sociais a que os sujeitos estão submetidos. Tempos, por sua vez, com características totalmente diferentes, levando a diversos conflitos internos e também com as pessoas que estão à volta (Grossin, 1991). De forma que o tempo durante a semana é curto, mas também o contido no final de semana; pois, é o momento em que o tempo deve ser suficiente para se fazer tudo o que não foi feito durante a semana: limpar a casa, estudar, ficar com a família, fazer compras, passear e até para descansar e "tirar o stress da semana".

Quando perguntados sobre o que gostariam de fazer ou o que fariam, no caso do aumento do tempo livre, em função da redução da jornada de trabalho, é interessante observar as diferenças de ênfases. Nas narrativas discursivas fica claro que diante da pergunta sobre o que gostariam de fazer, as respostas foram dirigidas às manifestações de desejos. Viajar, por exemplo, apareceu com grande destaque. Já quando a questão é o que fariam no caso da redução da jornada, as respostas foram mais práticas, apontando para a resolução de demandas pessoais ou familiares mais urgentes. Neste caso, a opção "viajar" desaparece totalmente das respostas, enquanto "descansar" e "estudar" ganham maior destaque.

É importante salientar também que ao falarem sobre um possível ganho de tempo livre, não se referem a novas atividades a serem desenvolvidas nesse tempo. Ao lembrarmos o que os 
trabalhadores haviam relatado (capítulo 6) sobre o que fizeram com o tempo liberado nas últimas reduções da jornada de trabalho, muitos disseram que aproveitaram para dormir mais e poucos para voltar a estudar. Sendo que muitos, inclusive, relataram que não haviam sentido essas reduções. O que nos remete, por exemplo, à discussão de Maresca (2004) sobre os usos do tempo liberado após a redução da jornada de trabalho na França, e Seifert (1997) sobre a Volkswagen na Alemanha. Isto é, de uma formação geral, o tempo liberado da jornada de trabalho - ou, no caso desta pesquisa, o tempo que se imagina vir a ser ganho - é utilizado para realizar mais do que já se fazia, mantendo assim as diferenças de usos do tempo entre mulheres e homens ou entre pessoas de gerações e situações econômicas diferentes.

Viajar, então, é um desejo que fica restrito ao tempo livre das férias; mas que nem sempre se concretiza. Pois, neste caso, há o conflito entre o momento em que é interessante para a Empresa que o trabalhador tire férias e o tempo que interessa ao próprio trabalhador. Acrescente-se ao quadro a difícil conciliação entre o tempo livre do trabalhador e da sua família - fillhos, esposas, namorados. Deve-se sublinhar ainda o conflito entre as diversas demandas em relação ao tempo livre e à remuneração oriundos das férias. A remuneração das férias contradiz sua vocação para o ‘tempo livre’ quando é canalizada para o estudo, a reforma da casa, a compra da casa ou do carro.

Há relatos que explicitam a dificuldade em separar o tempo dentro da fábrica e fora desta e, inclusive, que não conseguem parar de pensar no trabalho, mesmo estando fora da Empresa. Um tempo dedicado à busca contínua de soluções para os problemas enfrentados, para se destacar entre os outros trabalhadores, de sugestões para a melhoria da produção. Mas um tempo ainda tomado pela preocupação em não perder o emprego, o que pode levar a um tempo maior a ser dedicado ao estudo, como forma de se buscar controlar um futuro cada vez mais incerto (Leccard, 2005).

Não é apenas o tempo dedicado ao estudo e à preocupação com o trabalho que ocupam o tempo fora do local de trabalho, pois há ainda o tempo com o transporte. Neste caso é muito interessante perceber as diversas representações em torno do que é tempo de trabalho e de não trabalho. Essa diversidade de representações foi constatada também no capítulo 6, em relação ao tempo entre as $5 \mathrm{~h} 30$ e $6 \mathrm{~h}$ da manhã. Nesses dois casos, estamos falando de vivências de tempos que não são social ou institucionalmente considerados como tempo de trabalho. Entretanto, para alguns trabalhadores esses tempos são vivenciados e representados como tempos de trabalho, para outros não. De forma que não há uma representação única, sendo ainda diversos 
os motivos que levam os trabalhadores a considerarem este tempo como de trabalho ou de não trabalho.

Como explicita Zarifian (2001), é justamente quando analisamos o tempo a partir dos sujeitos que podemos encontrar, além da conservação - neste caso entender o tempo de transporte como tempo de não trabalho - também o novo, a criação e a invenção. Tanto no que se refere às vivências e às representações como nos discursos. Para alguns, o tempo de trabalho já começa no momento em que acordam ou iniciam a preparação para sair de casa. E são diversos os motivos para explicar porque esses tempos já são vivenciados e representados como tempos de trabalho, sobretudo pelo fato de ser obrigatório. Assim, vemos que os conflitos gerados entre os tempos socialmente definidos e os tempos vivenciados pelos sujeitos levam ao questionamento da definição social e institucionalmente reconhecida. Questionamentos que podem ser entendidos como gérmen de uma possibilidade de mudanças na própria definição institucional, afinal, são esses conflitos explícitos ou não, declarados ou não, individuais ou coletivos que constituem a própria dinâmica social, resultando em construções temporais diferentes.

Entendo, ainda, que o que leva os trabalhadores a terem a sensação de que a vida é corrida está não apenas relacionado à quantidade de tempo dedicado às atividades de trabalho, mas também à forma como as atividades são desenvolvidas e às sensações que se prolongam para além e aquém da jornada, pois estão impregnadas no corpo do trabalhador. Apesar da jornada de trabalho na Volkswagen ser menor, como o tempo de trabalho é intenso, há a sensação de que o tempo de trabalho ocupa o dia todo, pois o cansaço gerado em função desse tempo intenso, deixa as pessoas com menos disposição para outras atividades. Fora da empresa, se o dia ainda contém atividades relacionadas ao trabalho, mesmo que indiretamente, como o tempo de estudo ou o tempo de transporte, de fato sobra pouco tempo realmente livre.

E mais, o tempo de não trabalho, como as férias, também não é uma equação simples, já que além de ser definido pelo outro, também há dificuldade para conciliar com o tempo de não trabalho dos membros da família. Com isso, não é difícil compreender a sensação de falta de tempo realmente livre desses trabalhadores.

Finalmente, se fora do local de trabalho os trabalhadores ainda ficam preocupados com o trabalho, isso os deixa ainda mais tensos, principalmente, numa sociedade onde os horizontes temporais são cada vez mais restritos e o tempo futuro não traz mais consigo a expectativa de dias melhores, mas de dias incertos. 
or que analisar o tempo de trabalho a partir das vivências temporais cotidianas? Qual o valor heurístico de contextualizar a reflexão sobre tais vivências tanto no nível macro, tendo em conta as mudanças no tempo e no trabalho na sociedade atual, como no plano micro, observando as transformações ocorridas no chamado "chão de fábrica"? Isto é, o que essa perspectiva aportou de novo para a discussão e compreensão do tempo de trabalho na sociedade brasileira? Que questões podem ser então levantadas a partir dessa reflexão? Essas são, talvez, as indagaçõeschave para sistematizar, na forma de primeiras conclusões, o esforço analítico empreendido ao longo desta tese.

A primeira observação refere-se ao fato de que o tempo é antes de tudo uma experiência subjetiva, antes mesmo de se constituir como objeto de reflexão, medida de duração ou objeto de poder. Nesse sentido, e tal qual afirma Zarifian (2001), o tempo consiste em um fenômeno que, do ponto de vista analítico, tem o seu relevo inicial dado por sua dimensão qualitativa, antes de ser um mero fluir quantitativo, a ser gerenciado e controlado pelo montante do seu dispêndio, nas mais diferentes atividades. De forma que refletir sobre o tempo requer tomá-lo a partir da dimensão do vivido, do experimentado, do representado cotidianamente.

Assim, mesmo que o tempo apareça como único, preciso, uniforme e igual em todos os lugares, quando se analisam as narrativas discursivas dos sujeitos, como aquelas dos trabalhadores da Volkswagen aqui tratados, essa mesmice logo cede lugar ao novo, à explicitação de uma diversidade de tempos sociais. Mais ainda, revela-se toda a diversidade de vivências existentes em relação a um mesmo tempo social. Foi isso que me levou a formular o objeto de análise como os tempos de trabalho, antes que o tempo de trabalho, em suas inter-relações com os outros tempos sociais. 
Analisar as vivências temporais cotidianas de trabalhadores, contudo, não significa encontrar apenas criação e invenção. Essas vivências contêm tanto a conservação como a novidade, tanto a persistência como a surpresa (Zarifian, 2001). Todavia, conservação e persistência não significam simples reprodução, mas que as vivências individuais de tempos sociais estão remetidas a determinações mais amplas de uma cultura temporal, num momento histórico (Lopes, 2000). Ou seja, o tempo é, em cada sociedade, ao mesmo tempo experiência, representação, norma, valor, instituição, referência.

Vimos então que coexistem tempos diferentes, que se coordenam e se opõem, contraditórios e conflitantes, sendo comum, em todas as sociedades, a procura de uma ordem, de uma hierarquia, de uma valorização entre os diferentes tempos sociais (Mercure, 1995). Desse modo, cada sociedade constrói um tempo dominante e procura impor, com mais ou menos conflito, a ordem afeita a este tempo, com a sua lógica, suas características e seu modo de organização do conjunto dos tempos sociais e dos fenômenos a eles relacionados. Esse tempo dominante reflete o poder de uma classe ou grupo social que procura fazer prevalecer sua visão de mundo, expressa em uma concepção particular do uso e controle do tempo.

A ordem do tempo regula todas as atividades dos homens, "poder-se-ia dizer que ela é o mais nobre atributo de toda a dominação. Um poder recém-surgido, desejoso de afirmar-se, tem de promover uma reordenação do tempo" (Canetti, 1995). Não sem razão, vimos a burguesia assegurar seu poder impondo uma nova concepção de tempo, um tempo quantitativo e racional, que se apresenta como universal e que prefigura o tempo industrial, da sociedade moderna (Thompson, 1967). Entretanto, mesmo que em cada cultura temporal haja um tempo dominante, ele não é exclusivo (Grossin, 1991; Mercure, 1995). Assim se passa com os tempos de trabalho e de não-trabalho. Eles formam uma unidade contraditória e não simplesmente oposta. Por isso mesmo, para efeito de análise, não devem ser tomados como dois termos separados, cada qual dotado de características de sua própria existência (Chaú́, 2003). Ao contrário, para compreendêlos é preciso analisá-los em sua inter-relação.

A partir das narrativas discursivas dos trabalhadores da Volkswagen, vimos como as diversas temporalidades sociais coexistem e como os trabalhadores elaboram equações temporais que têm como objetivo buscar harmonizar essas temporalidades muitas vezes conflitantes. Tal foi o caso das narrativas sobre o trabalho noturno. Vimos que a entrada e a permanência nesse regime de turno têm nos tempos fora do local de trabalho sua motivação maior. Concomitantemente, a dificuldade de adaptação e os conflitos gerados entre as diversas 
temporalidades sociais no espaço fora da fábrica pressionam os trabalhadores para o abandono do trabalho noturno. Ou seja, para melhor compreender a permanência, ou não, nesse turno devemos tomá-la como fruto das inter-relações entre os diversos tempos sociais, e da relação que cada sujeito estabelece com essa diversidade temporal, já que as equações e decisões tomadas podem ser muito diferentes.

O mesmo transparece quando se analisam as vivências temporais cotidianas dos jovens trabalhadores. Entre eles, a possibilidade de dedicar um tempo maior ao estudo está vinculada à temporalidade do trabalho, isto é, à expectativa ou possibilidade de um novo trabalho. Adicionalmente, essa dedicação ao estudo é proporcionada pela inexistência de tempo utilizado com trabalho doméstico ou com o cuidado com os filhos, por exemplo, já que todos os jovens entrevistados moravam com os pais, eram solteiros e não tinham filhos. Finalmente, a mesma existência de diversos tempos sociais, bem como suas inter-relações, ficou explícita nas vivências das mulheres. Constatamos os conflitos gerados em torno dos tempos dedicados ao trabalho profissional e ao trabalho doméstico, na busca por um lugar no mercado de trabalho, e, ao mesmo tempo, a necessidade de preservar um tempo dedicado ao cuidado dos filhos e da casa. Como o dia continua a ter as mesmas 24 horas, uma vez expresso o conflito entre os diferentes tempos sociais, é forçoso solvê-lo pela hierarquização estabelecida entre eles; como resultado, em alguns casos muitos desses tempos são deixados de lado ou são totalmente reduzidos, como os tempos de lazer, os tempos dedicados à família, os tempos de descanso e os próprios tempos de estudo.

Outro recurso utilizado para compreender a diversidade de tempos sociais foi o de analisar uma cultura temporal diferente da nossa própria (Grossin, 1991). As alternativas seriam refletir sobre outras culturas temporais em outros momentos históricos ou ainda observar culturas coexistentes no mesmo momento, mas em espaços distintos. Foi isso o que se buscou ao refletir sobre a construção temporal do tempo de trabalho no Brasil, a partir do diálogo com o caso francês. Essa análise permitiu evidenciar as configurações próprias da construção social do tempo de trabalho na sociedade brasileira. Ela facultou não apenas explicitar as particularidades de cada uma das sociedades, como também o que lhes parece ser comum, e que talvez seja universal em certos contextos históricos.

A comparação das experiências francesa e brasileira destacou os papéis e espaços ocupados pelos diferentes atores sociais em torno das discussões sobre tempo de trabalho, as quais se referem tanto à redução da jornada de trabalho, como à sua intensificação e à sua flexibilização. 
No caso do Brasil, é difícil reconhecer algum momento em que tenha existido um amplo processo de discussão e negociação em torno da temática. Mesmo a partir de meados de 1990, quando empresários e governos puderam inserir novas regras de flexibilização do tempo de trabalho, tais mudanças foram implementadas sem um amplo processo social de discussão e negociação. O seu principal resultado prático foi a introdução do mecanismo do banco de horas, que possibilita à empresa continuar utilizando horas extras, sem limite mensal ou anual, e agora sem remunerá-las como tal. Mas, por seu turno, os trabalhadores tampouco conseguiram inserir na pauta político-institucional o tema da redução da jornada de trabalho, em que pesem os seus esforços no sentido de vincular o tema à questão da geração de emprego, assunto socialmente candente numa década de intenso encolhimento de boas oportunidades ocupacionais.

Já no caso francês, vimos que o governo teve papel preponderante no fomento ao debate e na alteração da legislação para redução da jornada; mas vimos também os limites da legislação e sua forte vinculação à correlação de força política entre os diversos atores. Explicitaram-se, sobretudo na mudança da Lei Aubry I para a Aubry II, em que as principais regras que objetivavam a criação de empregos foram abolidas: a necessidade de manter ou gerar empregos e a proibição de redefinir o tempo de trabalho. Neste caso, a remodelação significou a exclusão dos tempos de trabalho de feriados, de pausas individuais e coletivas, de troca de roupa ou ainda de formação. Como resultado, em muitos casos, a depender da correlação de forças presente nas negociações coletivas por empresa, foram poucos os dias livres conquistados.

Por isso mesmo, Brasil e França revelaram-se contextos sociais muito diferentes nos quais têm se dado as negociações por empresa sobre o tempo de trabalho. Isso ficou patente, em partes anteriores deste trabalho, quando analisei as negociações por empresa na França e na Volkswagen do Brasil. No entanto, em ambos os casos observaram-se aspectos que parecem ser comuns à construção temporal das sociedades contemporâneas: a pressão patronal para flexibilizar o tempo de trabalho a partir das necessidades da produção, e para retomar o controle do tempo do trabalhador dentro e fora dos locais de atividade profissional, num contexto histórico de redução do tempo de trabalho. Em ambas as sociedades vê-se, ademais, que o desemprego tem sido fator de relevo no processo de negociação coletiva, pressionando os trabalhadores e seus representantes a abrirem mão de direitos conquistados e a aceitarem as iniciativas das empresas no sentido da flexibilização do tempo de trabalho.

Mas, ao combinarmos a análise anterior, voltada aos planos macrossocial e institucional, com a compreensão do que se passava nos espaços microorganizacionais - nos "chãos de fábri- 
ca" - vimos que as mudanças no tempo de trabalho não se davam apenas em razão de alterações em sua extensão ou flexibilização, institucionalizadas no plano macro. Ao estudar um local de trabalho específico, no caso a Volkswagen do Brasil em sua planta mais antiga e sujeita a intensas transformações tecnológicas e organizacionais, observei os diversos fatores que afetam o tempo de trabalho, como eles têm sido negociados e como têm sido vivenciados. Atentei, sobretudo, à relação de influência recíproca entre as vivências individuais, a negociação coletiva, a legislação vigente e a cultura temporal de uma determinada sociedade, num dado momento histórico.

São inúmeras as transformações no local de trabalho com impacto sobre as temporalidades sociais, tanto dentro como fora da fábrica. Tais mudanças influenciaram o tempo de trabalho de forma mais ou menos explícita, mais ou menos direta ou mais ou menos intensa. Algumas inovações são mais recentes; outras, mais antigas. Algumas foram objeto de negociação, outras não. Algumas foram reivindicadas coletivamente, outras apenas no âmbito individual. Algumas, ainda, foram de ordem política, outras tecnológicas, organizacionais ou mesmo administrativas. Entretanto, apesar dessa diversidade, no que se refere aos impactos, as mudanças verificadas no período focalizado por esta pesquisa - de 1995 a 2005 - apontaram para a redução, a flexibilização e a intensificação do tempo de trabalho, tal como salientado pelos trabalhadores, pelos dirigentes sindicais e pelos próprios gerentes da empresa.

Tais impactos, por sua vez, além de se relacionarem à natureza e à forma das mudanças, também refletiram as vivências cotidianas dos trabalhadores em relação às modificações. Essas vivências expressam significados diferentes como aceitação, alteração, negação e reclamação, significados esses que variam a depender do tempo presente, do setor de alocação e da função que o trabalhador exerce, ou de atributos pessoais (como sexo e idade) ou sociais (como escolaridade, o fato de morar ou não com a família, ser ou não casado, ter ou não filhos). Papel igualmente importante têm a história de vida de cada um, dentro e fora da fábrica, as expectativas em relação aos tempos futuros e, ainda, o contexto macrossocial no qual estão inseridos. É nesse emaranhado de determinantes macrossociais, microinstitucionais e pessoais que são construidas as vivências temporais cotidianas dentro da Volkswagem do ABC.

Vimos então, no curso desta tese, que as mudanças que alteram de maneira mais explícita e direta o tempo de trabalho - como a redução, ampliação (hora extra) e a flexibilização desse tempo - têm sido objeto de discussão entre os trabalhadores e matéria de negociação coletiva. Não sem razão, uma das reclamações, tanto de trabalhadores da linha como de fora desta, refe- 
re-se justamente às formas de flexibilização implementadas pela empresa desde 1995, sobretudo o banco de horas e a chamada "semana Volks". Mas é interessante observar que a queixa dos trabalhadores concernia antes à redução que se verificou na remuneração (da PLR e da hora extra), que aos reflexos dessas mudanças na organização do trabalho e mesmo da vida de cada um. Assim, foi em razão da preocupação com relação à remuneração que o tema foi amplamente debatido e coletivamente negociado.

Como explicá-lo? Não pareceria paradoxal, dado tudo o que antes fora sustentado com respeito às interações entre os vários tempos sociais e às dificuldades expressas nas narrativas desses trabalhadores? Acredito que esse tipo de atitude tem a sua razão de ser no fato de que no Brasil, e portanto também na Volkswagen do ABC, o tempo pode ser flexibilizado, como sempre o foi, a partir da utilização da hora extra e de tantos outros instrumentos legais. Esta é uma diferença fundamental, que se evidencia quando observamos, por exemplo, uma outra realidade, como a francesa. Neste caso, a flexibilização é algo novo para os trabalhadores e talvez por isso mesmo objeto de tanta reclamação e recusa. No Brasil, por sua vez, a realização da hora extra é uma velha forma de flexibilizar o tempo de trabalho, largamente utilizada pelos trabalhadores como mecanismo de compensação, especialmente em fases de restrição de ganhos salariais, ou mesmo mobilizada como expediente para incrementar rendimento e, assim, custear expectativas, planos e iniciativas que resultam de outros espaços da vida individual. Perdeu, inclusive, o significado de horas a serem trabalhadas em momentos extraordinários (Calvete, 2006). Tal conceito mostra-se pouco adequado à realidade do Brasil, onde, em média, 40\% dos trabalhadores realizam hora extra (Dieese, 2007).

Mas se a hora extra perdeu o significado real de trabalho extraordinário, ao menos até recentemente ela ainda era entendida como uma hora a ser remunerada de forma diferenciada, como um tempo de trabalho a mais que, por isso mesmo, desorganiza as outras temporalidades sociais e precisa ser pago por esse seu efeito. Evidente pois, do ponto de vista do trabalhador, estar mais tempo no trabalho acarreta dedicar menos tempo à família, ao amor, ao descanso. Além disso, uma hora dedicada ao trabalho não tem o mesmo significado, do ponto de vista da vivência, que uma hora com a família ou de descanso, por exemplo. Entretanto, com a implantação do banco de horas, uma hora trabalhada a mais passa a ter o mesmo valor "monetário" que uma hora trabalhada a menos, ou seja, uma hora extra equivale a uma hora de folga. Mas se, guardadas as particularidades de cada país ou de cada empresa, são os empresários que definem essa equação, esse fato reforça a não-equivalência dessas horas do ponto de vista dos trabalha- 
dores. Assim, vemos que a hora extra continua a ser um tempo de trabalho que invade o tempo de não trabalho. Com o banco de horas, além de o trabalhador continuar sem o controle ou previsibilidade sobre quando ou quanto deve trabalhar (a mais ou a menos), essas horas ganham um status de equivalência seja do ponto de vista da produção seja do ponto de vista das vivências dos trabalhadores.

Ao longo da tese pudemos observar ainda outras mudanças diretas no tempo de trabalho que implicaram na sua intensificação e que ocorreram paralelamente à conquista de reduções na jornada de trabalho, como a diminuição dos intervalos e a intensificação do ritmo de trabalho nas linhas. A primeira foi amplamente questionada pelos trabalhadores e representantes sindicais, gerando resistências declaradas ou não, mas não resultou em acordos coletivos. Houve mudanças no tempo de trabalho de maneira mais indireta e implícita, em decorrência de mudanças tecnológicas, organizacionais, gerenciais e de gestão das pessoas. Dentre elas, podemos destacar:

(i) as mudanças que estão na pauta de reivindicação da entidade sindical e que foram negociadas, tendo como foco a questão do tempo de trabalho. Tal foi o caso da exclusão da meta de absenteísmo da discussão sobre a participação nos lucros e nos resultados (PLR);

(ii) os temas demandados pelo Sindicato para negociação e que também resultaram em acordos, mas nos quais o foco da discussão não foi o tempo de trabalho; assim ocorreu quanto à multitarefa implementada com o novo Plano de Cargos e Salários (PCS) e também com as células de produção. Em ambos os casos observou-se uma intensificação do ritmo de trabalho.

No caso da multitarefa, esta foi amplamente criticada pelos trabalhadores que participaram da pesquisa, sendo diversos os motivos explicitados. Entre os mais citados está o fato de que o desconhecimento do novo trabalho dificulta a meta de adiantar o serviço e ganhar um tempo livre de descanso ou para ir ao banheiro. Outra reclamação é que esse rodízio de função significa trabalhar sempre no setor onde a demanda esteja mais forte, mantendo-se assim sempre o trabalho em ritmo acelerado. Como já salientado por Grossin (1991), o rodízio pode até romper a rotina de se trabalhar sempre no mesmo serviço, mas não significa uma melhora em relação aos tempos impostos se o trabalhador apenas muda de uma linha para outra, geralmente sob maior pressão da demanda. No limite, mesmo que num determinado momento ele possa se deslocar para fora de uma das linhas, outro trabalhador assumirá o seu lugar, não alterando, com isso, a condição do posto de trabalho em si. Apesar disso, esses pontos não foram objeto de negociação. 
Há, finalmente, aquelas mudanças que não são apresentadas pelo movimento sindical como pauta, que podem até ter sido discutidas no local de trabalho, mas que não se transformaram em reivindicação para negociação. Entre elas, destaca-se a maior dificuldade para o trabalhador criar um tempo de não-trabalho nas novas e modernas linhas de montagem final, como as do Pólo e do Fox. Nesses casos, vimos que a linha continua sendo um dos grandes definidores da organização do tempo e do trabalho na Volkswagen do ABC. Nessas linhas modernas, as inovações tecnológicas implementadas pela Empresa resultam, se é que não tinham isso como objetivo, numa maior dificuldade para o trabalhador adiantar o seu trabalho e assim conquistar um pequeno tempo, libertando-se do tempo imposto da linha. Entretanto, essa reclamação que ouvi dos trabalhadores não se configurou em objeto de reivindicação coletiva; uma vez que o foco, naquele momento, tanto por parte dos trabalhadores como dos dirigentes sindicais era justamente modernizar a fábrica para garantir sua permanência no Brasil e a almejada ampliação da produção. Sem isso não havia horizonte para a manutenção dos seus empregos.

Um tema quase ausente da pauta sindical, mas muito citado nos discursos dos trabalhadores que não estão na linhas - ferramenteiros, trabalhadores da qualidade, do setor administrativo -, diz respeito à dimimuição dos prazos para execução das tarefas, aumentando o risco de gerar produtos com menor qualidade, num contexto em que há forte pressão da Empresa pela qualidade. A falta de tempo para realizar o trabalho, traduzida na pressão para que ele seja feito num espaço de tempo cada vez menor, ou então para que sejam feitos vários trabalhos ao mesmo tempo, é cada vez mais presente nas relações que se estabelecem na Volkswagem. Isso alimenta uma forte insatisfação tanto em relação ao processo como em relação ao resultado do trabalho. Entretanto, e novamente, tal insatisfação também não se traduziu em reivindicações ou em ações coletivas visando alterar essa realidade.

Assim, entre as mudanças introduzidas pela Volkswagen nos cotidianos de trabalho, aquelas que têm alterado mais profundamente o tempo de trabalho resultam da combinação entre duas formas de flexibilização: o banco de horas e o rodízio de função (a multitarefa). Essa combinação possibilita que os trabalhadores fiquem expostos a um tempo de trabalho intenso, a todo momento e em todos os espaços. Assim, quando a demanda por produção mostra-se alta, o trabalhador é chamado a trabalhar, quando não, ele é convidado a ficar em casa -para folgar as horas positivas do banco de horas, do banco de dias, da "semana Volks", das férias individuais e coletivas. Uma vez chamado a trabalhar, ele é alocado naquela função ou setor onde há maior demanda de trabalho, o que foi possibilitado pela multifunção. Tal combinação de flexibilização 
do tempo e da atividade de trabalho tem como conseqüência a extrema intensificação do tempo de trabalho, que ainda é somada às iniciativas da empresa para a redução das pausas coletivas e individuais. Já para a Empresa, essa extrema flexibilidade permite remunerar apenas os tempos efetivamente trabalhados por um ser que se torna cada vez mais (e por mais tempo) disponível (Durand, 2004).

Nessas condições, como relatado pelos trabalhadores pesquisados, o tempo de trabalho irá extrapolar o espaço da fábrica, tanto do ponto de vista qualitativo como quantitativo, alterando completamente o tempo fora do local de trabalho. Dizendo-o de modo ainda mais claro: estabelece-se uma outra forma de relação entre os tempos dentro e fora da fábrica pela qual o tempo fora do local de trabalho, isto é, aquele liberado da jornada de trabalho, já não pode mais ser tomado como sinônimo de tempo de não-trabalho. Do ponto de vista qualitativo, o tempo de não-trabalho é invadido pelo cansaço, pela sensação de que o tempo de trabalho ocupa o dia todo e, conseqüentemente, de que o tempo de não-trabalho é curto e insuficiente, o que faz a vida tornar-se "corrida". Do ponto de vista quantitativo, alguns autores (Grossin, 1991; Mercure, 1995; Sue, 1994) frisam que, nas sociedades contemporâneas, uma vez existindo um tempo liberado da jornada de trabalho, as pessoas buscam nele incluir um número cada vez maior de atividades, dentre elas algumas ainda relacionadas ao tempo de trabalho. O que provoca a necessidade de equações temporais cotidianas que buscam, sem sucesso, harmonizar a multiplicidade cada vez maior de tempos sociais. Essa situação gera uma sensação de extremo mal-estar, num contexto temporal que tem como características principais a urgência, a intensidade, a flexibilidade e a aceleração.

Esse tempo fora da jornada de trabalho, que é igualmente tomado pelo tempo de trabalho, também expressa um processo, antes frisado por Zarifian (1996), de aproximação entre os tempos e espaços de trabalho e de não-trabalho, de modo que as fronteiras entre um e outro tornam-se crescentemente fluidas. Vimos, então, que, ao longo da história de luta entre capital e trabalho, o primeiro impôs uma separação cada vez maior entre tempo e espaço de trabalho, transformando ainda o tempo de trabalho em algo inexoravelmente regular e contínuo e, por isso mesmo, independente da vontade ou das necessidades dos próprios trabalhadores (Thompson, 1967). Mas hoje, ao mesmo tempo em que os trabalhadores conquistam uma liberação do tempo contido na jornada de trabalho, o capital continua a intensificar este tempo contratado e remunerado, ao mesmo tempo em que busca eliminar a separação entre tempo de trabalho e de não-trabalho, que ele mesmo impôs, e pretende ampliar o controle tanto sobre um como sobre o outro. 
As narrativas dos trabalhadores da Volkswagen mostram que o tempo liberado da jornada de trabalho tem sido tomado, primeiramente, pelo cansaço resultante da intensificação e da pressão do tempo de trabalho dentro da fábrica. Em seguida, pelas novas temporalidades sociais que vão sendo construídas, relacionadas ou não ao trabalho - por exemplo, os jovens têm uma jornada de trabalho menor do que seus pais, mas ocupam esse tempo liberado com o estudo. Há ainda um tempo grande dentro da fábrica ou do transporte que, apesar de não ser social e institucionalmente considerado como tempo de trabalho, do ponto de vista da vivência dos trabalhadores tampouco pode ser denominado tempo livre, já que é um tempo imposto, determinado, que flui em espaços estabelecidos e com atividades igualmente estipuladas. $\mathrm{O}$ tempo fora da fábrica é invadido ainda pela crescente flexibilização do tempo de trabalho e, com isso, os trabalhadores perdem cada vez mais o controle e a previsibilidade de quando irão (ou não) trabalhar, o que lhes desorganiza o tempo fora do local de trabalho. Ademais, há que se lidar com a preocupação em relação ao emprego que persegue os trabalhadores mesmo quando estão fora do local de trabalho, em seus intentos de imaginar formas para resolver os problemas do trabalho, em sua urgência por sugestões para se destacar e manter-se no posto ou mover-se na carreira. Todas essas preocupações ocupam seu corpo e sua mente no pouco tempo livre restante.

Essa dinâmica social nutre-se dos conflitos mais amplos entre os tempos sociais diversos e plurais; nutre-se, da mesma forma, dos conflitos que se dão individualmente ou entre diferentes grupos. Dela resulta uma nova temporalidade social, marcada pela urgência, pelo imediato, pela tensão, intensidade e flexibilidade. Tempos de trabalho cada vez mais imprevisíveis e flexíveis, que têm como conseqüência tempos de não-trabalho também imprevisíveis e flexíveis, tanto no tempo presente como no tempo futuro. 
BIBLIOGRAFIA 
ABRAMO, L. Greve metalúrgica em São Bernardo: sobre dignidade e trabalho. In: KOVARICK, L. (Org). As lutas sociais e a cidade: São Paulo, passado e presente. Rio de Janeiro: Paz e Terra, 1993. p. 181-216.

AFSA, C.; BISCOURP, P. L'évolution des rythmes de travail entre 1995 et 2001: quel impact des 35 heures?, 2004. p. 173-198. (Économie et Statistique, n. 376 / 377).

AGUIAR, N. Múltiplas temporalidades de referência: trabalho doméstico e trabalho remunerado: análise dos usos do tempo em Belo Horizonte, Minas Gerais: um projeto piloto para zonas metropolitanas brasileira. Belo Horizonte: FAFICH/UFMG, 2000.

ANTUNES, R.. A rebeldia do trabalho: o confronto operário no ABC paulista: as greves de 1978/80. Campinas: UNICAMP, 1988.

Adeus ao trabalho?: ensaios sobre as metamorfoses e a centralidade do mundo do trabalho. São Paulo: Cortez; Editora da UNICAMP, 1995.

ARBIX, G. A. T. Trabalho: dois modelos de flexibilização. Lua Nova, CEDEC, São Paulo, n. 37, p. 171190, 1996.

Uma aposta no futuro: os três primeiros anos da Câmara Setorial da indústria automobilística e a emergência do meso-corporativismo no Brasil. 1995. Tese (Doutorado em Sociologia) - Faculdades de Filosofia, Letras e Ciências Humanas, Universidade de São Paulo, São Paulo, 1995.

.; ZILBOVICIUS, M. O consórcio modular da VW: um novo modelo de produção? In: ARBIX, G.; ZILBOVICIUS, M. De JK a FHC: a reinvenção dos carros. São Paulo: Scritta, 1997.

ARENDT, H. A condição Humana. Rio de Janeiro: Forense Universitária, 1991.

ASKENAZY. P.; BLOCH-LONDON C.; ROGER M. La réduction du temps de travail 1997- 2003: dynamique de construction de lois Aubry et premières évaluations. Paris: [s.n.], 2004, p.153-203. (Économie et Statistique, 376 / 377).

AZNAR, G. Trabalhar menos para trabalharem todos. São Paulo: Scritta, 1995.

BACAL, S. Lazer: teoria e pesquisa. São Paulo: Loyola, 1988.

BALTAR, P. Estrutura econômica e emprego urbano na década de 1990. In: PRONI, M.; HENRIQUE, W. Trabalho, mercado e sociedade. Campinas: UNESP: Instituto de Economia, Universidade Estadual de Campinas, Campinas, cap. 3, p. 107-152, 2003.

BARBOSA, M. S. Globalização e ação sindical: a experiência na Volkswagen. São Paulo, 2002. Mimeo. Sindicalismo em tempos de crise: a experiência na Volkswagen do Brasil. 2002. Dissertação (Mestrado em Economia) - Instituto de Economia, Universidade Estadual de Campinas, Campinas, 2002.

BARGAS, O. M. Novas estratégias do capitalismo e do movimento sindical. In: MARTINS, H. S.; RAMALHO, J. R. Terceirização: diversidade e negociação no mundo do trabalho. São Paulo: Hucitec; CEDI/NETS, 1994. 
BASSANINI, G. II tempo ritrovato: politiche dei tempi e rigenerazione urbana nel Nord Milano. Milano: Agenzia Sviluppo Nordmilano, n. 4, 2001. (Quaderno, 4).

BELLIVIER, M.. La réducion du temps de travail en Europe: positions syndicales. Paris: [s.n.], juin , 1996. (La Note de L'ISERES, 17).

BESSIN, M. Le Kairos dans l'analyse temporalle. Paris: [s.n.], 1998, p. 55-71. (Temps et Contretemps: approches sociologiques, 32).

. Le temps, une question de pouvoir. Paris: Mouvements, ed. n. 2, janv.-févr.. 1999. p. 47-48.

. Parcours de vie et temporalité. In: SEMINAIRE INTERDISCIPLINAIRE SUR L'URGENCE, 2000. Friboug. Texte. Fribourg: Université de Fribourg, 31 mars et 1. avril 2000.

BEZERRA, F. R. As empresas automobilísticas e suas estratégias de formação de recursos humanos: a referência da Volkswagen e da Mercedes-Benz do Brasil. Texto apresentado na 22a . Reunião Anual da ANPED, 1998.

BICUDO, M.A.V. Tempo, tempo vivido e história. Bauru: EDUSC, 2003.

BLASS, L. M. S. Jornada de trabalho: uma regulamentação de múltipla escolha. Revista Brasileira de Ciências Sociais, v. 13, n. 36, fev. 1998. p. 67-78.

BLOCH-LONDON, C.; PELISSE, J. Problèmes: la réduction du temps de travail: des politiques aux pratiques. Revue problèmes politiques et socieaux, Paris, n. 889, juin. 2003.

BORGES, C. O processo de mudança na jornada de trabalho e o setor terciário em países desenvolvidos: da década de 90 até nossos dias. In: DIEESE (Org.). Mercado de trabalho e modernização do setor terciário brasileiro: estudos DIEESE/CESIT. São Paulo: DIEESE; Campinas: CESIT/UNICAMP, 2005. CD-rom.

BOSI, E. O tempo vivo da memória: ensaios de psicologia social. São Paulo: Ateliê Editorial, 2003.

BOULIN, J. Y. Réduction du temps de travail: usage du temps et temps de la ville. In: TERSSAC, G.; TREMBLAY, D. G. Où va le temps de travail?, Paris: Octarès, 2000.

BOURDIEU, P. Algérie 60: Structures économiques et structures temporelles. Paris: Les Éditions de Minut, 1977.

BRANDÃO, C. Pesquisa participante. São Paulo: Brasiliense, 1999.

BRAVERMAN, H. Trabalho e capital monopolista: a degradação do trabalho no século XX. Rio de Janeiro: Zahar, 1977.

BRESCIANI, L. P. Da resistência à contratação: tecnologia, trabalho e ação sindical. Brasília: CNI; SESI/DN, 1994. (Série Indústria e Trabalho).

. Na zona do agrião: comissões de fábrica, trabalho e negociação coletiva na indústria automobilística brasileira. In: ARBIX, G.; ZILBOVICIUS, M. (Orgs.). De JK a FHC: a reinvenção dos carros. São Paulo: Scritta, 1997. 
. Os desejos e o limite: reestruturação industrial e a ação sindical no complexo automotivo brasileiro. In: LEITE, M. P. (Org.). O trabalho em movimento: reestruturação produtiva e sindicatos no Brasil. Campinas: Papirus, 1997.

; BENITES FILHO, F.A. Negociações Tripartites na Itália e no Brasil. São Paulo: LTr, 1995.

; BRATHWAITE, A. Os metalúrgicos de São Bernardo e Diadema: a contratação coletiva das inovações tecnológicas e organizacionais. São Paulo: CUT, jan. jun. 1992. p. 43-48. (Cadernos da CUT - Jurídico e Relações Sindicais, 7).

; CARDOSO, A. C. M. Entre o Fusca e o Mercosul: trabalho e relações industriais na Volkswagen do Brasil. [S.1.: s.n.], 1999. Estudo elaborado para o "Project on Transnational LabourManagement Dialogue and Labour Law and Labour Relations Branch". Mimeo.

; ODA, N. T. O ABC da nova indústria automotiva. São Bernardo: [s.n.], nov. 1997.

BRUNI, J. C. Tempo e trabalho intelectual. São Paulo: Tempo Social, USP, São Paulo, v. 3, n. 1-2, 1991.

CALVETE, C. S. Redução da jornada de trabalho: uma análise econômica para o Brasil. 2006. Tese (Doutorado em Economia) - Instituto de Economia, Universidade Estadual de Campinas, 2006.

CANETTI, E. Massa e poder. São Paulo: Schwarcz, 1995.

CARDOSO, A. C. M. Evolução das pautas e acordos dos metalúrgicos de São Paulo, Osasco e Guarulhos, e São Bernardo do Campo e Diadema 1978 - 1990. São Paulo, 1993. Mimeo. Relatório de Pesquisa de Iniciação Científica para a FAPESP.

. Emprego: estratégias e ação sindical nos anos 90: o caso dos metalúrgicos do Estado de São Paulo. Dissertação (Mestrado em Sociologia) - Faculdade de Filosofia, Letras e Ciências Humanas, Universidade de São Paulo, São Paulo, 1998a.

A difícil negociação do emprego em diversos espaços de ação sindical. In: CARVALHO NETO, A M.; Carvalho R. A. (Orgs.). Sindicalismo e negociação coletiva nos anos 90. Belo Horizonte: IRT / PUCMG, 1998b.

; JAGER, P.; CAMARGOS, R. A negociação da jornada de trabalho por meio do banco de horas. São Paulo: DIEESE. 2002. (Kit para Seminário).

Seminário).

; MELO, F. (Des)emprego: desafios à ação sindical. São Paulo: DIEESE, 2003. (Kit para

; et alii, Reduzir a Jornada é gerar empregos. Campanha pela Redução da jornada de trabalho sem redução de salários. São Paulo: DIEESE, 2004.

CARLEIAL, L.M.F. Firmas, flexibilidades e direitos no Brasil: para onde vamos? São Paulo em Perspectiva: revista da Fundação SEADE, São Paulo, v. 11, n. 1, 1997.

CARMO, P.S. História e ética do trabalho no Brasil. São Paulo: Moderna, 1998. 
CASTEL, R. Les metamorphoses de la question sociale. Paris: Fayard, 1995.

CASTRO, N.A. Modernização e trabalho no complexo automotivo brasileiro. In: CASTRO, N. A. (Org.). A máquina e o equilibrista: inovações na indústria automobilística brasileira, Rio de Janeiro: Paz e Terra, 1995.

Reestruturação produtiva, novas institucionalidades e negociação da flexibilidade. São Paulo em Perspectiva: revista da Fundação SEADE, São Paulo, v. 11, n. 1, 1997.

CHARPENTIER, P. et al. RTT et organisations du travail: 1'incidence des lois Aubry II. Paris: Dares Direction de l'animation de la recherche, des étides e de statistique. Ministère de L'Emploi et de la Solidarité, 2005. (Document d'etudes, 100).

CHABAUD, D.; FOUGEYROLLAS-SCHWEBEL, D. Sobre a autonomia relativa da produção e reprodução. In: KARTCHEVSKY-BULPORT. A. et al. O sexo do trabalho. Rio de Janeiro: Paz e Terra, 1986. p. 79-93.

CENTRAL ÚNICA DOS TRABALHADORES. A estratégia da CUT em relação ao Banco de Horas. São Paulo: Secretaria de Política Sindical da CUT, 1999. Conclusões e documentos do Seminário Nacional ocorrido nos dias 10 e 11 de outubro de 1998.

A redução da jornada de trabalho: França, Alemanha, EUA, Japão e Suécia. São Paulo: CUT, mar. 1996. (Textos para Debate: Internacional, 6).

1998. Mimeo.

Dossiê: banco de horas. São Paulo: Secretaria de Política Sindical da CUT Nacional, out.

CETTE, G.; DROMEL, N.; MEDA, D. Les déterminants du jugement des salariés sur la RTT. Économie et Statistique, [Paris], n. 376 / 377, 2004, p. 117-151.

CETTE, G.; TADDEI, D. Réduire le temps de travail: de la théorie à la pratique. Paris: Le Livre Poche. 1997.

CHESNEAUX, J. Habiter lê temps: présent, passe, futur: esquisse d'um dialogue politique. Paris: Bayard, 1996.

CLEMENT, C. Vers une désocialisation des contraintes temporelles du travail : le cas de OAO roulements à billes moscovite. In: LINHART, D.; MOUET, A. Le travail nous est compté: la construction des normes temporelles du travail. Paris: La Découverte, 2005. p. 74-113.

CONFEDERAÇÃO NACIONAL DOS METALÚRGICOS; CENTRAL ÚNICA DOS TRABALHADOR; DIEESE. Indústria automobilística e trabalho. São Paulo, 2001. Mimeo.

CORBIN, A. L'avènement des loisirs: 1850-1960. Paris: Flammarion, 1995.

COUTROT, T. Synthèse: Les conditions de travail des salariés après la réduction de leur temps de travail. Paris: Dares - Ministère de l'emploi, de la cohésion sociale et du logement, 2006. (Première Informations, 063).

DAL ROSSO, S. A jornada de trabalho na sociedade: o castigo de prometeu. São Paulo: LTr, 1996. 
DEDECCA, C. Anos 90: a estabilidade com desigualdade. In: PRONI, M.; HENRIQUE, W. Trabalho, mercado e sociedade. São Paulo: UNESP; Campinas: Instituto de Economia, Universidade Estadual de Campinas, Campinas, cap. 2, p. 71-106, 2003.

DELEGAÇÃO BRASILEIRA DE TRABALHADORES DA VW BRASIL; SUBSEÇÃO DIEESE / SINDICATO DOS METALÚRGICOS DO ABC. VW Brasil. São Paulo, 1996. Documento elaborado para a Conferência dos Trabalhadores da VW, em Wolfsburgo, Alemanha de 28/05/96 a 03/06/96.

DEMAZIÈRE, D. Le chômage de longue durée. Paris: PUF, 1995.

DEMAZIÈRE, D. La sociologie du chômage. Paris: La Decouverte, 1995.

DEMAZIÈRE, D. \& DUBAR, C. Trajetórias profissionais e formas identitárias: uma teorização. Contemporaneidade e Educação, São Paulo, ano 5, n. 8, 2000.

DEPARTAMENTO INTERSINDICAL DE ESTATÍSTICA E ESTUDOS SÓCIO ECONÔMICOS. $A$ crise cíclica da Volkswagen. Santo André: DIEESE, 2006. No prelo.

(Pesquisa DIEESE, 9).

Acordos e convenções coletivas: cláusulas selecionadas. São Paulo: DIEESE, 1993. . A situação do trabalho no Brasil. São Paulo. São Paulo: DIEESE, 2001.

n. 210, nov. / dez. 1998 .

Contrapartidas nos acordos de flexibilização de jornada. Boletim DIEESE, São Paulo,

Flexibilização da produção e das relações de trabalho no setor automotivo brasileiro.

São Paulo: DIEESE, 1999.

Indicadores da indústria automobilística brasileira. São Paulo, DIEESE, 2000.

Jornada de trabalho: lutas e história. Boletim DIEESE, São Paulo, n. 197, ago. 1997a.

34 p. Relatório técnico.

Jornada de trabalho: negociações coletivas 1996-2003. São Paulo: DIEESE, 2005.

Levantamento sobre a negociação de jornada de trabalho. São Paulo: DIEESE, 1999. Sistema de Acompanhamento de Contratações Coletivas - SACC/DIEESE.

O comportamento das negociações coletivas de trabalho nos anos 90: 1993-1996. São Paulo: DIEESE, 1999. (Pesquisa DIEESE n 15).

São Paulo, n. 197, ago. 1997 b.

. O movimento sindical luta pela redução da jornada de trabalho. Boletim DIEESE,

. Trabalho e reestruturação produtiva: 10 anos de linha de produção. São Paulo: DIEESE, 1994.

; SUBSEÇÃO METALÚRGICOS DO ABC. Autolatina: união contra quem? Trocando em Miúdos, São Paulo, n. 3, 1987. 
do ABC, 1993.

Autolatina Divisão Volkswagen. São Bernardo do Campo: Sindicato dos Metalúrgicos Brazilian automotive industry main information. São Bernardo, out. 1997. Mimeo. Globalização e setor automotivo. São Bernardo: Sindicato dos Metalúrgicos do ABC,

1996. .Pesquisa voluntariado Volkswagen: perfil. São Bernardo: Sindicato dos Metalúrgicos do ABC, 1998.

SUBSEÇÃO CONFEDERAÇÃO NACIONAL DOS METALÚRGICOS. Perfil das plantas automobilísticas: trajetórias de 1995 a 2000. São Paulo, 2000. Relatório de Pesquisa. Mimeo. . Indústria automobilística: velhos e novos desafios. São Paulo, 2002. Mimeo.

DE TERSSAC G.; THOEMMES, J.; FLAUTRE A. Régulation politique et régulation d'usage dans le temps de travail. [Paris]: PUF, 2004. p. 135-154. (Travail Humain, 2, tome 67).

DIÁRIO DO GRANDE ABC. Suplemento especial, Santo André, 2 de set. 1997. Suplemento especial, Santo André, 23 de mar. 2003.

DIAS, A. Redução do tempo de trabalho, adaptabilidade do horário e polivalência funcional. Coimbra: Coimbra Editora, 1997.

DOCTORS, M. (Org.). Tempo dos tempos. Rio de Janeiro: Jorge Zahar, 2003.

DUBAR, C. La socialisation: construction des identités sociales et professionnelles. [Paris]: Armand Colin, 2000.

DUBAR, C. El trabajo y las identidades profesionales y personales: trayectorias ocupacionales y mercado de trabajo. Revista Latinoamericana de Estudios del Trabajo. Santiago, año 7, n. 13. 2001.

DUBET, F. Sociologie de l'expérience. Paris, Éditions du Seuil, 1994.

L'experience sociale et lês conditions d'une sociologie clinique. Paris: Université Paris, 1998, p. 9-16. (Laboratoire de Changement Social, 7).

DUMAZEDIER, J. Sociologia empírica do lazer. São Paulo: Perspectiva; SESC, 1999.

DURAND, J. P. La chaîne invisible: travailler aujourd'hui: flux tendu et servitude volontaire. [Paris]: Seuil, 2004.

DURKHEIM, E. Da divisão do trabalho social. São Paulo: Abril Cultural, 1978. (Os Pensadores). Les formes élémentaires de la vie religieuse. Paris: Presses Universitaires de France, 1968.

DUSSUET, A. Genre et mobilisation de la subjectivité dans le travail: l'exemple des services à domicile aux personnes âgées. [S.1.: s.n.], 2006. Mimeo. 
ELIAS, N. Sobre o tempo. Rio de Janeiro: Jorge Zahar, 1998.

ENDE, M. Momo e o senhor do tempo, ou, a extraordinária história dos ladrões de tempo e da criança que trouxe de volta às pessoas o tempo roubado. São Paulo: Martins Fontes, 1995.

FAUSTO, B. Trabalho urbano e conflito social. Rio de Janeiro: Difel, 1976.

FAVENNEC-HÉRY, F. Le temps vraiment choisi. Droit Social, Paris, n. 3, 2000.

FISCHER, F. M. Fatores individuais e condiçöes de trabalho e de vida na tolerância ao trabalho em turnos. In: FISCHER, F. M.; MORENO, C. R. C.; ROTENBERG, L. Trabalho em turnos e noturno na sociedade 24 horas. Säo Paulo: Atheneu, 2003. p.65-76.

FORJAZ, M. C. Lazer e consumo cultural das elites. Revista Brasileira de Ciências Sociais. São Paulo, v. 3 , n. 6 , fev. 1988 .

FÓRUM NACIONAL SOBRE CONTRATO COLETIVO E RELAÇÕES DE TRABALHO NO BRASIL. Brasília: Ministério do Trabalho e Emprego, 1994.

FOUCAULT, M. Microfisica do poder. Rio de Janeiro: Graal, 1979.

Vigiar e punir. Petrópolis: Vozes, 1987.

FRACALANZA, P. S. Redução do tempo de trabalho: uma solução para o problema do desemprego? Tese (Doutorado em Sociologia) - Faculdade de Filosofia, Letras e Ciências Humanas, Universidade de São Paulo, 2001.

FREYSSENET, M. Quelques pistes nouvelles de conceptualisation du travail. Sociologie du Travail, [Paris], p. 105-122, 1994.

FRIDENSON, P. Le temps de travail, enjeu de luttes sociales. Futuribles, [Paris], n. 165-166, p. 19-28, mai-jun, 1992.

FUNDAÇÃO SISTEMA ESTADUAL DE ANÁLISE DE DADOS - SEADE. Produtividade e ajuste na indústria paulista. São Paulo, 1995 (Análises Ensaios).

. Movimento operário e sindical. São Paulo em Perspectiva: revista da Fundação Seade, São Paulo, v. 12, n. 1, 1998.

GADÉA, C., LALLEMENT, M. Les rationalisations du temps. In: TERSSAC G.; TREMBLAY, D.G. Où va le temps de travail? France, Octarès, 2000.

GERSHUNY, J. La répartition du temps dans les sociétés post-industrielles. Futuribles, [Paris], n. 165166, p. 215-226, mai. / jun. 1992.

GIDDENS, A. Política, sociologia e teoria social. São Paulo: Fundação Editora da UNESP, 1995. A constituição da sociedade. São Paulo: Martins Fontes, 2003.

GIRIBONE, J-L.; DUPUY, J-P.; MONGIN, O. Sociologie de l'expérience. Ëditions du Seuil, 1994. (La Coleur des Idées). 
A constituição da sociedade. São Paulo: Martins Fontes, 2003

GITAHY, L.; BRESCIANI, L. P. Reestruturação produtiva e trabalho na indústria automobilística brasileira. Campinas: IG; DPCT, 1998.

GORGEU, A. E MATHIEU, R. L'obsession du flux tendu: les usines d'équipement automobile des parcs industriels fournisseurs. In: LINHART, D.; MOUET, A. Le travail nous est compté: la construction des normes temporelles du travail. Paris: La Découverte, 2005. p. 23-62.

GORZ, A. Metamorfosis del trabajo: busqueda del sentido: crítica de la razón económica. Madrid: Editorial Sistema, 1995.

GROSSIN, W. Pour une science des temps: introduction à l'écologie temporelle. Nancy: Octares, 1991. Les temps de la vie quotidienne. Paris: Mouton \& Co, 1974.

GUARESCHI, P.; JOVCHELOVITCH, S. (Orgs.). Texto em representações sociais. Petrópolis: Vozes, 2003.

GUEDJ, F.; VINDT, G. Le temps de travail, une histoire conflictuelle. Paris: Éditions la Découverte et Syros, 1997.

GUELITA, R. Volks Anchieta abriga centro de decisões. Diário do Grande ABC, Caderno Economia, 31 ago. 1997. ago. 1997.

Volks quarentona persegue o seu futuro. Diário do Grande $A B C$, Caderno Economia, 31

GUIMARÃES, A. S.; AGIER, M. Identidades em conflito: técnicos e peões na petroquímica da Bahia. Revista Brasileira de Ciências Sociais, n. 13, p. 51-68, jun. 1990.

GUIMARÃES, A. S. A.; CASTRO, N. A. Trabalho, sindicalismo e reconversão industrial no Brasil dos anos 90. São Paulo em Perspectiva, revista da Fundação SEADE, São Paulo, v. 4, n. 2 p. 207-228, abr. / jun. 1990.

GUIMARÃES. N. A. Por uma sociologia do desemprego: contextos societais, construções normativas e experiências subjetivas. Revista Brasileira de Ciências Sociais. São Paulo: ANPOCS, v. 17, n. 50, out. 2002.

. Trajetórias inseguras, autonomização incerta: os jovens e o trabalho em mercados sob intensas transições ocupacionais. In: CAMARANO A. A. (Org.). Transição para a vida adulta ou vida adulta em transição? Rio de Janeiro: IPEA, 2006. p. 171-197.

GURVITCH, G. A multiplicidade des temps sociaux, In: La vocation actuelle de la sociologie, Paris: P.U.F., 1963, tomo II, p. 325-340.

KOVARICK, L. (Org). As lutas sociais e a cidade: São Paulo, passado e presente. Rio de Janeiro: Paz e Terra, 1993.

HARDMAN, F.; LEONARDI, V. História da indústria e do trabalho no Brasil: das origens aos anos 20. São Paulo: Ática, 1991. 
HARVEY, D. Condição Pós-Moderna. São Paulo: Loyola, 2003.

HASSARD, J. O indivíduo na organização - tempo de trabalho: outra dimensão esquecida nas organizações. Revue Internationale des Sciences Sociales - Unesco, v. 119, p. 97-100, 1989.

HATZFELD, N. Du regime du chronomètre au sacre du temps virtuel: une histoire de succession aux usines Peugeot (1946-1996). In: LINHART, D.; MOUET, A. Le travail nous est compté: la construction des normes temporelles du travail. Paris: La Découverte, 2005. p. 63-73.

HIRATA, H. Subjectivité et travail: les apports d'une perspective comparative internationale. [Paris], 2006. Mimeo.

HIRATA, H.; KERGOAT, D. A divisão sexual do trabalho revisitada. In: MARUANI, M.; HIRATA, H. As novas fronteiras da desigualdade: homens e mulheres no mercado de trabalho. São Paulo: SENAC, 2003. P. 111-123.

HIRATA, H. Introduction: lê travail dês femmes: nouveaux partages, nouvelles divisions. In: HIRATA, H.; SENOTIER D. Femmes et partage du travail. Paris: Syros, 1996. p. 7-20.

. Nova divisão sexual do trabalho?. São Paulo: Boitempo, 2002.

. Vida reprodutiva e produção: família e empresa no Japão In: KARTCHEVSKY, A. et al. $O$ sexo do trabalho. Rio de Janeiro: Paz e Terra, 1986.

HOBSBAWM, E. J. Da Revolução Industrial inglesa ao imperialismo. Rio de Janeiro: Forense Universitária, 2000a.

. Os trabalhadores: estudos sobre a história do operariado. São Paulo: Paz e Terra, 2000b.

1995.

. Era dos extremos: o breve século XX: 1914-1991. São Paulo: Companhia das Letras,

HORAS extras: o deslocamento de trabalhadores em empresas gigantes. Revista Consultor Juridico, 19 out. 2003. Disponível em: www.conjur.com.br/conjur.estadao.com.br/estatic/ext/10236,1>

HORTA, C. A. O braço direito do Grande $A B C$ : um estudo de caso do Diário do Grande ABC e sua inserção na regionalidade e nos conflitos das relações de trabalho. 2003. Dissertação (Mestrado em Administração) - Centro Universitário Municipal de São Caetano, São Caetano, 2003.

HUMPHREY, J. Os impactos das técnicas 'japonesas' de administração sobre o trabalho industrial no Brasil. In: CASTRO, A. N. (Org.). A máquina e o equilibrista: inovações na indústria automobilística brasileira. São Paulo: Paz e Terra, 1996.

HUSSON, M. Fim do trabalho ou redução de sua duração? Revista da Sociedade Brasileira de Economia Política, Rio de Janeiro, p. 5-23, 1999.

JORAND. Y. et al. Les réticences à entrer dans le cadre légal des 35 heures. Paris: Dares - Direction de l'animation de la recherche, des étides e des statistique. Ministère de l'emploi et de la solidarité, 2005. (Document d'études, 103). 
KERGOAT. D. Em defesa de uma sociologia das relações sociais: da análise crítica das categorias dominantes à elaboração de uma nova conceituação. In: KARTCHEVSKY-BULPORT. A. et al. O sexo do trabalho. Rio de Janeiro: Paz e Terra, 1986. p. 79-93.

KOWARICK, L. Trabalho e vadiagem: a origem do trabalho livre no Brasil. São Paulo: Brasiliense, 1987.

KREIN, J. D. Reforma no sistema de relações de trabalho no Brasil. In: DIEESE (Org.) Emprego e desenvolvimento tecnológico: artigos dos pesquisadores. São Paulo: DIEESE; Campinas: CESIT, 1999. (Seminários Internacional e Regionais "Emprego e Desenvolvimento Tecnológico, 2).

. Balanço da reforma trabalhista do governo FHC. In: PRONI, M.; HENRIQUE, W. Trabalho, mercado e sociedade: o Brasil nos anos 90. São Paulo: UNESP; Campinas: Instituto de Economia, Universidade Estadual de Campinas, Campinas, cap. 7, p. 279-322, 2003.

LABARI, I. Les dimensions symbolique et langagière des subjectivités au travail: Le cas des ouvrières marocaines dans les entreprises françaises délocalisées au Maroc. [Paris], 2006. Mimeo.

LABIT, A.; THOEMMES J. 20 ans de comparaison France-Allemagne: de l'effet sociétal à l'analyse de l'articulation des régulations globales et locales In: LALLEMENT, M.; SPURK, J. (Dir.). Stratégies de la comparaison internationale. Paris: Editions du CNRS, 2003. p. 23-38.

Le travail en groupe chez Volkswagen, enjeu de négociations entre syndicat et direction. In: L'AVEIR du travail à la chaîne: une comparaison internationale dans l'industrie automobile. Paris: La Découverte, 1998. p. 353-365.

LAFARGUE, P. O direito à preguiça. São Paulo: Hucitec; UNESP, 1999.

LALLEMENT, M. Temps, travail e modes de vie. Paris: Presses Universitaires de France, 2003. L'Harmattan, 2003.

(Org.). Figures du temps: les nouvelles temporalités du travail et la formation. Paris:

LECCARDI, C. Por um novo significado do futuro: mudança social, jovens e tempo. Tempo Social: revista de sociologia da USP, São Paulo, v. 17, n. 2. p. 35-57, 2005.

LEGRAND, M.; RIGAUX, N. La subjectivité dans la sociologie de l'experience de François Dubet. Paris: Université Paris, 1998. p. 57-68. (Laboratoire de Changement Social, 7).

LEITE, M. P. Reestruturação produtiva e sindicatos: o paradoxo da modernidade. In: LEITE, M. P. (Org.). O trabalho em movimento. São Paulo: Papiros, 1997.

Trabalho e sociedade em transformação: mudanças produtivas e atores sociais. São Paulo: Fundação Perseu Abramo, 2003.

LEITE LOPES, J. S. A tecelagem dos conflitos de classe na cidade das chaminés. São Paulo: Marco Zero, 1988.

LINHART, D. Trabalho: derrota, eles dizem. Revista Sociologia do Trabalho, Rio de Janeiro, n. 02, 1997. 
La modenisation des entreprises. Paris: La Découverte, [199-]

; MOUTET A. Le travail nous est compté: la construction des norms temporelles du travail.

Paris: La Découverte, 2005.

LIPIETZ, A. Genres, classes et partage du travail. In: HIRATA, H.; SENOTIER, D. Femmes et partage du travail. Paris: Syros, 1996, p. 57-72.

LONDON, C. B.; COUTROT, T. La réduction du temps de travail a-t-elle encore um avenir?. [S.1.: s.n.], 2001. Mimeo.

LOPES, J. C. C. A voz do dono e dono da voz: trabalho, saúde e cidadania no cotidiano fabril. São Paulo: Hucitec, 2000.

MAILARD, A. Travail et temps sociaux en éclats: introduction. Paris: [s.n.], 2006 (Les Mondes du Travail, 2).

MARESCA, B. Occupation du temps libre : une norme de consommation inégalement partagée. Paris: CRÉDOC - Centre de Recherche pour l'étude et l'Observation des Conditions de Vie. Paris, 2004. (Cahier de Recherche, 210).

MARUANI, M.; REYNAUD, E. Sociologie de l'emploi. Paris: La Decouverte, 1993.

Travail et emploi des femmes. Paris: La Decouverte, 2000.

MARTINS, G. J. F. Experiências dos trabalhadores nos processos participativos: (re)significação da subjetividade e do trabalho. 2001. Dissertação (Mestrado em Sociologia) - Faculdade de Filosofia, Letras e Ciências Humanas, Universidade de São Paulo, São Paulo, 2001.

MARTINS, H. S. Os dilemas do movimento sindical em face da terceirização. In: MARTINS, H. S.; RAMALHO, J.R. Terceirização: diversidade e negociação no mundo do trabalho. São Paulo: Hucitec; CEDI/NETS, 1994.

MARX, K. O capital. 12. ed. São Paulo: Bertand Brasil, 1985. v. 1.

MARX, R.; ZILBOVICIUS, M.; SALERNO, M. S. The modular consortium in a new VW truck plant in Brazil: new froms of assembler and suppliers relationship. Integrated Manufacturing Systems, [S.1.], v.8, n.5, p.292-8, 1997.

MATTOSO, J. O Brasil desempregado: como foram destruídos mais de 3 milhões de empregos nos anos 90. São Paulo: Fundação Perseu Abramo, 1999. . A desordem do trabalho. São Paulo: Scritta, 1995.

MÉDA, D. O trabalho: um valor em extinção. Lisboa: Fim de Século Edições, 1999.

MÉDA, D. et al. La place du travail dans l'identité. Paris: Dares - Direction de l'animation de la recherche, des études e des statistiques. Ministère de l'emploi et de la solidarité, 2005. (Document d'études, 92). 
MELCHIOR J. P. Les travailleurs sociaux face à la réduction de la durée du travail et à son intensification. 2006. Tese (Doutorado em Sociologia) - X- Nantere, Paris, 2006

MERCURE, D. Les temporalités sociales. Paris: L’Harmattan, 1995.

MISPELBLOM, F. B. Où commence, où s'arrête, le temps de travail. In: TEMPS, statut et conditions du travail. Bologna: Franco Angeli, 1999. Speciale VII Journées de Sociologie du Travail

MORIN M. L.; DE TERSSAC, G.; THOEMMES J. La négociation du temps de travail: l'emploi en jeu. Sociologie du Travail, Paris, v. 2, p. 191-207, 1998.

MOSCOVICI, S. Representações sociais: investigações em psicologia social. Petrópolis, RJ: Vozes, 2003.

MOUTET, A. Études de temps et intensification du travail dans l'industrie française de 1945 à la décennie 1960 In: LINHART, D.; MOUIET, A. Le travail nous est compté : la construction des normes temporelles du travail.Paris: La Découverte, 2005. p. 23-62.

NASSER, A. C. A. Sair para o mundo: trabalho, família e lazer na vida dos excluídos. São Paulo: Hucitec; Fapesp, 2001.

NORONHA, E. Greves na transição brasileira. 1992. Dissertação (Mestrado em Sociologia) - Instituto de Filosofia e Ciências Humanas - IFCH, Campinas, 1992.

OFFE, C. Trabalho e Sociedade: problemas estruturais e perspectives para o futuro da sociedade do trabalho. Vol. 1 - A crise. Rio de Janeiro: Edições Tempo Brasileiro, 1997.

OIT. Convention n. 01: hours of work (industry). Disponível em: <http://www.oit.org/ilolex/cgi-lex/ convde.pl?coo1> Acesso em: 20 out. 2006.

OLIVA-AUGUSTO, M. H. Retomada de um legado intelectual. Tempo Social: revista de sociologia da USP, São Paulo, v. 17, n. 2. p. 11-33, 2005.

2002.

Tempo, indivíduo e vida social. Ciência e Cultura, São Paulo, v. 54, n. 2, p. 30-33,

O moderno e o contemporâneo: reflexões sobre os conceitos de indivíduo, tempo e morte. Tempo Social: revista de sociologia da USP, São Paulo, v. 6, n. 1/2. p. 91-105, 1994 (editado em jun. 1995).

OLIVEIRA, R. D. Reengenharia do tempo. Rio de Janeiro: Rocco, 2003.

PADILHA, V. Tempo livre e capitalismo: um par imperfeito. Campinas: Alínea, 2000.

PELISSE, J. (2002). A la recherche du temps gagné: des salariés face aux 35 heures. Paris: Dares Direction de l'animation de la recherche, des étides e des statistique. Ministère de l'emploi et de la solidarité, 2002. (Document d'études, 54).

PEPIN, M. et al ( 2006). Renégocier la RTT: les enseignements de 16 démarches d'entreprise. Paris: Dares - Direction de l'animation de la recherche, des étides e des statistique. Ministère de l'emploi et de la solidarité, 2006. (Document d'études, 111). 
PESSANHA, E. G. F.; MOREL, R. L. M. Gerações operárias: rupturas e continuidades na experiência de metalúrgicos do Rio de Janeiro. Rio de Janeiro: [s.n.], 1991.

PIETTRE, B. Filosofia e ciência do tempo. Bauru, São Paulo: EDUSC, 1997.

POCHMANN, M. O trabalho sob fogo cruzado: exclusão, desemprego e precarização no final do século. São Paulo: Contexto, 1999.

PRADO, A. Por que reduzir a jornada de trabalho. São Paulo: [s.n.]. 2000. Mimeo.

PRESIDÊNCIA DA REPÚBLICA. O mercado de trabalho nos anos 90. Brasília: Presidência da República, 1995. (Coleção de documentos da Presidência da República, 4). Disponível em: <http:// www.planalto.gov.br/publi_04/COLECAO/PUBLICA.HTM>

PROMBERGER, M.; TRINCZEK, R. La política de jornada laboral como estratégia de aseguramiento del empleo: reducción y flexibilización de la jornada de trabajo em Alemania. Revista Latinoamericana de Estudios del Trabajo: Estructura y desafíos del (des) empleo México: LASTRA, ano 2, n. 2, p. 105 $125,1996$.

PUECH, I. Le temps du remue-ménage: conditions d'emploi et de travail de femmes de chambre. Sociologie du Travail, Paris, n. 46, p. 150-157, 2004.

RAMALHO, J. R. Estado-patrão e luta operária: o caso FNM. Rio de Janeiro: Paz e Terra, 1989.

As diversas faces da negociação no meio sindical brasileiro. In: MARTINS, H. S.; RAMALHO, J. R. Ramalho, Terceirização: diversidade e negociação no mundo do trabalho. São Paulo: Hucitec: CEDI/NETS, 1994.

. Trabalho, reestruturação produtiva e movimento sindical. In: REESTRUTURAÇÃO produtiva no Brasil. São Paulo: CNI; SESI, 1995, (Caderno Técnico, 22).

RIFKIN, J. O fim dos empregos: declínio inevitável dos níveis de emprego e a redução da força global de trabalho. São Paulo: Makran Books, 1995.

ROCHA, F. Adoniram Barbosa: o poeta da cidade. São Paulo: Ateliê Editorial, 2002.

RODRIGUES, I. J.; ARBIX, G. Novas estratégias sindicais diante do desemprego. São Paulo em Perspectiva: revista da Fundação Seade, São Paulo, v.10, n. 1 jan. / mar. p.77-86, 1996.

. Relações de trabalho e ação sindical no ABC paulista nos anos 1990. In: NABUCO, M. R.; NEVES, M. A. M. (Orgs.). Indústria automobilística: a nova geografia do setor produtivo. Rio de Janeiro: DP\&A, 2002.

RAMALHO, J. R. Organização Sindical e a Instalação de Novas Fábricas do Setor Automotivo: o caso do Sul Fluminense. In: RODRIGUES, I. J. (Org.) Novo sindicalismo vinte anos depois. Rio de Janeiro, São Paulo: Vozes: EDUC/UNITRABALHO, 1999.

RODRÍGUEZ-POSE, A.; ARBIX, G. Estratégias do Desperdício: a guerra entre estados e municípios por novos investimentos e as incertezas do desenvolvimento. Novos Estudos CEBRAP, São Paulo, 54, 1999. 
RONCI, D. Operárias divididas entre a casa e a fábrica. In: KARTCHEVSKY-BULPORT. A. et al. $O$ sexo do trabalho. Rio de Janeiro: Paz e Terra, 1986. p. 145-151.

ROSSI, V. L. S.; ZAMBONI, E. (Orgs.). Quanto tempo e tempo tem!. Campinas, São Paulo: Alínea, 2003.

RURENFRANTZ, J.; KANAUTH, P.; FISCHER, F. M. Trabalho em turnos e noturno. São Paulo: HUCITEC, 1989.

RUSSELL, B. O elogio ao ócio. Rio de Janeiro: Sextante. 2002

SADER, E. Trabalho, desemprego e tempo livre. LAZER numa sociedade globalizada= Leisure in a globalized society. São Paulo: SESC/WLRA, 2000. p. 191-200.

- Quando novos personagens entraram em cena: experiências, falas e lutas dos trabalhadores na Grande São Paulo, 1970-80. Rio de Janeiro: Paz e Terra, 1988.

SALERNO, M. S. Reestruturação produtiva e sindicatos. In: ENCONTRO DAANPOCS, 17, Caxambu. Anais. Caxambú, 1993.

. A trajetória histórica e as perspectivas de desenvolvimento da Autolatina no Brasil. In: CASTRO, N. A. (Org.). A máquina e o equilibrista: inovações na indústria automobilística brasileira. Rio de Janeiro: Paz e Terra, 1995.

. Automação flexível, gestão do tempo e processos de trabalho na indústria. Engenharia de Produção: revista da Fundação Carlos Alberto Vanzolini. São Paulo, n. 2, p. 26-38, 1989.

. Flexibilidade, organização e trabalho operatório: elementos para análise da produção na indústria. 1991. Tese (Doutorado em Engenharia) - Escola Politécnica da Universidade de São Paulo. São Paulo, 1991.

. Projeto de organizações integradas e flexíveis: processos, grupos e gestão democrática via espaços de comunicação-negociação. São Paulo: Atlas, 1999.

SATO, Leni. Astúcia e ambigüidade: as condições simbólicas para o replanejamento negociado do trabalho no chão-de-fábrica. 1997. 198f. Tese (Doutorado em Psicologia Social) - Departamento de Psicologia Social e do Trabalho, Universidade de São Paulo. São Paulo, 1997.

SEIFERT, H. Conséquences d'une réduction massive du temps de travail sur la division sexuée du travail familial : les cas de Volkswagen. Paris, 1997. p. 81-93. (Marché du Travail et Genre, Actes des rencontres européenes organisées par le GRD Mage, 2)

. Reduzir ou ampliar a jornada de trabalho. In: . O trabalho em extinção? saídas para superar o desemprego. Santiago: Centro de Estudos Konrad-Adenauer-Stiftung, 1996. (Traduções, $10)$.

SEMINÁRIO NACIONAL SOBRE REDUÇÃO DA JORNADA DE TRABALHO. São Paulo, textos... São Paulo: Secretaria de Política Sindical de 10 a 12 set. 2001. Mimeo

SENNETT, R. A corrosão do caráter: conseqüências pessoais do trabalho no novo capitalismo. 4. ed. Rio de Janeiro: Record, 2000. 
SHAFF, A. Linguagem e conhecimento. Coimbra: Livraria Almedina, 1964.

SILVA, A. S. O emprego "horista" na lesgislação do trabalho brasileira AFT. [S.1.:s.n.,200-].

SILVA, E. B. Refazendo a fábrica fordista? tecnologia e relações industriais no Brasil no final da década de 1980. In: HIRATA, H. S. (Org.). Sobre o "modelo" japonês: automatização, novas formas de organização e de relações de trabalho. São Paulo: Editora da Universidade de São Paulo, 1993.

SILVA, E. S. Saúde mental e trabalho. In : TUNDI, S. A. \& COSTA, N. R. (Org.). Cidadania e loucura: Políticas de saúde mental no Brasil. Petrópolis: Vozes, 1987.

SILVA, I, et al. A jornada de trabalho no Brasil: o debate e as propostas. In: ABERTURA e ajuste do mercado de trabalho no Brasil: políticas para conciliar os desafios de emprego e competitividade. Brasília: OIT/MTE, 1999.

SILVA, J. P. Três discursos, uma sentença: tempo e trabalho em São Paulo- 1906/1932. São Paulo: ANNABLUME; FAPESP, 1996.

SILVA, V.P. Negociação e câmara setorial. In: MARTINS, H. S.; RAMALHO, J. R. Terceirização: diversidade e negociação no mundo do trabalho. São Paulo: Hucitec: CEDI/NETS, 1994.

SINDICATO DOS METALÚRGICOS DO ABC. Redução da jornada, limite de hora extra e reorganização do tempo de trabalho: as propostas dos metalúrgicos do ABC. São Bernardo do Campo: [199-].

. Pesquisa voluntariado Volkswagen: Perfil. São Bernardo do Campo, 1998.

Reestruturação do complexo automotivo brasileiro: as propostas dos trabalhadores na Câmara Setorial. São Bernardo do Campo, 1992.

. Renovação e reciclagem da frota de veículos: as propostas dos metalúrgicos do ABC. São Bernardo do Campo, 1998.

. Um acordo histórico: as propostas dos trabalhadores da indústria automotiva e a proposta de acordo firmada em fevereiro de 1993. São Bernardo do Campo, 1993.

SINGER, P. Desemprego: uma solução não capitalista. Teoria \& Debate, São Paulo, n. 32, p. 38-42, jul. / ago. 1996.

SIQUEIRA NETO, J. F. Direito do trabalho e flexibilização no Brasil. São Paulo em Perspectiva, revista da Fundação SEADE, São Paulo, v. 11, n. 1, 1997.

SOCHACZEWSKI, S. As representações e o possível. In: MARTINS, J. S. Henri Léfèbvre e o retorno da dialética. São Paulo: Hucitec, 1996.

. A produção da vida: estudo do papel e lugar do trabalho na vida contemporânea. 1998. Tese (Doutorado em Sociologia) - Faculdade de Filosofia, Letras e Ciências Humanas, Universidade de São Paulo, São Paulo, 1998.

SOUZA, M. F. O tempo como construção social. Estudos, São Paulo, v. 27 n. 4, p. 755-770, out. / dez, 2000. 
STÉPHANE B.; PIALOUX M. Jeunes Ouvrier (e) s à l'usine: notes de recherche sur la concurrence garçons/filles et sur la remise em cause de la marculinité ouvrière, Paris, 2002. p. 73 (Travail, Genre et Sociétés n. 8).

SUE, R. Temps et ordre social: sociologie des temps sociaux. Paris: [s.n.], 1994.

SUGITA, K. Temps e travail au Japon: partage ou complémentarité. In: HIRATA, H.;

SENOTIER, D. (Orgs). Femmes et partage du travail. Paris: Syros, 1996.

TABBONI, S. Les temps sociaux. Paris: Armand Colin, 2006.

TADDEI, D. La réduction du temps de travail. Paris: La Documentation française, 1997.

TEDESCO, J. C. Usos de memórias: política, educação e identidade. Passo Fundo: UFPF, 2002.

TERSSAC G.; TREMBLAY, D.G. Quelques tensions contradictoires de l'évolution du temps de travail. In: TERSSAC G.; TREMBLAY, D.G. Où va le temps de travail? Paris: Octarès, 2000.

; THOEMMES, J.; FLAUTRE, A. Régulation politique et régulation d'usage dans le temps de travail. Le Travail Humain, tomo 67, n. 2, p. 135-154, 2004.

THOEMMES, J. Négociation du temps de travail er régulations intermediaires : le cas de Volkswagen. In: GROUX, G. (Dir.). L'action oublique négocié: approches à partir des 35 heures: France-Europe. Paris: L’Harmattan, 2001. p. 127-143. (Logiques Politiques).

. La construction du temps de travail : normes juridiques ou normes sociales?. Revue Droit et Société, Paris, n. 41, p. 15-32, 1999.

. La négociation du temps de travail et les composantes du référentiel temporel, Loisir et Société, Paris, v. 20, p. 51-72, 1997.

.Vers la fin du temps de travail. Paris: Presses Universitaires de France, 2000.

.; DE TERSSAC G. La construction des arrangements temporels : une analyse d'accord sur 11 ans dans une région. In: BOSCH, G. et al. (Dir.). Le temps de travail : nouveaux enjeux, nouvelles normes, nouvelles mesures. Bruxelles: Editions du DULBEA, 1997. p. 217-244.

.; LABIT, A. La «semaine de 4 jours» chez Volkswagen: un scénario original de sortie de crise? Travail et Employ, n. 64, p. 5-22, 1995.

THOMPSON, E. P. Time, work-discipline, and Industrial Capitalism. Past \& Presente: a journal of historical studies. Oxford, n. 38, dec. 1967.

TITTONI, J. Subjetividade e trabalho. Porto Alegre: Ortiz, 1994.

TREMBLAY, D. G.; VILLENEUVE D. L'aménagement et la réduction du temps de travail : les enjeux, les approches, les méthodes. Québec: Téle-université; Saint Martin, 1998.

TROYANO, A. A. Flexibilidade do emprego assalariado. São Paulo em Perspectiva: revista da Fundação SEADE, São Paulo, v. 5, n. 2, p. 84-95, 1991. 
UHL, M. Subjectivité et sciences humaines: essai de métasociologie. Paris: Beauchesne, 2005.

VELTZ, P. Temps et efficacité du travail: un lien à repenser. In: TERSSAC G.; TREMBLAY, D.G. Où va le temps de travail? France, Octarès, 2000.

VIARD, J. Le sacre du temps libre: le sacre du temps libre. [Paris]: L'Aube, 2001.

VIGOTSKI, L. S. Pensamento e linguagem. São Paulo: Martins Fontes, 1996.

VOLKSWAGEN. Volkswagen no Brasil. São Bernardo: VW Assuntos Corporativos, mar. 1998.

WAQUET, P. Em marge de la loi Aubry: travail effectif et vie personnelle du salarie. Droit Social, n.12, p. $963-994,1998$.

WEBER, M. A ética protestante e o espírito do capitalismo. São Paulo: Biblioteca Pioneira de Ciências Sociais, 1989.

WHITROW, G. J. O tempo na história: concepções de tempo da pré-história aos nossos dias. Rio de Janeiro: Jorge Zahar,1993.

YIN, Robert. Case study research: design and methods. Revised edition. Newbury Park: SAGE Publications, 1989.

ZAJDSZNAJDER, Luciano. Teoria e prática da negociação coletiva: política de negociação. Rio de Janeiro: José Olympio, 1985.

ZARIFIAN, P. Approche sociologique de l'expérience. [ S.1.: s.n.], 2006. Mimeo

Du travail à l'action. [S.1.:s.n.], 2006. Mimeo

Mimeo. . Savoir et/ou subjectivation: critique de la théorie du capitalisme cognitif. [S.1.:s.n.], 2004. . Je me souviens. [S.1.:s.n.], 2005. Mimeo.

. Le temps du travail: le temps-devenir face au temps-spacialisè. [S.1.:s.n.], 2001. Mimeo. . Temps et modernité: le temps comme enjeu du monde moderne. Paris: L'Harmattan, 2001.

. La notion de temps libre et les rapports sociaux de sexe dans le débat sur la réduction du temps de travail. In: HIRATA, H.; SENOTIER, D. Femmes et partage du temps du travail. Paris: Syros, 1996.

ZERUBAVEL. E. Hidden rhythms: schedules and calendars in social life. Califórnia: Paperback, 1985. 


\section{ANEXOS}




\section{ANEXO 1 \\ Roteiro das entrevistas}

Quadro 1

Roteiro das entrevistas com diretores do Sindicato

\begin{tabular}{|c|c|}
\hline Período/tema & Questões \\
\hline Primeira metade dos anos 80 & $\begin{array}{l}\text { - Mudanças tecnológicas e organizacionais versus justificativas da } \\
\text { empresa. } \\
\text { - Impactos sobre o tempo de trabalho: intensidade, ritmo. } \\
\text { - Ação/reação/participação dos trabalhadores. } \\
\text { - Negociações: demandas e realização. }\end{array}$ \\
\hline $\begin{array}{l}1986 \text { a } 1995 \\
\text { a) Autolatina } \\
\text { b) Câmara Setorial }\end{array}$ & $\begin{array}{l}\text { - Mudanças tecnológicas e organizacionais versus justificativas da } \\
\text { empresa. } \\
\text { - Impactos sobre o tempo de trabalho: intensidade, ritmo. } \\
\text { - Ação/reação/participação dos trabalhadores. } \\
\text { - Negociações: demandas e realização. }\end{array}$ \\
\hline $\begin{array}{l}1995 \\
\text { Negociação sobre redução } \\
\text { da jornada } \\
\text { A partir de } 1994 \\
\text { Acordos de Participação nos } \\
\text { Lucros ou Resultados }\end{array}$ & $\begin{array}{l}\text { - Processo de negociação. } \\
\text { - Ação/reação/participação dos trabalhadores. } \\
\text { - Processo de negociação: meta sobre absenteísmo. } \\
\text { - Ação/reação/participação dos trabalhadores. }\end{array}$ \\
\hline $\begin{array}{l}1995 \\
\text { Reestruturação das plantas }\end{array}$ & $\begin{array}{l}\text { - Processo de negociação. } \\
\text { - Ação/reação/participação dos trabalhadores. }\end{array}$ \\
\hline $\begin{array}{l}1995 \\
\text { Plano de cargos e salários }\end{array}$ & $\begin{array}{l}\text { - Processo de negociação. } \\
\text { - Principais reivindicações do movimento sindical e da empresa. } \\
\text { - Conteúdo sobre multifuncionalidade ou polivalência. } \\
\text { - Ação/reação/participação dos trabalhadores. }\end{array}$ \\
\hline $\begin{array}{l}\text { A partir de } 1995 \text { Banco de horas } \\
\text { e banco de dias }\end{array}$ & $\begin{array}{l}\text { - Processo de negociação. } \\
\text { - Prioridades definidas pela empresa e pelo movimento sindical. } \\
\text { - Ação/reação/participação dos trabalhadores. } \\
\text { - Mudanças para os trabalhadores: dentro e fora do local de trabalho. }\end{array}$ \\
\hline $\begin{array}{l}1996 \\
\text { Células de produção }\end{array}$ & $\begin{array}{l}\text { - Processo de negociação. } \\
\text { - Prioridades definidas pela empresa e pelo movimento sindical. } \\
\text { - Ação/reação/participação dos trabalhadores. } \\
\text { - Presença da questão do tempo de trabalho na negociação. } \\
\text { - Impactos sobre o tempo de trabalho. }\end{array}$ \\
\hline $\begin{array}{l}2002 \\
\text { Linha pólo }\end{array}$ & $\begin{array}{l}\text { - Mudanças presentes na linha. } \\
\text { - Mudanças na qualidade e quantidade de empregos. } \\
\text { - Mudanças no tempo de trabalho: ritmo e intensidade. }\end{array}$ \\
\hline Mudanças futuras na empresa & $\begin{array}{l}\text { - Instalação de novas linhas. } \\
\text { - Novas mudanças no tempo de trabalho. } \\
\text { - Renovação do acordo em } 2006 .\end{array}$ \\
\hline
\end{tabular}




\section{Quadro 2}

Roteiro das entrevistas com representantes de Comissões de Fábrica e Comitê Sindical de Empresa

\begin{tabular}{|c|c|}
\hline Tema & Questões \\
\hline Apresentação & $\begin{array}{l}\text { - Dados pessoais: nome completo, idade, local de nascimento, estado } \\
\text { civil, quantidade de filhos, com quem mora, estudante ou não. } \\
\text { - Quando entrou na Volkswagen e setores nos quais trabalhou. } \\
\text { - Relação com o sindicato: como se aproximou. }\end{array}$ \\
\hline O setor & $\begin{array}{l}\text { - O que é produzido e como é produzido no setor onde você trabalha? } \\
\text { - Quais as principais inovações tecnológicas implementadas na } \\
\text { empresa a partir dos anos } 90 \text { ? } \\
\text { - Quais as principais inovações organizacionais e gerenciais } \\
\text { implementadas na empresa a partir dos anos } 90 \text { e quais foram os } \\
\text { principais objetivos da empresa com essas mudanças? }\end{array}$ \\
\hline Pessoas & $\begin{array}{l}\text { - Qual o perfil das pessoas que trabalham nesse setor: idade, sexo, } \\
\text { tempo de casa e escolaridade? } \\
\text { - O que as pessoas pensam sobre o fato de trabalharem na } \\
\text { Volkswagen: o que mais gostam e o que não gostam. }\end{array}$ \\
\hline Outros setores & $\begin{array}{l}\text { - Qual a relação desse setor com os outros do ponto de vista da } \\
\text { organização do trabalho? } \\
\text { - Qual a relação dos trabalhadores desse setor com os outros? } \\
\text { - Como você vê os outros setores em termos de organização do } \\
\text { trabalho e trabalhadores? }\end{array}$ \\
\hline $\begin{array}{l}\text { Questões específicas } \\
\text { sobre jornada }\end{array}$ & $\begin{array}{l}\text { - Banco de horas: como funciona e o que os trabalhadores pensam } \\
\text { sobre ele. } \\
\text { - Semana } 4 \text { dias: como funciona e o que os trabalhadores pensam } \\
\text { sobre ela. } \\
\text { - 2001: como reagiram as pessoas do setor em relação à renovação do } \\
\text { acordo. } \\
\text { - Células: como funcionam / o que muda em relação ao tempo de } \\
\text { trabalho/ o que os trabalhadores pensam sobre o trabalho em célula. } \\
\text { - Metas para o setor: com funciona / o que os trabalhadores pensam } \\
\text { sobre elas. }\end{array}$ \\
\hline Futuro & $\begin{array}{l}\text { - A empresa tem apontado alguma nova mudança no tempo de } \\
\text { trabalho? Qual? } \\
\text { - O que tem sido discutido em relação à renovação do acordo? Quais } \\
\text { são as propostas de vocês e da empresa? } \\
\text { - Qual você acha que é a posição dos trabalhadores? }\end{array}$ \\
\hline A vida e o tempo de trabalho & $\begin{array}{l}\text { - Você sente que a qualidade e a quantidade do tempo dentro da } \\
\text { fábrica interferem no seu tempo fora dela? Como? } \\
\text { - O que normalmente você faz, durante a semana, antes e depois da } \\
\text { sua jornada de trabalho? } \\
\text { - O que você faz no final de semana? } \\
\text { - O que gostaria de fazer? }\end{array}$ \\
\hline
\end{tabular}


Quadro 3

Roteiro das entrevistas com gerentes da Empresa

\begin{tabular}{|c|c|c|}
\hline Setor & Tema & Questões \\
\hline $\begin{array}{l}\text { Relações } \\
\text { Trabalhistas }\end{array}$ & $\begin{array}{l}\text { Negociações } \\
\text { jornada }\end{array}$ & $\begin{array}{l}\text { - Quais as principais transformações no tempo de trabalho ao longo } \\
\text { dos anos } 80 \text { e, especialmente, dos anos } 90 \text { ? Quais as principais } \\
\text { razões para essas mudanças? } \\
\text { - Quais são os fatores (internos e externos) que influenciaram na } \\
\text { reorganização do tempo de trabalho? } \\
\text { - Atualmente, quais as formas de flexibilização do tempo de trabalho? } \\
\text { - } \text { Quais os resultados alcançados pela empresa, com esses novos } \\
\text { instrumentos, no que diz respeito à organização e competitividade? } \\
\text { - Como se deram os processos de negociação relativos ao tempo de trabalho? } \\
\text { - Para os trabalhadores, quais as maiores mudanças em função da } \\
\text { introdução da flexibilização do tempo de trabalho, dentro e fora do } \\
\text { local de trabalho? } \\
\text { - Quais são as maiores semelhanças e diferenças no que se refere às } \\
\text { mudanças no tempo de trabalho se compararmos a Volkswagen } \\
\text { Anchieta em relação ao modelo desenvolvido na Alemanha? } \\
\text { - Quais as principais tendências para a gestão do tempo de trabalho na } \\
\text { empresa pensando o futuro? }\end{array}$ \\
\hline RH & Trabalhadores & $\begin{array}{l}\text { - Perfil atual dos trabalhadores: evolução dos efetivos segundo } \\
\text { características básicas tais como: tipo de contrato, sexo, idade, } \\
\text { qualificação, setor de atividade na planta. } \\
\text { - Houve mudança no perfil em relação aos períodos anteriores? } \\
\text { - Qual o perfil que a empresa busca? } \\
\text { - Como se dá a relação entre a empresa e os trabalhadores? }\end{array}$ \\
\hline
\end{tabular}


Quadro 4

Roteiro das entrevistas com trabalhadores

\begin{tabular}{|c|c|}
\hline Tema & Questões \\
\hline $\begin{array}{l}\text { Apresentação: dados pessoais } \\
\text { e familiares }\end{array}$ & $\begin{array}{l}\text { - Nome completo, idade, local de nascimento, estado civil, quantidade } \\
\text { de filhos, com quem mora, estudante ou não. } \\
\text { - Nome completo, idade, local de nascimento, estado civil, quantidade } \\
\text { - O que você mais gosta de fazer na sua vida? }\end{array}$ \\
\hline $\begin{array}{l}\text { Usos do tempo fora do local } \\
\text { de trabalho }\end{array}$ & $\begin{array}{l}\text { Preenchimento de diário de usos do tempo: } \\
\text { - Atividades realizadas no último sábado (dia de folga) desde a hora } \\
\text { que acordou até a hora que foi dormir. } \\
\text { - Qual foi a atividade mais importante nesse dia? Por quê? } \\
\text { - Os sábados (dias de folga) são sempre assim ou são diferentes? } \\
\text { - Você leva trabalho para fazer em casa?. } \\
\text { - E o domingo, como foi? } \\
\text { - Existe algo que você gostaria muito de fazer nos seus dias de folga } \\
\text { - } \text { O que que não tem feito? } \\
\text { - O que sua família acha do tempo que você fica junto com ela? } \\
\text { - Atividades realizadas no dia de trabalho (último/penúltimo) desde a } \\
\text { hora que acordou até a hora que foi dormir. }\end{array}$ \\
\hline Usos do tempo em dias de trabalho & $\begin{array}{l}\text { - Preenchimento de diário de usos do tempo: } \\
\text { - Qual você considera como a atividade mais importante no seu dia de } \\
\text { semana? Por quê? } \\
\text { - O que ele você gostaria que fosse diferente no seu dia? Por quê? } \\
\text { - Os dias de trabalho são sempre assim ou são diferentes? } \\
\text { - Se você tivesse a sua jornada de trabalho reduzida em } 2 \text { horas, o que } \\
\text { você faria com essas } 2 \text { horas a mais de tempo livre? }\end{array}$ \\
\hline $\begin{array}{l}\text { Relação entre o tempo dentro e } \\
\text { fora do local de trabalho. }\end{array}$ & $\begin{array}{l}\text { - Você acha que a quantidade e a forma do tempo de trabalho dentro } \\
\text { da fábrica interfere na sua vida fora dela? Como isso acontece? } \\
\text { - E o contrário? Você acha que a sua vida fora da fábrica influencia } \\
\text { sua vida dentro da dela? Como? }\end{array}$ \\
\hline $\begin{array}{l}\text { Entendimento sobre o que é o } \\
\text { tempo dedicado ao trabalho e } \\
\text { tempo de não trabalho }\end{array}$ & $\begin{array}{l}\text { - Você estuda? Por quê? } \\
\text { - Quanto tempo, por semana, você utiliza com os estudos? } \\
\text { - Você acha que este tempo pode ser classificado como um tempo de } \\
\text { trabalho ou como tempo livre? } \\
\text { - Quanto tempo você gasta com transporte? } \\
\text { - Você acha que este tempo pode ser classificado como tempo de } \\
\text { trabalho ou como tempo livre? }\end{array}$ \\
\hline Jornada de Trabalho & $\begin{array}{l}\text { - Desde quando você trabalha aqui na Volkswagen? } \\
\text { - Fale um pouco sobre sua semana de trabalho: o que você faz, como } \\
\text { seu trabalho é organizado e quais são suas responsabilidades. } \\
\text { - Quais as principais mudanças do sistema de produção da Volkswagen } \\
\text { na sua área? } \\
\text { - Como isso interfere na organização e na divisão do tempo no seu dia } \\
\text { de trabalho? }\end{array}$ \\
\hline
\end{tabular}


Quadro 4

Resumo do roteiro das entrevistas com trabalhadores

\begin{tabular}{|c|c|}
\hline Tema & Questões \\
\hline Jornada de Trabalho & $\begin{array}{l}\text { - Seu trabalho mudou ao longo desse tempo? O que mais mudou? } \\
\text { - Quais as pausas existentes? O que você faz durante essas pausas? } \\
\text { - O que mais gosta do trabalho na Volkswagen? } \\
\text { - O que você não gosta do trabalho na Volkswagen? } \\
\text { - Você tem alguma doença profissional? } \\
\text { - Elas são comuns no seu setor? } \\
\text { - Há muita demanda por parte de empresa para você realizar hora } \\
\text { extra? } \\
\text { - E no seu setor? } \\
\text { - Como é a sua relação com o banco de dias (nem todos os setores } \\
\text { tiveram o banco de dias) e com a semana Volkswagen (semana de } 4 \\
\text { dias)? } \\
\text { - Se fosse para escolher entre a semana Volkswagen (com redução da } \\
\text { Participação nos Lucros e Resultados) e a semana normal (sem } \\
\text { redução da Participação nos Lucros e Resultados), por qual você } \\
\text { optaria? Por quê? }\end{array}$ \\
\hline Flexibilização da jornada & $\begin{array}{l}\text { Banco de Horas: } \\
\text { - Você tem horas positivas ou negativas? } \\
\text { - Para que você usa suas horas? } \\
\text { - Você tem alguma dificuldade para utilizar suas horas positivas? } \\
\text { - Em } 2001 \text {, na primeira assembléia que teve, você foi contra ou a favor } \\
\quad \text { para renovar o acordo de banco de horas e a semana } 4 \text { dias? Por quê? }\end{array}$ \\
\hline Sobre sistema de produção & $\begin{array}{l}\text { Células: } \\
\text { - Você trabalha em células? } \\
\text { - Mudou alguma coisa em relação ao tempo de trabalho? } \\
\text { Multifuncionalidade: } \\
\text { - Você exerce uma única função ou não? } \\
\text { - Você pode ser mudado de área? } \\
\text { - O que você acha disso? } \\
\text { Metas de produção: } \\
\text { - O que você acha das metas de produção? } \\
\text { - Estão de acordo ou não com a capacidade? } \\
\text { Programa de sugestão: } \\
\text { - Você já participou de algum programa de sugestão? } \\
\text { - Qual? } \\
\text { - Como teve a idéia e o que você sugeriu? } \\
\text { - Por que participou? }\end{array}$ \\
\hline Processo de negociação & $\begin{array}{l}\text { - Você é filiado ao sindicato? Se sim, desde quando e por quê? Se não, } \\
\text { por quê? } \\
\text { - Do seu ponto de vista, como o sindicato tem negociado o banco de } \\
\text { horas e a semana de } 4 \text { dias? } \\
\text { - O que você acha que precisaria ser modificado na sua jornada de } \\
\text { trabalho? Por quê? }\end{array}$ \\
\hline Futuro & - O que você planeja para seu futuro? \\
\hline
\end{tabular}


Quadro 5

Roteiro das entrevistas com trabalhadores de empresas terceiras

\begin{tabular}{|l|l|}
\hline Tema & \multicolumn{1}{|c|}{ Questões } \\
\hline Usos do tempo em dias de trabalho & $\begin{array}{l}\text { - Qual você acha que é a maior diferença entre ser um trabalhador da } \\
\text { Volkswagen e um trabalhador de uma empresa terceira? }\end{array}$ \\
\hline Jornada de Trabalho e Flexibilização & $\begin{array}{l}\text { - Qual sua jornada de trabalho? } \\
\text { - Quais as mudanças que ocorreram em sua jornada nos últimos } \\
\text { tempos? } \\
\text { - O que mais te incomodou e o que mais você gostou nessas } \\
\text { mudanças? }\end{array}$ \\
& $\begin{array}{l}\text { - O que você gostaria que fosse modificado no seu tempo de trabalho? } \\
\text { Por quê? }\end{array}$ \\
\hline
\end{tabular}

Quadro 6

Roteiro de entrevistas com trabalhadores aposentados

\begin{tabular}{|c|c|}
\hline Tema & Questões \\
\hline Tempo de Vida & $\begin{array}{l}\text { - Fale um pouco como está sua vida após a aposentadoria? } \\
\text { - O que mais mudou na sua vida? }\end{array}$ \\
\hline Usos do tempo em dias de trabalho & $\begin{array}{l}\text { Aposentados que não exercem nenhuma atividade de trabalho: } \\
\text { - Quando você entrou na Volkswagen e quando saiu? } \\
\text { - Por que saiu? } \\
\text { - Como era seu trabalho na Volkswagen? } \\
\text { - Quais eram as pausas existentes? O que você fazia durante essas } \\
\text { - pausas? } \\
\text { - Seu trabalho mudou ao longo deste tempo? O que mais mudou? } \\
\text { - O que você mais gostava e o que menos gostava no trabalho na } \\
\text { Apolkswagen? } \\
\text { - Quando você entrou na Volkswagen e quando saiu? } \\
\text { - Por que saiu? } \\
\text { - Como era seu trabalho na Volkswagen? } \\
\text { - Quais eram as pausas existentes? O que você fazia durante essas } \\
\text { - pausas? } \\
\text { - O que você mais gostava e o que menos gostava no trabalho na } \\
\text { - Como é seu trabalho atual? } \\
\text { - Qual a maior diferença em relação ao trabalho na Volkswagen? }\end{array}$ \\
\hline
\end{tabular}




\section{ANEXO 2 \\ Diário de usos do tempo'}

\begin{tabular}{|c|c|c|c|}
\hline $\begin{array}{l}\text { Hora de início e } \\
\text { fim da atividade }\end{array}$ & O que você fez & $\begin{array}{l}\text { O que mais você está fazendo? } \\
\text { (atividade mais importante) }\end{array}$ & $\begin{array}{c}\text { Com quem } \\
\text { (a segunda atividade } \\
\text { mais importante) }\end{array}$ \\
\hline & & & \\
\hline & & & \\
\hline & & & \\
\hline & & & \\
\hline & & & \\
\hline & & & \\
\hline & & & \\
\hline & & & \\
\hline & & & \\
\hline & & & \\
\hline & & & \\
\hline & & & \\
\hline & & & \\
\hline & & & \\
\hline & & & \\
\hline & & & \\
\hline & & & \\
\hline & & & \\
\hline & & & \\
\hline & & & \\
\hline & & & \\
\hline & & & \\
\hline & & & \\
\hline & & & \\
\hline & & & \\
\hline & & & \\
\hline & & & \\
\hline & & & \\
\hline & & & \\
\hline & & & \\
\hline & & & \\
\hline
\end{tabular}

1. Esse diário é uma adaptação do originalmente utilizado por Neuma Aguiar, no projeto realizado em Belo Horizonte, denominado "Trabalho doméstico e Trabalho remunerado: análise dos usos do tempo em Belo Horizonte, Minas Gerais - um projeto piloto para zonas metropolitanas brasileiras", no ano 2000. 


\section{EMBRIAGUE-SE}

Embriagar-se sempre é preciso. Tudo está nisto: é a única questão. Para não sentir o terrível fardo do Tempo que lhe dilacera os ombros e lhe encurva para a terra, embriagarse sem cessar é preciso.

Mas dê que? De vinho, poesia ou virtude, a bel prazer.

Mas embriague-se.

E se algumas vezes, nas escadarias de um palácio, na verde relva de um barranco, na solidão morna do seu quarto, você acordar, com a embriaguez já diminuída ou sumida, pergunte ao relógio, ao vento, à vaga, às estrelas, a tudo o que foge, a tudo o que geme, a tudo o que canta, a tudo o que fala, pergunte que horas são; e o relógio, o vento, a vaga, a estrela, as aves, Ihe responderão:

É hora de embriagar-se!

Para não ser escravo martirizado do Tempo embriague-se; sem cessar embriague-se!

De vinho, poesia ou virtude, a bel prazer. 